RODRIGO PINHEIRO ARALDI

\title{
LINHAGENS CELULARES DERIVADAS DE CULTIVOS PRIMÁRIOS DE NEOPLASIAS INFECTADAS PELO BPV COMO MODELO DE ESTUDO DA TRANSIÇÃO EPITÉLIO- MESÊNQUIMA
}

Tese apresentada ao Programa de Pósgraduação Interunidades em Biotecnologia USP/Instituto Butantan/IPT, para obtenção do Título de Doutor em Biotecnologia. 


\section{RODRIGO PINHEIRO ARALDI}

\section{LINHAGENS CELULARES DERIVADAS DE CULTIVOS PRIMÁRIOS DE NEOPLASIAS INFECTADAS PELO BPV COMO MODELO DE ESTUDO DA TRANSIÇÃO EPITÉLIO- MESÊNQUIMA}

Tese apresentada ao Programa de Pósgraduação Interunidades

em

Biotecnologia

USP/Instituto

Butantan/IPT, para obtenção do Título de Doutor em Biotecnologia.

Área de concentração: Biotecnologia

Orientadora: Dra. Rita de Cassia Stocco

Versão corrigida. A versão original eletrônica, encontra-se disponível tanto na Biblioteca do ICB quanto na Biblioteca Digital de Teses e Dissertações da USP (BDTD) 


\section{CATALOGAÇÃO NA PUBLICAÇÃO (CIP) \\ Serviço de Biblioteca e informação Biomédica \\ do Instituto de Ciências Biomédicas da Universidade de São Paulo}

Ficha Catalográfica elaborada pelo(a) autor(a)

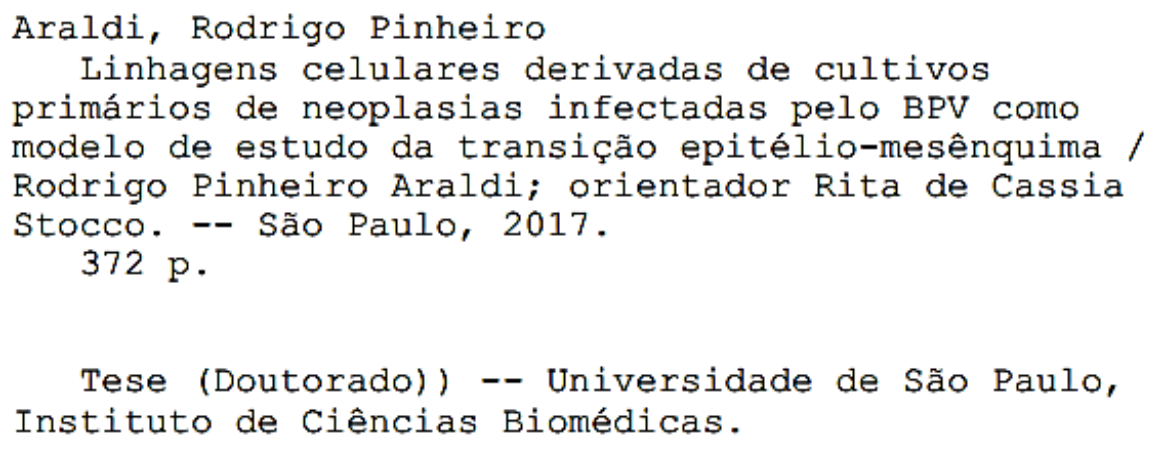

1. BPV. 2. Cultivo celular. 3. Transição epitéliomesênquima. 4. Oncologia. I. Stocco, Rita de Cassia , orientador. II. Título. 


\section{UNIVERSIDADE DE SÃO PAULO \\ Programa de Pós-Graduação Interunidades em Biotecnologia \\ Universidade de São Paulo, Instituto Butantan, Instituto de Pesquisas Tecnológıcas}

Candidato(a): Rodrigo Pinheiro Araldi

Titulo da Tese: Linhagens celulares derivadas de cultivos primários de neoplasias infectadas pelo BPV como modelo de estudo da transição epitélio-mesênquima

Orientador: Dra. Rita de Cassia Stocco

A Comissão Julgadora dos trabalhos de Defesa da Tese de Doutorado, em sessão pública realizada a ............................., considerou o(a) candidato(a):

\section{( ) Aprovado(a) ( ) Reprovado(a)}

Examinador(a): $\quad$ Assinatura:

Nome:

Instituição:

Examinador(a): $\quad$ Assinatura:

Nome:

Instituição:

Examinador(a): $\quad$ Assinatura:

Nome:

Instituição:

Examinador(a): $\quad$ Assinatura:

Nome:

Instituição:

Examinador(a): $\quad$ Assinatura:

Nome:

Instituição:

Presidente: Assinatura:

Nome:

Instituição: 


\section{DEDICATÓRIA}

À minha tia Madalena, por todo apoio e amor 


\section{AGRADECIMENTOS}

A Dra. Rita de Cassia Stocco, por ter acreditado no meu sonho e nesta proposta de pesquisa, tendo me dado a liberdade criativa necessária para o desenvolvimento desta tese, estando sempre presente.

A Dra. Adriana da Costa Neves, com quem tive o privilégio de trabalhar estes anos e cuja opinião foi de imenso valor na execução deste trabalho, bem como em minha formação.

A todos os meus colegas do Grupo Oncogênese Viral (Rodrigo Franco de Carvalho, Jacqueline Mazzuchelli de Souza, Diego Grando Módolo, Thaylene Alexandre de Lima, Roberta Fiusa Magnelli e Thalita Sant'Ana) pelo apoio durante a execução deste trabalho.

A Dra. Sueli Assaf, que há alguns anos me apresentou o fascinante universo da Patologia, instigando meu conhecimento, o que resultou nesta tese. Agradeço, ainda, pelo apoio e por todas as nossas tão prazeirosas conversas, através das quais passei a ver o mundo sobre outro prisma.

A Dra. Diva Denelle Spadacci Morena e Magna Soares pelo auxílio histológico e pelo carinho e preocupação com minha pessoa, fazendo com que nossa amizade se eternize a cada dia.

A Secretaria do Programa de Pós-graduação Interunidades em Biotecnologia pela prestativa atenção de suas secretárias Eliane, Fábia e Vânia pela atenção e apoio durante minha pós-graduação.

Ao Prof. Dr. Franco Peppino Roperto (Università degli Studi di Napoli Federicco II) e toda sua equipe (Roberta Lucà, Chiara, Dora e Francesca) por ter me recebido de forma tão carinhosa durante meu estágio na Itália.

Ao Laboratório de Biologia Celular do Instituto Butantan, especialmente a Simone Jared e Beatriz Maurício, sempre dispostas a colaborar e cuja colaboração foi fundamental na obtenção dos dados de microscopia eletrônica.

Aos funcionários e técnicos do Laboratório de Genética do Instituto Butantan (Eduardo, Dener, Ivone, Rose e Dilce).

Ao Prof. Dr. Sílvio Roberto Consonni (Departamento de Biologia, Universidade Estadual de Campinas - UNICAMP) por sua prestativa colaboração na microscopia eletrônica de transmissão e por nossas amplas discussões, que permitiram colocar em xeque o paradigma da replicação viral dos papilomavírus. 
AGRADECIMENTOS

À Fundação de Amparo à Pesquisa do Estado de São Paulo (FAPESP/CAPES) pelo apoio financeiro concedido por meio da bolsa de doutorado (processo 2014/20617-5) 
"Uma mente que tenha sido estirada por novas ideias nunca poderá recobrar a sua forma natural"

Albert Eisntein 


\section{RESUMO}

ARALDI, R. P. Linhagens celulares derivadas de cultivos primários de neoplasias infectadas pelo BPV como modelo de estudo da transição epitéliomesênquima. 2017 (372 f). Tese (Doutorado em Biotecnologia) - Instituto de Ciências Biomédicas, Universidade de São Paulo, São Paulo, 2017.

Embora reconhecido como um oncovírus, a ação do papilomavírus bovino (BPV) após a iniciação neoplásica permanece pouco explorada. A falta de atenção dada às linhagens celulares derivadas de neoplasias infectadas pelo BPV justifica a carência de estudos acerca do vírus na progressão e metastatização. Desta forma, este estudo buscou avaliar a participação do BPV na transição epitélio-mesênquima (TEM), processo patológico verificado durante a metástase. Para tanto, foram empregadas as seguintes linhagens: papiloma cutâneo, fibropapiloma, carcinoma de esôfago (CE) e pele saudável (controle). Os resultados da PCR mostraram a presença e manutenção de sequências de DNA de ao menos um dos tipos virais BPV-1, 2 e 4 ao longo das seis passagens das linhagens celulares derivadas das neoplasias infectadas pelo vírus. Adicionalmente, foi verificada a imunodetecção da proteína L1 do BPV, bem como a presença de partículas semelhantes a vírions no citoplasma destas células, sugerindo a infecção produtiva in vitro. A linhagem derivada de pele saudável não apresentou sequências de DNA viral, tampouco a imunomarcação da proteína L1, permitindo seu uso como controle. A avaliação do ciclo celular mostrou um aumento do percentual de células nas fases $S$ e G2-M nas linhagens celulares derivadas das neoplasias infectadas pelo BPV em relação à pele saudável. Tais linhagens mostraram uma redução no potencial de membrana mitocondrial $(\Delta \psi \mathrm{m})$, sugerindo a ativação da glicólise aeróbica, especialmente nas células de CE. Porém, as células infectadas pelo BPV apresentaram um aumento da produção de espécies reativas de oxigênio. $O$ estresse oxidativo pode justificar a clastogenicidade verificada nas linhagens derivadas de neoplasias infectadas pelo BPV. A ação clastogênica contribui com a aquisição do fenótipo-tronco, verificado pelo ensaio de tumor-esfera e pelo aumento dos níveis de expressão do fator Oct$3 / 4$ descritos nestas mesmas linhagens. Somado a estes resultados, foi verificado o sequestro citoplasmático, bem como a repressão da $\mathrm{E}$ - e $\mathrm{N}$-caderina nas células derivadas de CE. Tais resultados podem ser atribuídos à expressão aberrante do fator SLUG, descrito nesta linhagem. Estes resultados foram também observados na análise imunoistoquímica dos fragmentos de tecidos destas neoplasias. A análise morfológica das células infectadas pelo BPV mostrou a perda de polaridade e a presença de filopódios, verificados pela microscopia de contraste de fase, varredura e marcação de F-actina. Estes resultados sugerem a aquisição de um fenótipo mesenquimal. A aquisição do fenótipo migratório foi verificada por meio de timelapse microscopy, que mostrou que as células de pele saudável e papiloma cutâneo apresentam mesma velocidade média de deslocamento. Porém, as células de CE e fibropapiloma apresentaram as maiores velocidade de migração celular, sugerindo que a persistência da infecção e o envolvimento da derme favorecem a metástase. Estes dados mostram que as linhagens celulares são modelos úteis para estudar a patogenia do BPV, bem como indicam que o vírus favorece a metástase.

Palavras-chave: BPV. Cultivo celular. Transição epitélio-mesênquima. Oncologia. 


\begin{abstract}
ARALDI, R. P. Cell lines derived from BPV-infected neoplasms primary cultures as model to study epitelial-mesenchymal transition. 2017. (372 f). Thesis (Biothecnology) - Instituto de Ciências Biomédicas, Universidade de São Paulo, São Paulo, 2017.

Although recognized as an oncovirus, the bovine papillomavirus (BPV) action in after cancer initiation remains few explored. The lack of attention given to cell lines derived from BPV-infected neoplasms justifies the lack of studies about the virus role in cancer progression and metastasis. Thus, this study aimed to evaluate the BPV capability to the induce epithelial-mesenchymal transition (EMT), pathological process verified during metastasis. For that, it was employed the following cell lines: cutaneous papilloma, fibropapilloma, esophageal carcinoma (EC) and normal skin (control). PCR's results showed the presence and maintenance of DNA sequences of, at least, one of the viral types BPV-1, 2 and 4 along the six passages of cell lines derived from BPV-infected neoplasms. Additionally, it was verified the BPV L1 protein immunodetection, as well as the presence of virion-like particles in cytoplasm of these cells, suggesting the productive infection. Cell line derived from normal skin did not show viral DNA sequences, neither L1 immunodetection, allowing its use as control. Cell cycle analysis showed an increase in cell percentage in S and G2-M phases in cell lines derived from BPV-infected neoplasms in relation to normal skin. These cell lines showed a mitochondrial membrane potential $(\Delta \psi \mathrm{m})$ reduction, suggesting the activation of aerobic glycolysis, especially in EC cells. However, BPVinfected cells showed an increase in reactive oxygen species production. Oxidative stress can justify the high levels of clastogenicity verified in cell lines derived from BPV-infected neoplasms. Clastogenic action contributes to acquisition of stem-cell phenotype, verified through the tumorsphere assay and by the increase in Oct-3/4 expression leves, described in these cell lines. In addition, it was verified the $\mathrm{E}$ - and $\mathrm{N}$-cadherin cytoplasmic sequester and repression in cells derived from EC. These results can be attributed to the SLUG aberrant expression, described in this cell line. These data were also verified in transformed cells present in invasion front of tissue fragments. Morphological analysis of BPV-infected cells showed the loss of apicalpolarity and the presence of fillopodia, which detection was confirmed by the phase and scanning microscopy, as well as through the F-actin labelling. These results suggest the acquisition of mesenchymal phenotype. The acquisition of migratory phenotype was verified by time-lapse microscopy, which showed that normal skin and cutaneous papilloma have the same migratory velocity. However, EC and fibropapilloma cells showed the highest migration velocity, suggestinf that the viral persisitance and the dermal involviment lead to invasive phenotype, contributing to metastasis. These data show that cell lines are useful models to study the BPV pathogenesis, as well as indicate that the virus contributes to metastasis.
\end{abstract}

Keywords: BPV. Cell culture. Epithelial-mesenchymal transition. Oncology. 


\section{COMISSÃO DE ÉTICA NO USO DE ANIMAIS \\ INSTITUTO BUTANTAN (CEUAIB) \\ Av. Dr. Vital Brasil, 1500, CEP 05503-900, São Paulo, SP, Brasil \\ Telefone: (55) (011) 2627-9585 - Fax: (55) (011) 2627-9505 \\ ceuaib@butantan.gov.br}

São Paulo, 27 de outubro de 2014

\section{CERTIFICADO}

Certificamos que o projeto "Estudo da ação do papilomavírus bovino (BPV) na transição epitélio-mesênquima", protocolo n. 1319/14, sob a responsabilidade de Rita de Cássia Stocco e Rodrigo Pinheiro Araldi, não envolve a criação e/ou utilização de animais pertencentes ao filo Chordata, subfilo Vertebrata, para fins de pesquisa científica.

This is to certify that the proposal "Study of bovine papillomavirus (BPV) action in the epithelial-mesenchymal transition", protocol $\mathrm{n}^{\circ}$ 1319/14, under the responsibility of Rita de Cássia Stocco and Rodrigo Pinheiro Araldi, has been reviewed by the Institute Butantan Animal Care and Use Committee, and that it does not involve breeding and/or use of animals belonging to phylum Chordata, subphylum Vertebrata, in scientific research.

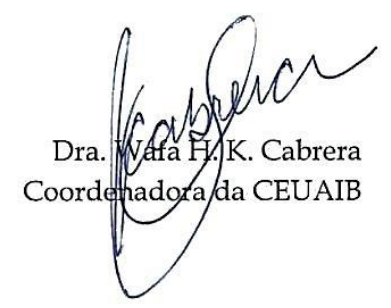




\section{Lista de llustrações}

Figura 1 - Organização do genoma de diferentes papilomavírus..........................4 41

Figura 2 - Animal com papilomatose bovina (PB) ...................................... 43

Figura 3 - Classificação morfológica dos diferentes tipos de papilomas .................43

Figura 4 - Organização dos genomas dos BPVs-1, 2 e 4 ................................ 47

Figura 5 - Organização do genoma e proteínas expressas pelo BPV ...................49

Figura 6 - Mecanismos de ativação do receptor de PDGF (PDGF $\beta R$ )....................54

Figura 7 - Ativação mitótica induzida pela fosforilação de $\mathrm{pRb}$............................59

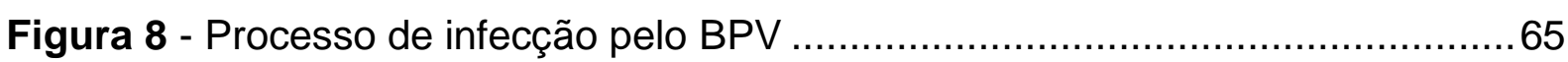

Figura 9 - Partículas de HPV em coilócitos .................................................6 66

Figura 10 - Expressão diferencial de proteínas virais ......................................68

Figura 11 - Classificação dos diferentes tipos de sarcóides equinos ......................71

Figura 12 - Identificação de sequência de BPV-2 em líquido amniótico ..................75

Figura 13 - Cinturão do câncer de esôfago da Ásia Central ................................. 82

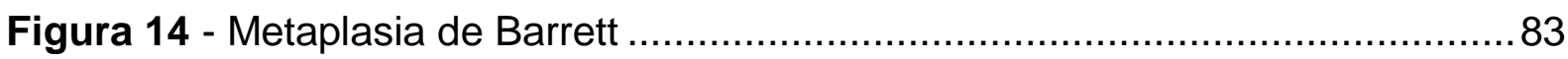

Figura 15 - Imagens de carcinoma de esôfago ('caraguatá") ............................ 86

Figura 16 - Geração do potencial de membrana mitocondrial ............................91

Figura 17 - Mutações induzidas pelo radical hidroxil ........................................93

Figura 18 - Alterações em nível de expressão verificadas na TEM .......................98

Figura 19 - Linhagens celulares de tecidos saudável e infectados pelo BPV ........110

Figura 20 - Resultado do teste de desagregação da monocamada.....................112

Figura 21 - Conversão do DCFH-DA a DCFH na presença de radicais livres .......123

Figura 22 - Classificação dos nucleóides de cometas de 0 a 2 .......................... 125

Figura 23 - Identidade da oncoproteína E6 do BPV-1 por Western blot ................132

Figura 24 - Fórmula estrutural da ciclofosfamida e da citocalasina B .................. 135

Figura 25 - Modelo esquemático da cultura de linfócitos ................................ 135

Figura 26 - Identificação de sequências de BPV nas linhagens celulares .............145

Figura 27 - Imunodetecção da proteína L1 do BPV ......................................147

Figura 28 - Níveis de expressão da proteína L1 do BPV ...............................148

Figura 29 - Elétron-micrografias das diferentes linhagens celulares .....................149

Figura 30 - Morfometria das partículas identificadas .................................... 151

Figura 31 - Avaliação do ciclo celular das diferentes linhagens celulares ..............152

Figura 32 - Percentual de células viáveis ............................................. 153 
Figura 33 - Análise do potencial de membrana mitocondrial ............................. 154

Figura 34 - Resultados do ensaio de MTT do peróxido de hidrogênio .................... 155

Figura 35 - Curva de citotoxicidade do peróxido de hidrogênio ........................... 156

Figura 36 - Níveis de produção de EROs nas diferentes linhagens celulares........ 157

Figura 37 - Evidências de estresse de retículo e macro-autofagia........................159

Figura 38 - Anisonucleose observada em células infectadas pelo BPV .................160

Figura 39 - Nucleóides observados nas diferentes linhagens celulares.................162

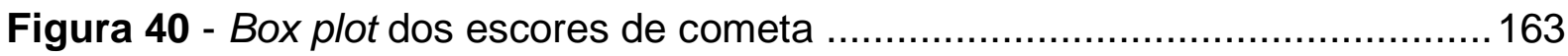

Figura 41 - Análise da influência da manipulação celular sobre a clastogênese.... 164

Figura 42 - Ensaio de oncosfera das diferentes linhages celulares ......................166

Figura 43 - Imunodetecção do fator de transcrição Oct-3/4 …............................. 168

Figura 44 - Níveis de expressão do marcador Oct-3/4 .....................................169

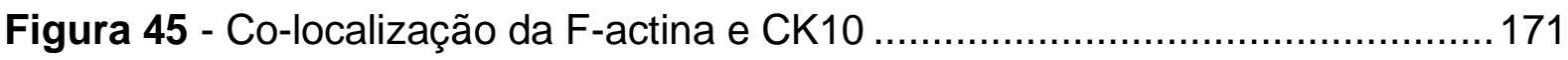

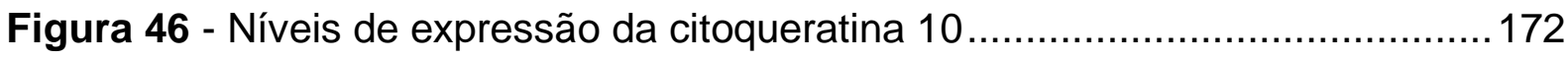

Figura 47 - Imunodetecção da glicoproteína E-caderina ....................................174

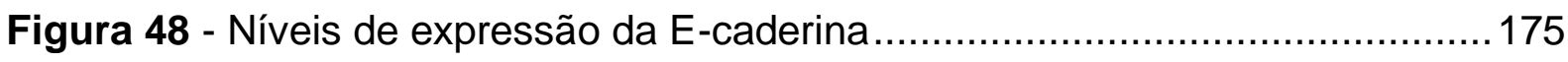

Figura 49 - Imunodeteç̧ão do fator de transcrição STAT3 ativo (Y705) ...............177

Figura 50 - Níveis de expressão do fator de transcrição STAT3 Y705 …..............178

Figura 51 - Imunodeteç̧ão do fator de transcrição SLUG ..................................180

Figura 52 - Níveis de expressão do fator de transcrição SLUG ...........................181

Figura 53 - Co-localização de F-actina e N-caderina em cultivos primários............ 183

Figura 54 - Níveis de expressão de N-caderina................................................ 184

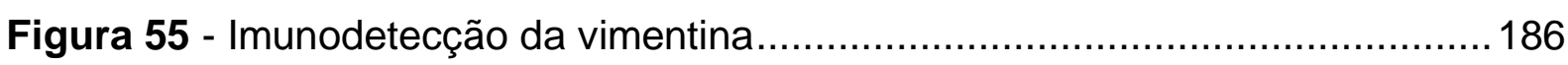

Figura 56 - Níveis de expressão do marcador mesenquimal vimentina ................. 187

Figura 57 - Imunodeteç̧ão da proteína vinculina .............................................. 188

Figura 58 - Níveis de expressão da vinculina ................................................189

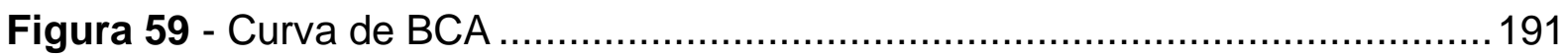

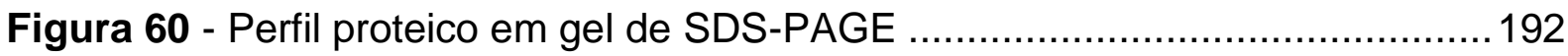

Figura 61 - Western blot usando anticorpos anti-E-caderina e N-caderina ............. 193

Figura 62 - Western blot usando anticorpos anti-STAT3 Y705 e anti-SLUG.......... 193

Figura 63 - Western blot usando anticorpos anti-vimentina e anti-vinculina............194

Figura 64 - Western blot usando anticorpos anti-CK10 ...................................194

Figura 65 - Análise morfológica das linhagens celulares ...................................196

Figura 66 - Análise morfológica por microscopia eletrônica de varredura...............197 
Figura 67 - Pontes intercitoplasmáticas observadas através da MEV .................. 198

Figura 68 - Detecção de F-actina por High-content screening .............................. 199

Figura 69 - Velocidade média de deslocamento celular ...................................201

Figura 70 - Análise histopatológica da pele saudável .......................................202

Figura 71 - Análise histopatológica das amostras de neoplasias benignas ...........203

Figura 72 - Análise histopatológica do carcinoma de esôfago bovino.....................204

Figura 73 - Hipergranulose verificada em fibropapiloma (papiloma 03) .................204

Figura 74 - Análise colorimétrica da matriz colagenosas ....................................206

Figura 75 - Imunodetecção da oncoproteína E5 do BPV em cortes histológicos ...208

Figura 76 - Imunodetecção da citoqueratina $10 \mathrm{em}$ tecido parafinado....................210

Figura 77 - Imunodeteç̧ão da Beta-catenina em tecido parafinado ......................212

Figura 78 - Imunodeteç̧ão do fator Oct-3/4 em tecido parafinado ........................214

Figura 79 - Imunodeteç̧ão do fator STAT3 Y705 em tecido parafinado ...............216

Figura 80 - Imunodeteç̧ão da N-caderina em tecido parafinado..........................218

Figura 81 - Imunodetecção da vimentina em tecido parafinado .............................220

Figura 82 - Análise da ação da oncoproteína E6 do BPV-1 no $\Delta \Psi \mathrm{m} \ldots \ldots \ldots \ldots \ldots \ldots \ldots . . . . . . . . . .221$

Figura 83 - Níveis de EROs após a adição da oncoproteína E6 de BPV-1 ............222

Figura 84 - Identificação de sequências de DNA viral em sangue periférico .........223

Figura 85 - Linfócitos binucleados com e sem alterações citogenéticas .................225

Figura 86 - Boxplot comparativo da frequência de micronúcleos .........................227

Figura 87 - Número de linfócitos mono, bi e polinucleados..................................228

Figura 88 - Célula com citocinese intercelular (neose) ….................................229

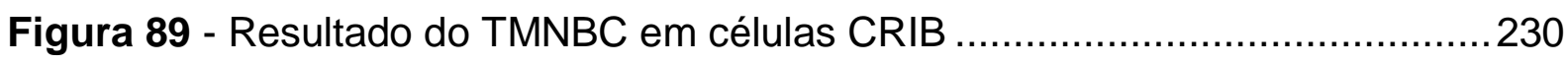

Figura 90 - Número de micronúcleos verificados em células CRIB .....................2230

Figura 91 - Análise do potencial clastogênico da oncoproteína E6 do BPV ...........232

Figura 92 - Boxplot comparativo entre os escores de cometa .............................233

Figura 93 - Transferência genética horizontal em pontes intercitoplasmáticas ......237

Figura 94 - Vírions de BPV e HPV visualizados por meio de MET ......................239

Figura 95 - Efeitos da oncoproteína E6 do BPV/HPV na produção de EROs ........246

Figura 96 - Formação de vesículas autofágicas ................................................249

Figura 97 - Modelo do potencial mutagênico do BPV .......................................2 258

Figura 98 - Junção de aderência mediada pela E-caderina..................................264

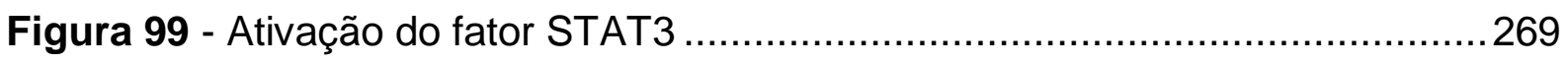

Figura 100 - Cariomegalia verificada por microscopia eletrônica...........................274 
Figura 101 - Modelo esquemático da formação de protusões celulares ................276

Figura 102 - Evolução das alterações celulares em função da duração da lesão.. 289 


\section{Lista de Tabelas}

Tabela 1 - Papilomavírus descritos em vertebrados 39

Tabela 2 - Interação da E6 com domínios PDZ de diferentes proteínas celulares ...56

Tabela 3 - Resumo das principais funções das proteínas late e early do BPV. 61

Tabela 4 - Resumo das funções das oncoproteínas do BPV 62

Tabela 5 - Evidências da participação do HPV no carcinoma de esôfago. .85

Tabela 6 - Resultados prévios empregando culturas de células 100

Tabela 7 - Sequência dos primers empregados na identificação do BPV 115

Tabela 8 - Anticorpos empregados na análise de TEM 127

Tabela 9 - Diluição dos anticorpos empregados no Western blot 129

Tabela 10 - Sequência dos primers empregados na identificação do BPV 134

Tabela 11 - Diluição dos anticorpos primários usados na IHQ. 141

Tabela 12 - Quantificação do DNA extraído 144

Tabela 13 - Sequências de BPV identificadas 146

Tabela 14 - Análise morfométrica das partículas observadas através da MET .....150

Tabela 15 - Percentual de células nas diferentes fase do ciclo celular ..................152

Tabela 16 - Análise de viabilidade celular através do ensaio de MTT. 155

Tabela 17 - Níveis de clastogenicidade das diferentes linhagens celulares 161

Tabela 18 - Resultados do teste post hoc de Dunn 162

Tabela 19 - Análise comparativa dos valores de escores 163

Tabela 20 - Curva de BCA $(\mu \mathrm{g} / \mathrm{mL})$. 190

Tabela 21 - Dosagem de proteínas extraídas dos diferentes cultivos primários .....190

Tabela 22 - Resultados do teste de Tukey 200

Tabela 23 - Quantificação das fibras de colágeno 207

Tabela 24 - Resultados do TMNBC em sangue periférico 224

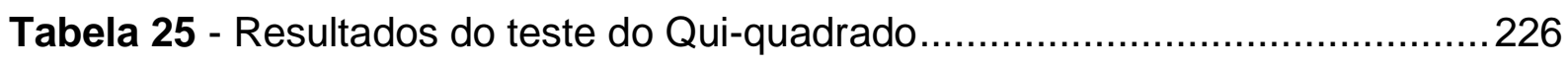

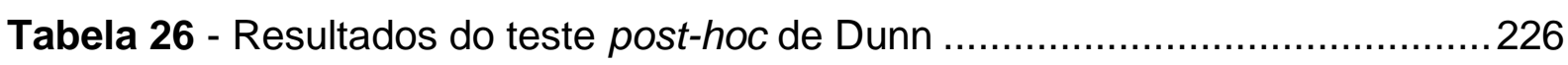

Tabela 27 - Resultados do teste post-hoc de Student Newman-Keuls..................227

Tabela 28 - Resultados do teste post-hoc de Dunn .............................................228

Tabela 29 - Análise do potencial clastogênico da oncoproteína E6 do BPV ..........231

Tabela 30 - Resultados estatísticos do teste post-hoc de Dunn............................233

Tabela 31 - Diferenças estatísticas entre os diferentes grupos ............................233

Tabela 32 - Evidências de infecção produtiva em sistemas in vitro........................240 


\section{Lista de Abreviaturas e Siglas}

a-SMA - alpha smooth-muscle actin (actina alfa de músculo liso)

A - Ampere

Acetil-CoA - acetil coenzima A

ADP - adenosina difosfato

AMP - adenosina monofosfato

AP-1 - proteína adaptadora de clatrina

ASO4 - 3-O-deacilato-44-monofosforil lipídeo A

Atg6 - autophage-related protein (proteína relacionada a autofagia)

ATP - adenosina trifosfato

BCA - ácido bicinconínico

BPV - papilomavírus bovino

Brd4 - proteína bromodomínio 4

C - citosina

CCEAC - Cinturão do Câncer Esofágico da Ásia Central

$\mathrm{CD}$ - cluster differentiation

Cdk - ciclina dependente de cinase

CD49f - cluster differentiation $49 f$ (integrina alfa 6)

CE - carcinoma de esôfago

CF - citometria de fluxo

$\mathrm{CISH}$ - chromogenic in situ hybridization (hibridização in situ cromogênica)

CK - citoqueratina

cm - centímetro 
CmPV-1 - Chelonia mydas papilomavírus tipo 1

COX - ciclooxigenase

CRPV-1 - Cotton rabbit papilomavírus tipo 1

CTC - células-tronco cancerígenas

DAB - 3,3-diaminobenzidina

DAPI - 4',6'-diamidino-2-fenilindol

DCFH - 2,7-diclorofluorescepina

DCFH-DA - diacetato de dicloro-diidro-fluoresceína

DCNT - doenças crônicas não transmissíveis

DENV - vírus da dengue

DMSO - dimetilsulfóxico

DNA - ácido desoxirribonucleico

DNMT1 - DNA metiltransferase

DSBs - double strand breaks (quebras duplas no DNA)

E - proteínas precoces (early)

EBV - Epstein-Barr vírus

E-caderina - caderina epitelial

E2BSs - E2 binding sites (sítios de ligação de E2)

E2F - fator de transcrição

E6AP - proteína ubiquitina ligase

EGF - epidermal growth fator (fator de crescimento epidermal)

EROs - espécies reativas de oxigênio

FADH - dinucleotídeo de adenina e flavina 
FBP1 - frutose-1,6-bifosfato 1

FGF - fibroblastic growth fator (fator de crescimento fibroblástico)

FOXM1 - fator de transcrição Foxhead box M1

5-FU - 5-fluouracil

G - guanina

g - grama

G1 - gap 1 (primeira fase da intérfase)

$\mathrm{Y}-\mathrm{H} 2 \mathrm{AX}$ - histona

HBV - vírus da hepatite B

HCV - vírus da hepatite C

HEB - hematúria enzoótica bovina

HIF - fator induzível de hipóxia

HPV - papilomavírus humano

HSV - vírus herpes simplex

HTLV - vírus da leucemia T humana

HUGO - Human Genome Organization

IBGE - Instituto Brasileiro de Geografia e Estatística

IARC - International Agency on Research in Cancer

IF - imunofluorescência

$\lg$ - imunoglobulina

IHQ-P - imunoistoquímica em tecido parafinado

IL - interleucina

INCA - Instituto Nacional de Câncer 
IPBC - índice de proliferação de bloqueio de citocinese

JNK - cinase c-Jun N-terminal

$\mathrm{Kb}-$ kilo base

kDa - kilo Dalton

KSHV - vírus do sarcoma de Kaposi

$\mathrm{kV}$ - kilo Volts

L- proteínas tardias (late)

LCR - long control region

LDH - lactato desidrogenase

LMA - low melting point agarose (agarose de baixo ponto de fusão)

MAM - membranas associadas a mitocôndria

MAPK - mitogen-activated protein kinase (proteína cinase ativadora de mitose)

MCT - receptores monocarboxilato

MEC - matriz extracelular

MET - microscopia eletrônica de transmissão

MEV - microscopia eletrônica de varredura

MHC - complexo principal de histocompatibilidade

min - minuto

$\mathrm{mL}-$ mililitro

mm - milímetro

$\mathrm{mM}$ - milimolar

MMP - metaloproteinase

MN - micronúcleo 
$\mathrm{MN}_{\mathrm{r} 0}$ - frequência de formação de micronúcleos

MTT - brometo de 3-(4,5-dimetiltiazol-2-yl)-2,5-difeniltetrazólio

$\mathrm{NADH}_{2}$ - dinucleotídeo de nicotina e adenina

$\mathrm{N}$-caderina - caderina neuronal

NCR - non-coding region (região não codificante)

ng - nanograma

NGS - next generation sequencing

$\mathrm{NIH}$ - National Institute of Health

NK - células natural killer

NMA - normal melting agarose (agarose de ponto normal de fusão)

nm - nanômetros

ORF - open reading frama (quadro aberto de leitura)

Ori - origem de replicação

PA - ponte anafásica

PB - papilomatose bovina

PBMC - peripheral blood mononuclear cells (células mononucleadas de sangue periférico)

$\mathrm{pb}$ - pares de base

PCR-RFLP - PCR Restriction Fragment Lengh Polymorphism (polimorfismo no comprimento do fragmento de restrição)

PDGF - platelet-derived growth fator (fator de crescimento derivado de plaquetas)

PDGF $\beta R$ - platelet-derived growth factor receptor beta (receptor beta do fator de crescimento derivado de plaquetas)

$\mathrm{PDH}$ - piruvato desidrogenase 
PHA - fitohemaglutinina A

$\mathrm{Pi}$ - fosfato inorgânico

PI3K - fosfatidilinositol-3-cinase

PPTs - poros de permeabilidade transitória

pRb - proteína retinoblastosma

PV - papilomavírus

qRT-PCR - reação da polimerase em cadeia em tempo real

RCA - Roling circle amplification

$\mathrm{RE}$ - retículo endoplasmático

RPA - replication protein A (proteína de replicação A)

RSV - vírus do sarcoma de Rous

SDS - sodium dodecyl sulfate (dodecil sulfato de sódio)

SDS-PAGE - sodium dodecyl sulfate-polyacrylamide gel (gel de acrilamida-dodecil sulfato de sódio)

SFB - soro fetal bovino

$\mathrm{S} 1 \mathrm{R}$ - receptor sigma 1

S - fase de síntese interfásica

SSBs - simple strand breaks (quebras simples no DNA)

TEM - transição epitélio-mesênquima

TGF $\beta$ - transforming growth factor $\beta$ (fator beta transformante de crescimento)

Th1 - linfócitos T helper (auxiliadores)

TLR - receptor Toll-like

TMB - 3,3,5,5-tetrametilbenzidina 
TMNBC - teste do micronúcleo com bloqueio de citocinese

URR - upstrem regulatory region (região regulatória a montante)

V - Volts

VEGF - vascular endotelial growth fator (fator de crescimento vascular endotelial)

VLP - vírus-like particles (partículas semelhantes a vírus)

W- Watts 


\section{Sumário}

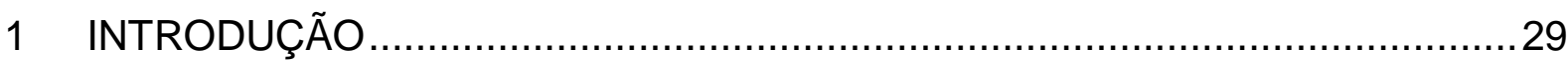

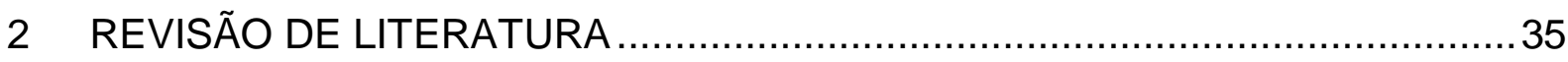

2.1 A participação de agentes infecciosos no processo oncogênico......................36

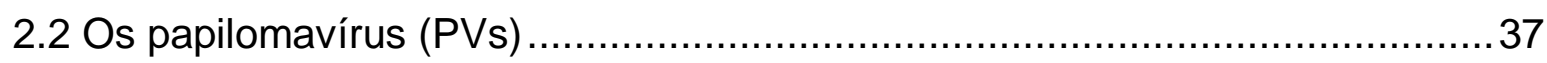

2.3 A história evolutiva dos papilomavírus ........................................................ 40

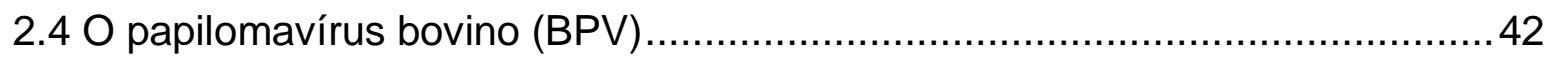

2.4.1 Aspectos clínicos e impactos econômicos da infecção pelo BPV .............. 42

2.4.2 Possíveis intervenções profiláticas e terapêuticas contra o BPV ................44

2.4.3 Aspectos genéticos e morfológicos do BPV ..........................................46

2.4.4 Proteínas expressas pelo BPV .............................................................. 49

2.4.4.1 Proteínas de replicação (E - early) .................................................. 49

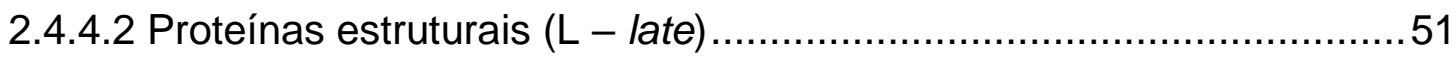

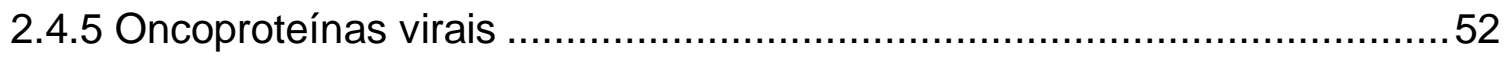

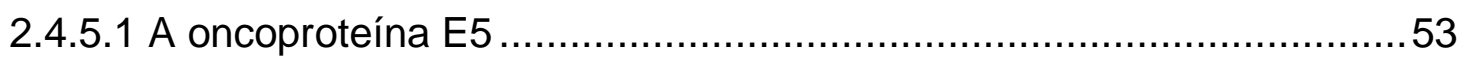

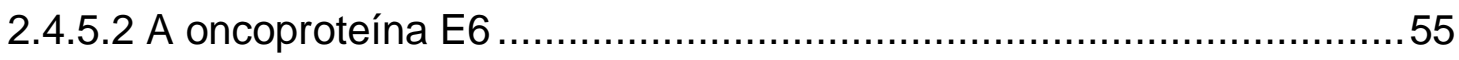

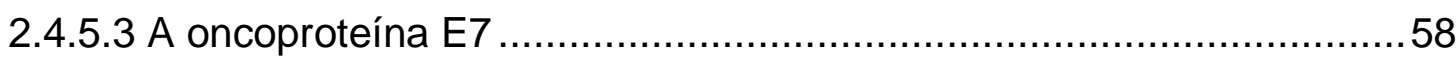

2.4.6 As vias de infecção pelo BPV e sua manifestação histopatológica ..........63

2.5 Sarcóide equino: um exemplo do fibrotropismo do BPV ................................68

2.6 Presença de BPV em sangue periférico …….........................................73

2.7 Métodos de identificação e tipagem de BPV .............................................76

2.8 O BPV como modelo de estudo do HPV ..................................................78

2.9 Neoplasias malignas associadas aos papilomavírus .................................79

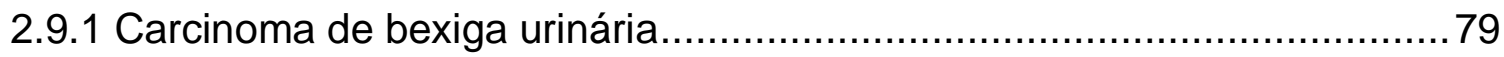

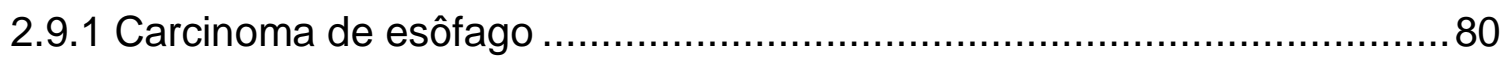

2.10 A história natural das neoplasias malignas .............................................. 87 
2.11 Alterações metabólicas após a iniciação neoplásica .90

2.12 A transição epitélio-mesênquima e a aquisição do fenótipo invasivo .95

$2.13 \mathrm{~A}$ busca por modelos in vitro que recapitulem a história natural dos PVs .....99

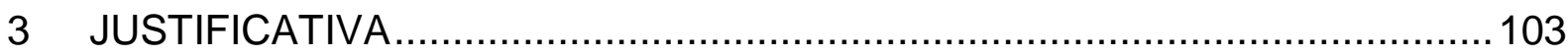

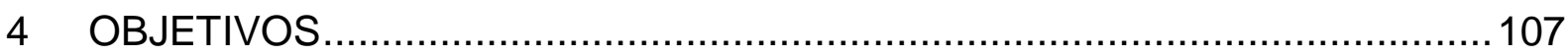

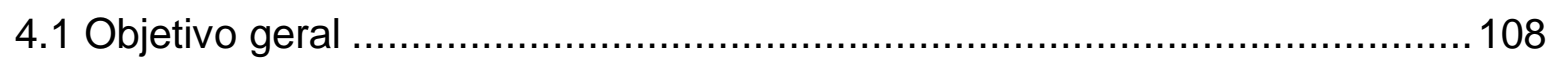

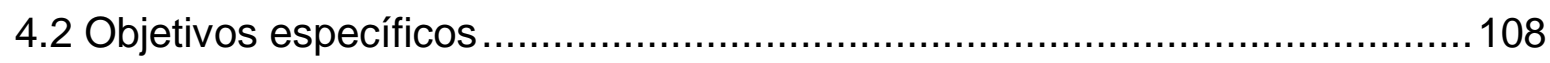

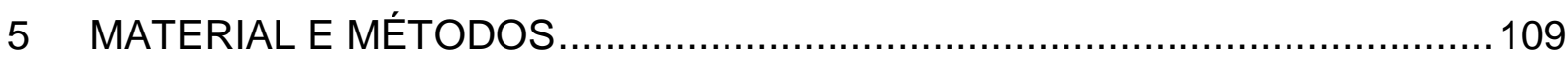

5.1 Análise das linhagens celulares como modelo de estudo da TEM ................110

5.1.1 Caracterização das linhagens celulares ................................................110

5.1.1.1 Obtenção e expansão das linhagens celulares ..............................110

5.1.1.2 Teste de viabilidade celular .................................................113

5.1.1.3 Identificação de sequências de DNA viral nas linhagens celulares .. 114

5.1.1.4 Imunodetecção da proteína L1 do BPV ......................................117

5.1.1.5 Microscopia eletrônica de transmissão (MET) ………………......119

5.1.1.6 Análise da cinética de divisão (ciclo celular) in vitro.........................120

5.1.2 Avaliação do metabolismo energético …………………………........121

5.1.2.1 Análise do potencial de membrana mitocondrial $(\Delta \psi \mathrm{m}) \ldots \ldots \ldots \ldots \ldots \ldots . . .121$

5.1.2.2 Análise da produção de espécies reativas de oxigênio (EROs) .......122

5.1.3 Avaliação de danos genéticos na cromatina hospedeira .......................124

5.1.4 Avaliação do potencial de desdiferenciação ..........................................126

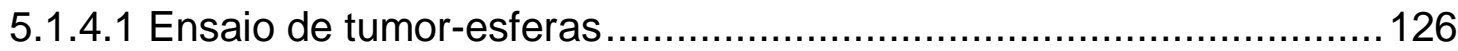

5.1.4.2 Imunodetecção do fator de transcição Oct-3/4..............................127

5.1.5 Análise dos níveis de expressão de marcadores associados a TEM .....127

5.1.5.1 Análise da especificidade dos anticorpos por Western blot..............128

5.1.6 Análises morfológicas e aquisição de fenótipo migratório .......................129

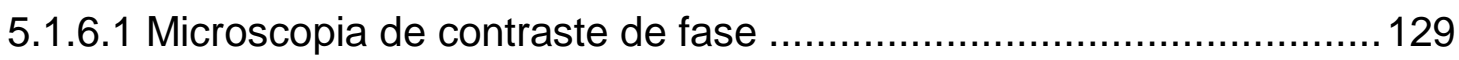


5.1.6.2 Microscopia eletrônica de varredura (MEV) 129

5.1.6.3 Identificação de F-actina por High-content screening (HCS) ............130

5.1.6.4 Video time-lapse microscopy ….............................................. 130

5.2 Estudos metabólicos e genéticos da oncoproteína E6 do BPV .....................131

5.2.1 Obtenção da oncoproteína recombinante E6 do BPV-1 …....................131

5.2.2 Efeitos da oncoproteína E6 do BPV sob o metabolismo celular .............132

5.2.3 Teste do micronúcleo com bloqueio de citocinese (TMNBC) .................133

5.2.3.1 Identificação de sequências de DNA viral em sangue periférico .......133

5.2.3.2 Teste do micronúcleo em sangue periférico .................................134

5.2.3.3 Teste do micronúcleo em células epiteliais ...................................137

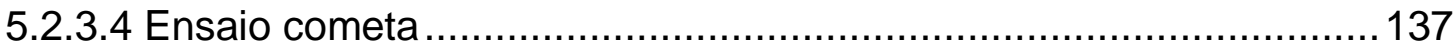

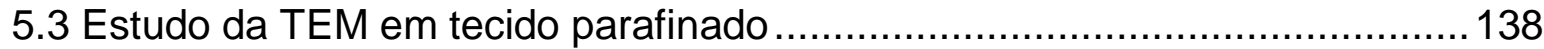

5.3.1 Análise histopatológica......................................................................... 138

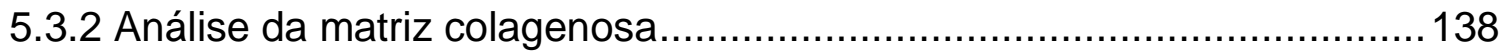

5.3.3 Imunoistoquímica em tecido parafinado (IHQ-P) ..................................139

5.3.3.1 Imunodetecção da oncoproteína E5 do BPV .................................139

5.3.3.1 Imunodetecção de marcadores da TEM .......................................140

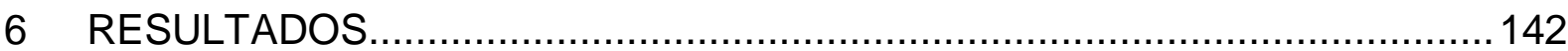

6.1 Análise das linhagens celulares como modelo de estudo da TEM ...............143

6.1.1 Evidências de infecção produtiva in vitro ...........................................143

6.1.1.1 Identificação de sequências de DNA viral .....................................143

6.1.1.2 Imunodetecção da proteína L1 do BPV ........................................146

6.1.1.3 Identificação de vírions por meio de MET ………...........................148

6.1.2 Análise do potencial proliferativo das diferentes linhagens celulares .....151

6.1.3 Análise do metabolismo celular das diferentes linhagens.......................153

6.1.3.1 Avaliação do potencial de membrana mitocondrial $(\Delta \psi \mathrm{m})$...............153

6.1.3.2 Análise da produção de espécies reativas de oxigênio (EROs) .......155 
6.1.3.3 Alterações ultra-estruturais 157

6.1.4 Níveis de clastogenicidade das diferentes linhagens celulares ..............160

6.1.5 Aquisição do fenótipo-tronco cancerígeno ……………………...........165

6.1.6 Análise do nível de expressão dos diferentes marcadores da TEM .......170

6.1.6.1 Marcadores epiteliais: Citoqueratina 10 (CK10) e E-caderina...........170

6.1.6.2 Fatores de transcrição nuclear: STAT3 e SLUG (Snail2) .................176

6.1.6.3 Marcadores mesenquimais: $\mathrm{N}$-caderina, vimentina e vinculina ........181

6.1.7 Western blot: confirmando a especificidade dos anticorpos ..................189

6.1.8 Análises morfológicas das diferentes linhagens celulares .....................195

6.1.8.1 Microscopia de contraste de fase e eletrônica de varredura (MEV) .195

6.1.8.2 Marcação de F-actina ............................................................. 198

6.1.8.3 Aquisição de fenótipo migratório: vide time-lapse microscopy .........199

6.2 Análises teciduais: validação dos resultados ...........................................201

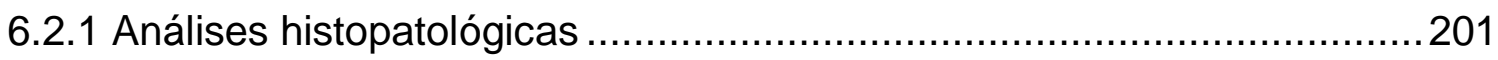

6.2.2 Análise da composição de colágeno da MEC ……..............................205

6.2.3 Análises imunoistoquímicas: validação dos resultados ............................207

6.2.3.1 Imunodetecção da oncoproteína E5 ………................................207

6.2.3.2 Imunodetecção da citoqueratina 10 ............................................209

6.2.3.3 Imunodetecção da Beta-catenina ...............................................211

6.2.3.4 Imunodetecção do fator de transcrição Oct-3/4 ….........................213

6.2.3.5 Imunodetecção do fator STAT3 Y705 ……................................214

6.2.3.6 Imunodetecção da N-caderina .................................................217

6.2.3.7 Imunodetecção da proteína mesenquimal vimentina ......................219

6.3 Estudos metabólicos e genéticos da oncoproteína E6 do BPV .....................220

6.3.1 Efeitos da oncoproteína E6 do BPV sob o metabolismo celular .............220

6.3.2 Análise do potencial mutagênico da oncoproteína E6 do BPV ................222

6.3.2.1 Teste do micronúcleo em sangue periférico ……..........................222 
6.2.2.2 Teste do micronúcleo citocinese em células epiteliais 229

6.2.2.3 Ensaio cometa em sangue periférico ............................................231

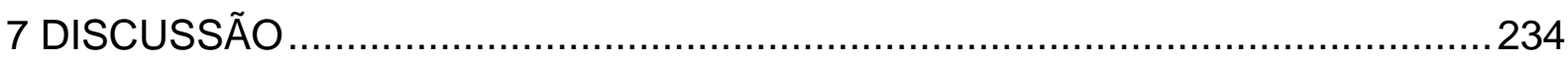

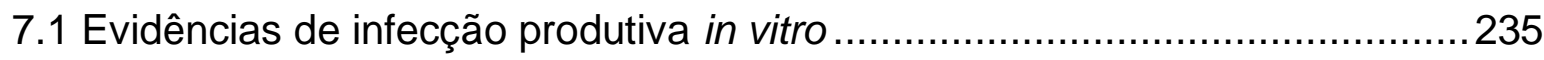

7.2 Análise do potencial proliferativo das diferentes linhagens celulares ............240

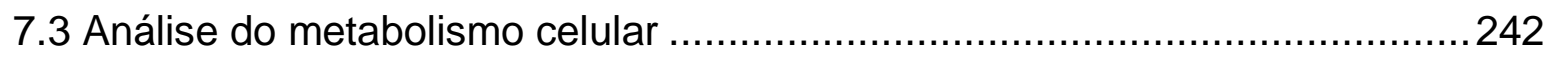

7.4 Alterações na ultra-estrutura associadas as deregulações metabólicas .......247

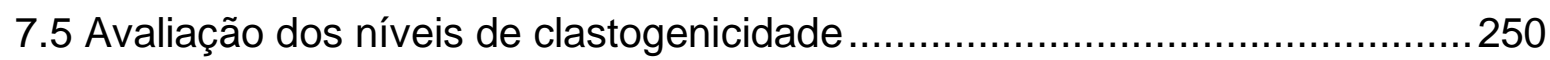

7.6 Análise do potencial mutagênico da oncoproteína E6 do BPV.....................252

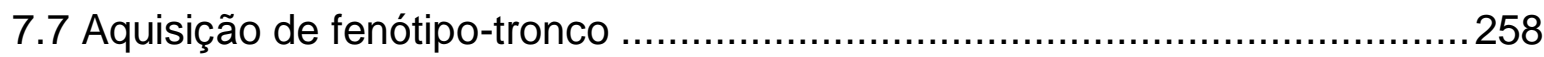

7.8 Análise do nível de expressão de marcadores associados a TEM ...............261

7.8.1 Citoqueratina 10 (CK10): Marcador epitelial ........................................261

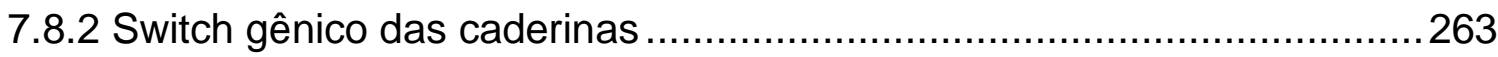

7.8.3 Fator de transcrição nuclear STAT3 Y705 ..........................................268

7.8.4 Marcadores mesenquimais: Vimentina e vinculina ..............................271

7.9 Análises morfológicas das diferentes linhagens celulares ..........................274

7.10 Análises teciduais: Demonstrando os resultados in vivo............................278

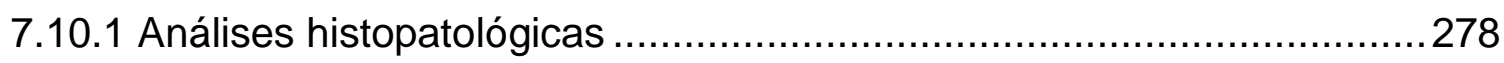

7.10.2 Análise da composição de colágeno na MEC ……….......................281

7.10.3 Imunodeteç̧ão da oncoproteína E5 do BPV .....................................281

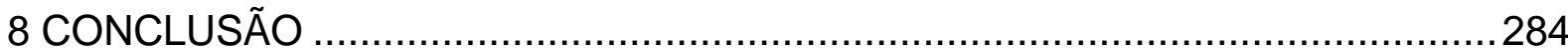

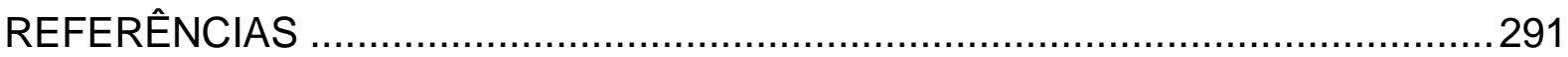

APÊNDICE 1 - Regiões de anelamento e extensão dos primers utilizados ............355

APÊNDICE 2 - Níveis de expressão de $\beta$-catenina .............................................357

APÊNDICE 3 - Velocidade de migração celular .....................................................358

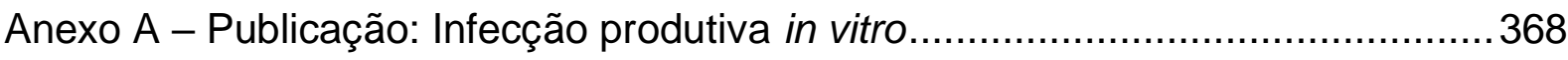

Anexo B - Publicação: Alterações metabólicas induzidas pelo BPV .......................369 
Anexo C - Publicação: potencial mutagênico da E6 …........................................370

Anexo D - Publicação: ação do BPV na metástase ............................................371

Anexo E - Revisão sistemática sobre papilomavírus .............................................372 
O papilomavírus bovino (BPV) é um pequeno vírus de DNA dupla-fita circular, com aproximadamente $8 \mathrm{~kb}$ pertencente a família Papillomaviridae (WHITE; HOWLEY, 2013). Atualmente, são conhecidos 15 tipos de BPV, os quais são classificados em quatro gêneros de acordo com a homologia de sequência da open reading frame (ORF) L1 (MUNDAY et al., 2015): Deltapapillomavirus (BPV-1, 2, 13 e 14), Epsilonpapillomavirus (BPV-5 e 8), Xipapillomavirus (BPV-3, 4, 6, 9, 10, 11 e 12) e Dyoxipapillomavirus (BPV-7) (GRINDATTO et al., 2015).

O BPV é um vírus cosmopolita, estando presente em $60 \%$ do rebanho bovino nacional (STOCCO DOS SANTOS et al., 1998), embora esse número possa ser ainda maior, já que o vírus pode ser assintomático (ARALDI et al., 2013a). A infecção pelo BPV pode resultar na papilomatose bovina (PB), doença neoplásica e infecto-contagiosa, caracterizada pela presença de múltiplos papilomas que podem regredir espontaneamente ou progredir à malignidade na presença de co-fatores (HE et al., 2016). Estes dados são preocupantes, sobretudo para o Brasil, que possui o segundo maior rebanho bovino efetivo do mundo, com aproximadamente 212,3 milhões de cabeças (IBGE, 2015). Este número faz da bovinocultura um dos principais destaques do agronegócio brasileiro, sendo um dos responsáveis pelo superávit da balança comercial de 2015, com um total de US\$300,47 milhões somente em maio deste mesmo ano (MAPA, 2015). No entanto, a partir de 1999, foi verificado o aumento da pecuária intensiva em face da expansão das lavouras de milho e soja (FERREIRA; CRESTANA, 2014), favorecendo a disseminação do BPV. Isto porque, a infecção pode se dar por meio do contato direto (animal a animal) ou indireto (por meio de superfícies ou objetos contaminados, tais como cercas, muros, cordas, bebedouros, comedouros, ordenhadeira mecânica etc.) (CUBIE, 2013; MURO; BOTTEIRA; PICCININ, 2008).

A infecção pelo BPV requer uma micro-lesão tecidual, expondo receptores proteoglicanos de sulfato de heparina presentes na membrana basal do epitélio (LJUBOJEVIC; SKERLEV, 2014). Ao se ligarem ao sulfato de heparina, os vírions sofrem uma série de alterações morfológicas, permitindo sua internalização por mecanismos de endocitose mediado por clatrina (DAY; LOWY; SCHILLER, 2003). As partículas virais são internalizadas em estruturas vacuolares que se associam a lisossomos, onde o conteúdo ácido destas organelas induzem mudanças no pK das proteínas do capsídeo (L1 e L2), promovendo a liberação do genoma viral, que permanece epissomal (DAY; LOWY; SCHILLER, 2003). Após a infecção, as 
proteínas precoces ( $\mathrm{E}$ - eraly) estimulam a divisão da célula hospedeira, garantindo um aporte de DNA polimerases à replicação viral (MOODY; LAIMINS, 2010). No entanto, de acordo com o paradigma da história natural dos papilomavírus (PVs), a expressão das proteínas tardias (L1 - late) e, portanto, a montagem de vírions somente é verificada nas camadas mais diferenciadas do epitélio (estrato granuloso e córneo) (MUNDAY, 2014b). Desta forma, a replicação e montagem dos PVs é estritamente dependente da diferenciação celular. Entretanto, nas últimas décadas, estudos têm demonstrado a presença de vírions de BPV em sítios não passíveis de diferenciação celular, como: placenta (ROPERTO et al., 2012) e sangue periférico (MELO et al., 2015; STOCCO DOS SANTOS et al., 1998). Resultados semelhantes também têm sido verificados na literatura do HPV (CHIOU et al., 2003; FORESTA et al., 2013; PESSOA, 2014).

O BPV é, ainda, considerado o melhor modelo de estudo do HPV (MUNDAY, 2014b). Isto porque estes vírus compartilham características genéticas, morfológicas e patogênicas em comum (MUNDAY, 2014b), sendo condiserados agentes etiopatogênicos do carcinoma de esôfago (CE) ( CAMPOS et al., 2013; WINKLER et al., 1985) .

O CE é a oitava malignidade humana mais frequente no mundo, sendo considerada a sexta causa mortis por neoplasia maligna (HERBSTER et al., 2012). A incidência do câncer de esôfago tem crescido nos últimos anos (JETHWA et al., 2008). Este fato requer atenção, pois o CE apresenta uma elevada mortalidade (HAN et al., 1996), a qual é 25\% superior a do câncer cervical (KAHRILAS; HIRANO, 2013).

Em humanos, O CE apresenta uma incidência variável de acordo com a região geográfica (ANTONSSON et al., 2010). Entre os países de alto risco para a doença encontram-se: China, Singapura, Iran, Suíça, África do Sul e Brasil (GUO et al., 2012; SYRJÄNEN, 2002). O Brasil registrou 10.780 casos incidentes de CE em 2014 e 7.636 óbitos pela doença em 2011 (INCA, 2014). A elevada incidência de CE na Ásia Central fez com que a região passasse a ser conhecida por Cinturão do Câncer Esofágico da Ásia Central (CCEAC) (NASROLLAHZADEH et al., 2015). Embora as razões que determinam a variação da incidência do $C E$ sejam desconhecidas (NASROLLAHZADEH et al., 2014; SYRJÄNEN, 2002), elas indicam a ação de fatores ambientais, como agentes infecciosos, na iniciação e promoção da malignidade (ANTONSSON et al., 2010). 
Poucos dados epidemiológicos acerca do CE em animais estão disponíveis, já que a doença em animais domésticos é considerada rara (TSIRIMONAKI et al., 2003). O CE em bovinos, também conhecido por caraguatá, é uma doença autolimitante, estando diretamente associada à infecção pelo BPV-4 (BORZACCHIELLO et al., 2003; MASUDA et al., 2011). Estudo recente, realizado no CCAC, mostrou uma forte associação estatística entre o CE em humanos e o contato com ruminantes, onde, por questões socioeconômicas e culturais, crianças com menos de três anos já têm contato direto com bovinos (NASROLLAHZADEH et al., 2015). Embora não esteja claro se o BPV pode ser transmitido a humanos, este dado sugere uma possível infecção cruzada. Sabe-se, ainda que na Ásia Central há um grande consumo de leite (NASROLLAHZADEH et al., 2015), produto este no qual sequências de DNA de BPV já foram identificadas (LINDSEY et al., 2009). Somados a isto, o capsídeo viral confere uma elevada resistância térmica ao vírion (MODOLO et al., 2017) que pode sobreviver à pasteurização (ZUR HAUSEN, 2012).

Desta forma, a literatura reconhece o BPV e o HPV como mutágenos associados à iniciação neoplásica (ARALDI et al., 2013a, 2015a; CALINISAN et al., 2002). No entanto, pouco se sabe acerca do papel destes vírus nas etapas subsequente a iniciação neoplásica. Neste sentido, compreender a ação destes vírus no processo oncogênico, sobretudo durante a metástase é fundamental. Isto porque, a metástase é a consequência mais dramática do câncer, sendo responsável por $90 \%$ dos óbitos tanto em humanos, como em animais (DEFAMIE; CHEPIED; MESNIL, 2014; SCHWITALLA, 2014).

A metástase corresponde a um processo de múltiplos passos, que tem início com a transição epitélio-mesênquima (TEM) (HUBER; KRAUT; BEUG, 2005). A TEM corresponde a um processo de reprogramação biológica, caracterizado por uma série de eventos nos quais células epiteliais adquirem fenótipo mesenquimal, conferindo capacidade migratória, invasiva e de resistência a anoikis ${ }^{1}$ (CICHON; RADISKY, 2014; KALLURI; WEINBERG, 2009; LEE; NELSON, 2012; HUBER; KRAUT; BEUG, 2005; RADISKY, 2005). A transdiferenciação de uma célula epitelial a mesenquimal requer alterações em diferentes níveis: bioquímico, genético e morfológico (LEE et al., 2006; LI; LI, 2015; RADISKY, 2005). Tais alterações ocorrem no sentido de promover a perda da adesão e a aquisição do fenótipo

\footnotetext{
${ }^{1}$ Anoikis - morte celular programada caracterizada pela perda de adesão da célula com a matriz extracelular (PAOLI; GIANNONI; CHIARUGI, 2013).
} 
migratório (LEE et al., 2006; LI; LI, 2015; RADISKY, 2005). Este fenótipo permite que células cancerígenas atinjam a circulação, podendo originar micro e macrometástases em órgãos distantes (DEFAMIE; CHEPIED; MESNIL, 2014; HUBER; KRAUT; BEUG, 2005).

A TEM emerge como uma resposta frente ao switching gênico da E-caderina para N-caderina (CICHON; NELSON; RADISKY, 2015; SCHWITALLA, 2014), seguido da repressão transcripcional da E-caderina por meio da ativação de fatores de transcrição nuclear como SNAIL e SLUG (YOSHIDA et al., 2009). Tais alterações levam a perda da polaridade apical-basal e a redução da interação intercelular (DEFAMIE; CHEPIED; MESNIL, 2014; THIERY, 2002). A redução dos níveis de Ecaderina ou seu sequestro nuclear resulta na translocação da $\beta$-catenina para 0 núcleo, onde esta induz a transcrição de genes associados a TEM, tais como: TWIST, SNAIL e SLUG (SCANLON et al., 2013). Durante a TEM, ao mesmo tempo em que se espera a repressão de marcadores epiteliais, é esperado um aumento dos níveis de expressão de proteínas mesenquimais, como: fibronectina, vimentina, vinculina, N-caderina, a-SMA (CICHON; RADISKY, 2014; FUKAWA et al., 2012; WANG; LI; SARKAR, 2010). Tais alterações conferem a perda de polaridade e aquisição de filopódios que conferem capacidade migratória às células epiteliais, contribuindo com a perda da homeostasia e da arquitetura tecidual (DEFAMIE; CHEPIED; MESNIL, 2014).

A TEM pode ser estimulada por diferentes sinais pleiotrópicos (RADISKY, 2005), incluindo vírus oncogênicos (RUBIN, 1985). Entretanto, as alterações no metabolismo energético têm sido apontadas como principais indutores da TEM (ARCHETTI, 2015; LU; TAN; CAI, 2015). Tais alterações estão sempre presentes em células cancerígenas, levando ao aumento da produção de espécies reativas de oxigênio (EROs) (CHEN et al., 2007). As EROs (ânion superóxido, peróxido de hidrogênio, radical hidroxil e âniom hidróxido) são produtos do metabolismo aeróbico das mitocôndrias (SCHIEBER; CHANDEL, 2014), que podem interagir com o DNA, proteínas e/ou lipídeos (BLEIER et al., 2015; FUKAWA et al., 2012), causando mutações (SCHIEBER; CHANDEL, 2014). As EROs ativam a expressão do fator de transcrição SNAIL, resultando na repressão transcripcional da E-caderina (BARRALLO-GIMENO; NIETO, 2005; LEE et al., 2006).

Compreender a ação do BPV nos mecanismos bioquímicos, genéticos e morfológicos que regulam a TEM é fundamental tanto para a compreensão do 
processo oncogênico, como para a identificação de proteínas supereguladas com valor biotecnológico para o desenvolvimento de novas terapias. Além do mais, a identificação de possíveis alvos terapêuticos apresenta importância clínica tanto para bovinos, como para humanos, dadas as semelhanças entre o BPV e o HPV. 
2 REVISÃO DE LITERATURA 


\subsection{A participação de agentes infecciosos no processo oncogênico}

A despeito dos novos métodos diagnósticos e dos avanços terapêuticos implementados nas últimas décadas na tentativa de combater o câncer, o número de pacientes que sucumbem pela doença tem aumentado globalmente (COLEMAN, 2013; VARGA; OLIVEIRA; GRETEN, 2014). Embora inicialmente considerado como uma doença de países desenvolvidos (INCA, 2011), há quatro décadas vem se observando uma maior incidência de câncer em países em desenvolvimento, incluindo o Brasil (INCA, 2016). Neste sentido, o envelhecimento da população, resultante dos avanços da medicina, criou um cenário de transição, no qual se verifica a redução das taxas de mortalidade por doenças infectocontagiosas e/ou parasitárias e um progressivo aumento do número de casos de doenças crônicas não transmissíveis (DCNT) e câncer (INCA, 2014; JEMAL; BRAY; FERLAY, 2011). Resultados semelhantes também têm sido descritos na medicina veterinária, onde é igualmente verificado um aumento da inicidência de neoplasias malignas (MISDORP, 1996), sobretudo em cães e gatos (BRØNDEN; FLAGSTAD; KRISTENSEN, 2007). Considerando que a idade ajustada da indicência de câncer entre animais e humanos é semelhante (MISDORP, 1996), a oncologia comparada tem um papel-chave no entendimento dos mecanismos moleculares da carcinogênese, permitindo identificar novos alvos terapêuticos tanto na medicina, como na veterinária (COTCHIN, 1962, 1976).

Se por um lado o aumento da incidência global de câncer é alarmante, por outro, estudos recentes mostram que $50 \%$ das malignidades poderiam ser evitadas pela redução da exposição a carcinógenos (OLIVEIRA; MÜLLER-COAN; PAGANO, 2016). Um exemplo disso é a redução da incidência de carcinoma gástrico verificado desde a década de 1930 como resultado na melhoria das condições de estocagem dos alimentos e o implemento da antibioticoterapia contra o Helicobacter pylory (SURESH, 2007).

A possibilidade das neoplasias serem ocasionadas por agentes infecciosos é discutida há séculos (GRANER, 2000). Em 1845 foi descrita pela primeira vez a transmissão de verrugas vulgares após o contágio com instrumentos cirúrgicos usados para a remoção de um condiloma (MÜNGER et al., 2004). Em 1858, Wood propôs em seu livro Practice of Medicine que o câncer poderia ser difundido como uma doença de caráter infeccioso (GRANER, 2000). Entretanto, a associação entre 
agentes infecciosos e o câncer somente foi proposta na segunda metade do século XIX por Rudolf Maier (GRANER, 2000; ZUR HAUSEN, 2009), visto que tal associação foi difícil de ser comprovada, já que o tempo entre a infecção e a malignização pode ser de 15-40 anos (ZUR HAUSEN, 2009).

Nas últimas quatro décadas, o envolvimento dos agentes infecciosos com 0 câncer tem despertado grande atenção (DAMANIA, 2016), isto porque, uma a cada cinco neoplasias malignas humanas é causada por tais agentes $(\mathrm{NCl}, 2014$; RIBEIRO-MÜLLER; MÜLLER, 2014). Dentre estes, os vírus ocupam uma posição de destaque, havendo mais de 600 diferentes vírus oncogênicos conhecidos (GREEN, 1972), sendo responsáveis por $2 / 3$ de todos os casos de câncer associados a agentes infecciosos (MUSHTAQ; DAREKAR; KASHUBA, 2016; OLIVEIRA; MÜLLER-COAN; PAGANO, 2016). Neste contexto, o HPV ocupa uma posição de destaque, sendo responsável por 27,9\% (ZUR HAUSEN, 2009) a 30,0\% de todos os casos incidentes de câncer associado a agentes infecciosos (BRAVO; SANJOSÉ; GOTTSCHLING, 2010), resultando em 250.000 óbitos/ano (LOWY, 2016).

\subsection{Os papilomavírus (PVs)}

Os PVs são pequenos vírus de DNA dupla-fita circular, capazes de infectar todos os vertebrados (GARCÍA-VALLVÉ; ALONSO; BRAVO, 2005; WHITE; HOWLEY, 2013). Estes vírus possuem genomas de 6.953 pb (CmPV-1 - Chelonia mydas papilomavírus tipo 1) a 8.607 pb (CRPV-1 - Cotton rabbit papilomavírus tipo 1) (VAN DOORSLAER, 2013). Os PVs pertencem à família Papillomaviridae (MUNDAY, 2014b), que apresenta tropismo para tecido epitelial e mucoso (HE et al., 2016; LIU et al., 2005). Atualmente, mais de 280 diferentes tipos de PVs são conhecidos (MUNDAY, 2014b), os quais são classificados em 49 gêneros de acordo com o International Committee on Virus Taxonomy (ICTV, 2014).

A classificação filogenética dos PVs é realizada com base na homologia de sequências da Open Reading Frame (ORF) L1, a mais conservada entre os diferentes sorotipos virais (ANJOS et al., 2010; BERNARD; CALLEJA-MACIAS; DUNN, 2006; DE VILLIERS, 2013; DE VILLIERS et al., 2004; MUNDAY, 2014b). Diferenças acima de 10\% na homologia de sequências da na ORF L1 determinam um novo tipo, ao passo que diferenças entre 2 e 10\%, um novo subtipo viral (DE VILLIERS et al., 2004). 
A presença de sequências de PVs já foi identificada em mais de 50 diferentes espécies, conforme tabela 1 (GOTTSCHLING et al., 2011). Entretanto, os PVs ocorrem com maior frequência em bovinos (BÖRKÜ et al., 2007; HAGA et al., 2013). A não identificação de PVs em algumas espécies é um reflexo claro da falta de esforços em estudos que visam a identificação viral, bem como resultado de métodos diagnósticos inadequados (BRAVO; SANJOSÉ; GOTTSCHLING, 2010). Isto porque os agentes infecciosos, sobretudo de etiologia viral, frequentemente desafiam a habilidade diagnóstica (MADOFF; KASPER, 2013). 
Tabela 1 - Papilomavírus descritos em vertebrados

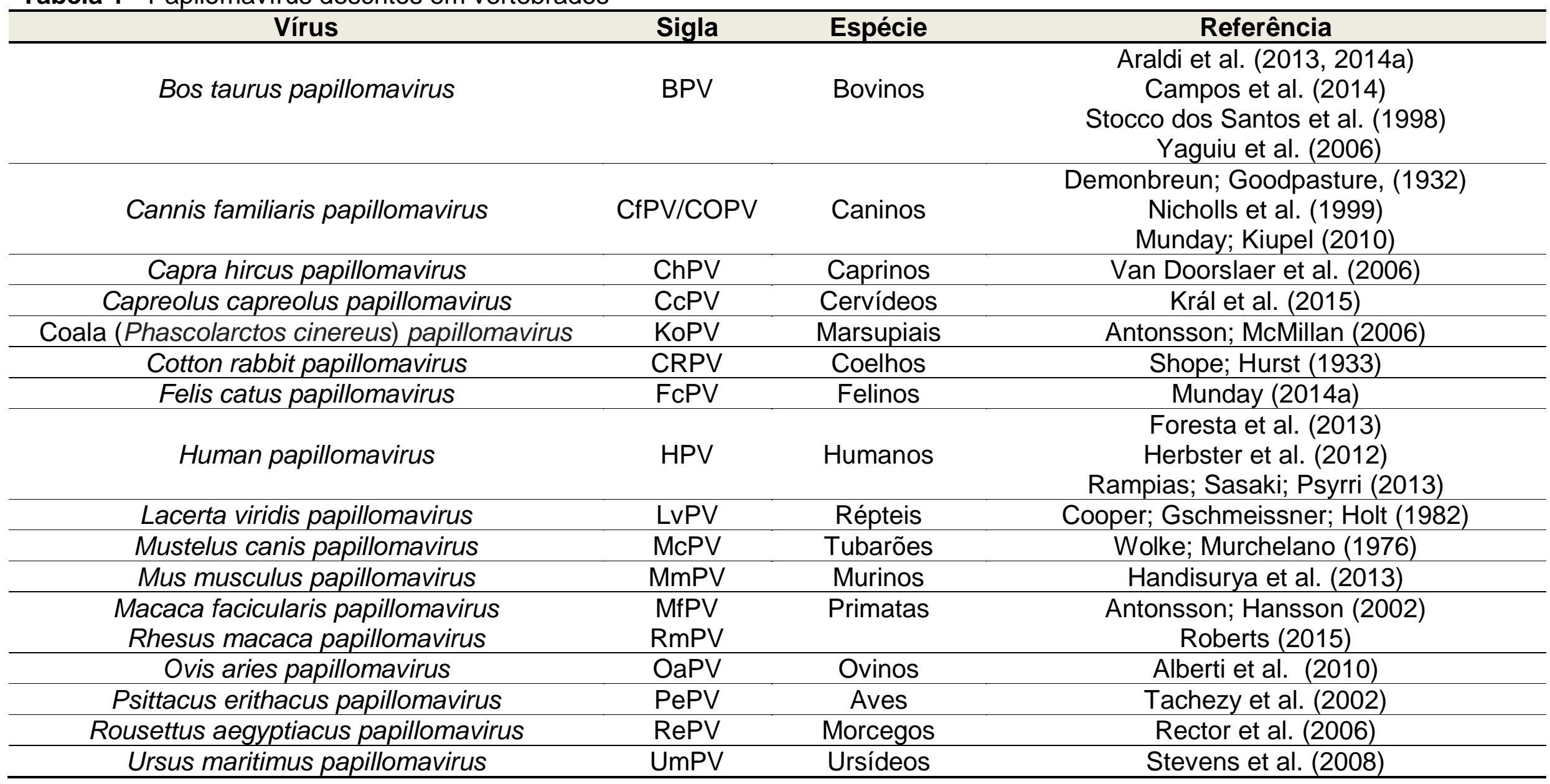




\subsection{A história evolutiva dos papilomavírus}

A origem das viroses em geral ainda permanece incerta (HOLLAND; DOMINGO, 1998). Embora a espécie originária dos PVs permaneça desconhecida (BERNARD, 1994), estudos sugerem que estes vírus teriam surgido concomitantemente com os tetrápodes na Era Paleozóica, Período Carbonífero, há 330 milhões de anos (RECTOR; VAN RANST, 2013). Desta forma, os PVs constituem uma das mais antigas e extensas famílias de vírus conhecidas (CUBIE, 2013; RECTOR; VAN RANST, 2013).

Estudos baseados em filogenia molecular sugerem que os PVs tenham se originado na África e se disseminado por todos os continentes (BERNARD, 1994). Tal disseminação não teria ocorrido de forma pandêmica, mas sim em um período de tempo superior a um milhão de anos (BERNARD, 1994).

A evolução genotípica dos PVs ocorreu de forma simultânea com a diversificação dos mamíferos, sendo direcionada por múltiplas forças evolutivas (BRAVO; SANJOSÉ; GOTTSCHLING, 2010). Entre os múltiplos passos na evolução dos PVs, encontra-se a adição de blocos de sequências previamente presentes em seus hospedeiros (GARCíA-VALLVÉ; ALONSO; BRAVO, 2005). Tal adição contribuiu significativamente com diversidade genotípica destes vírus (GARCÍAVALLVÉ; ALONSO; BRAVO, 2005). Deste modo, a co-divergência emerge como uma importante força filodinâmica na evolução dos PVs (GOTTSCHLING et al., 2011).

Estudos filogenéticos apontam que os PVs co-evoluíram com seus respectivos hospedeiros (BERNARD, 1994; VILLARREAL; DEFILIPPIS, 2000). Uma prova desta co-evolução é a presença da homologia de sequências e o conteúdo $\mathrm{G}+\mathrm{C}$ (guanina e citosina) (BLACK, 1968). Os PVs possuem de $41-49 \%$ de $\mathrm{G}+\mathrm{C}$, valor este semelhante ao de humanos, que varia de 40 a $42 \%$ (BLACK, 1968). Além do mais, sondas de hibridização cromogênica in situ (CISH) para o vírus do papiloma de Shope (CRPV) apresentam homologia com sequência do genoma de coelhos (BLACK, 1968). Outra evidência que sustenta tal co-evolução é a semelhança dos mecanismos de replicação entre os PVs e os eucariotos (LEATHERWOOD, 1998; VILLARREAL; DEFILIPPIS, 2000). Estes dados sugerem que os PVs podem ter se originado a partir de fragmentos do genoma de um ancestral comum dos amniotas (BLACK, 1968; RECTOR; VAN RANST, 2013; VAN 
DOORSLAER, 2013). Outra evidência desta hipótese é a semelhança na organização do genoma de diferentes tipos de PVs, conforme mostrado na figura 1.

Figura 1 - Organização do genoma de diferentes papilomavírus

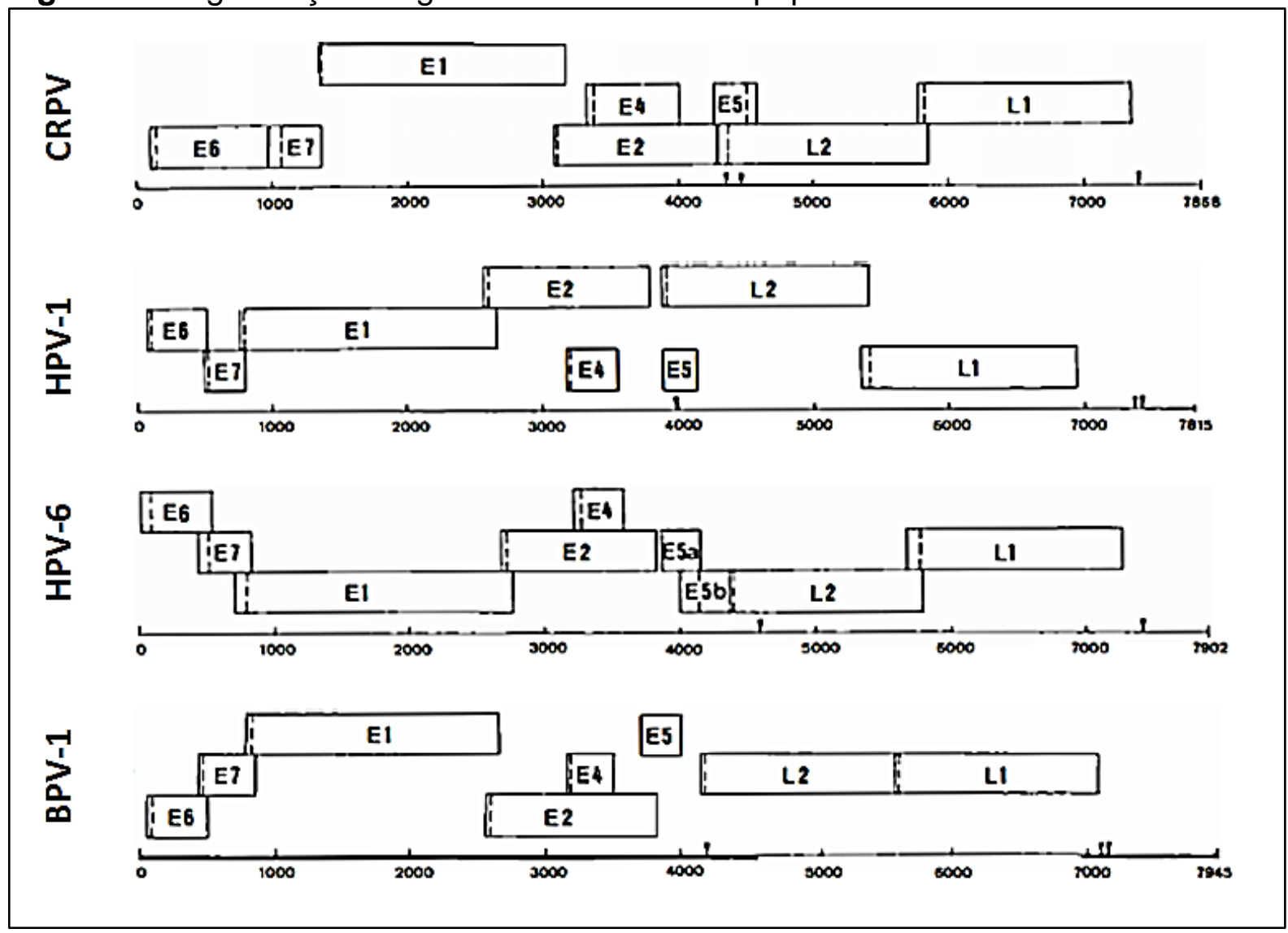

Semelhanças na organização do genoma entre o papilomavírus de Shope (CRPV), humano (HPV-1 e 6) e o BPV-1. Fonte: Modificado de Danos et al. (1985).

O aumento do contato físico da espécie humana com animais, como resultado do processo de domesticação, favoreceu a transmissão enzoótica (GOTTSCHLING et al., 2007). A transmissão interespécies requer estratégias de adaptação ao novo hospedeiro nos primeiros estágios da infecção (GOTTSCHLING et al., 2011). Neste sentido, os PVs se encontram bem adaptados aos seus respectivos hospedeiros (BERNARD, 1994).

Baseados nesse panorama evolutivo, García-Vallvé et al. (2005) desenvolveram um modelo hipotético. Este modelo propõe a existência de um protopapilomavírus, contendo a região URR-E1-E2-L2-L1, capaz de infectar amniotos primitivos. Com a divergência da linhagem dos mamíferos, há 150 milhões de anos, ocorreu a adição das ORFs E6 e E7 a este proto-papilomavírus. A interação dos PVs com seus respectivos hospedeiros tornou-se mais específica, resultando em 
uma co-evolução. Tal processo gerou a adição da ORF E5 no sítio frágil entre E2 e L2 (BRAVO; FELEZ-SANCHEZ, 2015).

Análises filogenéticas mostram, ainda, que os $\mathrm{PVs}$ adquiriram capacidade oncogênica após infectar a espécie humana (GARCÍA-VALLVÉ; ALONSO; BRAVO, 2005). Tal fato sugere que o BPV pode ter se originado a partir da transmissão do HPV para bovinos, em decorrência da domesticação destes ruminantes (GARCíAVALLVÉ; ALONSO; BRAVO, 2005).

Ao longo da evolução dos PVs, a baixa imunogenicidade, associada a mecanismos de evasão do sistema imune representam as principais vantagens evolutivas adquiridas por estes vírus (BERNARD, 1994). Tais mecanismos permitiram o estabelecimento de uma interação comensal com seus respectivos hospedeiros (BERNARD, 1994).

\subsection{0 papilomavírus bovino (BPV)}

\subsubsection{Aspectos clínicos e impactos econômicos da infecção pelo BPV}

O BPV é um vírus cosmopolita, estando presente em todos os continentes, independentemente do nível de tecnificação da exploração pecuária (CASCALES et al., 2009; HE et al., 2016). Estima-se que 60\% do rebanho bovino nacional esteja infectado com o vírus (STOCCO DOS SANTOS et al., 1998). Entretanto, este número pode ser ainda maior, já que o BPV pode ser assintomático (ARALDI et al., 2013a; SILVA et al., 2013b). A infecção pelo BPV é endêmica tanto no gado de corte como leiteiro (ARALDI, 2015; CLAUS et al., 2009). Entretanto, o BPV apresenta uma maior aptidão por este (CASCALES et al., 2009).

O BPV é o agente causador da papilomatose bovina (PB), também conhecida por "figueira" ou "verrucose" (MURO; BOTTEIRA; PICCININ, 2008), doença infectocontagiosa e neoplásica, caracterizada pela presença de múltiplos papilomas (figura 2), que podem regredir espontaneamente dentro de 20 meses ou, progredir à malignidade (CAMPO, 2002, 2006; HE et al., 2016; MONTEIRO et al., 2008; STOCCO DOS SANTOS et al., 1998; TURK et al., 2005; YAGUIU et al., 2006). 
Figura 2 - Animal com papilomatose bovina (PB)

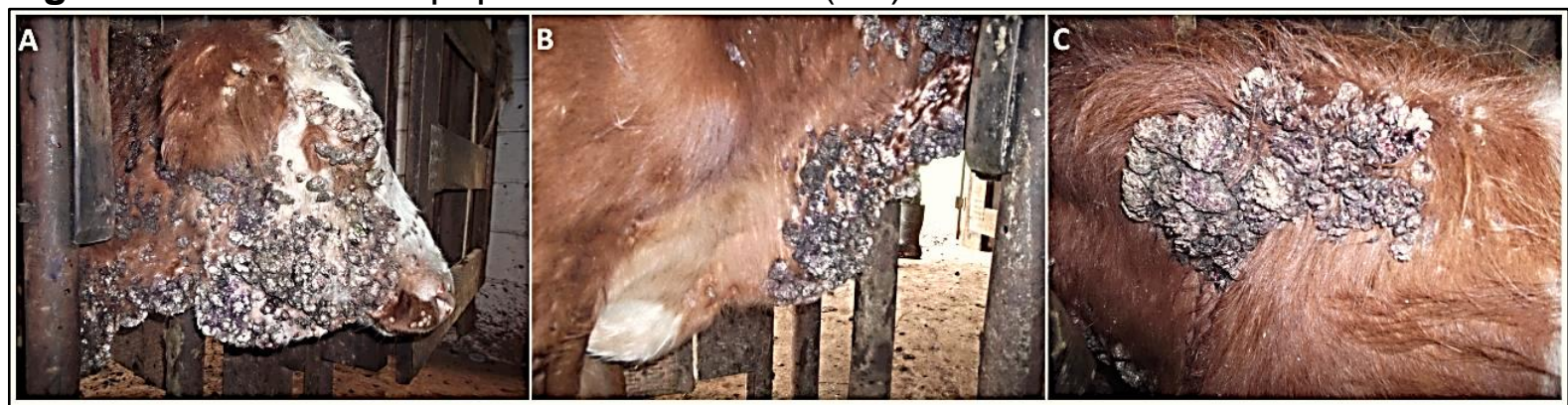

Animal jovem, com nove meses, da raça Simental, apresentando PB. São observados inúmeros papilomas na face $(A)$, região da prega ventral do pescoço $(B)$ e região dorsal $(C)$.

Os papilomas cutâneos são neoplasias proliferativas benignas de patogênese complexa (BÖRKÜ et al., 2007). Embora a PB acometa preferencialmente animais jovens, a doença pode se dar em todas as idades (BÖRKÜ et al., 2007). Os papilomas possuem predileção por áreas mais vascularizadas e sujeitas a atritos físicos (ÖZSOY; ÖZYILDIZ; GÜZEL, 2011). Os papilomas são histologicamente caracterizados pela hiperplasia do epitélio de revestimento, apresentando um alargamento das cristas interpapilares que se estendem acima da mucosa (MONTEIRO et al., 2008). Morfologicamente, os papilomas são classificados em: (1) típicos - lesões com aspecto de "couve-flor", apresentando uma base de inserção ampla ou estreita, (2) pedunculados - lesões que se destacam por apresentarem massas exofíticas conectadas ao tecido por uma base estreita, que forma um pedúnculo, (3) planos ou atípicos - massas exofíticas densas e planas, totalmente conectadas ao tecido, (4) filamentosos - apresentam uma superfície altamente queratinizada e uma implementação basal delgada, estando presentes nas mamas, (5) grão de arroz - lesão pequena que se assemelha ao formato de um grão de arroz (MONTEIRO et al., 2008). Uma representação destes diferentes morfotipos de papilomas cutâneos é apresentada na figura 3 .

Figura 3 - Classificação morfológica dos diferentes tipos de papilomas

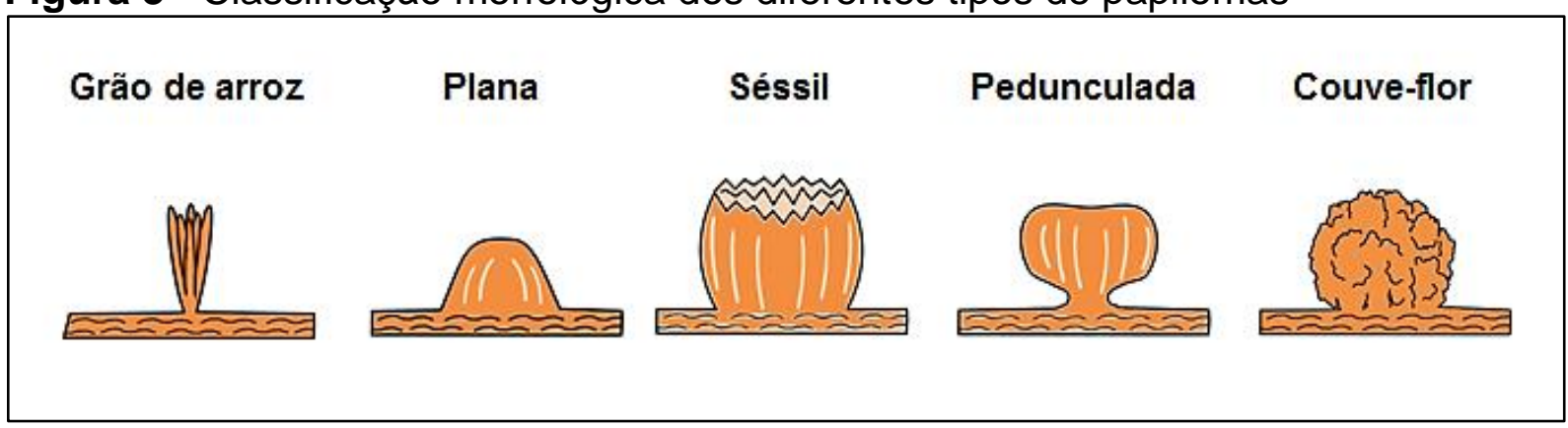


A persistência da PB pode levar a dificuldade de alimentação e respiração, requerendo a eutanásia no animal (CAMPO, 2002). Por esta razão, a doença não somente representa um problema de buiatria, mas também de ordem econômica (CAMPO, 2002; SANTOS et al., 2014). A PB também retarda o crescimento dos animais, provocando perda de peso (MUNDAY, 2014b). A doença também predispõe o animal às infecções bacterianas oportunistas (MUNDAY, 2014b), sobretudo nas tetas e úberes, o que favorece quadros de mastite, causando dor na ordenha e redução do fluxo de leite (CAMPO, 2002; MURO; BOTTEIRA; PICCININ, 2008; SANTOS et al., 2014). Os papilomas podem obstruir completamente as tetas, sobretudo em fêmeas primíparas, impedindo o fluxo do leite e a higienização (MONTEIRO et al., 2008). A PB leva, ainda, à depreciação do valor do couro (MONTEIRO et al., 2008). A busca por intervenções profiláticas e/ou terapêuticas representa um importante investimento biotecnológico, já que a intervenção medicamentosa com drogas que estimulam o sistema imune, tal como o antihelmíntico ivermectina, não apresentaram resultados satisfatórios (BÖRKÜ et al., 2007).

\subsubsection{Possíveis intervenções profiláticas e terapêuticas contra o BPV}

Atualmente há poucas formas de tratamento da PB (MURO; BOTTEIRA; PICCININ, 2008). Dentre estes métodos está à excisão cirúrgica dos papilomas seguido da cauterização (MURO; BOTTEIRA; PICCININ, 2008). Entretanto, tal método mostra-se ineficiente em rebanhos com alta incidência da doença, pois inviabiliza o procedimento cirúrgico em todo o plantel (MURO; BOTTEIRA; PICCININ, 2008). O controle de ectoparasitas também tem sido sugerido como um possível método de redução da incidência da PB. Isto porque estudo apontou que a o controle biológico de carrapatos reduz a frequência da doença (WILLIAM; KIRUBAHARAN; UTHUMANN, 1992). Outro método frequentemente empregado no tratamento da PB é a auto-hemoterapia (HAMAD; AL-BANNA; YASEEN, 2012; LETO et al., 2011; VIVAS et al., 2015). O método consiste na retirada e injeção imediata de um volume de $10 \mathrm{~mL}$ de sangue venoso por via intramuscular (LETO et al., 2011). A auto-hemoterapia induz um estímulo imunológico inespecífico que pode resultar na "queda" das verrugas (LETO et al., 2011) em um prazo médio de 44 dias (HAMAD; AL-BANNA; YASEEN, 2012). Entretanto, o método não impede o 
reaparecimento das lesões dentro de alguns meses, sendo, portanto, paliativo (LETO et al., 2011).

Neste cenário, poucas intervenções médicas propostas no último século podem se igualar aos efeitos que a imunização exerceu sobre a longevidade humana (SCHUCHAT; JACKSON, 2013). Por este motivo, a vacinação é considerada a medida de maior sucesso na prevenção, controle e erradicação de doenças de etiologia viral (RIBEIRO-MÜLLER; MÜLLER, 2014). A imunização abranda consideravelmente os aspectos clínicos da doença, reduzindo, consecutivamente, complicações decorrentes da mesma (SCHUCHAT; JACKSON, 2013). Além do mais, a imunização reduz a transmissão e disseminação do agente infeccioso (SCHUCHAT; JACKSON, 2013). Neste sentido, os programas de vacinação visam controlar, eliminar ou até mesmo erradicar uma determinada doença (SCHUCHAT; JACKSON, 2013). Embora o conceito de erradicação esteja associado à redução do número de casos a zero em uma determinada área geográfica, o termo também é usado para designar a redução da transmissão de uma doença em uma área específica (SCHUCHAT; JACKSON, 2013).

Vacinas profiláticas contra o HPV estão disponíveis no mercado desde 2006 (RIBEIRO-MÜLLER; MÜLLER, 2014). Tais vacinas são baseadas em VLPs (virus like particles) da proteína estrutural L1, já que está pode se auto-organizar em pentâmeros (MARIGLIANI et al., 2012).

Entre as vacinas disponíveis contra o HPV estão a Cervarix, produzida pela Glaxo-Smith Klein (GSK) e a Gardasil, pela Merck (RIBEIRO-MÜLLER; MÜLLER, 2014). A Cervarix é uma vacina bivalente, conferindo proteção contra o HPV-16 e 18, empregando VLPs de L1 produzidos em leveduras e sulfato de hidrofosfato de alumínio como adjuvante (RIBEIRO-MÜLLER; MÜLLER, 2014). A Gardasil é uma vacina quadrivalente, conferindo proteção contra o HPV-6, 11 (associados a verrugas genitais), 16 e 18 (alto risco), empregando VLPs de L1 produzidos em células de insetos e 3-O-deacilato-44-monofosforil lipídeo A (ASO4) como adjuvante (RIBEIRO-MÜLLER; MÜLLER, 2014). Estudos mostram que tais vacinas são bem toleradas e genotoxicamente seguras (RIBEIRO-MÜLLER; MÜLLER, 2014). Por estes motivos, mais de 30 países, incluindo o Brasil, incluíram a vacinação contra o HPV em seus programas de imunização (RIBEIRO-MÜLLER; MÜLLER, 2014).

Entretanto, tais vacinais possuem dois importantes fatores limitantes: 0 elevado custo de produção e o baixo espectro de cobertura, dada a diversidade de 
tipos de HPV (RIBEIRO-MÜLLER; MÜLLER, 2014). Desta forma, são necessárias novas plataformas vacinais que apresentem um menor custo efetivo de produção (RIBEIRO-MÜLLER; MÜLLER, 2014). Neste sentido, as plataformas baseadas em proteínas recombinantes expressas em Escherichia coli despontam como a melhor alternativa, já que apresentam um menor custo de produção (RIBEIRO-MÜLLER; MÜLLER, 2014). Além do mais, a proteína L1 apresenta uma elavada termoestabilidade sob temperatura ambiente, reduzindo os custos logísticos de transporte da vacina (SABOO et al., 2016).

Embora duas vacinas profiláticas contra o HPV estejam disponíveis no mercado (Cervarix e Gardasil), até o momento não há vacinais comerciais contra o BPV. A ideia de desenvolver uma vacina contra a PB teve início com a injeção de extrato de papilomas de Shope na década de 1940 (SHOPE, 1937). Desde então, diferentes modelos vacinais foram propostos na literatura (CAMPO et al., 1993, 1997; CHANDRACHUS et al., 1995; GAUKROGER et al., 1996; KIRNBAUER et al., 1996). Entretanto, nenhum produto vacinal contra a PB foi licenciado até o momento. Porém, os resultados obtidos até a presente data mostram que as proteínas estruturais L1 e L2 são importantes candidatos à vacinação profilática, ao passo que as proteínas precoces E6 e E7 apresentam uma ação terapêutica (CAMPO, 1997a; CAMPO et al., 1997; MAZZUCHELLI-DE-SOUZA et al., 2013).

\subsubsection{Aspectos genéticos e morfológicos do BPV}

Atualmente 15 tipos de BPVs são descritos na literatura (SILVA et al., 2016), os quais são classificados em quatro gêneros: Deltapapillomavirus (BPV-1, 2, 13 e 14), Epsilonpapillomavirus (BPV-5 e 8), Xipapillomavirus (BPV-3, 4, 6, 9, 10, 11, 12 e 15) e Dyoxipapillomavirus (BPV-7) (GRINDATTO et al., 2015). Um estudo recente baseado em Roling Circle Amplification (RCA) e Next Generation Sequencing (NGS) identificou seis novos supostos tipos de BPVs, desta forma o número de tipos de BPV pode ser ainda maior do que atualmente conhecido (DAUDT et al., 2016).

Os Delta e Epsilonpapillomavirus (BPV-5) causam papilomas e fibropapilomas, ao passo que os Xipapillomavirus, apenas papilomas verdadeiros (TOMITA et al., 2007; YUAN et al., 2007; TAN et al., 2012b). Por este motivo, alguns autores dividem os BPVs em dois subgrupos: A - associados a fibropapilomas e B a papilomas (CAMPO, 1997b). A prevalência dos diferentes tipos virais não é homogênea (SANTOS et al., 2014). Entretanto, os tipos virais 1, 2 e 4 são os mais 
frequentes (SANTOS et al., 2014), estando associados a diferentes malignidades (CAMPOS et al., 2013; STOCCO DOS SANTOS et al., 1998).

Os BPV-1 e 2 são sorotipos semelhantes (SHAFTI-KERAMAT et al., 2009), estando associados ao câncer de bexiga urinária (BALCOS et al., 2008; COSTA; MEDEIROS, 2014). Além do mais, eles compreendem os tipos virais mais prevalentes, estando presentes em $90 \%$ das amostras (GRINDATTO et al., 2015). O BPV-4 está diretamente associado a câncer do trato digestório superior, incluindo o câncer de esôfago (CE) (COSTA; MEDEIROS, 2014). Um modelo esquemático da organização do genoma dos BPV-1, 2 e 4 é mostrado na figura 4. Recentemente, estudo mostrou a presença de sequências virais, bem como de transcritos de BPV13 em amostras de tumores uroteliais de bovinos, o que permite discutir este tipo viral como oncogênico (ROPERTO et al., 2015a).

Figura 4 - Organização dos genomas dos BPVs-1, 2 e 4

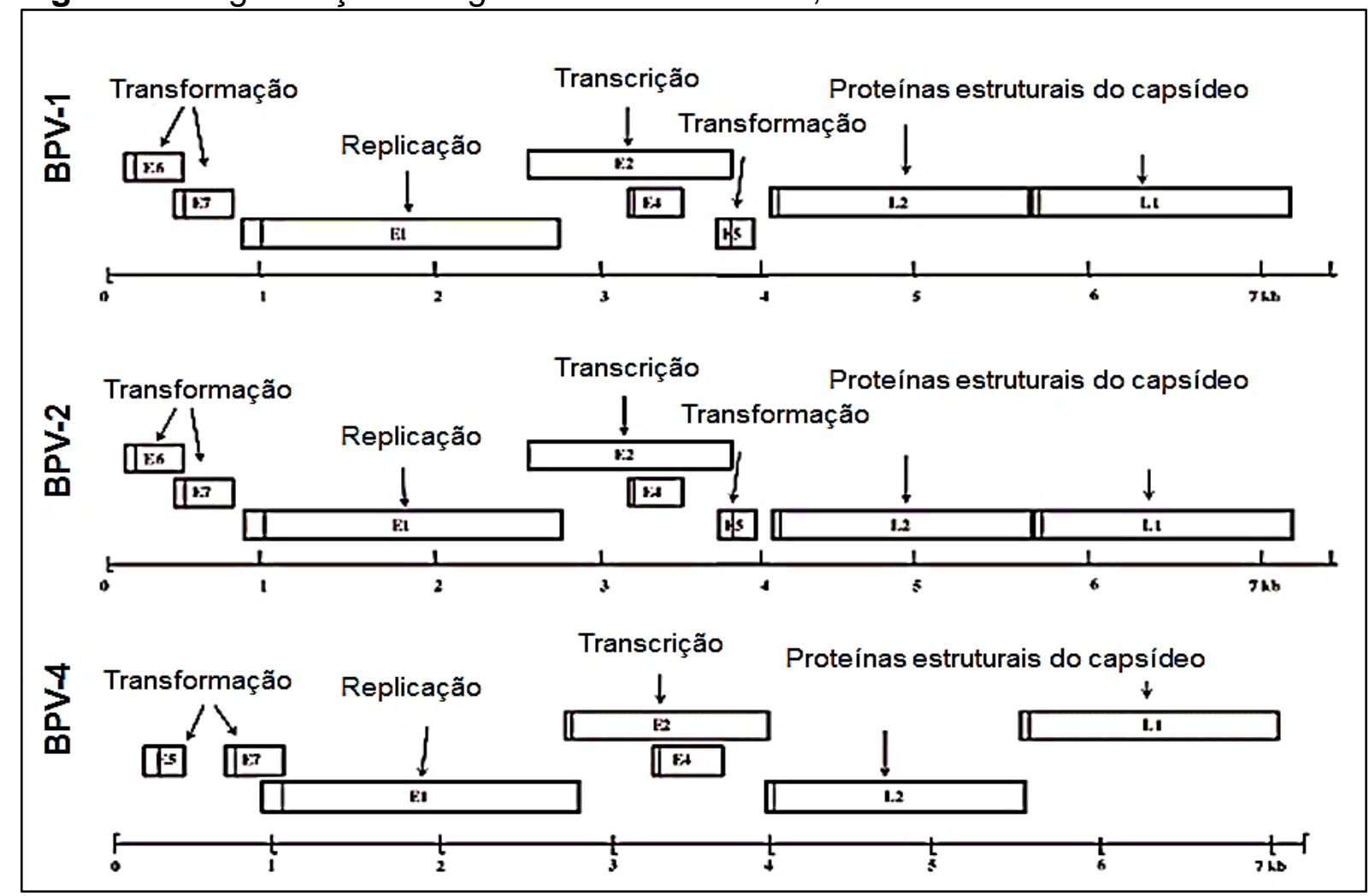

Nota-se a ausência da ORF E6 no genoma do BPV-4, sendo esta uma característica compartilhada pelos Xipapillomavirus. Fonte: Modificado de Nasir e Campo (2008).

Embora considerados espécie-específicos (DE VILLIERS et al., 2004), o BPV representa a única exceção conhecida até o presente momento. Isto porque, os BPVs-1, 2, 8 e 13 estão associados a infecções cruzadas (FREITAS et al., 2011; ZHU et al., 2014). A infecção cruzada é mais uma importante evidência evolutiva da 
co-divergência dos PVs (BRAVO; SANJOSÉ; GOTTSCHLING, 2010). Sequências de BPV já foram identificadas em búfalos (PANGTY et al., 2010; SILVESTRE et al., 2009), girafas (VAN DYK et al., 2011), tapirs (KIDNEY; BERROCAL, 2008), zebras (LÖHRDR et al., 2005; WILLIAMS et al., 2011), camelos (SCHULMAN et al., 2003), felinos (MUNDAY et al., 2015), iaque (DONG; ZHU; HAGA, 2016) e cavalos (OTTEN et al., 1993; MARTENS; DE MOOR; DUCATELLE, 2001; BOGAERT et al., 2008; MOSSERI et al., 2014).

Os vírions de PVs são morfológica e estruturalmente conservados (CAMPO, 2006), apresentando uma taxa de divergência de 1\% a cada 40-80 mil anos, número este um milhão de vezes inferior à taxa observada em vírus de RNA (VAN DOORLAER; BURK, 2010; VARSANI et al., 2006).

Os vírions do BPV apresentam um diâmetro de 45-60 nm (ARALDI et al., 2014a; CRAWFORD; CRAWFORD, 1963; LIU et al., 1997). O capsídeo viral do BPV é estruturalmente idêntico ao do HPV (LARSEN; STORGAARD; FEY, 1987), apresentando uma configuração icosaédrica (LIU et al., 1997) e um peso molecular de 56 kDa (LARSEN; STORGAARD; FEY, 1987). A ausência de envelope confere termorresistência aos PVs (FERNANDES et al., 2009). Por este motivo, o BPV pode sobreviver até 30 minutos a $80^{\circ} \mathrm{C}$ sem perder sua capacidade infectante (ZUR HAUSEN, 2012). Além do mais, devido a esta resistência térmica, o BPV é capaz de sobreviver à pasteurização do leite (ZUR HAUSEN, 2012).

O BPV apresenta um genoma de DNA dupla-fita circular que, quando distendido, possui 2,25 $\mu \mathrm{m} \pm 5 \%$ (WALDECK; RÖSL; ZENTGRAF, 1984). O DNA viral encontra-se associado a proteínas semelhantes a histonas (LETO et al., 2011). As regiões genômicas dos PVs são sobrepostas de acordo com a temporalidade da expressão proteica (GOTTSCHLING et al., 2007; LETO et al., 2011). Deste modo, o genoma viral é constituído por três regiões: early $(\mathrm{E})$, late $(\mathrm{L})$ e long control region (LCR) (BORZACCHIELLO, 2007; CHALLBERG; KELLY, 1989; LETO et al., 2011). A região $E$ codifica proteínas não estruturais com funções replicativas e regulatórias (CATROXO et al., 2013). A LCR, também conhecida por non-coding region (NCR) ou upstream regulatory region (URR) (LETO et al., 2011), ocupa 10\% do genoma, sendo a região menos conservada entre os PVs (BERNARD, 1994). Embora a região LCR não codifique nenhum polipeptídeo, ela contém a origem da replicação (ori), com 521 pb (CHALLBERG; KELLY, 1989; WALDECK; RÖSL; ZENTGRAF, 1984). A LCR possui, ainda, elementos que agem em cis, regulando os níveis de 
transcrição (CHALLBERG; KELLY, 1989). Um modelo da organização do genoma do BPV bem como da expressão temporal de suas proteínas é mostrada na figura 5.

Figura 5 - Organização do genoma e proteínas expressas pelo BPV

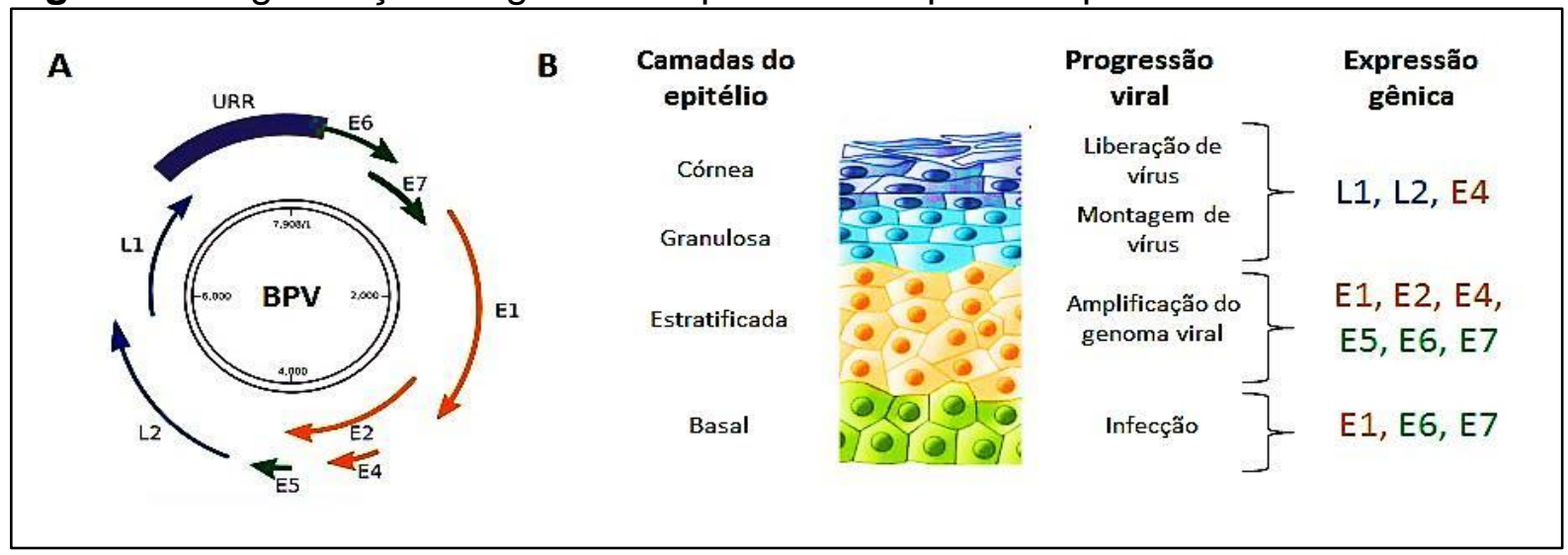

A) Modelo esquemático da organização do genoma do BPV. B) Expressão das proteínas virais de acordo com a diferenciação do tecido epitelial. Fonte: Modificado de Bravo, Féliz-Sánchez (2015).

\subsubsection{Proteínas expressas pelo BPV}

\subsubsection{Proteínas de replicação (E - early)}

As ORFs E1 e E2 são primeiramente expressas após a infecção viral, já que seus produtos gênicos são essenciais ao início da replicação (FERRARO et al., 2011). A ORF E1 representa a segunda região mais conservada entre os PVs (ENEMARK et al., 2000; FORSLUND et al., 1999). Esta ORF codifica a proteína E1, com 68 kDa, que apresenta três domínios funcionais (KARLIN et al., 1984; SEO et al., 1993). Estes domínios são: (1) domínio amino-terminal, que se liga a região motivo da Cdk2 induzindo a fosforilação desta, (2) domínio central, que se liga a proteína E2, resultando no complexo E1-E2 e (3) domínio carbóxi-terminal, que atua como helicase dependente de ATP (GARCÍA-VALLVÉ; ALONSO; BRAVO, 2005; SEDMAN; STENLUND, 1998; WALLACE; GALLOWAY, 2014). Estudos apontam que mutações na região carbóxi-terminal inibem a função helicase (SCHUCK; STENLUND, 2015). O complexo E1-E2 se liga a origem de replicação do DNA viral (ori) (ENEMARK et al., 2000; SCHUCK; STENLUND, 2015). Após esta ligação, a proteína $\mathrm{E} 1$ forma complexo di-hexamérico na ori (GAUSON et al., 2016), atraindo topoisomerase I, DNA polimerase a e RPA (replication protein A), necessários à replicação (SCHUCK; STENLUND, 2015). Desta forma, a proteína E1 apresenta função homóloga às proteínas iniciadoras de outros vírus oncogênicos como o SV40 e poliomavírus T (ENEMARK et al., 2000). De acordo com Schuck e Stenlund 
(2015), a proteína E1 é, ainda, capaz de induzir quebras simples (SSBs - simple strand breaks) e duplas (DSBs - double strand breaks) no DNA hospedeiro.

A E2 é uma proteína modular, com 48 kDa (SEO et al., 1993), composta pelos domínios: (1) carbóxi-terminal e (2) domínio de transativação amino-terminal (WALLACE; GALLOWAY, 2014). O domínio carbóxi-terminal de E2 se liga a proteína Brd4, caracterizada por apresentar dois bromodomínios (SCHWEIGER et al., 2007; SCHWEIGER; YOU; HOWLEY, 2006). Os bromodomínios interagem com resíduos de lisina de histonas acetiladas, estando envolvidos nos processos de remodelamento da cromatina (SCHWEIGER; YOU; HOWLEY, 2006), onde atuam como um super-enhancer, recrutando diferentes proteínas que participam da transcrição gênica (HELFER; YAN; YOU, 2014; JANG; SHEN; MCBRIDE, 2014). Além do mais, o complexo E2-Brd4 se liga a cromossomos mitóticos (SCHWEIGER; YOU; HOWLEY, 2006; BORZACCHIELLO; ROPERTO, 2008), garantindo uma distribuição equitativa de cópias virais às células filhas após a citocinese (CAMPO, 2006; WALLACE; GALLOWAY, 2014).

A proteína E2 atua como um importante regulador transcripcional das ORFs E6 e E7 (GARCÍA-VALLVÉ; ALONSO; BRAVO, 2005; BOGAERT et al., 2008; CAl et al., 2013; MITTAL; BANKS, 2016). Isto porque, quando presente em altos níveis de expressão, a E2 se liga a sequências palindrômicas 5 - ACCG(N) ${ }_{4} \mathrm{CGGT}$ - 3' presentes em quatro sítios de ligação de E2 (E2BSs - E2 binding sites) na LCR, incluindo no promotor P97 (CAl et al., 2013; MÜNGER et al., 2004). A ligação de E2 ao E2BS de P97 impede o reconhecimento e ligação da RNA polimerase II, reprimindo a transcrição de E6 e E7 (GARCÍA-VALLVÉ; ALONSO; BRAVO, 2005). Desta forma, a E2 é um repressor transcripcional de E6 e E7, já que ambos os genes encontram-se na mesma ORF, sendo regulados pelo promotor P97 (GARCíAVALLVÉ; ALONSO; BRAVO, 2005). No entanto, sob baixos níveis, promove o recrutamento de fatores transcripcionais, necessários para originar o complexo aberto de transcrição (HELFER; YAN; YOU, 2014; JANG; SHEN; MCBRIDE, 2014). Por regular os níveis de expressão de E6 e E7, a E2 controla o número de cópias virais (MOODY; LAIMINS, 2010).

A proteína E2 é um importante regulador epigenético, sendo capaz de interagir com o complexo p300/CBP-p/CAF (WALLACE; GALLOWAY, 2014), reconhecido como ativador global da transcrição (CHINNADURAI, 2011). Tal 
interação induz a hipoacetilação de TP53, reduzindo os níveis de expressão de p53 (WALLACE; GALLOWAY, 2014).

A ORF E4 codifica uma família de proteínas geradas por meio de splicing alternativo seguido de modificações pós-traducionais (CAMPO, 1997b). O produto gênico desta ORF representa cerca de $30 \%$ do total de proteínas expressas pelo vírus (CAMPO, 1997b). A E4 é a proteína mais expressa em papilomas (DOORBAR, 2013), sobretudo nos estágios tardios da infecção (RAMPIAS; SASAKI; PSYRRI, 2013). Tal fato justifica uma elevada imunodetecção desta proteína nas camadas suprabasal e granulosa do epitélio (RAMPIAS; SASAKI; PSYRRI, 2013). Desta forma, a proteína E4 é um importante marcador de atividade patogênica dos PVs (DOORBAR, 2013). A proteína E4 é capaz de interagir com filamentos de citoqueratina, auxiliando a replicação viral (CAMPO, 1997b). Além do mais, a proteína E4 está associada ao processo de maturação viral e remodelamento da matriz extracelular (MEC) (FERRARO et al., 2011). A proteína E4 também afeta a estabilidade dos queratinócitos, favorecendo a libreação dos vírions (MÜNGER et al., 2004).

\subsubsection{Proteínas estruturais ( $L$ - late)}

A ORF L1 é a mais conservada entre os PVs (BERNARD; CALLEJA-MACIAS; DUNN, 2006; HAGA et al., 2013). Por este motivo, ela é empregada na classificação e estudos filogenéticos destes vírus (HAGA et al., 2013). A ORF L1 codifica a proteína L1, com aproximadamente 55 kDa (RIBEIRO-MÜLLER; MÜLLER, 2014), sendo a maior proteína que compõe o capsídeo viral (BUCK; DAY; TRUS, 2013). A proteína L1 é capaz de se auto-organizar em pentâmeros, que compõem o capsídeo viral (RIBEIRO-MÜLLER; MÜLLER, 2014). A proteína L1 possui um papel chave nos mecanismos de infecção viral, garantindo a ancoragem do capsídeo nos receptores de sulfato de heparina (BUCK; DAY; TRUS, 2013). Tal ancoragem é essencial para garantir a infecção celular (FLORIN; SAPP; SPODEN, 2012). Por se tratar de uma proteína tardia, a L1 é expressa nas camadas diferenciadas do epitélio (BUCK et al., 2004). Deste modo, a imunodetecção desta proteína é considerada a principal evidência da infecção produtiva (COSTA; MEDEIROS, 2014; NASIR; REID, 1999), caracterizada pela montagem de partículas virais que resultam na morte celular (GREEN, 1972). 
A proteína L2 possui entre 64-78 kDa em análises de SDS-PAGE (WANG; RODEN, 2013). A variação de peso molecular é resultado de mudanças póstraducionais como a glicosilação (WANG; RODEN, 2013). Durante a morfogênese, a proteína L2 se liga ao DNA viral favorecendo a encapsidação bem como, auxilia na liberação de partículas virais (CAMPO, 2006; GARCÍA-VALLVÉ; ALONSO; BRAVO, 2005). A proteína $L 2$ induz, ainda, a relocalização da proteína $L 1$ para domínios subnucleares promielocíticos (BUCK et al., 2004).

Uma terceira proteína estrutural, L3, foi recentemente descrita, estando presente exclusivamente no BPV-4 (CATROXO et al., 2013). Entretanto, sua função ainda permanece desconhecida (CATROXO et al., 2013).

\subsubsection{Oncoproteínas virais}

As proteínas E5, E6 e E7 apresentam ação transformante, atuando nos primeiros estágios da carcinogênese (ANJOS et al., 2010; CHEN; LEE, 2015). Por este motivo, elas são classificadas como oncoproteínas (BOGAERT et al., 2007; CHEN et al., 1993; MOODY; LAIMINS, 2010).

A oncoproteína E5 apresenta um maior potencial transformante em relação a E6, ao passo que a E6 possui uma ação transformante mais pronunciada do que a E7 (CAMPO, 2006). Embora a oncoproteína E7 apresente o menor potencial transformante, ela possui a maior ação mitogênica dentre as oncoproteínas (CHEN et al., 1993). Estudo sugere que cada uma das oncoproteínas do BPV pode induzir transformação celular per se (SCHILLER; VASS; LOWY, 1984). Entretanto, a ação transformante da oncoproteína E6 de BPV per se não foi analisada até a presente data, sobretudo porque esta oncoproteína é de difícil obtenção. A ação sinérgica destas oncoproteínas induz uma série de alterações citogenéticas, tais como: mitose multipolar, pontes anafásicas, anomalias centroméricas e aneuploidias (DUENSING; MÜNGER, 2002; MOODY; LAIMINS, 2010). Estudos também mostram que as oncoproteínas E6 e E7 podem aumentar os níveis de expressão da DNA metiltransferase (DNMT1) (LEONARD et al., 2012), promovendo a metilação de citosina de ilhas $\mathrm{CpG}$, contribuindo para o silenciamento de genes supressores tumorais (LEONARD et al., 2012) e manutenção do fenótipo transformado (JACQUIN et al., 2013). 


\subsubsection{A oncoproteína E5}

A E5 do BPV é a oncoproteína mais bem estudada, já que seu potencial transformante é conhecido desde a década de 1960 (ROBERTS, 2015), podendo levar a transformação in vitro e in vivo (CAMPO, 2006; DIMAIO, 2014; RAMPIAS; SASAKI; PSYRRI, 2013; SILVESTRE et al., 2009). A E5 é, ainda, responsável pelo fibrotropismo, que resulta no comprometimento da derme (DIMAIO, 2014).

A oncoproteína E5 é codificada pela ORF E5, originalmente denominada E8 em HPV (GARCÍA-VALLVÉ; ALONSO; BRAVO, 2005). Porém, como análises da proteína mostram que ela apresentava homologia com a E5 dos Deltapapillomavirus, sua ORF passou a ser denominada E5 (GARCÍA-VALLVÉ; ALONSO; BRAVO, 2005). A oncoproteína E5 de BPV-1 é uma proteína transmembrana (COSTA; MEDEIROS, 2014), composta por 43-44 aminoácidos (BURKHARDT et al., 1989; DIMAIO, 2014; TOMITA et al., 2007). A E5 caracteriza-se por apresentar uma região central hidrofóbica que atua como domínio transmembrana (DIMAIO, 2014). A proteína contém, ainda, dois resíduos de cisteína em sua porção carbóxi-terminal (DIMAIO, 2014). Tais resíduos conferem estabilidade ao homodímero composto por dois monômeros de E5 (DIMAIO, 2014).

A oncoproteína E5 induz mudanças na composição e dinâmica das membranas celulares, apresentando uma ação mais pronunciada no complexo de Golgi (BALCOS et al., 2008; BORZACCHIELLO, 2007; BURKHARDT et al., 1989; GARCÍA-VALLVÉ; ALONSO; BRAVO, 2005). Por esta razão, a E5 promove alterações no tráfego de proteínas de membrana (ROBERTS, 2015). Estudos mostram que a E5 é capaz de se ligar à subunidade vacuolar da $\mathrm{H}^{+}$ATPase (BURNETT; JAREBORG; DIMAIOT, 1992), induzindo a alcalinização da membrana interna da organela (KRAWCZYK et al., 2010). Tal alcalinização promove o sequestro da cadeia pesada do complexo principal de histocompatibilidade de classe II (MHC-II), sendo este um importante mecanismo de evasão imune (VENUTI et al., 2011). Além do mais, a E5 promove a inibição transcricional de $\mathrm{MHC}$-I, bem como a redução dos níveis de expressão de cicloxigenase (COX), (BORZACCHIELLO, 2007; TOMITA et al., 2007; VENUTI et al., 2011). Estes mecanismos conferem uma baixa imunogenicidade ao vírus, permitindo quadros de infecção persistente (WILLIAMS et al., 2014). 
A oncoproteína E5 é, também, capaz de se ligar a proteína ductina, componente dos conéxons, levando a inibição das junções tipo gap e, portanto, a comunicação intercelular (CAMPO, 1997b, 2006; BORZACCHIELLO; ROPERTO, 2008). As junções tipo gap são fundamentais na homeostasia tecidual (CAMPO, 2006). Estudo aponta, ainda, que a oncoproteína E5 contribui com a perda da adesão focal, interferindo na diferenciação do epitélio (RAMPIAS; SASAKI; PSYRRI, 2013).

A oncoproteína E5 é capaz de se ligar ao receptor beta do fator de crescimento derivado de plaquetas (PDGF $\beta R$ - platelet-derived growth factor receptor beta) (figura 7) (CHAMBERS et al., 2003; COSTA; MEDEIROS, 2014; DIMAIO, 2014). O PDGFßR é um receptor tirosino-quinase presente na superfície celular (NICOLAS et al., 2013). Em situações normais, o receptor é ativado pelo fator de crescimento derivado de plaquetas (PDGF), resultando na dimerização do mesmo (DIMAIO, 2014). Esta dimerização induz a transautofosforilação de um resíduo de tirosina, presente no domínio intracelular do receptor (DIMAIO, 2014). Este mecanismo leva à sinalização intracelular, ativando diferentes quiinases, como: A-cdk2, MAPK, JNK, PI3K e c-Src (BORZACCHIELLO, 2007; CHAMBERS et al., 2003). Tais moléculas induzem a proliferação celular (DIMAIO, 2014).

$\mathrm{Na}$ presença do papilomavírus, dímeros da oncoproteína E5 formam complexo com o domínio transmembrana de PDGF $\beta R$, resultando na dimerização e ativação do receptor (figura 6) (DIMAIO, 2014; ROPERTO et al., 2012).

Figura 6 - Mecanismos de ativação do receptor de PDGF (PDGFßR)

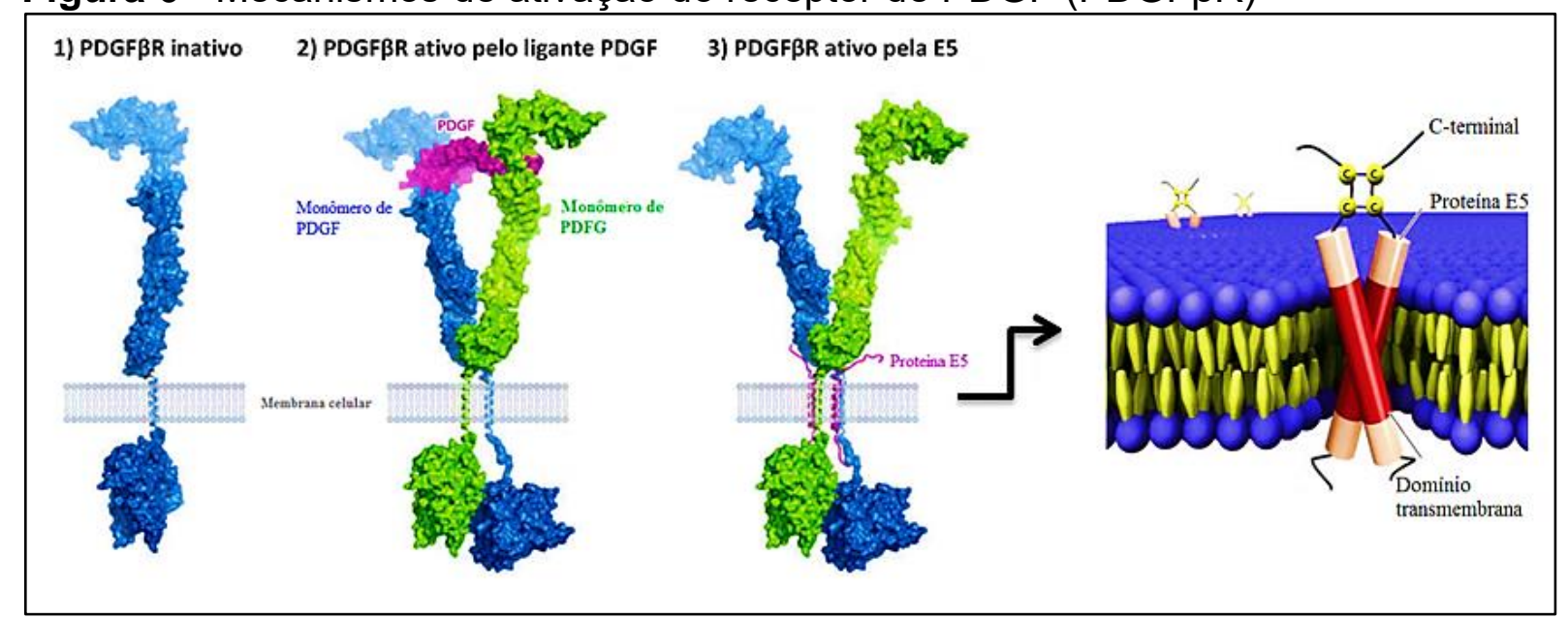

1) monômero de PDGF $\beta R$ inativo. 2) ligação do ligante PDGF ao seu receptor (PDGF $\beta R$ ), resultando na dimerização e ativação deste. 3) ligação de dímeros da oncoproteína E5 ao domínio transmembrana de PDGFßR, induzindo a dimerização e ativação deste. Fonte: DiMaio (2014). 
A ligação da oncoproteína E5 ao PDGFßR leva a ativação de fosfatidilinositol3-cinase (PI3K), que ativa a via de AKT (COSTA; MEDEIROS, 2014). Tal ativação induz a expressão de ciclina D3, resultando na desregulação do ciclo celular (COSTA; MEDEIROS, 2014; VENUTI et al., 2011). A ativação da via PI3K/AKT é, ainda, responsável por induzir alterações no metabolismo energético (HENNESSY et al., 2005; VIVANCO; SAWYERS, 2002), discutidas na seção 2.11.

O PDGFßR é o único receptor ativado por proteínas dos PVs (DIMAIO, 2014). Este fato indica uma interação altamente específica entre a proteína viral (E5) e a maquinaria celular hospedeira (DIMAIO, 2014). Tal especificidade de interação sustenta o modelo evolutivo hipotético, no qual se sugere que a ORF E5 tenha sido a última das ORFs a se integrar ao genoma viral (DIMAIO, 2014). Estudos mostram, ainda, que a E5 forma hexâmetros, originando canais iônicos, que são requeridos na ativação mitogênica (DIMAIO, 2014; WETHERILL et al., 2012). Este dado faz com que a E5 seja considerada uma viroporina ${ }^{2}$ (WETHERILL et al., 2012). Desta forma, a oncoproteína E5 possui caráter mitogênico, estimulando a expressão da ciclina dependente de cinase A (Cdk2), que controla o checkpoint da fase G1 para síntese (CAMPO, 2006). A ativação do PDGFßR recruta pericitos, células contráteis que mantém contato físico com células endoteliais de capilares e vênulas, estimulando a angiogênese (PIETRAS; OSTMAN, 2010).

\subsubsection{A oncoproteína E6}

A E6 corresponde a uma pequena oncoproteína, com 151-158 aminoácidos (HPV) (BOULET et al., 2007; RISTRIANI et al., 2000) ou 137 aminoácidos (BPV-1) (MAZZUCHELLI-DE-SOUZA et al., 2013; TONG et al., 1998), sem atividade enzimática conhecida (TAN et al., 2012b). A E6 dos HPVs de alto risco se caracteriza pela presença de ums região de ligação a proteínas com domínio PDZ de classe I (PSD-95/Dlg/ZO-1), presente na região carbóxi-terminal e quatro motivos evolutivamente conservados entre os PVs (Cys-X-X-Cys) (BOON et al., 2015; CHEN; HONG; ANDROPHY, 1997; NOMINÉ et al., 2006; TONG et al., 1998). Entretanto, a região não está presente em BPVs (MISCHO et al., 2013) e HPVs de alto risco (BOON et al., 2015) e em HPVs de baixo risco (BOON et al., 2015). Esta

\footnotetext{
${ }^{2}$ Grupo de proteínas com 60-120 aminoácidos que regulam a formação de vesículas citoplasmáticas, tráfego de glicoproteínas e permeabilidade de membrana, favorecendo a liberação de partículas virais (GONZALES; CARRASCO, 2003).
} 
região é capaz de se ligar a diferentes proteínas celulares, promovendo a perda de contato intercelular (BOON et al., 2015) e, portanto, favorecendo a metástase (JAMES; ROBERTS, 2016). Um resumo dos efeitos da interação do domínio PDZ da oncoproteína E6 com diferentes proteínas celulares é mostrado na tabela 2.

Tabela 2 - Interação da E6 com domínios PDZ de diferentes proteínas celulares

\begin{tabular}{|c|c|c|}
\hline Proteína & Função celular & Efeitos do PDZ da E6 \\
\hline DLG1 & $\begin{array}{l}\text { Polaridade, proliferação, divisão } \\
\text { assimétrica, migração e adesão }\end{array}$ & Degradação \\
\hline SCRIB & Polaridade, proliferação e apoptose & Degradação \\
\hline MPDZ & $\begin{array}{l}\text { Integrante da zônula de oclusão e } \\
\text { crescimento celular }\end{array}$ & Degradação \\
\hline MAG-1 & $\begin{array}{l}\text { Integrante da zônula de oclusão, } \\
\text { polaridade, proliferação, migração }\end{array}$ & Degradação \\
\hline MAG-2 & $\begin{array}{l}\text { Integrante da zônula de oclusão, } \\
\text { polaridade, receptor de tráfego } \\
\text { celular, sobrevivência }\end{array}$ & Degradação \\
\hline MAG-3 & $\begin{array}{l}\text { Polaridade, receptor de tráfego } \\
\text { celular, sobrevivência }\end{array}$ & Degradação \\
\hline TAX1BP3 & $\begin{array}{l}\text { Polaridade, motilidade e transporte } \\
\text { de íon }\end{array}$ & Formação de complexo \\
\hline GIPC1 & $\begin{array}{l}\text { Receptor de superfície, tráfego e } \\
\text { sinalização de TGF } \beta\end{array}$ & Degradação \\
\hline INADL & $\begin{array}{l}\text { Integrante da zônula de oclusão e } \\
\text { polaridade }\end{array}$ & Degradação \\
\hline DLG4 & $\begin{array}{l}\text { Receptor em neurônio, polarização } \\
\text { de célula epitelial }\end{array}$ & Degradação \\
\hline PTPN3 & $\begin{array}{l}\text { Tirosina fosfatase, regulador de } \\
\text { crescimento celular }\end{array}$ & Degradação \\
\hline GOPC & Tráfego intracelular & Degradação \\
\hline PTPN13 & $\begin{array}{lccc}\text { Fosfatase associada } & \text { a } & \text { Fas, } \\
\text { crescimento celular e apoptose } & \end{array}$ & Degradação \\
\hline SLC9A3R1 & $\begin{array}{l}\text { Ancoragem de citoesqueleto, } \\
\text { receptor ligado a proteína G }\end{array}$ & $\begin{array}{l}\text { Degradação da forma } \\
\text { forsforilada }\end{array}$ \\
\hline SDCBP2 & $\begin{array}{llr}\begin{array}{l}\text { Proliferação, } \\
\text { sinalização }\end{array} & \begin{array}{c}\text { sobrevivência } \\
\text { mediada }\end{array} & \text { e } \\
\text { fosfatidilinositol } & & \text { por }\end{array}$ & $\begin{array}{l}\text { Regulação negativa de } \\
\text { mRNA }\end{array}$ \\
\hline PARD3 & Polaridade e divisão assimétrica & $\begin{array}{l}\text { Alteração da localização } \\
\text { subcelular }\end{array}$ \\
\hline PDZRN3 & $\begin{array}{l}\text { Ubiquitina ligase E3, polaridade } \\
\text { planar }\end{array}$ & Degradação \\
\hline
\end{tabular}

Fonte: James; Roberts (2016).

Embora a oncoproteína E6 do BPV e HPV apresentem ação anti-apoptótica, os mecanismos moleculares que levam à perda de p53 são distintos entre os vírus (LIU et al., 2005). A oncoproteína E6 do HPV forma um complexo trimérico, ligando- 
se a motivos ricos em leucina (LXXL) (RAMIREZ et al., 2015) da ubiquitina ligase E6AP e a p53, por meio de seu domínio PDZ (TAN et al., 2012b; ZANIER et al., 2005, 2007). Tal complexo (E6-E6AP-p53) endereça a p53 ao proteosoma $26 \mathrm{~S}$ (CAI et al., 2013), resultando na degração proteolítica da mesma (LIU; BALEJA, 2008; ZANIER et al., 2005). A E6 do BPV-1, assim com a dos tipos virais HPV-5 e 8 (ZANIER et al., 2007), não se liga a p53, tampouco promove a degradação da proteína supressora tumoral p53 (HOWLEY, 1990; LIU et al., 2005; WERNESS; LEVINE).

A p53 é uma fosfoproteína nuclear, com 375 aminoácidos e um peso molecular de 53 kDa (CAVALCANTI-JÚNIOR; KLUMB; MAIA, 2002). A proteína foi descrita em 1979 e apresenta função de "guardiã do genoma", por monitorar a integridade do genoma e impedir a proliferação descontrolada de células com mutações (CAVALCANTI-JÚNIOR; KLUMB; MAIA, 2002; FETT-CONTE; SALLES, 2002). Isto porque a p53 age como um fator de transcrição, ativando a expressão do gene p21, cujo produto gênico é um inibidor proteico da Cdk4 (FETT-CONTE; SALLES, 2002). Desta forma, a p53 e a p21 são importantes reguladores da proliferação celular, conferindo estabilidade genômica (SHAMANNA et al., 2013).

Infecções virais, em geral, conferem um efeito estressante à célula hospedeira, que promove a superexpressão da p53 (SHAMANNA et al., 2013). Esta ação representa uma ameaça ao ciclo de replicação viral (SHAMANNA et al., 2013). Por esta razão, a seleção natural levou diferentes vírus oncogênicos a expressarem proteínas capazes de se ligar e inativar p53 (SHAMANNA et al., 2013). Entre estas proteínas estão: o antígeno T do SV40, a proteína E1B do adenovírus, a proteína HBx do vírus da hepatite B (HBV) e a E6 dos PVs (CUNINGHAME; JACKSON; ZEHBE, 2014; SHAMANNA et al., 2013).

A E6 pode se ligar a paxilina (proteína de adesão focal) (MOODY; LAIMINS, 2010; TURNER, 2000) e a subunidade gama do complexo adaptador de clatrina AP1 (TONG et al., 1998). Estas interações podem levar a alterações no citoesqueleto e no tráfego vesicular, resultando no sequestro citoplasmático de proteínas como a p53 (CHAMBERS et al., 2003). Estudo aponta, ainda, que a oncoproteína pode se ligar à fibulina 1, causando alterações na matriz extracelular (MEC) que contribuem com o fenótipo invasivo (MOODY; LAIMINS, 2010).

A oncoproteína E6 do BPV induz a transformação (LIU et al., 2002) e a imortalização celular (BOON et al., 2015), promovendo um aumento nos níveis de 
expressão das telomerases (CUNINGHAME; JACKSON; ZEHBE, 2014). Isto porque a oncoproteína E6 promove a superexpressão de FOXM1 (Foxhead box M1) (CHEN; LEE, 2015), resultando na expressão de ciclina B1, ciclina D1 e cdc25 (CHEN; LEE, 2015). Tais proteínas levam à proliferação celular (CHEN; LEE, 2015). Além do mais, FOXM1 participa da via de Wnt/ß-catenina, contribuindo com um fenótipo invasivo (CHEN; LEE, 2015). Entretanto, a transformação não é uma ação exclusiva da oncoproteína E6, posto que os BPVs do gênero Xipapillomaviusi, que não possuem a ORF E6, também apresentam elevado potencial transformante (LIU et al., 2002). Tal fato justifica o papel oncogênico do BPV-4, um representante dos Xipapillomavirus, nos cânceres do trato digestório superior (LIU et al., 2002).

A oncoproteína E6 de BPV se liga ao motivo $L X X L L$ do regulador transcricional MAML1, inibindo a via de sinalização Notch, que atua como repressora tumoral em células epiteliais (TAN et al., 2012b; WHITE; HOWLEY, 2013). Além disso, a oncoproteína inibe o sistema de reparo de SSBs, permitindo o acúmulo de mutações somáticas (LIU; BALEJA, 2008; WALLACE; GALLOWAY, 2014). Tal inibição se dá pela interação com as proteínas XRCC1 e $\mathrm{O}^{6}$-metilguanina-DNA-metiltransferase, envolvidas no reparo de SSBs (WALLACE; GALLOWAY, 2014). Estudo envolvendo a E6 de HPV mostrou que a oncoproteína é capaz de induzir a multinucleação, levando a alterações citogenéticas (WALLACE; GALLOWAY, 2014). Desta forma, a oncoproteína participa da iniciação e promoção tumoral. A E6 também pode induzir a expressão do fator de crescimento vascular endotelial (VEGF

- vascular endotelial growth fator), levando a angiogênese (LÓPEZ-OCEJO et al., 2000).

\subsubsection{A oncoproteína E7}

A oncoproteína E7 possui 127 aminoácidos zinco-ligantes (BORZACCHIELLO, 2007). Esta proteína é capaz de interagir com o motivo conservado LXCXE da proteína supressora tumoral pRb, induzindo sua fosforilação (MOODY; LAIMINS, 2010; WHITE; HOWLEY, 2013). Tal ação promove a liberação do fator de transcrição nuclear E2F, que regula as fases G1-S (LONGO, 2013). O E2F se liga ao domínio transativador, recrutando diversos modificadores da cromatina, como deacetilases de histonas (HDAC) (MOODY; LAIMINS, 2010). Desta forma, a oncoproteína E7 induz a expressão constitutiva de genes responsivos ao fator E2F, como cliclina A e E (MOODY; LAIMINS, 2010). Por este motivo, a 
expressão da oncoproteína E7 resulta na perda do checkpoint de G1/S, levando a um aumento do número de células nas fases $\mathrm{S}$ e G2/M (figura 7) (FERRARO et al., 2011; LIU; BALEJA, 2008; SACCO; SIEPI; CRESCENZI, 2003). A interação de oncoproteínas virais com a pRb não é exclusiva dos PVs, sendo também observada com proteína E1A do adenovírus e antígeno T do SV40 (WHITE et al., 2015).

Figura 7 - Ativação mitótica induzida pela fosforilação de pRb

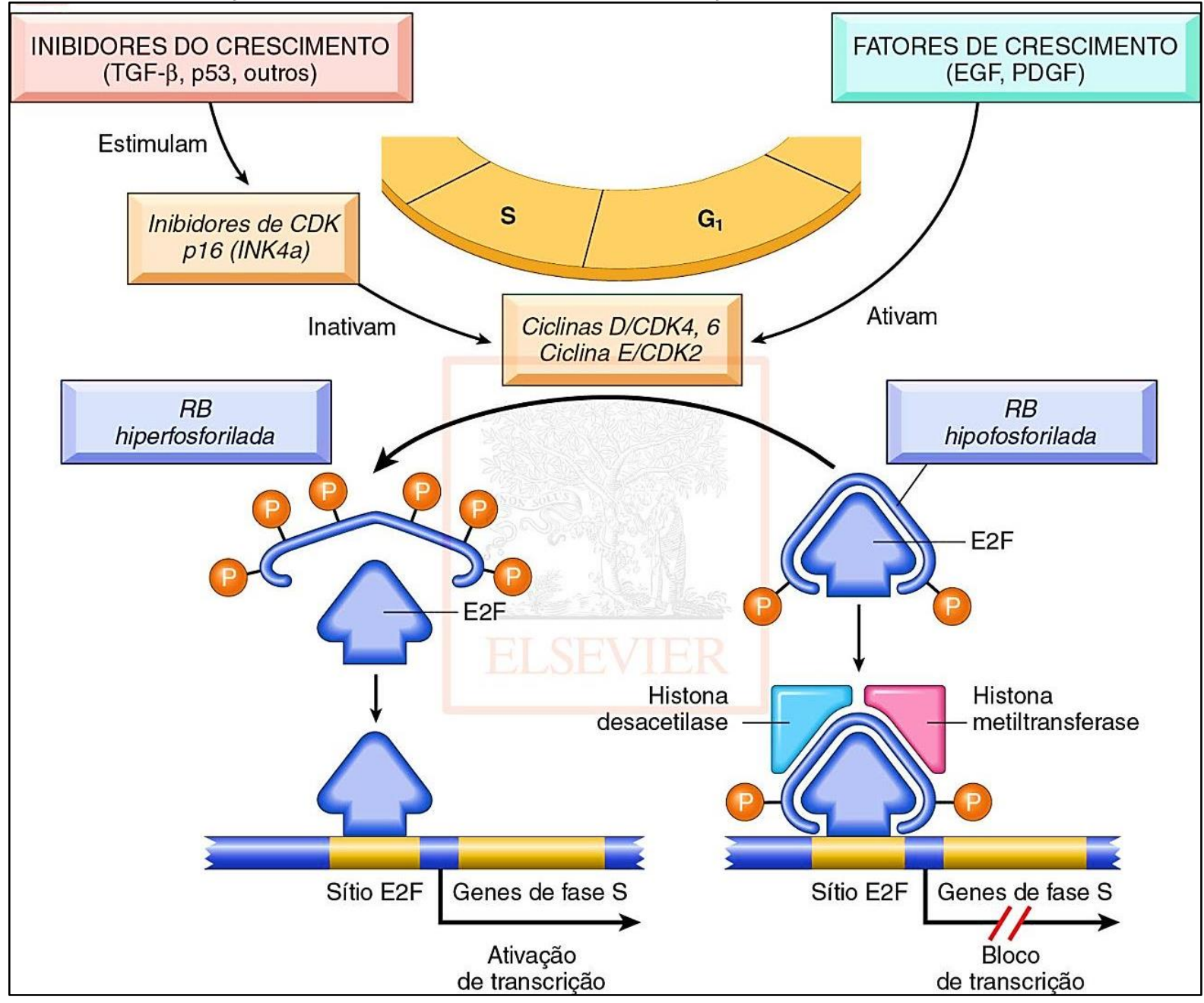

A ativação de fatores de crescimento (EGF e PDGF) induzida pela oncoproteína E5 e/ou a expressão da oncoproteína E7 do BPV levam a fosforilação da proteína retinoblastoma (pRB). Esta ação resulta na liberação do fator de transcrição nuclear E2F, que se encontra ligado a pRB quando esta se encontra hiposforilada. Tal ação promove a translocação nuclear de E2F, que se liga a regiões consenso do DNA, ativando a expressão de ciclinas que regulam o checkpoint $\mathrm{G} 1$ para S. Fonte: Kumar, Abbas e Aster (2013).

A oncoproteína E7 interage com a dineína, proteína que compõe o aparelho mitótico, induzindo alterações no alinhamento dos cromossomos, ao mesmo tempo em que favorece a reduplicação celular, levando a poliploidia (WALLACE; GALLOWAY, 2014). 
A oncoproteína E7 induz quebras no DNA (clastogênese), contribuindo para a desregulação do ciclo celular (ARALDI et al., 2013a; PARK et al., 2014). Além do mais, estudo aponta que a E7 aumenta os níveis de expressão da deacetilase Sirt1, modulando a atividade da $\mathrm{y}-\mathrm{H} 2 \mathrm{AX}$ (PARK et al., 2014). A $\mathrm{y}-\mathrm{H} 2 \mathrm{AX}$ participa do sistema de reparo, reconhecendo DSBs (CHOWDHURY et al., 2005; MORRISON et al., 2004; SEDELNIKOVA; PILCH, 2003). Desta forma, a oncoproteína E7 impede o reparo de DSBs (PARK et al., 2014), induzindo a instabilidade genômica em larga escala (WALLACE; GALLOWAY, 2014) ao mesmo tempo em que induz a expressão de telomerases, levando à imortalização celular (MOODY; LAIMINS, 2010).

A oncoproteina E7 interage com regiões TATA box, levando à redução dos níveis de expressão de interleucina 18 (IL-18) (LEE et al., 2001). A IL-18 é uma importante citocina pró-inflamatória que medeia a resposta por linfócitos $\mathrm{T}$ helper 1 (Th1) (LEE et al., 2001). Desta forma, a redução dos níveis de expressão da IL-18 promove uma baixa produção de intérferon gama (INF-y) por células mononucleares de sangue periférico (PBMCs). (LEE et al., 2001).

Um resumo das funções das diferentes proteínas e oncoproteínas dos PVs é mostrada nas tabelas 3 e 4 . 
Tabela 3 - Resumo das principais funções das proteínas late e early do BPV

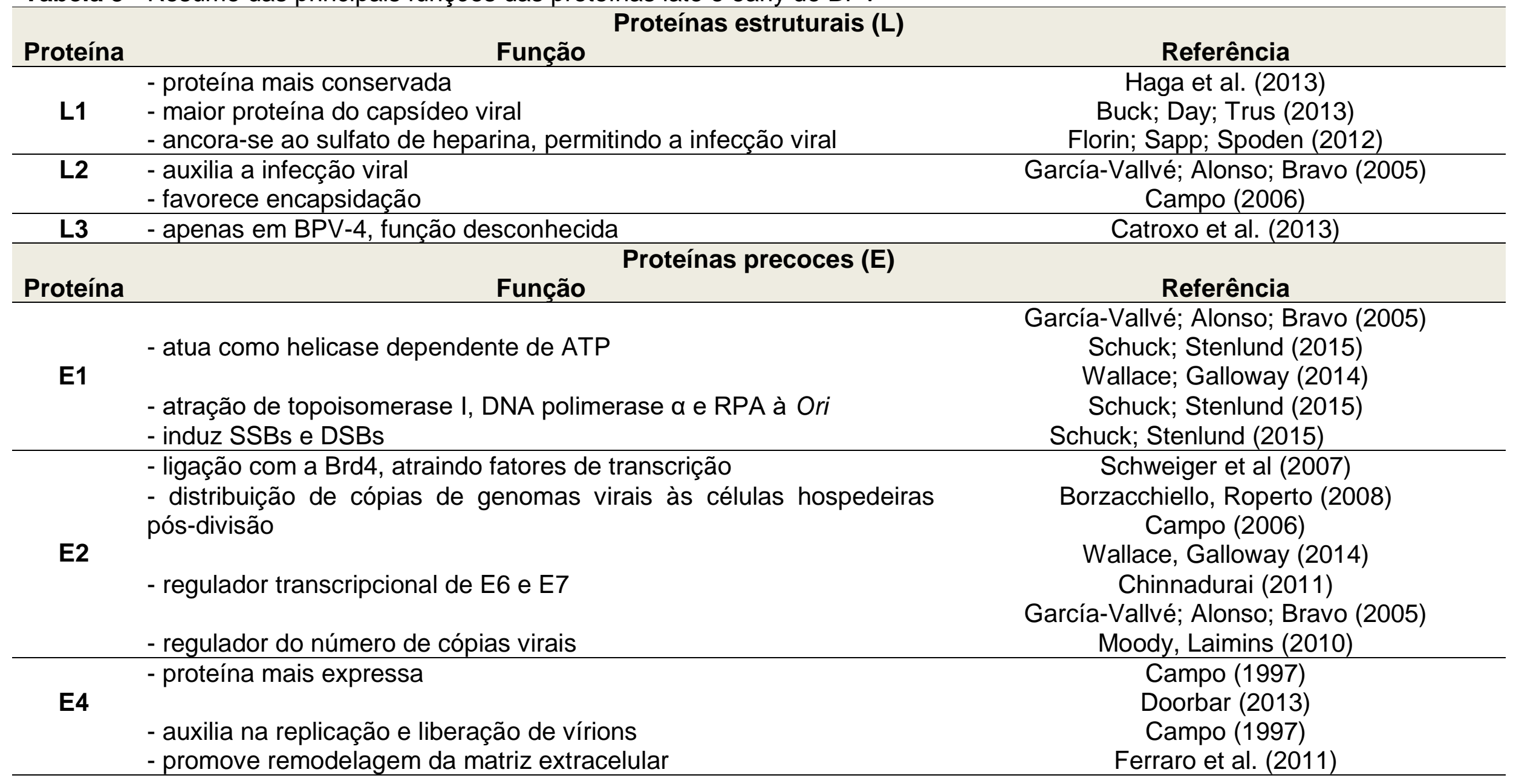


Tabela 4 - Resumo das funções das oncoproteínas do BPV

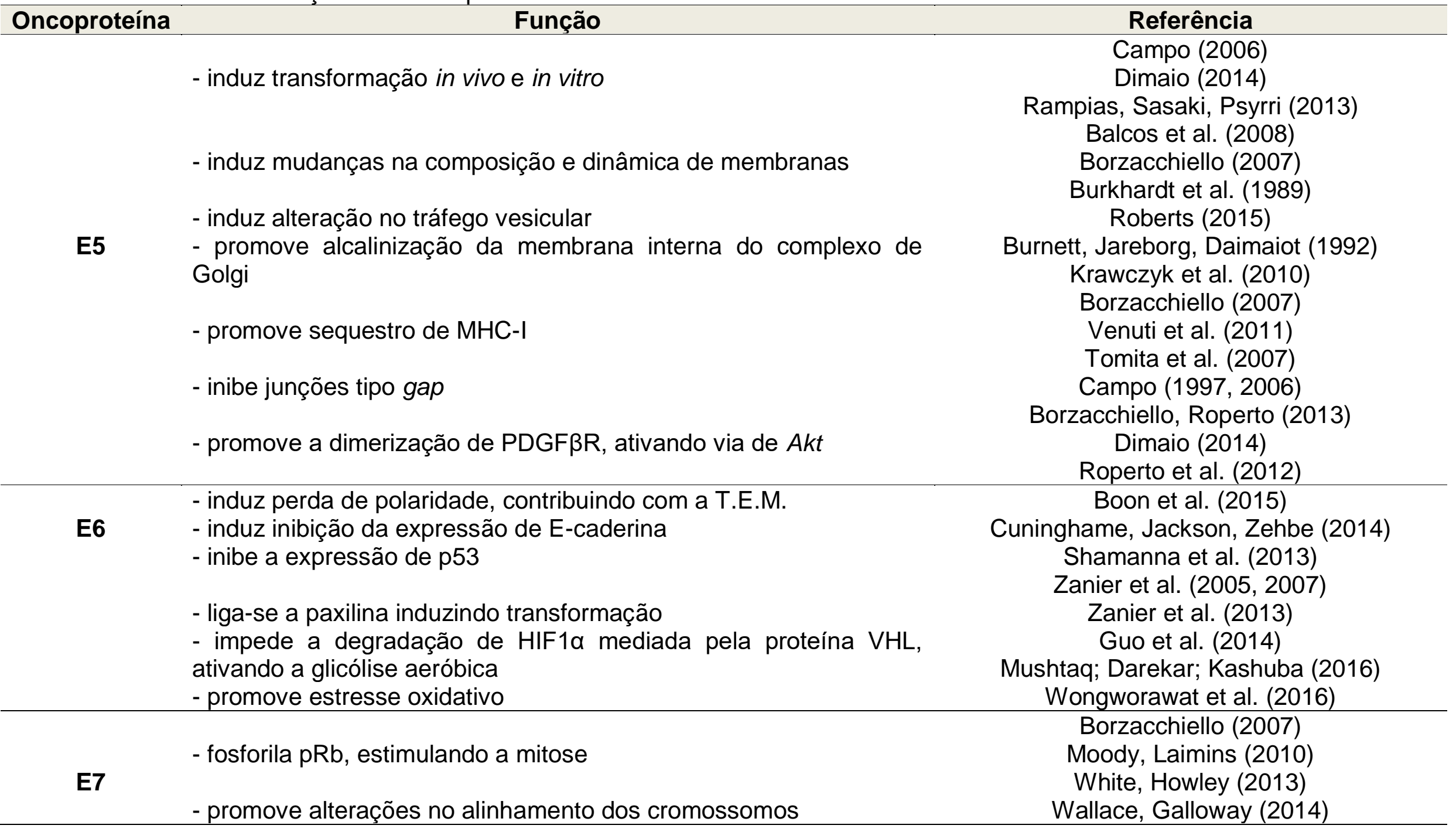




\subsubsection{As vias de infecção pelo BPV e sua manifestação histopatológica}

A transmissão dos BPV pode se dar por meio do contato direto (animal a animal) ou indireto (por meio de superfícies ou objetos contaminados, tais como cercas, muros, cordas, bebedouros, comedouros, ordenhadeira mecânica etc.) (CUBIE, 2013; MURO; BOTTEIRA; PICCININ, 2008). Estudos apontam, ainda, que o vírus pode ser transmitido por insetos (FINLAY et al., 2009) e carrapatos (MURO; BOTTEIRA; PICCININ, 2008).

A mucosa e a pele são os locais mais comuns de entrada de diferentes microrganismos (PIER, 2013), incluindo os PVs (LJUBOJEVIC; SKERLEV, 2014; MOODY; LAIMINS, 2010). Os estudos acerca dos mecanismos de infecção dos PVs são baseados no BPV-1 (FLORIN; SAPP; SPODEN, 2012). A infecção pelo BPV requer uma micro-lesão tecidual, expondo receptores de proteoglicanos de sulfato de heparina (GREBER, 2016; LJUBOJEVIC; SKERLEV, 2014), necessários na primeira fase da infecção (BUCK; DAY; TRUS, 2013; HARTL et al., 2011). Isto porque, o tratamento com heparinase previne a infecção viral (KINES et al., 2016). A micro-lesão garante ao vírus o acesso aos queratinócitos basais (LIU; BALEJA, 2008), nos quais se inicia a infecção produtiva (CAMPO, 1997b). Estudos recentes apontam que as integrinas a6 (CD49f) e a integrina 332 (laminina 5) também são alvos de ligação da proteína L1 (FLORIN; SAPP; SPODEN, 2012) porém, não obrigatórios à infecção (SIBBET et al., 2000).

O sulfato de heparina é um receptor de internalização comum a diferentes vírus, incluindo o herpes vírus simples (HSV) (KINES et al., 2016; PIER, 2013). A ligação da proteína L1 a esses receptores gera uma primeira mudança conformacional da estrutura icosaédrica do capsídeo viral (BUCK; DAY; TRUS, 2013). Esta mudança expõe a porção amino-terminal da proteína menor do capsídeo, L2 (BUCK; DAY; TRUS, 2013). A porção amino-terminal de L2 é, então, clivada pela proteína furina, presente na membrana da célula hospedeira (BUCK; DAY; TRUS, 2013). A furina é uma proteína com atividade proteolítica, capaz de interagir com diferentes fatores de crescimento, receptores celulares e virais (BASSI et al., 2001). Estudo indica que a superexpresão de furina está relacionada com fenótipo mais agressivo de tumores de cabeça de pescoço em humanos (BASSI et al., 2001), mostrando a importância desta nos mecanismos de infecção. A clivagem da porção amino-terminal de L2 pela furina resulta em uma segunda mudança 
conformacional do capsídeo, permitindo a ligação deste a diferentes receptores (BUCK; DAY; TRUS, 2013). Estudos apontam que a integrina a6ß4 é o principal receptor para a internalização viral, porém não o único (BUCK; DAY; TRUS, 2013). Isto porque células que não expressam esta integrina também são infectadas pelo vírus (SHAFTI-KERAMAT et al., 2003).

Após sofrer mudanças conformacionais, o BPV é internalizado por mecanismos de endocitose mediado por clatrina (DAY; LOWY; SCHILLER, 2003). Desta forma, as partículas virais são internalizadas em estruturas vacuolares que se associam a lisossomos (DAY; LOWY; SCHILLER, 2003). Tal associação resulta na formação de uma fagolissomo (DAY; LOWY; SCHILLER, 2003). A liberação do conteúdo ácido dos lisossomos promove alterações no $\mathrm{pH}$ e, portanto, do pK das proteínas estruturais, promovendo o desmonte do capsídeo e a liberação do genoma viral (DAY; LOWY; SCHILLER, 2003). Após a liberação do genoma do BPV, este se encontra na forma epissomal e em múltiplas cópias na célula hospedeira (CAMPO, 2002; COTA et al., 2015; MUNDAY, 2014b), ao passo que HPV se integra ao genoma hospedeiro (MUNDAY, 2014b) por meio de sítios frágeis (MONTE; PEIXOTO, 2010; MOODY; LAIMINS, 2010). Vírus epissomais, como o BPV (TSUNOKAWA et al., 1986), se replicam até atingir um determinado número de cópias por célula (WALDECK; RÖSL; ZENTGRAF, 1984; YANG; OKAYAMA; HOWLEY, 1985). Estudo recente, empregando qRT-PCR, mostrou que células de papilomas cutâneos apresentam cerca de 2,2 × $10^{4}$ cópias de genoma viral, ao passo que células de carcinoma urotelial apresentam cerca de 0,0002 cópias (COTA et al., 2015). Estes dados estão de acordo com a o paradigma do ciclo de replicação os PVs, que reconhece que tumores malignos não apresentam infecção produtiva (CHALLBERG; KELLY, 1989). Um modelo esquemático da infecção viral é mostrado na figura 8. 
Figura 8 - Processo de infecção pelo BPV

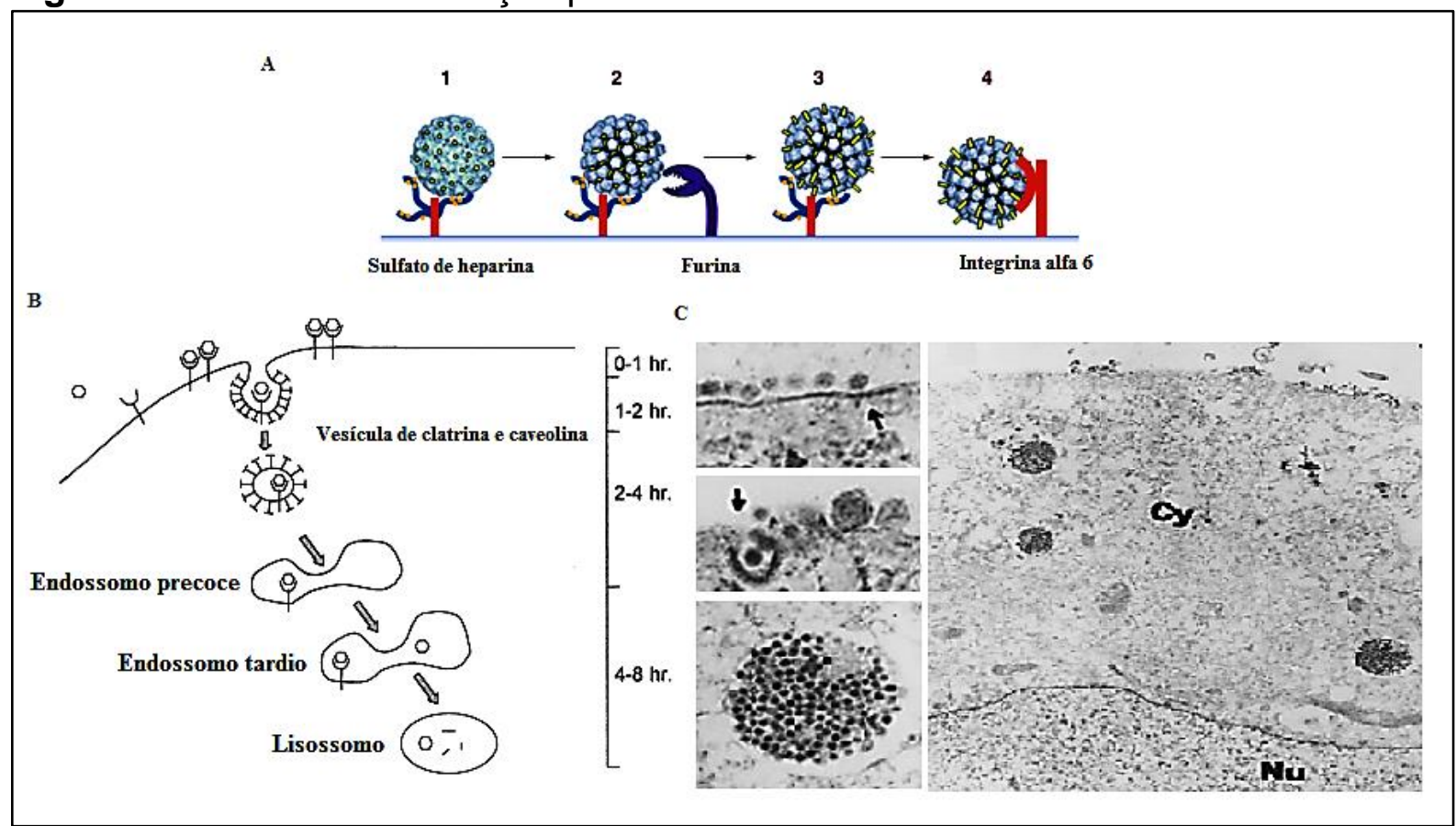

A) Reconhecimento e ligação da proteína L1 a receptores de sulfato de heparina (1) promovem mudança conformacional no capsídeo viral, expondo a porção amino-terminal de L2 (2). Tal porção é reconhecida pela proteína furina, levando a uma segunda mudança conformacional (3), que permite a ligação da partícula viral a integrina a6. B) Esta ligação resulta na internalização das partículas de BPV por meio da formação de vesículas dependentes de clatrina. Tais vesículas formam endossomos precoces, que se associam a lisossomos, resultando em fagolisossomos. A liberação do conteúdo dos lisossomos nestas vesículas leva a acidificação e mudança do pK das proteínas estruturais, permitindo a liberação do material genético. O DNA viral é endereçado ao núcleo, iniciando seu ciclo de replicação. C) Fotomicrografia eletrônica mostrando partículas virais infectando a célula hospedeira, resultando na formação de fagolissomos. Fonte: Modificado de Day et al. (2003), Schiller et al. (2009) e Zhou et al. (1998).

Os PVs não expressam polimerases (MOODY; LAIMINS, 2010). Por este motivo, estes vírus induzem a célula hospedeira a entrar na fase $\mathrm{S}$, em um processo conhecido por amplificação (MOODY; LAIMINS, 2010). Desta forma, os PVs usam as polimerases produzidas por seu hospedeiro para replicar seu genoma (MOODY; LAIMINS, 2010). Por este motivo, a avaliação do ciclo celular de células infectadas por BPV mostra uma redução da proporção de células na fase G1 e um subsequente aumento do número em fase $\mathrm{S}$ e G2/M (POTOCKI et al., 2014). Este dado confirma a ação mitogênica do vírus (POTOCKI et al., 2014). Ainda de acordo com o mesmo estudo, foi observado um aumento no número de eventos poliploides em células infectadas, como consequência do estresse mitótico (POTOCKI et al., 2014). A estimulação da mitose, promovida pelo BPV, resulta em aberrações citogenéticas, tais como: aneuploidias, falhas e quebras de cromátides, formação de 
cromossomos dicêntricos e cromossomos em anéis (ANJOS et al., 2010; CAMPOS et al., 2013; STOCCO DOS SANTOS et al., 1998).

A rápida proliferação dos PVs resulta no desenvolvimento de massas exofíticas (papilomas) (MUNDAY, 2014a), que se caracterizam por uma nítida hipertrofia de todas as camadas do epitélio, conhecida por acantose (CUBIE, 2013). A acantose é acompanhada de projeções interpapilares que apontam radialmente para o centro da lesão (FERRARO et al., 2011). Tais projeções digitiformes dão o nome de papiloma a estas lesões (FERRARO et al., 2011).

À medida que ocorre a diferenciação do epitélio e a maturação das partículas virais, observa-se um processo de epidermização e queratinização (FERRARO et al., 2011). Tais processos são histologicamente evidenciados pelo aumento do número de grânulos de queratina no estrato granuloso, apresentando um efeito histopatologicamente descrito por hipergranulose (FERRARO et al., 2011).

A montagem viral ocorre nas camadas mais diferenciadas do epitélio (MUNDAY, 2014a). A liberação das partículas virais ocorre por meio da degeneração de células da camada granulosa (BROBST; HINSMAN, 1966; BUCK; DAY; TRUS, 2013; MUNDAY, 2014a). A presença de partículas virais de PV em coilócitos da camada granulosa e células em descamação da camada córnea é mostrada na figura 9.

Figura 9 - Partículas de HPV em coilócitos

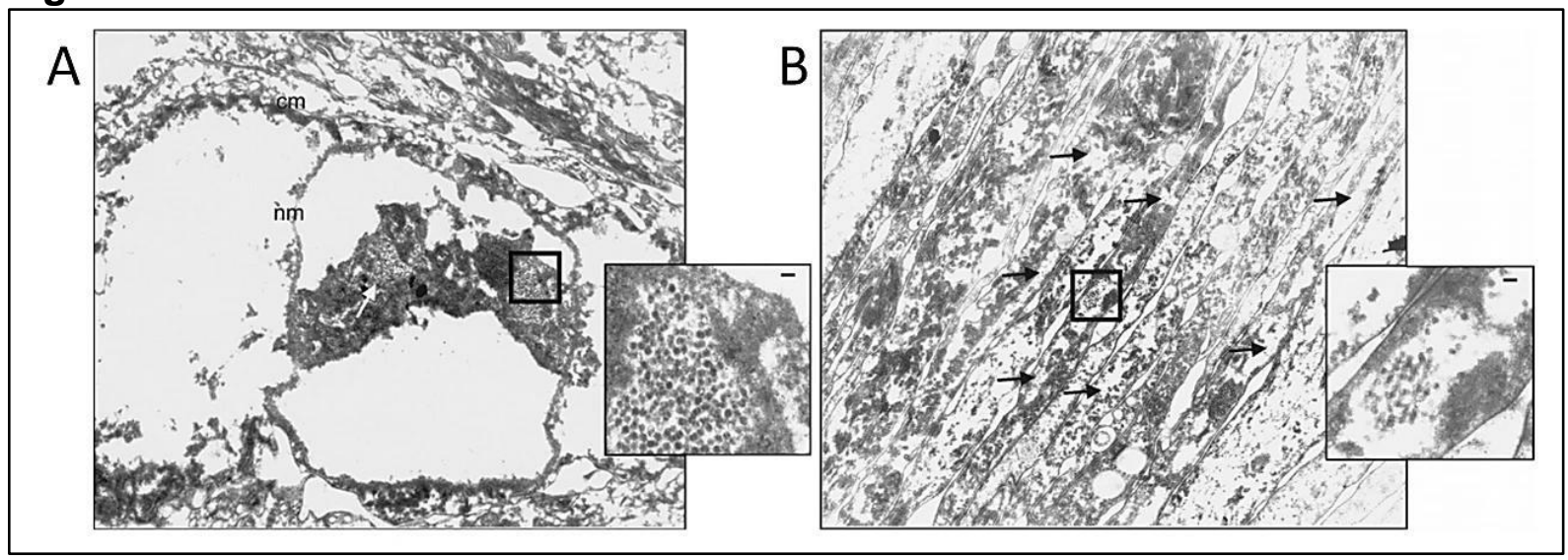

Fotomicroscopia eletrônica indicando a presença de partículas de HPV-11 em coilócitos da camada granulosa (A) e em células em descamação da camada córnea (B). Imagens obtidas em aumento de 8.250X. Fonte: Modificado de Bryan; Brown (2001).

A degeneração resulta na aquisição de um fenótipo queratinocítico das células da camada suprabasal e granulosa, originando os coilócitos (ARALDI et al., 2014b; BOGAERT et al., 2010; FERRARO et al., 2011; JELÍNEK; TACHEZY, 2005; 
ROGOVSKYY et al., 2012). O termo coilócito vem do grego koillos, que significa cavidade (FERRARO et al., 2011). Este termo foi incialmente proposto por Koss e Durfee em 1956 para se referir à alteração citopática onde se observa um halo proeminente e um núcleo excêntrico e picnótico (FERRARO et al., 2011). A coilocitose é discutida como um marcador patognomônico das infecções por PVs (KRAWCZYK et al., 2008; MONTE; PEIXOTO, 2010). A formação dos coilócitos é atribuída às oncoproteínas E5 e E6, embora os mecanismos de vacuolização permaneçam desconhecidos (KRAWCZYK et al., 2008, 2010). Entretanto, estudo indica que a vacuolização citoplasmática contribui para a fragilidade dos queratinócitos, facilitando a liberação de partículas virais para o ambiente (KRAWCZYK et al., 2008). Desta forma, os coilócitos são células destinadas a apoptose (KRAWCZYK et al., 2008). A apoptose emerge como resultado da inibição da síntese de macromoléculas celulares e da replicação do DNA, garantindo a liberação de partículas virais ao ambiente (WANG; KIEFF, 2013). Neste cenário, o BPV pode induzir tanto a apoptose em coilócitos, permitindo a liberação e disseminação de partículas virais, como inibir a morte celular (PIER, 2013). A inibição da apoptose, observada nas camadas menos diferenciadas do epitélio, garante a persistência da infecção viral, maximizando o número de cópias e a expressão diferencial até que se complete o processo de montagem viral (PIER, 2013). Desta forma, os vírus podem permanecer latentes (MANGLENNON; DOOBAR, 2012).

Após montadas, as partículas virais são liberadas junto à camada córnea (BROBST; HINSMAN, 1966; BUCK; DAY; TRUS, 2013). Os vírions permanecem imersos na matriz de queratina que compõe esta camada. Este mecanismo confere mais um sistema de evasão imune (BUCK; DAY; TRUS, 2013). Isto porque a morfologia icosaédrica dos PVs é imunorreativa (BUCK; DAY; TRUS, 2013). Além do mais, a queratina confere proteção física às partículas virais, já que estas não são envelopadas (BROBST; HINSMAN, 1966). A hiperqueratinização do epitélio é esperada, justificando a hipergranulose (TAN et al., 2012a). No final do período de infecção viral, pode haver uma redução da carga viral, o que pode tornar o vírus indetectável, mesmo que por meio de PCR (WANG; KIEFF, 2013).

Desta forma, o ciclo replicativo do BPV é dependente da diferenciação celular do epitélio, conforme figura 10 (MCBRIDE; DLUGOSZ; BAKER, 2000; WHITE; HOWLEY, 2013). Tal dependência resulta em uma nítida dificuldade de obtenção de 
partículas virais por meio de sistemas in vitro, incluindo culturas organotípicas (CERQUEIRA et al., 2016; DOORBAR, 2016; MCBRIDE; DLUGOSZ; BAKER, 2000; WHITE; HOWLEY, 2013).

Figura 10 - Expressão diferencial de proteínas virais

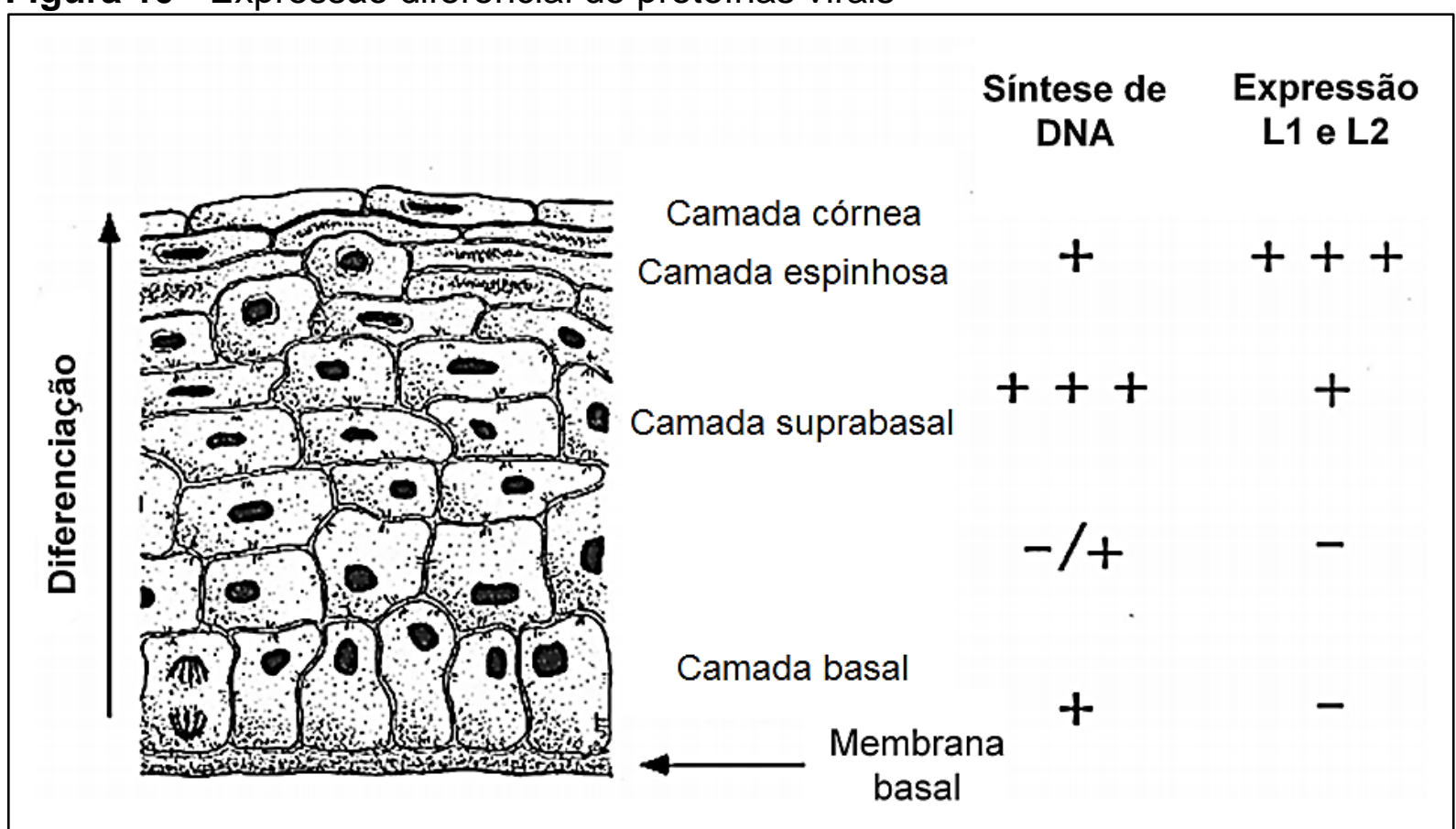

Esquema mostrando a expressão diferencial de proteínas do BPV. Enquanto a expressão de proteínas precoces (E) é verificada em todas as camadas do epitélio, estimulando a divisão celular, a expressão das proteínas tardias (L), responsáveis pela montagem do capsídeo, é restrita as camadas mais diferenciadas do epitélio. Fonte: Modificado de Laimins (1996).

\subsection{Sarcóide equino: um exemplo do fibrotropismo do BPV}

Embora considerado epitélio e mucosotrópico, o BPV pode infectar fibroblastos, causando lesões semelhantes a sarcomas, conhecidas por sarcóides equinos (CHAMBERS et al., 2003). O sarcóide equino foi descrito pela primeira vez por Jackson (1936), sendo considerado um tumor bifásico, pois afeta o componente epitelial e mesenquimal. O sarcóide equino, conhecido também por fibroma ou fibrossarcoma (CHAMBERS et al., 2003), corresponde a uma neoplasia benigna da pele mais observado em cavalos desde a sua descrição (BERGVALL, 2013; JACKSON, 1936; OTTEN et al., 1993; NASIR; REID, 1999; MARTENS et al., 2000; MOSSERI et al., 2014). Entretanto, diferentemente dos papilomas, os sarcóides raramente apresentam regressão espontânea (ANGELOS et al., 1991). Os sarcóides equinos afetam animais entre um e seis anos (OTTEN et al., 1993), causando neoplasias benignas fibroblásticas altamente invasivas, porém não metastáticas. 
(NASIR; REID, 1999). Tais tumores causam uma substancial morbidade e importantes prejuízos econômicos (CHAMBERS et al., 2003) uma vez que provocam alterações estéticas e comprometimento funcional (ANGELOS et al., 1991; OTTEN et al., 1993). Estima-se que 11,5\% de todos os cavalos devam apresentar sarcóides ao longo de suas vidas (KNOTTENBELT, 2005).

O sarcóide apresenta etiologia multifatorial (BERGVALL, 2013). Entretanto, os Deltapapillomavirus são reconhecidos como principais agentes etiopatogênicos da doença (BERGVALL, 2013; BOGAERT et al., 2008; CHAMBERS et al., 2003; NASIR; REID, 1999). A associação entre sarcóides e o BPV foi primeiramente demonstrada por Olson e Cook em 1951 (BRANDT et al., 2008). Sequências de BPV-1 e 2 são identificadas em 100\% dos sarcóides (MARTENS; DE MOOR; DUCATELLE, 2001; GAYNOR et al., 2015). Além do mais, sequências destes tipos virais são encontradas em mais de $2 / 3$ de cavalos sadios e assintomáticos (BRAVO; SANJOSÉ; GOTTSCHLING, 2010). Entretanto, tais neoplasias são consideradas sítios de infecção abortiva, uma vez que a presença de vírions não foi reportada até o momento. (BOGAERT et al., 2008, 2010; BRANDT et al., 2008; NASIR; REID, 1999), embora a presença de transcritos de L1 de BPV-1 foi identificada por meio de RT-PCR em sarcóides (NASIR; REID, 1999). Estudos recentes consideram que infecções produtivas são caracterizadas pela expressão das proteínas estruturais (L1 e/ou L2) (NASIR; REID, 1999). No entanto, a confirmação da presença de partículas virais requer a análise de microscopia eletrônica de transmissão (MET) (BOGAERT et al., 2010).

Além do mais, assim como nos bovinos, o vírus pode se manter assintomático, permanecendo latente na derme e/ou epiderme. (BERGVALL, 2013; BOGAERT et al., 2008; BRANDT et al., 2008). A latência pode ser definida pela presença de DNA viral sem nenhuma evidência clínica ou histopatológica da infecção (BOGAERT et al., 2008). Estudo mostra que $70 \%$ dos cavalos assintomáticos portadores do BPV vivem em contato direto com o gado (BERGVALL, 2013). Este dado sugere que a infecção cruzada do BPV em equinos representa uma infecção errática (OTTEN et al., 1993).

A latência viral é outra característica compartilhada entre BPV e HPV. Estudos mostram que o BPV pode se manter em latência tanto em bovinos (ARALDI et al., 2013a; SILVA et al., 2013b) e equinos (BOGAERT et al., 2008), quanto em humanos infectados pelo HPV (ASTORI et al., 1998; FORSLUND et al., 2004; 
MARAN et al., 1995). Entretanto, a presença do vírus induz alterações cromossômicas (MELO et al., 2011; STOCCO DOS SANTOS et al., 1998), incluindo a clastogênese, que eleva a susceptibilidade ao câncer (ARALDI, 2015; ARALDI et al., 2013a, 2015a; CALINISAN et al., 2002).

Os sarcóides são observados com mais frequência em áreas mais susceptíveis a traumatismos, tais como: abdómen, pescoço, região paragenital e peitoral (ANGELOS et al., 1991; OTTEN et al., 1993; MARTENS et al., 2000). Estudos mostram o trauma tecidual como fator necessário à manifestação clínica da doença (BOGAERT et al., 2010).

Algumas raças como a Árabe são mais susceptíveis ao desenvolvimento de sarcóides (BOGAERT et al., 2008; KNOTTENBELT, 2005). A razão para isto é a presença de certos haplótipos do MHC-II, como W3 e B1, que se mostram mais predispostos à gênese de sarcóides (CHAMBERS et al., 2003). A presença de determinados alelos do MHC-II leva a respostas imunológicas que favorecem a infecção pelo BPV (BOGAERT et al., 2008; CHAMBERS et al., 2003). Estudo aponta ainda um forte padrão familial de susceptibilidade ao sarcóide, sugerindo uma contribuição autossômica recessiva (KNOTTENBELT, 2005).

Os mecanismos de transmissão do BPV em equinos ainda permanecem não totalmente elucidados (BOGAERT et al., 2008; CHAMBERS et al., 2003). Entretanto, acredita-se que os insetos sejam os principais vetores de transmissão (CHAMBERS et al., 2003; YUAN et al., 2007). Isto porque, sequências de BPV-1 foram encontradas em moscas Musca automnalis, Fannia carnicularis e Stomoxys calcinatrans (BERGVALL, 2013).

Em seu hospedeiro usual (bovinos), a infecção pelo BPV tem início na epiderme, migrando para a derme, onde pode infectar fibroblastos e induzir a transformação (BOGAERT et al., 2010). Entretanto, em equinos, onde o vírus encontra uma condição sub-ótima, a infecção tem início na derme, a qual não permite sustentar o ciclo de replicação viral, que é dependente da diferenciação do epitélio (BOGAERT et al., 2010). Desta forma, o BPV pode resultar em uma infecção abortiva, que favorece a progressão maligna, ou o vírus infecta queratinócitos, iniciando seu ciclo de replicação (BOGAERT et al., 2010). Estes dados sustentam a co-evolução dos papilomavírus com seus hospedeiros, revelando uma adaptação do BPV ao ecossistema equino (BOGAERT et al., 2010). 
Os sarcóides equinos são classificados em seis diferentes histiotipos: oculto, verrucoso, nodular, fibroblástico, misto e maligno (KNOTTENBELT, 2005), conforme figura 11. Estudo aponta que $84 \%$ dos cavalos apresentam mais de um tipo histológico de sarcóide (GOODRICH et al., 1998).

Figura 11 - Classificação dos diferentes tipos de sarcóides equinos

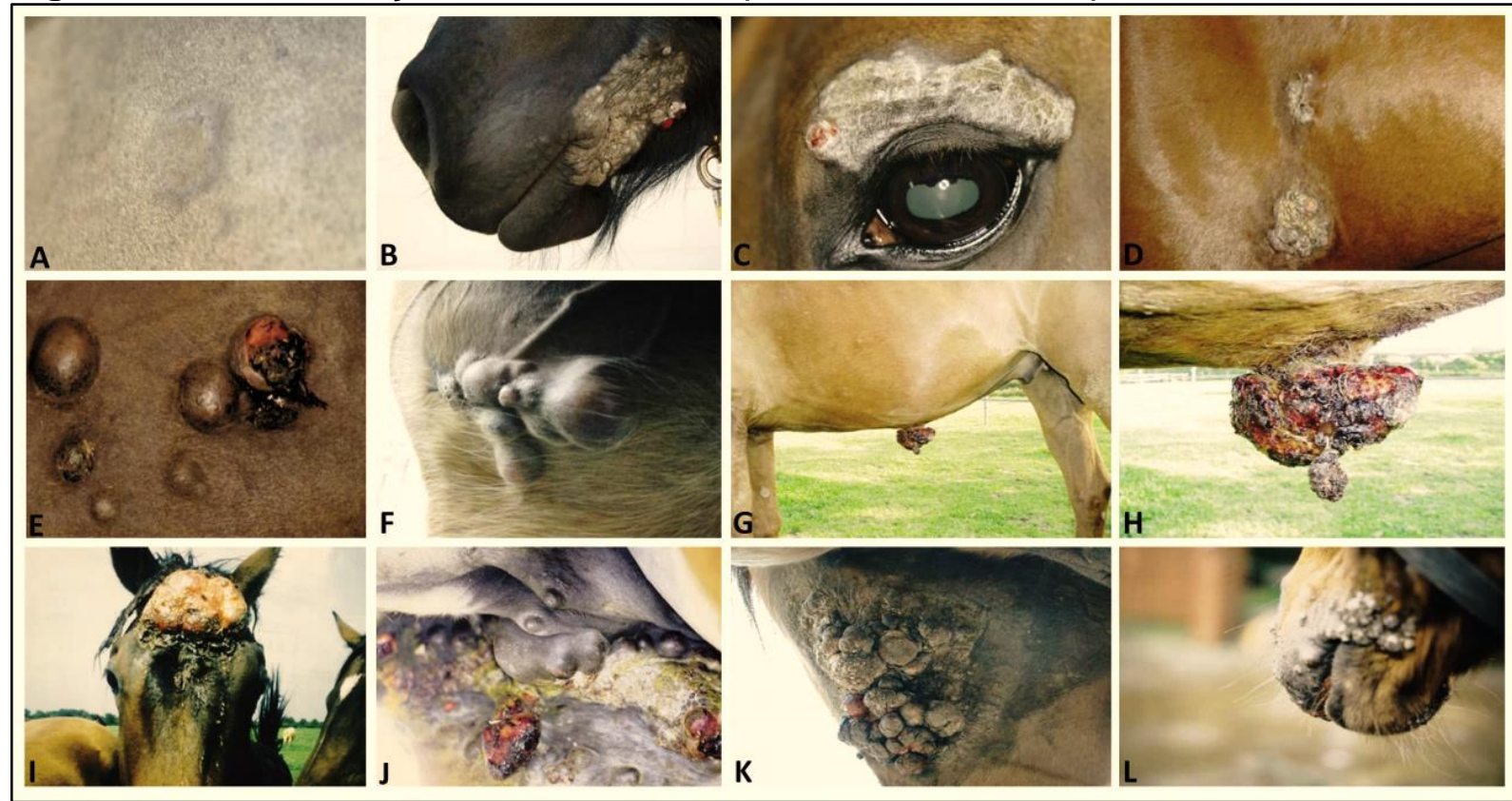

Sarcóide oculto na região medial da coxa $(A)$, sarcóide verrucoso na face $(B)$, região periocular $(C)$ e dos ombros (D), sarcóide nodular tipo $A(E)$ e tipo $B(F)$ na região medial da coxa, sarcóide fibroblástico tipo 1 (pedunculado) no abdómen ventral $(\mathrm{G}$ e H) e tipo 2 (séssil) na face (I), sarcóide misto na região axilar (J), sarcóide maligno (K e L). Fonte: Modificado de Knottenbelt (2005).

Os mecanismos patogênicos do sarcóide ainda são pouco compreendidos (BOGAERT et al., 2010). Os sarcóides são caracterizados por lesões com intensa proliferação de fibroblastos organizados em espirais ou feixes fusiformes, semelhantes àqueles observados em fibropapilomas (MARTENS et al., 2000). componente epidérmico, presente apenas em sarcóides verrucosos e mistos, encontra-se hiperplásico e hiperqueratótico (MARTENS et al., 2000), apresentando uma invaginação dérmica (BOGAERT et al., 2010). Outra importante característica histopatológica destas lesões é a presença de fibroblastos anaplásicos e pleomórficos, com orientação perpendicular à membrana basal, observados na junção dermo-epidermal (MARTENS et al., 2000). Estudo envolvendo CISH aponta uma maior quantidade de DNA viral nesta junção (BOGAERT et al., 2010), justificando a transformação fibroblástica observada nesta área (MOSSERI et al., 2014). 
O comportamento invasivo do sarcóide se deve ao aumento nos níveis de expressão de diferentes metaloproteinases (MMPs), como: MMP-1, 2 e 9 (MOSSERI et al., 2014; YUAN et al., 2010). A MMP-1 degrada a laminina e o colágeno IV, levando a perda da arquitetura e desorganização tecidual (MOSSERI et al., 2014), ao mesmo tempo em que promove a invasão da matriz extracelular, conforme já mostrado em ensaios de migração em Matrigel 3D (YUAN et al., 2010). A invasão tecidual representa a maior dificuldade terapêutica no tratamento do sarcóide equino (MOSSERI et al., 2014).

Os mecanismos moleculares do sarcóide equino são pouco compreendidos (YUAN et al., 2007). Estudos envolvendo a imunodetecção da proteína supressora tumoral p53 por meio de imunoistoquímica em tecido parafinado (IHQ-P) apontam uma imunomarcação perinuclear, sugerindo um sequestro citoplasmático de p53 ( CHAMBERS et al., 2003; MARTENS et al., 2000; YUAN et al., 2008). Além do mais, não se observa perda de função do gene TP53, de modo que o fenótipo selvagem é preservado (YUAN et al., 2008).

Atualmente os tratamentos disponíveis para o sarcóide equino, assim como aqueles usados para a PB, são pouco eficientes ou apresentam diversos efeitos colaterais (BERGVALL, 2013). Entre estes tratamentos, encontram-se: (1) a excisão cirúrgica das lesões, que leva à recidiva da doença em 50-64\% dos casos em até seis meses (BERGVALL, 2013; LANCASTER; OLSONF; MEINKE, 1977; MARTENS; DE MOOR; DUCATELLE, 2001; MOSSERI et al., 2014); (2) tratamento a laser, cuja recidiva é observada em 38\% dos casos (MARTENS et al., 2001); (3) crioterapia, a qual se mostra ineficiente para lesões acima de $2 \mathrm{~cm}^{2}$ (CARR, 2009) e (4) quimioterapia com injeção intramuscular de cisplatina em emulsão lipídica ou 5fluorouracil (5-FU) em emulsão aquosa. Ambas terapias apresentam elevado risco de nefro e hepatotoxicidade (STEWART; RUSH; DAVIS, 2006). Além do mais o tratamento quimioterápico falha por não se estender além da área local afetada (MOSSERI et al., 2014).

Os sarcóides emergem após a exposição a um traumatismo (NASIR; REID, 1999), coincidindo com a biologia da infecção e replicação dos PVs. Por isso, o tratamento cirúrgico resulta em recidiva das lesões, uma vez que a incisão cirúrgica representa um traumatismo tecidual (NASIR; REID, 1999). Acreditava-se que a presença de DNA de BPV nas margens cirúrgicas era responsável pela recidiva da doença (MARTENS; DE MOOR; DUCATELLE, 2001). Entretanto, trabalho recente 
mostrou a recidiva da doença após a excisão cirúrgica de tumores cujas margens encontram-se livres de DNA viral (TAYLOR et al., 2014). Este estudo apontou que a recidiva está relacionada à outra via que não a presença de vírus nas margens cirúrgicas. Neste sentido, Nasir et al. (1997) tentaram identificar sequências de BPV em sangue periférico de burros com sarcóide equino. Entretanto, tal tentativa não obteve sucesso. O motivo para a falta de sucesso pode ser justificado pelo desenho do primer empregado no diagnóstico molecular, que deve apresentar uma elevada sensibilidade. Entretanto, Brandt et al. (2008) identificaram pela primeira vez sequências de DNA de BPV em sangue periférico de animais clinicamente afetados pelo sarcóide. A presença de sequências virais em células mononucleadas de sangue periférico (PBMCs - peripheral blood mononuclear cells) é apontada como a principal causa para a recidiva da doença, já que o sangue contribui para a disseminação viral e com a infecção de novo (BRANDT et al., 2008).

\subsection{Presença de BPV em sangue periférico}

Nos últimos anos, o sangue vem sendo discutido como um possível sítio de infecção produtiva para o BPV (SANTOS et al., 2014). Isto porque, sequências de BPV-1, 2, 3, 4, 6, 8 e 10 já foram identificadas em PBMCs de bovinos (ARALDI et al., 2013a, 2014b; BOCANETI et al., 2014; DINIZ et al., 2009; FREITAS et al., 2003; MELO et al., 2011; ROPERTO et al., 2008; SANTOS et al., 2014; SILVA et al., 2013b; STOCCO DOS SANTOS et al., 1998) e equinos (BRANDT et al., 2011). Dentre estes, o BPV-1 e 2 são os tipos mais frequentemente identificados em PBMCs, ao passo que os tipos BPV-4 e 10 são menos relatados (SANTOS et al., 2014).

A presença de DNA viral em PBMCs não é exclusiva dos BPVs. Isto porque, sequências de HPV já foram igualmente identificadas em PBMCs (BODAGHI et al., 2005; PAO et al., 1991; PESSOA, 2014) e plasma de pacientes com carcinoma cervical (DONG et al., 2002). Desta forma, a possibilidade de transmissão do HPV via transfusão sanguínea ou por meio de insetos hematófagos não pode ser excluída (BRAVO; SANJOSÉ; GOTTSCHLING, 2010; KRÁL et al., 2015).

Um estudo realizado em Taiwan (China) revelou uma importante associação entre HPV e o risco para o câncer de pulmão, que representa a neoplasia mais frequente a nível mundial (CHIOU et al., 2003). De acordo com o estudo, a presença de sequências de HPV-16 eleva em 6,5 vezes a probabilidade de desenvolver a 
malignidade, ao passo que o HPV-18 eleva em 9,2 vezes (CHIOU et al., 2003). Os autores mostraram, ainda, que a co-infecção pelo HPV-16 e 18 aumenta em 75,7\% a chance de desenvolver câncer de pulmão em relação a indivíduos não infectados (CHIOU et al., 2003). Outro trabalho revelou a presença de sequências de DNA, bem como de transcritos de E6 do HPV, por meio de RT-PCR, em 92,3\% das amostras de PBMCs de pacientes com câncer cervical em estágio avançado (IVb) (PAO et al., 2014). Resultados semelhantes foram também observados por Aceto et al. (2010) e Lawson et al. (2009), revelando a presença do HPV em PBMCs de pacientes com câncer de mama em estágio avançado (IV). Outra importante evidencia da presença do HPV no sangue é a manifestação do papiloma laringeal, tipo tumoral benigno mais comumente observado na infância (SYRJANEN; PURANEN, 2000). Sequências de HPV foram, também, identificadas em retinoblastomas de crianças com até três anos de Recife-PE, onde se verificou a expressão das proteínas E1^E7, E6 e L1 (PESSOA, 2014). Desta forma, a presença do genoma viral em sangue periférico faz dos PVs um problema de saúde pública (COSTA; MEDEIROS, 2014).

Sequências de BPV-1, 2 e 4 já foram identificadas em oócitos, ovário, útero (FREITAS et al., 2003; YAGUIU et al., 2006), placenta e líquido amniniótico (figura 12) (FREITAS et al., 2007; ROPERTO et al., 2012; YAGUIU et al., 2008). Além do mais, sequências destes tipos virais foram, também, identificadas em PBMCs de bezerros recém-nascidos e assintomáticos (FREITAS et al., 2003). A identificação do BPV nestes tecidos sugere que o vírus pode ser transmitido por via vertical (ARALDI, 2014a; FREITAS et al., 2003). Neste sentido, o desenvolvimento de vacinas terapêuticas se faz necessário, posto que a infecção pode ocorre in útero (ARALDI, 2014a), dificultando a profilaxia. 
Figura 12 - Identificação de sequência de BPV-2 em líquido amniótico

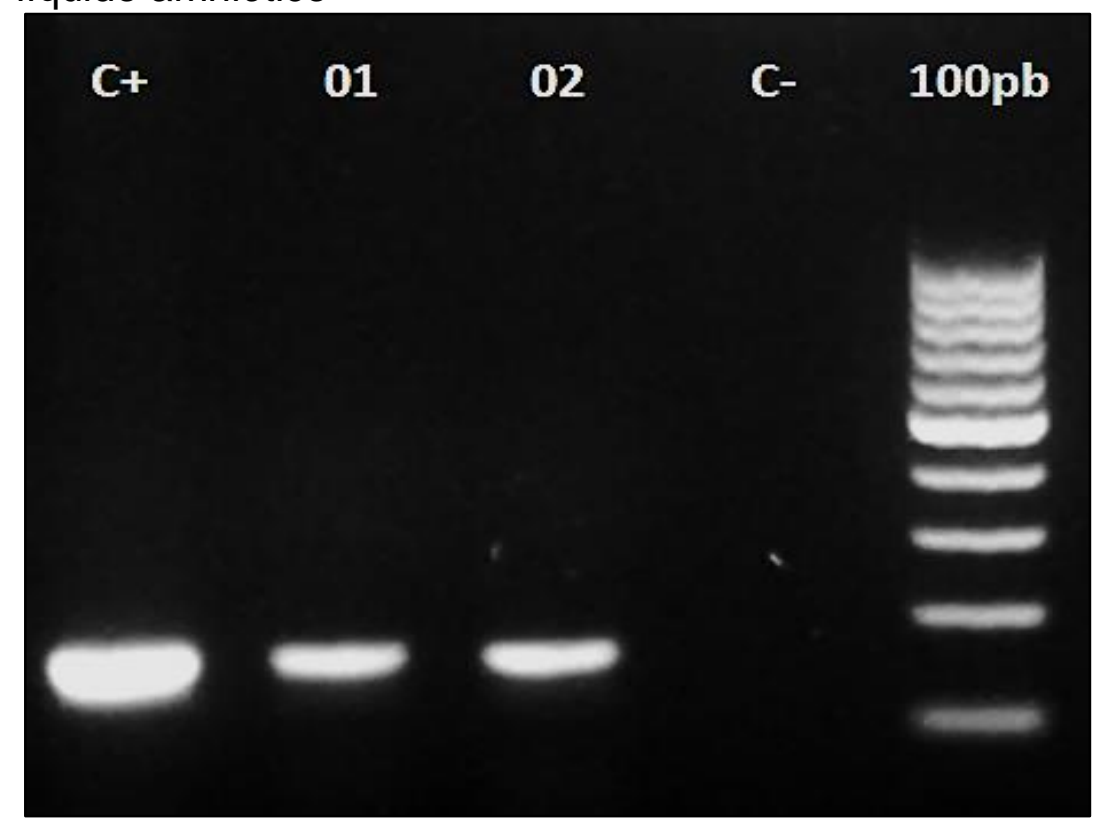

Identificação de sequência de BPV-2 em duas amostras de líquido amniótico coletado de animal prenho apresentando carcinoma de esôfago. Fonte: Araldi (dado não publicado).

A presença do DNA viral em PBMCs sugere que o sangue pode atuar como veículo disseminador, resultando em uma infecção de novo em epitélio e mucosas (ARALDI, 2014a; BRANDT et al., 2008; KRÁL et al., 2015). A comprovação do papel disseminador de partículas virais foi mostrada por Roperto et al. (2011), que observou a expressão da oncoproteína E5 de BPV-2 em mais de 50\% dos linfócitos CD4+ e CD8+ de bovinos com carcinoma urotelial. O sangue é discutido como um sítio transiente de infecção, já que os PVs são epitélio e mucosotrópicos (SANTOS et al., 2014). No entanto, a expressão da protéina L1 de BPV, identificada em mais de $20 \%$ das células CD4+ e linfócitos T circulantes (ROPERTO et al., 2011), sugere a presença de infecção produtiva em PBMCs.

De acordo com Munday et al. (2014), a presença de infecção produtiva por PVs em PBMC mudará o entendimento da história natural dos PVs. Neste sentido, Melo et al. (2015) identificaram, pela primeira vez, a presença de estruturas semelhantes a partículas virais de BPV no citoplasma de PBMCs por meio de MET. Os autores também identificaram a presença de sequências de BPV nestas células por meio de PCR-RFLP (PCR Restriction Fragment Lengh Polymorphism), sequenciamento e CISH bem como mostraram a presença de transcritos de L1 por meio de RT-PCR. Estes resultados demonstram que a infecção produtiva pode ocorrer mesmo na 
ausência de diferenciação celular. Tais dados refletem a necessidade de revisar a história natural dos PVs.

\subsection{Métodos de identificação e tipagem de BPV}

Conhecer a diversidade e prevalência dos diferentes tipos de BPV é fundamental para o desenvolvimento de novos métodos terapêuticos (SILVA et al., 2013a), já que a imunidade é espécie-específica (CLAUS et al., 2007). Neste sentido, o diagnóstico deve ser realizado no menor tempo e custo possível (MADOFF; KASPER, 2013). Diferentes técnicas têm sido empregadas na identificação de PVs, tais como: Southern blot, Dot blot (LETO et al., 2011), análise histopatológica e IHQ-P (ELZEIN et al., 1991), CISH, PCR (MUNDAY, 2014a), empregando primers específicos ou degenerados (ARALDI, 2014a; ARALDI et al., 2014b; MELO et al., 2014), isolamento viral e MET (ARALDI et al., 2014a; GOLDSMITH; MILLER, 2009; PEREIRA, 2008). Dentre estes métodos, a PCR é a técnica mais empregada devido a sua alta sensibilidade (LETO et al., 2011). A PCRRFLP também tem sido empregada na identificação e tipagem do BPV, mostrando uma correlação de 95\% em termos de fidedignidade às análises de sequenciamento (CARVALHO et al., 2013; KAWAUCHI et al., 2015; MARTENS et al., 2000).

A PCR em tempo real (qRT-PCR), embora permita avaliar o número de cópias virais, é o método de menor potencial de reprodutibilidade entre os laboratórios (GUO et al., 2012). Por este motivo, a PCR convencional, seguida de sequenciamento representa o método diagnóstico mais empregado e confiável na tipagem viral (ARALDI et al., 2014a; MELO et al., 2014). Entretanto, não há o reconhecimento de um primer "padrão-ouro" na identificação de sequências de PVs (ANTONSSON et al., 2010).

Se por um lado os primers específicos mostram-se mais sensíveis, eles não permitem detectar os 15 tipos de BPVs de forma simultânea (ARALDI et al., 2014a). Além do mais, tais primers não permitem detectar novos supostos tipos virais (ARALDI et al., 2014a). Até 2014, evidências apontavam que o primer para o BPV-1 poderia se anelar com igual eficiência a sequências de BPV-2, questionando sua especificidade (HAGA et al., 2013). Isto porque, os BPV-1 e 2 são considerados sorotipos semelhantes (SHAFTI-KERAMAT et al., 2009). Entretanto, um estudo comparativo entre primers específicos para BPV-1, 2 e 4, empregando genomas 
clonados de BPV-1 a 6, comprovou a especificidade destes primers (ARALDI et al., 2014a).

Entre os diferentes pares de primers degenerados descritos na literatura, 0 FAP59/FAP64, desenhado por Forslund et al. (1999), é um dos mais empregados na identificação de sequências tanto do HPV, como do BPV. O par de primers foi desenhado com base na homologia de sequências da ORF L1 do HPV (FORSLUND et al., 1999) e, mais tarde, optimizado para a identificação de sequências do BPV (OGAWA et al., 2004). O par de primers FAP59/FAP64 tem sido empregado na identificação de sequências de BPV tanto em papilomas (OGAWA et al., 2004), quanto em sarcóides equinos (LANGE et al., 2013). Além do mais, este par de primer já permitiu identificar novos tipos de BPV, incluindo o BPV-9 e 10 (HATAMA; NOBUMOTO; KANNO, 2008). Embora os primers degenerados apresentem uma sensibilidade inferior a dos específicos, eles permitem detectar todos os tipos virais, bem como os supostos novos tipos de forma simultânea (ARALDI et al., 2014a). No entanto, a literatura registra inúmeros problemas de identificação viral com alguns destes primers. O par de primers MY09/MY11, por exemplo, não se mostrou eficiente na identificação de sequência de BPV, seja em amostras clínicas (ZHU et al., 2014) ou em cópias de genomas virais clonados de BPV-1 a 6 (ARALDI et al., 2014a). Dentre os diferentes pares de primers degenerados descritos na literatura, 0 MY09/MY11 é o que registra a menor sensibilidade (ARALDI et al., 2014a), inclusive na identificação de sequências de HPV em amostras clínicas (MARTELLIMARZAGÃO et al., 2010; PESSOA, 2014).

Estudos baseados na identificação e tipagem do BPV mostram que a coinfecção por mais de um tipo viral é frequente (ARALDI et al., 2013a, 2014b; CARVALHO et al., 2012; CLAUS et al., 2007, 2009; DINIZ et al., 2009; HAGA et al., 2013; HE et al., 2016; LINDSEY et al., 2009; SANTOS et al., 2014; STOCCO DOS SANTOS et al., 1998). Este dado justifica a necessidade de desenvolvimento de vacinas multivalentes direcionadas contra diferentes tipos virais (MUNDAY, 2014b).

Embora PCR seja amplamente empregada no diagnóstico viral, a técnica não permite identificar a localização e o estado físico (integrado ou epissomal) dos PVs (MUNDAY, 2014a). Neste sentido, a CISH permite identificar a localização do genoma viral e seu estado físico (BLACK, 1968; MUNDAY, 2014a). Além do mais, nos últimos anos, a imunodetecção da proteína estrutural L1, empregando anticorpos comerciais anti-L1, tem sido usada como um indicador de possível 
infecção produtiva (ARALDI, 2014a; LONGWORTH; LAIMINS, 2004; MUNDAY, 2014b; NASIR; REID, 1999;; ROPERTO et al., 2011).

Somado a essas técnicas, a análise histopatológica das lesões é um importante método diagnóstico diferencial (CASCALES et al., 2009; MONTEIRO et al., 2008). Isto porque, permite identificar tumores intra-epiteliais com potencial oncogênico (MONTEIRO et al., 2008). A análise histopatológica dos fragmentos de papilomas mostra, frequentemente, a presença de: atipia, hiperplasia da epiderme (acantose) e derme, hiperqueratose orto e paraqueratótica, coilocitose, hipergranulose (CASCALES et al., 2009; HE et al., 2016; ZHU et al., 2014). Tais alterações são igualmente observadas em lesões por HPV (FERRARO et al., 2011; JELÍNEK; TACHEZY, 2005).

\subsection{O BPV como modelo de estudo do HPV}

Os PVs são considerados espécie-específicos (CAMPO, 2002; KOLLER; OLSON, 1972). Tal fato resulta da ausência de modelos animais que sustentem a infecção pelo HPV (CAMPO, 2006). A especificidade em termos de hospedeiro dos PVs foi comprovada na década de 1970 (KOLLER; OLSON, 1972). No estudo, bezerros recém-nascidos, hâmsters, pôneis e macacos Rhesus (Macaca mulata) foram inoculados com partículas de BPV e HPV isoladas por ultracentrifugação (KOLLER; OLSON, 1972). Os resultados mostram que apenas o BPV foi capaz de infectar as espécies analisadas (KOLLER; OLSON, 1972). Devido sua capacidade de infectar diferentes espécies, o BPV é considerado o melhor modelo de compreensão dos processos oncogênicos associados ao vírus (CAMPO, 2002, 2006; COSTA; MEDEIROS, 2014; KOLLER; OLSON, 1972; LIU et al., 2005). Neste sentido, estudos envolvendo a PB atraem grande interesse, seja pelos aspectos econômicos, decorrentes das perdas registradas na bovinocultura, como também pela buiatria e pelo interesse científico (CAMPO, 2002, 2006; LIU et al., 2002).

As pesquisas envolvendo o BPV têm contribuído sobremaneira com 0 entendimento dos mecanismos moleculares associados à oncogênese viral (COSTA; MEDEIROS, 2014; MUNDAY, 2014b). Além do mais, muitas são as semelhanças entre o BPV e o HPV (MUNDAY, 2014b). Isto porque estes vírus são morfologica e patologicamente semelhantes (CAMPO, 2006; KARLIN et al., 1984). Além disso, o BPV e o HPV compartilham vias de infecção em comum, podendo ser transmitidos verticalmente (CARVALHO et al., 2003; FREITAS et al., 2003; 
MUNDAY, 2014b). Estes vírus também compartilham mecanismos carcinogênicos e fisiopatológicos em comum (LIU et al., 2005). Por estas razões, as malignidades associadas ao BPV (câncer de bexiga e trato digestório superior) serão tratadas de forma comparativa ao HPV na seção 2.9.

\subsection{Neoplasias malignas associadas aos papilomavírus}

\subsubsection{Carcinoma de bexiga urinária}

Embora considerados raros, os carcinomas de bexiga urinária em bovinos são frequentes em países como Bélgica, Turquia, Panamá e Brasil (PAMUKCU; GOKSOY; PRICE, 1967). Estas neoplasias acometem tanto a epiderme quanto a derme (BALCOS et al., 2008; COSTA; MEDEIROS, 2014), representando 0,01\% das malignidades em bovinos (ROPERTO et al., 2015b).

O papel etiopatogênico do BPV no carcinoma de bexiga foi demostrado pela primeira vez em 1955 no Brasil e na África (PLOWRIGH, 1955). Hoje, sabe-se que o BPV possui um importante papel promotor no carcinoma urotelial e hemangiotelioma de capilares subjacentes (BALCOS et al., 2008; CAMPO, 2006; RUSSO et al., 2016; WOSIACKI et al., 2002). Estima-se que carcinoma urotelial associado ao BPV tenha causado um prejuízo econômico de quatro milhões de euros entre os anos de 2000 e 2006 em Azores, Portugal (COSTA; MEDEIROS, 2014). Entretanto, a capacidade promotora do câncer de bexiga não é restrita apenas ao BPV, visto que sequências de HPV já foram identificadas em neoplasias do trato urinário de humanos, reforçando o papel do BPV como modelo nos estudos oncogênicos (CAMPO, 2002).

Clinicamente, o carcinoma de bexiga é caracterizado por um quadro de hematúria enzoótica bovina (HEB) que conduz à anemia e ao emagrecimento progressivo (WOSIACKI et al., 2002). A HEB está presente em mais de $90 \%$ das neoplasias de bexiga urinária (RESENDES et al., 2011), sendo majoritariamente observada em bovinos de três a cinco anos, sem preferência por raça (WOSIACKI et al., 2002). A HEB está associada a fatores ambientais como: (1) a falta ou excesso de molibdênio no solo e, (2) o consumo de plantas tóxicas, tais como: Pteridium aquilinum, $P$. esculentum, $P$. revolution, Chelanthes seiberi, Encephalartos hildebrandti, Ranunaelus montana, R. acris, Climatis vitalbai (WOSIACKI et al., 2002). Entretanto, em face de sua ampla distribuição biogeográfica, a $P$. aquilinum possui um importante agente etiopatogênico da HEB, bem como um co-fator para o carcinoma de bexiga urinária (OLIVEIRA, 2012). 
A $P$. aquilinum é uma planta invasora da família Polypodiacea (DIAS et al., 2012), presente em áreas de clima tropical e temperado (WOSIACKI et al., 2006), com elevada umidade, solos pobres, ácidos e com baixos níveis de cálcio e fósforo (OLIVEIRA, 2012; POTTER; BAIRD, 2000). A samambaia apresenta uma ampla distribuição na região Sul do Brasil, onde a HEB acomete $56,4 \%$ do rebanho, resultando em importantes prejuízos econômicos (DIAS et al., 2012). A ingestão crônica de 2-3 g/dia/peso corpóreo (PAMUKCU; PRICE; BRYAN, 1976; XU, 1992) ou aguda de $10 \mathrm{~kg} /$ dia desta pteridófita (TOKARNIA; DOBERREINER; PEIXOTO, 2000) pode levar a inapetência, anorexia, emagrecimento progressivo, andar cambaleante, diarreia sanguinolenta, tosse, disfagia, regurgitação, pancitopenia, halitose e HEB (COSTA et al., 2011; TOBAR et al., 2011). Por apresentar elevados níveis de compostos mutagênicos, carcinogênicos e imunossupressores como a quercetina, ptaquilosídeos e o ácido shikímico, a ingestão da $P$. aquilinum favorece a infecção pelo BPV (BENISTON et al., 2001; BONADIES et al., 2004; DIAS et al., 2012; SHAHIN; SMITH; PRAKASH, 1999).

Os tipos virais BPV-1 e 2 são importantes co-fatores etiológicos da HEB (CAMPO, 1997b, 2002; PAVELSKI et al., 2014; ROPERTO et al., 2005). Estes tipos virais estão diretamente associados à gênese de lesões pré-malignas na bexiga urinária (PAVELSKI et al., 2014). Além do mais, o vírus induz a hiperplasia epitelial e a proliferação fibroblástica (CHEVILLE; OLSON, 1964), ao mesmo tempo em que causa alterações genéticas que contribuem com a instabilidade genômica e a iniciação tumoral (ARALDI, 2014b; ARALDI et al., 2013a; MELO et al., 2011; STOCCO DOS SANTOS et al., 1998). Deste modo, bovinos infectados pelo BPV que se alimentam da $P$. aquilinum apresentam maior probabilidade de desenvolverem neoplasias malignas. Isto porque, os ptaquilosídeos promovem uma redução dos níveis de zinco intracelular, levando a inativação das células NK (natural killer), contribuindo para a persistência da infecção (COSTA; MEDEIROS, 2014) e a reativação de vírus latentes (PAVELSKI et al., 2014).

\subsubsection{Carcinoma de esôfago}

O carcinoma de esôfago (CE) é a oitava malignidade humana mais frequente no mundo, sendo considerada a sexta causa mortis por neoplasia maligna (ANTONSSON et al., 2010; HERBSTER et al., 2012). Considerado o terceiro câncer gastrointestinal mais comum (FELIN et al., 2008), o CE apresenta é mais frequente 
em indivíduos de sexo masculino (BJØRGE et al., 1997). Em 2002 foram registrados 462.000 casos da doença a nível mundial (ANTONSSON et al., 2010). De acordo com Instituto Nacional de Câncer (INCA), o Brasil registrou 7.636 óbitos pela doença em 2011 e, 10.780 novos casos em 2014 (INCA, 2014). Estes dados requerem atenção, uma vez que o CE uma elevada mortalidade (HAN et al., 1996), a qual é 25\% superior a do câncer cervical (KAHRILAS; HIRANO, 2013). Isto porque, de acordo com o National Institute of Health, apenas $18,4 \%$ dos pacientes diagnosticados com CE entre 2006-2012 sobreviveram por mais de cinco anos nos Estados Unidos (NIH, 2017).

Entre os sinais clínicos de CE estão: disfagia ${ }^{3}$ progressiva, emagrecimento, odinofagia $^{4}$, anorexia, quadro febril e dor retroesternal (FELIN et al., 2008; HASTER; OWYANG, 2013). Sintomas estes semelhantes àqueles observados em bovinos (BORZACCHIELLO et al., 2003). O diagnóstico da doença requer endoscopia digestiva alta (EDA), acompanhada de biópsia (FELIN et al., 2008; HASTER; OWYANG, 2013), procedimento relativamente custoso, sobretudo no setor veterinário. Este fato dificulta a obtenção de dados epidemiológicos acerca do CE em bovinos. Somado a isto, o diagnóstico é, normalmente, realizado muito tardiamente, a partir do surgimento da disfagia, resultando em um pior prognóstico (FELIN et al., 2008). Uma das razões que justifica o diagnóstico tardio é a ausência de dispepsia ${ }^{5}$ (HASTER; OWYANG, 2013). Apenas 10\% dos pacientes apresentam uma sobrevida de cinco anos (FELIN et al., 2008).

Poucos dados epidemiológicos acerca do CE em animais estão disponíveis. Em humanos, o CE apresenta uma incidência variável de acordo com a região geográfica (ANTONSSON et al., 2010; BJØRGE et al., 1997; GUO et al., 2012; NASROLLAHZADEH et al., 2015; SYRJÄNEN, 2002). Entre os países de alto risco para a doença encontram-se: China, Singapura, Iran, Suíça, África do Sul e Brasil (BEY et al., 1976; GUO et al., 2012; HAN et al., 1996; SYRJÄNEN, 2002). A elevada incidência de CE na Ásia Central fez com que a região passasse a ser conhecida por Cinturão do Câncer Esofágico da Ásia Central (CCEAC, figura 13) (NASROLLAHZADEH et al., 2015). Embora as razões que determinam a variação da incidência do CE sejam desconhecidas (NASROLLAHZADEH et al., 2015;

\footnotetext{
${ }^{3}$ Disfagia - dificuldade de deglutir alimentos (HASTER; OWYANG, 2013).

${ }^{4}$ Odinofagia - dor causada ou agravada pela deglutição (KAHRILAS; HIRANO, 2013).

${ }^{5}$ Dispepsia - desconforto ou dor em ardência crônica ou recidivante no abdómen superior (HASTER; OWYANG, 2013).
} 
SYRJÄNEN, 2002), elas indicam a ação de fatores ambientais, como agentes infecciosos, na indução e promoção da malignidade (ANTONSSON et al., 2010; CHANG et al., 1992).

Figura 13 - Cinturão do câncer de esôfago da Ásia Central

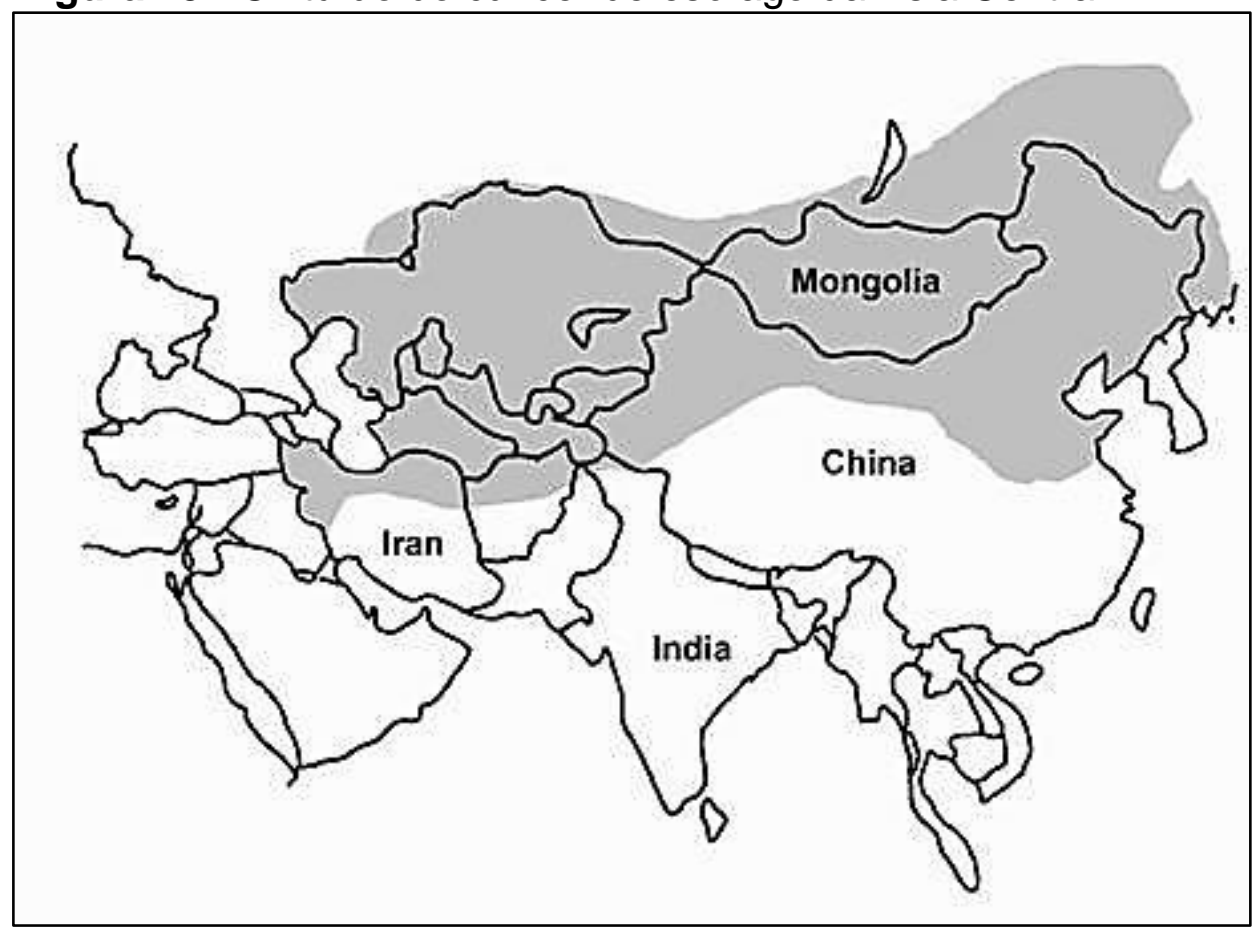

Fonte: Kamangar et al.(2007)

O tabagismo e etilismo são apontados como os principais fatores de risco para O CE em humanos (HAN et al., 1996; HASTER; OWYANG, 2013; LAGERGREN et al., 1999; SYRJÄNEN, 2002). Entretanto, por razões sócioculturais, o tabagismo e etilismo não justificam a elevada incidência da doença no CCEAC (NASROLLAHZADEH et al., 2015). A deficiência de certos micronutrientes, tais como vitamina $A, B$ e $C$, ingestão de alimentos quentes e baixo consumo de vegetais e frutas também contribuem para a malignidade em humanos (HAN et al., 1996; HASTER; OWYANG, 2013; SYRJÄNEN, 2002), da mesma forma que a deficiência de fósforo e cobalto estão relacionadas com o CE em bovinos (PLOWRIGHT; LINSELL; PEERS, 1970). O refluxo crônico da secreção ácida é outro importante fator etiológico do CE (HASTER; OWYANG, 2013). O refluxo leva a metaplasia de Barrett, caracterizada pela substituição da mucosa normal do esôfago distal por epitélio colunar especializado, conforme figura 14 (HASTER; OWYANG, 2013). Entretanto, estudos recentes apontam o papel etiopatogênico de diferentes 
agentes infecciosos no $\mathrm{CE}$, tais como: citomegalovírus (CMV), Epstein-Barr vírus (EBV), herpes simples e HPV (SYRJÄNEN, 2002).

Figura 14 - Metaplasia de Barrett

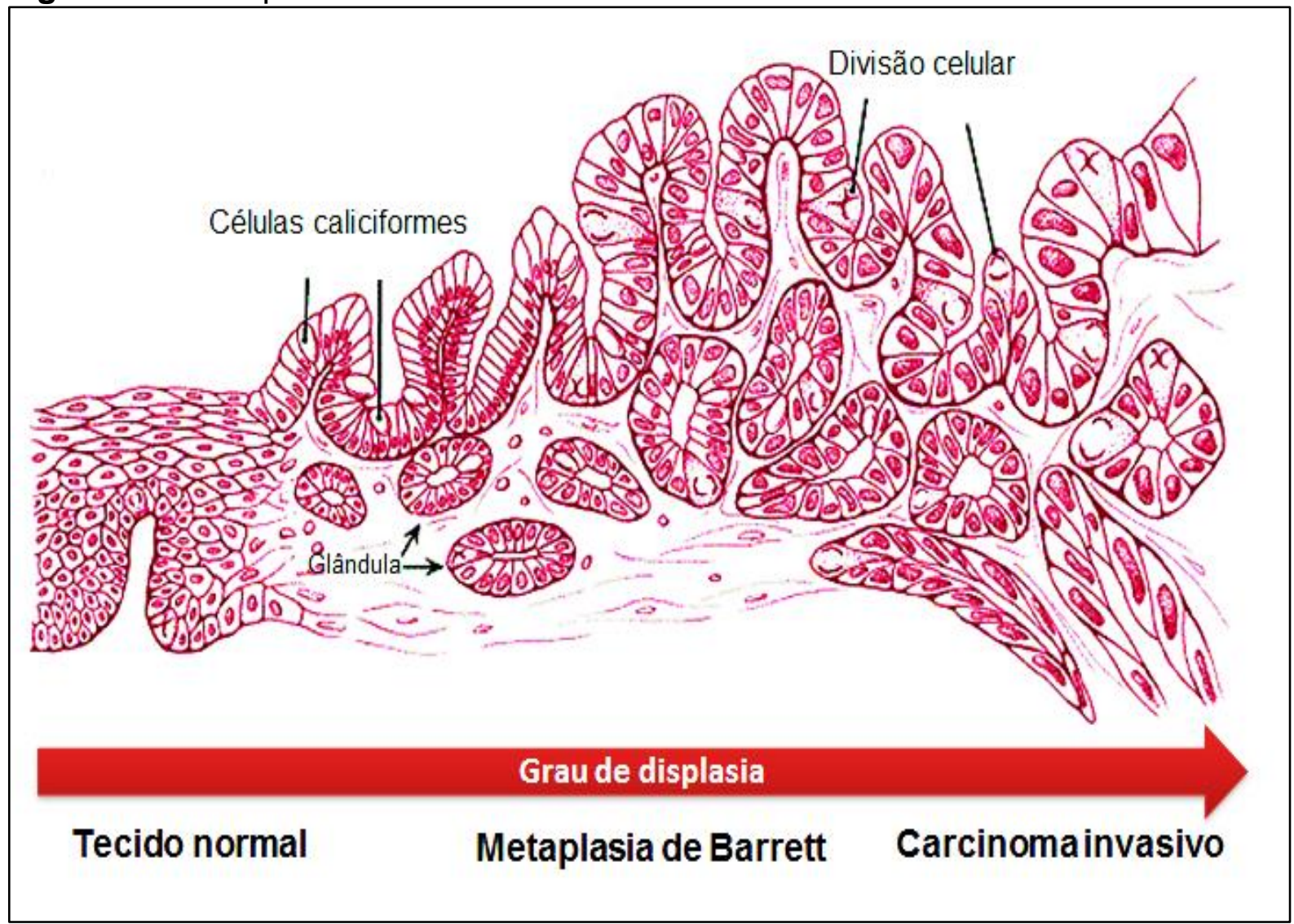

Progressão displásica do tecido esofágico, mostrando a substituição da mucosa do esôfago por células caliciformes especializadas, configurando a metaplasia de Barrett. O aumento do grau de displasia desta alteração, associada a proliferação celular resulta em um carcinoma invasivo. Fonte: Modificado de Johns Hopkins Pathology (http://pathology2.jhu.edu/beweb/Definition.cfm).

A associação entre o HPV e o CE foi proposta pela primeira vez por Syrjänen (1982). Desde então, as infecções pelo HPV têm recebido especial atenção por sua associação com o CE (HAN et al., 1996). Em sua 18ª edição, o Tratado de Medicina Interna de Harrinson já considera a participação do HPV no CE (KAHRILAS; HIRANO, 2013). O HPV é considerado o principal fator de risco para o CE em indivíduos não tabagistas e/ou etilistas (HERBSTER et al., 2012). Estudos recentes mostram, também, a associação entre o HPV e a metaplasia de Barrett e o adenocarcinoma de esôfago (VIEIRA; LOPES; VELOSA, 2013).

Embora a associação entre o HPV e lesões pré-malignas de cérvice uterina seja conhecida desde a década de 1970 (SYRJÄNEN, 2002), o reconhecimento do papel etiológico do HPV no câncer de esôfago em humanos teve sua história 
marcada por uma literatura, a priori, controversa (LAVERGNE; DE VILLIERS, 1999). Se por um lado a expressão de proteínas de HPV foi observada em amostras de CE por meio de IHQ-P (HILLE et al., 1986; KULSKI et al., 1986; WINKLER et al., 1985) e, sequências de DNA viral foram identificadas por meio de CISH (CHANG et al., 1993; COOPER; TAYLOR; GOVIND, 1995; TOGAWA et al., 1994), por outro, os estudos sorológicos contestavam tais resultados (DILLNER et al., 1995; HAN et al., 1996; LAGERGREN et al., 1999).

Entretanto, hoje se sabe que os resultados controversos obtidos pela sorologia se devem a problemas metodológicos, decorrentes da sensibilidade dos diferentes métodos diagnósticos empregados, bem como de erros de interpretação dos resultados (GUO et al., 2012; LAVERGNE; DE VILLIERS, 1999; SYRJÄNEN, 2002). Isto porque os testes sorológicos empregavam anticorpos não comerciais, direcionados contra proteínas do capsídeo viral de HPV-16 e 18 (DILLNER et al., 1995; LAGERGREN et al., 1999). Entretanto, os PVs apresentam uma infecção abortiva em carcinomas, tanto em humanos (SYRJÄNEN, 2002). Desta forma, a ausência de expressão das proteínas tardias (L1 e L2) pode justificar a ausência de soropositividade em amostras infectadas pelo HPV. Outro motivo que levou à controvérsia entre a associação do HPV com o CE foi o paradigma de ciclo de infecção e replicação viral. Isto porque, até aquele momento, o HPV era visto exclusivamente como epitélio e mucosotrópico, sendo desconhecida a presença de vírus no sangue periférico (DILLNER et al., 1995).

Não somente os estudos sorológicos mostraram-se a priori inconclusivos. Estudos moleculares, empregando PCR como ferramenta diagnóstica, também revelaram uma baixa prevalência de DNA de HPV em amostras de neoplasias esofágicas provenientes da Austrália (ANTONSSON et al., 2010; ANTONSSON; KNIGHT; WHITEMAN, 2016). Entretanto, tal resultado foi decorrente do local de coleta de tais amostras, já que a Austrália não se encontra entre as áreas geográficas de alto risco (ANTONSSON et al., 2010). A doença é mais prevalente no CCEAC e em países em desenvolvimento, como o Brasil (CAMPO, 2006). Além do mais, problemas envolvendo a sensibilidade e especificidade dos primers empregados no diagnóstico são extensivamente reportados na literatura (ARALDI et al., 2014a; DE VILLIERS, 2013; LAVERGNE; DE VILLIERS, 1999; SILVA et al., 2013a). Porém, evidências da ação do HPV no CE têm se acumulado nos últimos 20 anos, conforme resumido na tabela 5 . 
Tabela 5 - Evidências da participação do HPV no carcinoma de célula escamosa de esôfago

\begin{tabular}{|c|c|c|}
\hline Evidências & País & Referências \\
\hline - identificação de sequências de DNA de HPV-6, 11, 16 e 18 & - China & Chang et al. (1990) \\
\hline - identificação de sequências de DNA de HPV-6, $11,16,18$ ou 30 & $\begin{array}{l}\text { - China } \\
\text { - Portugal }\end{array}$ & $\begin{array}{c}\text { Chang et al. (1993) } \\
\text { Vieira; Lopes; Velosa (2013) }\end{array}$ \\
\hline - identificação de sequências de DNA de HPV-16 e 18 & - Portugal & Fidalfo et al. (1995) \\
\hline - identificação de HPV-16 por método sorológico & - China & Han et al. (1996) \\
\hline - identificação de sequências de DNA de HPV-6, 11, 16, 18, 31 e 33 & - China e EUA & Suzuk et al. (1996) \\
\hline - identificação de sequências de DNA de HPV-16 & - China & Li et al. (2001) \\
\hline - identificação de sequências de DNA de HPV-16 e 18 & - Iran & Farhadl et al. (2005) \\
\hline - identificação de HPV-16 & - Suécia & Dreilich et al. (2006) \\
\hline - presença de coilócitos na análise histopatológica & - Oslo & $\begin{array}{l}\text { Bjørge et al. (1997) } \\
\text { Syrjänen (2002) }\end{array}$ \\
\hline
\end{tabular}


Além do mais, associação entre os HPVs de alto risco e o CE é plausível, posto que a espécie correlata (BPV) está diretamente associado a doença em bovinos (BORZACCHIELLO et al., 2003; CAMPO, 2006; LAVERGNE; DE VILLIERS, 1999; LINDSEY et al., 2009).

O CE em animais domésticos é considerado raro (TSIRIMONAKI et al., 2003). Entretanto, a ausência da epidemiologia da doença tanto em nível nacional como internacional pode subestimar a importância do CE em ruminantes. O CE em bovinos, também conhecido por caraguatá (figura 15) está diretamente associada ao mucosotropismo do BPV-4 (BORZACCHIELLO et al., 2003; MASUDA et al., 2011).

Figura 15 - Imagens de carcinoma de esôfago ('caraguatá")

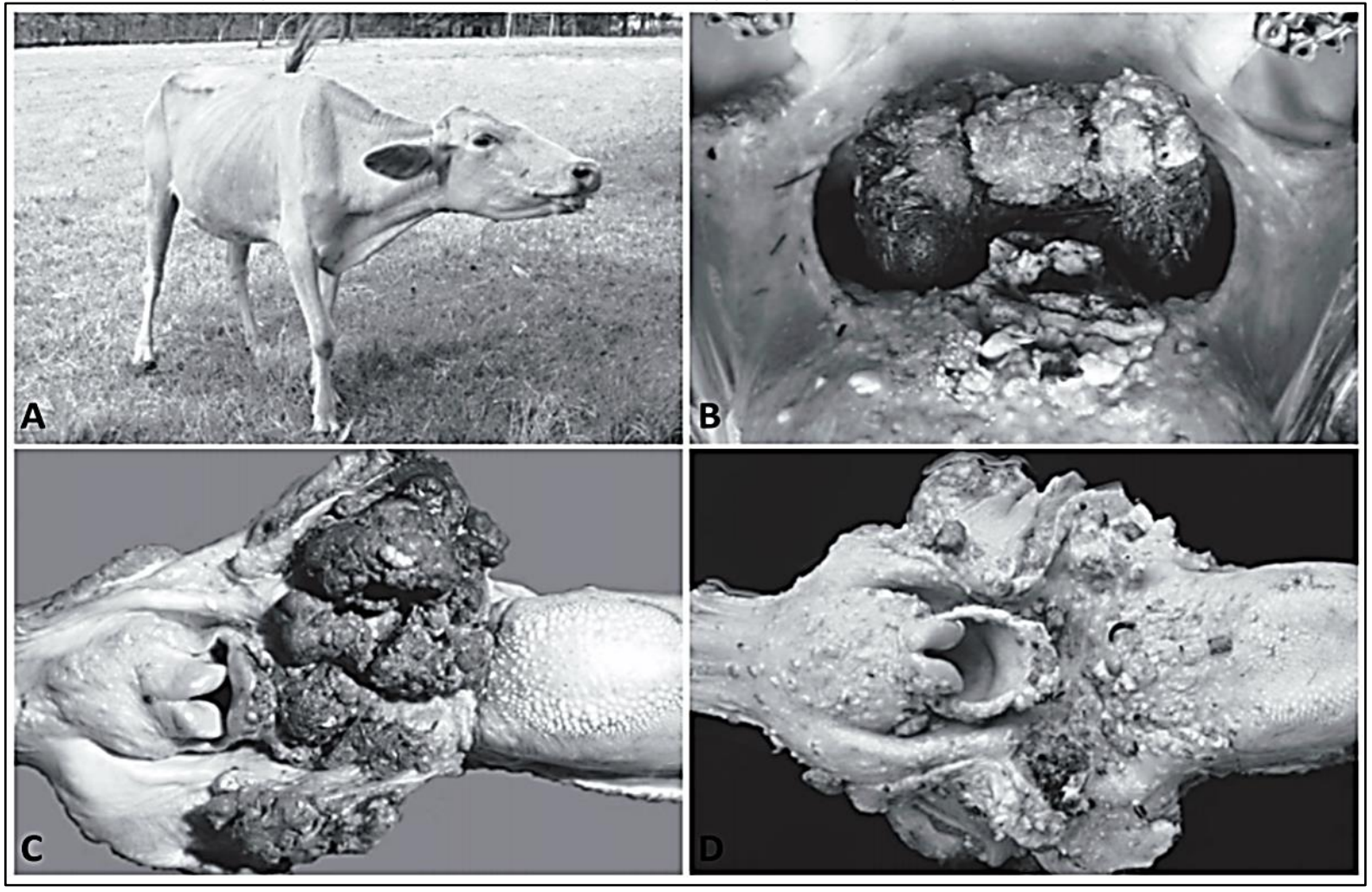

A) Tosse e distensão do pescoço, sinais característicos da neoplasia. B) Carcinoma de célula escamosa (CCE) exofítico e pedunculado na base da língua. C) CCE exofítico na faringe/orofaringe. D) Papilomatose acentuada na região cranial do trato digestório superior. Fonte: Souto et al. (2006).

Estudo realizado na Alemanha mostrou que médicos veterinários que manipulavam bovinos apresentavam mais verrugas vulgares (BOSSE; CHRISTOPHERS, 1964). Estudo recente, realizado no CCEAC, mostrou uma forte associação estatística entre o CE em humanos e o contato com ruminantes, onde, por questões socioeconômicas e culturais, crianças com menos de três anos já têm contato direto com bovinos (NASROLLAHZADEH et al., 2015). Sabe-se, ainda que 
na Ásia Central há um grande consumo de leite (NASROLLAHZADEH et al., 2015), onde sequências de DNA de BPV já foram identificadas (LINDSEY et al., 2009). Neste sentido, a termorresistência do capsídeo viral do BPV permite sua sobrevivência mesmo após a pasteurização do leite (ZUR HAUSEN, 2012). Estudo também demonstrou uma elevada incidência de verrugas nas mãos de açougueiros, as quais foram atribuídas a infecções por HPV-7, tipo viral também relacionado ao carcinoma de pulmão (SHU et al., 2011). Embora não esteja claro se o BPV pode ser transmitido a humanos, estes dados sugerem que o BPV possa ser um agente etiopatogênico adicional do CE em humanos.

Sabe-se que o HPV tem uma ação mais crítica na iniciação do que na manutenção do CE (HAN et al., 1996), apresentando um mecanismo hit and run (BJØRGE et al., 1997). Este mecanismo também é observado na biologia do BPV-4, que atua nos primeiros passos da transformação celular, porém, não é requerido na progressão maligna (SYRJÄNEN, 2002).

Reconhecer CE decorrentes de infecções pelos PVs é importante no direcionamento clínico da terapêutica (ANTONSSON et al., 2010). Isto porque, CE HPV-positivos são mais susceptíveis a radioterapia (GILLISON et al., 2000; MORK et al., 2001; SETTLE et al., 2009). Além do mais, compreender os mecanismos moleculares que regulam a diferenciação, crescimento e invasão é fundamental na busca de novos quimioterápicos (FELIN et al., 2008).

Embora a associação entre o PV e o CE esteja clara, os mecanismos carcinogênicos do vírus ainda permanecem não totalmente elucidados (HERBSTER et al., 2012). Neste sentido, os estudos com cultura de células primárias de $C E$ representam um importante avanço na oncologia, pois permitem análises sob condições controladas (BEY et al., 1976).

\subsection{A história natural das neoplasias malignas}

O câncer é definido por um conjunto de doenças de alta complexidade, com causa multifatorial (MORIN et al., 2013; WEINSTEIN, 1988a). A despeito dos avanços no campo na oncologia, o número de óbitos pela doença permanece elevado, fazendo do câncer um importante problema de saúde pública (SACHS; CLEVERS, 2014). Teorias que buscam descrevem o processo oncogênico têm sido propostas há séculos (RUBIN, 1985). Embora tais teorias permaneçam em discussão até os dias atuais (SONNENSCHEIN; SOTO, 2008), os avanços na 
tecnologia de sequenciamento de exoma têm reunido evidências que sustentam o modelo estocástico, também conhecido por teoria da mutação somática (ALEXANDROV; STRATTON, 2014; SONNENSCHEIN; SOTO, 2008).

O modelo estocástico foi inicialmente proposto pelo médico cirurgião e oncologista Karl-Heinrich Bauer em 1928 (BRÜCHER; JAMALL, 2014). Este modelo se baseia nas premissas de que o câncer é resultante de uma única célula somática que acumulou mutações randômicas, afetando genes que regulam a proliferação celular (BRÜCHER; JAMALL, 2014; INGBER, 2008; SONNENSCHEIN; SOTO, 2008; WEINSTEIN et al., 1984). Tais mutações são resultantes de um processo cumulativo que opera desde a primeira divisão celular após a fertilização do ovócito secundário (ALEXANDROV; STRATTON, 2014). Considerando tais premissas, o câncer é uma consequência natural da multicelularidade, decorrente de um desequilíbrio de cooperação entre proto-oncogenes e genes supressores tumorais (ARNAL et al., 2016). Tal desequilíbrio pode ser decorrente de mutações endógenas ou exógenas, induzidas por agentes ambientais de natureza física, química e/ou biológica (BUTEL, 2000). Neste sentido, os estudos sobre o processo oncogênico associado às viroses têm trazido importantes avanços na oncologia, permitindo estabelecer paradigmas na biologia do câncer (BUTEL, 2000; MCFADDEN et al., 2016).

Desta forma, a biologia molecular contemporânea reconhece que o processo oncogênico apresenta uma dinâmica evolutiva Darwiniana (CRESPI; SUMMERS, 2005), na qual se verifica uma série de alterações sequenciais que caracterizam a história natural da doença (LACONI; DORATIOTTO; VINEIS, 2008). A luz da evolução, a carcinogênese pode ser definida como um processo de múltiplas etapas, decorrente da evolução clonal de células somáticas, governado por mudanças graduais e herdáveis na subpopulação neoplásica e pressão de seleção que promove a proliferação de fenótipos mais bem adaptados ao seu microambiente (SMALLBONE et al., 2007). Entre as múltiplas etapas descritas durante a carcinogênese estão: a iniciação, progressão, promoção e metástase (FARBER, 1984; HANAHAN; WEINBERG, 2011; KLAUNIG; KAMENDULIS, 2004).

A iniciação é um processo irreversível, resultante da exposição de célula normal a um agente capaz de promover danos no material genético (mutágeno), levando a instabilidade genômica (BURRELL; SWANTON, 2014; CERUTTI, 1988; DIGIOVANNI, 1992; FARBER, 1984; NEGRINI; GORGOULIS; HALAZONETIS, 
2010; WEINSTEIN, 1988b). Entretanto, a instabilidade genômica é necessária, porém não suficiente para promover a carcinogênese, (CERUTTI, 1988; ZUR HAUSEN, 2009). Isto porque, embora as alterações genéticas elevem o fitness das células iniciadas, favorecendo a expansão de subclones geneticamente instáveis (CERUTTI, 1988; GERLINGER et al., 2014), alterações no metabolismo celular são adicionalmente requeridas para garantir o aporte energético (RODRIGUEZ, 2016; WEINSTEIN et al., 1984). Desta forma, a perda da inibição do potencial de crescimento, alterações morfológicas e metabólicas caracterizam a promoção do câncer (BLACK, 1968; FARBER, 1984; LEUNG; BRUGGE, 2012). Por esta razão, Peyton Rous definiu a progressão como um "processo no qual o tumor vai de ruim para pior" (YU; MOUW; WEAVER, 2011).

A promoção neoplásica, por sua vez, é caracterizada pela expansão clonal de células bioquímica e morfologicamente alteradas (CERUTTI, 1988; DIGIOVANNI, 1992). Desta forma, a expansão clonal de células sem danos no DNA leva a formação de neoplasias benignas, tais como papilomas ou pólipos, ao passo que a expansão de células geneticamente instáveis, a neoplasias malignas (CERUTTI, 1988). Neste sentido, a expansão de sub-clones de células cancerígenas leva a formação de sub-populações celulares geneticamente distintas, justificando a extensa heterogeneidade do microambiente neoplásico (BURRELL; SWANTON, 2014). Desta forma, se por um lado as células cancerígenas são simpatricamente originadas, por outro, a expansão de um determinado sub-clone pode levar a extinção de seu ancestral em um processo conhecido por "varredura clonal" (clonal sweep) (BURRELL; SWANTON, 2014; CRESPI; SUMMERS, 2005). Porém, considerando que a competição é a maior força de adaptação dentro do câncer, diferentes sub-clones podem evoluir em paralelo em um processo de evolução ramificada, elevando a heterogeneidade (BURRELL; SWANTON, 2014; YU; MOUW; WEAVER, 2011) e desorganização da arquitetura normal do tecido (INGBER, 2008; SONNENSCHEIN; SOTO, 2008). A competição entre sub-clones de células cancerígenas leva a adaptações como a aquisição do fenótipo glicolítico e a invasão de tecidos adjacentes, resultando em metástases (CRESPI; SUMMERS, 2005; FANG; GILLIES; GATENBY, 2008). 


\subsection{Alterações metabólicas após a iniciação neoplásica}

O ganho de potencial proliferativo verificado durante a promoção do câncer requer importantes mudanças no metabolismo energético a fim de fornecer o aporte de energético necessário à replicação (RODRIGUEZ, 2016; SALAZAR-ROA; MALUMBRES, 2016).

Os carboidratos são as principais fontes de energia das células (LEATHERWOOD, 1998), que convertem a glicose a piruvato por meio da glicólise (CUNINGHAME; JACKSON; ZEHBE, 2014). Sob condições aeróbicas, o piruvato é convertido a acetil-CoA, que é direcionado às mitocôndrias, onde participa do ciclo dos ácidos tricarboxílicos (CUNINGHAME; JACKSON; ZEHBE, 2014). Durante este processo, o dinucleotídeo de adenina e flavina (FADH) e o dinucleotídeo de nicotina e adenina $\left(\mathrm{NADH}_{2}\right)$ doam elétrons a complexos proteicos da cadeia transportadora de elétrons, gerando uma força próton-motora decorrente do transporte de prótons $\left(\mathrm{H}^{+}\right)$do espaço intermembrana para a matriz mitocondrial através da ATP sintase (CUNINGHAME; JACKSON; ZEHBE, 2014). Esta força próton-motora origina o potencial de membrana mitocondrial $\left(\Delta \Psi_{\mathrm{m}}\right)$ (AKERMAN; WIKSTRIJM, 1976; GOTTLIEB et al., 2003), requerido à síntese de adenosina trifosfato (ATP), que se dá pela ligação da adenosina difosfato (ADP) ao fosfato inorgânico (Pi) verificada na ATP sintase, conforme figura 16 (CUNINGHAME; JACKSON; ZEHBE, 2014). 
Figura 16 - Geração do potencial de membrana mitocondrial

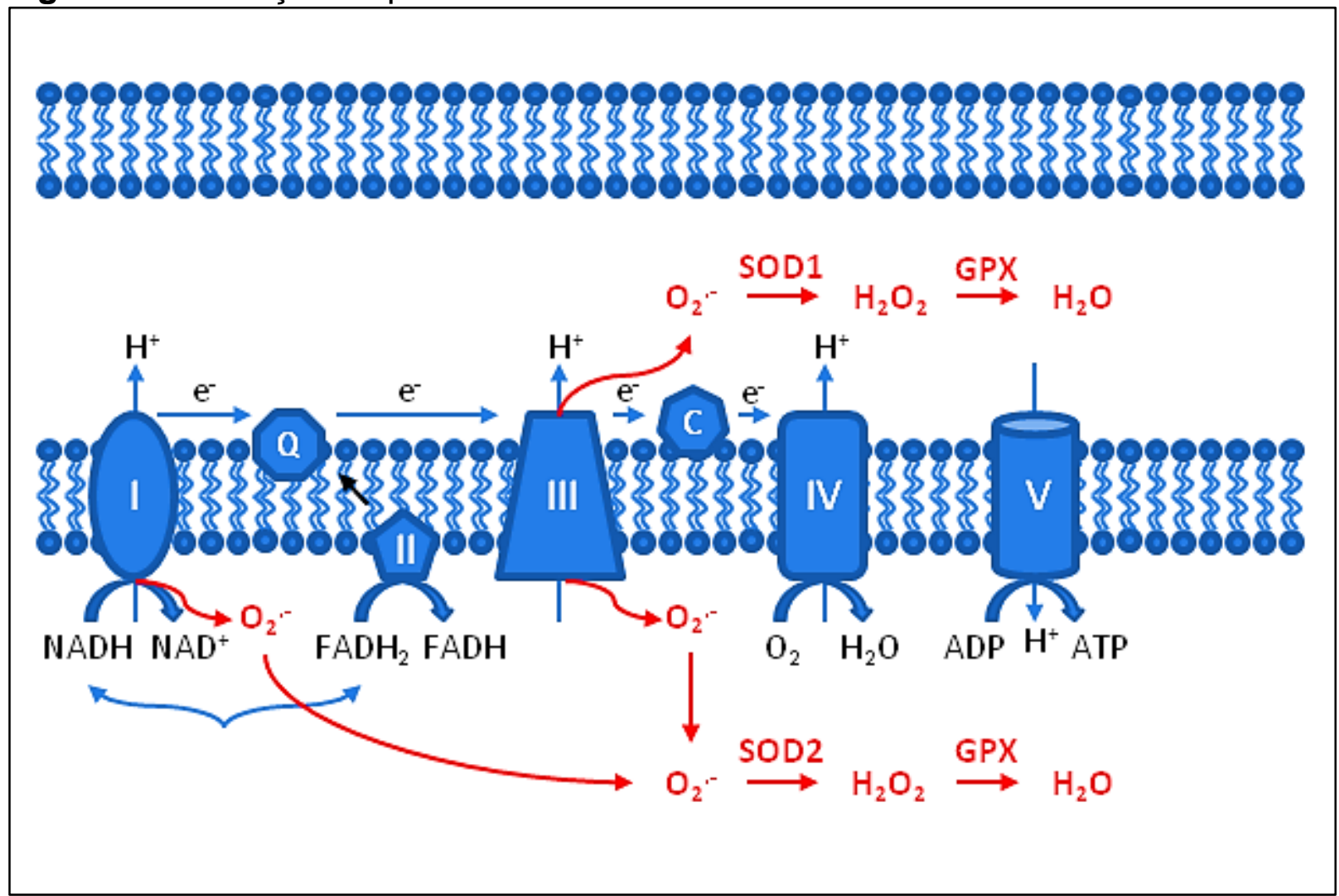

O elétron $(\bar{e})$ liberado do NADH é transferido do complexo I para a coenzima Q. O elétron $(\bar{e})$ liberado do $\mathrm{FADH}_{2}$ é transferido do complexo II para a coenzima Q. Tais transferências promovem a oxidação do complexo III, promovendo a transferência de dois elétrons para o citocromo c. Um total de quatro elétrons do citocromo c são transferidos para uma molécula de oxigênio. Este processo resulta na redução de uma molécula de água. O movimento de elétrons dos complexos I-IV resulta na força próton-motora, formando um gradiente de hidrogênio necessário à síntese de ATP. Fonte: Modificado de Li et al. (2013).

A manutenção do $\Delta \Psi \mathrm{m}$ é fundamental à sobrevivência celular (LY; GRUBB; LAWEN, 2003). Isto porque, a redução do $\Delta \Psi_{\mathrm{m}}$ promove a abertura de poros de permeabilidade transitória (PPTs), canais responsivos a $\mathrm{K}^{+}, \mathrm{Ca}^{2+}$ e $\mathrm{Mg}^{2+}$, que permitem a passagem de substâncias de até $1,5 \mathrm{kDa}$ (LY; GRUBB; LAWEN, 2003). A abertura dos PPTs resulta na liberação de fatores apoptogênicos como o citocromo $c$, que se liga ao fator 1 de ativação de proteases (Apaf-1), ativando caspase 9 (LI; DIETZ; VAN HARSDORF, 1999), levando a inibição da síntese de ATP (GOTTLIEB et al., 2003).

Se por um lado o metabolismo oxidativo confere um elevado saldo energético (32 mol de ATP), por outro ele resulta na produção de espécies reativas de oxigênio (EROs), incluindo: ânion superóxido $\left(\mathrm{O}_{2^{*}}\right)$, peróxido de hidrogênio $\left(\mathrm{H}_{2} \mathrm{O}_{2}\right)$, ânion hidroxil $\left(\mathrm{OH}^{*}\right)$, oxigênio singleto $\left({ }^{1} \mathrm{O}_{2}\right)$, radical peroxil $\left(\mathrm{LOO}^{*}\right)$, aldoxil $\left(\mathrm{LO}^{*}\right)$, hidroperóxido lipídico ( $\mathrm{LOOH}$ ), peroxinitrito (OWOO-), ácido hipocloroso ( $\mathrm{HOCl})$ e ozônio $\left(\mathrm{O}_{3}\right)$ (CICHON; RADISKY, 2014; LEE; NELSON, 2012; LI; JIA; TRUSH, 
2016; RECZEK; CHANDEL, 2015; SCHIEBER; CHANDEL, 2014). As EROs são produtos resultantes da redução parcial do oxigênio (AKERMAN; WIKSTRIJM, 1976; RECZEK; CHANDEL, 2015; WALLACE, 2010). Isto porque, o oxigênio molecular $\left(\mathrm{O}_{2}\right)$ é reduzido a radical superóxido $\left(\mathrm{O}_{2}^{-}\right)$, de acordo com a reação:

$$
\mathrm{O}_{2}+\bar{e} \rightarrow \mathrm{O}_{2}^{-}
$$

O radical superóxido é convertido a peróxido de hidrogênio $\left(\mathrm{H}_{2} \mathrm{O}_{2}\right)$ pela superóxido dismutase 1 (SOD1) ou 2 (SOD2), de acordo com a reação de Fenton (KLAUNIG; KAMENDULIS, 2004; WARIS; AHSAN, 2006):

$$
\mathrm{O}_{2}^{-}+2 \bar{e} \rightarrow 1 / 2 \mathrm{O}_{2}+1 / 2 \mathrm{H}_{2} \mathrm{O}_{2}
$$

O peróxido de hidrogênio pode reagir com o oxigênio molecular, gerando radical hidroxil ( ${ }^{*} \mathrm{OH}$ ) através da reação de Harber-Weiss (DE MARCO, 2013):

$$
\mathrm{O}_{2}+\mathrm{H}_{2} \mathrm{O} \rightarrow \mathrm{O}_{2}+\mathrm{OH}^{-}+\cdot \mathrm{OH}
$$

Desta forma, $1-2 \%$ de todo oxigênio $\left(\mathrm{O}_{2}\right)$ é reduzido para oxigênio singleto $\left({ }^{1} \mathrm{O}_{2}\right)$ (TURRENS, 2003), em uma reação que requer um $\Delta \Psi_{\mathrm{m}}$ de $-160 \mathrm{mV}$ (MURPHY, 2009). O oxigênio singleto é capaz de se ligar a lipídeos, levando a formação de hidroxiperóxido e endoperóxido, que podem se ligar a resíduos de metionina, triptofano, histidina e cisteína (DE MARCO, 2013). Além do mais, o radical hidroxil é reconhecido como a principal ERO, podendo interagir com o DNA, induzindo diversas mutações, tal como mostrado na figura 17 (BLEIER et al., 2015; FUKAWA et al., 2012; KUO; YANG, 2008). 
Figura 17 - Mutações induzidas pelo radical hidroxil

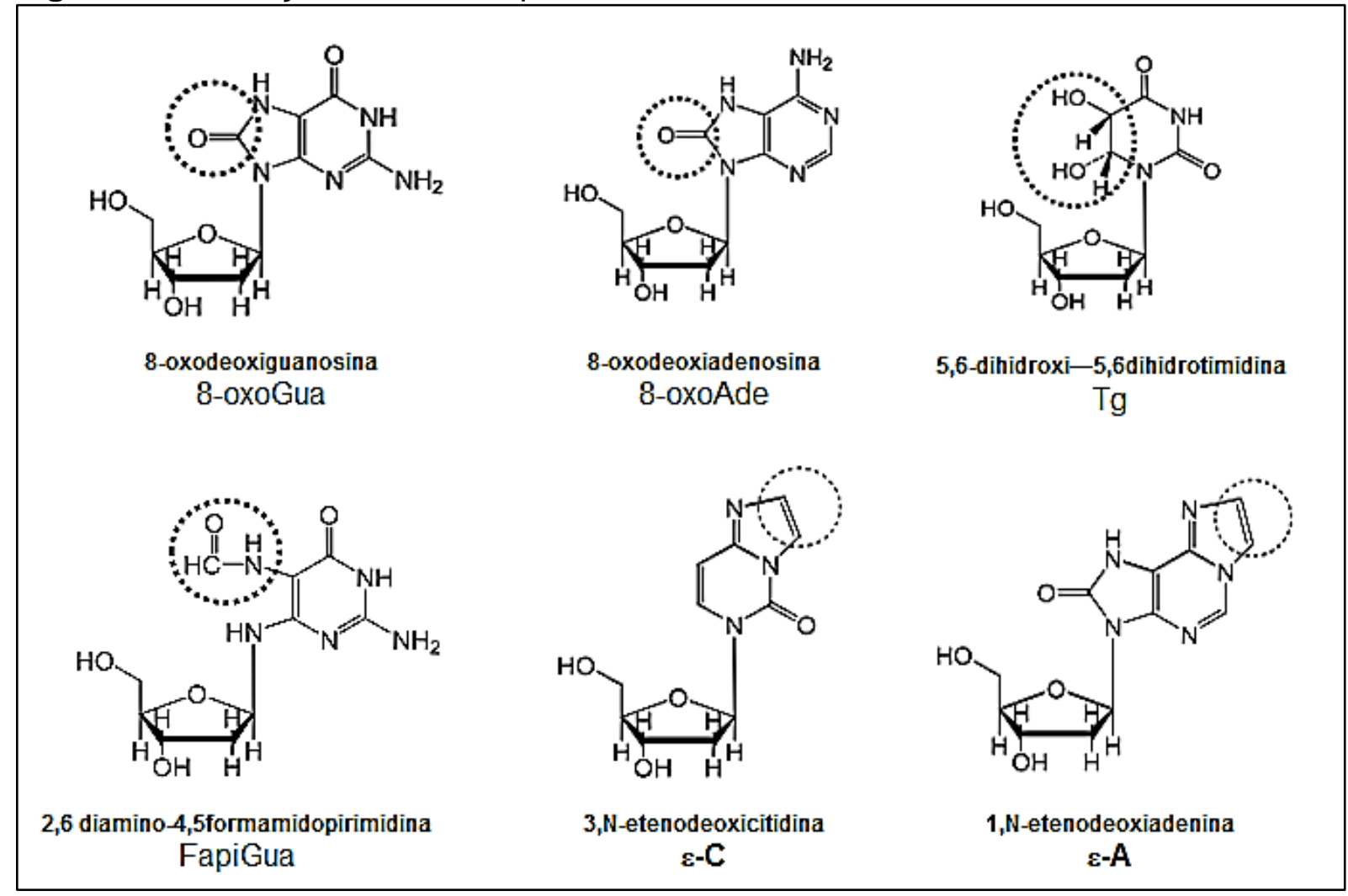

Diferentes lesões no DNA induzidas pelo radical hidroxil. Fonte: Modificado de De Marco (2013).

Embora historicamente reconhecidas como tóxicas, hoje se sabe que as EROs atuam em diferentes processos de sinalização celular (LI et al., 2013). Isto proque, o ânion superóxido $\left(\mathrm{O}_{2}^{-}\right)$, produzido pelo complexo III da cadeia transportadora de elétrons, pode ser convertido a peróxido de hidrogênio $\left(\mathrm{H}_{2} \mathrm{O}_{2}\right)$ pela enzima isoforma 1 da enzima superóxido dismutase (SOD1) (CUNINGHAME; JACKSON; ZEHBE, 2014). Quando no citosol, o peróxido de hidrogênio se difunde e passa a atuar como segundo mensageiro, mediando a oxidação de resíduos de cisteína (Cys) presentes em proteínas (BLEIER et al., 2015; SCHIEBER; CHANDEL, 2014). Sob pH fisiológico, tais resíduos estão presentes na forma de ânion tiolato (Cys-S), sendo susceptível a oxidação (SCHIEBER; CHANDEL, 2014). Uma vez oxidado, este ânion adquire a forma protonada (Cys-SH) (SCHIEBER; CHANDEL, 2014). Desta forma, o peróxido de hidrogênio oxida o ânion tiolato para a forma sulfênica (Cys-SOH), causando mudanças alostéricas, alterando a função proteica de forma irreversível (SCHIEBER; CHANDEL, 2014). Desta forma, as EROs agem como mensageiros secundários, promovendo a imunomodulação e/ou a divisão celular (BLEIER et al., 2015; LEE; NELSON, 2012; SCHIEBER; CHANDEL, 2014). 
As EROs são essenciais na ativação de receptores Tool-like, como TLR1, TLR2 e TLR4, que participam da resposta imune (SCHIEBER; CHANDEL, 2014). Neste sentido, estudos apontam que a oncoproteína E5 de BPV induz a redução dos níveis de expressão de TLR4 (DELIGEOROGLOU et al., 2013; MOSSERI et al., 2014). Resultados semelhantes também foram observados em infecções pelo HPV (BOCCARDO; LEPIQUE; VILLA, 2010; HASAN et al., 2007; LEPIQUE et al., 2009). Estes dados sugerem que os PVs são capazes de interagir com metabolismo celular, garantindo a imuno evasão e, portanto, a persistência da infecção viral.

No entanto, durante o processo oncogênico, é verificado uma reprogramação do metabolismo energético nas sub-populações que compõe o microambiente neoplásico (HANAHAN; WEINBERG, 2011). A compreensão dos mecanismos que regulam tais alterações laureou o bioquímico alemão Otto Warburg com o Prêmio Nobel de Medicina em 1931 (FERREIRA, 2010; WARBURG, 1953). De acordo com a teoria proposta por Warbug, as células cancerígenas direcionam seu metabolismo para a via glicolítica como forma alternativa de obtenção de energia em resposta a redução da pressão parcial de oxigênio (OLSON; SCHELL; RUTTER, 2016). Tal processo ficou conhecido por "efeito Warburg", termo introduzido na década de 1970 por Efraim Racker (LIBERTI; LOCASALE, 2016).

Desta forma, o "efeito Warburg" emerge como uma consequência da expansão clonal de células cancerígenas, verificada nas neoplasias sólidas, que leva ao distanciamento de vasos sanguíneos, reduzindo o aporte de oxigênio (MORENO-SÁNCHEZ et al., 2014; SMALLBONE et al., 2007). Por esta razão, tal efeito é observado na fase pré-invasiva do câncer (FANG; GILLIES; GATENBY, 2008).

O aumento da cinética de divisão cria uma microambiente de hipóxia, verificado a uma distância de 100-200 $\mu \mathrm{m}$ dos vasos sanguíneos, levando a redução da tensão de oxigênio e, por consequência, a transcrição de fatores induzíveis de hipóxia (HIF) (ZHOU et al., 2006). O fator HIF é um heterodímero formado por uma subunidade alfa (HIF-1 $\alpha, 2 \alpha$ ou $3 \alpha$ ) e uma subunidade beta (HIF-1 $\beta$ ) (ZHOU et al., 2006). Enquanto a subunidade HIF-1 $\beta$ é constitutivamente expressa, a expressão de HIF-1 $1 \alpha$ é dependente da hipóxia, fazendo desta subunidade um sensor celular de oxigênio (ZHOU et al., 2006). Tal capacidade se deve a ligação e hidroxilação do oxigênio aos resíduos 402 e/ou 564 de prolina presentes no domínio de degradação dependente de oxigênio ( $\mathrm{ZHOU}$ et al., 2006). Uma vez hidroxilado, o fator HIF-1a se 
hetodimeriza com a subunidade HIF-1 $\beta$, podendo se ligar a sequência 5'-ACGTC-3', ativando mais de 70 genes associados a carcinogênese (FANG; GILLIES; GATENBY, 2008; KISE; KINUGASA-KATAYAMA; TAKAKURA, 2016; ZHOU et al., 2006).

A ativação do fator HIF reduz a atividade da piruvato desidrogenase (PDH) (RODRIGUEZ, 2016) e aumenta a expressão da lactato desidrogenase (LDA), resultando na produção de lactato (CUNINGHAME; JACKSON; ZEHBE, 2014). Considerando que o metabolismo oxidativo é mais eficiente do que o glicolítico (FANG; GILLIES; GATENBY, 2008; HANAHAN; WEINBERG, 2011), o "efeito Warburg" aumenta de forma compensatória a expressão de transportadores de glicose (GLUT) (WARBURG, 1953). Tal ação se dá pelo aumento da razão entre a adenosina monofosfato (AMP) e trifosfato (ATP), que promove a ativação alostérica da fosfofrutoquinase, ativando a glicólise e a expressão dos transportadores GLUT (FANG; GILLIES; GATENBY, 2008). Porém, o aumento do influxo de glicose direciona a síntese de glicogênio mediada pela enzima glicogênio sintase (GSK3) (FERREIRA, 2010; LU; FORBES; VERMA, 2002). Por esta razão, as células cancerígenas reduzem a expressão de GSK3, aumentando a taxa glicolítica (VANDER HEIDEN; CANTLEY; THOMPSON, 2009; WARBURG, 1953). Tais ações aumentam a produção de lactato, que passa a ser exportado para o meio extracelular por transportadores monocarboxilatos (MCT4), cuja expressão é aumentada durante a glicólise aeróbica (RODRIGUEZ, 2016).

Considerando que processo oncogênico segue uma dinâmica Darwiniana, no qual a competição por oxigênio e nutrientes representa a principal força de pressão do microambiente neoplásico, o "efeito Warburg" confere uma importante vantagem adaptativa às células cancerígenas, fornecendo aporte energético e contribuindo para a aquisição do fenótipo invasivo (ASGARI et al., 2015; GARBER, 2004; SMALLBONE et al., 2007). Neste sentido, a acidificação do meio extracelular, resultante da produção de lactato, atua na seleção de células com fenótipo migratório, contribuindo para a metástase (SMALLBONE et al., 2007).

\subsection{A transição epitélio-mesênquima e a aquisição do fenótipo invasivo}

A aquisição do fenótipo invasivo requer complexas alterações genéticas, bioquímicas e morfológicas que têm início com um processo conhecido por transição epitélio-mesênquima (TEM). A TEM corresponde a um processo de reprogramação 
biológica, que resulta na perda da adesão e a aquisição do fenótipo invasivo (CICHON; RADISKY, 2014; HUBER; KRAUT; BEUG, 2005; KALLURI; WEINBERG, 2009; LEE; NELSON, 2012; RADISKY, 2005). Tal processo foi verificado pela primeira vez em 1908 por Frank Lillie e, mais tarde descrito por Elizabeth Hay na Universidade de Harvard em culturas 3D de células epiteliais da córnea (HAY, 2005; THIERY, 2002; ZAVADIL et al., 2008).

Considerando a dinâmica Darwiniana da história natural do câncer, a TEM pode ser discutida como uma consequência da plasticidade celular dos metazoários (SCHWITALLA, 2014; THIERY, 2002), resultante da competição entre os diferentes sub-clones que compõe o microambiente neoplásico (KLAUNIG; KAMENDULIS, 2004; SMALLBONE et al., 2007).

As neoplasias de origem epitelial (carcinomas) representam $90 \%$ de todas as malignidades (INGBER, 2008). As células epiteliais são caracterizadas pela manutenção da polaridade apical-basal e pela adesão intercelular (LEE et al., 2006; RADISKY, 2005). As células mesenquimais, por sua vez, não apresentam polaridade, tampouco adesão, sendo morfologicamente irregulares e fusiformes (LEE et al., 2006; LEE; NELSON, 2012). Desta forma, em tecidos saudáveis, o epitélio forma uma barreira física que o separa dos tecidos adjacentes (LEE; NELSON, 2012). No entanto, em certas circunstâncias, células epiteliais podem adquirir um fenótipo mesenquimal de forma reversível por meio da TEM. Tais circunstâncias são verificadas durante a embriogênese onde: (1) na gastrulação a TEM origina a mesoderma, responsável pela formação dos músculos, ossos e tecidos conectivos; (2) na delaminação da crista neural, resulta na formação de células da glia, células neurais, tecido glandular adrenal e células da epiderme que contém pigmentos (CICHON; NELSON; RADISKY, 2015; LEE; NELSON, 2012; RADISKY; LABARGE, 2008; TIAN et al., 2015). Na vida adulta, embora crucial para a regeneração tecidual (RADISKY; LABARGE, 2008), a ativação inapropriada da TEM pode resultar em importantes distúrbios da homeostasia e integridade do tecido epitelial, contribuindo para doenças como o câncer (CICHON; RADISKY, 2014). Por esta razão, a TEM é classificada em: (1) tipo 1 - observada durante a embriogênese; (2) tipo 2 - presente na regeneração e cicatrização e; (3) tipo 3 associada a carcinogênese, migração, invasão e metástase (KALLURI; WEINBERG, 2009; SCANLON et al., 2013). A TEM de tipo 3 é reconhecida tanto em carcinomas, quanto em sarcomas (THIERY, 2002). 
A manutenção da polaridade celular é fundamental para garantir a homeostasia tecidual (ROYER; LU, 2011). Por esta razão, a perda da polaridade apical-basal é reconhecida como a principal característica da TEM (ROYER; LU, 2011). Embora a perda da polaridade seja regulada por diferentes mecanismos, 0 swtiching gênico da E-caderina para N-caderina tem sido discutido como o principal evento que leva a TEM (CICHON; NELSON; RADISKY, 2015; HUBER; KRAUT; BEUG, 2005; LEE et al., 2006; ROYER; LU, 2011; THIERY, 2002; WANG; LI; SARKAR, 2010).

A E-caderina é uma glicoproteína transmembrana (LEE et al., 2006), expressa constitutivamente, que medeia interações homofílicas cálcio-dependentes com domínios de imunoglobulinas, formando pontes adesivas (DEFAMIE; CHEPIED; MESNIL, 2014; SCANLON et al., 2013; THIERY, 2002). A E-caderina se conecta indiretamente aos microfilamentos de actina por meio de $\alpha, \beta$ e $\gamma$-catenina, presentes no citoplasma (SCANLON et al., 2013; THIERY, 2002). Tais interações são responsáveis pela organização do citoesqueleto, controlando a polaridade apicalbasal (DEFAMIE; CHEPIED; MESNIL, 2014). A E-caderina participa, ainda, da formação de desmossomos (THIERY, 2002) e junções tipo gap, conferindo adesão intercelular (DEFAMIE; CHEPIED; MESNIL, 2014; FALK; KELLS; BERTHOUD, 2014).

Dentre as múltiplas alterações verificadas nas células cancerígenas, é observada a redução dos níveis de expressão da E-caderina, evento este que pode se dá por diferentes mecanismos, incluindo: hipermetilação de ilhas CpG (THIERY, 2002), deacetilação de histonas e interação de repressores (SNAIL e SLUG) com Ebox próximos ao promotor (HUBER; KRAUT; BEUG, 2005; YOSHIDA et al., 2009).

A repressão da E-caderina e/ou seu sequestro citoplasmático resulta na translocação da $\beta$-catenina para o núcleo (SCANLON et al., 2013), onde esta atua como repressor transcricional da E-caderina (ZAVADIL et al., 2008) e ativador transcricional de genes associados com a TEM, como: TWIST, SNAIL (SNAIL1) e SLUG (SNAIL2) (SCANLON et al., 2013). Tais genes codificam fatores de transcrição nuclear com zinc-fingers na porção carbóxi-terminal capazes de se ligarem às regiões E-box a montante do gene da E-caderina, levando a redução dos níveis de expressão desta glicoproteína (LEE; NELSON, 2012). Desta forma, a TEM resulta na formação de células com fenótipo fibroblastóide, caracterizadas pela alta capacidade migratória (DEFAMIE; CHEPIED; MESNIL, 2014). 
Durante a TEM, ao mesmo tempo em que se espera a repressão de produtos gênicos expressos em epitélio, é esperado um aumento dos níveis de expressão de proteínas mesenquimais, tais como: fibronectina, vimentina, N-caderina, a-SMA, conforme figura 18 (CICHON; RADISKY, 2014; FUKAWA et al., 2012; WANG; LI; SARKAR, 2010). Não obstante, as células em TEM apresentam elevados níveis de expressão de metaloproteinases (MMP-2, MMP-3 e MMP-9), que auxiliam na degradação da lâmina basal e da MEC, favorecendo a migração e a perda da arquitetura tecidual (DEFAMIE; CHEPIED; MESNIL, 2014).

Figura 18 - Alterações em nível de expressão verificadas na TEM

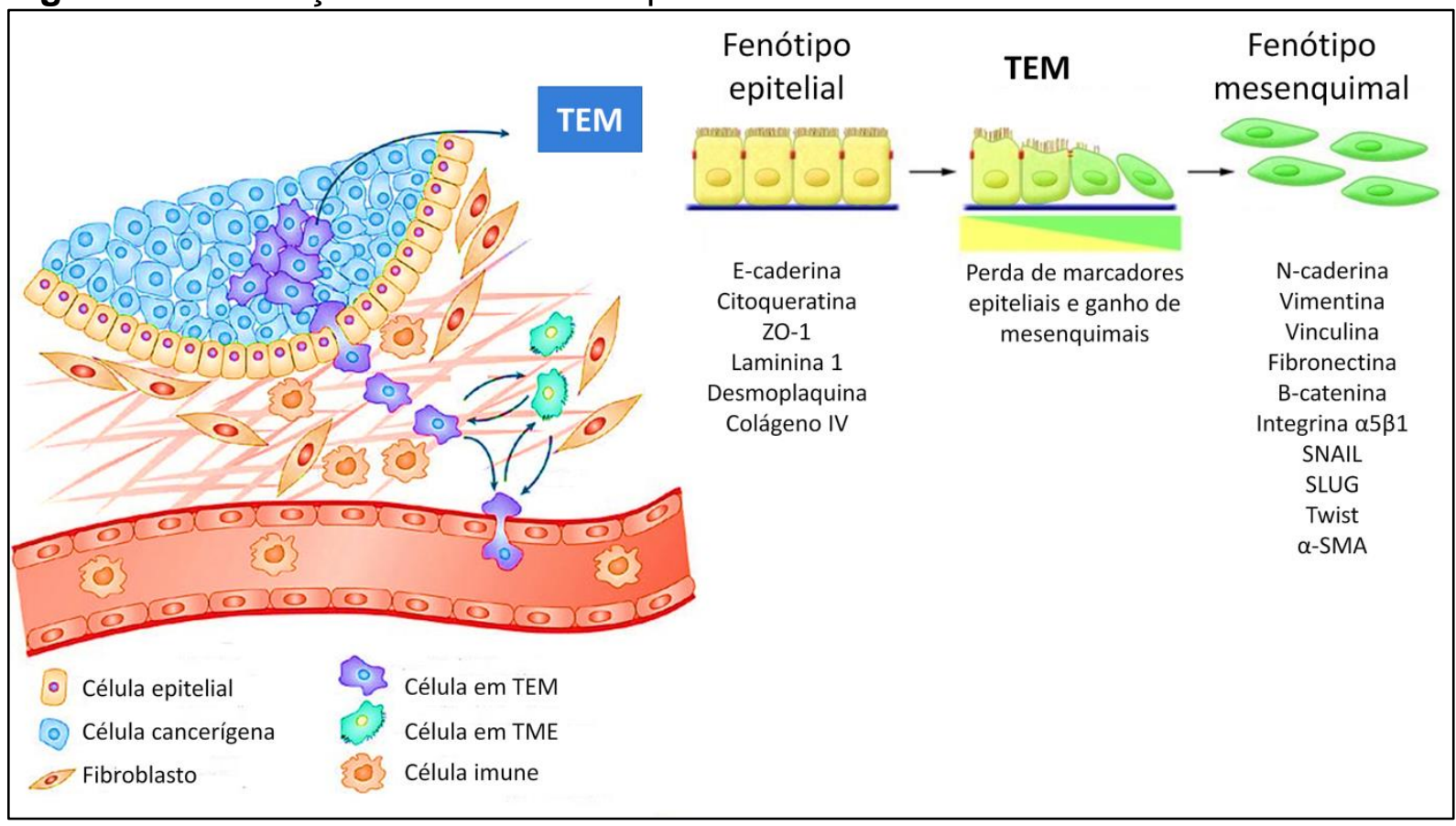

Células em transição epitélio-mesênquima (TEM) apresentam uma redução dos níveis de expressão dos marcadores epiteliais e um consecutivo aumento dos níveis de expressão dos marcadores mesenquimais, levando a aquisição de um fenótipo mesenquimal reversível. Fonte: Modificado de Peinado; Olmeda; Cano (2007) e Kalluri; Weinberg (2009).

A TEM pode ser estimulada por diferentes sinais pleiotrópicos (RADISKY, 2005), incluindo vírus oncogênicos (RUBIN, 1985). Entretanto, as alterações no metabolismo energético têm sido apontadas como principais indutores da TEM (ARCHETTI, 2015; LU; TAN; CAI, 2015). Neste sentido, estudos mostram que o estresse oxidativo estimula a TEM de tipo 3, levando à metástase (AGUILAR et al., 2016; CHEN et al., 2007; MARCUCCI; STASSI; DE MARIA, 2016; SHIBANUMA; MORI; ISHIKAWA, 2016). 


\subsection{A busca por modelos in vitro que recapitulem a história natural dos PVs}

Os cultivos celulares são fundamentais nos estudos da biologia do câncer (SACHS; CLEVERS, 2014). Neste sentido, o HPV tem uma importante contribuição histórica, posto que a primeira linhagem celular estabelecida (HeLa) foi obtida a partir do cultivo primário de carcinoma cervical infectado pelo HPV-18 cirurgicamente excisado da paciente Henrietta Lacks em 1951 (SACHS; CLEVERS, 2014). Desde então, o potencial de cultivos primários e/ou linhagens celulares derivadas de cultivos primários tem sido extensivamente explorado na oncologia (SACHS; CLEVERS, 2014).

A despeito dos resultados obtidos a partir de cultivos celulares derivados de neoplasias associadas ao HPV/BPV (tabela 6), pouca atenção tem sido dada a estes sistemas, sobretudo no que diz respeito ao estudo da biologia viral. Isto porque, de acordo com o paradigma do ciclo de replicação e montagem viral, as culturas 2D não são permissivas a infecção produtiva, já que esta é dependente da diferenciação do epitélio (CERQUEIRA et al., 2016; DOORBAR, 2016). 
Tabela 6 - Resultados prévios empregando culturas de células

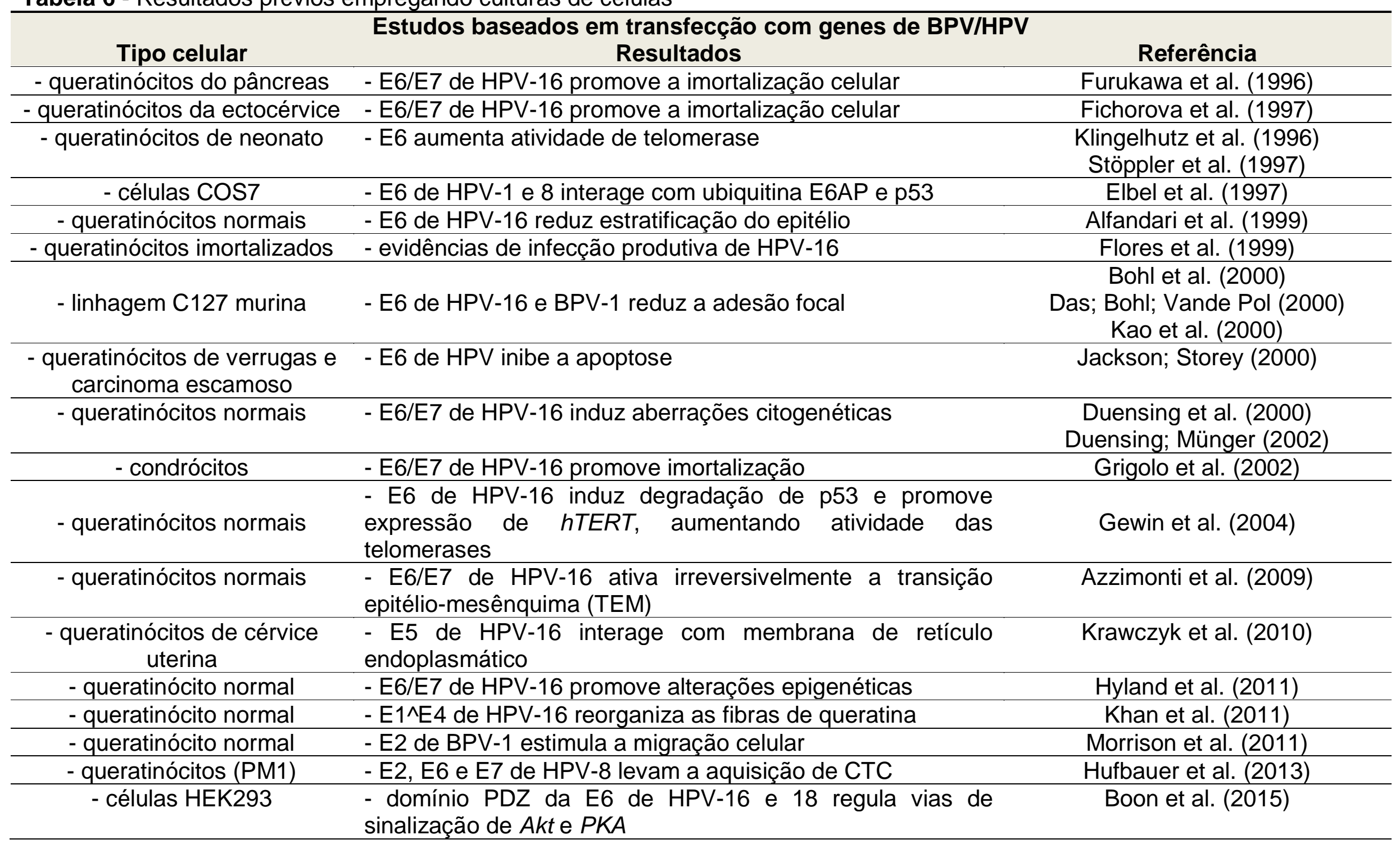




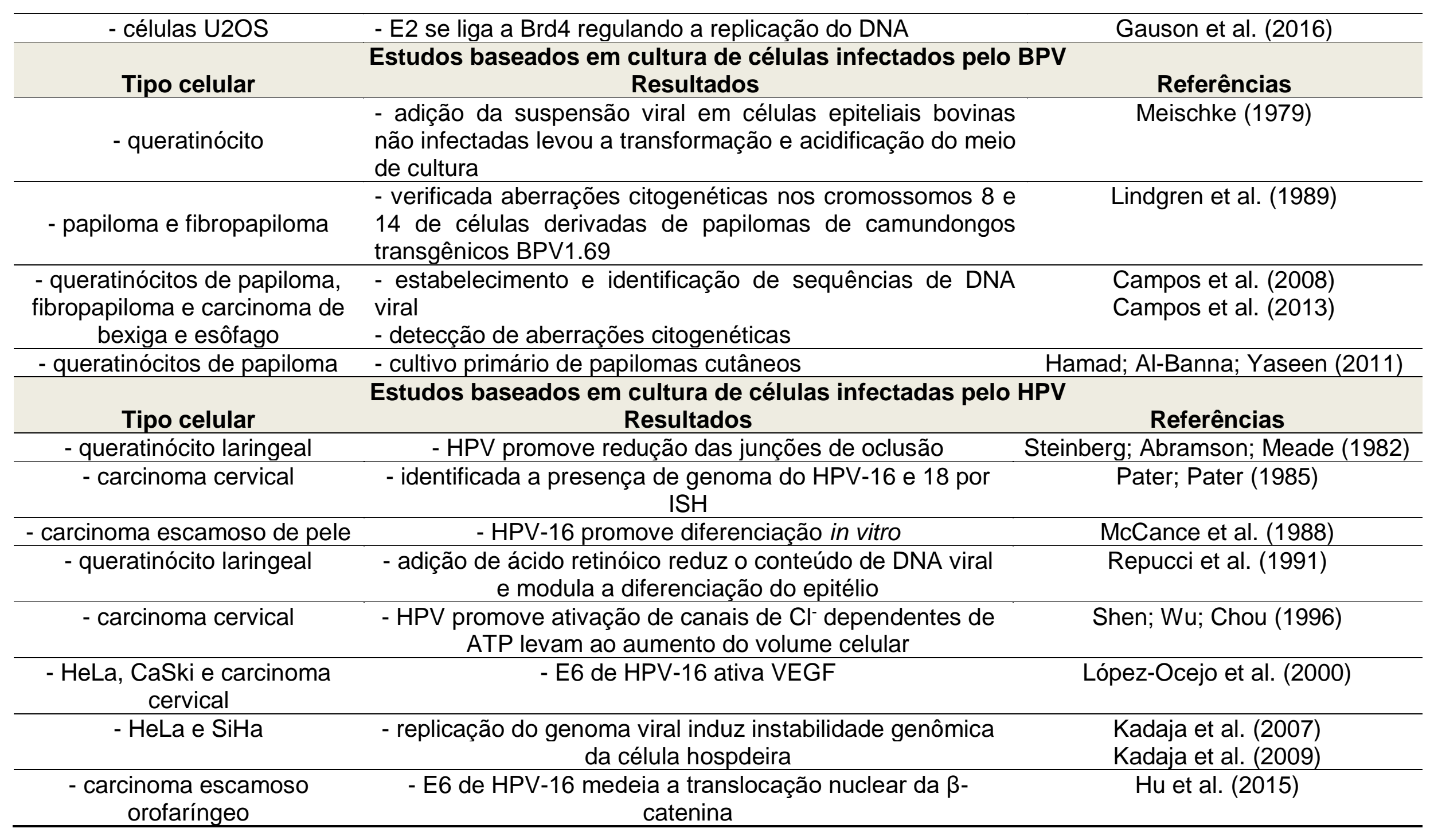


Desde de 2008, o Laboratório de Genética do Instituto Butantan tem se dedicado ao estudo de cultivos primários derivados de neoplasias benignas (papilomas e fibropapilomas) e malignas (carcinoma de bexiga urinária e esôfago) infectadas pelo BPV (CAMPOS et al., 2008). Apesar das dificuldades de adaptação as condições in vitro e a perda do potencial de crescimento após diversas passagens que levam a taxa de $1-10 \%$ de sucesso para a obtenção de uma linhagem celular (SACHS; CLEVERS, 2014), nosso grupo conseguiu obter com êxito linhagens celulares derivadas de neoplasias infectadas pelo BPV (CAMPOS et al., 2008, 2013). Estudos baseados nestas linhagens mostraram que elas apresentam aberrações citogenéticas (CAMPOS et al., 2013) semelhantes àquelas verificadas em PBMCs (MELO et al., 2015, 2011; STOCCO DOS SANTOS et al., 1998) e tecidos infectados pelo vírus (ARALDI et al., 2015a). Em um estudo recente, Melo (2015) descreveu a expressão da proteína L1 do BPV nas linhagens celulares derivadas das neoplasias infectadas pelo BPV, sugerindo pela primeira vez que os sistemas in vitro podem ser permissivos a infecção produtiva. Estes dados sugerem que as linhagens celulares derivadas dos cultivos primários de lesões infectadas são modelos úteis tanto nos estudos da biologia viral como da interação do vírus com a célula hospedeira.

Embora reconhecido como um carcinógeno de tipo I, pouco se sabe acerca do potencial metastático das células infectadas pelo BPV. Isto porque, animais acometidos por câncer são, em geral, destinados ao abate, não havendo um acompanhamento clínico que permita estudar a história natural da doença. Neste sentido, as linhagens celulares derivadas de neoplasias infectadas pelo BPV emergem como importantes modelos para investigar o potencial invasivo e migratório das células infectadas pelo vírus. 
Mesmo em face dos últimos avanços no diagnóstico e tratamento do câncer, o número de óbitos pela doença tem crescido (VARGA; OLIVEIRA; GRETEN, 2014). Além do mais, o número de casos incidentes de câncer, tanto em humanos (INCA, 2009), como em animais, tem aumentado a cada ano (BRØNDEN; FLAGSTAD; KRISTENSEN, 2007; MISDORP, 1996). Estudos recentes mostram que 2/3 dos casos incidentes de câncer estão associados a algum tipo de agente infeccioso (MUSHTAQ; DAREKAR; KASHUBA, 2016; OLIVEIRA; MÜLLER-COAN; PAGANO, 2016). Dentre estes agentes, o HPV é apontado como o vírus oncogênico mais prevalente, estando presente em $30 \%$ das neoplasias malignas associadas a agentes infecciosos (BRAVO; FELEZ-SANCHEZ, 2015; BRAVO; SANJOSÉ; GOTTSCHLING, 2010; ZUR HAUSEN, 2009). Embora alarmantes, estes dados sugerem que medidas profiláticas e/ou terapêuticas que visam erradicar tais agentes infecciosos poderiam reduzir em até $50 \%$ o número de casos incidentes de câncer em humanos (OLIVEIRA; MÜLLER-COAN; PAGANO, 2016).

Os PVs não só representam um desafio para a oncologia médica, como também para a veterinária. Neste sentido, em face das semelhanças morfológicas e patogênicas, o BPV também se tornou um importante modelo de estudo do HPV (CAMPO, 2002; BORZACCHIELLO; ROPERTO, 2008; MUNDAY, 2014b). Além do mais, ambos os vírus podem ser disseminados por via hematogênica ( $\mathrm{CHIOU}$ et al., 2003; FORESTA et al., 2013; KRÁL et al., 2015), fazendo dos PVs um problema de saúde pública (COSTA; MEDEIROS, 2014).

A ausência de dados epidemiológicos acerca do percentual de cânceres atribuídos ao BPV faz com que o vírus seja negligenciado. No entanto, a ação etiopatogênica do BPV no câncer de bexiga urinária como do trato gastrointestinal superior é amplamente reconhecida (BOCANETI et al., 2014; ROPERTO et al., 2015b). Desta forma, o vírus não somente representa um problema de buiatria, mas também de ordem econômica, já que $60 \%$ do rebanho bovino Brasileiro encontra-se infectado pelo BPV, do qual cerca de $40 \%$ apresenta a PB (STOCCO DOS SANTOS et al., 1998). Estes dados são alarmantes, uma vez que, de acordo com o Instituto Brasileiro de Geografia e Estatística (IBGE) o Brasil possui o segundo maior rebanho bovino efetivo do mundo, com aproximadamente 212,3 milhões de cabeças (IBGE, 2015), o que faz da bovinocultura é um dos principais destaques do agronegócio brasileiro (PESQUISA FAPESP, 2016; SILVA; ABRITA; SANTOS, 2014), sendo um 
dos responsáveis pelo superávit da balança comercial de 2015, com um total de US\$ 300,47 milhões somente em maio de 2015 (MAPA, 2015).

Desde 2004, o Brasil assumiu a liderança nas exportações de carne bovina, negociando $1 / 5$ da carne comercializada internacionalmente (SILVA; ABRITA; SANTOS, 2014). Este fato foi responsável por um aumento de $400 \%$ no valor das exportações, que atingiu o recorde de US\$ 5,7 bilhões em 2013 (SILVA; ABRITA; SANTOS, 2014). Parte desta conquista é atribuída à redução do rebanho bovino norte-americano e a seca na Austrália que favoreceram todos os elos da cadeia produtiva nacional (AURÉLIO-NETO, 2014; TEIXEIRA; HESPANHOL, 2014). Além do mais, a oferta e demanda de carne bovina no mundo registraram índices recorders (AURÉLIO-NETO, 2014; TEIXEIRA; HESPANHOL, 2014). Este cenário pode ser justificado pelo aumento da população mundial, que deverá atingir 9,6 bilhões de habitantes até 2050 (AURÉLIO-NETO, 2014; TEIXEIRA; HESPANHOL, 2014), seguido da modernização do campo e o melhoramento genético registrado a partir da década de 1960, que levaram ao aumento da produtividade (AURÉLIONETO, 2014; TEIXEIRA; HESPANHOL, 2014).

No entanto, pesquisa baseada em dados censitários do IBGE mostrou que até meados do século XX havia o predomínio da pecuária extensiva (AURÉLIONETO, 2014). Porém, tal sistema resultava no desgaste do solo, levando a uma dificuldade de manter o rebanho (AURÉLIO-NETO, 2014). Por esta razão, a partir de 1999, o Brasil adotou uma pecuária intensiva, impulsionada pela expansão das lavouras de milho e soja (FERREIRA; CRESTANA, 2014). Neste novo cenário, o Estado de São Paulo ganhou uma posição de destaque por apresentar o maior número de animais em confinamento (FERREIRA; CRESTANA, 2014). Este novo cenário favoreceu a disseminação de doenças de caráter infectocontagioso como a PB. Entretanto, as perdas atribuídas ao BPV não são exclusivas do Brasil. Estima-se que o câncer de bexiga associado ao vírus tenha causado um prejuízo de quatro milhões de euros entre os anos 2000-2006 em Azores, Portugal (COSTA; MEDEIROS, 2014). Desta forma, o impacto econômico do BPV na bovinocultura mundial é inestimável (COSTA; MEDEIROS, 2014).

Embora o potencial oncogênico dos PVs seja reconhecido desde 1995 pela International Agency for Research on Cancer (IARC), ação destes vírus nas etapas subsequentes a iniciação neoplásica permanece pouco explorada (HAGA et al., 2013; POTOCKI et al., 2014). Isto é um reflexo da falta de atenção dada aos cultivos 
primários e/ou linhagens celulares derivadas das neoplasias infectadas pelos PVs, que emergem como alternativas plausíveis para tais estudos.

No entanto, considerando que metástase é a consequência mais dramática do câncer, sendo responsável por 90\% dos óbitos (KRAMER et al., 2012; SIMPSON; ANYIWE; SCHIMMER, 2008; YAMAGUCHI; CONDEELIS, 2007), já que a maioria das malignidades metastáticas são incuráveis (GERLINGER et al., 2014), avaliar o comportamento in vitro de células derivadas de neoplasias infectadas pelos PVs é fundamental na compreensão da história natural dos cânceres associados a estes vírus. Tendo em vista que metástase tem início com a TEM, que confere de forma reversível um fenótipo invasivo e migratório, estudar as alterações genéticas, bioquímicas e morfológicas que levam a TEM poderá levar a identificação de biomarcadores prognósticos. Além do mais, descrever o potencial das linhagens de células derivadas de neoplasias infectadas pelo BPV como modelo de estudo do processo oncogênico permitirá explorar os sistemas in vitro na bioprospecção de alvos terapêuticos contra o câncer. 
4 OBJETIVOS 


\subsection{Objetivo geral}

Este estudo teve por objetivo demonstrar o potencial, até o momento pouco explorado, das linhagens celulares derivadas de cultivos primários de neoplasias benignas (papiloma e fibropapiloma) e malignas (carcinoma de esôfago) infectadas pelo BPV como modelos de estudo do processo oncogênico associado ao vírus. O estudo também buscou descrever a ação da oncoproteína E6 do BPV sob o metabolismo celular, bem como demonstrar sua ação mutagênica per se.

\subsection{Objetivos específicos}

1. Caracterizar as linhagens celulares como modelos de estudo para oncologia:

$\checkmark$ Identificar a presença de sequências de DNA de BPV;

$\checkmark$ avaliar a possível presença de infecção produtiva in vitro;

$\checkmark$ avaliar o potencial hiperproliferativo do BPV in vitro;

$\checkmark$ avaliar o metabolismo energético das diferentes linhagens celulares;

$\checkmark$ avaliar os níveis de clastogenicidade das diferentes linhagens celulares;

$\checkmark$ avaliar a potencial tronco das diferentes linhagens celulares;

$\checkmark$ analisar os níveis de expressão de marcadores epiteliais (citoqueratina 10, Ecaderina), mesenquimais ( $\mathrm{N}$-caderina, vimentina, vinculina) e fatores de transcrição nuclear (STAT3 Y705, SNAIL, SLUG e $\beta$-catenina) nas diferentes linhagens celulares;

$\checkmark$ analisar a morfologia celular das diferentes linhagens celulares;

$\checkmark$ avaliar a capacidade migratória das diferentes linhagens celulares.

2. Analisar a interação da oncoproteína E6 do BPV-1 com a célula hospedeira:

$\checkmark$ avaliar a ação da oncoproteína E6 do BPV sob o metabolismo energético;

$\checkmark$ analisar o potencial genotóxico/clastogênico da oncoproteína E6 do BPV.

3. Validar os resultados in vitro em amostras de tecido parafinado:

$\checkmark$ realizar a análise histopatológica dos fragmentos de tecido que originaram as linhagens celulares estudadas;

$\checkmark$ avaliar a matriz colagenosa dos respectivos tecidos;

$\checkmark$ avaliar os níveis de expressão de diferentes marcadores epiteliais e mesenquimais no material parafinado. 


\subsection{Análise das linhagens celulares como modelo de estudo da TEM}

\subsubsection{Caracterização das linhagens celulares}

\subsubsection{Obtenção e expansão das linhagens celulares}

De acordo com as normas vigentes de biossegurança, recomenda-se que a cultura de células infectadas por agentes biológicos como o BPV seja realizada em laboratórios de nível dois de biossegurança (NB2), certificados por órgãos competentes (HELGASON; MILLER, 2004). Por esta razão, todos os métodos empregados neste estudo foram realizados na câmara NB2 do Laboratório de Genética do Instituto Butantan, aprovada pela Comissão Técnica Nacional de Biossegurança (CTNBio), conforme extrato de parecer número 3.465/2012 publicado no Diário Oficial da União de 13 de novembro de 2012.

Obtenção das linhagens celulares: As linhagens celulares de pele saudável, papiloma cutâneo, fibropapiloma e carcinoma de esôfago (figura 19) foram estabelecidas por Campos et al. (2013) e Melo (2015) e fazem parte do acervo biológico do Laboratório de Genética do Instituto Butantan, permanecendo preservadas em nitrogênio líquido a $-196^{\circ} \mathrm{C}$.

Figura 19 - Linhagens celulares de tecidos saudável e infectados pelo BPV

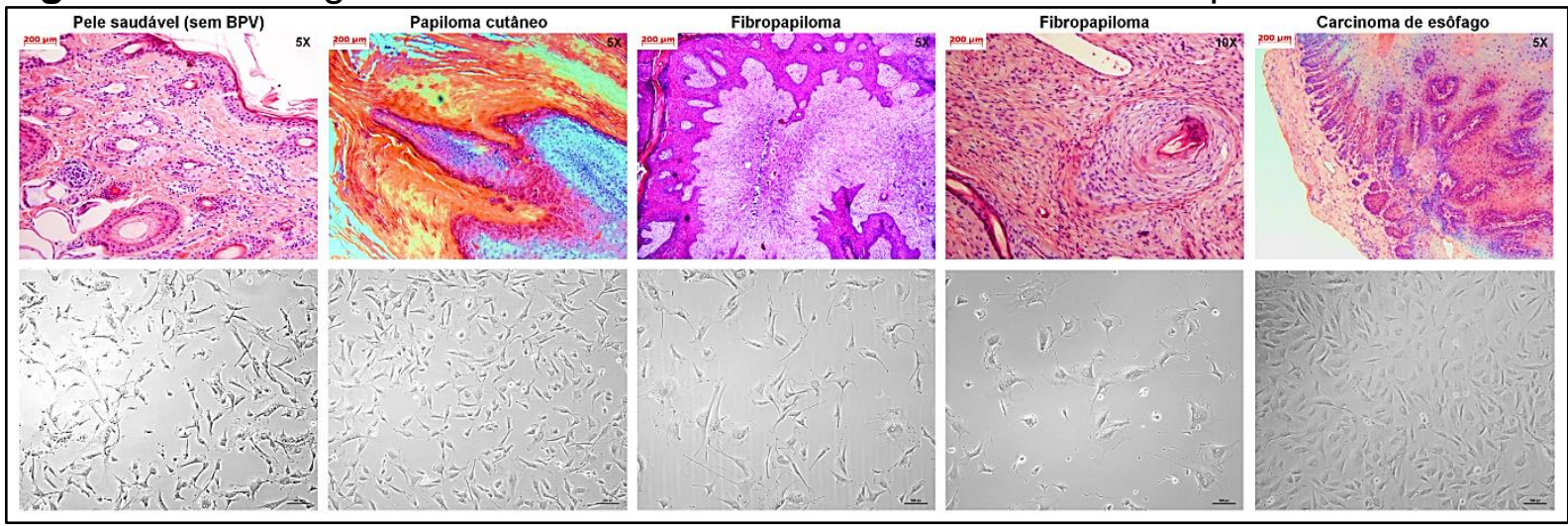

Descongelamento: Os tubos de criopreservação, contendo as diferentes linhagens celulares, foram transferidos do nitrogênio líquido para o banho-Maria a 37 - C. Após o descongelamento, as células foram transferidas para tubos de polipropileno de fundo cônico de $15 \mathrm{~mL}$, contendo $4 \mathrm{~mL}$ de meio DMEM (Cultilab, Campinas, Brasil), suplementando com $15 \%$ de soro fetal bovino (SFB) (Cultilab, Campinas, Brasil) e 1\% de ampicilina-estreptomicina (Cultilab, Campinas, Brasil) a $37 \stackrel{\circ}{\circ}$ (meio completo). Os tubos foram centrifugados a $300 \mathrm{~g}$ por 10 minutos em centrífuga Mikro 22R (Hettich, Berlim, Alemanha), descartando-se o sobrenadante 
por inversão. O pellet foi homogeneizado com $1 \mathrm{~mL}$ do meio de cultura e, transferido para frascos de cultura com área de $25 \mathrm{~cm}^{2}$ (Biofil, China) contendo $4 \mathrm{~mL}$ de meio nas condições descritas. As garrafas foram incubadas em estufa Inc 108 (Memmert, Alemanha) a $37 \stackrel{\circ}{\circ}$, com atmosfera de $5 \%$ de $\mathrm{CO}_{2}$ e $45 \%$ de umidade. Após 24 horas de incubação, o meio foi removido por inversão. As células foram lavadas com $2 \mathrm{~mL}$ de PBS estéril a $37^{\circ} \mathrm{C}$. Um volume de $5 \mathrm{~mL}$ de meio de cultura a $37^{\circ} \mathrm{C}$ foi transferido para as garrafas. O material foi incubado em estufa, nas condições descritas até se obter uma confluência de $80 \%$. Esta etapa corresponde a primeira passagem ( $\mathrm{P} 1)$.

Desagregação celular: Em se tratando de cultura de células aderentes, a desagregação da monocamada se faz necessária. Neste sentido, dois métodos foram previamente testados: (1) desagregação enzimática, com uso de solução de tripsina e EDTA (Cultilab, Campinas, BrasiL) e, (2) não enzimática, com emprego de solução de EDTA (250 mg/L em PBS, pH 6,0). Os resultados mostraram que ambos os métodos, enzimático e não enzimático, apresentaram-se satisfatórios na desagregação da monocamada. Entretanto, o método não enzimático mostrou uma maior preservação da morfologia celular, conforme mostrado na figura 20. Por esta razão, este método foi preferencialmente adotado. 
Figura 20 - Resultado do teste de desagregação da monocamada

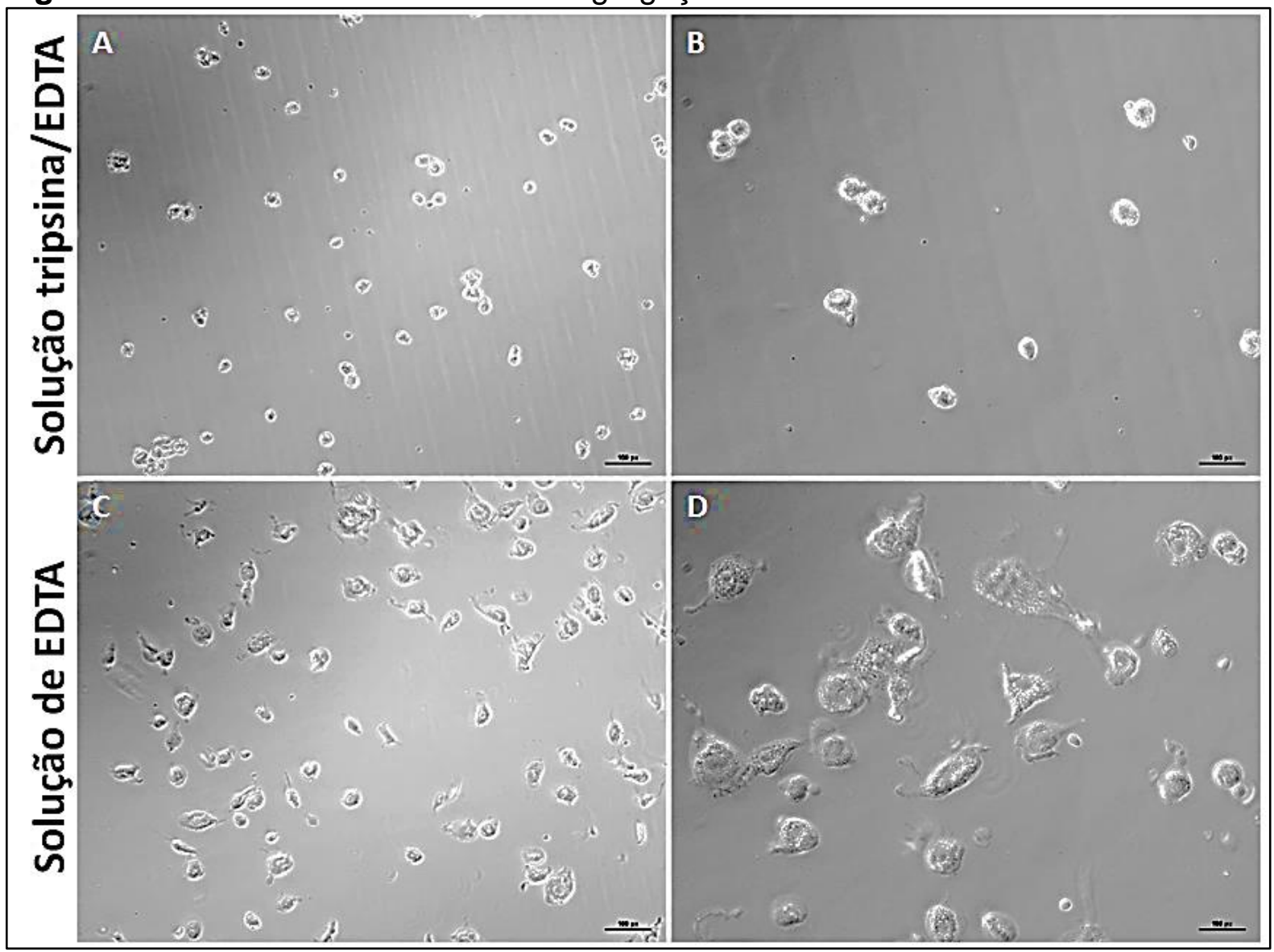

Fotomicroscopia com contraste de fase do teste de desagregação da monocamada de células de pele saudável empregando o tratamento enzimático com solução de tripsina e EDTA por cinco minutos, em aumento total de $100 \times$ (A) e $200 \mathrm{X}(\mathrm{B})$, mostrando células arredondadas e com volume reduzido, indicando alterações morfológicas. Teste de desagregação da monocamada de pele saudável empregando o tratamento não enzimático com solução de EDTA por cinco minutos, em aumento total de $100 \times$ (C) e $200 \times$ (D). Teste mostrou desagregação satisfatória, no mesmo período de tempo, porém, método não enzimático mostrou maior preservação da morfologia celular. Barra de escala de $100 \mu \mathrm{m}$.

Repique: O meio de cultura contido nos frascos foi transferido para tubos de centrífuga de fundo cônico de $15 \mathrm{~mL}$. As células aderentes foram lavadas com $2 \mathrm{~mL}$ PBS estéril a $37 \stackrel{\circ}{ }$. Após a lavagem, um volume de $2 \mathrm{~mL}$ da solução de EDTA a 37 ${ }^{\circ} \mathrm{C}$ foi adicionado a cada frasco de cultura, permitindo a desagregação da monocamada. O material foi incubado por cinco minutos em estufa, nas condições descritas. Após este período, a suspensão celular foi transferida para os tubos de centrífuga contendo o meio de cultura. Os tubos foram centrifugados a $300 \mathrm{~g}$ por seis minutos a temperatura ambiente. O sobrenadante foi descartado por inversão. O pellet foi homogeneizado com $1 \mathrm{~mL}$ de meio completo a $37^{\circ} \stackrel{\circ}{ } \mathrm{C}$. Um volume de 200 $\mu \mathrm{L}$ da suspensão celular foi transferido para frascos de cultura de $25 \mathrm{~cm}^{2}$ contendo 5 $\mathrm{mL}$ de meio a $37^{\circ} \mathrm{C}$. Os frascos foram incubados em estufa nas condições descritas. Os repiques foram realizados até a sexta passagem (P6). 
Criopreservação do estoque de células: Um frasco de cultura da segunda passagem (P2) foi destinado à criopreservação, permitindo assim a manutenção do acervo biológico. Para tanto, as células foram submetidas à desagregação não enzimática. O pellet foi homogeneizado com 1,5 mL de meio de congelamento: $70 \%$ de meio DMEM, 20\% de DMSO (Merck, Alemanha) e 10\% SFB. A suspensão celular foi transferida para tubos de criopreservação de $2 \mathrm{~mL}$, que foram transferidos para Nalgene Cryo $1^{\circ} \mathrm{C}$, contendo isopropanol e mantidos a $-80 \stackrel{\circ}{ } \mathrm{C}$ por 24 horas. Este procedimento garante uma maior viabilidade celular, pois confere uma ação protetora contra a força de cisalhamento decorrente do processo de criopreservação. Após este período, os criotubos foram transferidos para o nitrogênio líquido.

\section{$\underline{\text { 5.1.1.2 Teste de viabilidade celular }}$}

Estimar a viabilidade celular é fundamental para o sucesso da cultura de células (ALTMAN; RANDERS; RAO, 1993). Por este motivo, foi realizado o ensaio de exclusão do corante azul de tripano das seis passagens de cada uma das respectivas linhagens celulares.

Os testes baseados na exclusão de corantes são os mais frequentemente usados para avaliar a viabilidade celular (LOUIS; SIEGEL, 2011). Dentre estes, o método baseado no corante azul de tripano é o mais empregado, justificando assim seu uso (ALTMAN; RANDERS; RAO, 1993; HELGASON; MILLER, 2004; LOUIS; SIEGEL, 2011; MASCOTTI; MCCULLOUGH; BURGER, 2000; STROBER, 2001). O ensaio se baseia no princípio de que células viáveis não se coram com azul de tripano, permanecendo incolores e brilhantes (LOUIS; SIEGEL, 2011; MASCOTTI; MCCULLOUGH; BURGER, 2000). A ausência de coloração se deve a integridade da membrana plasmática das células viáveis, que impede a entrada do corante (MASCOTTI; MCCULLOUGH; BURGER, 2000). Já as células não viáveis são coradas de azul devido à perda da integridade da membrana plasmática (MASCOTTI; MCCULLOUGH; BURGER, 2000; STROBER, 2001).

A cada passagem celular, uma alíquota de $100 \mu \mathrm{L}$ da suspensão celular pósdesagregação não enzimática foi transferida para tubos de polipropileno de $1,5 \mathrm{~mL}$ estéril. Um volume de $300 \mu \mathrm{L}$ de azul de tripano a 0,4\% (m/v) (Sigma-Aldrich, Alemanha) foi adicionado ao tudo. A solução foi homogeneizada e incubada por cinco minutos a temperatura ambiente, conforme proposto por Louis e Siegel (2011). 
Após esta incubação, o material foi transferido para a câmara de Neubauer (hemocitômetro). O material foi analisado em campo claro no microscópio binocular Axiophot (Car Zeiss, Alemanha), com aumento total de $100 \mathrm{X}$, sendo avaliado o número de células viáveis (CV - brilhantes) e não viáveis (CNV - azuis) em quadro quadrantes ( $A, B, C$ e D). Com base na média de $C V$ e $C N V$, foi calculada a concentração de células viáveis $([\mathrm{CV} / \mathrm{mL}])$ e não viáveis $([\mathrm{CNV} / \mathrm{mL}])$, bem como a porcentagem de células viáveis (\%CV). Tais valores foram obtidos de acordo com Helgason e Miller (2004), empregando as seguintes fórmulas:

$$
\begin{gathered}
{[\mathrm{CV}]=\overline{\mathrm{x}} \text { de } \mathrm{CV} \times \mathrm{FD} \times \mathrm{FC}} \\
{[\mathrm{CNV}]=\overline{\mathrm{x}} \text { de } \mathrm{CNV} \times \mathrm{FD} \times \mathrm{FC}} \\
\% \mathrm{CV}=\frac{\mathrm{n}^{\circ} \text { de } \mathrm{CV}}{\mathrm{n}^{\circ} \text { de células totais }} \times 100
\end{gathered}
$$

onde: $\bar{x}$ - média, CV - células viáveis, CNV - células não viáveis, FD - fator de diluição (neste estudo igual a 4) e FC - fator de correção da câmara de Neubauer (igual a $10^{4}$ ).

\subsubsection{Identificacão de sequências de DNA viral nas linhagens celulares}

Um frasco de cultura de cada passagem (P1-P6) das diferentes linhagens foi destinado à identificação de sequências virais. $O$ material foi submetido à desagregação celular, conforme descrito na seção 5.1.1.1. As células foram ressuspendidas em $1 \mathrm{~mL}$ de PBS estéril, sendo destinado à extração de DNA.

Extração do DNA genômico e viral: O DNA foi extraído empregando o QIAamp DNA Blood Mini kit (Qiagen, Alemanha). Um volume de $400 \mu \mathrm{L}$ da suspensão celular foi transferido para tubos de polipropileno de 1,5 mL estéril contendo $40 \mu \mathrm{L}$ de protease $\mathrm{K}$. Um volume de $400 \mu \mathrm{L}$ do tampão de lise contido no kit foi adicionado aos tubos. O material foi homogeneizado por inversão e incubado em termobloco TS-100 (Biosan, EUA) a $56{ }^{\circ} \mathrm{C}$ por 10 minutos. Após esta incubação, foi adicionado aos tubos um volume de $400 \mu \mathrm{L}$ de etanol absoluto. $\mathrm{O}$ material foi levado ao vórtex Combi-spin modelo FVL-2400N (Biosan, EUA) e, então, transferido para a coluna contida no kit. Os tubos foram centrifugados a $6.000 \mathrm{~g}$ por um minuto em centrífuga refrigerada Micro 22R (Hettich, Alemanha), descartando-se o filtrado. Um volume de $500 \mu \mathrm{L}$ do tampão de lavagem 1 foi adicionado às colunas, que foram 
centrifugadas nas condições descritas anteriormente, descartando-se o filtrado. Um volume de $500 \mu \mathrm{L}$ do tampão de lavagem 2 foi adicionado à coluna. Os tubos foram centrifugados a $20.000 \mathrm{~g}$ por três minutos a $27 \stackrel{\circ}{ } \mathrm{C}$, descartando-se o filtrado. $\mathrm{O}$ material foi centrifugado nas condições descritas para garantir a remoção do etanol residual. As colunas foram transferidas para novos tubos de polipropileno de 1,5 mL estéril. Um volume de $100 \mu \mathrm{L}$ do tampão de eluição contido no kit foi adicionado às colunas. O material foi incubado por cinco minutos a temperatura ambiente e, então, centrifugado a $6.000 \mathrm{~g}$ por dois minutos. O eluído foi estocado a $-20 \stackrel{\circ}{ } \mathrm{C}$.

Quantificação do DNA: O DNA extraído foi quantificado em espectrofotômetro BioPhotometer Plus (Eppendorf, Alemanha), onde foi realizada a leitura de uma alíquota de 2,0 $\mu \mathrm{L}$ das respectivas amostras em comprimentos de onda de 230, 260 e $280 \mathrm{~nm}$, calculando a concentração de em ng/ $\mu \mathrm{L}$ através da fórmula:

$$
\text { [DNA] = leitura da } \mathrm{DO}_{260} \times 50 \times \text { fator de diluição }
$$

onde: $\mathrm{DO}$ (densidade óptica) e $1 \mathrm{DO}_{260}$ equivale a $50 \mu \mathrm{L}$ de DNA dupla-fita.

As razões $A_{260} / A_{280}$ e $A_{260} / A_{230}$ foram determinadas para avaliar a pureza do DNA obtido, onde valores inferiores a 1,7 indicam contaminação por proteínas e, superiores a 2,0, contaminação por RNA.

Identificação e tipagem viral: As amostras de DNA foram submetidas à identificação de sequências virais por meio de PCR, empregando os pares de primers específicos para BPV-1, 2 e 4, cujas sequências são mostradas na tabela 7 . As regiões de anelamento e as sequencias amplificadas com estes primers são mostradas no apêndice 1 .

Tabela 7 - Sequência dos primers empregados na identificação do BPV

\begin{tabular}{cccc}
\hline Primer & Sequência (5'-3') & Gene alvo & Amplicon (pb) \\
\hline BPV-1 & $\begin{array}{l}\text { GAGCGCCTGCTAACTATAGGA } \\
\text { ATCTGTTGTTTGGGTGGTGAC }\end{array}$ & L1 & 301 \\
\hline BPV-2 & $\begin{array}{l}\text { GTTATACCACCCAAAGAAGACCCT } \\
\text { CTGGTTGCAACAGCTCTCTTTCTC }\end{array}$ & L1 & 164 \\
\hline BPV-4 & $\begin{array}{l}\text { GCTGACCTTCCAGTCTTAAT } \\
\text { CAGTTTCAATCTCCTCTTCA }\end{array}$ & E7 & 170 \\
\hline
\end{tabular}


Parâmetros da PCR: Foram realizadas reações com volume total de $25,0 \mu \mathrm{L}$, sendo: 10,0 $\mu \mathrm{L}$ de DreamTaq Green (Thermo Scientifc, EUA), 1,0 $\mu \mathrm{L}$ do primer forward, 1,0 $\mu \mathrm{L}$ do primer reverse, 8,0 $\mu \mathrm{L}$ de água livre de DNase e 5,0 $\mu \mathrm{L}$ da amostra de DNA. As reações foram levadas ao termociclador PTC-100 Programable Thermal Controller (MJ Research, EUA) e submetidas ao seguinte ciclo: três minutos a $94{ }^{\circ} \mathrm{C}$ (desnaturação inicial), 35 ciclos de 50 segundos a $94 \stackrel{\circ}{ } \mathrm{C}$ (desnaturação), um minuto a $60 \stackrel{\circ}{\circ}$ (anelamento) e um minuto a $72{ }^{\circ} \mathrm{C}$ (extensão) e, cinco minutos a 72 ${ }^{\circ} \mathrm{C}$ (extensão final).

Obtenção dos genomas controle: Cópias de genomas virais de BPV-1 (AB626705), BPV-2 (M20219.1) e BPV-4 (X0581.1), previamente clonados em vetor PAT153, foram empregados como controle positivo das respectivas reações de PCR. Estes genomas fazem parte do acervo biológico do Laboratório de Genética do Instituto Butantan. Em detalhes: E. coli Top10 transformadas foram transferidas para tubos de polipropileno de fundo cônico de $50 \mathrm{~mL}$ contendo $12 \mathrm{~mL}$ de meio Luria Bertani (LB) suplementado com $25 \mu \mathrm{L}$ de ampicilina na concentração de $25 \mu \mathrm{g} / \mathrm{mL}$. $\mathrm{O}$ material foi incubado overnight em shaker a $37^{\circ} \mathrm{C}$ a $250 \mathrm{rpm}$. Após este período, o material foi centrifugado por 30 minutos a $14.000 \mathrm{~g}$ para a sedimentação das células bacterianas e, submetido à extração de DNA plasmidial (MiniPrep).

MiniPrep: A extração de DNA plasmidial foi realizada com o emprego do kit PureLink Quick Plasmid Miniprep (Invitrogen, Löhne, Alemanha). O material sedimentado foi homogeneizado com $250 \mu \mathrm{L}$ do tampão de ressuspensão, contido no kit. Um volume de $250 \mu \mathrm{L}$ do tampão de lise foi adicionado à suspensão celular. O material foi homogeneizado por meio de inversão dos tubos e, incubado por cinco minutos a temperatura ambiente. Um volume de $350 \mu \mathrm{L}$ do tampão de precipitação foi adicionado aos tubos. $O$ material foi centrifugado a $14.000 \mathrm{~g}$ por 10 minutos. $\mathrm{O}$ sobrenadante foi transferido para as colunas do kit. O material foi lavado com $2 \mathrm{~mL}$ do tampão de lavagem e, centrifugado a $14.000 \mathrm{~g}$ por um minuto, descartando-se o filtrado. Uma lavagem adicional foi realizada utilizando $500 \mu \mathrm{L}$ do tampão de lavagem. Nesta etapa, o material foi incubado por um minuto à temperatura ambiente e, posteriormente, centrifugado nas condições descritas por um minuto, descartando-se o filtrado. Um volume de $700 \mu \mathrm{L}$ do tampão de lavagem, contendo etanol, foi adicionado às colunas. $O$ material foi centrifugado a $12.000 \mathrm{~g}$ por um minuto, descartando-se o filtrado. A etapa de centrifugação foi repetida para a remoção do etanol residual. As colunas foram transferidas para tubos de 
polipropileno de $1,5 \mathrm{~mL}$ estéril. Um volume de $75 \mu \mathrm{L}$ do tampão de eluição foi adicionado às colunas. $O$ material foi incubado por um minuto a temperatura ambiente e, centrifugado a $12.000 \mathrm{~g}$ por três minutos. O eluído foi estocado a $-20{ }^{\circ} \mathrm{C}$, sendo empregado como controle positivo das reações de PCR.

Eletroforese: Os produtos da PCR foram analisados em gel de agarose a $2 \%$, em tampão TAE 1X (Tris-acetato EDTA) (0,04 M Tris base, $1 \mathrm{M}$ ácido acético glacial, 50 mM EDTA, pH 8,0) corado com 1\% de GelRed (Biotium, Hayward, EUA). A corrida eletroforética foi realizada em cuba Horizon 11.14 (Life Technology, Carlsbad, EUA), empregando a fonte PowerPac Basic (BioRad, Singapura) a $100 \mathrm{~V}$, $300 \mathrm{~mA}$ por duas horas. Como marcador, foi utilizado o 100 pb DNA Ladder (Invitrogen, Carlsbad, EUA). O gel foi analisado no transluminador BioDoc Analyze (Biometra, Goettingen, Alemanha) e, as imagens capturadas com auxílio do software BioDoc Analyse versão 2.1 (Biometra, Goettingen, Alemanha).

\subsubsection{Imunodetecção da proteína L1 do BPV}

A imunodetecção da proteína estrutural L1 em células infectadas pelo BPV é considerada uma importante evidência de infecção produtiva (NASIR; REID, 1999; ROPERTO et al., 2012). Por este motivo, a expressão desta proteína foi avaliada nas diferentes linhagens celulares por meio de imunofluorescência (IF) e citometria de fluxo (CF).

Imunofluorescência indireta: Um total de $1 \times 10^{5}$ células na terceira passagem (P3) foi transferido para placa de seis poços, contendo uma lamínula estéril de $24 \mathrm{x}$ $24 \mathrm{~mm}$ por poço e $2,0 \mathrm{~mL}$ de meio completo. $O$ material foi cultivado até se obter uma confluência de $80 \%$. O meio foi aspirado com auxílio de pipeta Pasteur descartável e, o material foi lavado por cinco minutos com PBS estéril a $37^{\circ} \mathrm{C}$, tendo sido realizadas três lavagens. As células foram fixadas com formaldeído tamponado a 4\% diluído em PBS, por 30 minutos. Após a fixação, as células foram lavadas por cinco minutos com PBS estéril a $4 \stackrel{\circ}{\circ}$, por três vezes e, permeabilizadas por 10 minutos com solução de Triton X-100 (Sigma, Alemanha) a 0,01\%, diluído em PBS. Após esta etapa, as células foram lavadas por cinco minutos com PBS a $4 \stackrel{\circ}{\circ} \mathrm{C}$ por três vezes. O material foi incubado overnight com o anticorpo monoclonal anti-L1 [BPV-1/1H8 + CAMVIR] (Abcam, Cambridge, Reino Unido), na diluição de 1:100, permanecendo em câmara úmida a $4{ }^{\circ} \mathrm{C}$, coberto com parafilm. Após esta incubação, o material foi lavado por cinco minutos com PBS a $4 \stackrel{\circ}{C}$ por três vezes 
sendo, então, incubado com o anticorpo secundário anti-lgG de camundongo conjugado com FITC (Sigma, Alemanha), na diluição de 1:200, por três horas a $4 \stackrel{\circ}{ } \mathrm{C}$ em câmara úmida. As células foram lavadas por cinco minutos com PBS a $4 \stackrel{\circ}{\mathrm{C}}$ por três vezes. As lamínulas foram montadas em lâminas empregando 20,0 $\mu \mathrm{L}$ do meio ProLong Gold (Invitrogen, Carlsbad, EUA), contendo DAPI. O material foi analisado em microscópio de epifluorescência Axio Scope A1 (Carl Zeiss, Alemanha) com aumento de $400 \mathrm{X}$.

Citometria de fluxo: Um frasco de cultura de cada linhagem celular na terceira passagem (P3) foi destinado à citometria de fluxo para avaliar os níveis de expressão da proteína estrutural L1. Para tanto, as células foram submetidas à desagregação não enzimática, conforme seção 5.1.1.1. Um volume de $100 \mu \mathrm{L}$ da suspensão celular pós-desagregação foi transferida para a câmara de Neubauer para contagem celular. Um total de $1 \times 10^{6}$ células foi transferido para tubos de polipropileno de 1,5 mL. As células foram lavadas com PBS a $4 \stackrel{\circ}{\circ} \mathrm{C}$ e fixadas em solução de paraformaldeído a $1 \%$ por duas horas. Após a fixação, o material foi centrifugado por cinco minutos a $300 \mathrm{~g}$, permitindo a remoção do fixador. Um volume de $1 \mathrm{~mL}$ de PBS a $4 \stackrel{\circ}{\circ} \mathrm{C}$ foi adicionado por tubo. O material foi centrifugado por cinco minutos a $300 \mathrm{~g}$, descartando-se o sobrenadante. Esta etapa foi realizada por três vezes a fim de garantir a remoção de resíduos de formol.

As células foram incubadas com BSA a 1\% (Sigma, Alemanha) diluída em PBS por 20 minutos. Após este período, o material foi centrifugado a $300 \mathrm{~g}$ por cinco minutos, descartando-se o sobrenadante. As células foram ressuspendidas em 100 $\mu \mathrm{L}$ de PBS a $4{ }^{\circ} \mathrm{C}$, acrescido de $1,0 \mu \mathrm{L}(1: 100)$ do anticorpo primário anti-L1 [BPV1/1H8 + CAMVIR] (Abcam, Cambridge, Reino Unido) e, incubadas por duas horas a 4 ํ․ Após este período, o material foi centrifugado por cinco minutos a $300 \mathrm{~g}$, descartando-se o sobrenadante. As células foram ressuspendidas em $100 \mu \mathrm{L}$ de PBS a $4 \stackrel{\circ}{\circ}$, acrescido de $0,5 \mu \mathrm{L}$ do anticorpo secundário (1:200) Alexa Fluor 488 anti-IgG1 produzido em camundongo (Invitrogen, Carlsbad, EUA) e, incubadas por duas horas a $4 \stackrel{\circ}{ } \mathrm{C}$. O material foi centrifugado nas condições descritas, descartandose o sobrenadante. As células foram ressuspendidas em $100 \mu \mathrm{L}$ de PBS a $4{ }^{\circ} \mathrm{C}$, vortexadas e analisadas no citômetro Accuri C6 (BD Bioscience, EUA), empregando o filtro FL1. Os resultados foram exportados na extensão FCS e analisados através do software FlowJo (TreeStar, Oregon, EUA) por meio de histogramas. As análises estatísticas foram realizadas com base no percentual de células imunomarcadas, 
conforme proposto por Bashashati e Brinkman (2009) e Lugli, Roederer e Cossarizza (2010).

\subsubsection{Microscopia eletrônica de transmissão (MET)}

A fim de detectar a presença de vírions de BPV, as diferentes linhagens celulares, na sexta passagem (P6) foram submetidas a MET. Este procedimento foi realizado no Laboratório Nacional de Biociências (LNBio), com a colaboração do Dr. Sílvio Roberto Consonni. Para tal análise, as linhagens celulares foram expandidas em placas de seis poços (Biofil, China), contendo uma lamínula de $24 \times 24 \mathrm{~mm}$ (Knitell, Alemanha), previamente lavada e autoclavada nas condições descritas na seção 5.1.1.1, até se obter uma confluência de 80-90\%. Nesta fase, o meio foi removido com auxílio de pipeta Pasteur descartável e o material foi lavado com PBS estéril por cinco minutos. As células foram fixadas com glutaraldeído a 2,5\%, diluído

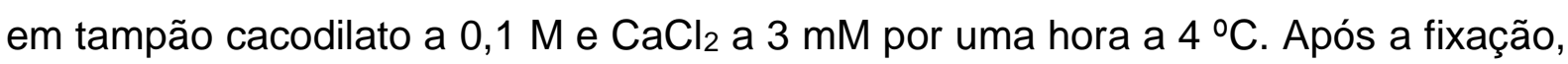
o material foi lavado por dois minutos em tampão cacodilato, tendo sido realizadas cinco lavagens. As células foram tratadas com tetróxido de ósmio $\left(\mathrm{OsO}_{4}\right)$ a $1 \%$ diluído em tampão cacodilato a $0,1 \mathrm{M}$, contendo $3,0 \mathrm{mM}$ de $\mathrm{CaCl}_{2}$ e $0,8 \%$ de ferrocianeto de potássio, permanecendo incubado nesta solução por 30 minutos a 4 @C. O material foi lavado por dois minutos com água ultrapura (Mili-Q) por cinco

vezes e, contrastado com acetato de uranila a $2 \%$ filtrado por uma hora a temperatura ambiente. Após esta etapa, as células foram lavadas com água ultrapura nas condições descritas e, desidratadas em concentrações crescentes de etanol $(20 \%, 50 \%, 70 \%, 80 \%, 90 \%$ e $100 \%)$ a $4 \stackrel{\circ}{\circ}$, por três minutos. O material foi submetido a uma desidratação adicional com etanol 100\% a temperatura ambiente por três minutos. As células foram embebidas na solução 1:1 de resina Epon-etanol, sob agitação, por 30 minutos a temperatura ambiente. Foram realizadas quatro trocas completas de resina Epon em intervalos de uma hora e, uma última troca overnight. O material foi transferido para estufa a $60 \stackrel{\circ}{\mathrm{C}}$ por 72 horas para a polimerização da resina. Os blocos de resina foram submetidos a cortes ultrafinos e analisados no microscópio eletrônico Leo 906E (Carls Zeiss, Alemanha) e as imagens foram capturadas com auxílio da câmera Mega View III e do software ITEM versão E 23082007 (Olympus Soft Imaging Solutions, Alemanha, $\mathrm{GmbH}$ ), empregando uma voltagem de $80 \mathrm{kV}$ e corrente constante de $1 \mathrm{~A}$ em aumentos de 
até $100.000 \mathrm{X}$. As morfometrias foram realizadas com software AxioVision versão 4.9.1.0 (Carl Zeiss, Alemanha).

\subsubsection{Análise da cinética de divisão (ciclo celular) in vitro}

O ciclo celular foi avaliado por meio de citometria de fluxo, método amplamente empregado no estudo de proliferação e morte celular (DARZYNKIEWICZ; BEDNER; SMOLEWSKI, 2001; NUNEZ, 2001). A CF permite avaliar a distribuição das células nas diferentes fases do ciclo celular bem como, determinar a cinética de progresso de tais fases de modo rápido, acurado e quantitativo (JAYAT; RATINAUD, 1993). O método realiza uma mensuração multiparamétrica do conteúdo de DNA (DARZYNKIEWICZ; BEDNER; SMOLEWSKI, 2001). Desta forma, células na fase $G_{0} / G_{1}$ apresentam uma unidade de DNA (1C), células na fase $S$ apresentam entre uma e duas unidades de DNA $(1>C<2)$ e células em $\mathrm{G}_{2} / \mathrm{M}$, duas unidades de DNA (2C) (DARZYNKIEWICZ; BEDNER; SMOLEWSKI, 2001).

Para esta avaliação, foi empregada uma garrafa de cultura de cada uma das respectivas linhagens na terceira passagem (P3). A monocamada foi submetida à desagregação não enzimática, empregando solução de EDTA a $0,02 \%$, conforme seção 5.1.1.1. As células foram transferidas para tubos de polipropileno de fundo cônico de $15 \mathrm{~mL}$ contendo o meio de cultura contido nas garrafas. O material foi centrifugado por cinco minutos a $300 \mathrm{~g}$, descartando-se o sobrenadante por inversão. O pellet foi homogeneizado com $2 \mathrm{~mL}$ de PBS a $37^{\circ} \mathrm{C}$ e centrifugado nas condições descritas. Este procedimento permite a remoção de eventuais resíduos do meio de cultura. Após a centrifugação, o sobrenadante foi descartado por inversão. As células foram fixadas com $2 \mathrm{~mL}$ de etanol $70^{\circ}$ a $4^{\circ} \mathrm{C}$. O material permaneceu a $20{ }^{\circ} \mathrm{C}$ até $\mathrm{O}$ momento da análise. Desta forma, a avaliação do ciclo celular das diferentes linhagens foi realizado no mesmo dia.

No dia da análise, o material foi centrifugado por oito minutos a $300 \mathrm{~g}$, descartando-se o sobrenadante. $\mathrm{O}$ pellet foi homogeneizado com $2 \mathrm{~mL}$ de PBS a 4 ${ }^{\circ} \mathrm{C}$. O material foi centrifugado nas condições descritas, descartando-se o sobrenadante. $O$ pellet foi homogeneizado com $300 \mu \mathrm{L}$ de PBS estéril e transferido para tubos de citometria. O material foi incubado a $4{ }^{\circ} \mathrm{C}$ com $4,0 \mu \mathrm{L}$ de RNase (20 $\mathrm{mg} / \mathrm{mL}$ ) (Invitrogen, Carlsbad, EUA) por 40 minutos. Este procedimento permite a degradação enzimática de RNAs, evitando resultados inespecíficos decorrentes da 
intercalação do iodeto de propídeo (IP) a estas moléculas (DARZYNKIEWICZ; BEDNER; SMOLEWSKI, 2001). O material foi homogeneizado com 2,0 mL de PBS estéril e centrifugado nas condições descritas. O sobrenadante foi descartado por inversão. Um volume de $300 \mu \mathrm{L}$ de PBS estéril foi adicionado ao pellet. O material foi incubado com 3,0 $\mu \mathrm{L}$ de IP a $10 \mathrm{mM}$ (Sigma-Aldrich, Alemanha) por duas horas protegido da luz. Após este período, o material foi lavado com 3,0 mL de PBS e centrifugado nas condições descritas. O pellet foi homogeneizado com $300 \mu \mathrm{L}$ de PBS e analisado empregando o citômetro FACSCalibur (BD Bioscience, EUA) empregando laser de Argon de $488 \mathrm{~nm}$ (canal FL1).

\subsubsection{Avaliação do metabolismo energético}

\subsubsection{Análise do potencial de membrana mitocondrial ( $\Delta \psi \mathrm{m})$}

Considerando que a redução do $\Delta \Psi \mathrm{m}$ sugere a ativação da glicólise aeróbica ("efeito Warburg") como via alternativa de obtenção de energia, o potencial de membrana mitocondrial das diferentes linhagens celulares foi avaliado empregando a sonda comercial MitoTracker Deep Red FM (Invitrogen, Carlsbad, EUA).

Diversas moléculas têm sido empregadas como indicadoras de $\Delta \Psi \mathrm{m}$ (SCADUTO; GROTYOHANN, 1999). Tais sondas são cátions lipofílicos que se distribuem na matriz mitocondrial e no espaço intermembrana (SCADUTO; GROTYOHANN, 1999). Dentre as sondas disponíveis encontram-se: a saframina (AKERMAN; WIKSTRIJM, 1976; VALLE; PEREIRA-DA-SILVA; VERCESI, 1986), o JC-1, a DiOC6 e a rodamina 123 (LY; GRUBB; LAWEN, 2003; SCADUTO; GROTYOHANN, 1999). Embora estas sondas tenham sido amplamente empregadas, elas apresentam alguns problemas metodológicos (VALLE; PEREIRADA-SILVA; VERCESI, 1986). Isto porque, o influxo destas moléculas depende do cotransporte de diferentes íons, como $\mathrm{Ca}^{2+}$ ou $\mathrm{K}^{+}$(VALLE; PEREIRA-DA-SILVA; VERCESI, 1986). Desta forma, estas sondas avaliam o $\Delta \Psi \mathrm{m}$ dependente do cotransporte iônico (VALLE; PEREIRA-DA-SILVA; VERCESI, 1986). Por esta razão, este estudo avaliou o $\Delta \Psi_{\mathrm{m}}$ por meio de imunofluorescência e citometris de fluxo, empregando a sonda MitoTracker Deep Red FM, a qual permite avaliar o potencial de membrana mitocondrial $\left(\Delta \Psi_{\mathrm{m}}\right)$ de forma independente do transporte de íons.

Imunofluorescência indireta: Um total de $5 \times 10^{3}$ células das respectivas linhagens, na terceira passagem (P3) foi transferido por poço, em uma placa de seis poços, contendo uma lamínula de $24 \times 24 \mathrm{~mm}$ estéril e $2,0 \mathrm{~mL}$ de meio completo. A 
passagem P3 foi escolhida a fim de evitar resultados falso-positvos decorrentes da possível influência da manipulação celular. O material foi incubado por 24 horas a 37 ${ }^{\circ} \mathrm{C}$ com $5 \%$ de saturação de $\mathrm{CO}_{2}$. Após este período, $1 \mathrm{mM}$ da sonda MitoTracker Deep Red FM (Invitrogen, Carlsbad, EUA), diluída em DMSO, foi adicionado. O material foi incubado por 40 minutos a $37^{\circ} \mathrm{C}$. O meio foi removido com auxílio de pipeta de Pasteur estéril. As células foram lavadas por cinco minutos com PBS estéril, tendo sido realizadas duas lavagens. As células foram fixadas em formaldeído tamponado a $4 \%$ a $4{ }^{\circ} \mathrm{C}$ por 30 minutos. O material foi lavado por duas vezes com PBS e as lamínulas foram montadas sobre lâminas empregando $20 \mu \mathrm{L}$ de ProLong Gold contendo DAPI (Invitrogen, Carlsbad, EUA). O material foi analisado em microscópio de epifluorescência Axio Scope A1 (Carl Zeiss, Alemanha) em aumento total de 400X.

Citometria de fluxo: Um total de $5 \times 10^{4}$ células das respectivas linhagens foi transferido para frascos de cultura de $25 \mathrm{~cm}^{2}$, contendo meio $4 \mathrm{~mL}$ de meio completo e incubado nas condições descritas na seção 5.1.1.1 até se obter uma confluência de $80 \%$. Nesta confluência, $1 \mathrm{mM}$ da sonda $1 \mathrm{mM}$ da sonda MitoTracker Deep Red FM (Invitrogen, Carlsbad, EUA), diluída em DMSO, foi adicionado por frasco. O material foi incubado por 40 minutos a $37^{\circ} \mathrm{C}$. Após este tempo, a monocamada foi desagregada conforme descrito na seção 5.1.1. As células foram homogeneizadas com 1,0 mL de PBS e centrifugadas a $300 \mathrm{~g}$ por cinco minutos, descartando-se o sobrenadante. O pellet foi homogeneizado com $200 \mu \mathrm{L}$ de PBS, vortexado por cinco segundos e analisado no citômetro de fluxo BD Accuri C6 (BD Bioscience, EUA), empregando o filtro FL4. Os resultados foram analisados no software FlowJo, por meio de histogramas. As análises comparativas foram baseadas no percentual de células e mediana de fluorescência, conforme proposto por de-Sá-Júnior et al. (2016).

\subsubsection{Análise da produção de espécies reativas de oxigênio (EROs)}

Considerando que o aumento da produção das EROs leva ao estresse oxidativo, favorecendo a TEM (CICHON; RADISKY, 2014), os níveis de EROs foram avaliados por meio de CF. Tal análise foi realizada por meio do ensaio de diacetato de dicloro-diidro-fluoresceína (DCFH-DA), considerado o método mais recomendado para avaliar o estresse oxidativo (ARANDA et al., 2013), devido sua alta sensibilidade de detecção de EROs (FERREIRA et al., 2014; RASTOGI et al., 2010). 
Isto porque, na presença de radicais livres, o DCFH-DA é oxidado a 2,7diclorofluorescepina (DCFH) (figura 21), que apresenta autofluorescência.

Figura 21 - Conversão do DCFH-DA a DCFH na presença de radicais livres

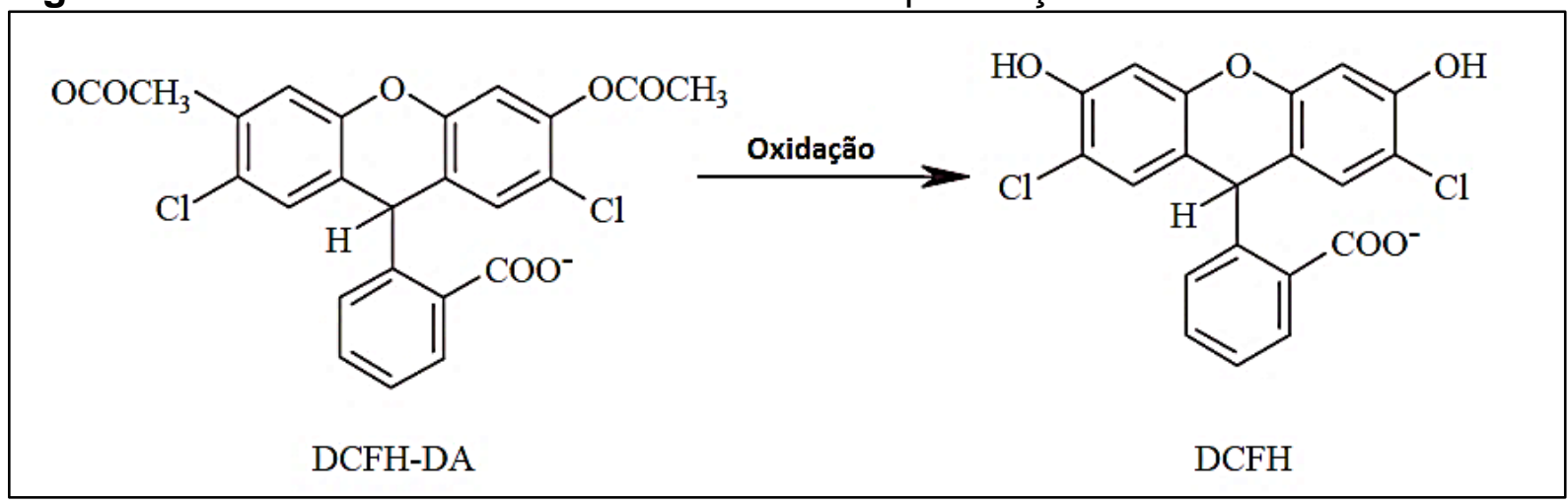

Oxidação do DCFH-DA na presença de espécies reativas de oxigênio, resultando na formação do DCFH, cujo produto apresenta fluorescência. Fonte: Gomes, Fernandes, Lima (2005).

As diferentes linhagens celulares, na terceira passagem (P3), foram subcultivadas em frascos de cultura de $25 \mathrm{~cm}^{2}$, contendo $2,0 \mathrm{~mL}$ de meio completo até se obter uma confluência de $80 \%$. Um volume de $80 \mu \mathrm{L}$ da sonda DCFH-DA foi adicionado por frasco de cultura. O material foi incubado por 40 minutos a $37^{\circ} \mathrm{C}$, conforme proposto por Aranda et al. (2013). Após este período, o meio foi removido e a monocamada foi submetida a desagregação não enzimática, conforme seção 5.1.1.1. As células foram homogeneizadas com $200 \mu \mathrm{L}$ de PBS e analisadas no citômetro BD Accuri C6 (BD Bioscience, EUA), empregando o canal FL1. Os resultados foram analisados por meio de histogramas baseados no percentual de células e na mediana de fluorescência, conforme proposto por de-Sá-Júnior et al. (2016).

Como controle positico, foi empregado o peróxido de hidrogênio (100 $\mu \mathrm{M})$, cuja concentração de uso foi determinada pelo ensaio colorimétrico do MTT (brometo de 3-(4,5-dimetiltiazol-2-yl)-2,5-difeniltetrazólio). Em detalhes: Um total de 5 $X 10^{4}$ células de pele saudável foi transferido para placas de 96 poços, contendo 200 $\mu \mathrm{L}$ de meio completo por poço. O material foi incubado por 24 horas a $37^{\circ} \mathrm{C}$, com diluições seriadas de 200-0 $\mu \mathrm{M}$ de peróxido de hidrogênio. O meio foi removido e as células, lavadas com $200 \mu \mathrm{L}$ de PBS a $37^{\circ} \mathrm{C}$. Um volume de $100 \mu \mathrm{L}$ da solução de MTT $(0,5 \mathrm{mg} / \mathrm{mL})$ foi adicionado por poço, permanecendo incubado por seis horas a $37{ }^{\circ} \mathrm{C}$. A solução de MTT foi removida e um volume de $100 \mu \mathrm{L}$ de DMSO foi adicionado por poço. A placa foi incubada por cinco minutos sob mesa agitadora. 
Após esta etapa, o material permaneceu cinco minutos sem agitação para a estabilização. As leituras foram realizadas no leitor de ELISA Multiskan EX (Thermo Scientific, EUA), em comprimento de onda de $540 \mathrm{~nm}$. As análises estatísticas foram realizadas por meio do software BioEstat versão 5.0 (AYRES et al., 2007). O ensaio foi realizado em triplicata, tendo como controle apenas a linhagem de pele saudável, na ausência do peróxido de hidrogênio.

\subsubsection{Avaliação de danos genéticos na cromatina hospedeira}

Pré-preparo das lâminas: Lâminas de 26 X 76 mm (Knitell, Alemanha) foram imersas em bécker contendo solução de agarose de ponto normal de fusão (NMA normal melting agarose) (Invitrogen, Carlsbad, EUA) a 1,5\%, diluída em tampão PBS livre de $\mathrm{Ca}^{2+}$ e $\mathrm{Mg}^{2+}$ a $60 \stackrel{\circ}{ } \mathrm{C}$, tendo um de seus lados limpos com papel toalha. As lâminas permaneceram na posição horizontal overnight, em temperatura ambiente, para a completa secagem da agarose. A concentração de 1,5\% de NMA foi estabelecida com base na literatura (ARALDI et al., 2014c; AZQUETA et al., 2011; HARTMANN et al., 2003). De acordo com os autores, a concentração de 1,5\% permite a migração de segmentos livres de DNA, resultantes da clastogênese, evitando-se resultados falso-negativos decorrentes de concentrações elevadas de NMA.

Obtenção do material biológico: Um frasco de cultura de $25 \mathrm{~cm}^{2}$, com confluência de $80 \%$, das seis diferentes passagens (P1-P6) das cinco linhagens celulares estudadas foi destinado ao ensaio cometa. As células foram submetidas a desagregação da monocamada, conforme descrito na seção 5.1.1.1. O material lavado com 2,0 mL de PBS estéril e centrifugado a $300 \mathrm{~g}$, descartando-se o sobrenadante. O pellet foi homogeneizado com $200 \mu \mathrm{L}$ de PBS. Um volume de 20,0 $\mu \mathrm{L}$ da suspensão celular foi transferido para um tubo de polipropileno de $0,2 \mathrm{~mL}$ e acrescido de $170 \mu \mathrm{L}$ de agarose de baixo ponto de fusão (LMA - low melting point) (Fermentas, Lituânia) a 0,8\%, diluída em PBS, a 37 ㄷ. O material foi homogeneizado e transferido para as lâminas pré-cobertas com agarose NMA a $1,5 \%$ e coberto com lamínula. As lâminas foram levadas a geladeira a $4 \stackrel{\circ}{ } \mathrm{C}$ por 20 minutos para a solidificação da agorose LMA. A lamínula foi cuidadosamente removida e as lâminas foram inseridas em um coply contendo solução de lise $(71,0$ $\mathrm{mL}$ da solução estoque de 2,5 M NaCl, 100 mM EDTA, $10 \mathrm{mM}$ Tris- $\mathrm{HCl}$, acrescido de $0,8 \mathrm{~mL}$ de Triton $\mathrm{X}-100$ e $8,0 \mathrm{~mL}$ de DMSO) a 4 ํ․ O coply contendo as lâminas 
foi envolvido por papel alumínio para evitar a exposição a luz e, transferido para a geladeira por uma hora. A partir deste momento, as demais etapas foram realizadas com as luzes do laboratório apagadas para evitar eventuais danos no DNA.

Eletroforese: As lâminas foram lavadas em PBS por cinco minutos. O material foi transferido para cuba horizontal Horizon 20.25 (Life Technology, Carlsbad, EUA), tendo sido adicionado o tampão de eletroforese (300 mM NaOH, 1 mM EDTA, pH > 13,0). O material permaneceu imerso no tampão por 40 minutos para a remoção das histonas. Após este período, iniciou-se a corrida eletroforética nas seguintes condições: $24 \mathrm{~V}(0,74 \mathrm{~V} / \mathrm{cm}), 300 \mathrm{~mA}$ durante 30 minutos. A cuba eletroforética foi revestida por placas de gelo para garantir que o material permanecesse a $4^{\circ} \mathrm{C}$ durante o experimento.

Neutralização: Após a eletroforese, o material foi neutralizado em solução neutralizadora $(400 \mathrm{mM}$ de Tris- $\mathrm{HCl}, \mathrm{pH} 7,5)$ por cinco minutos. A neutralização é recomendada para evitar eventuais danos ao DNA (ARALDI et al., 2014c; ROJAS; LOPEZ; VALVERDE, 1999).

Análise do material: $O$ material foi corado com $20 \mu \mathrm{L}$ de iodeto de propídeo (IP) $4 \mu \mathrm{g} / \mathrm{mL}$ e analisado em microscópio de epifluorescência Axio Scope A1 (Carl Zeiss, Alemanha) no aumento total de $400 \mathrm{X}$. Foi analisado um total de 100 nucleóides por lâmina, os quais foram classificados em: 0 (sem dano), 1 (dano intermediário) e 3 (dano máximo), conforme a figura 22.

Figura 22 - Classificação dos nucleóides de cometas de 0 a 2

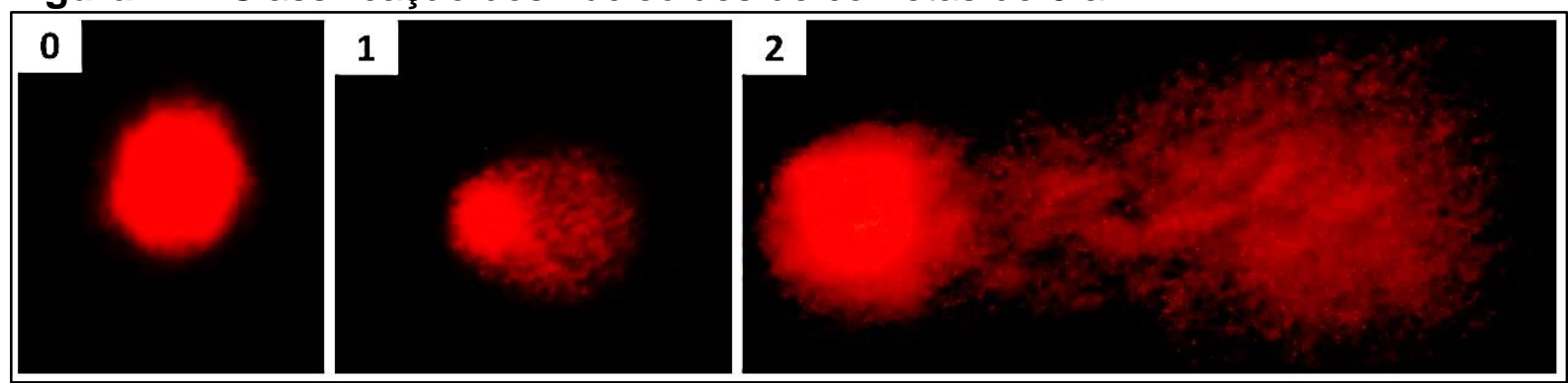

Nucleóide de classe 0 (sem dano), nucleóide de classe 1 (dano intermediário) e nucleóide de classe 2 (dano máximo).

Análise estatística: Com base no número de nucleóides observados por classe, foi obtido o valor do escore por lâmina, conforme a fórmula:

$$
\Sigma=\left[\left(\mathrm{N}_{\mathrm{c} 0} \times 0\right)+\left(\mathrm{N}_{\mathrm{c} 1} \times 1\right)+\left(\mathrm{N}_{\mathrm{c} 2} \times 2\right)\right]
$$


onde: $N_{c 0}$ (número de nucleóides observados na classe 0), $N_{c 1}$ (número de nucleóides observados na classe 1) e $N_{C 2}$ (número de nucleóides observados na classe 2).

Com base nos valores de escores obtidos, foi realizado o teste de KruskalWallis seguido do teste post-hoc de Dunn, ambos com nível de significância de $5 \%$. A análise gráfica foi realizada por meio de boxplot e regressão linear simples, calculando-se o coeficiente de Pearson, empregando o software BioEstat (AYRES, 2007).

\subsubsection{Avaliação do potencial de desdiferenciação}

Considerando que a instabilidade genômica (PASI et al., 2011), decorrente dos danos genéticos induzidos pelo vírus (ARGYLE; BLACKING, 2008), e a perda da polaridaridade apical-basal verificada na TEM podem levar a desdiferenciação celular (RADISKY; LABARGE, 2008), a aquisição do fenótipo-tronco das diferentes linhagens celulares foi avaliada por meio do ensaio de tumor-esferas e dos níveis de expressão do fator de transcrição nuclear Oct-3/4.

\subsubsection{Ensaio de tumor-esferas}

O ensaio de tumor-esferas tem sido apontado como o melhor método para a identificção de células com fenótipo-tronco, incluindo as CTCs (MOORE; HOUGHTON; LYLE, 2012). Por esta razão, este método foi adotado para investigar a aquisição de fenótipo-tronco das diferentes linhagens celulares. Em detalhes: um total de $5 \times 10^{5}$ células, na sexta passagem (P6), foi transferido por poço, em uma placa de seis poços pré-preparada com $1,0 \mathrm{~mL}$ de agarose a $2 \%$, diluída em PBS estéril/poço (já em fase sólida), contendo $2,0 \mathrm{~mL}$ de meio completo. O material foi incubado em estufa a $37 \stackrel{\circ}{\circ}$, com atmosfera de $5 \%$ de $\mathrm{CO}_{2}$ por 24 horas. O material foi levado ao microscópio invertido e as imagens foram capturadas em aumento total de 100 X. Esta análise foi realizada na P6 com o objetivo de avaliar se mesmo após as passagens e os danos no material genético as células ainda mantinham a capacidade de formar tumor-esferas. 


\subsubsection{Imunodeteccão do fator de transcição Oct-3/4}

Considerando que o fator de transcrição nuclear Oct-3/4 (POU5F1) é apontando como um importante biomarcador de células-tronco cancerígenas (CTCs) (ARGYLE; BLACKING, 2008), os níveis de expressão deste fator foram analisados por meio de IF e CF, conforme metodologia descrita na seção 5.1.1.4, empregando o anticorpo monoclonal anti-Oct-3/4, produzido em camundongo (referência sc-5279) (Santa Cruz Biotechnology, EUA), na dilução de 1:100.

\subsubsection{Análise dos níveis de expressão de marcadores associados a TEM}

A fim de avaliar a transdiferenciação de células epiteliais a mesenquimais, foram avaliados os níveis de expressão de marcadores frequentemente desregulados durante a TEM, incluindo proteínas epiteliais, mesenquimais e fatores de transcrição nuclear. Tais análises foram realizadas por meio de IF e CF, conforme os métodos descritos na seção 5.1.1.4. Os diferentes anticorpos primários empregados nesta análise, bem como suas respectivas diluições são mostrados na tabela 8.

Tabela 8 - Anticorpos empregados na análise de TEM

\begin{tabular}{cccccc}
\hline \multicolumn{7}{c}{ Marcadores epiteliais } \\
Anticorpo anti & m/pAb & Produzido & Fabric. & Diluição & Ref. \\
\hline Citoqueratina 10 & mAb & camundongo & Dako & $1: 100$ & M7002 \\
E-caderina & pAb & cabra & Dako & $1: 100$ & M3613 \\
N-caderina & mAb & camundongo & S. Cruz & $1: 100$ & sc1500 \\
\hline \multicolumn{7}{c}{ Marcadores mesenquimais } \\
Anticorpo anti & m/pAb & Produzido & Fabric. & Diluição & Ref. \\
\hline Vinculina & mAb & coelho & Sigma & $1: 100$ & V4139 \\
Vimentina & mAb & camundongo & Dako & $1: 50$ & M7025 \\
\hline \multicolumn{7}{c}{ Fatores de transcrição } \\
Anticorpo anti & m/pAb & Produzido & Fabric. & Diluição & Ref. \\
\hline B-catenina & mAb & camundongo & S. Cruz & $1: 100$ & sc376841 \\
SLUG & pAb & coelho & S. Cruz & $1: 50$ & sc15391 \\
STAT3 Y705 & pAb & coelho & Imuny & $1: 50$ & IM0448 \\
\hline ATA
\end{tabular}

Anticorpos monoclonais (mAb), policlonais (pAb) e suas respectivas referências (Ref.). S. Cruz fabricante Santa Cruz.

As reações de IF foram realizadas empregando os anticorpos secundários anti-IgG conjugado com FITC e TRIC. Para as citometria de fluxo, foram empregados os anticorpos secundários anti-lgG Alexa Fluor 488 (anticorpos primários produzidos em camundongo) e 633 (anticorpos primários produzidos em coelhos) (Invitrogen, Carlsbad, EUA). 


\subsubsection{Análise da especificidade dos anticorpos por Western blot}

A fim de verificar a especificidade dos anticorpos empregados na análise da TEM, foi realizado o Western blot. Para tanto, uma garrafa de cada cultivo celular na segunda passagem (P2) foi submetida à desagregação da monocamada, conforme seção 5.1.1.1. Esta passagem foi escolhida com o objetivo de evitar eventuais influências decorrentes da manipulação celular que pudessem interferir na regulação gênica. As células foram transferidas para tubos de polipropileno de $1,5 \mathrm{~mL} e$ lavadas com $1,0 \mathrm{~mL}$ de PBS estéril a $4{ }^{\circ} \mathrm{C}$. A suspensão celular foi centrifugada a $300 \mathrm{~g}$ por cinco minutos, desprezando-se o sobrenadante. O pellet foi ressuspenso em $200 \mu \mathrm{L}$ de tampão RIPA (Tris-HCl 50 mM pH 8,0, NaCl 150 mM, 1\% de Triton-X, $0,5 \%$ de desoxicolato, $0,1 \%$ de SDS e $1 \mathrm{mM}$ de PMSF) e transferido para gelo por 20 minutos. O lisado foi centrifugado a $14.000 \mathrm{rpm}$ por 10 minutos a $4 \stackrel{\circ}{\circ} \mathrm{C}$. O sobrenadante foi aspirado e transferido para um novo tubo de polipropileno estéril e armazenado em freezer $-80 \stackrel{\circ}{\circ}$.

As proteínas foram quantificadas empregando o método do ácido bicinconínico (BCA), método baseado na redução do cobre $\mathrm{Cu}^{2+}$ para $\mathrm{Cu}^{+}$. Este método foi empregado devido sua elevada compatibilidade com detergentes, como 0 Triton-X empregado no tampão RIPA. A quantificação foi realizada em colaboração com a Dra. Anita Mitico Tanaka Azevedo (Laboratório de Herpetologia do Instituto Butantan), utilizando o método proposto por Smith et al. (1985).

Um total de $40 \mathrm{ng}$ de proteína foi homogeneizada com 7,0 $\mu \mathrm{L}$ do tampão Laemmili ( $8 \%$ de SDS, 40\% de glicerol, $240 \mathrm{mM}$ de Tris- $\mathrm{HCl} 1 \mathrm{M} \mathrm{pH} \mathrm{6,8,31 \%} \mathrm{de}$ água destilada, $0,04 \%$ de azul de bromofenol e $5 \%$ de $\beta$-mercaptoetanol) e incubado por cinco minutos a $100 \stackrel{\circ}{\mathrm{C}}$ no termobloco para a desnaturação das proteínas. As amostras foram aplicadas em gel de SDS a $12 \%$ e submetidas a eletroforese para separação proteica nas seguintes condições: 30 minutos a $30 \mathrm{~V}$ e três horas a $80 \mathrm{~V}$, utilizando o tampão de eletroforese (25 mM de Tris, $192 \mathrm{mM}$ de glicina e $0,01 \%$ de SDS) e 7,0 $\mu \mathrm{L}$ do marcador Full-range Rainbow (GE Healthcare, EUA). Para cada corrida foram utilizados dois géis, sendo um destinado a transferência (blotting) e outro submetido a coloração por três horas com o corante PageBlue Protein Stainng Solution (Thermo Fisher Scientific, EUA), destinado à análise do perfil proteico.

As proteínas foram transferidas para membrana de nitrocelulose. Após a transferência, a membrana foi bloqueada com leite Molico a 5\% diluído em PBS e 
acrescido de $0,1 \%$ de Tween 20 por uma hora. Na sequência, a membrana foi lavada por cinco minutos com PBS acrescido de 0,1\% de Tween 20, sendo realizadas três lavagens. A membrana foi incubada overnight a $4 \stackrel{\circ}{ } \mathrm{C}$, sob agitação, com $30 \mathrm{~mL}$ da solução de leite a $5 \%$ contendo os anticorpos nas diluições mostradas na tabela 9. A membrana foi lavada por cinco minutos com PBS acrescido de 0,1\% de Tween 20, sendo realizadas três lavagens e, então, incubada com o anticorpo secundário conjugado com peroxidase, conforme tabela 9 , por uma hora, a $4 \stackrel{\circ}{\circ}$, sob agitação. A membrana foi lavada com PBS e revelação realizada com $1,0 \mathrm{~mL}$ do substrato TMB-Blotting Substrate Solution (Thermo Fisher Scientific, EUA) $(3,3,5,5-$ tetrametilbenzidina). A membrana foi fotografa com câmera digital Finepix modelo AV (Fujifilm, Japão).

Tabela 9 - Diluição dos anticorpos empregados no Western blot

\begin{tabular}{cccc}
\hline Primário & Diluição & Secundário & Diluição \\
\hline E-caderina & $1: 1000$ & Anti-lgG coelho HRP (Santa Cruz, EUA) & $1: 1000$ \\
N-caderina & $1: 500$ & Anti-lgG camundongo HRP (Santa Cruz, EUA) & $1: 0000$ \\
Vimentina & $1: 2000$ & Anti-lgG camundongo HRP (Santa Cruz, EUA) & $1: 1000$ \\
Vinculina & $1: 1000$ & Anti-lgG coelho HRP (Santa Cruz, EUA) & $1: 1000$ \\
B-catenina & $1: 1000$ & Anti-lgG camundongo HRP (Santa Cruz, EUA) & $1: 1000$ \\
SLUG & $1: 1000$ & Anti-lgG coelho HRP (Santa Cruz, EUA) & $1: 1000$ \\
\hline
\end{tabular}

\subsubsection{Análises morfológicas e aquisição de fenótipo migratório}

\subsubsection{Microscopia de contraste de fase}

A avaliação morfológica das passagens 1 a 6 (P1-P6) das diferentes linhagens celulares foi realizada por meio de microscopia com contraste de fase, empregando o microscópio invertido Nikon Eclipse Ti (Nikon, Japão). As imagens foram adquiridas com o software NIS-Elements Br versão 3.0 (Nikon, Japão) em aumentos de 100 X e 200 X. Esta avaliação teve por objetivo identificar alterações morfológicas compatíveis com a transformação maligna, tais como: perda de polaridade e presença de organelas sugestivas de fenótipo migratório (lamelipódios e filopódios).

\subsubsection{Microscopia eletrônica de varredura (MEV)}

Para esta análise, as diferentes linhagens foram expandidas em placas de seis poços, contendo uma lamínula de $22 \times 22 \mathrm{~mm}$, previamente lavadas e autoclavadas. As células foram cultivadas até se obter uma confluência de $60 \%$. 0 
meio foi removido com auxílio de pipeta Pasteur. O material foi lavado por duas vezes com 2,0 mL de PBS estéril a $37 \stackrel{\circ}{\circ}$ e, fixado com solução fixadora de Karnovisky (50 mL de parafolmadeido $8 \%, 10 \mathrm{~mL}$ de glutaraldeído $25 \%$ e $40 \mathrm{~mL}$ de PBS 0,2 M pH 7,3). As análises foram realizadas no microscópio eletrônico de varredura Quanta 250 (Fei Company, Holanda), trabalhando-se com feixes primários acelerados entre $10-15 \mathrm{kV}$. O processamento e análise do material foi realizado no Laboratório de Biologia Celular do Instituto Butantan.

\subsubsection{Identificação de F-actina por High-content screening (HCS)}

A fim de confirmar a presença de filopódios nos diferentes cultivos primários, as células foram marcadas com micotoxina faloidina e analisadas por meio HCS. Tal procedimento foi realizado no Hospital das Clínicas (USP - São Paulo), com a colaboração da Dra. Thatiana Correa de Melo. Para tanto, as células foram expandidas em placas de 96 poços de fundo preto liso (Corning, EUA), empregando meio DMEM completo, até se obter uma densidade de $5 \times 10^{3}$ células $/ \mathrm{cm}^{3}$. As células foram fixadas com paraformaldeído a $4 \%$ e lavadas por três vezes com DPBS (PBS suplementado com $0,01 \%$ de cloreto, $0,13 \mathrm{~g} / \mathrm{L}$ de cálcio e $0,1 \mathrm{~g} / \mathrm{L}$ de cloreto de magnésio). As células foram permeabilizadas com solução de Triton X100 (Sigma, Alemanha) a 0,1\% em PBS por 10 minutos e marcadas com a micotoxina faloidina (Sigma, Alemanha). As células foram lavadas com DPBS e os núcleos foram corados com 0,1 g/mL de Hoechst 33342 (Molecular Probe, EUA) por 10 minutos. As placas foram lidas no High-content screening (Molecular Devices, EUA) e as imagens, capturadas usando o software MicroHCS (Molecular Devices, EUA).

\subsubsection{Video time-lapse microscopy}

Considerando que as alterações genéticas, metabólicas e morfológicas verificadas durante a TEM convergem para a aquisição do fenótipo migratório, a velocidade de migração das diferentes linhagens celulares foi avaliada por meio de vídeo time-lapse microscopy. Tal análise foi realizada no Centro de Facilidades para a Pesquisa (CEFAP -USP), empregando o InCell Analyzer 2200 (GE Healthcare, EUA). Em detalhes: Um total de $2 \times 10^{5}$ células, na segunda passagem (P2), foi transferido para uma placa de 96 poços contendo $200 \mu \mathrm{L}$ de meio DMEM completo. A placa foi incubada a $37^{\circ} \mathrm{C}$, com atmosfera de $5 \%$ de $\mathrm{CO}_{2}$, sendo capturada uma 
imagem/campo a cada 15 minutos, em um total de 80 time-points (20 horas). As imagens capturadas foram analisadas usando o software ImageJ versão $1.5 \mathrm{e}$, calculando-se a velocidade média de migração $(\mu \mathrm{m} / \mathrm{mim})$ de cada célula, em um total de 20 células/linhagem. Baseado nestes valores, foi realizada a Análise de Variância (ANOVA) paramétrica, seguida do teste pos-hoc de Tukey, ambos com nível de significância de 5\%. As análises estatísticas foram realizadas usando o software GraphPad Prism versão 5.0 (GraphPad Software, San Diego California, EUA).

\subsection{Estudos metabólicos e genéticos da oncoproteína E6 do BPV}

Considerando que a variante de splicing da oncoproteína E6 (E6*) do HPV-16 mostrou que a proteína induz o estresse oxidativo, levando a danos no DNA (WILLIAMS et al., 2014) e, que tais alterações são eventos chave na TEM (ARCHETTI, 2015; LU; TAN; CAI, 2015), este estudo também avaliou o papel da oncoproteína E6 do BPV no metabolismo celular, bem como investigou o potencial mutagênico desta oncoproteína per se.

\subsubsection{Obtenção da oncoproteína recombinante E6 do BPV-1}

A oncoproteína recombinante E6 do BPV-1 foi expressa e purificada em Eschirichia coli BL21, de acordo com (Mazzuchelli-de-Souza et al. (2013), sendo então submetida a diálise para a remoção de resíduos de uréia e imidazol remascentes do processo de purificação proteica. A diálise foi realizada em cassetes Slide-A-Lyzer (3K-12 mL) (Thermo Scientific, Carlsbad, EUA), contendo $10 \mathrm{~mL}$ da suspensão proteica. Os cassetes foram transferidos para becker contendo $2 \mathrm{~L}$ de tampão de diálise (20 mM Tris- $\mathrm{HCl}$ e $500 \mathrm{mM} \mathrm{NaCl}, \mathrm{pH}$ 8,0), permanecendo neste tampão por 24 horas a $4{ }^{\circ} \mathrm{C}$ sob agitação, com troca de tampão a cada oito horas.

A identidade da proteína foi confirmada por meio Western blot e espectrometria de massa, que foi capaz de identificar quatro sequências peptídicas:
K.DFHVVIR.E,
(2) K.DFHVVIR.E,
(3) R.HVLFNEPFCK.T E

R.LWQGVPVTGEEAELLHGK.T. Estas sequências foram analisadas através da base da dados SWISS-PROT (http://www.ebi.ac.uk/uniprot), que apontou um escore de 94, demonstrando que a oncoproteína purificada possui identidade com a E6 de BPV-1 (número de acesso VE6_BPV1). 
Figura 23 - Identidade da oncoproteína E6 do BPV-1 por Western blot

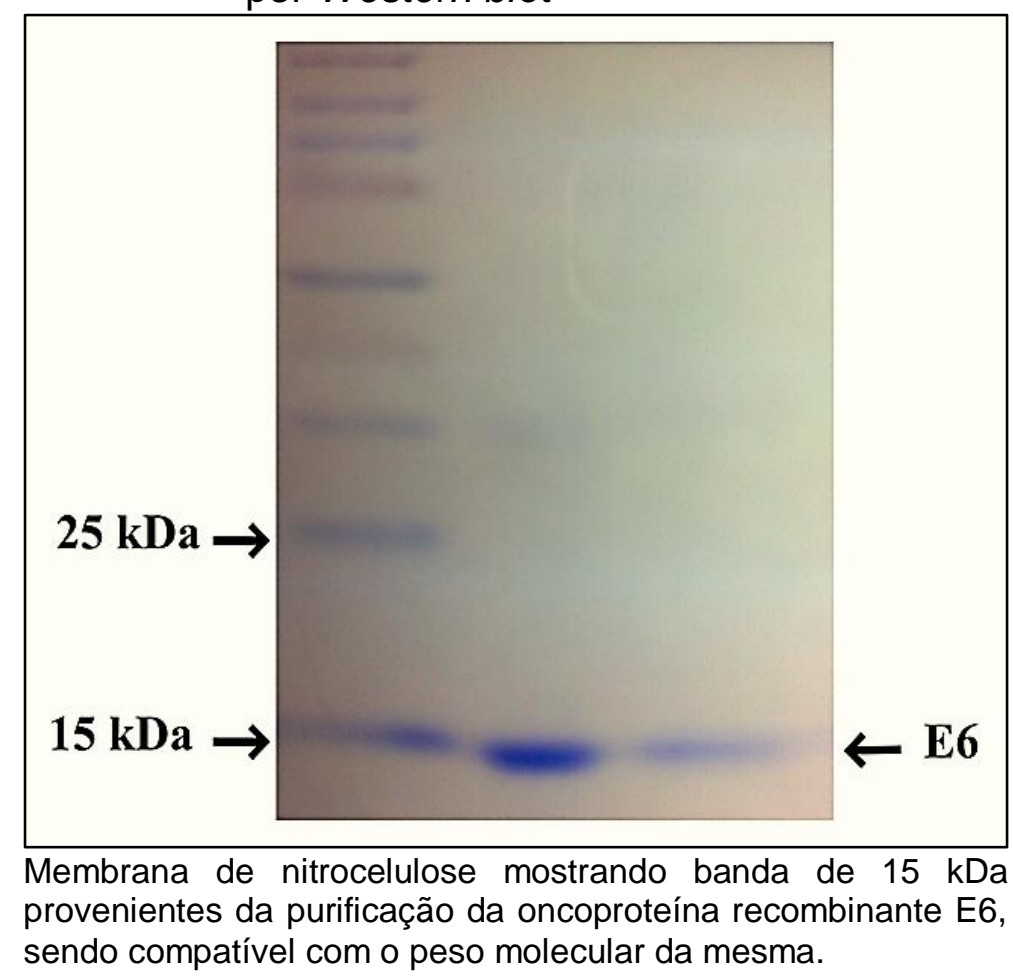

\subsubsection{Efeitos da oncoproteína E6 do BPV sob o metabolismo celular}

A ação da oncoproteína recombinante E6 do BPV-1 sobre o metabolismo energético foi verificada por meio da avaliação do $\Delta \psi m$ e da produção de EROs. Para tanto, células de pele saudável, não infectadas pelo BPV, na segunda passagem (P2), foram tratadas com $1 \mu \mathrm{g} / \mathrm{mL}$ da oncoproteína recombinante E6 do BPV-1 dialisada por 24 horas. A concentração da oncoproteína foi baseada em estudos de vacinologia, uma vez que a oncoproteína E6 tem sido discutida como um possível produto terapêutico contra a PB (MAZZUCHELLI-DE-SOUZA et al., 2013). A opção de tratar células saudáveis com a oncoproteína para avaliar seus efeitos sob o metabolismo energético foi adotada em face da inexistência de tecnologias de silenciamento deste gene do BPV por meio de RNA de interferência (siRNA). Após a incubação com a oncoproteína, as células foram destinadas a avaliação do $\Delta \psi m$, utilizando a sonda comercial MitoTracker Deep Red FM, e ao ensaio de DCFH-DA, para análise de produção de EROS, conforme descrito nas seções 5.1.2. 


\subsubsection{Teste do micronúcleo com bloqueio de citocinese (TMNBC)}

\subsubsection{Identificacão de sequências de DNA viral em sanque periférico}

Coleta das amostras de sangue periférico: Foram coletados $5 \mathrm{~mL}$ de sangue periférico de cinco bezerros assintomáticos (Bos taurus, Simental). A opção por bezerros reduz eventuais resultados falso-positivos da correlação positiva entre idade e danos no DNA (HEUSER et al., 2008) e do status endrócrino e imune, verificados no período de transição ${ }^{6}$, que resulta em clastogênese (THARWAT; ENDOH; OIKAWA, 2012). O sangue foi coletado por meio de venopunção da veia jugular, empregando tubos a vácuo contendo heparina potássica (análise mutagênica) e EDTA (identificação de sequências virais).

Transporte do material biológico: O sangue coletado foi transportado para o Laboratório de Genética do Instituto Butantan em caixas térmicas, evitando assim eventuais danos no material genético que pudessem induzir resultados falsopositivos. O transporte em caixas térmicas permitiu, também, a preservação da viabilidade celular, necessária para garantir o sucesso das culturas destinadas ao teste do micronúcleo com bloqueio de citocinese (TMNBC).

Extração do DNA genômico e viral: O material destinado à identificação de sequências de BPV foi conservado a -20 ํ․ O DNA foi extraído empregando o QIAamp DNA Blood Mini Kit (Qiagen, Alemanha), conforme descrito na seção

\subsubsection{3.}

Identificação e tipagem viral: A não identificação de sequências de BPV nas amostras de sangue periférico é fundamental para garantir a fidedignidade dos resultados obtidos nos testes mutagênicos. Isto porque estudos apontam que a presença de sequências virais está associada a danos na cromatina hospedeira (ARALDI et al., 2013a; MELO et al., 2011; STOCCO DOS SANTOS et al., 1998). Desta forma, as amostras de DNA fora submetidas à identificação de sequências virais por meio de PCR, empregando os pares de primers específicos para BPV-1, 2 e 4 (tabela 7) e degenerados Delta-Epsilon e Xi (tabela 10).

\footnotetext{
${ }^{6}$ Período que compreende três semanas antes e após o parto
} 
Tabela 10 - Sequência dos primers empregados na identificação do BPV

\begin{tabular}{clcc}
\hline Primer & \multicolumn{1}{c}{ Sequência (5'-3') } & Gene alvo & Amplicon \\
\hline Delta-Epsilon & CCAGAYTAYYTMAAAATGGC & L1 & $430 \mathrm{pb}$ \\
& ATAAMKGCTAGCTTATATTC & & \\
\hline $\mathrm{Xi}$ & TWYAATAGDCCVTTTTGGAT & L1 & $600 \mathrm{pb}$ \\
& TTMCGCCTACGCTTTGGCGC & & \\
\hline \multicolumn{2}{l}{ Nucleotídeos degenerados: Y (C ou T), M (C ou A), K (T ou G), W (A ou T), D (C, G ou T) e V (A, C }
\end{tabular}
ou $\mathrm{G})$.

Parâmetros da PCR: As reações empregando os pares de primer degenerados Delta-Epsilon e Xi foram submetidas aos seguintes ciclos: 10 minutos a $94{ }^{\circ} \mathrm{C}$ (denaturação inicial), 45 ciclos de um minuto a $94{ }^{\circ} \mathrm{C}$ (denaturação), um minuto a $52 \stackrel{\circ}{\circ}$ (anelamento), um minuto a $72 \stackrel{\circ}{\circ}$ (extensão) e 10 minutos a $72 \stackrel{\circ}{\circ}$ (extensão final). A eletroforese foi realizada conforme descrito na seção 5.1.1.3.

\subsubsection{Teste do micronúcleo em sanque periférico}

As amostras de sangue periférico foram divididas em três grupos: (1) controle negativo, (2) controle positivo e (3) experimental. Cada grupo foi incubado em tubos de centrífuga de fundo cônico de $15 \mathrm{~mL}$ contendo: $4,5 \mathrm{~mL}$ de meio RPMI 1640 (Cultilab, Campinas, Brasil), suplementado com $0,5 \mathrm{~mL}$ de soro fetal bovino (SFB) (Cultilab, Campinas, Brasil) e 0,1 mL de fitohemaglutinina A (PHA) (Cultilab, Campinas, Brasil) e $200 \mu \mathrm{L}$ de sangue total. A incubação de sangue total é preferencialmente recomendada, uma vez que 0 isolamento de células mononucleares de sangue periférico (PBMCs) pode induzir danos no DNA decorrentes das etapas de centrifugação (COLLINS, 2004). O material foi incubado em estufa de cultura Orion modelo 502A (Fanen, São Paulo, Brasil) a $37^{\circ} \mathrm{C}$ por oito horas. Após este período, um volume de $1,25 \mu \mathrm{L}$ da solução de ciclofosfamida monoidratada (Sigma-Aldrich, Alemanha) (figura 24A), na concentração de 50 $\mu \mathrm{g} / \mathrm{mL}$, diluída em PBS estéril foi adicionado ao grupo controle positivo. O grupo experimental foi incubado com 10,0 $\mu \mathrm{L}$ da oncoproteína recombinante E6 do BPV-1, na concentração final de $1 \mu \mathrm{g} / \mathrm{mL}$. Esta concentração foi baseada em estudos prévios envolvendo a vacinação terapêutica contra a papilomatose bovina (CHANDRACHUD et al., 1994). Após 44 horas de início do procedimento, as culturas foram tratadas com $6 \mu \mathrm{L}$ de citocalasina B (Sigma-Aldrich, Alemanha) (figura 24B), diluída em dimetilsulfóxido (DMSO), na concentração de $6 \mu \mathrm{g} / \mathrm{mL}$. 
Figura 24 - Fórmula estrutural da ciclofosfamida e da citocalasina B

A

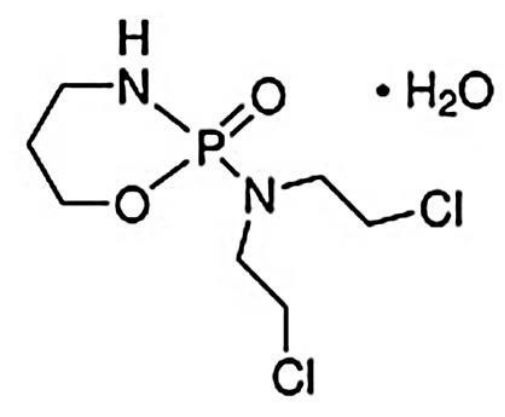

B

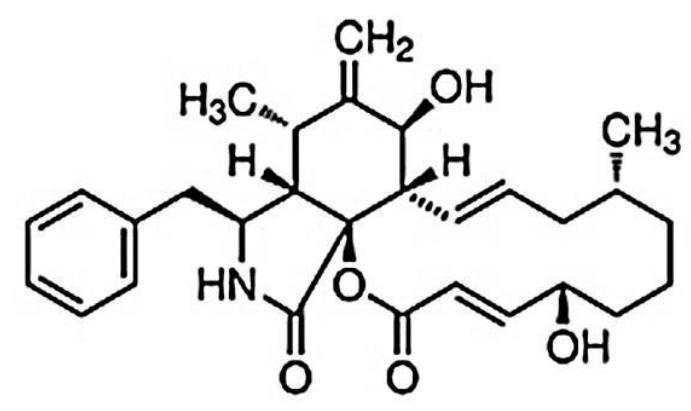

A) Ciclofosfamida; B) citocalasina B. Fonte: Sigma-Aldrich.

A citocalasina B é um metabólito isolado do fungo Drechslera dematioidea, que impede a polimerização da actina (MAC-LEAN-FLETCHER; POLLARD, 1980). Esta ação impede a citocinese, originando linfócitos binucleados sem causar danos no material genético (DEGEN et al., 1997). A concentração de citocalasina B foi escolhida com base em Kirsch-Volders et al. (2003), onde é recomendada a adição de $6 \mu \mathrm{g} / \mathrm{mL}$ da droga para culturas de sangue total e $3 \mu \mathrm{g} / \mathrm{mL}$ para PBMCs. As culturas foram incubadas por 72 horas, pois tempos superiores de incubação podem induzir danos genéticos (MCKELVEY-MARTIN et al., 1993). Um modelo esquemático dos tempos de cultivo celular é mostrado na figura 25.

Figura 25 - Modelo esquemático da cultura de linfócitos

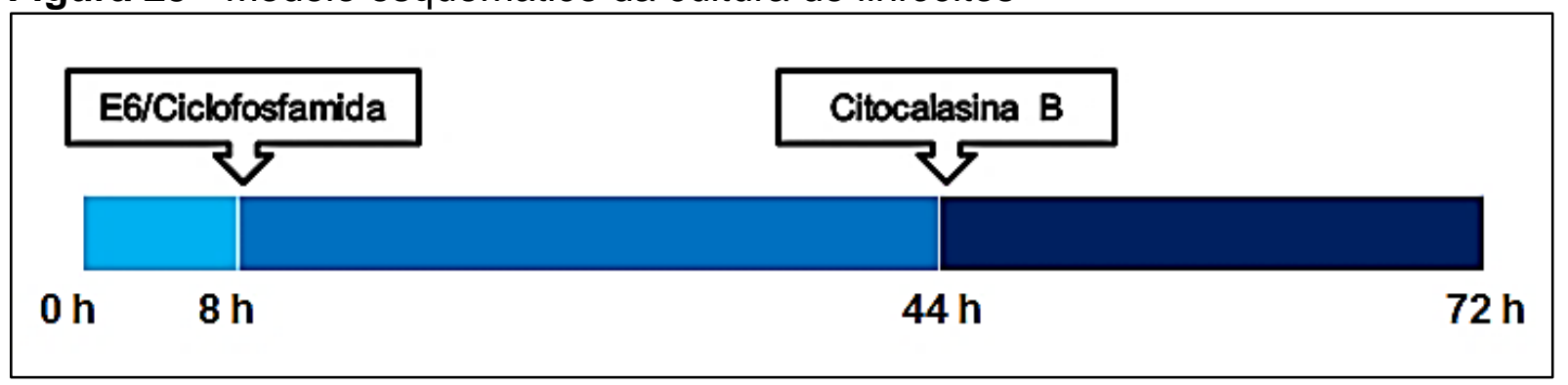

Modelo esquemático mostrando o tempo de aplicação do tratamento com a proteína E6 (grupo experimental) e ciclofosfamida e a adição da citocalasina B.

Após 72 horas, as culturas foram interrompidas com a adição de 0,5 $\mathrm{mL}$ do fixador Carnoy (3:1 metanol-ácido acético) por cinco minutos em temperatura ambiente. Os tubos foram centrifugados por 10 minutos a $300 \mathrm{~g} \mathrm{em}$ centrifuga Mikro 22R (Hettich, Berlim, Alemanha). O sobrenadante foi descartado por inversão. Este procedimento foi realizado por três vezes. 
Após a última centrifugação, o material foi aspirado e transferido para lâminas previamente limpas com álcool $70^{\circ}$. As lâminas foram secas em temperatura ambiente, fixadas em metanol absoluto (Merck, Alemanha) e coradas com solução de $2 \%$ de Giemsa (Merck, Alemanha) em tampão PBS pH 6,8 por oito minutos. O material foi lavado três vezes em água destilada por três minutos. As lâminas foram montadas com Entelan (Merck, Alemanha) e analisadas em microscópio binocular Axiophot (Carl Zeiss, Alemanha) com aumento total de $1.000 \mathrm{X}$. As imagens foram capturadas empregando o software AxioVision versão 4.7 (Carl Zeiss, Alemanha).

Análise estatística: Um total de 1.000 células foi analisado por lâmina, observando-se a frequência de linfócitos mono, bi, tri e polinucleados. Foi, também, analisado o número de linfócitos com micronúcleos (MNs) e pontes anafásicas (PA). Com base na frequência de linfócitos binucleados com micronúcleo, foram realizados os testes do Qui-quadrado $\left(\chi^{2}\right)$ e Kruskal-Wallis, seguido do teste post-hoc de Dunn. Os testes foram realizados através do software BioEstat (AYRES et al., 2007), com nível de significância de $5 \%$. O teste do Qui-quadrado permitiu avaliar diferenças estatísticas significativas dentro dos respectivos grupos. Já o teste de Kruskal-Wallis permitiu analisar as diferenças estatísticas entres os diferentes grupos.

Com base na frequência de linfócitos binucleados com MNs, foi calculada a frequência de formação de micronúcleos $\left(\mathrm{MN}_{\mathrm{r}}\right)$, de acordo com a seguinte fórmula:

$$
M N_{r}=a / b
$$

onde: a (número de linfócitos binucleados com MN) e b (número total de linfócitos binucleados).

Foi, também, calculado o índice de proliferação de bloqueio de citocinese (IPBC), que permite avaliar a toxicidade celular. O IPBC foi calculado de acordo com a fórmula:

$$
\text { IPBC }=\left(1 \times N_{1}\right) \times\left(2 \times N_{2}\right) \times\left(3 \times N_{n}\right) / 1.000
$$

onde: $\mathrm{N}_{1}$ (número de células mononucleadas), $\mathrm{N}_{2}$ (número de células polinucleadas) e $\mathrm{N}_{\mathrm{n}}$ (número de células polinucleadas). 


\subsubsection{Teste do micronúcleo em células epiteliais}

Considerando o cárater epiteliotrópico do BPV, o potencial genotóxico da oncoproteína foi adicionalmente avaliado em células CRIB (células epiteliais de rim bovino não infectado pelo BPV). As células foram expandidas em placas de seis poços, contendo uma lamínula estéril/poço, com 2,0 mL de meio DMEM completo. Após obter uma confluência de $60 \%$, as células foram tratadas com $50 \mu \mathrm{g} / \mathrm{mL}$ de ciclofosfamida (controle positivo) e1 $\mu \mathrm{g} / \mathrm{mL}$ da oncoproteína recombinante E6 do BPV-1. Como controle negativo foram empregadas células CRIB sem a adição de nenhuma droga. Após uma hora, foi adicionado $6 \mu \mathrm{g} / \mathrm{mL}$ de citocalasina $B$. As células foram incubadas por 24 horas a $37^{\circ} \mathrm{C}$. Após este tempo, o meio foi removido com auxílio de pipeta Pasteur e as células foram lavadas com PBS estéril a $4 \stackrel{\circ}{\circ} \mathrm{C}$. $\mathrm{O}$ material foi fixado por uma hora com solução de formaldeído a $4 \%$. As células foram lavadas por cinco minutos com PBS, sendo realizadas três lavagens e, então coradas com Giemsa puro (Merck, Alemanha) por um minuto. A lamínula foi transferida para lâminas de microscopia e analisadas em microscópio binocular Axiophot (Carl Zeiss, Alemanha) com aumento total de $1.000 \mathrm{X}$. As imagens foram capturadas empregando o software AxioVision versão 4.7 (Carl Zeiss, Alemanha).

Análise estatística: Um total de 1.000 células foi analisado por lâmina, observando-se a frequência de linfócitos mono, bi, tri e polinucleados. Foi, também, analisado o número de linfócitos com micronúcleos (MNs) e pontes anafásicas (PA). Os resultados foram apresentados na forma de histograma.

\subsubsection{Ensaio cometa}

As amostras de sangue foram fracionadas em três alíquotas de $200 \mu \mathrm{L}$ cada. As alíquotas foram distribuídas em tubos de polipropileno de $1,5 \mathrm{~mL}$ contendo 200 $\mu \mathrm{L}$ de meio RPMI 1640, compondo os grupos: (1) controle negativo (não incubado com nenhuma droga), (2) controle positivo (incubado com $50 \mu \mathrm{g} / \mathrm{mL}$ de ciclofosfamida) e (3) experimental (tratado com $1 \mu \mathrm{g} / \mathrm{mL}$ da oncoproteína recombinante E6 do BPV-1). Todas as culturas foram estabelecidas na ausência de antibiótico. O material foi incubado por uma hora em estufa a $37^{\circ} \mathrm{C}$, de acordo com Araldi et al. (2014c, 2015b). Após este período, os tubos foram centrifugados a $390 \mathrm{~g}$ por um minuto em centrífuga Hettich Mikro 22R (Berlim, Alemanha), descartando-se o sobrenadante. Um volume de $10 \mu \mathrm{L}\left(0,8 \times 10^{8}\right.$ células $\left./ \mathrm{mL}\right)$ do material 
centrifugado foi transferido para tubos de polipropileno de $0,2 \mathrm{~mL}$ e acrescido de 75 $\mu \mathrm{L}$ de agarose de baixo ponto de fusão (LMA - low melting agorose) a 37 C. O volume final de $85 \mu \mathrm{L}$ da suspensão celular foi aspirado com auxílio de pipeta e transferido para as lâminas pré-cobertas com NMA a 1,5\%. As demais etapas deste método foram realizadas conforme descrito na seção 5.1.3.

\subsection{Estudo da TEM em tecido parafinado}

\subsubsection{Análise histopatológica}

As amostras clínicas de pele saudável, papiloma cutâneo (papiloma 01), fibropapiloma (papiloma 02 e 03) e carcinoma de esôfago foram cirurgicamente coletadas, fixadas em formalina tamponada a $10 \%$ por 48 horas, desidratadas em concentrações crescentes de etanol e emblocadas em parafina. Tais blocos fazem parte do acervo biológico do Laboratório de Genética do Instituto Butantan. Os blocos de tecido foram submetidos a cortes de 4-5 $\mu \mathrm{m}$ e transferidos para lâminas silanizadas. Os cortes foram destinados à análise histopatológica e a imunoistoquímica (IHQ-P). Para a análise histopatológica, os cortes foram submetidos à coloração usual de hematoxilina-eosina (HE) e analisados em campo claro, empregando o microscópio binocular Axiophoto (Carl Zeiss, Alemanha) em diferentes aumentos (50-400 X). As imagens foram capturadas com o software ZEN (Carl Zeiss, Alemanha).

\subsubsection{Análise da matriz colagenosa}

A análise quantitativa das fibras de colágeno foi realizada pela técnica de coloração de Picrosírius red. Esta técnica permite identificar as fibras colagenosas através de método colorimétrico, no qual fibras de colágeno tipo I apresentam a coloração vermelho-alaranjada, enquanto fibras de tipo III, na cor amareloesverdeada (RIBEIRO et al., 2015). Os cortes foram desparafinizados, hidratados e colocados em solução corante de picro-sirius por 40 minutos e imersos em solução aquosa de hidróxido de sódio a $0,5 \%$ sob agitação até perder a cor vermelha. O material foi corado com hematoxilina e lavado em água destilada. As lâminas foram montadas empregando o meio Tissue Teck (Sakura Finetik, Holanda) e analisadas no microscópio binocular Olympus Bx51 em campo claro e com polarizador Olympus $45 \mathrm{MM}$ para luz transmitida em aumento total de $100 \mathrm{X}$. A quantificação das fibras de colágeno foi realizada com base no percentual de área, usando o software ImageJ, 
de acordo com Hadi et al. (2011). Este procedimento foi realizado no Laboratório de Fisiopatologia do Instituto Butantan, contando com a colaboração da Dra. Diva Denelle Spadacci Morena.

\subsubsection{Imunoistoquímica em tecido parafinado (IHQ-P)}

A IHQ-P é um importante método que permite identificar proteínas de interesse no contexto tecidual. Neste sentido, este método foi proposto para validar os resultados verificados nas linhagens celulares derivadas de neoplasias infectadas pelo BPV, permitindo assim o uso dos sistemas in vitro como modelos de estudo do processo oncogênico associado aos PVs.

\subsubsection{Imunodeteccão da oncoproteína E5 do BPV}

A imunodetecção da oncoproteína E5 do BPV foi realizada através de IHQ-P. Tal experimento foi realizado no Dipartimento de Medicina Veterinaria e Produzioni Animali da Università degli Studi di Napoli Ferderico II, sob a supervisão dos Profs. Dr. Sante Roperto e Dr. Franco Pepino Roperto.

Os cortes foram submetidos à desparafinização por 30 minutos em xilol e hidratados por 10 minutos em etanol 100\%. Após estas etapas, os cortes foram incubados por 20 minutos em temperatura ambiente com solução de 1:4 metanolperóxido de hidrogênio a $3 \%$, permitindo, assim, o bloqueio da peroxidase endógena. Os cortes foram reidratados por cinco minutos nas concentrações decrescentes de etanol 95\%, 80\% e 70\%. As lâminas foram lavadas em PBS por 5 minutos submetidos à recuperação antigênica. Tal procedimento foi realizado em micro-ondas, empregando solução de citrato de sódio pH 6,0 em dois ciclos de cinco minutos cada a 450 e $700 \mathrm{~W}$, respectivamente. As lâminas foram transferidas para caixa térmica contendo gelo para o resfriamento da solução. Os cortes foram lavados por cinco minutos com PBS e incubadas por 40 minutos com soro de burro a 20\% (Sigma, Alemanha) para o bloqueio de eventuais ligações inespecíficas. O bloqueio com este soro foi realizado uma vez que o anticorpo secundário empregado no ensaio (anti-lgG de ovelha) foi produzido em burro. Os cortes foram incubados em câmara úmida overnight com o anticorpo policlonal anti-E5 produzido em ovelha na diluição de 1:500 em PBS. Após a incubação, o material foi lavado por 5 minutos em PBS e incubado com o anticorpo secundário biotinilado anti-lgG de burro (Santa Cruz Biotechnology, EUA) na diluição de 1:100 por uma hora. Os cortes foram 
lavados por cinco minutos em PBS por duas vezes, sendo então incubado com a estreptavidina por 20 minutos. A imunomarcação foi revelada com 3,3diaminobenzidina (DAB). Os cortes foram contra corados com hematoxilina por dois minutos e, então, submetidos à desidratação em etanol 70\%, 80\%, 95\% e 100\% por dois minutos e, na sequência, transferidos para xilol por cinco minutos. As lâminas foram montadas empregando o meio Tissue Tek e analisadas em campo claro empregando o microscópio binocular DM 4000B (Leica, Alemanha) em aumentos de $50-400 \mathrm{X}$.

\subsubsection{Imunodeteccão de marcadores da TEM}

Desparafinização: Os cortes foram desparafinizados empregando dois banhos consecutivos de xilol $100 \%$ por 30 minutos, solução $1: 1$ xilol-álcool $100^{\circ}$ por 30 minutos, dois banhos consecutivos de álcool $100^{\circ}$ por 5 minutos, álcool 95 por 5 minutos, álcool 70ำ por 5 minutos, hidróxido de amônio $10 \%$ em álcool 95ำ por 10 minutos e quatro lavagens em água destilada por 5 minutos cada.

Recuperação Antigênica: Este procimento foi realizado em micro-ondas, empregando solução de citrato de sódio pH 6,0 em dois ciclos de cinco minutos cada a 450 e $700 \mathrm{~W}$, respectivamente. As lâminas foram transferidas para caixa térmica contendo gelo para o resfriamento da solução. Os cortes foram lavados por cinco minutos com PBS por duas vezes.

Imuno-detecção: O procedimento de marcação foi realizado de acordo com kit $E_{\text {EnVision }}{ }^{\mathrm{M}}$ + System HRP (AEC) (Dako, Carpinteria, EUA) que permite uma melhor amplificação do sinal. A peroxidase endógena foi bloqueada com o peroxidase block, contido no kit, por 10 minutos. O material foi lavado com TBS (50 mM Tris-Cl, 150 $\mathrm{mM} \mathrm{NaCl}, \mathrm{pH} 7,6)$ por cinco minutos por três vezes e tratado com Triton X-100 a $0,01 \%$ por 20 minutos. As lâminas foram lavadas com PBS por 5 minutos e, bloqueadas com BSA a $5 \%$ por 40 minutos. Os cortes foram incubados overnight com os anticorpos primários (tabela), as lâminas foram lavadas com TBS-T (TBS, $0,2 \%$ de Tween-20) a $2 \%$ por duas vezes. Sob os cortes, foram aplicadas duas gotas do anticorpo secundário, conjugado com peroxidase (peroxidase labelled polymer), contido no kit. Em seguida, o material foi mantido por uma hora a $4 \stackrel{\circ}{\mathrm{C}} \mathrm{em}$ câmara úmida. As lâminas foram lavadas com TBS-T por cinco minutos por três vezes e, tratadas com duas gotas do substrato cromógeno AEC por 15 minutos. $O$ material foi lavado em água destilada por 5 minutos e contra corado com 
hematoxilina Mayer por 8 minutos. As lâminas foram lavadas com água destilada e mergulhadas hidróxido de amônio $0,037 \mathrm{M}$, para a remoção do excesso de hematoxilina. Em seguida, as lâminas foram lavadas com água destilada e montadas com o meio de montagem Faramount (Dako, Carpinteria, EUA). As lâminas foram analisadas em microscópio óptico binocular Axiophot (Carls Zeiss, Alemanha) com objetivas de $10 \mathrm{X}, 20 \mathrm{X}$ e $40 \mathrm{X}$. As imagens foram capturadas através do software AxioVision versão 4.7.2.

Controles: Foram empregados dois controles negativos, sendo eles: um fragmento de tecido cutâneo de um bezerro assintomático BPV-negativo (pele saudável) e, compondo o controle negativo do experimento, um fragmento de papiloma cutâneo (papiloma 01) sem a adição do anticorpo primário, constituindo o controle negativo da reação. Considerando que os anticorpos primários empregados são destinados ao uso humano, cortes de carcinoma de estômago e lábio humano foram inseridos como controle positivo. Tais blocos foram gentilmente cedidos pela Dra. Adriana da Costa Neves.

Tabela 11 - Diluição dos anticorpos primários usados na IHQ

\begin{tabular}{cccc}
\hline Anticorpo & m/pAb & Fabricante & Diluição \\
\hline E5 & $\mathrm{pAb}$ & - & $1: 500$ \\
Citoqueratina 10 & $\mathrm{mAb}$ & Dako & $1: 200$ \\
Vimentina & $\mathrm{mAb}$ & Dako & $1: 200$ \\
B-catenina & $\mathrm{pAb}$ & Santa Cruz & $1: 100$ \\
STAT3 Y705 & pAb & Immuny & $1: 100$ \\
\hline
\end{tabular}


6 RESULTADOS 


\subsection{Análise das linhagens celulares como modelo de estudo da TEM}

\subsubsection{Evidências de infecção produtiva in vitro}

\subsubsection{Identificacão de sequências de DNA viral}

A identificação de sequências de DNA viral nas diferentes linhagens celulares foi realizada por meio de PCR convencional. Para tanto, tais linhagens foram repicadadas até a sexta passagem e submetidas à extração de DNA. Os resultados da quantificação do DNA extraído são mostrados na tabela 12.

- Os resultados da PCR mostraram a ausência de sequências de DNA viral nas seis passagens da linhagem de pele saudável (figura 26). Entretanto, as linhagens celulares derivadas de papilomas cutâneo (papiloma 01), fibropapiloma (papilomas 02 e 03) e carcinoma de esôfago mostraram-se co-infectadas por pelo menos um dos tipos virais BPV-1, 2 e/ou 4 (figura 26). Tais linhagens não somente mostraram a presença de sequências de DNA viral, como também revelaram a manutenção destas sequências ao longo das seis passagens estudadas (figura 26). Os resultados da PCR são apresentados de forma resumida na tabela 13. 
Tabela 12 - Quantificação do DNA extraído

\begin{tabular}{|c|c|c|c|}
\hline \multicolumn{4}{|c|}{ Controle negativo } \\
\hline Passagem & {$[D N A] n g / \mu L$} & $A_{260} / A_{280}$ & $A_{260} / A_{230}$ \\
\hline P1 & 58,0 & 2,52 & 1,64 \\
\hline P2 & 30,0 & 1,54 & 1,11 \\
\hline P3 & 13,0 & 1,87 & 1,76 \\
\hline P4 & 15,0 & 1,98 & 3,00 \\
\hline P5 & 13,0 & 1,58 & 1,34 \\
\hline P6 & 10,0 & 1,21 & 2,06 \\
\hline \multicolumn{4}{|c|}{ Papiloma cutâneo 01} \\
\hline Passagem & [DNA] $n g / \mu L$ & $\mathbf{A}_{260} / \mathbf{A}_{280}$ & $A_{260} / A_{230}$ \\
\hline P1 & 26,0 & 2,44 & 1,18 \\
\hline P2 & 10,0 & 1,94 & 0,64 \\
\hline P3 & 43,0 & 2,37 & 4,62 \\
\hline P4 & 43,0 & 2,03 & 2,43 \\
\hline P5 & 14,0 & 1,89 & 3,07 \\
\hline P6 & 13,0 & 1,44 & 1,14 \\
\hline \multicolumn{4}{|c|}{ Papiloma cutâneo 02} \\
\hline Passagem & [DNA] $n g / \mu L$ & $\mathbf{A}_{260} / \mathbf{A}_{280}$ & $A_{260} / A_{230}$ \\
\hline P1 & 22,0 & 2,40 & 2,87 \\
\hline P2 & 43,0 & 2,03 & 1,63 \\
\hline P3 & 27,0 & 2,19 & 3,44 \\
\hline P4 & 18,0 & 1,87 & 3,15 \\
\hline P5 & 37,0 & 1,64 & 2,00 \\
\hline P6 & 27,0 & 2,13 & 1,64 \\
\hline \multicolumn{4}{|c|}{ Papiloma cutâneo 03} \\
\hline Passagem & [DNA] $n g / \mu L$ & $\mathbf{A}_{260} / \mathbf{A}_{280}$ & $A_{260} / A_{230}$ \\
\hline P1 & 38,0 & 1,48 & 2,70 \\
\hline P2 & 48,0 & 1,78 & 2,90 \\
\hline P3 & 40,0 & 1,71 & 2,38 \\
\hline P4 & 44,0 & 1,81 & 2,24 \\
\hline P5 & 32,0 & 1,76 & 1,70 \\
\hline P6 & 43,0 & 1,78 & 1,13 \\
\hline \multicolumn{4}{|c|}{ Carcinoma de esôfago } \\
\hline Passagem & [DNA] $n g / \mu \mathrm{L}$ & $A_{260} / A_{280}$ & $A_{260} / A_{230}$ \\
\hline P1 & 18,0 & 1,29 & 1,79 \\
\hline P2 & 24,0 & 2,41 & 1,17 \\
\hline P3 & 22,0 & 2,12 & 2,21 \\
\hline P4 & 21,0 & 1,89 & 2,12 \\
\hline P5 & 19,0 & 1,77 & 1,98 \\
\hline P6 & 23,0 & 1,56 & 2,13 \\
\hline
\end{tabular}


Figura 26 - Identificação de sequências de BPV nas linhagens celulares

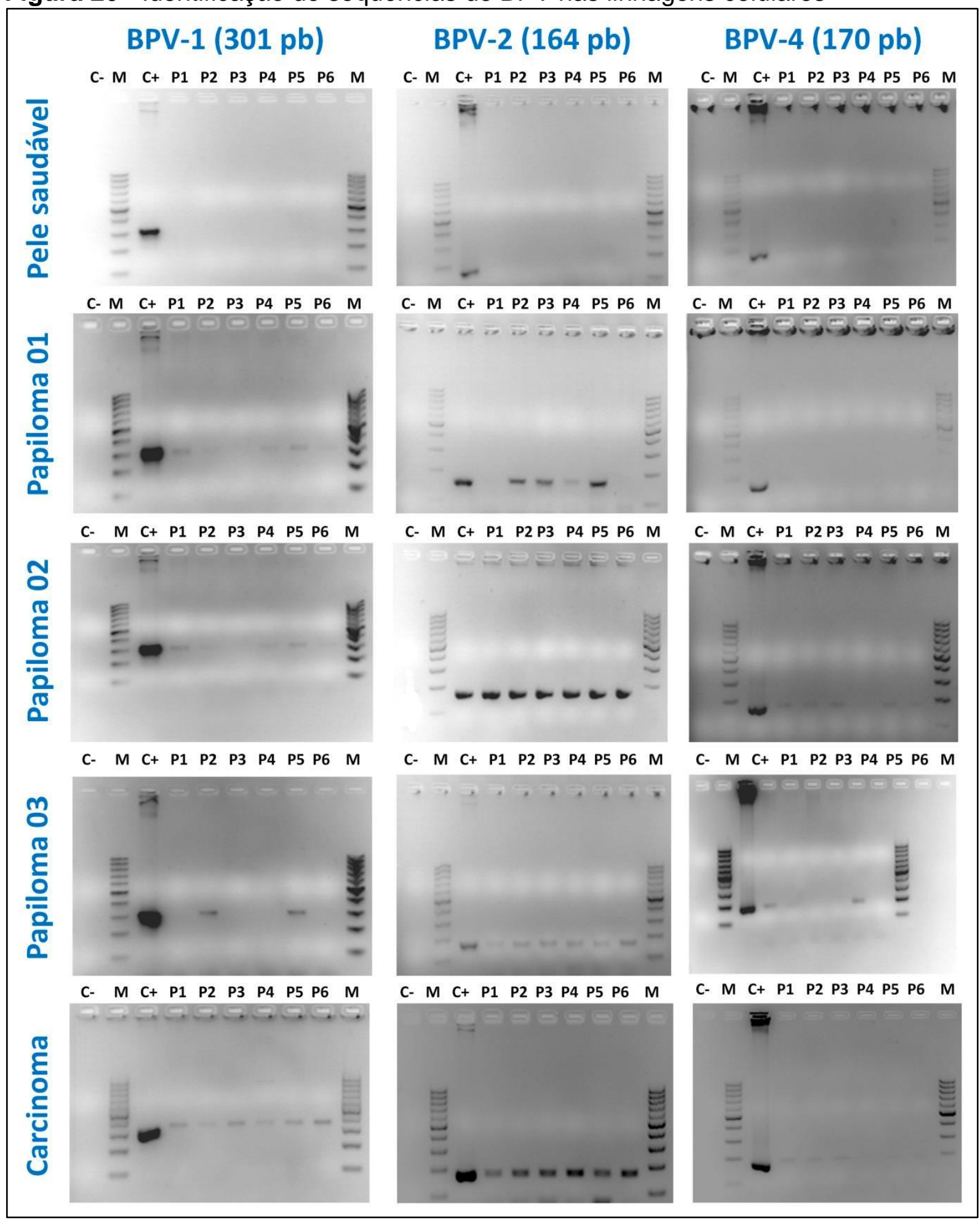

Imagens de géis de eletroforese mostrando amplicons de: BPV-1 (301 pb), BPV-2 (164 pb) e BPV-4 $(170 \mathrm{pb})$. Imagens apontam a co-infecção por estes tipos virais nas três linhagens celulares de papiloma cutâneo, bem como na de carcinoma de esôfago. Marcador de 100 pb. 
Tabela 13 - Sequências de BPV identificadas

\begin{tabular}{|c|c|c|c|c|c|c|}
\hline \multirow[b]{2}{*}{ Linhagem } & \multicolumn{6}{|c|}{ Tipo de BPV identificado por passagem } \\
\hline & P1 & P2 & P3 & P4 & P5 & P6 \\
\hline Pele saudável & - & - & - & - & - & - \\
\hline Papiloma 01 & 1 & 1 e 2 & 2 & 1 e 2 & 1 e 2 & 1 \\
\hline Papiloma 02 & 1,2 e 4 & 1,2 e 4 & 2 e 4 & 1 e 2 & 1,2 e 4 & 1,2 e 4 \\
\hline Papiloma 03 & 2 e 4 & 1,2 e 4 & 2 & 2 e 4 & 1 e 2 & 2 \\
\hline Carcinoma & 1,2 e 4 & 1,2 e 4 & 1,2 e 4 & 1 e 2 & 1,2 e 4 & 1 e 2 \\
\hline
\end{tabular}

Identificação de sequências de DNA de BPV nas seis diferentes passagens $(P)$ das linhagens celulares de pele saudável, papiloma cutâneo (01), fibropapiloma (papiomas 02 e 03) e carcinoma de esôfago (carcinoma). Verifca-se a presença e manutenção de sequências de DNA viral ao longo das seis passagens das linhagens derivadas de neoplasias infectadas pelo BPV.

\subsubsection{Imunodeteccão da proteína L1 do BPV}

Os resultados da imunodetecção da proteína L1 do BPV, principal constituinte do capsídeo viral, mostraram a expressão desta proteína nas linhagens celulares derivadas de cultivos primários de neoplasias infectdas pelo BPV, a qual foi identificada através de IF (figura 27) e CF (figura 28). Estes resultados sugerem que os sistemas in vitro são sítios passíveis de infecção produtiva. A linhagem celular de pele saudáve, por sua vez, não mostrou a expressão da proteína L1 do BPV (figuras 27 e 28), confirmando a ausência de infecção viral nestas células. 
Figura 27 - Imunodetecção da proteína L1 do BPV

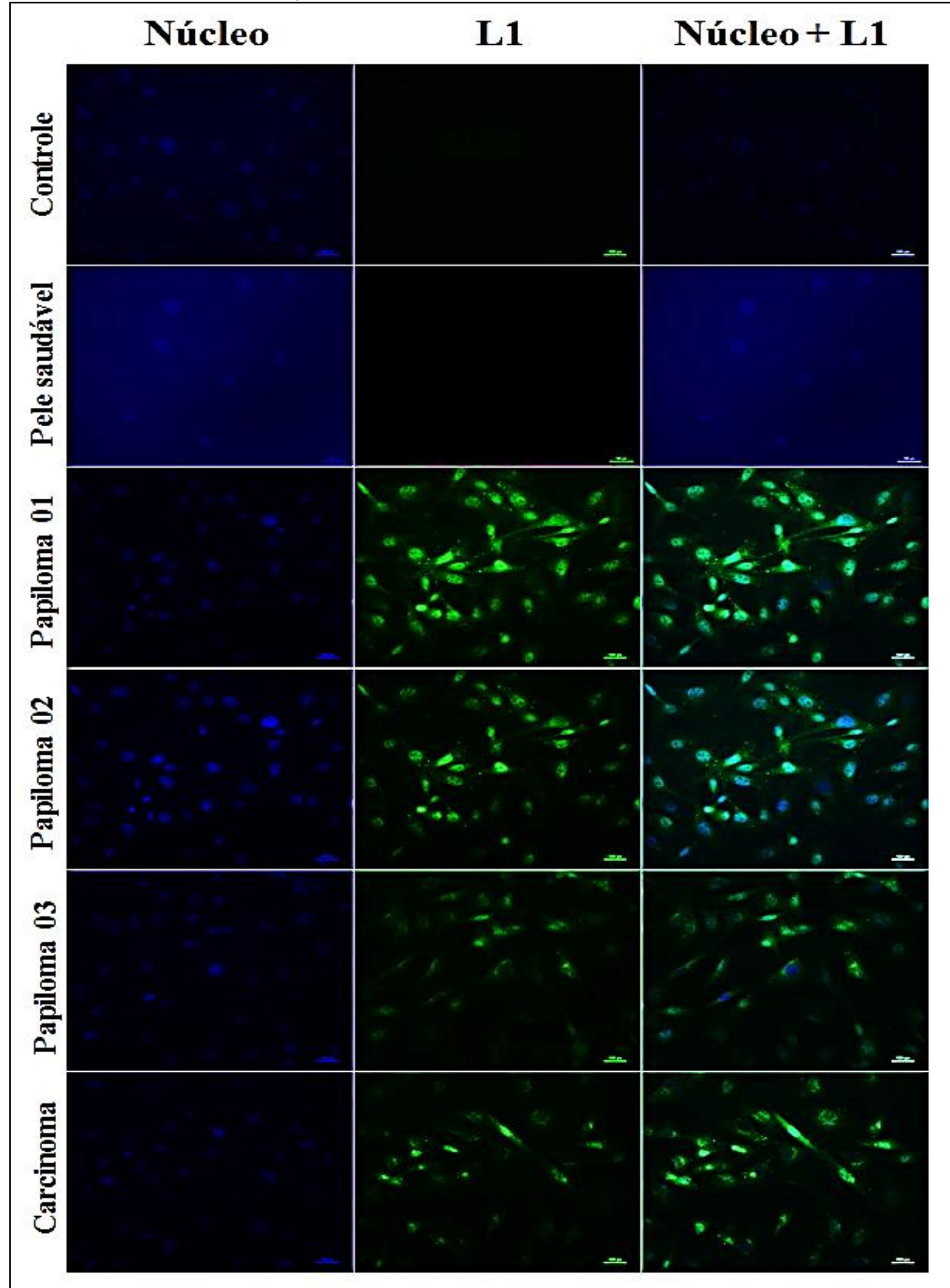

Fotomicroscopias mostrando a ausência de marcação inespecífica do anticorpo secundário anti-lgGFITC em células de papiloma cutâneo (controle), bem como a ausência de imunodetecção da proteína L1 do BPV nas células de pele saudável. Verifica-se a imunomarcação citoplasmática e nuclear da proteína L1 nas células derivadas de papiloma cutâneo (papiloma 01), fibropapiloma (papiloma 02 e 03) e carcinoma de esôfago. Imagens obtidas com tempo de exposição de $8 \mathrm{~ms}$ (núcleo, DAPI) e $300 \mathrm{~ms}$ (L1), empregando objetiva de $40 \mathrm{X}$. Barar de escala de $400 \mu \mathrm{m}$. Células na terceira passagem (P3). 
Figura 28 - Níveis de expressão da proteína L1 do BPV

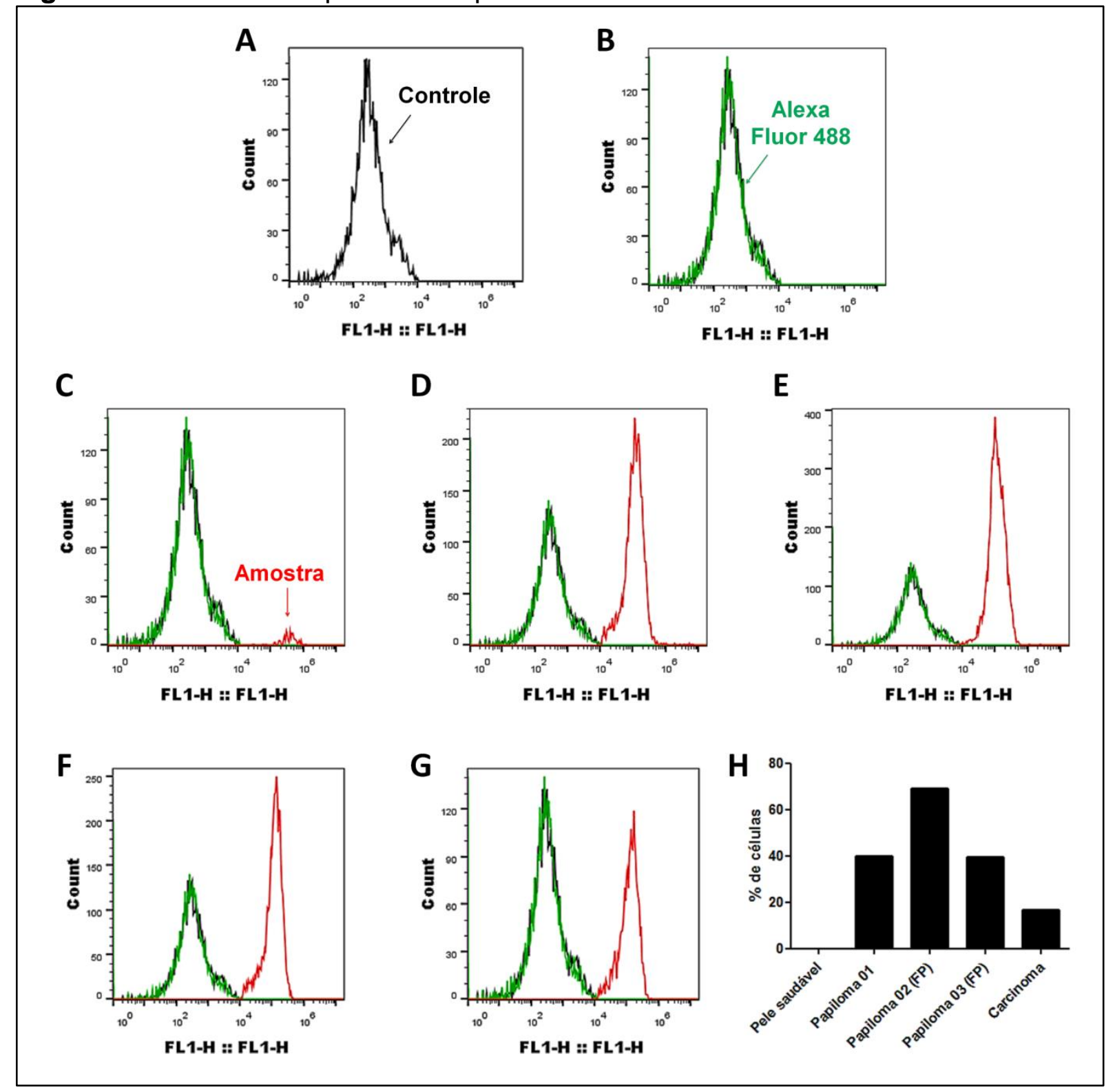

Resultados da citometria de fluxo empregando o anticorpo anti-L1 de BPV: A) células de papiloma cutâneo não incubada com anticorpo primário e/ou secundário (controle), mostrando ausência de autofluorescência; B) células de papiloma cutâneo incubadas exclusivamente com anticorpo secundário (Alexa Fluor 488), mostrando ausência de imunomarcação inespecífica; células incubadas com anticorpo primário e secundário (amostra): C) pele saudável, D) papiloma 01 (papiloma cutâneo), E) papiloma 02 (FP), F) papiloma 03 (FP) e G) carcinoma de esôfago. H) Histograma baseado no percentual de células imunomarcadas mostrando ausência de expressão da proteína L1 nas células derivadas de pele saudável e expressão naquelas derivadas de papiloma cutâneo, fibropapiloma (FP) e carcinoma de esôfago. Células analisadas na terceira passagem (P3). Total de 10.000 eventos analisados.

\subsubsection{Identificacão de vírions por meio de MET}

Os resultados da MET mostraram a ausência de estruturas com morfologia compatível com vírions do BPV tanto no núcleo (figura 29A) como no citoplasma de células de pele saudável (figura 29B), confirmando a ausência de infecção viral 
nesta linhagem. No entanto, as células derivadas das neoplasias infectadas pelo vírus apresentaram estruturas esféricas e elétron-densas, presentes em vesículas citoplasmáticas (figura 29C-F).

Figura 29 - Elétron-micrografias das diferentes linhagens celulares

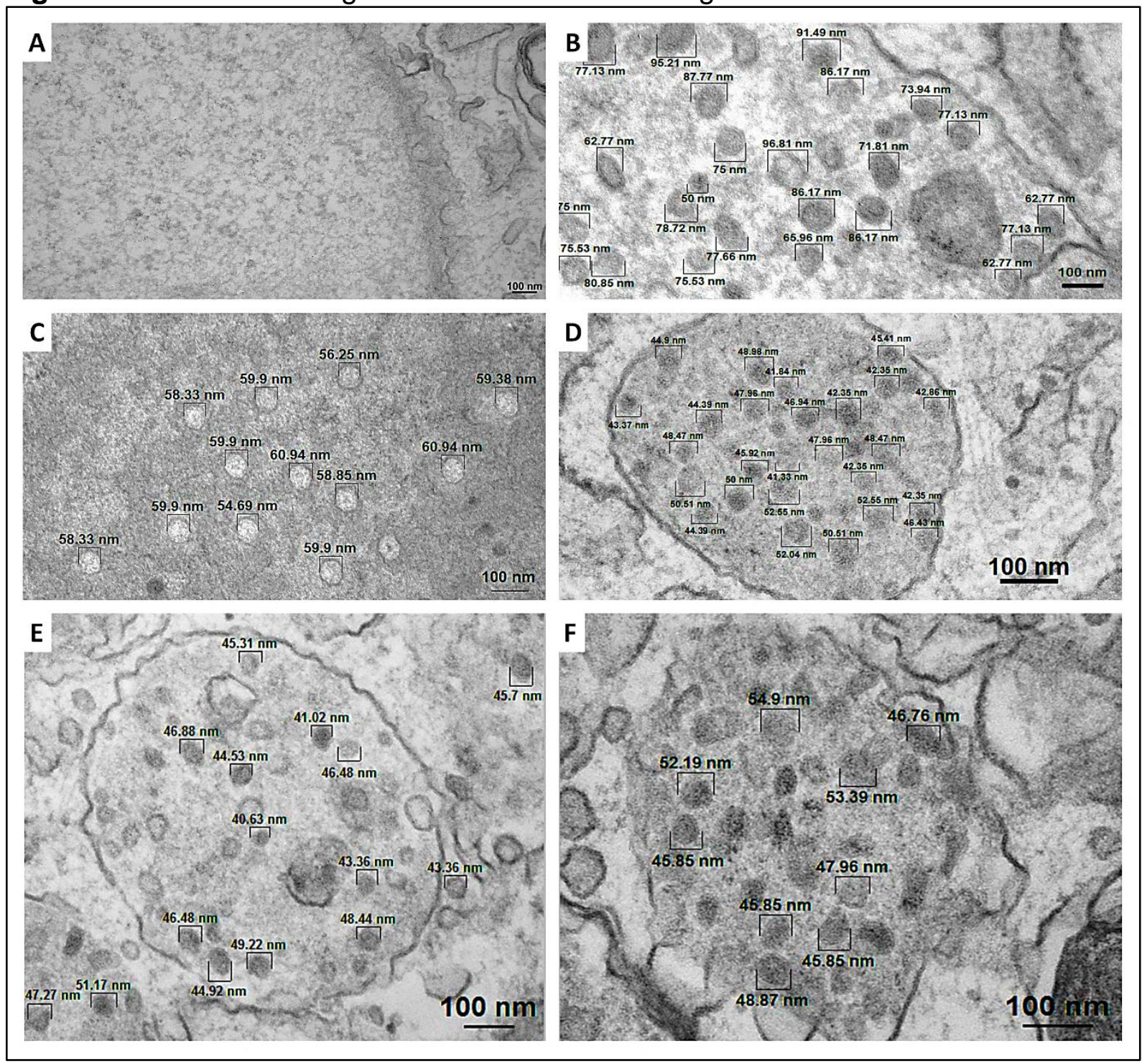

Elétron-micrografias mostrando ultra-estrutural do núcleo (A) e citoplasma de células de pele saudável, sendo observadas estruturas esféricas, com envoltório e diâmetros médio de 77,29ะ10,60 $\mathrm{nm}$, não compatíveis com a morfologia de vírions de BPV (B). Células de papiloma cutâneo 01 mostrando a presença de estruturas cristalinas no citoplasma, com diâmetro médio de 58,94t1,85 $\mathrm{nm}$, compatíveis com a morfologia icosaédrica do BPV (C). Células de fibropapiloma: papiloma 02 (D) e 03 (E) mostrando estruturas esféricas e elétron-densas com diâmetro médio de 46,46 $\pm 3,61 \mathrm{~nm}$ e $45,65 \pm 2,87 \mathrm{~nm}$, respectivamente, compatíveis com vírions de BPV. Células de carcinoma de esôfago mostrando estruturas esféricas com diâmetro médio de 49,06 $\pm 3,53 \mathrm{~nm}$ compatíveis com vírions de BPV. Aumento total de: 60.000 X (A-D e F) e 77.500 (E). Células analisadas na sexta passagem (P6).

A análise morfométrica (tabela 14) mostrou a presença de estruturas esféricas, envoltas por membrana biológica e com diâmetro superior a $75 \mathrm{~nm}$ no citoplasma das células de papiloma cutâneo (figuras 29B e 30). Tais estruturas são 
incompatíveis com a morfologia dos vírios de BPV, que não apresentam envoltório membranoso. As células derivadas de neoplasias infectadas pelo BPV, por sua vez, apresentaram estruturas com diâmetro entre 41,02 e 61,94 nm, valores estes compatíveis com o diâmetro dos vírios de BPV (figuras 29 e 30). Considerando os resultados da PCR (seção 6.1.1.1) e da imunodetecção da proteína L1 (seção 6.1.1.2), bem como a presença das estruturas identificadas por meio da MET na sexta passagem (figura 29), estes resultados sugerem que os sistemas in vitro são passíveis de infecção produtiva.

Tabela 14 - Análise morfométrica das partículas observadas através da MET

\begin{tabular}{|c|c|c|c|c|}
\hline \multicolumn{5}{|c|}{ Cultivos primários } \\
\hline Pele saudável & Papiloma 01 & Papiloma 02 & Papiloma 03 & Carcinoma \\
\hline 91,49 & 56,25 & 44,90 & 45,31 & 54,90 \\
\hline 77,13 & 59,90 & 45,41 & 45,70 & 46,76 \\
\hline 92,21 & 59,38 & 49,98 & 41,02 & 52,19 \\
\hline 87,77 & 58,33 & 41,84 & 46,88 & 53,39 \\
\hline 86,17 & 59,90 & 42,35 & 44,53 & 45,85 \\
\hline 73,94 & 60,94 & 47,96 & 46,48 & 47,96 \\
\hline 62,77 & 60,94 & 42,35 & 40,63 & 45,85 \\
\hline 75,00 & 58,85 & 42,86 & 43,36 & 45,85 \\
\hline 96,81 & 59,90 & 43,37 & 43,36 & 48,87 \\
\hline 71,81 & 54,69 & 44,39 & 46,48 & - \\
\hline 77,13 & 58,33 & 46,94 & 48,44 & - \\
\hline 50,00 & 59,90 & 48,47 & 49,22 & - \\
\hline 75,00 & - & 47,96 & 44,92 & - \\
\hline 78,72 & - & 48,47 & 47,27 & - \\
\hline 86,17 & - & 45,92 & 51,17 & - \\
\hline 62,77 & . & 41,33 & - & - \\
\hline 86,17 & - & 42,35 & - & - \\
\hline 77,13 & - & 50,51 & - & - \\
\hline 75,53 & - & 50,00 & - & - \\
\hline 80,85 & - & 52,55 & - & - \\
\hline 75,53 & - & 52,55 & - & - \\
\hline 77,66 & - & 42,35 & - & - \\
\hline 65,96 & - & 44,39 & - & - \\
\hline 86,17 & - & 52,04 & - & - \\
\hline 77,13 & - & 50,51 & - & - \\
\hline 62,77 & - & 46,43 & - & - \\
\hline $\bar{x}=77,29$ & $\bar{x}=58,94$ & $\bar{x}=46,46$ & $\bar{x}=45,65$ & $\bar{x}=49,06$ \\
\hline$D P=10,60$ & $D P=1,85$ & $\mathrm{DP}=3,61$ & $D P=2,87$ & $\mathrm{DP}=3,53$ \\
\hline
\end{tabular}

$\bar{x}-$ média, DP - desvio padrão 
Figura 30 - Morfometria das partículas identificadas

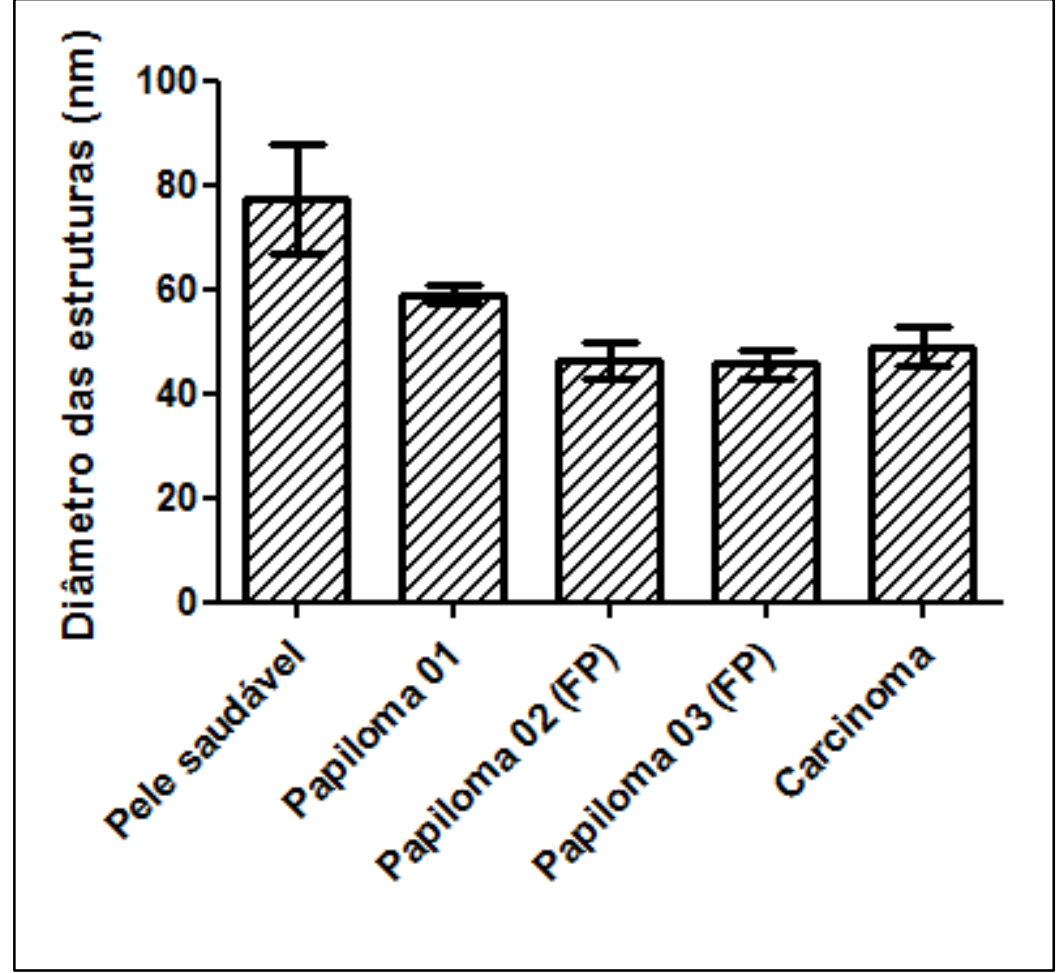

Resultados da análise morfométrica das partículas identificadas no citoplasma dos diferentes cultivos primários. Nota-se que as partículas observadas nas células de pele saudável apresentam um diâmetro superior a $60,0 \mathrm{~nm}$ e uma maior variabilidade de tamanho, indicando a ausência de uma isometria. Já as partículas observadas nas células derivadas de papiloma cutâneo, fbropapiloma (FP) e carcinoma de esôfago apresentam um diâmetro compatível com morfologia dos vírions de BPV, além de apresentarem uma maior isometria.

\subsubsection{Análise do potencial proliferativo das diferentes linhagens celulares}

A análise cinética da divisão celular (ciclo celular) mostrou um aumento do percentual de células nas fases $S$ e $G_{2}-M$ nas linhagens celulares derivadas de cultivos primários de neoplasias infectadas pelo BPV em relação a pele saudável (tabela 15, figura 31). Dentre as linhagens infectadas, a linhagem de fibropapiloma (papiloma 02) apresentou o maior potencial proliferativo (52,78\% das células em fase S), conforme mostrado na tabela 15 e figura 31. 
Tabela 15 - Percentual de células nas diferentes fase do ciclo celular

\begin{tabular}{ccccc}
\hline Linhagem & $\mathbf{G}_{\mathbf{0}}-\mathbf{G}_{\mathbf{1}}$ & $\mathbf{S}$ & $\mathbf{G}_{\mathbf{2}}-\mathbf{M}$ & Apoptose \\
\hline Pele saudável & 83,25 & 11,85 & 4,90 & 1,96 \\
Papiloma 01 & 63,36 & 27,49 & 9,15 & 1,87 \\
Papiloma 02 (FP) & 40,49 & 52,78 & 6,73 & 18,6 \\
Papiloma 03 (FP) & 75,92 & 12,31 & 11,77 & 1,01 \\
Carcinoma de esôfago & 68,57 & 30,14 & 1,29 & 10,09 \\
\hline
\end{tabular}

FP - fibropapiloma

Figura 31 - Avaliação do ciclo celular das diferentes linhagens celulares

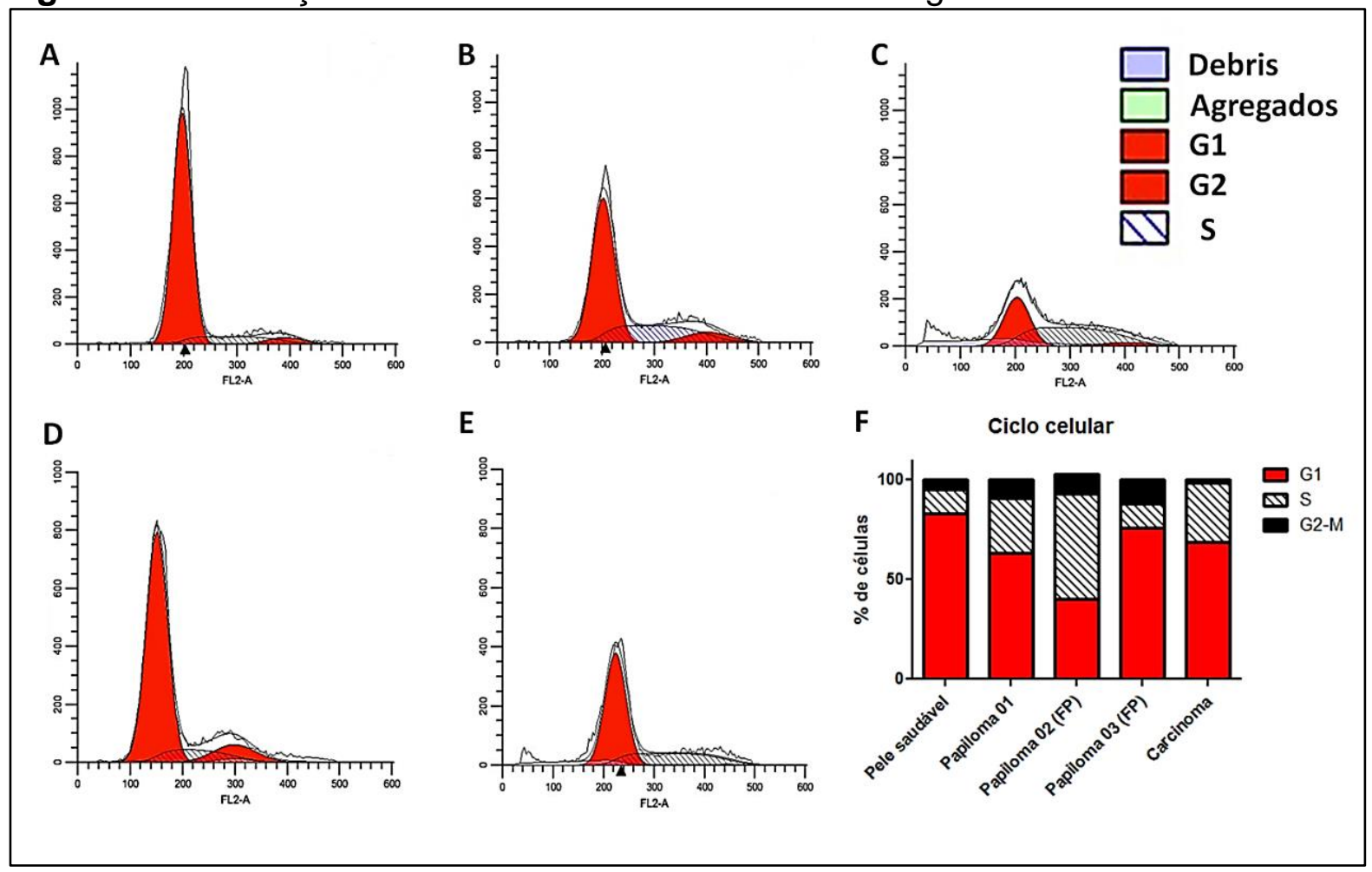

Análise do ciclo celular por meio de citometria de fluxo dos cultivos primários de: A) pele saudável, B) papiloma 01 (papiloma cutâneo), C) papiloma 02 (FP), D) papiloma 03 (FP) e E) carcinoma de esôfago. F) Histograma baseado no percentual de células por fase do ciclo celular: gap1 (G1), síntese (S) e gap2-mitose (G2-M). Verifica-se um aumento do percentual de células nas fases S e G2-M nas linhagens infectadas pelo BPV, demonstrando o potencial hiperproliferativo do vírus. Análise realizada na terceira passagem (P3). Total de 20.000 eventos analisados. FP - fibropapiloma.

Adicionalmente ao potencial proliferativo verificado in vitro, o ensaio de exclusão do corante azul de tripano mostrou que tanto a linhagem celular não infecta pelo BPV, como aquelas infectadas pelo vírus apresentaram um percentual de células viáveis superior a $75 \%$ (figura 32 ). Estes resultados sugerem que os sistemas in vitro mimetizam o potencial proliferativo verificado in vivo, sendo uma evidência adicional do valor científico das culturas de células derivadas de neoplasias infectadas pelos PVs como modelo de estudo da biologia viral e carcinogênese. 
Figura 32 - Percentual de células viáveis

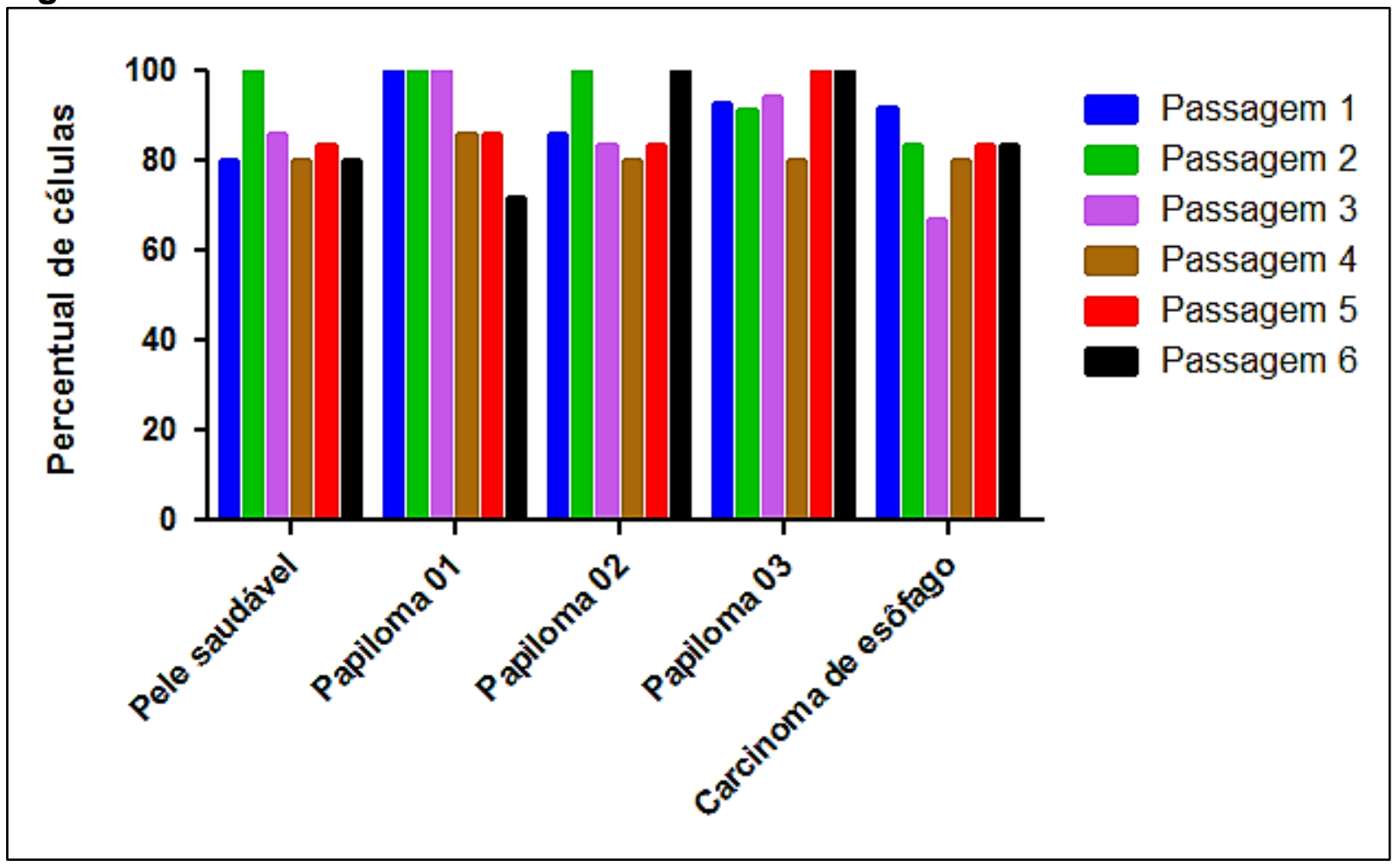

\subsubsection{Análise do metabolismo celular das diferentes linhagens}

\subsubsection{Avaliação do potencial de membrana mitocondrial ( $\Delta \psi \mathrm{m})$}

A avaliação do $\Delta \psi m$ mostrou uma redução do percentual de células marcadas pela sonda MitoTracker nas linhagens derivadas de cultivos primários de fibropapilomas (papilomas 02 e 03) e CE em relação a pele saudável (figura 33A e $B)$. Dentre estas linhagens, as células de CE apresentaram a maior redução do $\Delta \psi m$ (figura 33B), sugerindo a restrição do metabolismo oxidativo a um reduzido percentual de células. As células de papiloma cutâneo, por sua vez, apresentaram um $\Delta \psi \mathrm{m}$ semelhante ao das células de pele saudável (figura 33B). Porém, foi observado um aumento da média de intensidade e fluorescência (MIF) nas células de papiloma 02 (fibropapiloma) e CE (figura 33C), linhagens estas que apresentaram o menor percentual de células marcadas pela sonda (figura 33B). Estes resultados sugerem um mecanismo compensatório de obtenção de energia, supostamente associado a redução do metabolismo oxidativo. 
Figura 33 - Análise do potencial de membrana mitocondrial

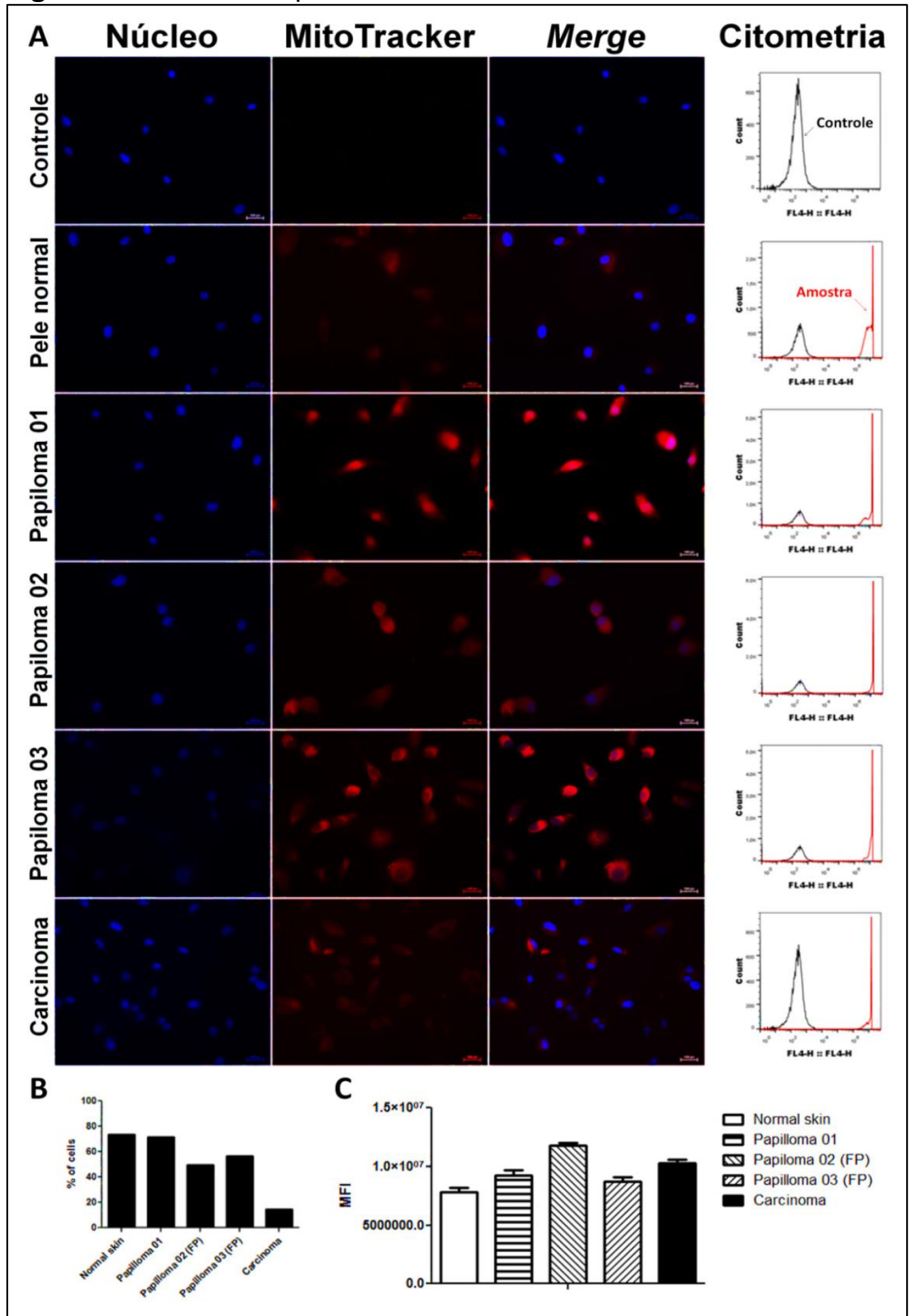

Fotomicrografias e histogramas da citometria de fluxo mostrando: ausência de marcação inespecífica nas células de pele saudável não incubada com a sonda MitoTracker (controle) e presença de sinal de fluorescência nas células tratadas com a sonda (amostra). Resultados mostram a preservação do potencial de membrana mitocondrial $\left(\Delta \Psi_{\mathrm{m}}\right)$ nos cultivos primários de pele saudável (não infectado pelo BPV) e papiloma cutâneo 01. Porém, verifica-se a perda do $\Delta \Psi_{\mathrm{m}}$ nas linhagens de fibropapiloma (papiloma 02 e 03) e carcinoma de esôfago, mostrado pela redução do percentual de células marcadas pela sonda (B). C) Histograma apresentando a média de intensidade de fluorescência (MIF) e o desvio padrão das diferentes linhagens. Teste de Bonferroni (ANOVA, $\mathrm{p}<0,0001$ ) confirmou que os cultivos de fibropapiloma (papiloma 02) e carcinoma apresentaram as maiores médias de fluorescência $(C)$, sugerindo um efeito compensador em relação a perda do $\Delta \Psi \mathrm{m}(\mathrm{B})$. Imagens obtidas com objetiva de $40 \mathrm{X}$, barra de escala de $100 \mu \mathrm{m}$. Total de 10.000 eventos analisados. Análises realizadas na terceira passagem (P3). 


\subsubsection{Análise da producão de espécies reativas de oxigênio (EROs)}

Considerando que o ensaio de DCFH-DA requer um controle positivo, normalmente realizado através do tratamento com peróxido de hidrogênio (RASTOGl et al., 2010), faz-se necessário determinar a concentração de uso deste peróxido de acordo com o tipo celular. Desta forma, o ensaio de MTT foi realizado para determinar o índice de citotoxicidade de $50 \%\left(\mathrm{IC}_{50}\right)$ do peróxido de hidrogênio nas células bovinas. A análise foi realizada em triplicada e o $\mathrm{IC}_{50}$ foi calculado com base na média das absorbâncias. Células não tratadas com o peróxido de hidrogênio $(0 \mu \mathrm{M})$ foram empregadas como controle negativo. Os resultados colorimétricos da triplicata, bem como as leituras do espectrofotômetro são mostrados nas figura 34 e 35 e tabela 16.

Figura 34 - Resultados do ensaio de MTT do peróxido de hidrogênio

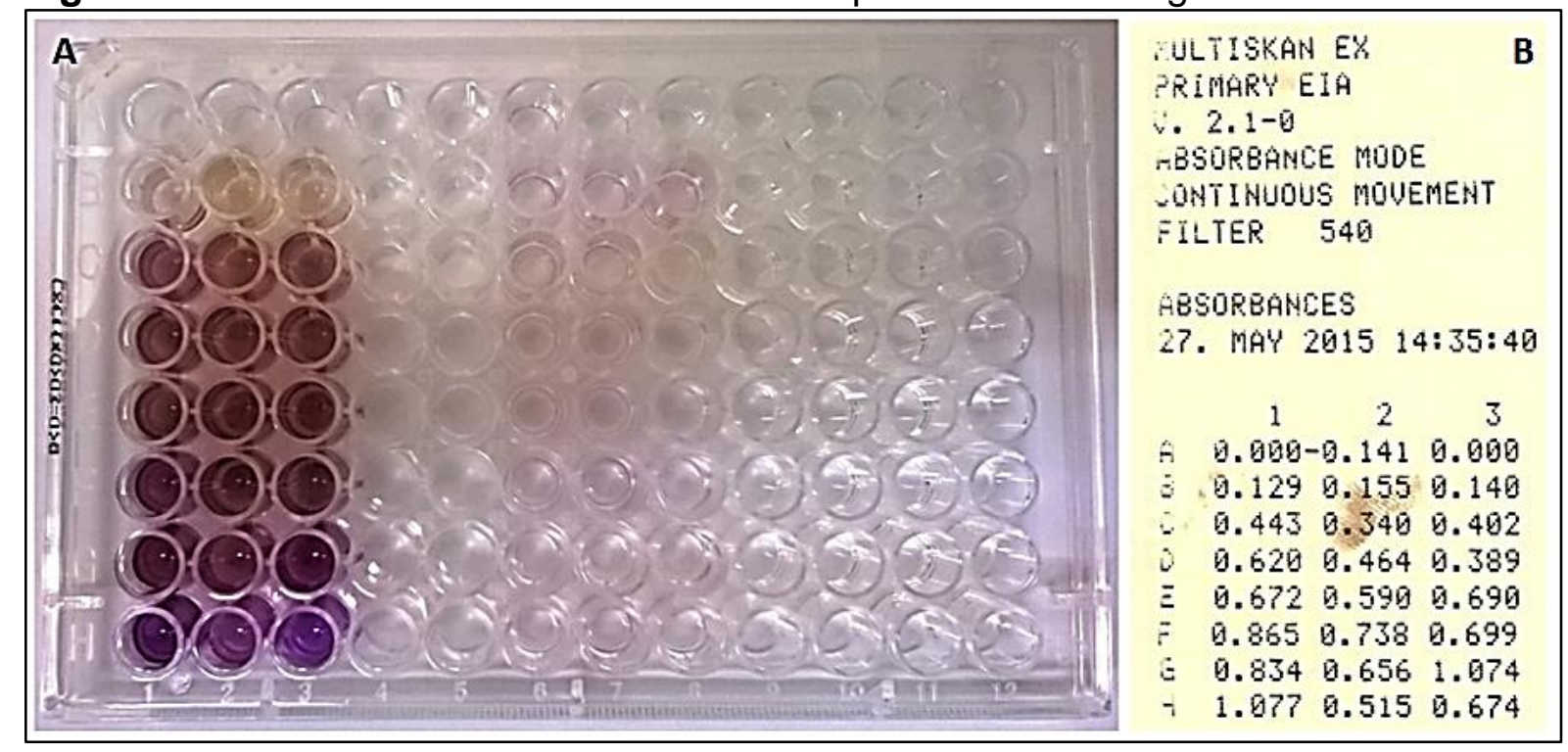

A) Placa de 96 poços tratada, mostrando colunas 1, 2 e 3 tradadas com peróxido de hidrogênio 200

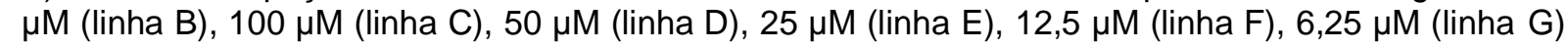
e células sem tratamento, $0 \mu \mathrm{M}$ (linha H). B) Leituras de absorbância realizadas no leitor de placas.

Tabela 16 - Análise de viabilidade celular através do ensaio de MTT

\begin{tabular}{cccccc}
\hline Amostra & $\mathbf{L 1}$ & $\mathbf{L 2}$ & $\mathbf{L 3}$ & $\overline{\boldsymbol{x}}$ & $\mathbf{I C}(\%)$ \\
\hline $\mathbf{2 0 0 , 0 0} \boldsymbol{\mu M}$ & 0,129 & 0,155 & 0,140 & 0,141 & 18,670 \\
$\mathbf{1 0 0 , 0 0} \boldsymbol{\mu M}$ & 0,443 & 0,340 & 0,402 & 0,395 & 52,310 \\
$\mathbf{5 0 , 0 0 0} \boldsymbol{\mu M}$ & 0,620 & 0,464 & 0,389 & 0,491 & 65,030 \\
$\mathbf{2 5 , 0 0 0} \boldsymbol{\mu M}$ & 0,672 & 0,590 & 0,690 & 0,650 & 86,090 \\
$\mathbf{1 2 , 5 0 0} \boldsymbol{\mu M}$ & 0,865 & 0,738 & 0,699 & 0,767 & 101.58 \\
$\mathbf{6 , 2 5 0} \boldsymbol{\mu M}$ & 0,834 & 0,656 & 1,074 & 0,854 & 113,11 \\
$\mathbf{0 , 0 0 0} \boldsymbol{\mu M}$ & 1,077 & 0,515 & 0,674 & 0,755 & 100,00 \\
\hline
\end{tabular}

Leitura (L) dos valores de absorbância obtidos no ensaio de MTT do peróxido de hidrogênio em diferentes concentrações, expressas em molaridade $(M)$, seguido das médias $(\bar{x})$ e do incide de citotoxicidade (IC), expresso em porcentagem. 
Figura 35 - Curva de citotoxicidade do peróxido de hidrogênio

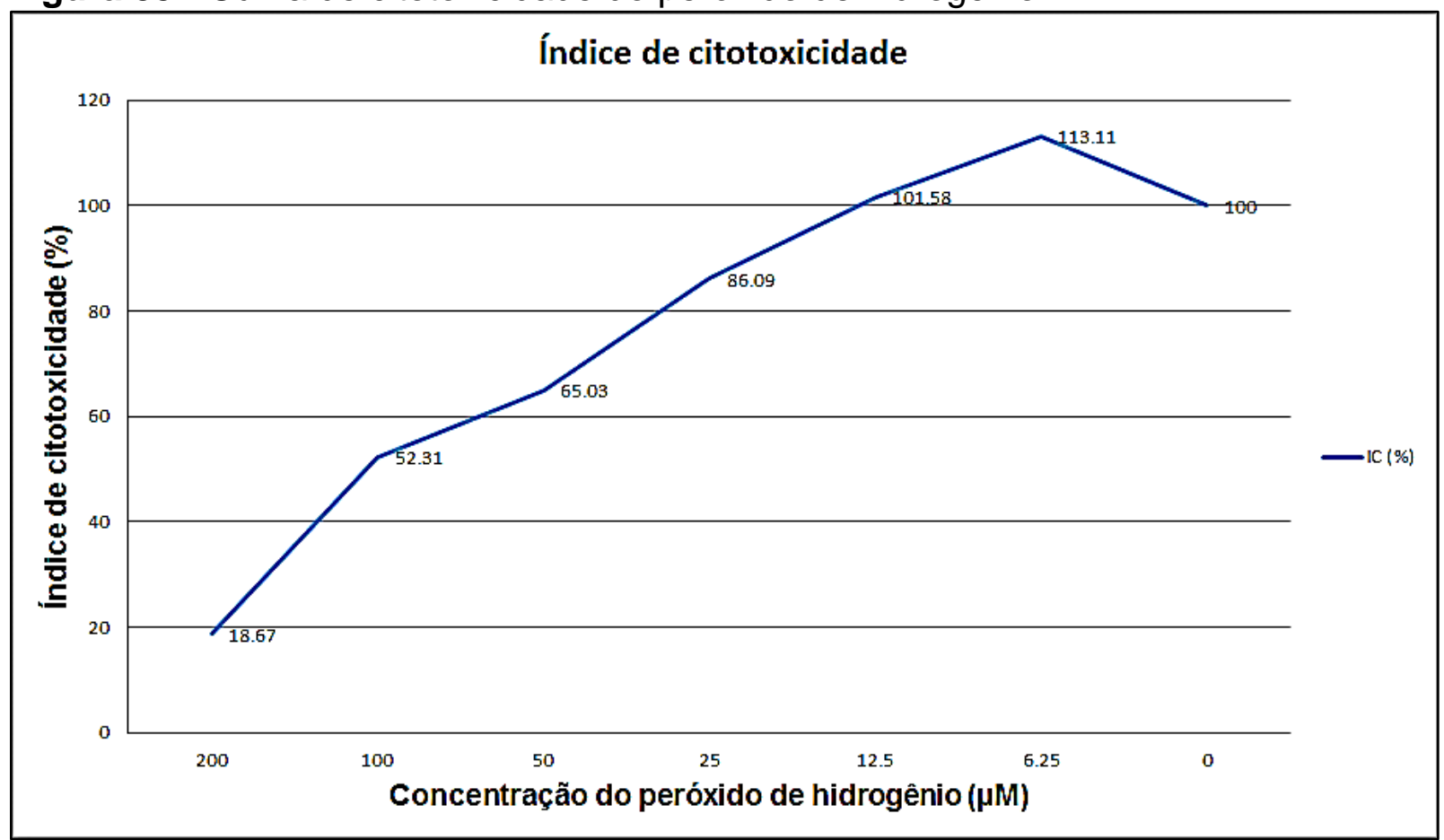

Curva de citotoxicidade mostrando um valor de $\mathrm{IC}_{50}$ igual a $100 \mu \mathrm{M}$.

Os resultados apontaram que a concentração de $100 \mu \mathrm{M}$ de peróxido de hidrogênio apresenta um índice de citotoxicidade de 50\%. Baseado neste resultado, esta concentração foi empregada como controle positivo na análise de produção de EROs por meio do ensaio de DCFH-DA.

Os resultados do ensaio de DCFH-DA mostraram um expressivo aumento nos níveis de EROs nas células de papiloma cutâneo, fibropapiloma e CE em relação à pele saudável (figura 36A e B). As células de pele saudável, por sua vez, apresentaram a maior MIF (figura 36C), porém restrita a um reduzido percentual de células (figura 36B). As células de CE também mostraram uma elevada MIF (figura $36 \mathrm{C}$ ), porém restrito a um reduzido percentual de células (figura $36 \mathrm{~B}$ ), reforçando a existência de um mecanismo compensatório de obtenção de energia, conforme verificado pela análise do $\Delta \psi \mathrm{m}$ (figura 33 ). Estes resultados sugerem que a infecção viral induz importantes desregulações metabólicas, favorecendo a TEM. 
Figura 36 - Níveis de produção de EROs nas diferentes linhagens celulares

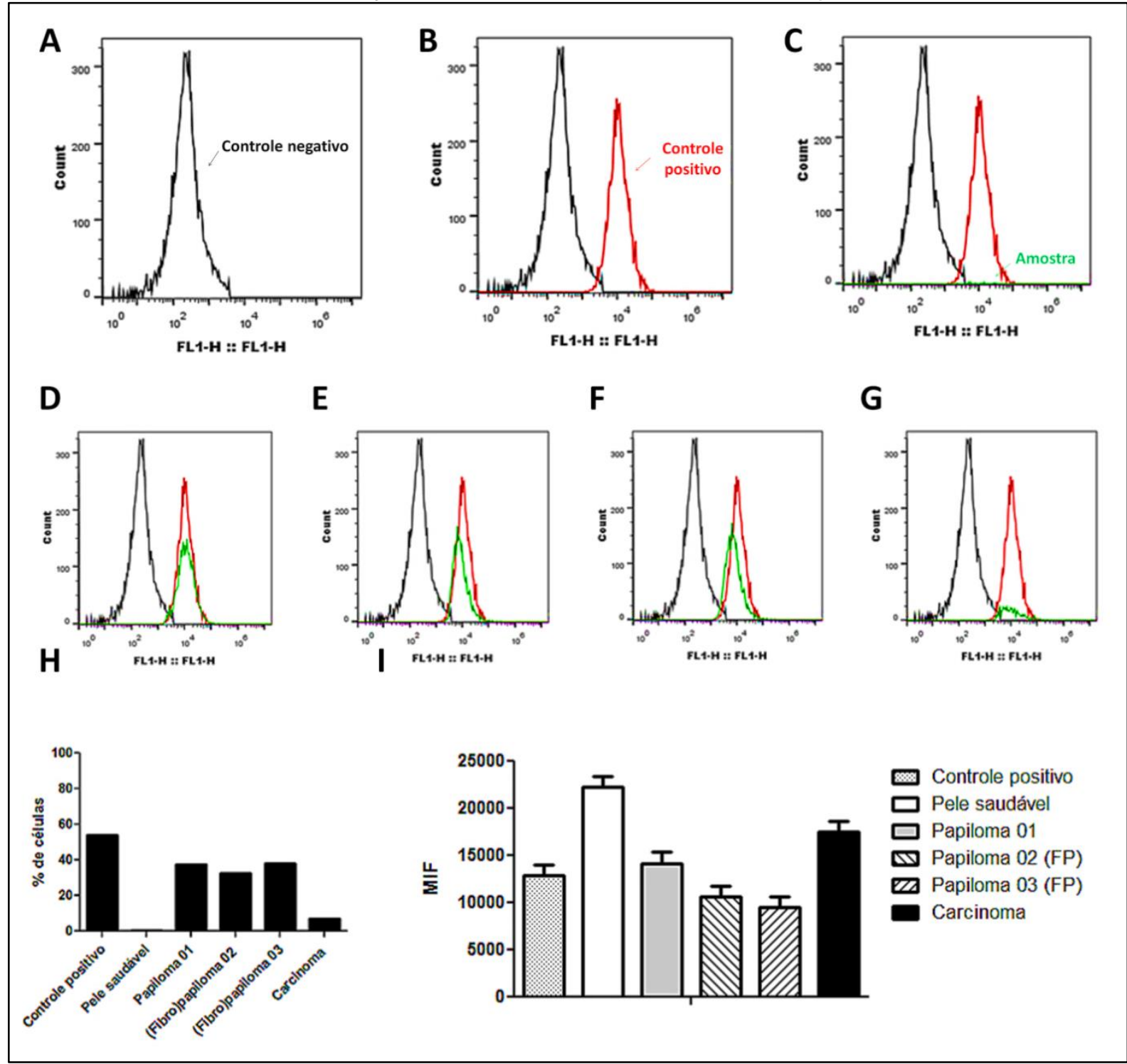

Histogramas mostrando: A) células de pele saudável não incubadas com a sonda DCFH-DA (controle negativo), mostrando ausência de autofluorescência; B) células de pele saudável tratadas com 100 $\mu \mathrm{M}$ de peróxido de hidrogênio (controle positivo), mostrando aumento dos níveis de fluorescência da sonda, indicando aumento da produção de espécies reativas de oxigênio (EROs); células incubadas com a sonda: pele saudável (C), papiloma cutâneo 01 (D), 02 (E), 03 (F) e carcinoma de esôfago (amostras) (G). Nota-se um aumento dos níveis de EROs nas células de papiloma cutâneo. H) Histograma baseado no percentual de células produzindo EROs, verifica-se que todas as linhagens celulares infectadas pelo BPV apresentaram níveis elevados de EROs, porém inferiores aquele verificado no controle positivo. I) Histograma baseado na média de intensidade de fluorescência (MIF). Nota-se uma redução da MIF nas células infectadas pelo BPV, sobretudo em fibropapilomas (papiloma 02 e 03), porém há um expressivo aumento do percentual de células produtoras de EROs (H). Total de 10.000 eventos analisados. Análises realizadas na terceira passagem (P3).

\section{$\underline{\text { 6.1.3.3 Alteracões ultra-estruturais }}$}

A análise ultra-estrutural, realizada por meio da MET, mostrou a presença de retículos endoplasmáticos (RE) dilatados e inúmeros autofagolissomos e corpos multivesiculares (CMV) nas linhagens celulares derivadas de papiloma cutâneo, fibropapiloma e CE (figura 37). Tais resultados sugerem a presença do estresse de 
RE e macro-autofagia nestas células. Curiosamente, as células derivadas do papiloma 02 (fibropapiloma) e CE, que apresentaram uma abundante quantidade de autofagolissomos e CMV (figura 37), também apresentaram um significativo aumento do volume nuclear (anisonucleose), seguido da dilatação da carioteca (figura 38). As células derivadas da pele saudável, por sua vez, mostraram a preservação da morfologia do RE e um restrito número de autofagolisossomos (figura 37). 
Figura 37 - Evidências de estresse de retículo e macro-autofagia

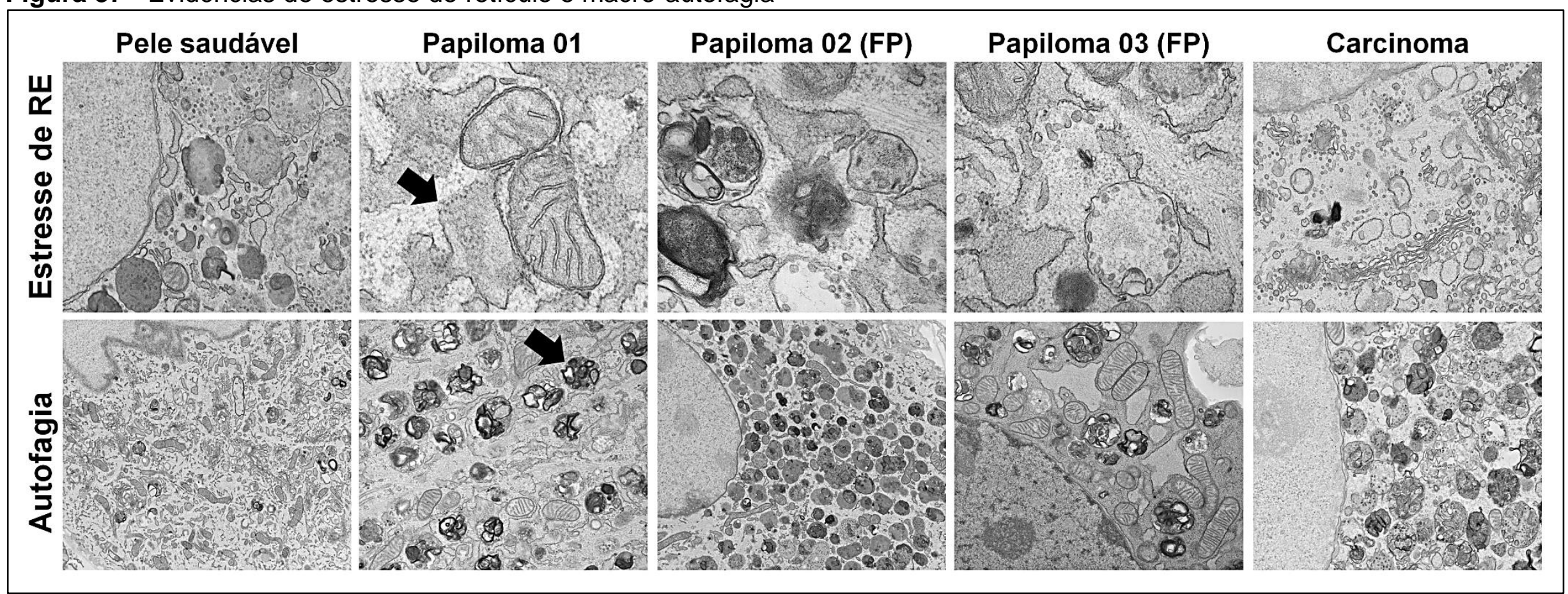

Micrografias eletrônicas mostrando a presença de retículos endoplasmáticos (RE) com morfologia preservada e restrita quantidade de vesículas autofágicas nas células derivadas do cultivo primário de pele saudável não infectada pelo BPV. Já nas células derivadas do cultivo primário de papiloma cutâneo (papiloma 01), fibropapiloma (papilomas 02 e 03) e carcinoma de esôfago verifica-se a presença de dilatações nos retículos endoplasmáticos (mostrado pela seta), indicando estresse de retículo, bem como, nota-se a presença de inúmeras vesículas autofágicas (apontadas pela seta), indicando a macro-autofagia nestas células. Aumentos totais de: Estresse de RE - 21.560 X, 60.000 X, 60.000 X, 60.000 X e 16.700 X; Autofagia - 6.000 X, 16.700 X, 6.000 X, 12.900 X, $12.930 \mathrm{X}$. 
Figura 38 - Anisonucleose observada em células infectadas pelo BPV

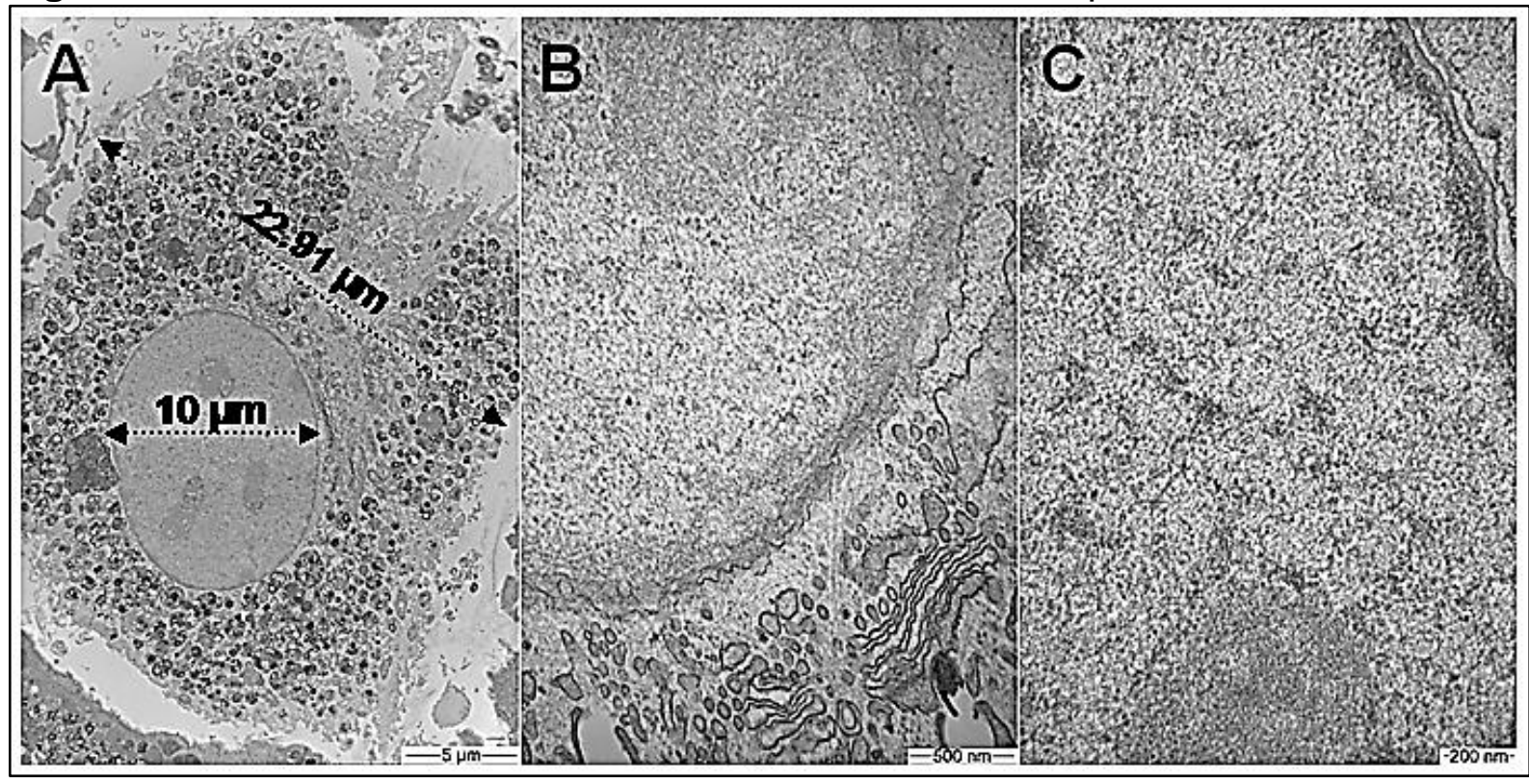

Elétromicrografia mostrando: A) aumento do volume nuclear (anisonucleose) em célula de papiloma 02 (3.597 X), B e C) anisonucleose seguida da dilatação da carioteca em célula de carcinoma de esôfago (4.646 X e 35.760 X, respectivamente).

\subsubsection{Níveis de clastogenicidade das diferentes linhagens celulares}

Considerando que o aumento dos níveis de EROs descrito na seção 6.1.3.2 pode levar a danos genéticos, incluindo SSBs e DSBs, os níveis de clastogenicidade das seis passagens (P1-P6) das diferentes linhagens celulares foram avaliados por meio do ensaio cometa. Os resultados desta análise mostraram que as células derivadas de papiloma cutâneo, fibropapiloma e CE apresentaram elevados valores de escore em relação à pele saudável (tabela 17, figura 39). Com base nos valores dos escores (tabela 17), foi realizado o teste de Kruskal-Wallis, que mostrou diferenças estatísticas significativas entre as linhagens celulares estudadas $(H=20,1952$ e $p=0,0005)$. Baseado neste resultado foi realizado o teste post-hoc de Dunn (tabela 18), que mostrou que as células derivadas de CE apresentam os maiores níveis de clastogenicidade (tabela 19, figura 40). As células derivadas de fibropapiloma, por sua vez, apresentaram valores de escores intermediários a pele saudável e CE (tabela 19, figura 40), sendo uma evidência adicional de que os fibropapilomas podem ser considerados lesões pré-neoplásicas. Entretanto, as células de papiloma cutâneo apresentaram escores estatisticamente semelhantes à pele saudável (tabela 19, figura 40). 
Tabela 17 - Níveis de clastogenicidade das diferentes linhagens celulares

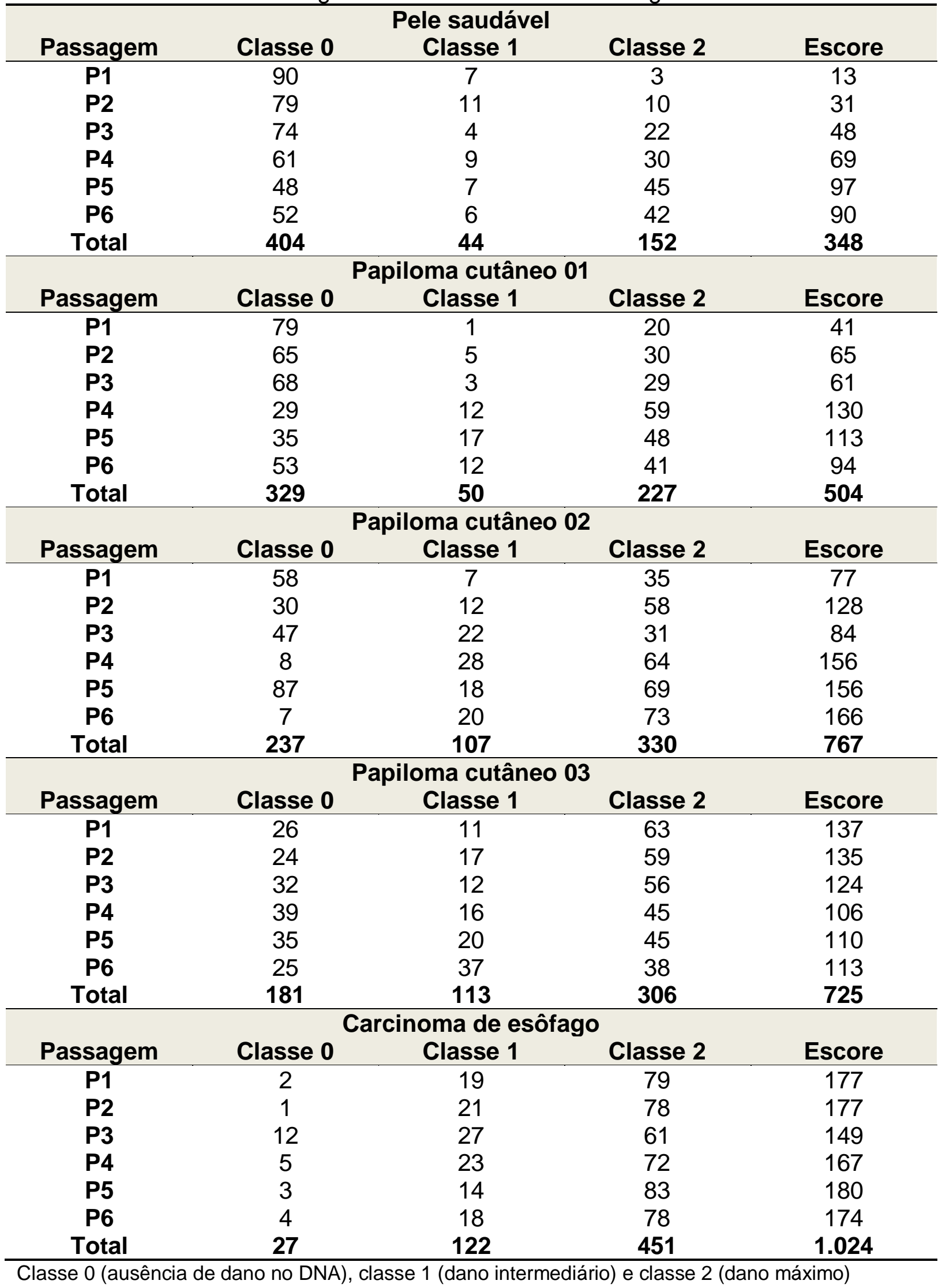


Figura 39 - Nucleóides observados nas diferentes linhagens celulares

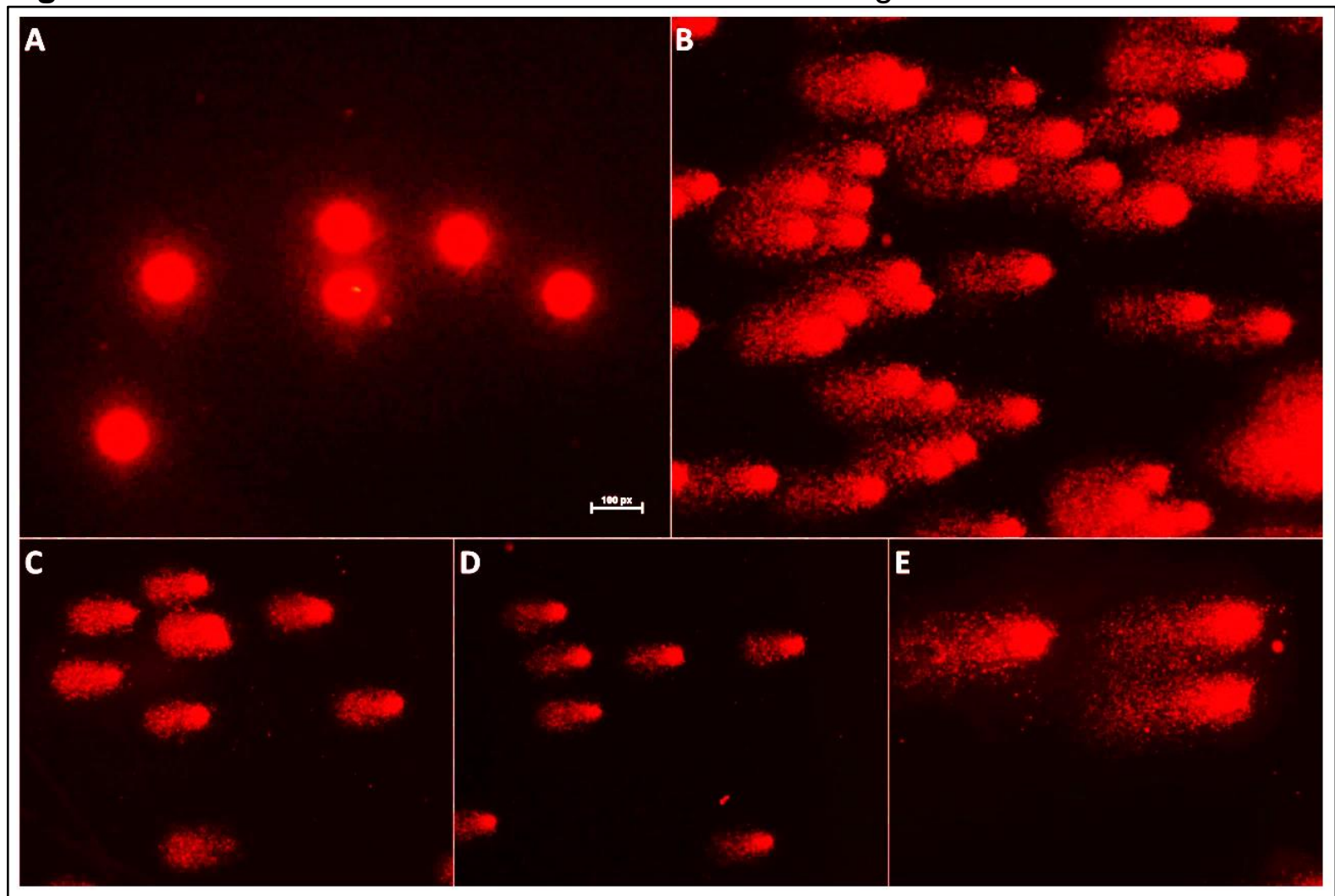

Fotomicroscopia indicando nucleóides de classe zero (sem dano), observados na linhagem de pele saudável (A); nucleóides de classe dois (dano máximo), observados nas linhagens de papiloma cutâneo 01 (B), fibropapiloma - papiloma 02 (C) e 03 (D) e carcinoma de esôfago (E). Imagens capturadas com tempo de exposição de 600 ms e objetiva de 40 X. Barra de escala de $100 \mu \mathrm{m}$.

Tabela 18 - Resultados do teste post hoc de Dunn

\begin{tabular}{ccccc}
\hline Comparação & Diferença de posto & Z-calculado & Z-crítico & p \\
\hline PS e P01 & 3,9167 & 0,7706 & 2,807 & $\mathrm{~ns}$ \\
PS e P02 & 11,8333 & 2,3282 & 2,807 & $\mathrm{~ns}$ \\
PS e P03 & 10,7500 & 2,1150 & 2,807 & $\mathrm{~ns}$ \\
PS e CE & 21,0000 & 4,1317 & 2,807 & $<0,05$ \\
P01 e P02 & 7,9167 & 1,5576 & 2,807 & $\mathrm{~ns}$ \\
P01 e P03 & 6,8333 & 1,3444 & 2,807 & $\mathrm{~ns}$ \\
P01 e CE & 17,0833 & 3,3611 & 2,807 & $<0,05$ \\
P02 e P03 & 1,0833 & 0,2131 & 2,807 & $\mathrm{~ns}$ \\
P02 e CE & 9,1667 & 1,8035 & 2,807 & $\mathrm{~ns}$ \\
P03 e CE & 10,2500 & 2,0167 & 2,807 & $\mathrm{~ns}$ \\
\hline
\end{tabular}

PS (pele saudável), P01 (papiloma 01), P02 (papiloma 02), P03 (papiloma 03), CE (carcinoma de esôfago), ns (valores estatísticos não significativos). 
Tabela 19 - Análise comparativa dos valores de escores

\begin{tabular}{|c|c|c|c|c|c|}
\hline Passagem & $\begin{array}{c}\text { Pele } \\
\text { saudável }\end{array}$ & $\begin{array}{c}\text { Papiloma } \\
01\end{array}$ & $\begin{array}{c}\text { Papiloma } \\
02 \text { (FP) }\end{array}$ & $\begin{array}{c}\text { Papiloma } \\
03 \text { (FP) }\end{array}$ & $\begin{array}{l}\text { Carcinoma de } \\
\text { esôfago }\end{array}$ \\
\hline $\mathbf{P 1}$ & $13^{\mathbf{a}^{*}}$ & $41^{\mathrm{a}}$ & $77^{\mathrm{a}, \mathrm{b}}$ & $137^{\mathrm{a}, \mathrm{b}}$ & $177^{\mathrm{b}}$ \\
\hline P2 & $31^{a}$ & $65^{\mathrm{a}}$ & $128^{\mathrm{a}, \mathrm{b}}$ & $135^{\mathrm{a}, \mathrm{b}}$ & $177^{\mathrm{b}}$ \\
\hline P3 & $48^{\mathrm{a}}$ & $61^{a}$ & $84^{\mathrm{a}, \mathrm{b}}$ & $124^{\mathrm{a}, \mathrm{b}}$ & $149^{b}$ \\
\hline P4 & $69^{a}$ & $130^{\mathrm{a}}$ & $156^{\mathrm{a}, \mathrm{b}}$ & $106^{\mathrm{a}, \mathrm{b}}$ & $167^{\mathrm{b}}$ \\
\hline P5 & $97^{a}$ & $113^{a}$ & $156^{\mathrm{a}, \mathrm{b}}$ & $110^{\mathrm{a}, \mathrm{b}}$ & $180^{\mathrm{b}}$ \\
\hline P6 & $90^{\underline{a}}$ & $94^{\mathrm{a}}$ & $166^{\mathrm{a}, \mathrm{b}}$ & $113^{\mathrm{a}, \mathrm{b}}$ & $174^{\mathrm{b}}$ \\
\hline
\end{tabular}

*números seguidos de letras iguais indicam a ausência de diferenças estatísticas significativas. FP fibropapiloma

Figura 40 - Box plot dos escores de cometa

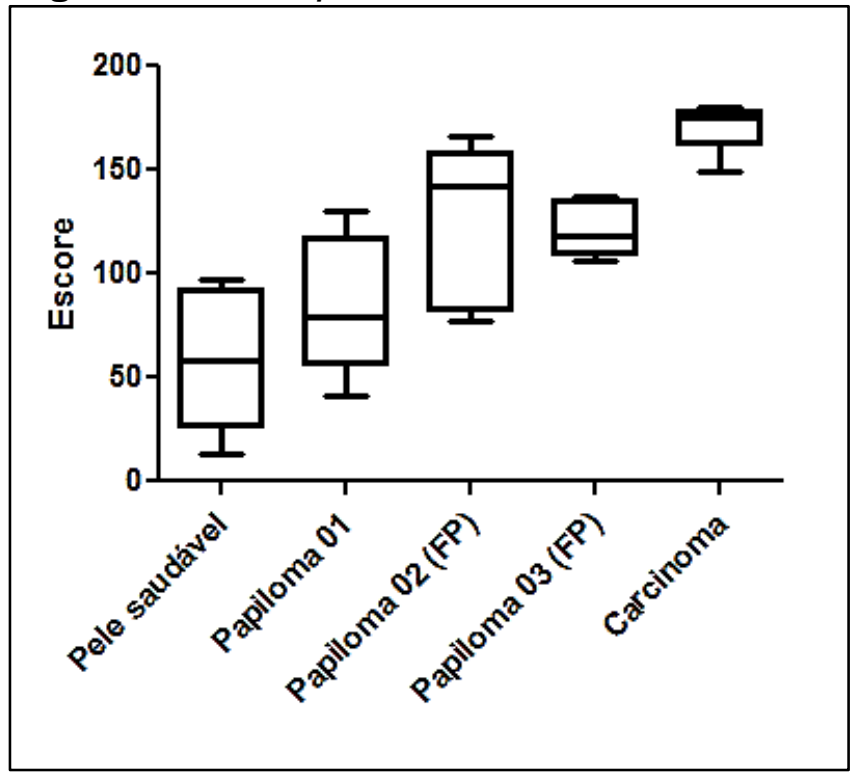

Verifica-se que as células de carcinoma de esôfago apresentam os maiores valores de escore, ao passo que as células de fibropapiloma (FP) apresentam valores intermediários de escores em relação à pele saudável e papiloma cutâneo 01, que apresentam medianas estatisticamente semelhantes.

A fim de avaliar a possível influência da manipulação celular nos níveis de clastogênese, foram realizadas regressões lineares baseadas nos valores de escore por passagem. Os resultados mostraram que apenas o cultivo primário de pele saudável é mais susceptível a danos genéticos induzidos pela manipulação celular, tendo apresentando um coeficiente de Pearson mais significativo (figura 41, $\mathrm{R}=0,9716$ ). Os demais cultivos apresentam coeficientes pouco significativos (figura $41,0,75>R<0,82$ ), valores estes que podem ser justificados pelos elevados valores de escores observados desde a primeira passagem. Além do mais, o cultivo de CE mostrou o menor coeficiente de Pearson $(0,05)$, mostrando a manutenção dos níveis de clastogenicidade ao longo das passagens (figura 41). 
Figura 41 - Análise da influência da manipulação celular sobre a clastogênese

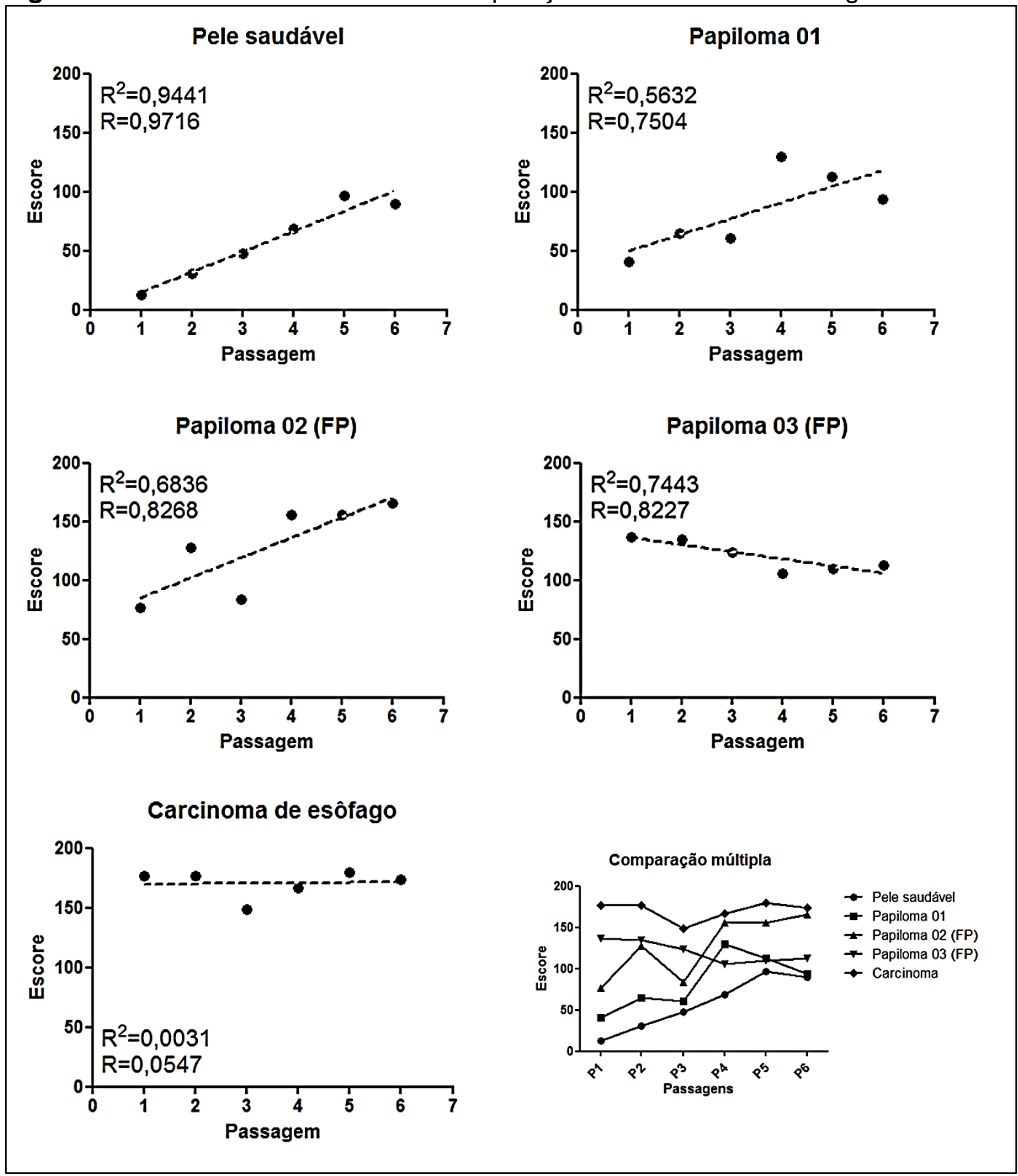

Regressão linear simples mostrando coeficientes de determinação $\left(R^{2}\right)$ e correlação/Pearson (R). Verifica-se uma forte correlação linear positiva nos valores de escores do cultivo primário derivado da pele saudável, sugerindo uma possível influência da manipulação celular sob os níveis de clastogenicidade. No entanto, as linhagens de papiloma (01) e fibropapiloma (02 e 03) apresentam uma fraca correlação, indicando pouca influência das condições in vitro sobre os níveis de clastogenicidade. O cultivo de carcinoma de esôfago apresenta ausência de correlação, reforçando que a infecção viral e a evolução da doença levam a danos genéticos. 


\subsubsection{Aquisição do fenótipo-tronco cancerígeno}

Considerando que a instabilidade genética tem sido apontada como a principal responsável pela reprogramação celular (ARGYLE; BLACKING, 2008; PASI et al., 2011), levando a aquisição de um fenótipo semelhante a células-tronco cancerígenas (CTC-like), as diferentes linhagens foram submetidas ao ensaio de tumoresfera. Os resultados desta análise mostraram que as linhagens celulares derivadas de cultivos primários de papiloma cutâneo, fibropapiloma e CE formaram agregados celulares (tumoresferas), sugerindo a aquisição do fenótipo CTClike(figura 42). Já a linhagem celular derivada de pele saudável não infectada pelo BPV mostrou a ausência de tumoresferas (figura 42), indicando a ausência de fenótipo-tronco. 
Figura 42 - Ensaio de oncosfera das diferentes linhages celulares

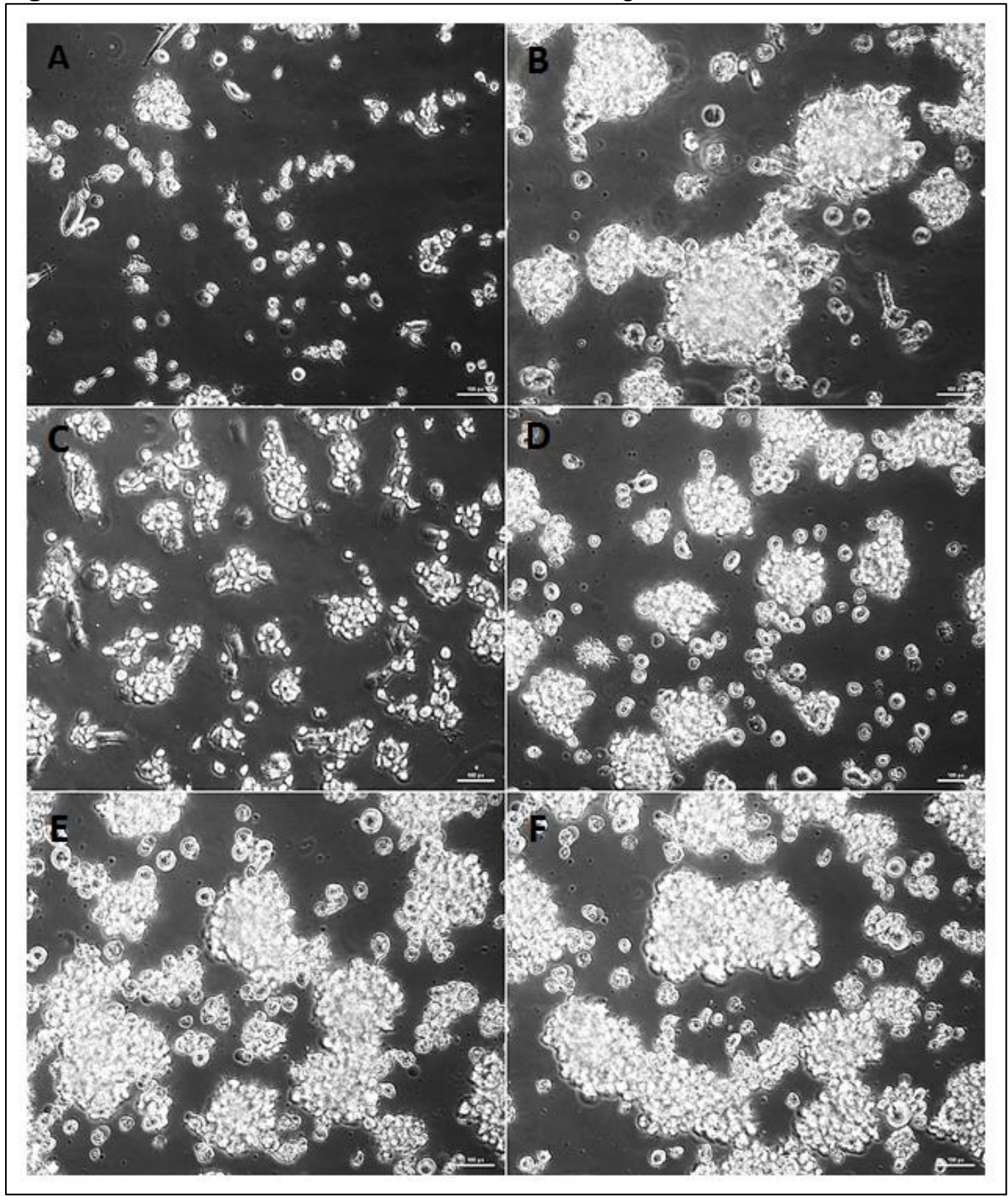

Fotomicrografias do ensaio de tumoresfera mostrando a ausência de agregados celulares nas linhagens derivadas de cultivo primário de pele saudável $(A)$ e a presença de tumoresferas nas linhagens derivadas de papiloma cutâneo (B), fibropapiloma (C - papiloma 02 e D - papiloma 03) e carcinoma de esôfago (E e F). Imagens obtidas com objetiva de 100 X. Barra de escala de $100 \mu \mathrm{m}$.

Baseado nos resultados do ensaio de tumoresfera (figura 42), os níveis de expressão do fator de transcrição Oct-3/4 (POU5F1) foram analisados por meio de IF e CF. O fator Oct-3/4 é reconhecido por ser um marcador de pluripotência expresso em células metastáticas e CTC-like (VON JOEST; BUA; LI, 2016). Os 
resultados desta análise mostraram um aumento dos níveis de expressão deste marcador nas linhagens celulares derivadas de cultivos primários de papiloma cutâneo, fibropapiloma e CE em relação à pele saudável (figuras 43 e 44). Estes resultados foram confirmados por meio da IF, sendo verificada a expressão citoplasmática e nuclear do fator Oct-3/4 nas linhagens celulares derivadas de cultivos primários de neoplasias infectadas pelo BPV (figura 43). As células de pele saudável apresentam uma discreta marcação citoplasmática (figura 43). Estes dados reforçam os resultados obtidos através do ensaio de formação de tumoresferas (figura 42). Os controles negativos da IF (figura 43) e CF (figura 44) não apresentaram marcações inespecíficas. 
Figura 43 - Imunodetecção do fator de transcrição Oct-3/4

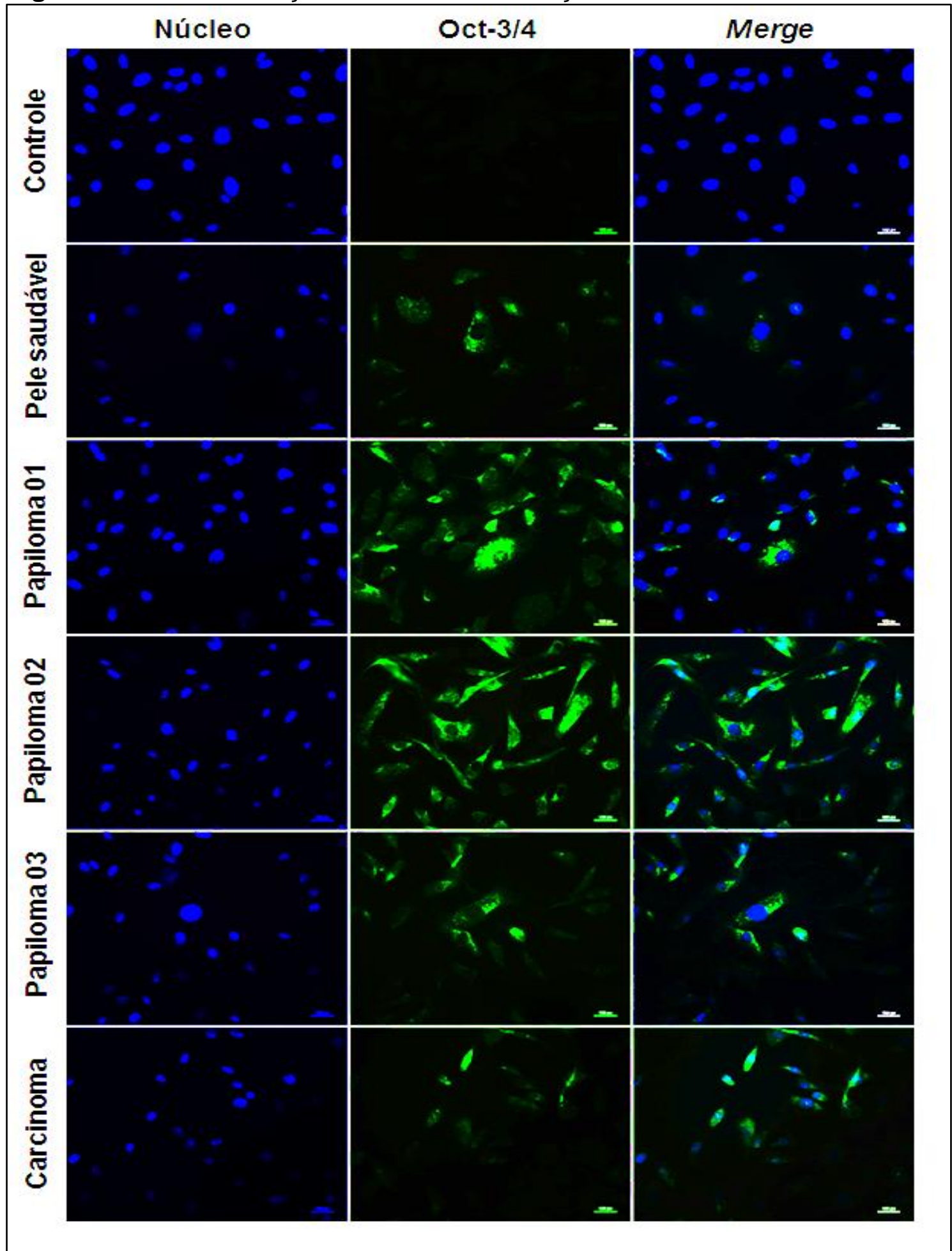

Imunodetecção do marcador de pluripotência Oct-3/4 mostrando: A) ausência de marcação inespecífica do anticorpo secundário em células de papiloma 01 incubadas exclusivamente com 0 anticorpo anti-lgG-FITC; B) discreta imunomarcação citoplasmática e perinuclear em células de pele saudável (não infectadas pelo BPV); intensa imunomarcação citoplasmática e nuclear do fator de transcrição Oct-3/4 nos cultivos primários derivados de papiloma cutâneo (papiloma 01), fibropapiloma (papiloma 02 e 03) e carcinoma de esôfago. Imagens obtidas com tempo de exposição de 8 ms (núcleo, DAPI) e 300 ms (Oct-3/4) com objetiva de 40 X. Barra de escala de $200 \mu \mathrm{m}$. 
Figura 44 - Níveis de expressão do marcador Oct-3/4

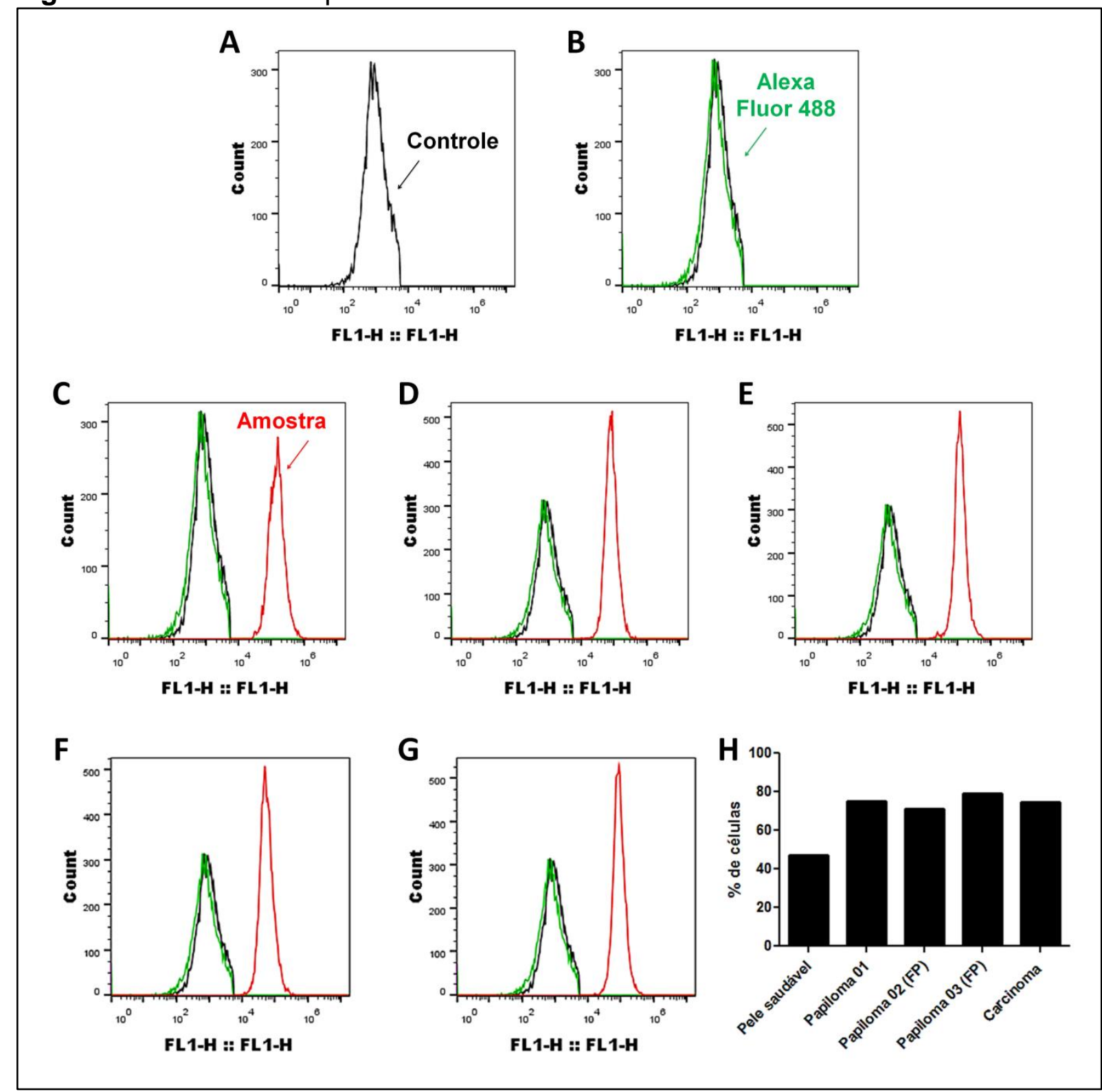

Resultados da citometria de fluxo empregando o anticorpo anti-Oct-3/4: A) células de papiloma cutâneo não incubadas com anticorpo primário e/ou secundário (controle); B células de papiloma cutâneo incubadas exclusivamente com anticorpo secundário (Alexa Fluor 488), mostrando ausência de imunomarcação inespecífica; células incubadas com anticorpo primário e secundário (amostra): C) pele saudável, D) papiloma 01 (papiloma cutâneo), E) papiloma 02 (FP), F) papiloma 03 (FP) e G) carcinoma de esôfago. H) Histograma baseado no percentual de células imunomarcadas mostrando aumento dos níveis de expressão do marcador Oct-3/4 nos cultivos primários infectados pelo BPV em relação a pele saudável. Total de 10.000 eventos analisados. Células analisadas na segunda passagem (P2). FP - fibropapiloma. 


\subsubsection{Análise do nível de expressão dos diferentes marcadores da TEM}

\subsubsection{Marcadores epiteliais: Citoqueratina 10 (CK10) e E-caderina}

Tendo em vista que a TEM é marcada pela aquisição de um fenótipo mesenquimal, é esperada uma redução dos níveis de expressão de marcadores epiteliais citoqueratina 10 (CK10) e E-caderina. Os resultados desta análise mostraram uma expressiva imunomarcação citoplasmática e nuclear no marcador CK10 nas linhagens celulares derivadas de cultivos primários de papiloma cutâneo e CE (figura 45). O aumento dos níveis de expressão deste marcador nestas linhagens celulares foi confirmado por meio de CF (figura 46). As linhagens celulares de fibropapiloma, por sua vez, apresentaram níveis de expressão de CK10 semelhantes ao das células de pele saudável não infectada pelo BPV (figura 46), confirmando o fibrotropismo viral. Entretanto, foi verificada a imunomarcação nuclear de CK10 nas células de fibropapiloma, a qual não foi observada nas células de pele saudável (figura 45). Os resultados da IF também mostraram uma expressiva marcação de F-actina junto a membrana plasmática das linhagens celulares derivadas de cultivos primários de neoplasias infectadas pelo BPV (figura 45), sugerindo a presença de lamelipódios e filopódios. As linhagens celulares derivadas de fibropapiloma e CE apresentaram, ainda, uma importante polinucleação, sugerindo a presença de neose nestas células (figura 45). Os controles negativos da IF (figura 45) e CF (figura 46) não apresentaram marcações inespecíficas. 
Figura 45 - Co-localização da F-actina e CK10

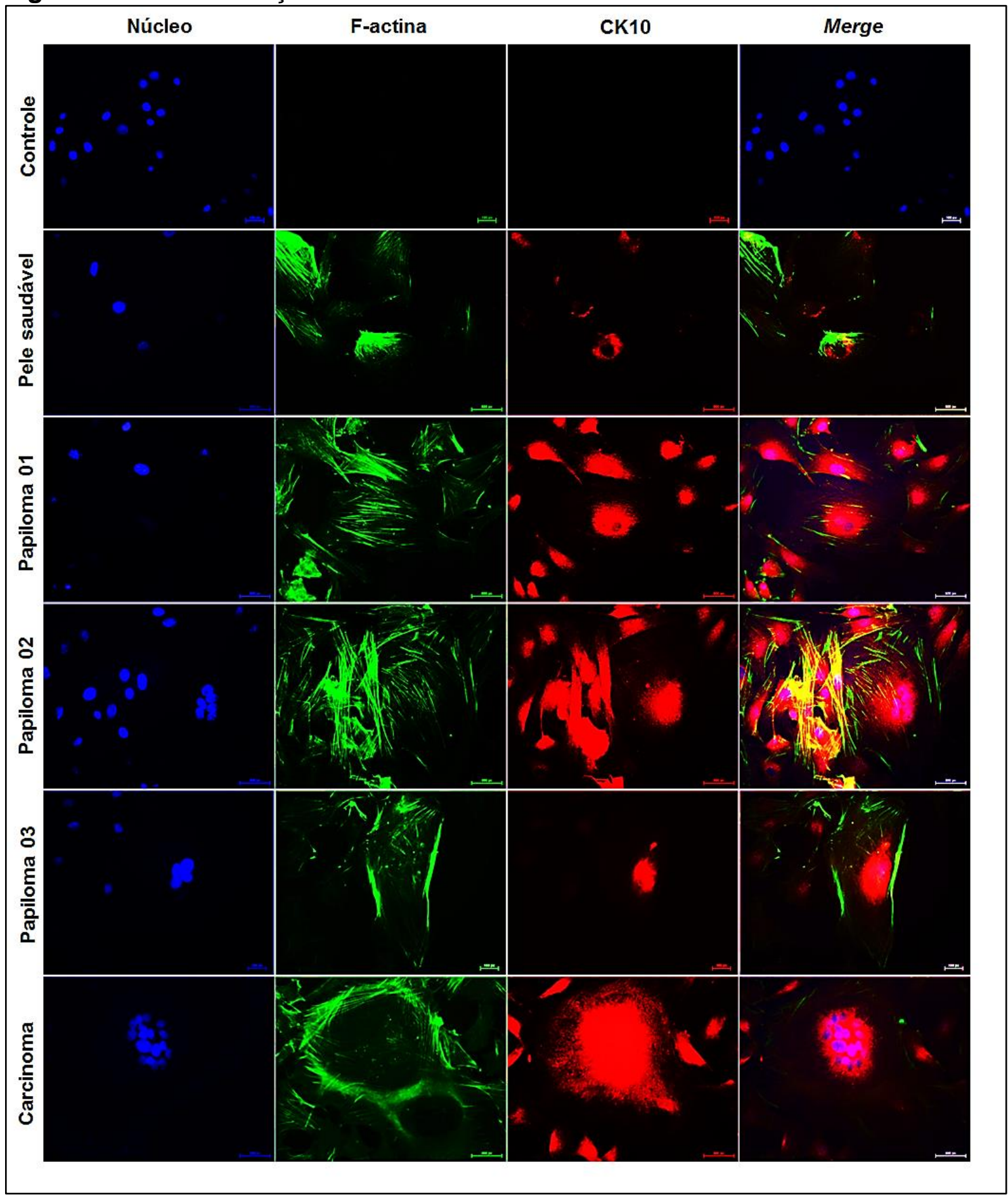

Ausência de marcação inespecífica nas células de papiloma cutâneo não tratadas com a micotoxina faloidina, porém incubadas com o anticorpo secundário anti-lgG conjugado com TRITC (controle). Discreta marcação de F-actina e CK10 em células de pele saudável (não infectadas pelo BPV). Intensa marcação de F-actina junto à membrana plasmática de células de papiloma cutâneo (papiloma 01), fibropapiloma (papiloma 02 e 03) e carcinoma de esôfago. Verifica-se uma intensa imunomarcação de CK10 nas células de papiloma 01, 02 (FP) e carcinoma. Células infectadas pelo BPV apresentam-se polinucleadas. Imagens obtidas com objetiva de $40 \mathrm{X}$, com tempo de exposição de 8 ms (núcleo, DAPI), 200 ms (F-actina) e 300 ms (CK10). Análise realizada na segunda passagem (P2). Barra de escala de $100 \mu \mathrm{m}$. FP - fibropapiloma. 
Figura 46 - Níveis de expressão da citoqueratina 10

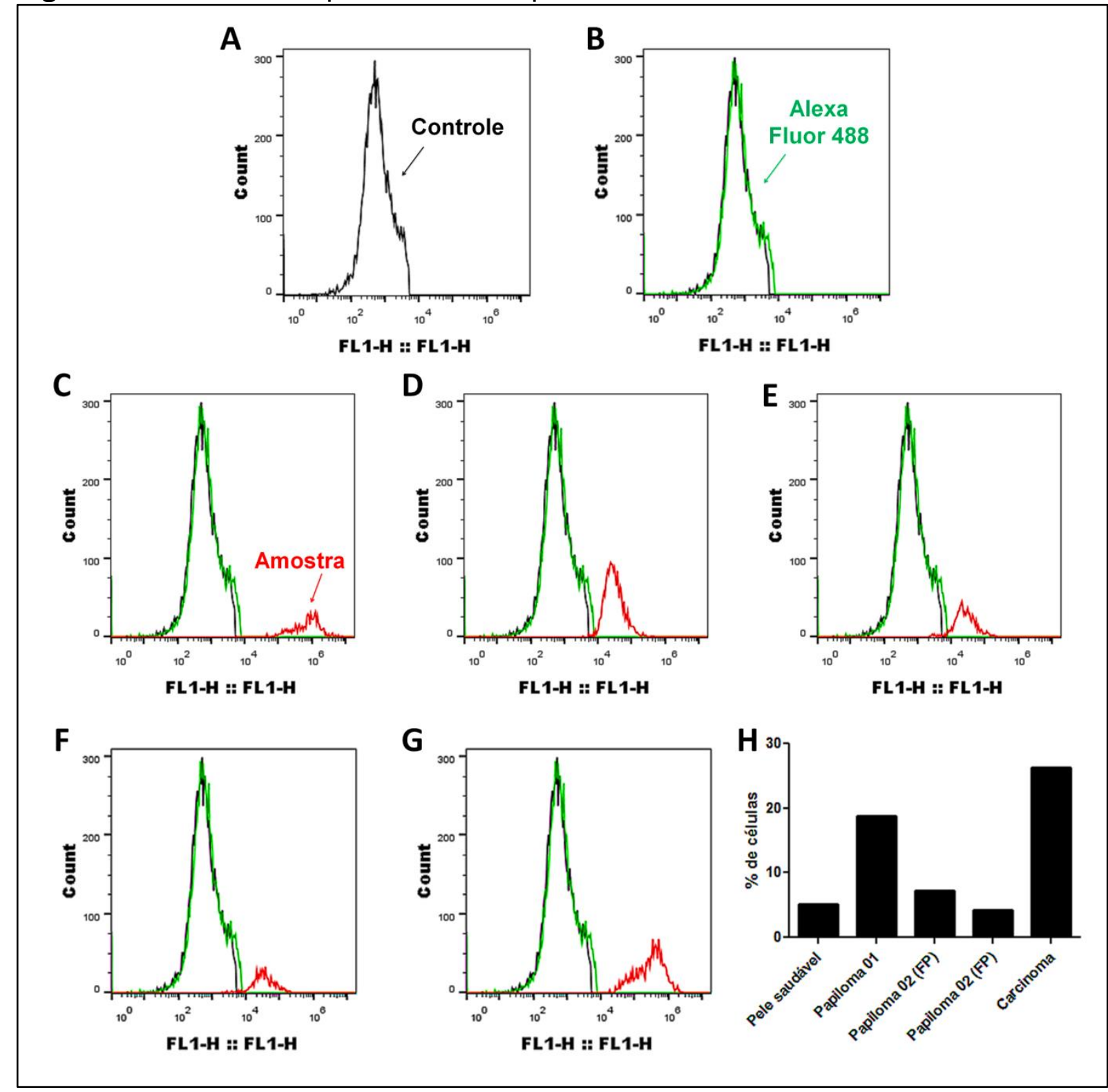

Resultados da citometria de fluxo empregando o anticorpo anti-CK10 A) células de papiloma cutâneo não incubadas com anticorpo primário e/ou secundário (controle); B células de papiloma cutâneo incubadas exclusivamente com anticorpo secundário (Alexa Fluor 488), mostrando ausência de imunomarcação inespecífica; células incubadas com anticorpo primário e secundário (amostra): C) pele saudável, D) papiloma 01 (papiloma cutâneo), E) papiloma 02 (FP), F) papiloma 03 (FP) e G) carcinoma de esôfago. H) Verifica-se um aumento dos níveis de expressão da CK10 nas células de papiloma cutâneo (papiloma 01) e carinoma de esôfago, reforçando o epiteliotropismo nestas lesões. Total de 10.000 eventos analisados. Células analisadas na segunda passagem (P2). FP fibropapiloma.

Somado a estes resultados, foi verificada a imunomarcação perinuclear e nuclear do marcador epitelial E-caderina nas linhagens celulares derivadas de cultivos primários de CE (figura 47), sugerindo um possível sequestro citoplasmático desta glicoproteína. As linhagens celulares derivadas de cultivo primário de papiloma cutâneo e fibropapiloma mostraram um aumento dos níveis de expressão da Ecaderina, sugerindo a manutenção da adesão celular e, portanto, o caráter benigno 
destas neoplasias (figura 48). A linhagem celular derivada de CE, por sua vez, mostrou uma expressiva redução dos níveis de expressão da E-caderina, reforçando o potencial migratório das células cancerígenas (figura 48). Os controles negativos da IF (figura 47) e CF (figura 48) não apresentaram marcações inespecíficas. 
Figura 47 - Imunodetecção da glicoproteína E-caderina

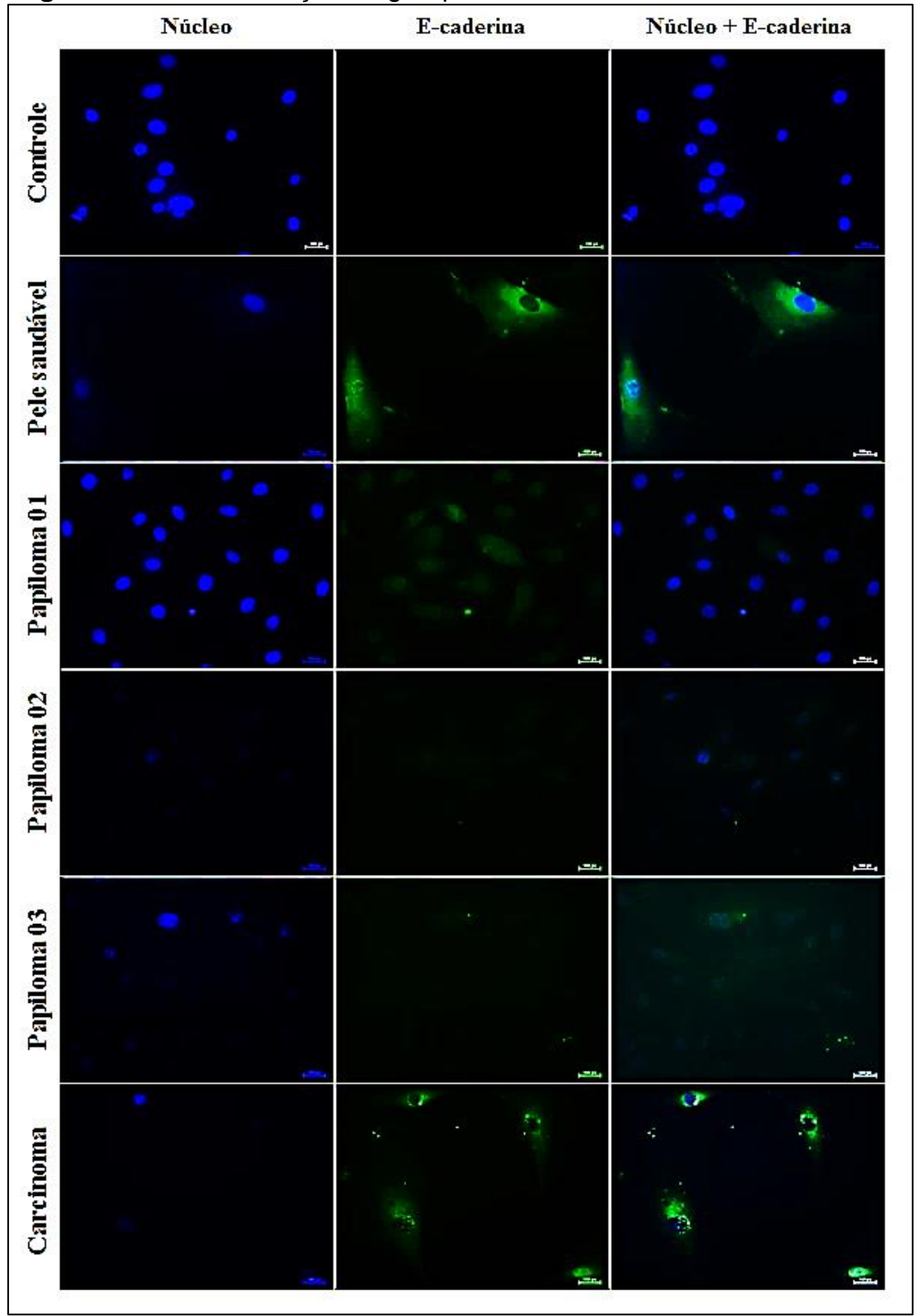

Imunofluorescência mostrando: ausência de marcação inespecífica no controle negativo (células de papiloma cutâneo incubada apenas com o anticorpo secundário anti-lgG conjugado com FITC, expressão citplásmática difuda da E-caderina nas células de pele saudável e papiloma cutâneo. Verifica-se a imunomarcação perinuclear e nuclear da E-caderina na linhagem de carcinoma de esôfago, sugerindo sequestro citoplasmático da glicoproteína. Imagens capturadas com tempo de exposição de $8 \mathrm{~ms}$ (núcleo, DAPI) e $300 \mathrm{~ms}$ (E-caderina) com objetiva de $40 \mathrm{X}$. Barra de escala de $100 \mu \mathrm{m}$. 
Figura 48 - Níveis de expressão da E-caderina

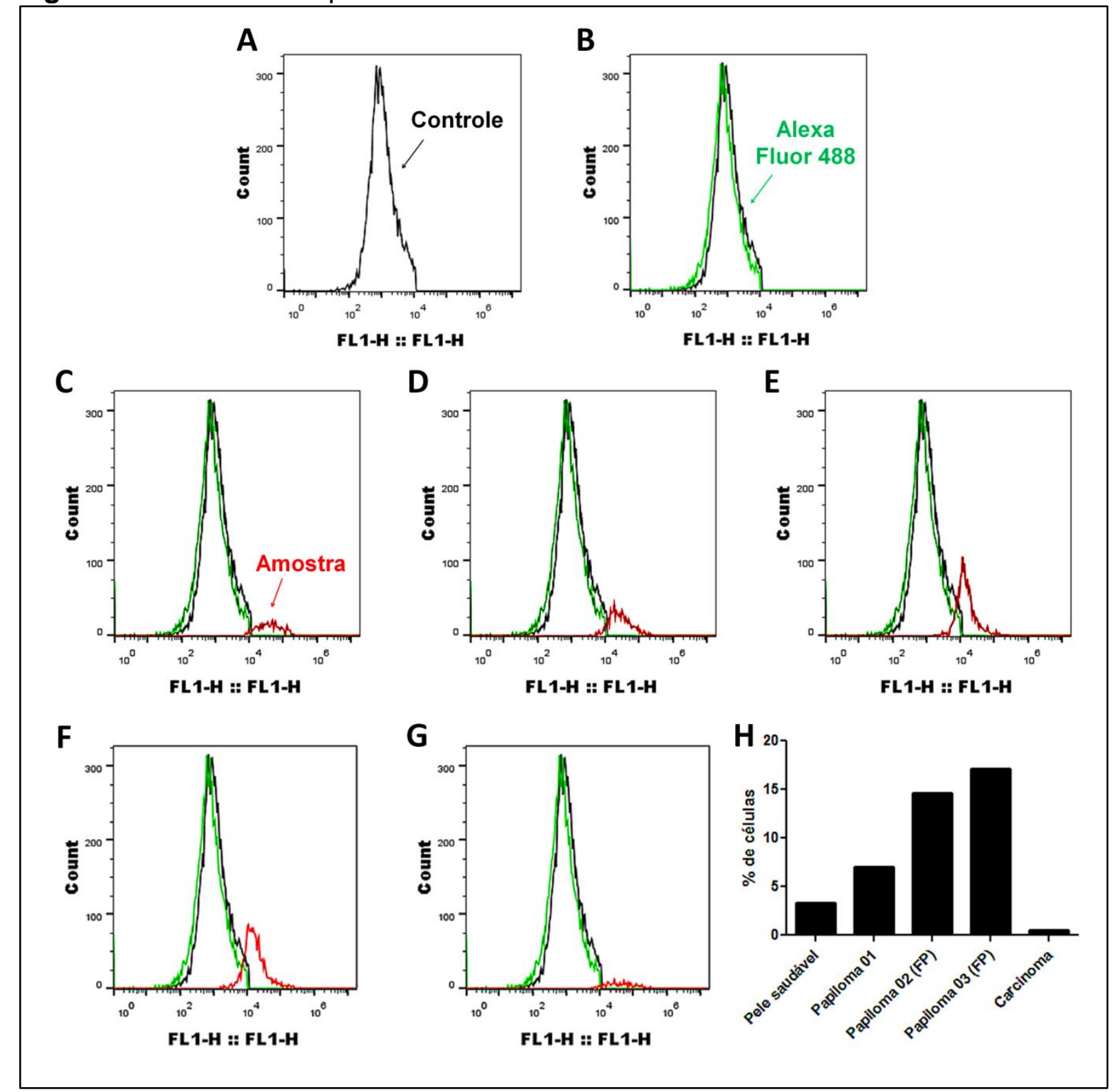

Resultados da citometria de fluxo empregando o anticorpo anti-E-caderina: A) células de papiloma cutâneo não incubadas com anticorpo primário e/ou secundário (controle); B células de papiloma cutâneo incubadas exclusivamente com anticorpo secundário (Alexa Fluor 488), mostrando ausência de imunomarcação inespecífica; células incubadas com anticorpo primário e secundário (amostra): C) pele saudável, D) papiloma 01 (papiloma cutâneo), E) papiloma 02 (FP), F) papiloma 03 (FP) e G) carcinoma de esôfago. H) Histograma baseado no percentual de células imunomarcadas mostrando aumento dos níveis de expressão do marcador epitelial E-caderina nos cultivos derivados de papiloma e fibropapiloma (neoplasia benigna) e a redução dos níveis de expressão na linhagem de carcinoma de esôfago em relação a pele saudável. Total de 10.000 eventos analisados. Células analisadas na segunda passagem (P2). FP - fibropapiloma. 


\subsubsection{Fatores de transcrição nuclear: STAT3 e SLUG (Snail2)}

A atividade ótima do fator STAT3 é essencial para a manutenção das funções celulares no epitélio, incluindo a integridade da interação epitélio-mesênquima (LEVY; LEE, 2002; SRIURANPONG et al., 2003). Por esta razão, os níveis de expressão de STAT3 ativo (Y705) foram analisados por meio de IF e CF. Os resultados da IF análise mostram a presença de STAT3 Y705 no citoplasma e no núcleo das células derivadas de cultivos primários de papiloma cutâneo, fibropapiloma e CE (figura 49). Tais linhagens também apresentaram um aumento do percentual de células expressando o fator STAT3 ativo em relação a pele saudável (figura 50). Os controles negativos da IF (figura 49) e CF (figura 50) não apresentaram marcações inespecíficas. 
Figura 49 - Imunodetecção do fator de transcrição STAT3 ativo (Y705)

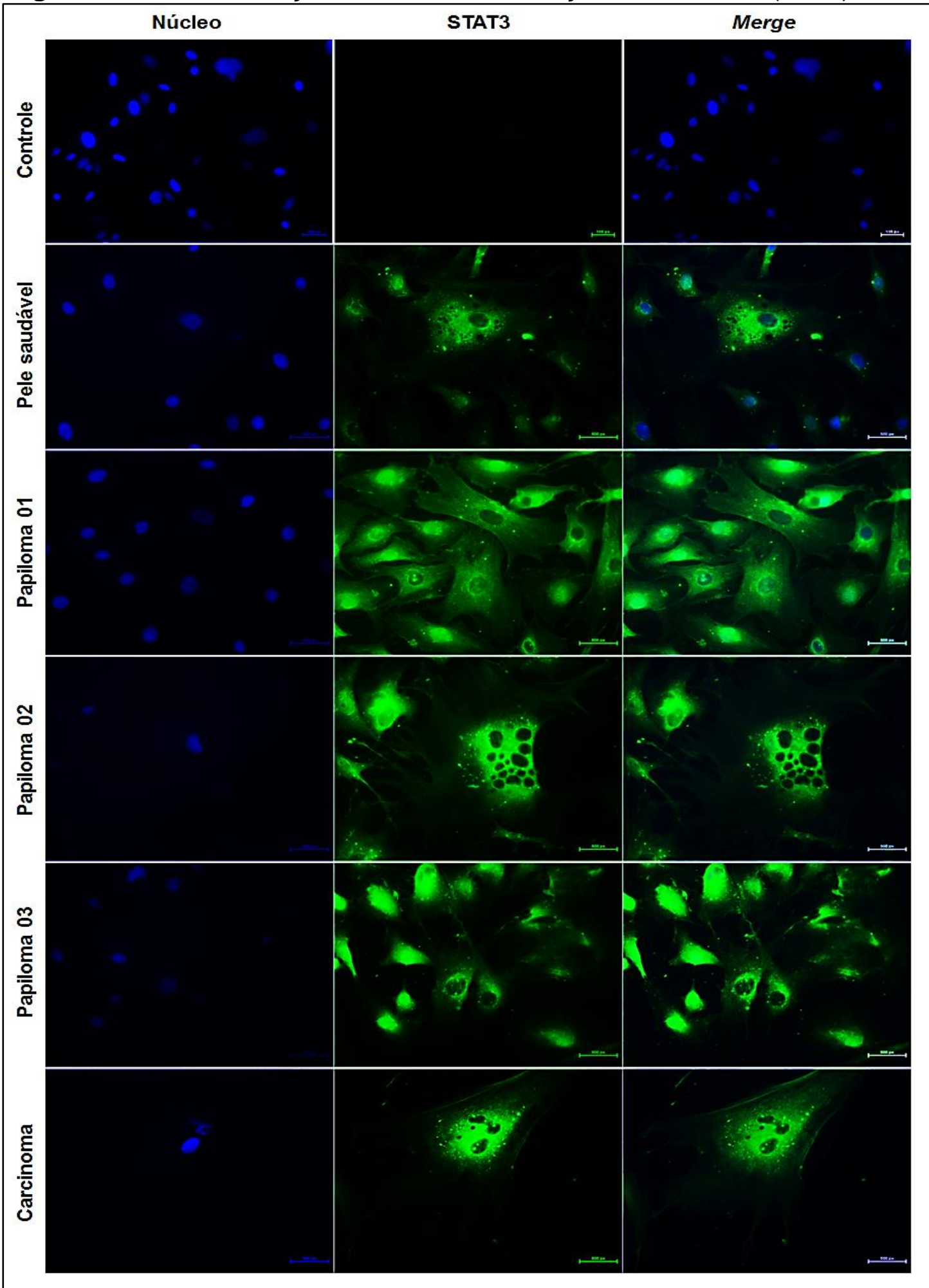

Imunofluorescência mostrando: ausência de marcação inespecífica no controle negativo (células de papiloma cutâneo incubadas apenas com o anticorpo secundário conjugado com FITC); expressão citplásmática difusa, mas não nuclear do fator de transcrição STAT3 Y705 em células de pele saudável. Imunodetecção perinuclear e nuclear do fator de transcrição STAT3 Y705 nas células de papiloma cutâneo (papiloma 01), fibropapiloma (papiloma 02 e 03) e carcinoma de esôfago. Imagens capturadas com tempo de exposição de 8 ms (núcleo, DAPI) e 300 ms (STAT3 Y705) com objetiva de 40 X. Barra de escala de $200 \mu \mathrm{m}$. 
Figura 50 - Níveis de expressão do fator de transcrição STAT3 Y705

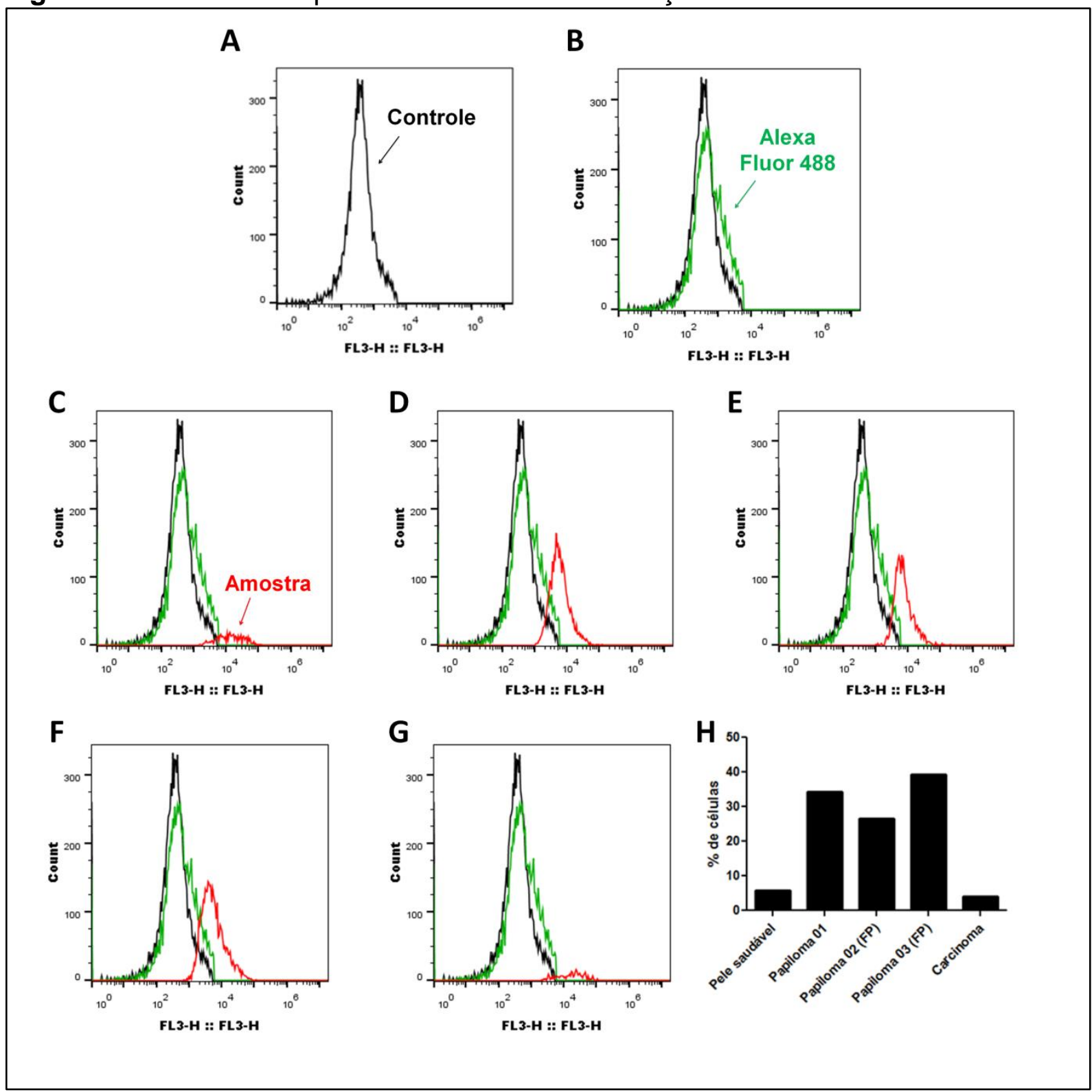

Resultados da citometria de fluxo empregando o anticorpo anti-STAT3 Y705: A) células de papiloma cutâneo não incubadas com anticorpo primário e/ou secundário (controle); B células de papiloma cutâneo incubadas exclusivamente com anticorpo secundário (Alexa Fluor 488), mostrando ausência de imunomarcação inespecífica; células incubadas com anticorpo primário e secundário (amostra): C) pele saudável, D) papiloma 01 (papiloma cutâneo), E) papiloma 02 (FP), F) papiloma 03 (FP) e G) carcinoma de esôfago. H) Histograma baseado no percentual de células imunomarcadas mostrando aumento dos níveis de expressão do fator STAT3 ativo nas linahgens de papiloma e fibropapiloma (neoplasia benigna).Verifica-se que as células de pele saudável e carcinoma apresentam níveis de expressão de STAT3 semelhantes. Total de 10.000 eventos analisados. Células analisadas na segunda passagem (P2). FP - fibropapiloma.

Considerando a redução dos níveis de expressão da E-caderina verificada na linhagem celular de cultivo primário de CE (figura 48), os níveis de expressão, bem como a localização celular do fator SLUG foram analisadas. Os resultados desta análise mostraram a imunodetecção citoplasmática e perinuclear do fator SLUG nas linhagens celulares derivadas de cultivos primários de neoplasias infectadas pelo 
BPV (figura 51). Interessantemente, foi verificado o aumento dos níveis de expressão desta fator nas linhagens celulares derivadas de papiloma cutâneo e CE (figura 52), sugerindo que a expressão aberrante de SLUG se restringe a infecção epitelial. As linhagens celulares de fibropapiloma, por sua vez, apresentaram níveis de expressão semelhantes a pele saudável não infectada pelo BPV (figura 52). Os controles negativos da IF (figura 51) e CF (figura 52) não apresentaram marcações inespecíficas. 
Figura 51 - Imunodetecção do fator de transcrição SLUG

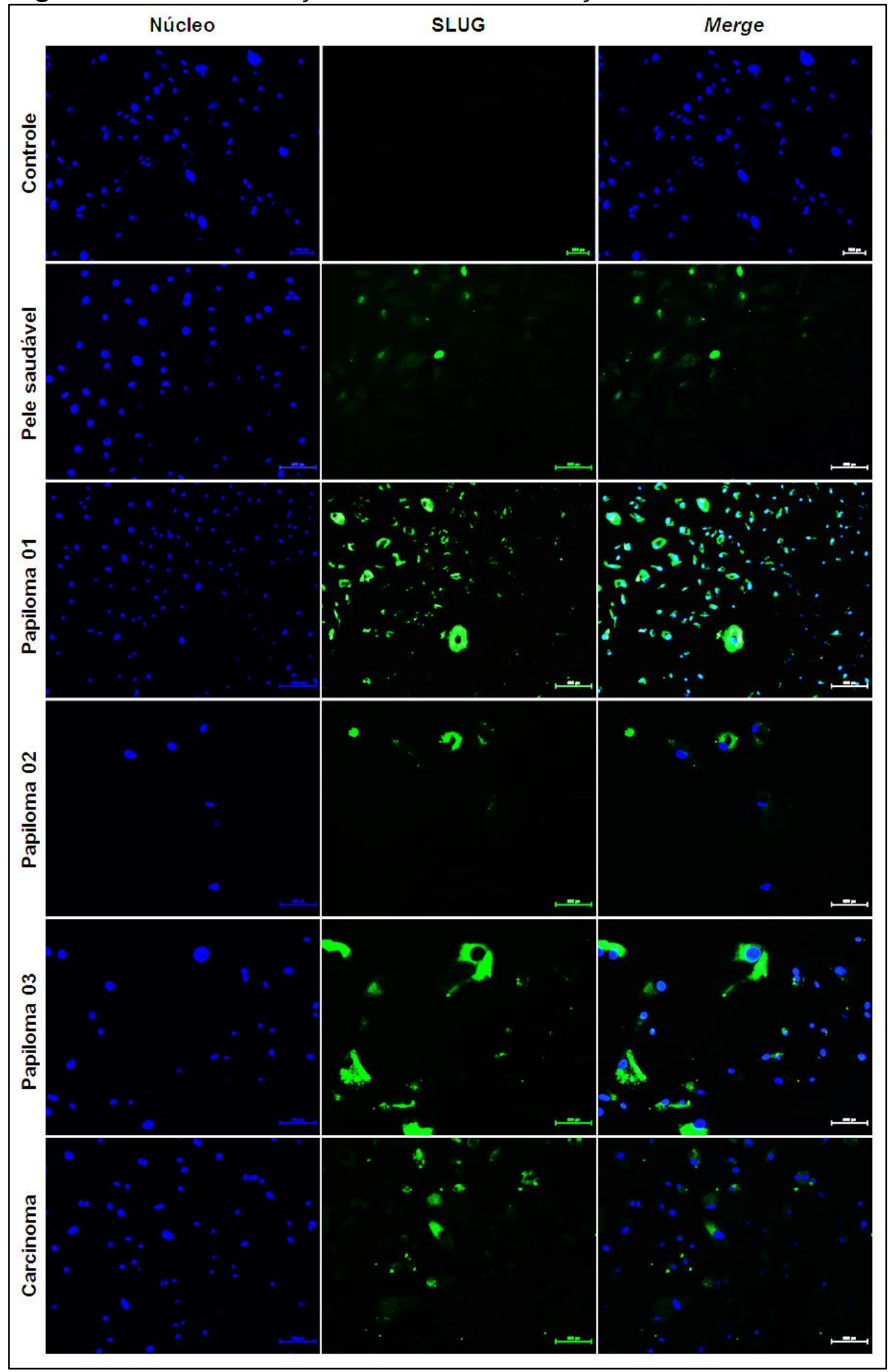

Imunofluorescência mostrando: ausência de marcação inespecífica no controle negativo (células de papiloma cutâneo incubadas apenas com o anticorpo secundário conjugado com FITC); marcação nuclear do fator de transcrição SLUG restrita a um reduzido número de células de pele saudável. Imunodetecção citoplasmática e perinuclear do fator de transcrição SLUG nas células de papiloma cutâneo (papiloma 01), fibropapiloma (papiloma 02 e 03) e carcinoma de esôfago. Imagens capturadas com tempo de exposição de 8 ms (núcleo, DAPI) e 300 ms (STAT3 Y705) com objetiva de 40 X. Barra de escala de $200 \mu \mathrm{m}$. 
Figura 52 - Níveis de expressão do fator de transcrição SLUG

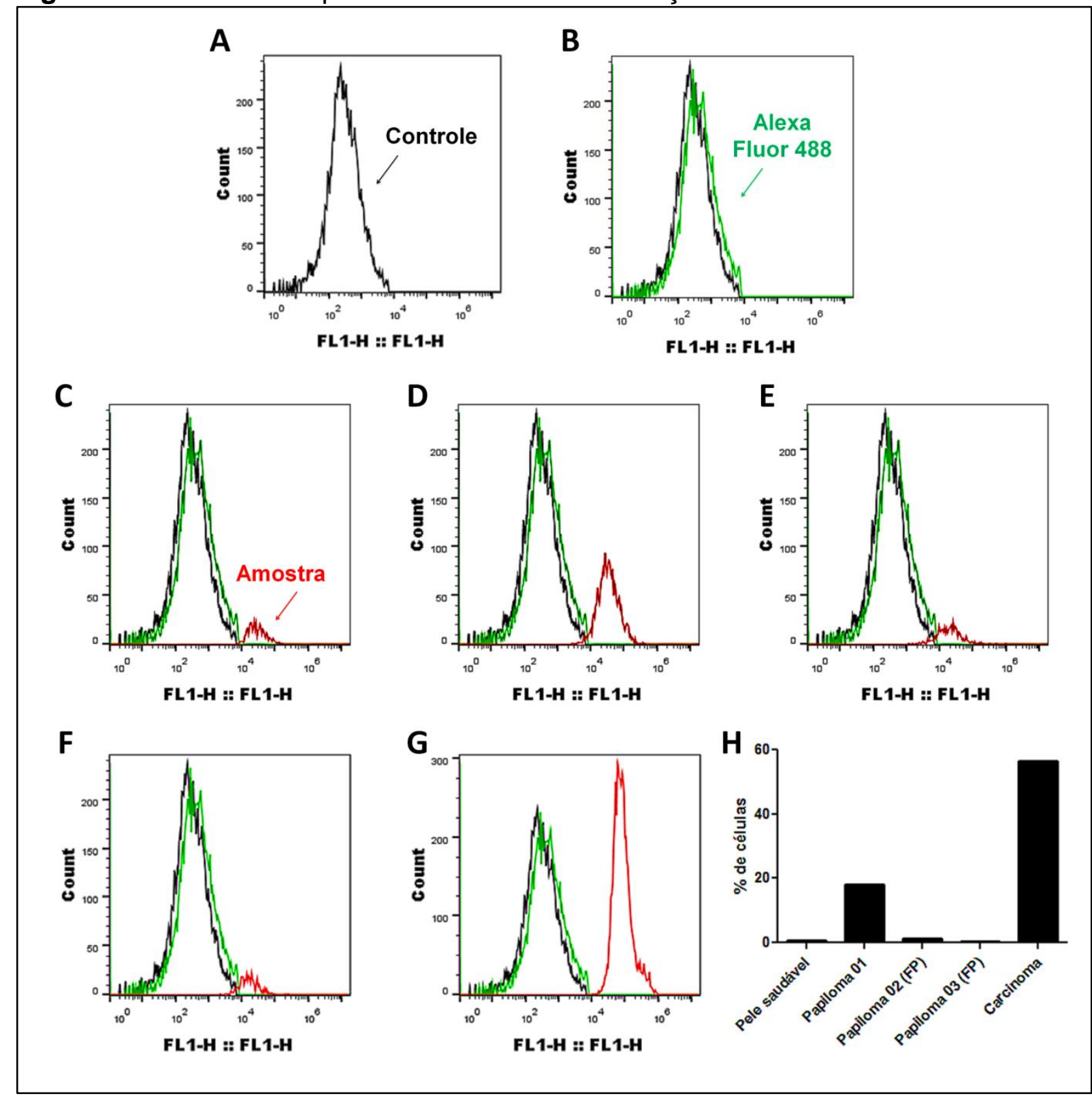

Resultados da citometria de fluxo empregando o anticorpo anti-SLUG: A) células de papiloma cutâneo não incubadas com anticorpo primário e/ou secundário (controle); B células de papiloma cutâneo incubadas exclusivamente com anticorpo secundário (Alexa Fluor 488), mostrando ausência de imunomarcação inespecífica; células incubadas com anticorpo primário e secundário (amostra): C) pele saudável, D) papiloma 01 (papiloma cutâneo), E) papiloma 02 (FP), F) papiloma 03 (FP) e G) carcinoma de esôfago. H) Histograma baseado no percentual de células imunomarcadas mostrando aumento dos níveis de expressão do fator SLUG nas linahgens de papiloma cutâneo e carcinoma de esôfago. Verifica-se que as células de pele saudável e fibropapiloma apresentam níveis de expressão de SLUG semelhantes. Total de 10.000 eventos analisados. Células analisadas na segunda passagem (P2). FP - fibropapiloma.

\subsubsection{Marcadores mesenquimais: N-caderina, vimentina e vinculina}

Os resultados da IF mostraram uma expressiva imunomarcação nuclear de Ncaderina nas linhagens celulares derivadas de cultivos primários de papiloma cutâneo, fibropapiloma e CE, sugerindo um sequestro deste marcador mesenquimal 
(figura 53). Estas linhagens também apresentaram a marcação de F-actina e Ncaderina em lamelipódios, especialmente em células "gigantes" e polinucleadas, sugerindo a aquisição de um fenótipo migratório (figura 53). A linhagem derivada de pele saudável não infectada pelo BPV, por sua vez, apresentou uma marcação difusa de $\mathrm{F}$-actina e $\mathrm{N}$-caderina (figura 53). Interessantemente, as linhagens celulares derivadas de cultivos primários de papiloma cutâneo e fibropapiloma apresentaram um aumento do percentual de células expressando $\mathrm{N}$-caderina em relação a pele saudável (figura 54), reforçando o caráter benigno destas neoplasias. Por outro lado, a linhagem derivada de CE apresentou uma redução dos níveis de expressão deste marcador (figura 54), reforçando a aquisição do fenótipo migratório. Os controles negativos da IF (figura 49) e CF (figura 50) não apresentaram marcações inespecíficas. Estes resultados sugerem que as células infectadas pelo BPV não apresentam o switching gênico das caderinas, mas sim alterações no tráfego vesicular, levando ao sequestro destas glicoproteínas e, por consequência, a redução da adesão celular. 
Figura 53 - Co-localização de F-actina e N-caderina em cultivos primários

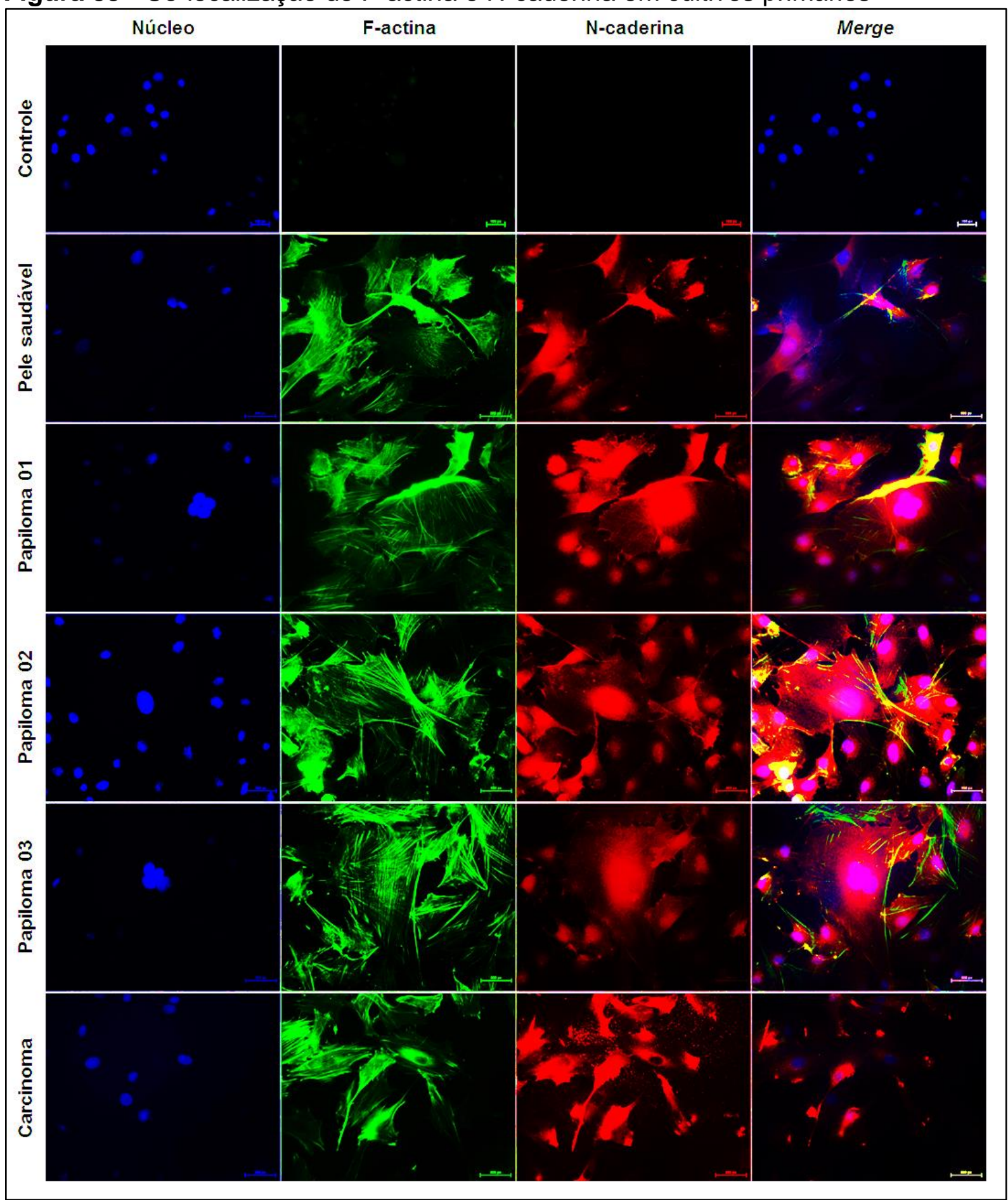

Imunofluorescência mostrando marcação da F-actina e a imunodetecção da N-caderina nos cinco diferentes cultivos primários. Verifica-se a ausência de marcação inespecífica no controle (papiloma cutâneo incubado apenas com anticorpo secundário conjugado a TRITC). Nota-se uma imunomarcação difusa da F-actina e da N-caderina na linhagem de pele saudável, onde alterações nucleares não foram observadas. As células infectadas pelo BPV: papiloma cutâneo, fibropapiloma (papiloma 02 e 03) e carcinoma de esôfago mostraram a co-localização da F-actina e N-caderina em sítios de lamelipoidia. Foram, ainda, observadas figuras de células "gigantes" e polinucleadas, com figuras de endorreduplicação, indicando um efeito neótico nos cultivos de papiloma, fibropapiloma e carcinoma de esôfago. Imagens capturadas com tempo de exposição de 5 ms (núcleo, DAPI) e 300 ms ( F-actina e N-caderina), com objetiva de 40 X. Barra de escala de $100 \mu \mathrm{m}$. 
Figura 54 - Níveis de expressão de N-caderina

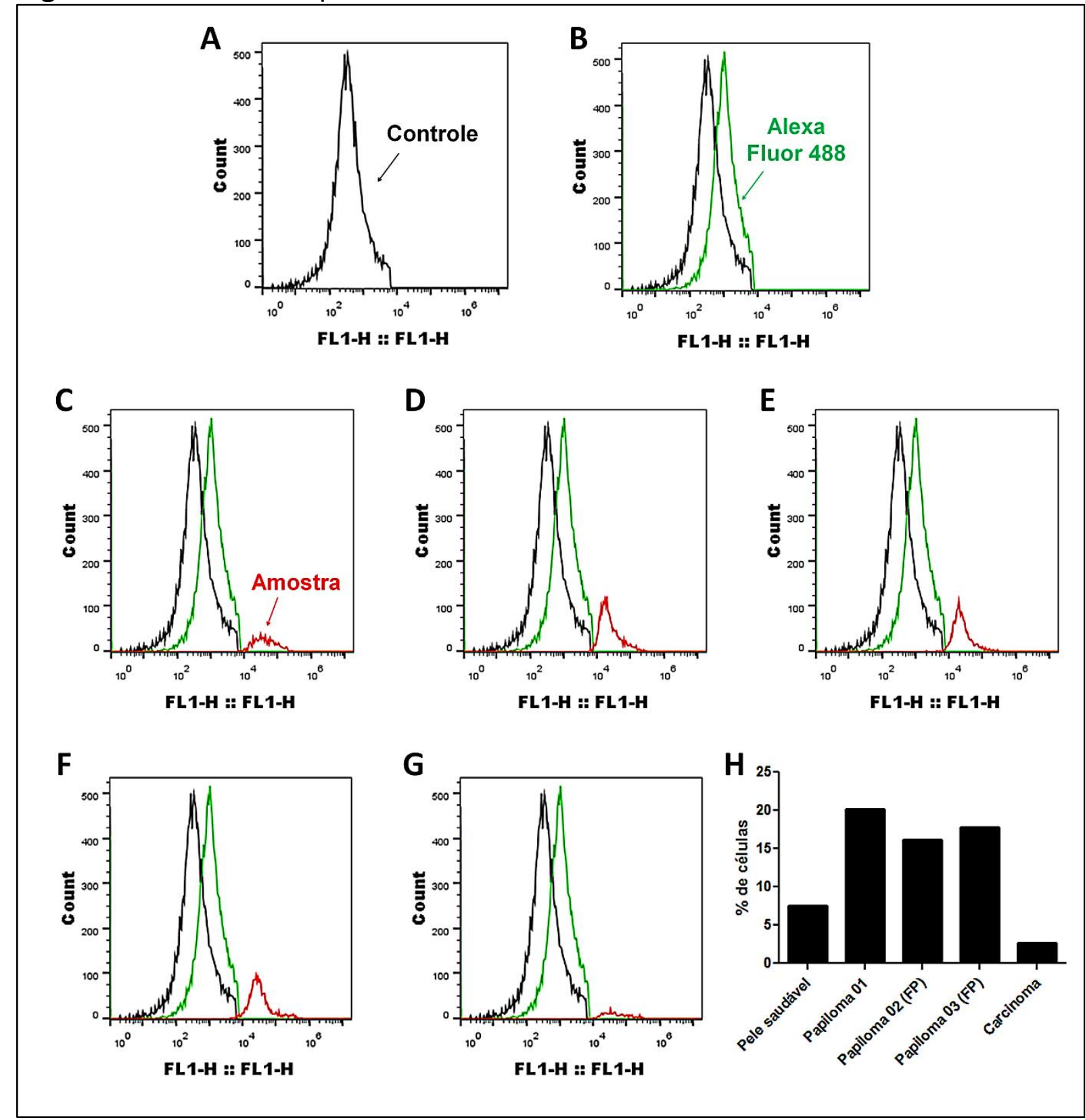

Resultados da citometria de fluxo empregando o anticorpo anti-N-caderina: A) células de papiloma cutâneo não incubadas com anticorpo primário e/ou secundário (controle); B células de papiloma cutâneo incubadas exclusivamente com anticorpo secundário (Alexa Fluor 488), mostrando ausência de imunomarcação inespecífica; células incubadas com anticorpo primário e secundário (amostra): C) pele saudável, D) papiloma 01 (papiloma cutâneo), E) papiloma 02 (fibropapiloma), F) papiloma 03 (fibropapiloma) e G) carcinoma de esôfago. H) Histograma baseado no percentual de células imunomarcadas mostrando aumento dos níveis de expressão de $\mathrm{N}$-caderina nos cultivos primários de papiloma e fibropapiloma (neoplasia benigna).Verifica-se que as células de carcinoma de esôfago apresentam níves reduzidos de $\mathrm{N}$-caderina em relação à pele saudável. Total de 10.000 eventos analisados. Células analisadas na segunda passagem (P2).

Considerando que a vimentina (VIM) é a principal proteína do citoesqueleto de células mesenquimais (CASTRO-MUÑOZLEDO et al., 2014) e que sua expressão aberrante está associada a formação de lamelipódios (EZZELL et al., 
1997), os níveis de expressão desta proteína foram avaliados. Os resultados desta análise mostraram um expressivo aumento dos níveis de expressão da VIM nas linhagens celulares derivadas de cultivos primários de papiloma cutâneo, fibropapiloma e CE em relação a pele saudável não infectada pelo BPV (figuras 55 e 56). Os controles negativos da IF (figura 55) e CF (figura 56) não apresentaram marcações inespecíficas. Somados a estes resultados, foi verificado um expressivo aumento do marcador mesenquimal vinculina nas linhagens celulares derivadas de cultivos primários de neoplasias infectadas pelo BPV (figuras 57 e 58). Tendo em vista que a expressão aberrante da vinculina também está associada a formação de lamelipódios (EZZELL et al., 1997), o aumento dos níveis de expressão da vinculina representa uma evidência adicional da aquisição do fenótipo migratório das linhagens celulares derivadas de cultivos primários infectados pelo BPV. Desta forma, os resultados combinados da avaliação dos níveis de expressão de marcadores epiteliais, fatores de transcrição e marcadores mesenquimais confirmam reforçam a TEM nas linhagens celulares derivadas de cultivos primários de papiloma cutâneo, fibropapiloma e CE. 
Figura 55 - Imunodetecção da vimentina

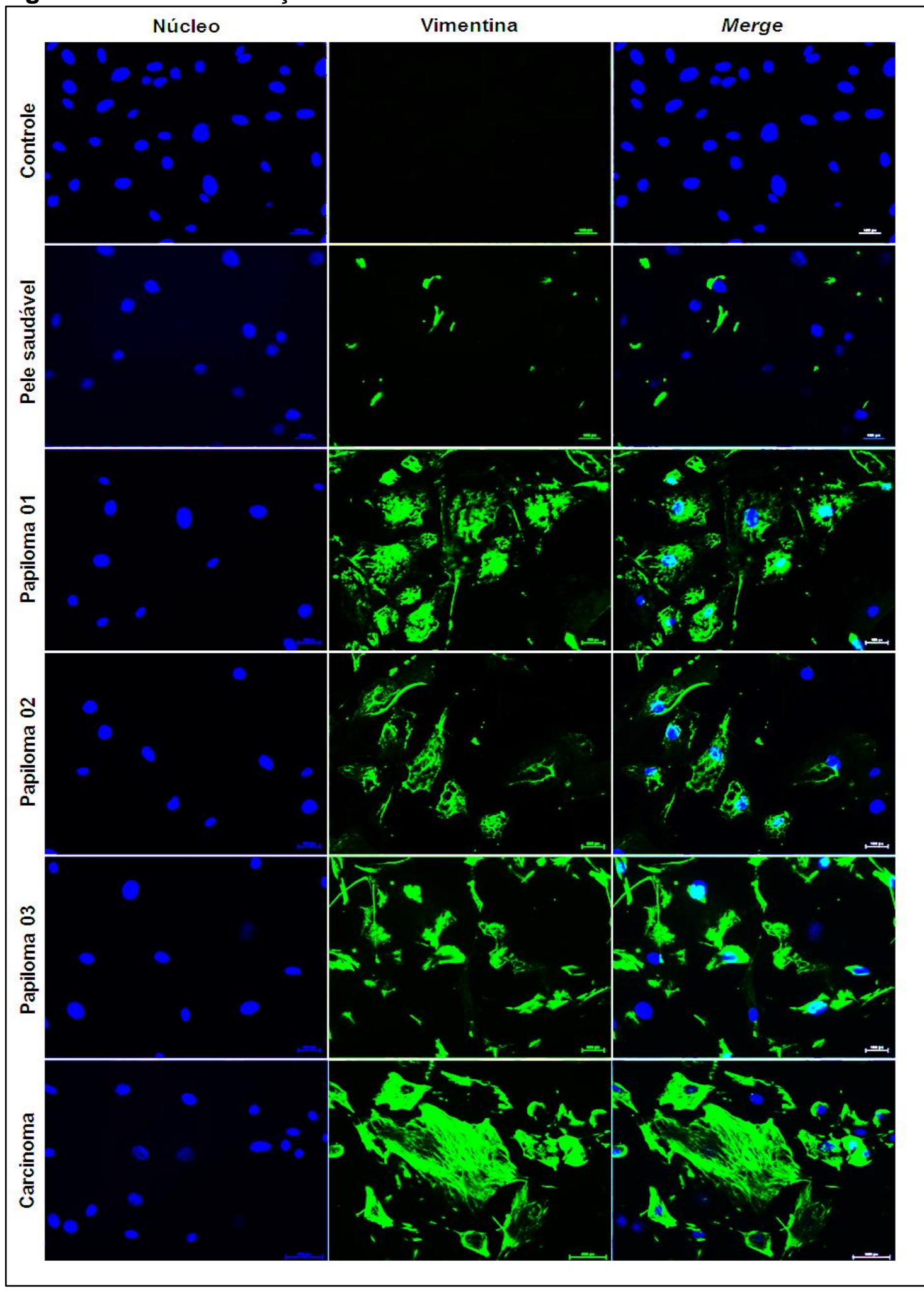

Verifica-se a ausência de marcação inespecífica no controle (papiloma 01 incubado apenas com anticorpo secundário conjugado a FITC). Nota-se uma imunomarcação citoplasmática difusa da vimentina nos diferentes cultivos primários. Resultados mostram uma maior imunomarcação nas linhagens de papiloma cutâneo 01, 02, 03 e carcinoma de esôfago em relação à pele saudável. Imagens capturadas com tempo de exposição de $5 \mathrm{~ms}$ (núcleo, DAPI) e $300 \mathrm{~ms}$ ( F-actina e Ncaderina), com objetiva de $40 \mathrm{X}$. Barra de escala de $100 \mu \mathrm{m}$ 
Figura 56 - Níveis de expressão do marcador mesenquimal vimentina

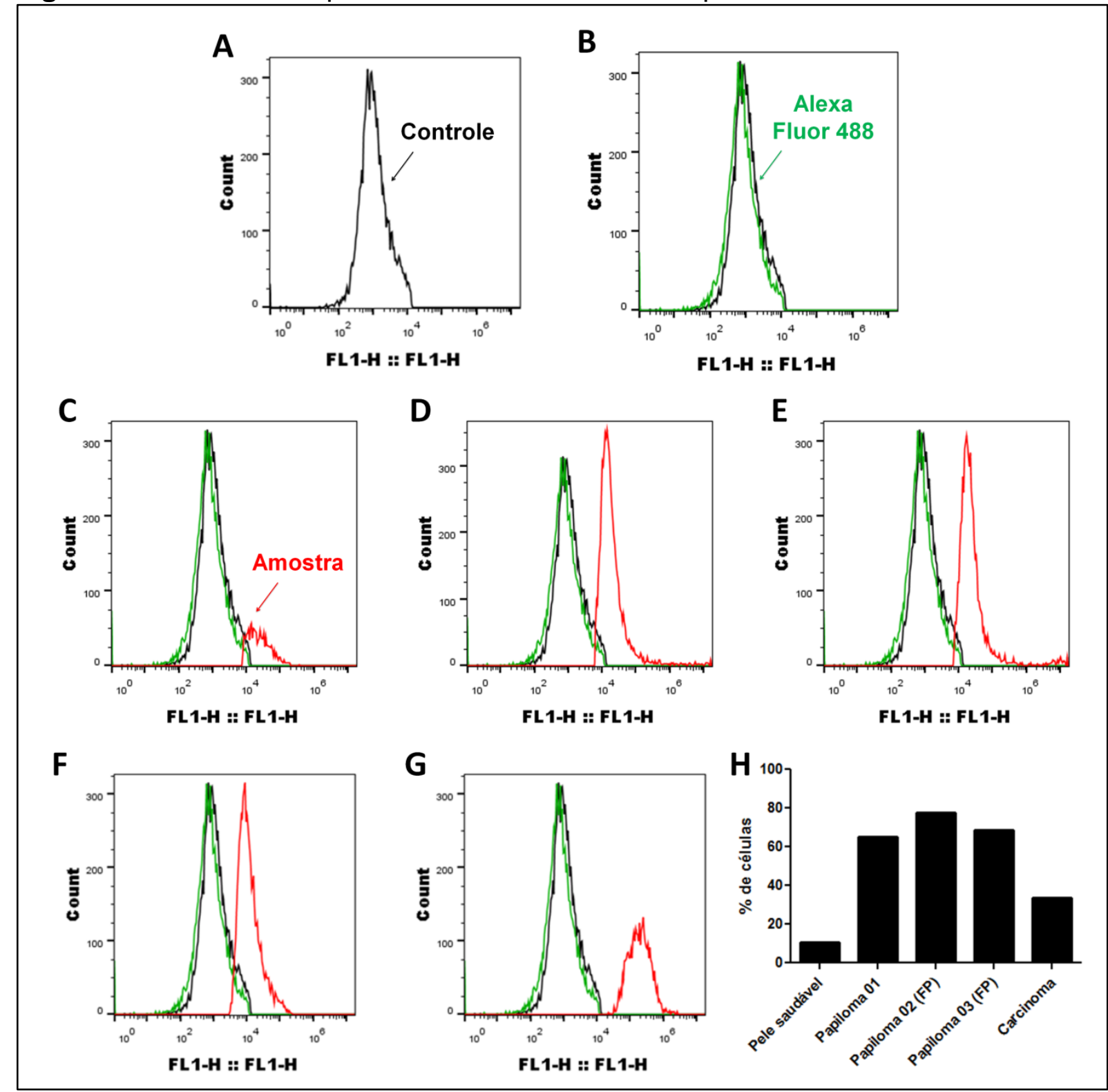

Resultados da citometria de fluxo empregando o anticorpo anti-vimentina: A) células de papiloma cutâneo não incubadas com anticorpo primário e/ou secundário (controle); B células de papiloma cutâneo incubadas exclusivamente com anticorpo secundário (Alexa Fluor 488), mostrando ausência de imunomarcação inespecífica; células incubadas com anticorpo primário e secundário (amostra): C) pele saudável, D) papiloma 01 (papiloma cutâneo), E) papiloma 02 (FP), F) papiloma 03 (FP) e G) carcinoma de esôfago. H) Histograma baseado no percentual de células imunomarcadas mostrando aumento dos níveis de expressão de vimentina nos cultivos primários de papiloma, fibropapiloma e carcinoma de esôfago. Total de 10.000 eventos analisados.Células analisadas na segunda passagem (P2). 
Figura 57 - Imunodetecção da proteína vinculina

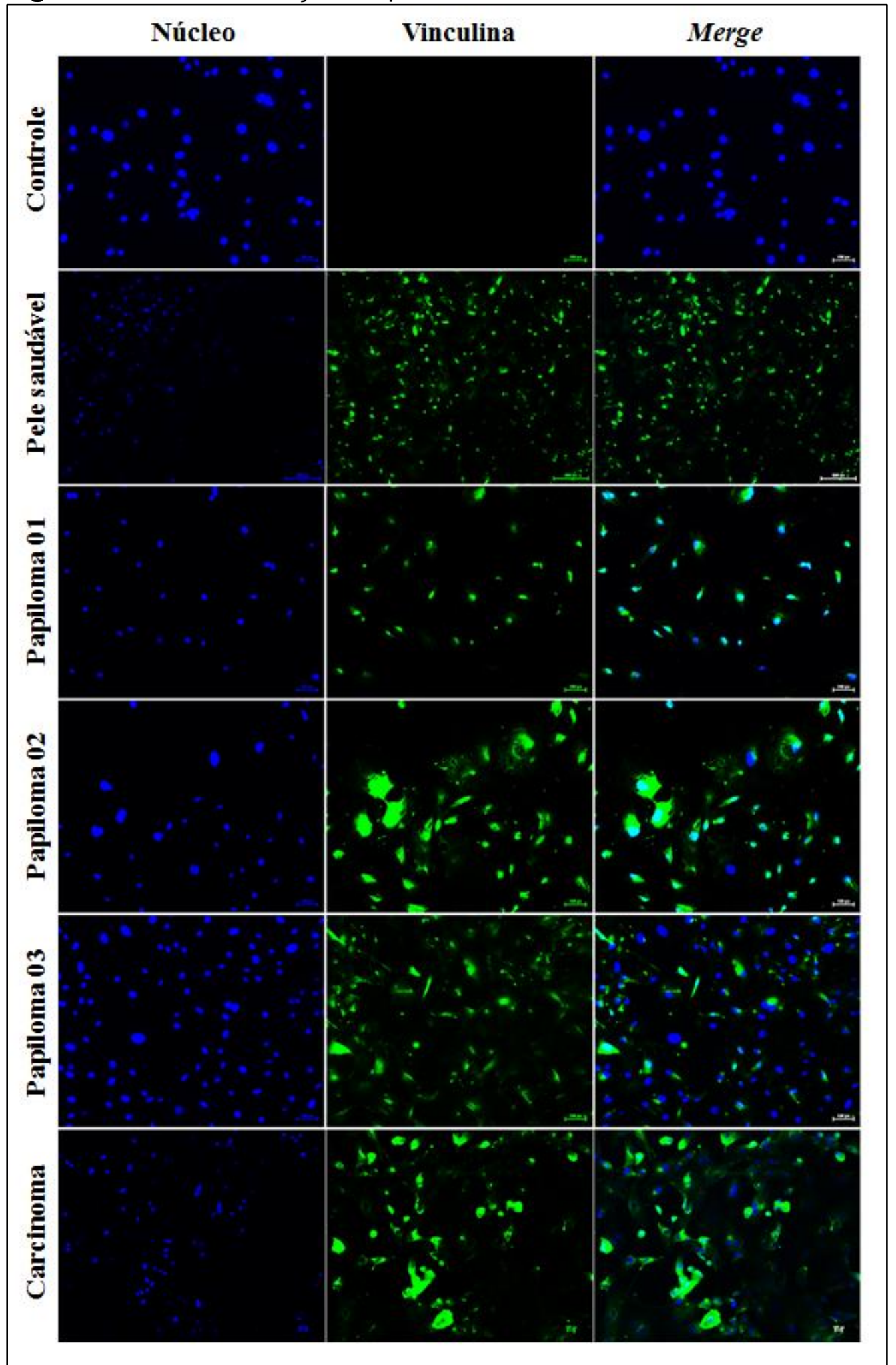

Verifica-se a ausência de marcação inespecífica no controle (papiloma 01 incubado apenas com anticorpo secundário conjugado a FITC). Nota-se uma imunomarcação citoplasmática difusa da vinculina nos diferentes cultivos primários. Resultados mostram uma maior imunomarcação nas linhagens de papilom 02, 03 (fibropapiloma) e carcinoma de esôfago em relação à pele saudável. Imagens capturadas com tempo de exposição de $5 \mathrm{~ms}$ (núcleo, DAPI) e $300 \mathrm{~ms}$ (F-actina e Ncaderina), com objetiva de 40 X. Barra de escala de $100 \mu \mathrm{m}$. 
Figura 58 - Níveis de expressão da vinculina

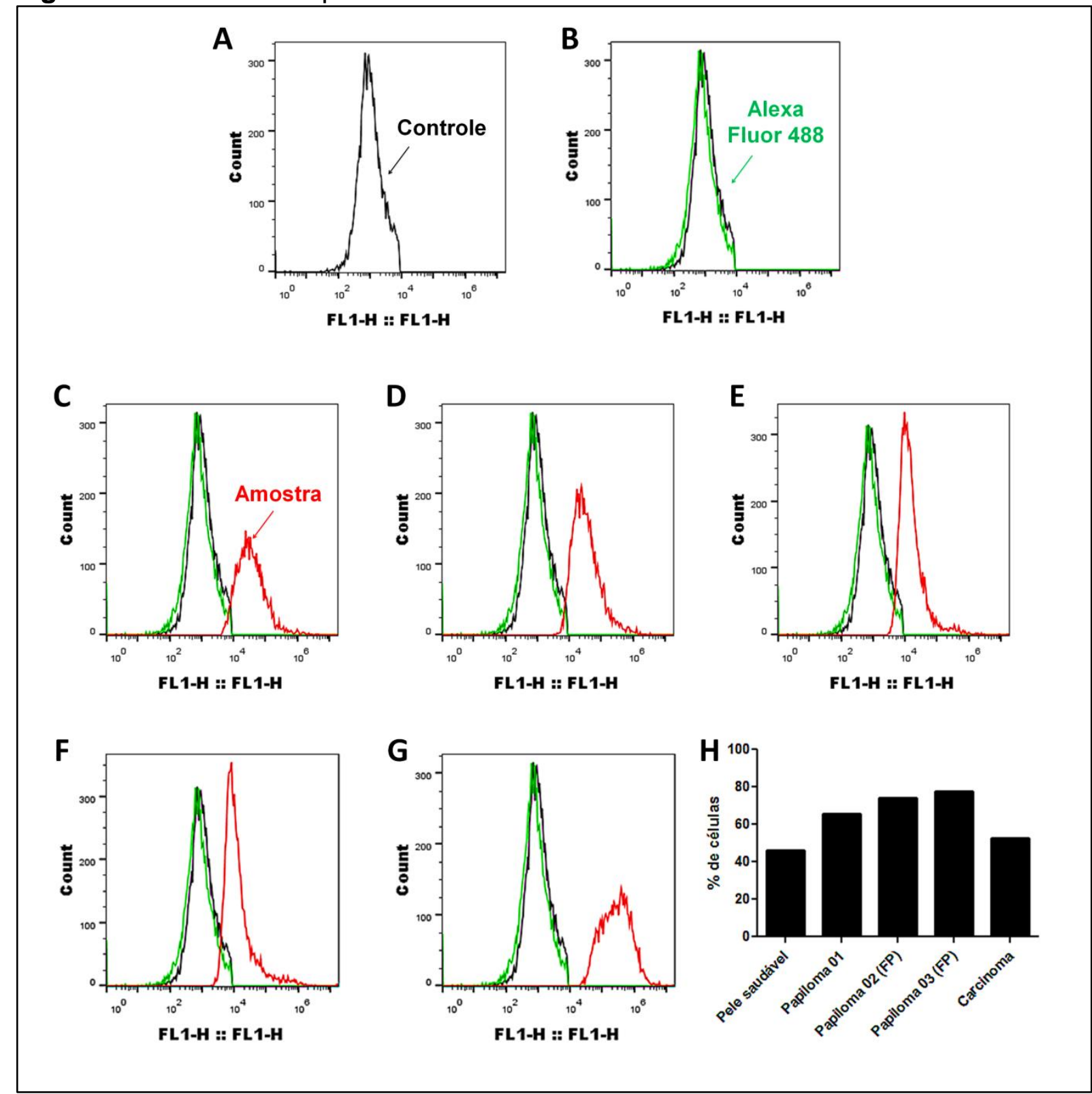

Resultados da citometria de fluxo empregando o anticorpo anti-vinculina: A) células de papiloma cutâneo não incubadas com anticorpo primário e/ou secundário (controle); B células de papiloma cutâneo incubadas exclusivamente com anticorpo secundário (Alexa Fluor 488), mostrando ausência de imunomarcação inespecífica; células incubadas com anticorpo primário e secundário (amostra): C) pele saudável, D) papiloma 01 (papiloma cutâneo), E) papiloma 02 (FP), F) papiloma 03 (FP) e G) carcinoma de esôfago. H) Histograma baseado no percentual de células imunomarcadas mostrando aumento dos níveis de expressão de vinculina nos cultivos primários de papiloma, fibropapiloma e carcinoma de esôfago. Total de 10.000 eventos analisados.Células analisadas na segunda passagem (P2).

\subsubsection{Western blot: confirmando a especificidade dos anticorpos}

A despeito do elevado nível de conservação das proteínas avaliadas neste estudo, o Western blot é fundamental para confirmar a especificidade dos anticorpos. Isto porque, nos últimos anos, a inespecificidade de alguns anticorpos 
tem levado a importantes problemas, incluindo a identificação de falsos marcadores tumorais (BAKER, 2015). Por esta razão, a especificidade dos anticorpos empregados neste estudo foi avaliada por meio de Western blot. Para tanto, as células derivadas de pele saudável, papiloma cutâneo, fibropapiloma e CE foram submetidas à extração proteica usando o tampão RIPA. Além destas células, linhagens comerciais de células VERO (células epiteliais de rim de macaco verde) e HeLa (células de carcinoma cervical apresentando genoma de HPV-18 integrado) foram empregadas como controles adicionais. As proteínas extraídas foram dosadas pelo método colorimétrico do ácido bicinconínico (BCA). Os resultados desta dosagem são apresentados nas tabelas 20 e 21 e figura 59.

Tabela 20 - Curva de BCA $(\mu \mathrm{g} / \mathrm{mL})$

\begin{tabular}{cccccc}
\hline $\mathbf{B C A}(\boldsymbol{\mu} \mathbf{g} / \mathbf{m L})$ & $\mathbf{A}_{\mathbf{5 7 0} \mathbf{1}}$ & $\mathbf{A}_{\mathbf{5 7 0} \mathbf{2}}$ & $\mathbf{A}_{\mathbf{5 7 0} \mathbf{3}}$ & $\overline{\boldsymbol{x}} \mathbf{A}_{\mathbf{5 7 0}}$ & $\mathbf{A}_{\mathbf{5 7 0}}$ branco \\
\hline $\mathbf{5 0 0 , 0 0}$ & 0,277 & 0,343 & 0,305 & 0,308 & 0,213 \\
$\mathbf{2 5 0 , 0 0}$ & 0,198 & 0,216 & 0,240 & 0,218 & 0,122 \\
$\mathbf{1 2 5 , 0 0}$ & 0,147 & 0,163 & 0,164 & 0,158 & 0,062 \\
$\mathbf{6 2 , 5 0 0}$ & 0,126 & 0,131 & 0,136 & 0,131 & 0,036 \\
$\mathbf{3 1 , 2 5 0}$ & 0,111 & 0,112 & 0,118 & 0,114 & 0,018 \\
$\mathbf{1 5 , 6 2 5}$ & 0,103 & 0,103 & 0,108 & 0,105 & 0,009 \\
$\mathbf{0 , 0 0 0}$ & 0,092 & 0,092 & 0,103 & 0,096 & 0,000
\end{tabular}

$\bar{x}$ - média das absorbâncias no comprimento de onda de $570 \mathrm{~nm}$

Tabela 21 - Dosagem de proteínas extraídas dos diferentes cultivos primários

\begin{tabular}{ccccccc}
\hline Amostras & $\mathbf{A}_{570} \mathbf{1}$ & $\mathbf{A}_{570} \mathbf{2}$ & $\mathbf{A}_{570} \mathbf{3}$ & $\overline{\boldsymbol{x}} \mathbf{A}_{570}$ & $\mathbf{A}_{570}$ branco & {$[\boldsymbol{\mu g} / \mathbf{m L}]$} \\
\hline Pele saudável & 0,179 & 0,168 & 0,179 & 0,175 & 0,079 & 183,92 \\
Papiloma 01 & 0,190 & 0,165 & 0,154 & 0,170 & 0,074 & 170,33 \\
Papiloma 02 (FP) & 0,138 & 0,136 & 0,148 & 0,141 & 0,045 & 98,50 \\
Papiloma 03 (FP) & 0,163 & 0,168 & 0,151 & 0,161 & 0,065 & 148,83 \\
C. de esôfago & 0,217 & 0,210 & 0,197 & 0,208 & 0,112 & 266,67 \\
VERO & 0,200 & 0,191 & 0,165 & 0,185 & 0,090 & 210,08 \\
HeLa & 0,154 & 0,167 & 0,154 & 0,159 & 0,063 & 142,75 \\
\hline
\end{tabular}

$\bar{x}$ - média das absorbâncias no comprimento de onda de $570 \mathrm{~nm}$. FP - fibropapiloma 
Figura 59 - Curva de BCA

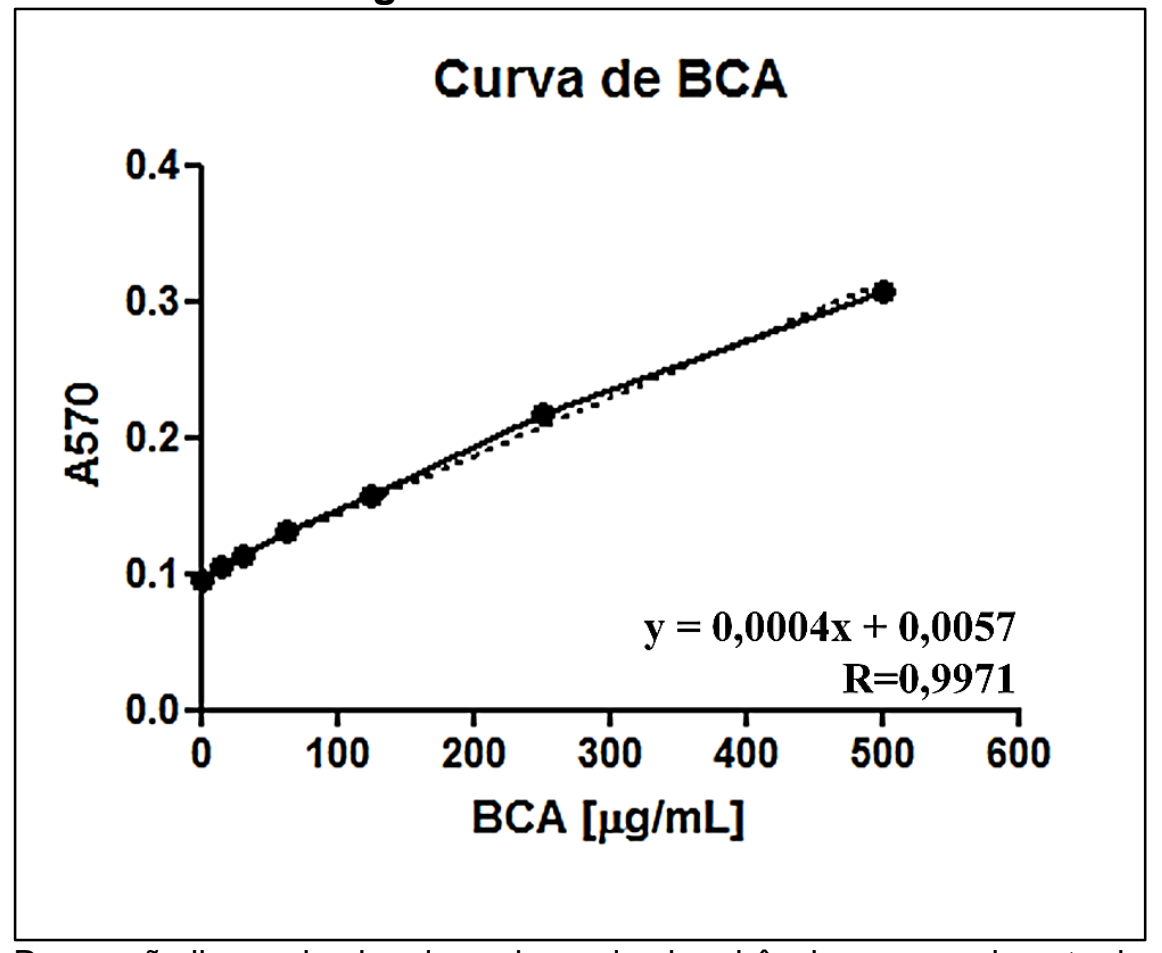

Regressão linear simples dos valores de absorbância no comprimento de onda de $570 \mathrm{~nm}$ (A570) das respectivas concentrações do ácido bicinconínico (BCA). Resultados mostram um coeficiente de determinação $\left(R^{2}=0,9943\right)$ e correlação/Pearson $(R=0,9971)$.

O perfil proteico foi avaliado empregando gel de SDS-PAGE a $12 \%$. Os resultados desta análise (figura 60), somados a dosagem proteica (tabela 21), mostraram que o método de extração empregado foi satisfatório para a obtenção de uma concentração de proteínas totais necessárias ao Western blot. 
Figura 60 - Perfil proteico em gel de SDS-PAGE

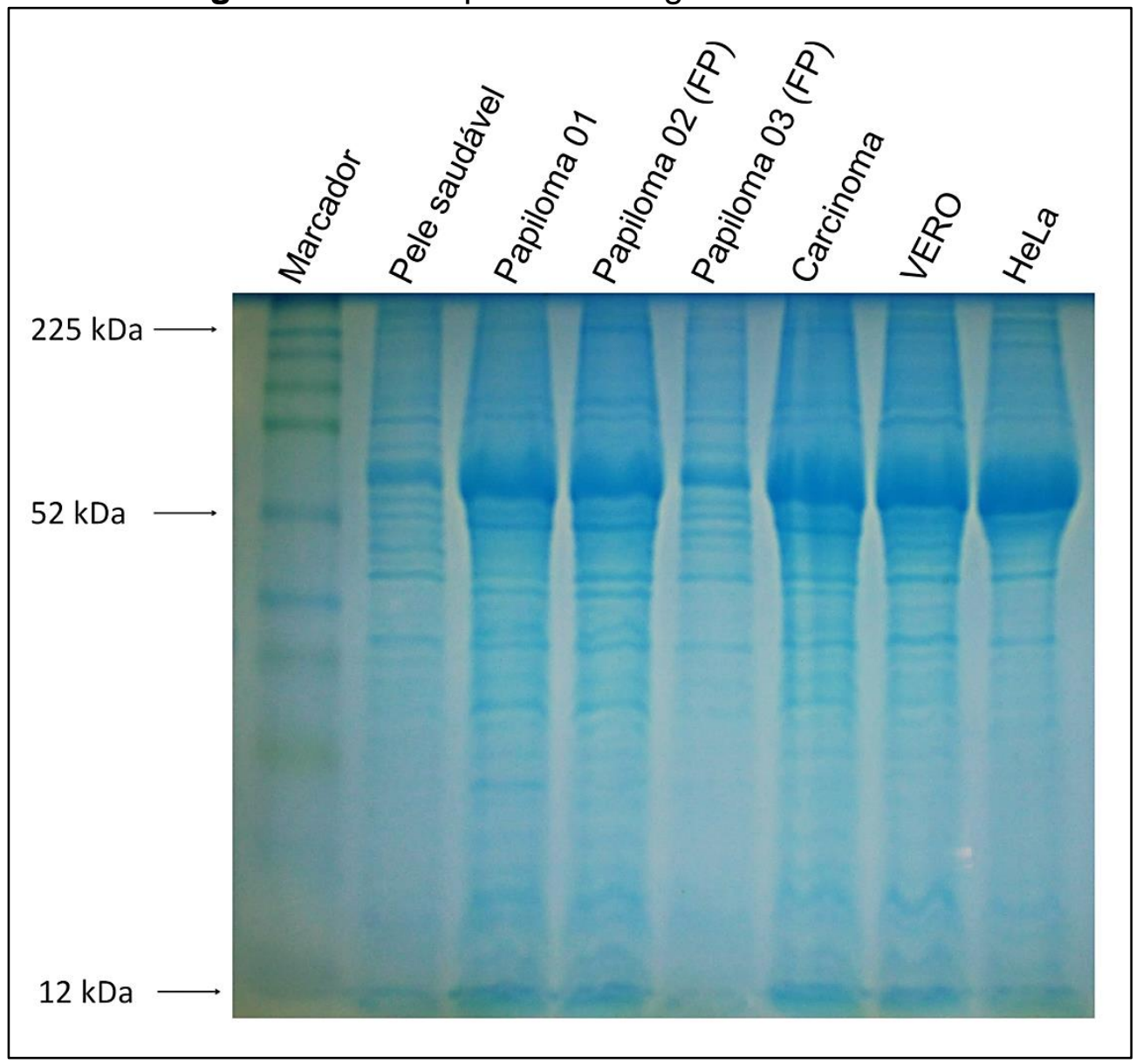

Gel de SDS-PAGE a $12 \%$ mostrando o perfil proteico dos diferentes cultivos primários. Marcador empregado: Full-Range Rainbow. Verifica-se uma elevada concentração de proteínas totais. Corrida eletroforética de três horas a $80 \mathrm{~V}$.

Baseado nestes resultados, um total de $50 \mu \mathrm{g}$ de proteínas foi aplicado por poço e empregado nas reações de imunoblot para a verificação da especificidade dos anticorpos empregados neste estudo. Os resultados confirmaram a especificidade dos anticorpos contra: as glicoproteínas E-caderina e N-caderina (figura 61), os fatores de transcrição nuclear STAT3 Y705 e SLUG (figura 62) e maracadores mesenquimais vimentina e vinculina (figura 63). A especificidade do anticorpo anti-CK10 não pode ser verificada por meio de Western blot, uma vez que, de acordo com os dados do fabricante, o mesmo não é indicado para este método, justificando assim a ausência de imunomarcação na membrana, conforme figura 64 . 
Figura 61 - Western blot usando anticorpos anti-E-caderina e N-caderina

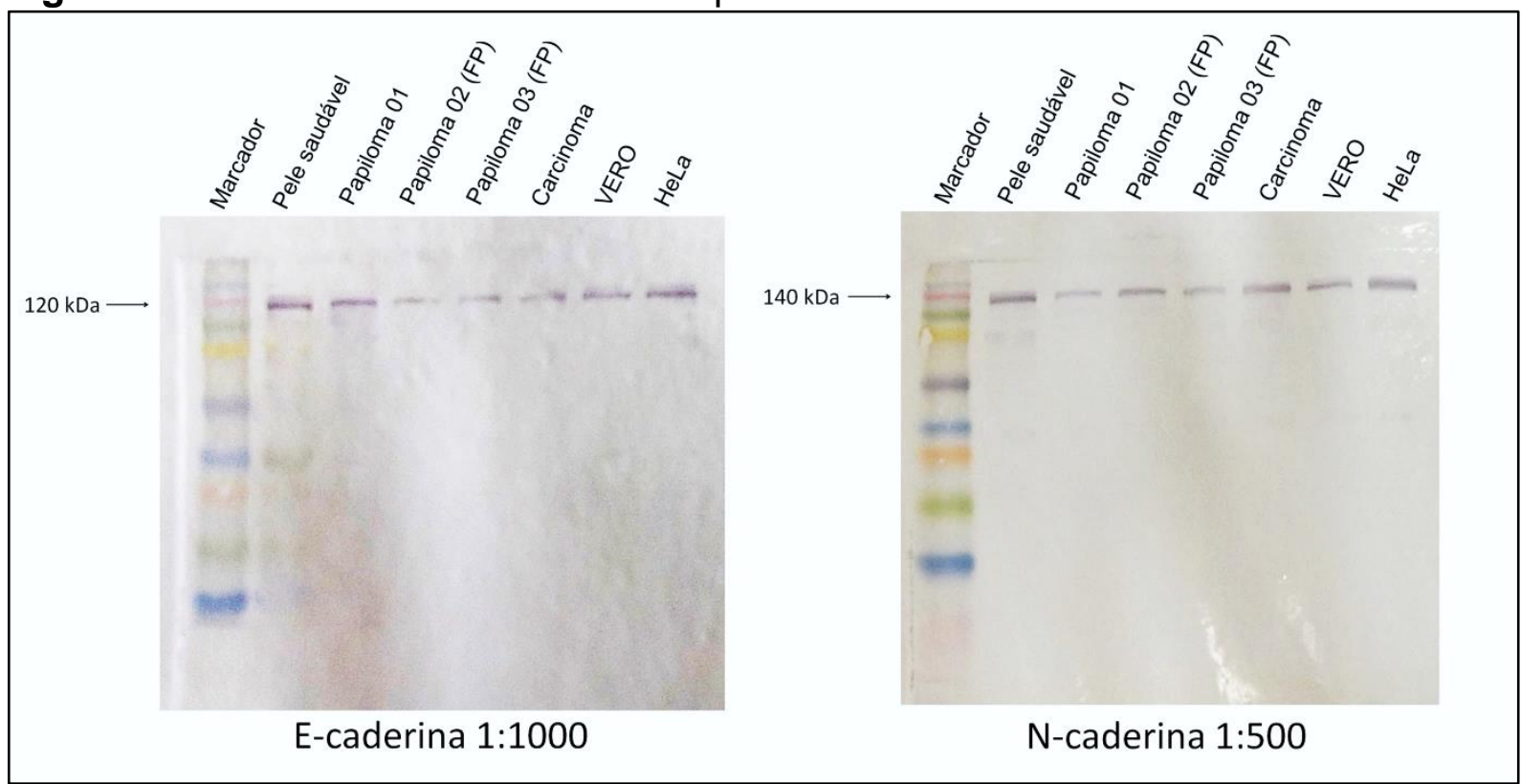

Membrana de nitrocelulose apresentando uma única banda, com peso molecular de $120 \mathrm{kDa}$, correspondente a proteína epitelial E-caderina, e $140 \mathrm{kDa}$, correspondente a N-caderina demonstrando a especificidade destes anticorpos. Reações realizadas empregando os anticorpos anti-Ecaderina (sc-1500, Santa Cruz Biotechnology) e N-caderina (M3613, Dako). Marcador empregado: Full-Range Rainbow (GE Healthcare, EUA). FP - fibropapiloma.

Figura 62 - Western blot usando anticorpos anti-STAT3 Y705 e anti-SLUG

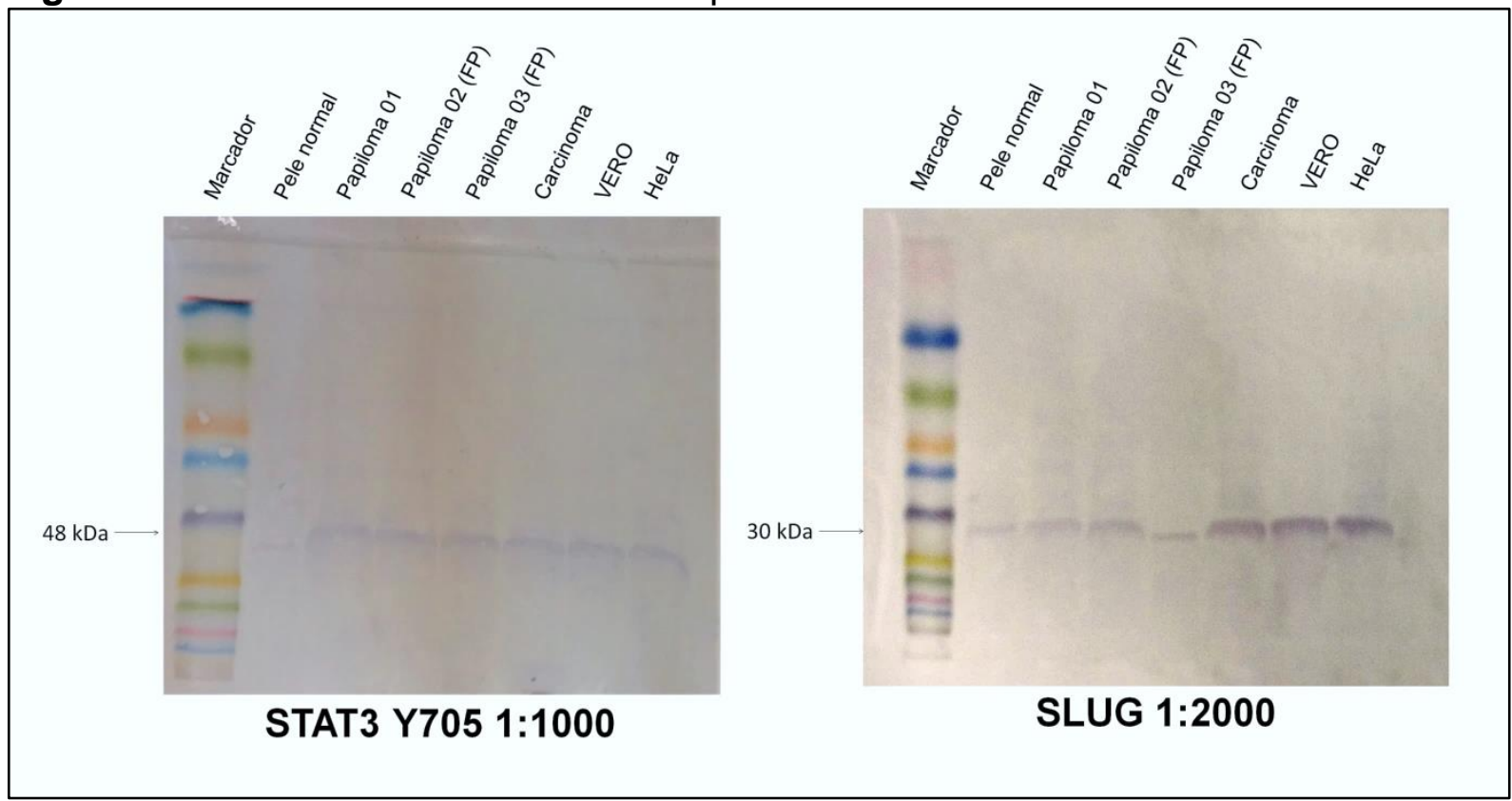

Membrana de nitrocelulose apresentando uma única banda, com peso molecular de $48 \mathrm{kDa}$, correspondente a proteína STAT3 alfa, e $30 \mathrm{kDa}$, correspondente ao fator SLUG, demonstrando a especificidade destes anticorpos. Reações realizadas empregando os anticorpos policlonais antiSTAT3 Y705 em coelho (Immuny, Brasil) e anti-SLUG (sc-15391) produzida em coelho (Santa Cruz Biotecnologia, EUA). Marcador empregado: Full-Range Rainbow (GE Healthcare, EUA). FP fibropapiloma. 
Figura 63 - Western blot usando anticorpos anti-vimentina e anti-vinculina

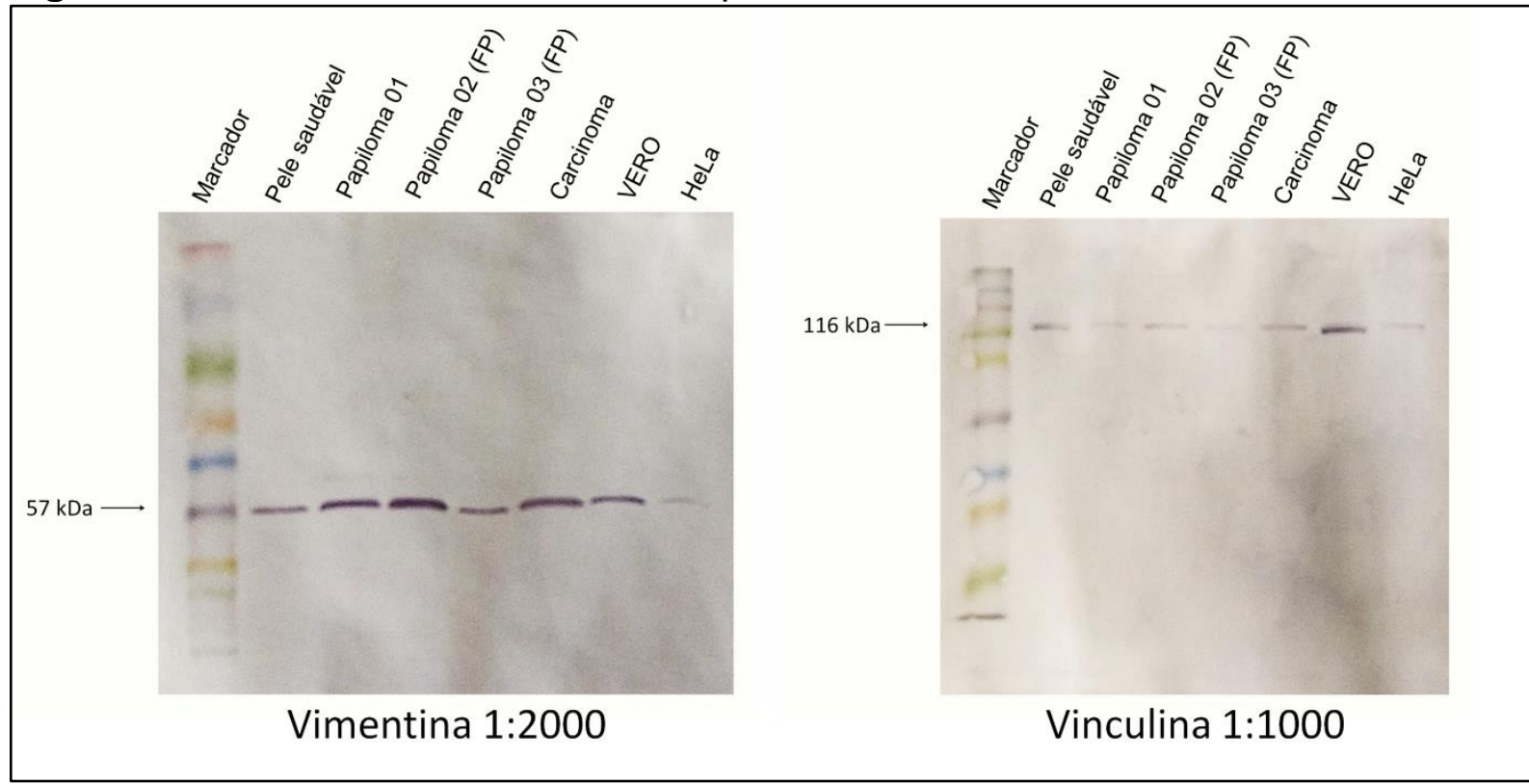

Membrana de nitrocelulose apresentando uma única banda, com peso molecular de $57 \mathrm{kDa}$, correspondente a proteína mesenquimal vimentina, e $116 \mathrm{kDa}$ (vinculina) demonstrando a especificidade destes anticorpos. Reações realizadas empregando os anticorpos anti-vimentina clone V9 produzido em camundongo (Dako, Alemanha) e anti-vinculina produzida em coelho (Sigma, Alemanha). Marcador empregado: Full-Range Rainbow (GE Healthcare, EUA). FP - fibropapiloma.

Figura 64 - Western blot usando anticorpos anti-CK10

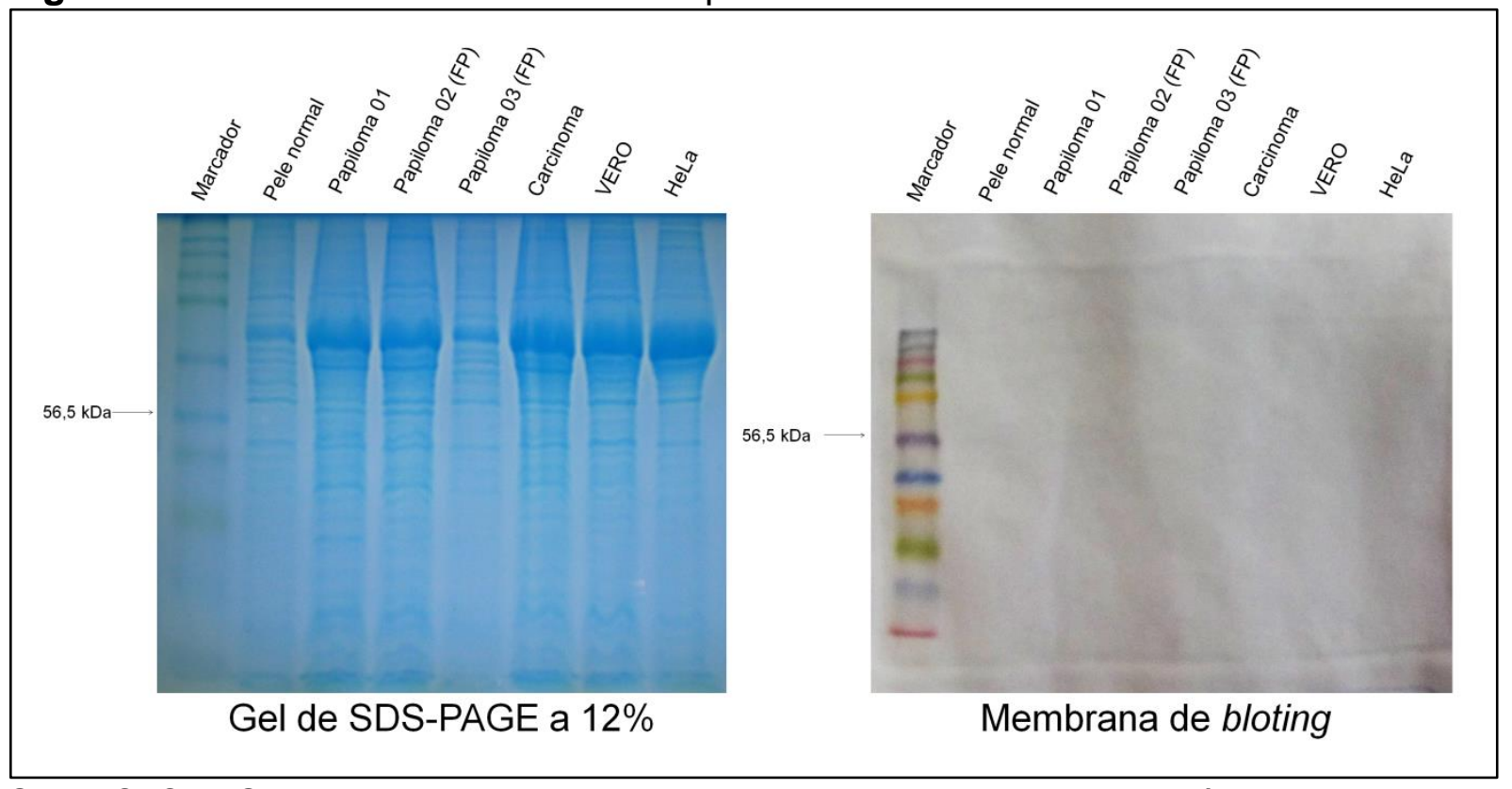

Gel de SDS-PAGE a $12 \%$ mostrando banda de $56,5 \mathrm{KDa}$, condizente com a proteína citoqueratina 10 (CK10). Membrana de nitrocelulse mostrando a ausência de banda após bloting empregando anticorpo anti-CK10 clone DE-K10 (Dako, Alemanha). A ausência de banda pode ser atribuída ao anticorpo, que segundo o data sheet, não é indicado para Western blot. Eventuais problemas de transferência são descartados, uma vez que o marcador foi devidamente transferido à membrana de nitrocelulose. Marcador empregado: Full-Range Rainbow (GE Healthcare, EUA). FP - fibropapiloma. 


\subsubsection{Análises morfológicas das diferentes linhagens celulares}

\subsubsection{Microscopia de contraste de fase e eletrônica de varredura (MEV)}

As diferentes linhagens celulares foram submetidas à análise morfológica ao longo das seis passagens (P1-P6) por meio de microscopia de contraste de fase. Os resultados desta análise mostraram diferenças morfológicas significativas entre as células infectadas e não infetctadas pelo BPV (figura 65). As células infectadas apresentaram perda de polaridade apical-basal, apresentando uma morfologia semelhante a fibroblastos, com extensas projeções citoplasmáticas e abundantes filopódios (figura 65), sugerindo a aquisição de fenótipo migratório. A presença destas protrusões foi confirmada por meio de MEV (figura 66), que também mostrou a presença de pontes intercitoplasmáticas, sobretudo nas linhagens celulares derivadas de cultivos primários de neoplasias infectadas pelo BPV (figura 67). A presença destas pontes sugere a transferência gênica horizontal, contribuindo para a manutenção de cópias episomais do vírus. 
Figura 65 - Análise morfológica das linhagens celulares

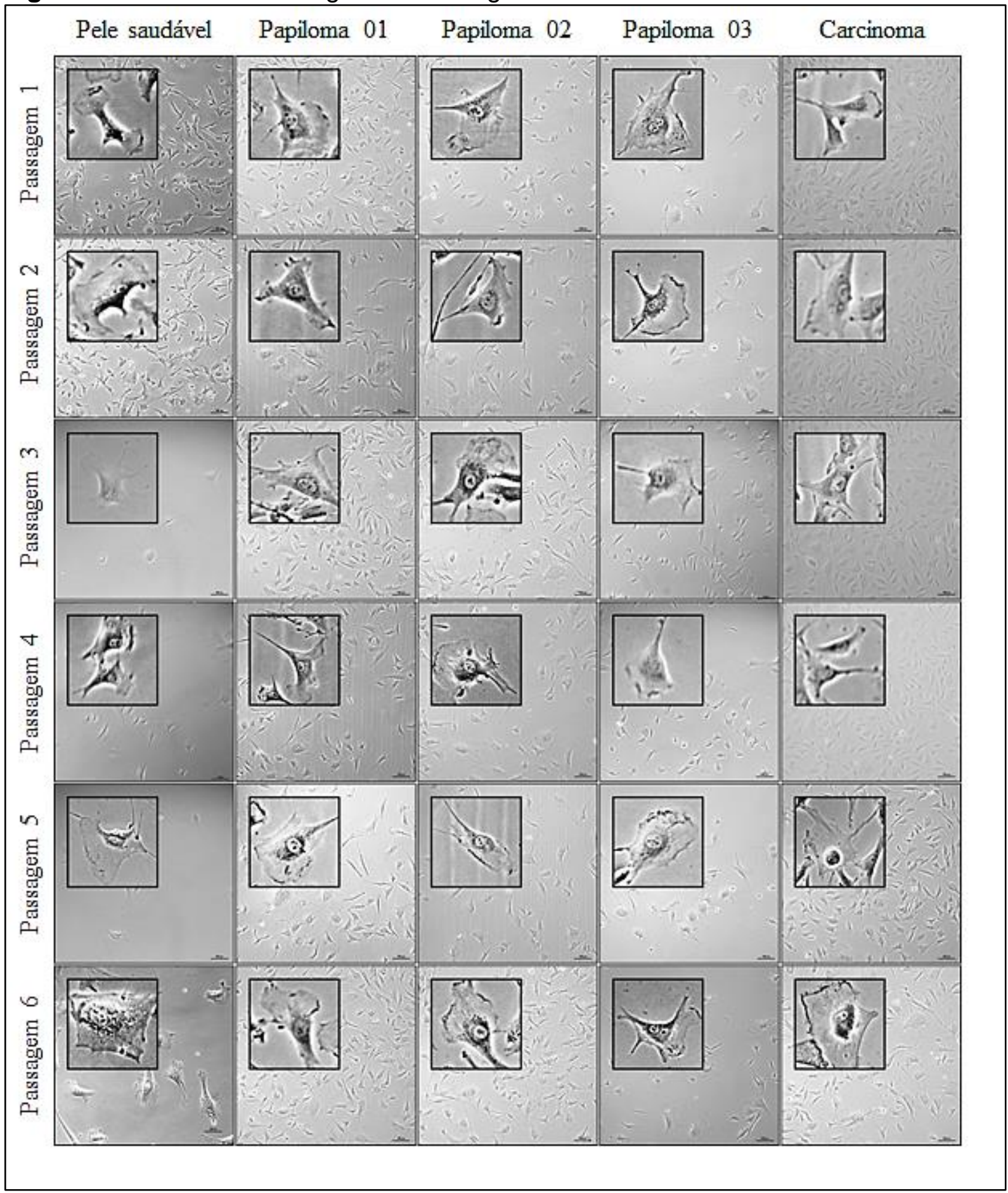

Fotomicrografia dos diferentes cultivos primários ao longo das seis passagens. Observa-se a manutenção da polaridade apical-basal nas células de pele saudável. As células infectadas pelo BPV (papiloma cutâneo, fibropapiloma e carcinoma de esôfago) mostram a perda de polaridade e a presença de abundantes filopódios. Tais células apresentam, ainda, extensas projeções citoplasmáticas. Imagens obtidas com objetiva de 20 X. Barra de escala de $100 \mu \mathrm{m}$. 
Figura 66 - Análise morfológica por microscopia eletrônica de varredura

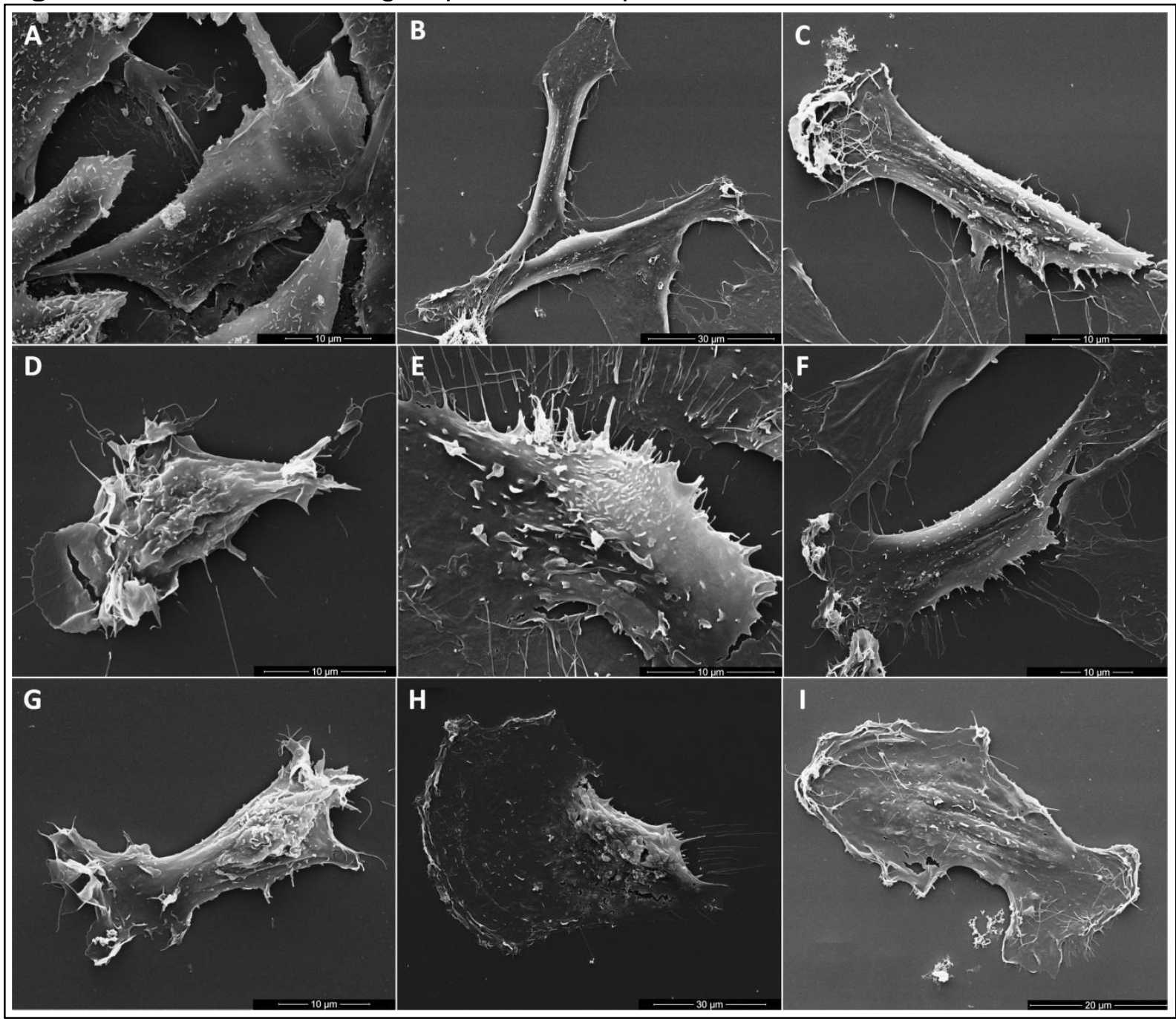

Fotomicroscopia eletrônica de varredura de: A) célula semelhante a queratinócito, apresentando morfologia e polaridade preservadas, com reduzida quantidade de filopódios, observada na linhagem de pele saudável em aumento de $6.664 \mathrm{X}$; B) células semelhantes a fibroblastos, apresentando morfologia fusiforme, observada na linhagem de pele saudável em aumento de 3.256 X; C) célula semelhante a queratinócito apresentando discreta perda de polaridade, contendo lamelipódios e filopódios, observado em linhagem de papiloma cutâneo - amostra 01 em aumento de 6.788 X; D) célula com perda de polaridade e presença de lamelipódios e filopódios observado em linhagem de papiloma cutâneo - amostra 01 em aumento de $9.388 \mathrm{X}$; E) célula apresentam abundante quantidade de lamelipódios e filopódios observado na linhagem de papiloma cutâneo - amostra 02 em aumento de $9.829 \mathrm{X}$; células semelhantes a queratinócitos apresentando perda de polaridade e presença de filopódios observadas em linhagem de papiloma cutâneo - amostra 03 em aumentos de $5.537 \mathrm{X}(\mathrm{F}) \mathrm{e}$ $2.893 \mathrm{X}(\mathrm{G})$, células de carcinoma esoágico com perda de polaridade e presença de filopódios em aumentos de $2.899 \times(\mathrm{H})$ e $5.293 \times(\mathrm{I})$. 
Figura 67 - Pontes intercitoplasmáticas observadas através da MEV

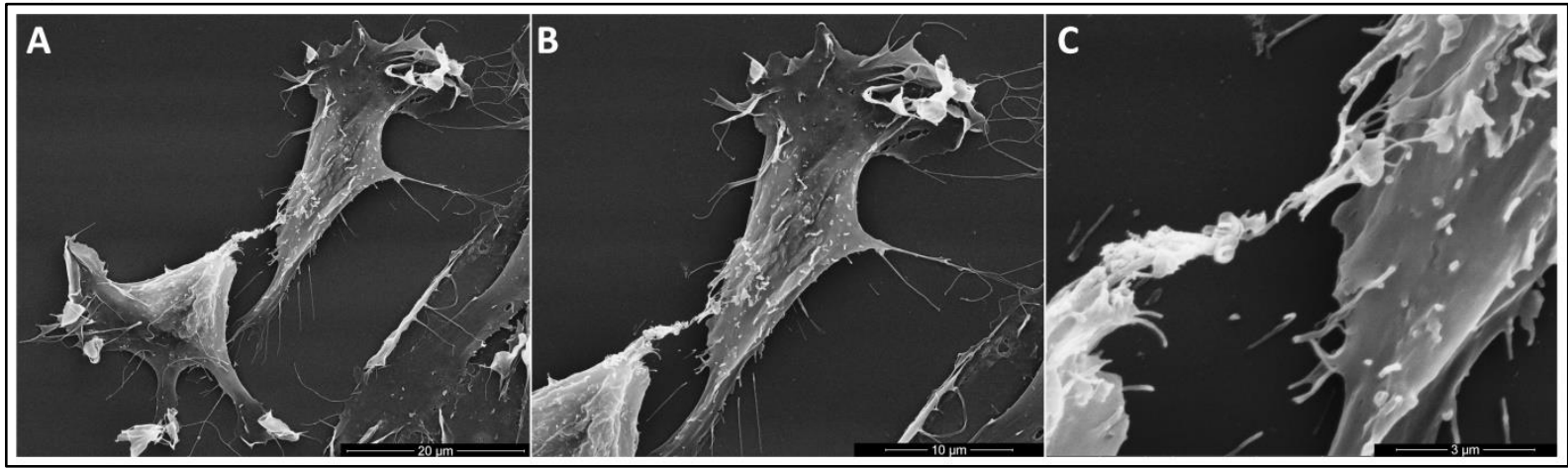

Aumentos totais de: $35.580 \times(A), 42.700 \times(B)$ e $60.850 \times(C)$.

\subsubsection{Marcação de F-actina}

A fim de confirmar a presença dos filopódios, foi realizada a marcação de Factina por meio de High-content screening (HCS). Os resultados desta análise mostraram a presença de F-actina junto a membrana plasmática, sobretudo em sítios de lamelipoidia e filopoidia (figura 68). Além do mais, foi vericada a marcação nuclear da F-actina, especialmente em células com cariomegalia infectadas pelo BPV (figura 68 B-F). 
Figura 68 - Detecção de F-actina por High-content screening

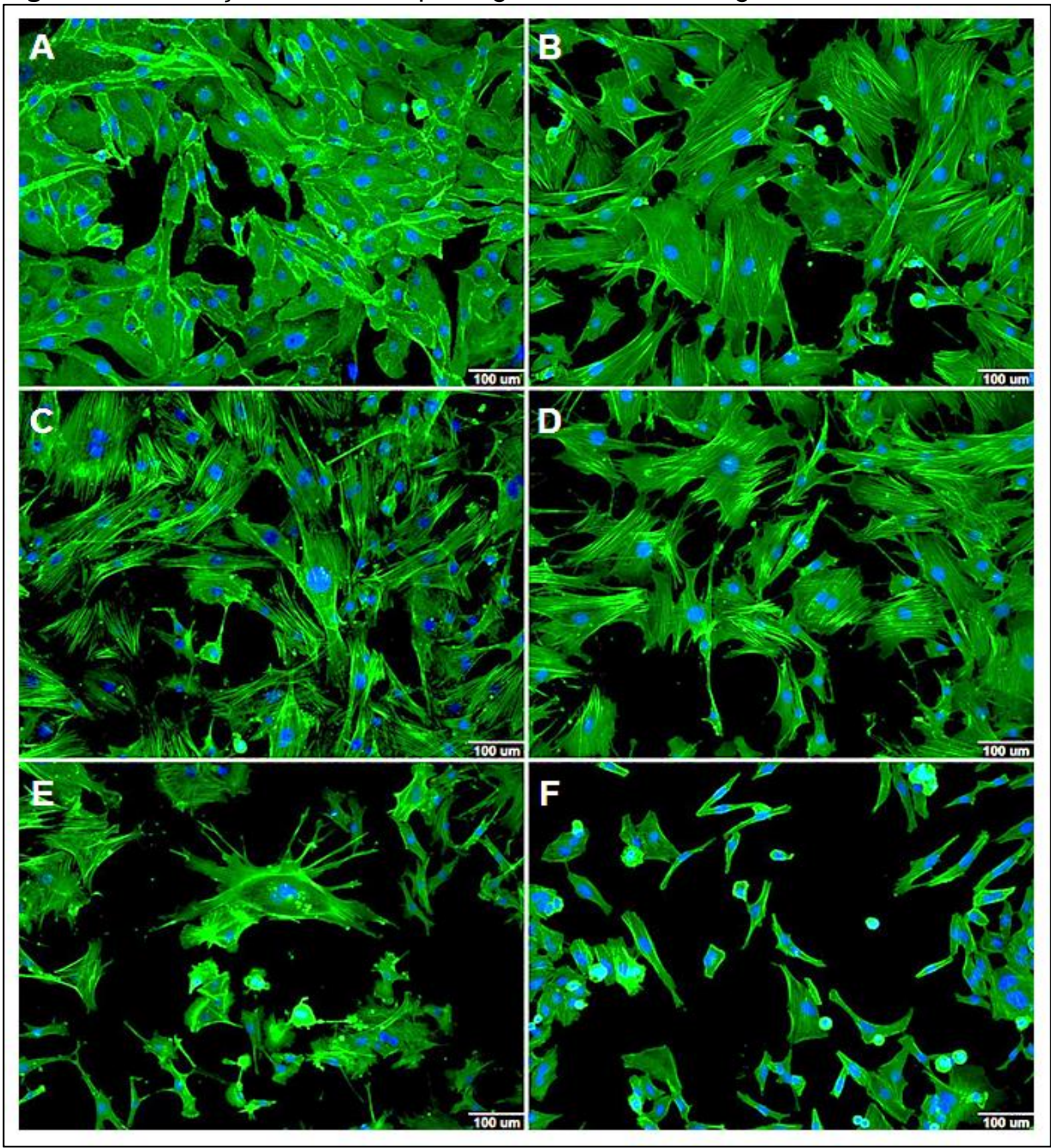

Marcação de F-actina em: A) pele saudável, B) papiloma cutâneo, C) papiloma 02 (fibropapiloma), D) papiloma 03 (fibropapiloma), E e F) carcinoma de esôfago. Nota-se uma intensa marcação de Factina na membrana plasmática de células derivadas da pele saudável porém, em sítios de contato intercelular. As células derivadas de papiloma cutâneo, fibropapiloma e carcinoma de esôfago mostram a presença de F-actina em lamelipódios e filopódios, verificados em células isoladas. Observa-se ainda marcação nuclear de F-actina em células de carcinoma de esófago (E). Imagens obtidas com objetiva de 20 X. Células na segunda passagem (P2).

\subsubsection{Aquisição de fenótipo migratório: vide time-lapse microscopy}

Considerando que os filopódios detectados pela microcopia de contrate de fase (figura 65) e MEV (figura 66) sugere a aquisição de um fenótipo migratório, sendo esta a principal característica da TEM, a velocidade de migração celular foi 
determinada por meio da vídeo time-lapse microscope. Os resultados desta análise são mostrados no apêndice 3 . Baseado nas médias de velocidade $(\mu \mathrm{m} / \mathrm{min})$ de 20 horas de filmagem (apêndice 3) foi realizada uma análise de variância paramétrica (ANOVA), que mostrou haver diferenças estatísticas significativas entre as velocidades médias de deslocamento celular $(p<0,0001)$. Com base neste resultado, foi realizado o teste post-hoc de Tukey, que mostrou as células de pele saudável e papiloma cutâneo apresentam velocidades de migração estatisticamente semelhantes (tabela 22). As células de fibropapiloma (papiloma 03) e CE apresentaram as maiores velocidades de migração ao passo que, as células de papiloma 02 (fibropapiloma) apresentaram uma velocidade de migração intermediária (tabela 22, figura 69). Estes resultados confirmam a aquisição do fenótipo migratório nas linhagens celulares derivadas de cultivos primários de CE e fibropapiloma, bem como indicam que os fibropapilomas são lesões pré-neoplásicas.

Tabela 22 - Resultados do teste de Tukey

\begin{tabular}{cccc}
\hline Linhagem & Diferença da média & $\mathbf{q}$ & $\mathbf{P}<\mathbf{0 , 0 5}$ \\
\hline PS and P01 & $-0,02171$ & 2,818 & Não \\
PS and P02 & 0,00468 & 0,608 & Não \\
PS and P03 & $-0,04973$ & 6,457 & Sim \\
PS and CE & $-0,06675$ & 8,666 & Sim \\
P01 and P02 & 0,02639 & 3,426 & Não \\
P01 and P03 & $-0,02803$ & 3,639 & Não \\
P01 and CE & $-0,04504$ & 5,848 & Sim \\
P02 and P03 & $-0,05441$ & 7,065 & Sim \\
P02 and CE & $-0,07143$ & 9,274 & Sim \\
P03 and CE & $-0,01702$ & 2,209 & Não \\
\hline
\end{tabular}

PS - pele saudável, P01 - papiloma cutâneo 01, P02 - papiloma cutâneo 02, P03 - papiloma cutâneo 03, CE - carcinoma de esôfago, ns - não significativo 
Figura 69 - Velocidade média de deslocamento celular

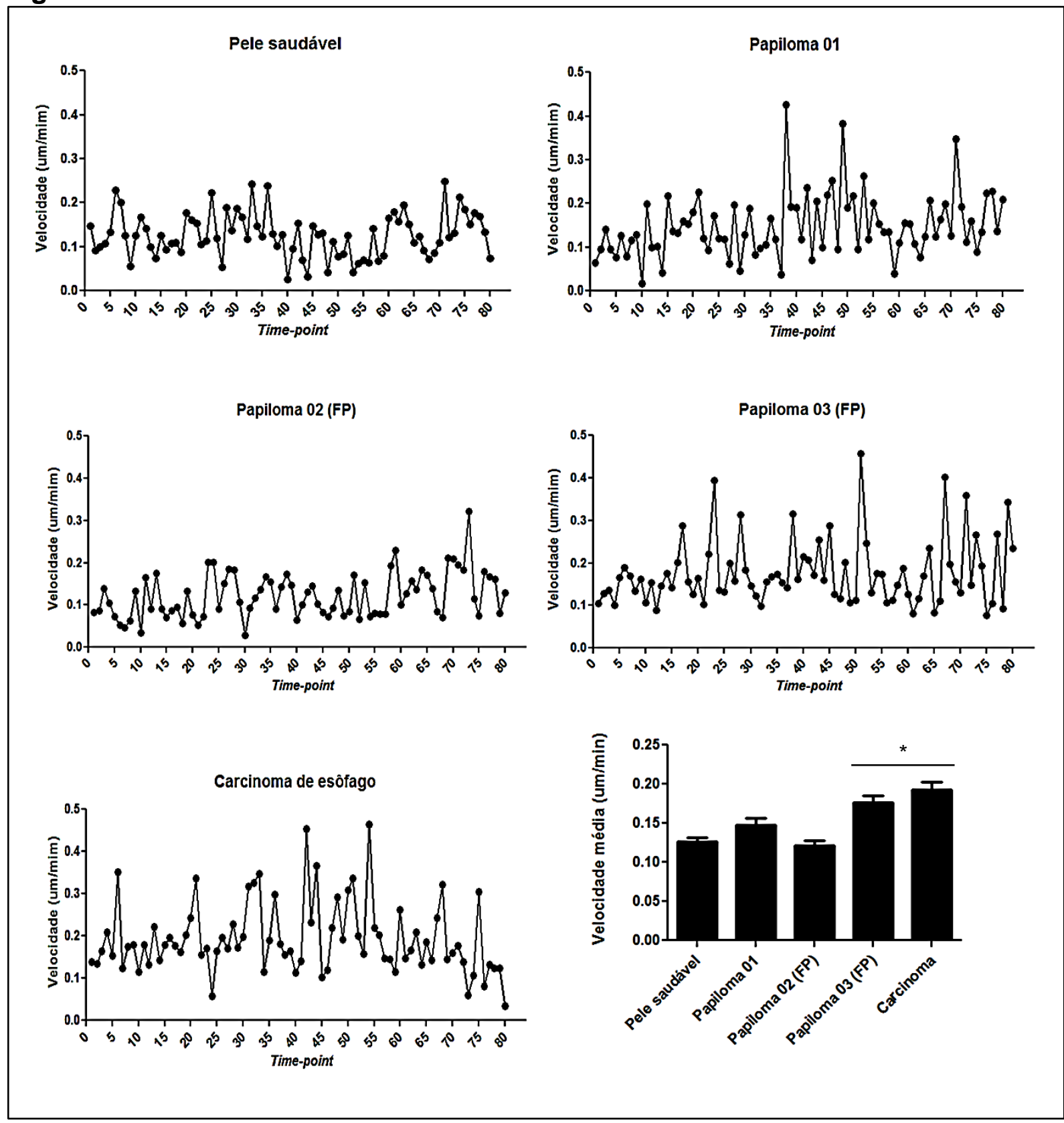

Velocidade de deslocamento celular em $\mu \mathrm{m} / \mathrm{min}$ ao longo de 80 time-points em um total de 20 horas de filmagem. Histograma baseado na velocidade média de deslocamento mostrando que as células derivadas de fibropapiloma (papiloma 03) e carcinoma de esôfago apresentam as maiores velocidades de deslocamento e, portanto, os maiores fenótipos invasivos.

\subsection{Análises teciduais: validação dos resultados}

\subsubsection{Análises histopatológicas}

A análise histopatológica do fragmento de tecido saudável mostrou a preservação da hierarquia tecidual, ausência de atipia e a presença de anexos (glândula sebácea e folículos pilosos) (figura 70). Estes resultados confirmam a 
ausência de infecção pelo BPV, a qual foi verificada por meio de PCR das células derivadas deste fragmento de tecido (figura 26).

Figura 70 - Análise histopatológica da pele saudável

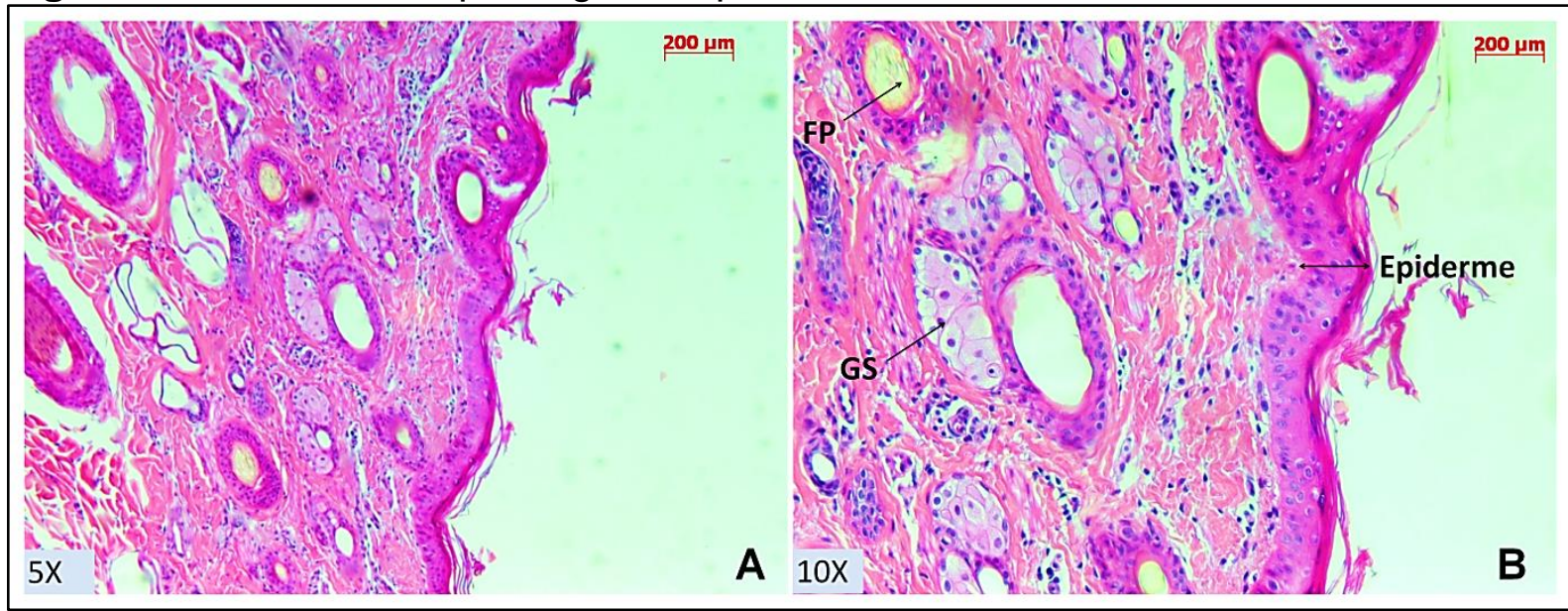

Fotomicrografias de corte histológico de fragmento de pele saudável, mostrando a organização tecidual, ausência de atipia e presença de anexos dérmicos (folículo piloso - FP e glândula sebácea - GS). Imagens capturas com objetivas de 5 X (A) e 10 X (B).

A análise histopatológica dos fragmentos de papiloma cutâneo e fibropapiloma mostrou importantes efeitos histo e citopáticos associados à infecção pelo BPV. Foi observada uma expressiva hiperplasia da camada suprabasal (acantose) (figuras 71A, B, E, F, I e J), a qual foi igualmente observada em um papiloma adjacente ao carcinoma de esôfago (figuras 72G-I). As amostras de fibropapiloma (papiloma 02 e 03) apresentaram um estroma fibro-elástico com uma expressiva proliferação fibroblástica (figuras 71B e C), não observada no papiloma cutâneo (papiloma 01) (figura 71A). Tais características permitem classificar essas amostras como fibropapilomas. Tanto o papiloma cutâneo, como o fibropapiloma mostraram a presença de coilócitos na camada hipergranulosa (figuras 71B, F e I). A coilocitose foi igualmente verificada no carcinoma (figura 72C) e papiloma de esôfago (figura 72I). Os resultados mostraram, ainda. uma evidente hiperqueratose ortoqueratótica (figuras 71E e F) e paraqueratótica (figuras 71A, I e J) nos fragmentos de papiloma e fibropapiloma. Somado a estes resultados, foi verificada uma abundante quantidade de grânulos de cerato-hialina na camada hipergranulosa, sobretudo da amostra 03 (figura 73), a qual apresentou uma expressiva hiperqueratose (figura 73I). 
Figura 71 - Análise histopatológica das amostras de neoplasias benignas

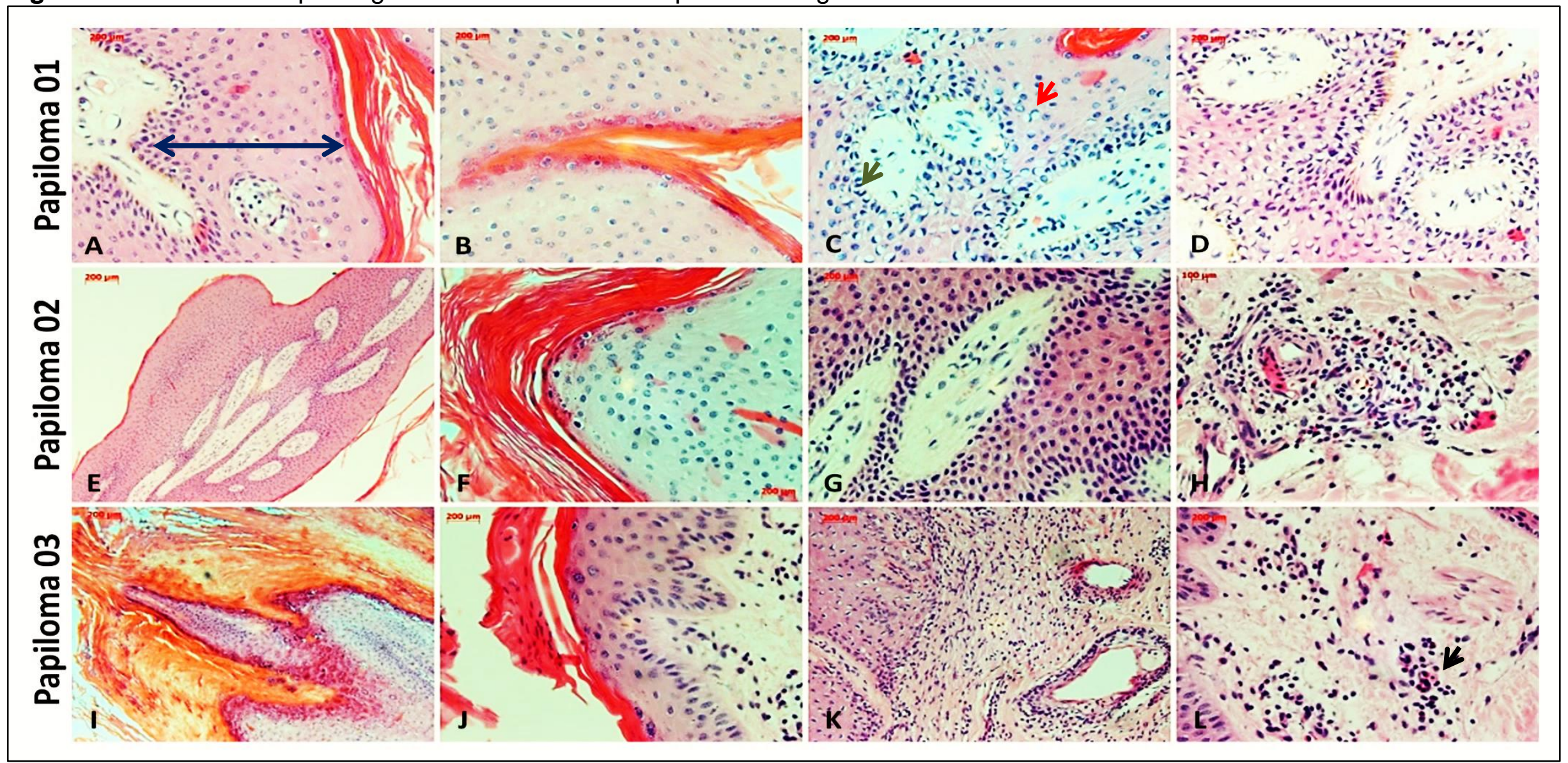

Fotomicrografias de papilomas cutâneos mostrando: hiperplasia da camada suprabasal (acantose, seta em azul), presença de coilócitos (seta em vermelho) e hiperquestose ortoqueratótica (A. E, F e G) e paraqueratótica (B e J). Verifica-se uma hiperproliferação fibroblástica nas amostras de papiloma 02 (F) e 03 $(\mathrm{J}$ e K). Nota-se a presença de abundantes células mitóticas próximas a junção dermo-epidermal do papiloma 01 (C, seta em verde)) e um expressivo infiltrado inflamatório mononuclear nos fibropapilomas $02(\mathrm{H})$ e 03 (L, seta em preto). Imagens mostram a presença de células basais despolarizadas e a presença de células epitelióides na junção dermo-epidermal, sugerindo transição epitélio-mesênquima (D, G e J). Aumentos de $5 \times(E$ e I), 10 X (J e K) e 20 $X(A, B, C, D, F, G, H$ e L). 
Figura 72 - Análise histopatológica do carcinoma de esôfago bovino

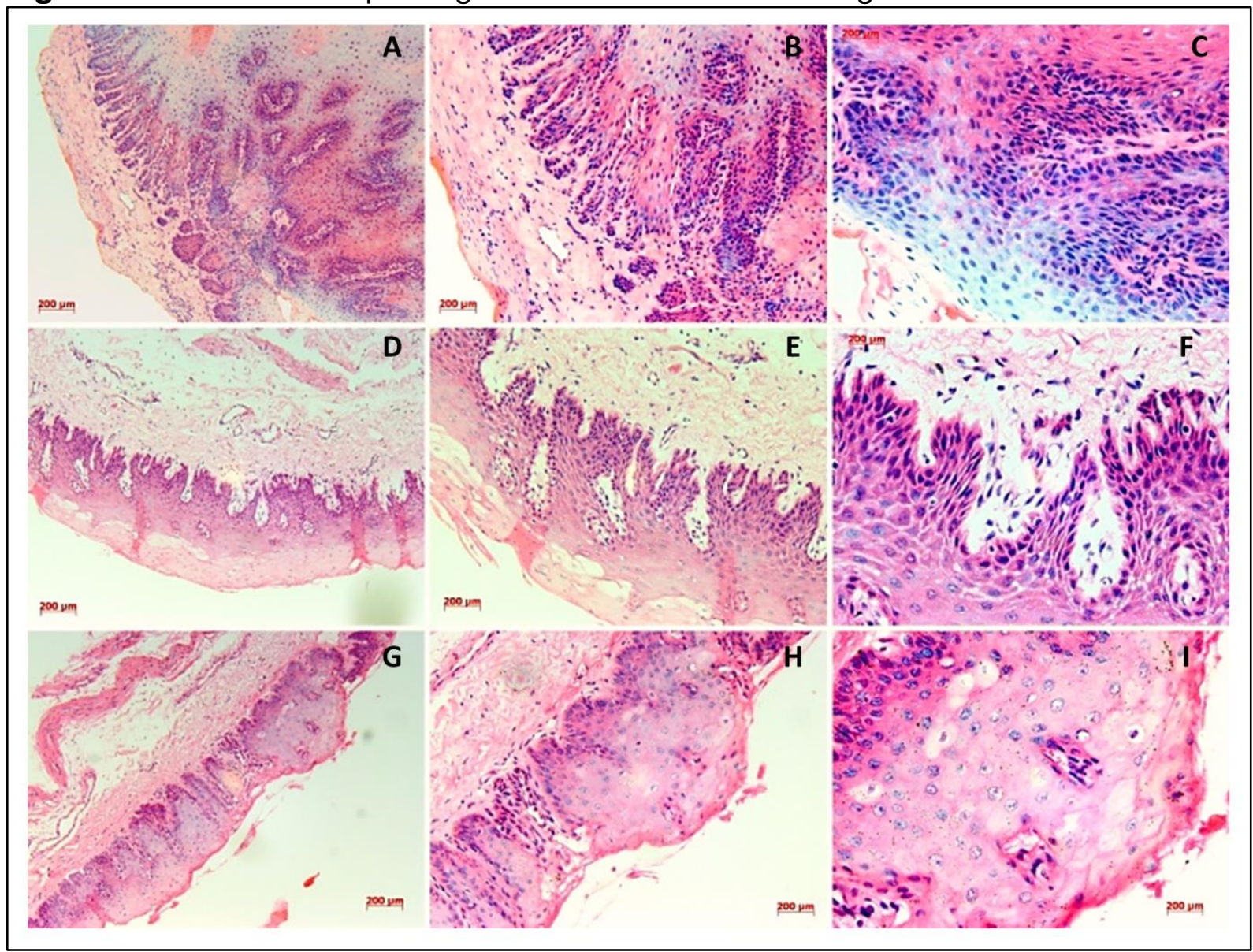

Fotomidrografias de cortes histológicos de carcinoma de esôfago bovino mostrando: desorganização tecidual, compatível com neoplasia maligna (A e B), fonte de invasão apresentando células epiteliais na derme, compatível com processo metastático (C), metaplasia de Barret verificada no tecido adjacente ao carcinoma ( $D$ e $E$ ), com presença células despolarizadas na derme (F), papiloma adjacente à região de metaplasia $(\mathrm{G}$ e H), mostrando acantose e coilocitose (I). Imagens obtidas em aumento de $5 \times(A, D$ e G), $10 \times(B, E$ e H) e $20 \times(C, F$ e I).

Figura 73 - Hipergranulose verificada em fibropapiloma (papiloma 03)

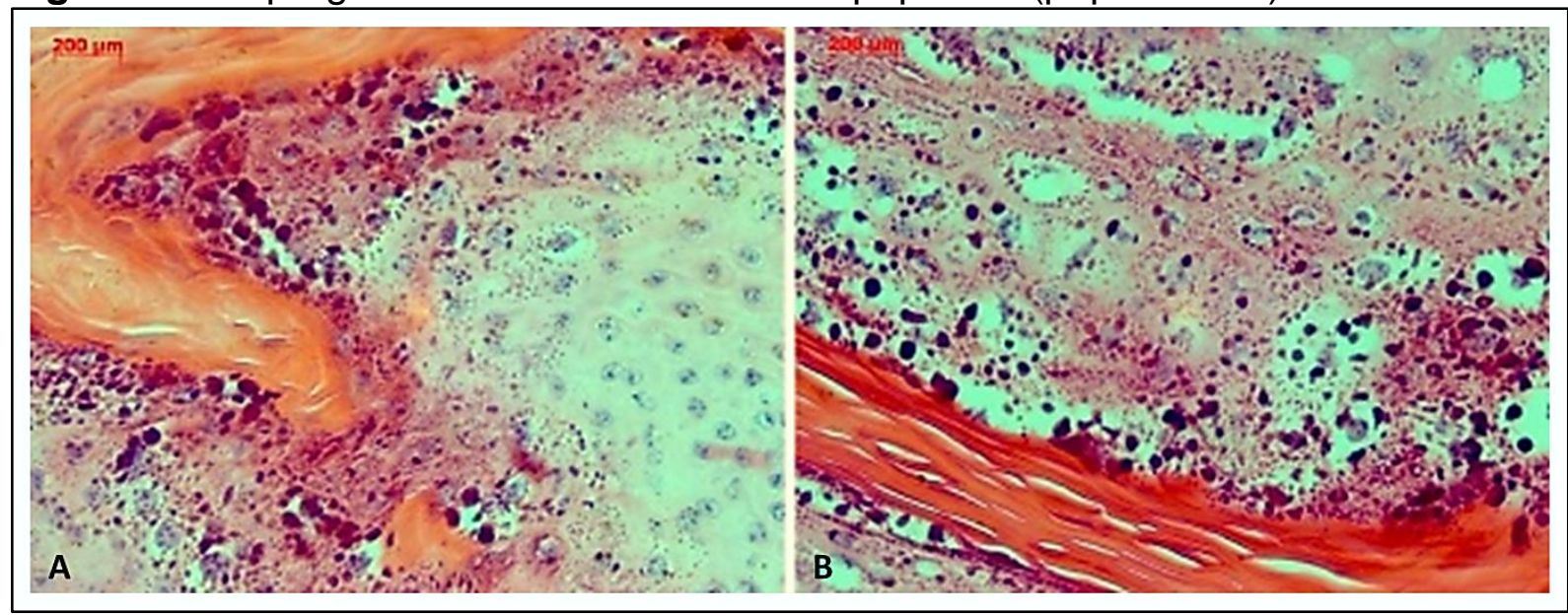

Fotomicrografias de cortes histológicos da amostra 03 (fibropapilomas) mostrando uma abundante quantidade de grânulos citoplasmáticos na camada hipergranulosa. Imagens obtidas em aumento de $200 \mathrm{X}$. 
Enquanto o tecido saudável mostrou-se estruturalmente bem diferenciado, apresentando células organizadas em nichos especializados (figura 70), a análise histopatológica do fragmento de CE revelou uma ampla desorganização tecidual (figura 72A, B e C), a qual pode ser atribuída a hiperproliferação celular (SCHWITALLA, 2014). Os resultados também mostraram a presença de um estroma reativo, contendo ilhas de células epitelióides no fonte de invasão (figura 72E e F). A presença destas ilhas celulares no estroma indicam um fenótipo invasivo e migratório, representando uma fase avançada da doença. Além do mais, verifca-se que as células presentes no fronte de invasão e nas ilhas celulares presentes na derme apresentam uma morfologia fibroblastóide, com perda de polaridade apicalbasal, sendo compatíveis com o fenótipo esperado durante a TEM.

\subsubsection{Análise da composição de colágeno da MEC}

A análise da composição de colágeno foi realizada através da coloração com Picrosírius red. Sob o comprimento de onda de $540 \mathrm{~nm}$ (luz polarizada), fibras de colágeno tipo I são visualizadas na cor vermelho-alaranjado, enquanto fibras de tipo III, na cor amarelo-esverdeado (RIBEIRO et al., 2015). Os resultados desta análise mostraram uma redução da quantidade de fibras de tipo III e um aumento das fibras de tipo I nas amostras de tecido infectadas pelo BPV (papiloma, fibropapiloma e carcinoma de esôfago) em relação à pele saudável (figura 74, tabela 23). Estes dados sugerem que a infecção viral leva ao remodelamento da MEC, favorecendo a migração celular. 
Figura 74 - Análise colorimétrica da matriz colagenosas

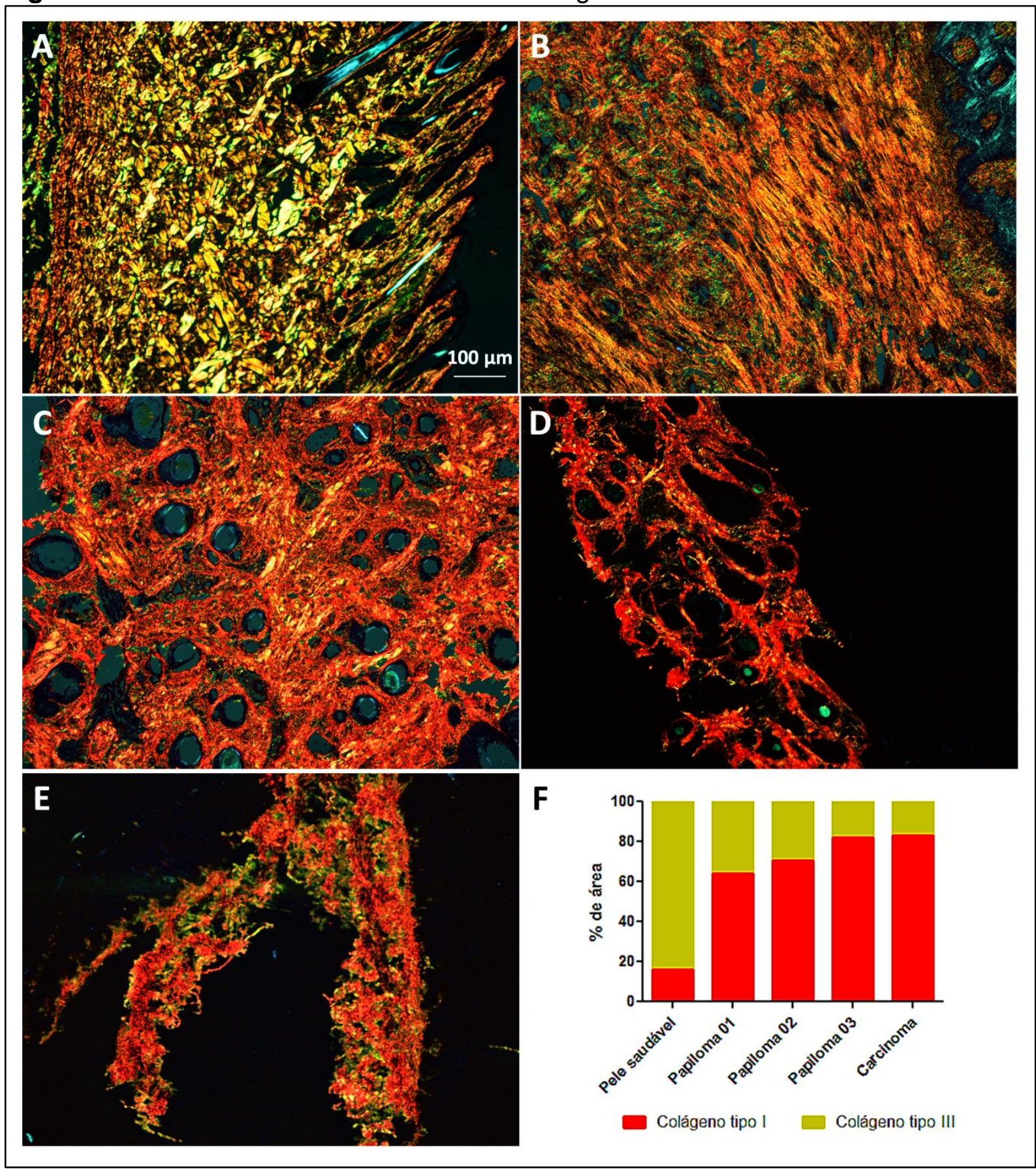

Fotomicrografias mostrando a presença de fibras colagenosas de tipo I (vermelho) e III (amareloesverdeado) identificadas pelo método de Picrosírius red nas amostras de pele saudável (A), papiloma cutâneo 01 (B), fibropapiloma 02 (C), 03 (D) e carcinoma de esôfago (E). Verifica-se um aumento das fibras de tipo I nas amostras de papiloma e carcinoma de esôfago. Imagens capturadas com objetiva de $10 \mathrm{X}$. 
Tabela 23 - Quantificação das fibras de colágeno

\begin{tabular}{ccccc}
\hline & \% de área da lâmina & \multicolumn{2}{c}{ \% de área do corte } \\
Amostra & Tipo I & Tipo III & Tipo I & Tipo III \\
\hline Pele saudável & 14,770 & 75,855 & 16,30 & 83,70 \\
Papiloma 01 & 42,806 & 24,040 & 64,04 & 35,96 \\
Papiloma 02 (FP) & 53,365 & 22,226 & 70,59 & 29,41 \\
Papiloma 03 (FP) & 22,075 & 4,7870 & 82,18 & 17,82 \\
Carcinoma de esôfago & 25,839 & 5,2370 & 83,15 & 16,85 \\
\hline
\end{tabular}

FP- fibropapiloma.

\subsubsection{Análises imunoistoquímicas: validação dos resultados}

\subsubsection{Imunodeteccão da oncoproteína E5}

Considerando que oncoproteína E5 é reconhecida como a principal proteína transformante do BPV (DIMAIO; MATTOON, 2001; VENUTI et al., 2011), a imunodetecção desta oncoproteína foi realizada para confirmar a presença do vírus nas amostras teciduais, bem como para demonstrar a possível ação do vírus na TEM, já que a E5 promove a perda da adesão focal, contribuindo para a invasão de células cancerígenas no fronte neoplásico (RAMPIAS; SASAKI; PSYRRI, 2013). Os resultados da IHQ-P mostraram a ausência de expressão da oncoproteína nos fragmentos de pele saudável, confirmando a ausência de infecção pelo vírus nesta amostra (figura 75A). Foi também verificada a ausência de marcação na linhagem de papiloma cutâneo incubado apenas com o anticorpo secundário (figura 75B), demonstrando a ausência de imunomarcação inespecífica do anticorpo secundário. No entanto, foi observada a imunodetecção da oncoproteína E5 na membrana plasmática dos fragmentos de papiloma cutâneo (figura 75C), fibropapiloma (figura 75D e E) e CE (figura 75F). Tal imunomarcação foi verificada em todas as camadas do epitélio, estando de acordo com a biologia viral. 
Figura 75 - Imunodetecção da oncoproteína E5 do BPV em cortes histológicos

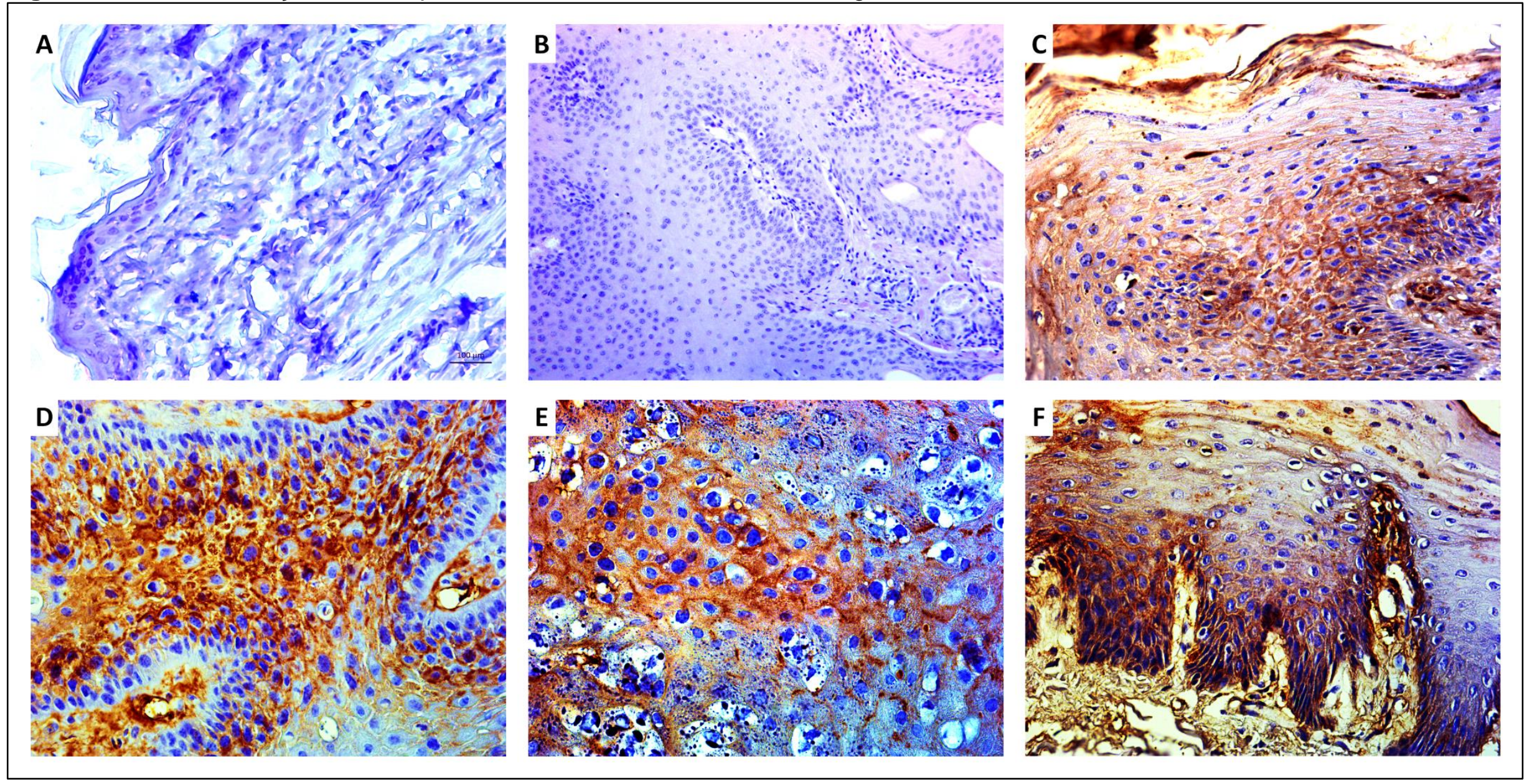

Fotomicrografias mostrando: A) ausência de imunomarcação da proteína E5 do BPV em fragmento de pele saudável; B) ausência de marcação inespecífica do anticorpo secundário em fragmento de papiloma cutâneo 01; imunodetecção da oncoproteína E5 na membrana plasmática de células epiteliais de papiloma cutâneo $01(C)$, fibropapilomas - papiloma $02(D)$ e $03(E)$ e carcinoma de esôfago (F). Verifica-se uma intensa imunomarcação no fronte de invasão neoplásica no corte histológico de carcinoma de esôfago. Imagens obtidas com objetivas de: 20 X (A), 10 X (B) e 40 X (C-F). Barra de escala de 100 $\mu \mathrm{m}$. 


\subsubsection{Imunodeteccão da citoqueratina 10}

Os resultados da IHQ-P mostraram a expressão da citoqueratina 10 (CK10) nas camadas mais diferenciadas do epitélio (a partir da camada suprabasal) das amostras analisadas (figura 76). Foi verificado o aumento da expressão da expressão da CK10 na amostra de papiloma 01 (papiloma cutâneo) (figura 76 A), confirmando o epiteliotropismo do BPV verificado em papilomas verdadeiros. As amostras de papiloma 02 e 03 (fibropapilomas) e CE mostraram uma expressiva redução da imunomarcação de CK10, embora tenham apresentado uma evidente acantose (figura 76), sugerindo um maior comprometimento dérmico nestas neoplasias. $O$ controle negativo mostrou ausência de marcação inespecífica. 
Figura 76 - Imunodetecção da citoqueratina 10 em tecido parafinado

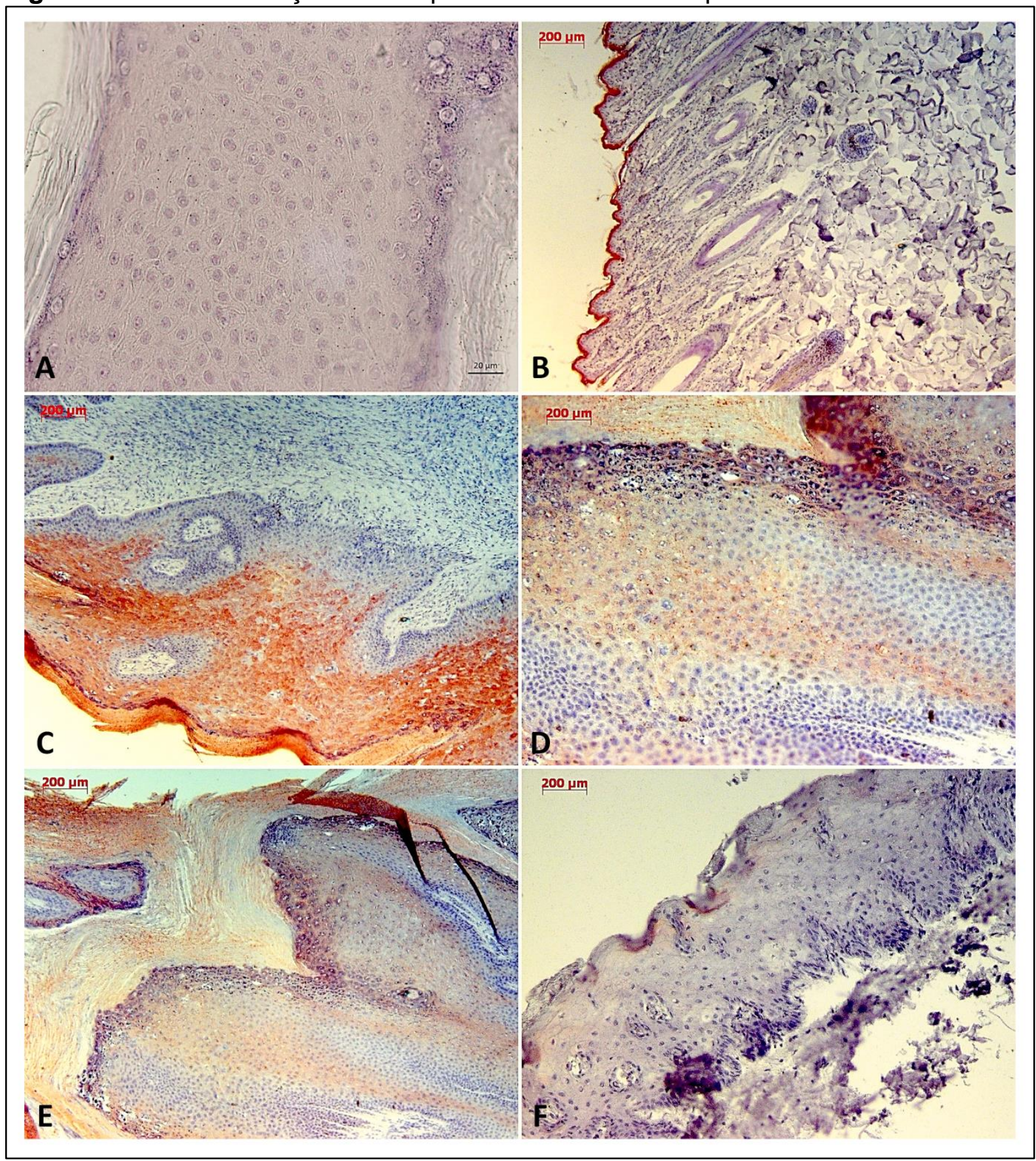

Fotomicrografias mostrando: A) ausência de marcação inespecífica no controle negativo (tecido de papiloma cutâneo incubado exclusivamente com o anticorpo secundário conjugado com HRP; B) imunomarcação de citoqueratina 10 (CK10) restrita ao epitélio de tecido de pele saudável não infectada pelo BPV; C) expressiva imunomarcação de CK10 verificada da camada suprabasal a córnea em tecido de papiloma cutâneo (papiloma 01); redução dos níveis de CK10 no epitélio de tecido de fibropapiloma (D - papiloma 02 e $E$ - papiloma 03) e carcinoma de esôfago ( $F$ ). Imagens capturadas com objetiva de: 20 X (A), 5 X (B, C e E) e 10 X (D e F). Barra de escala de $200 \mu \mathrm{m}$. 


\subsubsection{Imunodeteccão da Beta-catenina}

Os resultados da IHQ-P mostraram a imunomarcação da $\beta$-catenina junto a membrana plasmática das amostras de pele saudável (figura 77B), papiloma cutâneo (figura 77C) e fibropapiloma (papiloma 02) (figura 77D). A amostras de papiloma cutâneo (figura 77C) e CE (figura 77F) mostram a imunomarcção nuclear da $\beta$-catenina, sugerindo a aquisição de um fenótipo mesenquimal nestas células. $A$ amostra de fibropapiloma (papiloma 03), por sua vez, mostrou uma importante redução dos níveis de expressão da $\beta$-catenina (figura 77E). $O$ controle negativo mostrou a ausência de imunomarcção inespecífica (figura 77A). 
Figura 77 - Imunodetecção da Beta-catenina em tecido parafinado

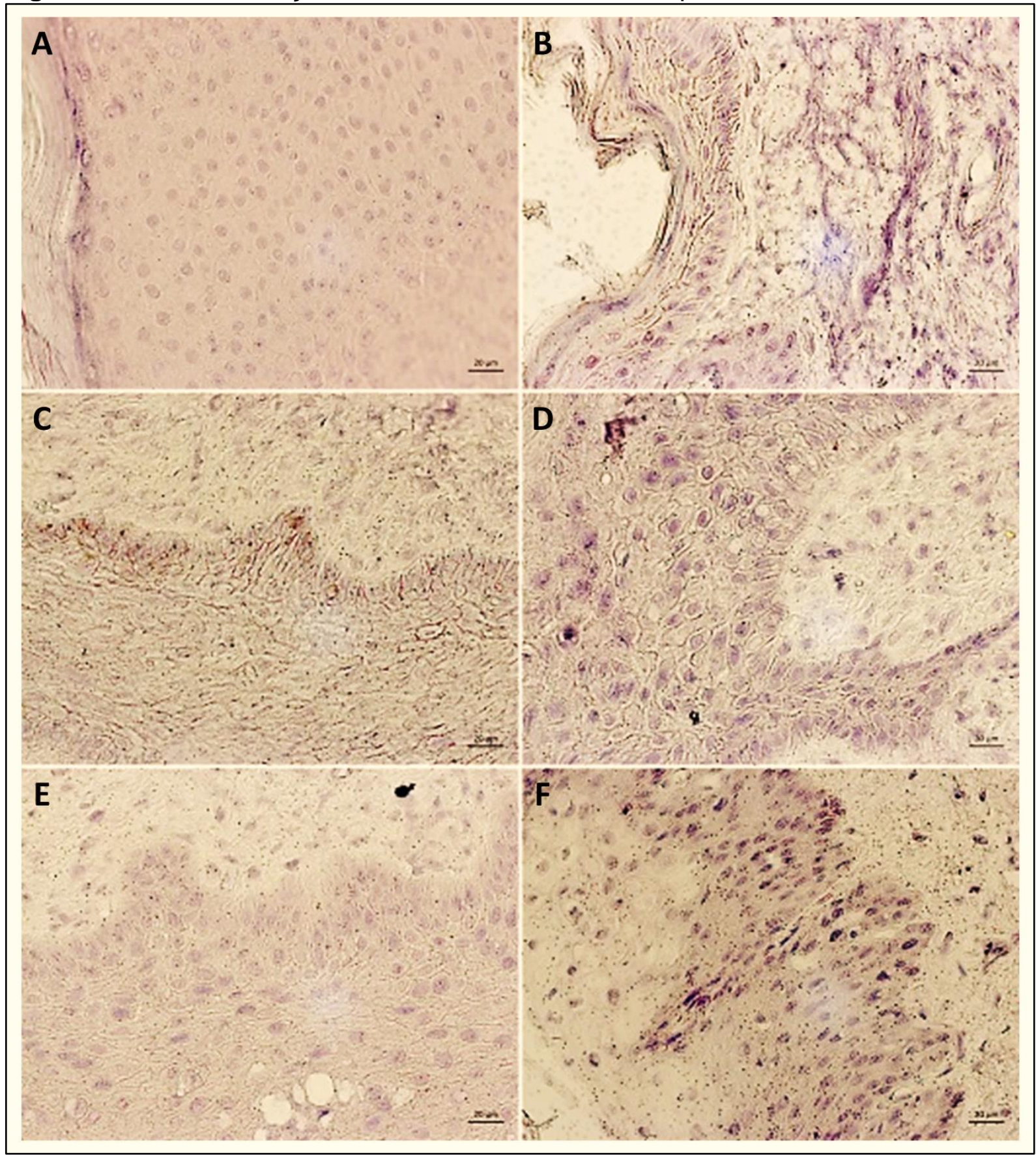

Fotomicrografias mostrando: A) ausência de marcação inespecífica no controle negativo (tecido de papiloma cutâneo incubado exclusivamente com 0 anticorpo secundário conjugado com HRP; imunomarcação de beta-catenina junto à membrana plasmática em amostras de pele saudável $(\mathrm{B})$, papiloma cutâneo ( $\mathrm{C}$ - papiloma 01), fibropapiloma ( $\mathrm{D}$ - papiloma 02 e $\mathrm{E}$ - papiloma 03) e carcinoma de esôfago (F). Nota-se uma expressiva redução da imunomarcação desta proteína nas amostras de fibropapiloma 03 (E) e CE (F). Imagens capturadas com objetiva de: 20 X (A, C, D e F) e 5 X (B). Barra de escala de $200 \mu \mathrm{m}$. 


\subsubsection{Imunodeteccão do fator de transcricão Oct-3/4}

Os resultados da IHQ-P mostraram a imunomarcação do fator de transcrição nuclear Oct-3/4 na amostra de pele saudável (figura $78 \mathrm{C}$ ). Porém, tal marcação foi verificada exclusivamente em células do folículo piloso (figura 78C). As amostras de papiloma cutâneo (figura 78D) e fibropapiloma (figura 78D-E) apresentaram uma expressiva imunomarcação nuclear do fator Oct-3/4 tanto em queratinócitos como células epitelióides da junção dermo-epidermal e derme. As células que apresentaram marcação nuclear de Oct-3/4 também mostraram um fenótipo despolarizado, compatível com a TEM (figura 78). A amostra de C, por sua vez, não apresentou marcação deste fator (figuras $79 \mathrm{H}$ e I). Tal resultado pode ser atribúido ao elevado índice mitótico do $\mathrm{CE}$, verificado pelas inúmeras imagens de células em divisão (figura 78I). O controle negativo mostrou a ausência de imunomarcação inespecífica (figura 78A), ao passo que o controle positico mostrou a expressão de Oct-3/4 restrita a algumas células do epitélio do carcinoma labial (figura 78B). 
Figura 78 - Imunodetecção do fator Oct-3/4 em tecido parafinado

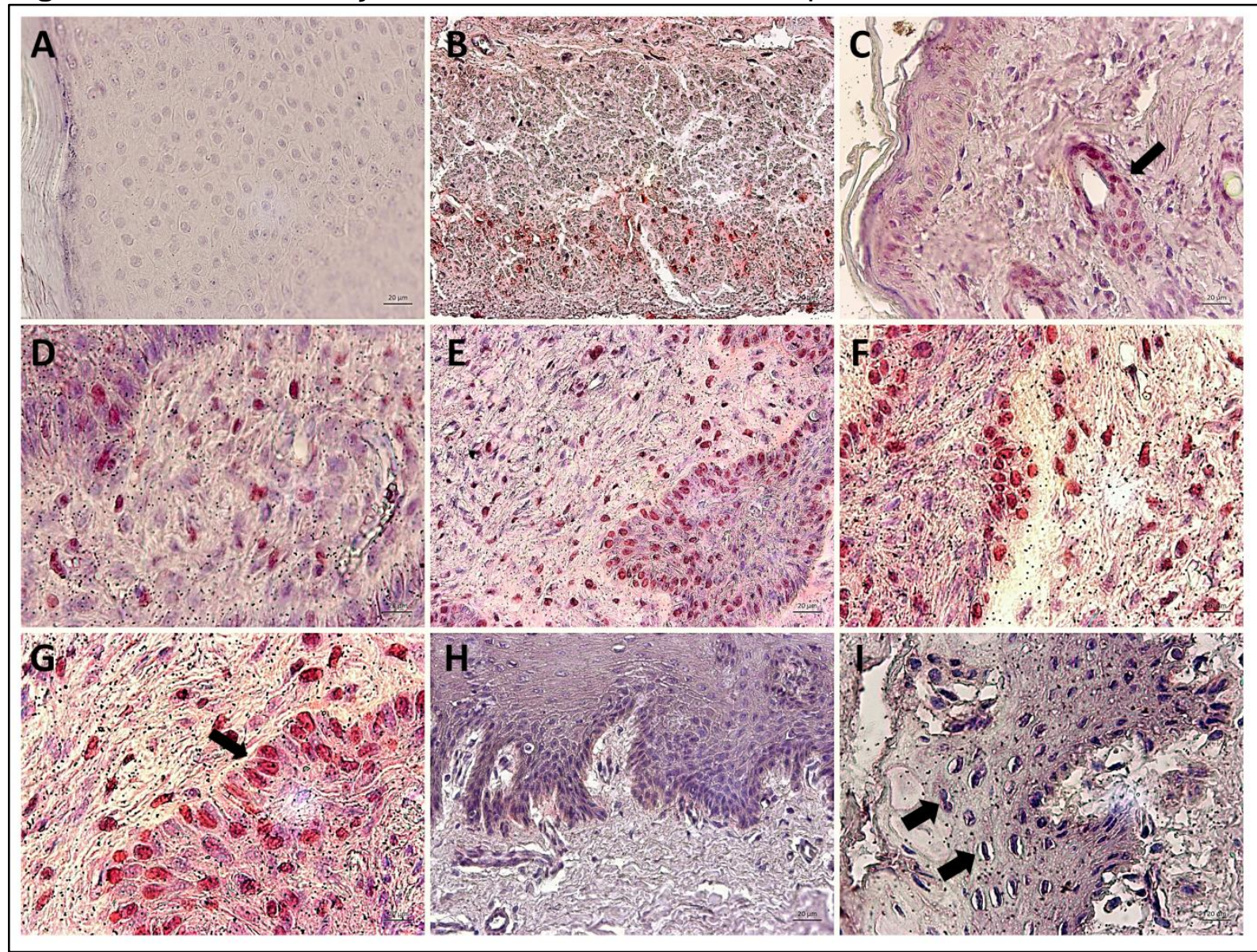

Fotomicrografias mostrando: A) ausência de marcação inespecífica no controle negativo (tecido de papiloma cutâneo incubado exclusivamente com 0 anticorpo secundário conjugado com HRP; imunomarcação nuclear do fator de transcrição Oct-3/4, sugerindo a aquisição de fenótipo CTC-like em amostras de: B) carcinoma de estômago humano (empregado como controle positivo); C) pele saudável, onde se verifica a imunomarcação deste fator restrita a células do folículo piloso (indicado pela seta); D) papiloma 01 (papiloma cutâneo), E e F) papiloma 02 (FB) e G) papiloma 03 (FB). Imagens mostram uma expressiva imunomarcação em queratinócitos basais despolarizados (indicado pela seta). Amostra de carcinoma de esôfago não apresentou expressão do fator Oct-3/4 (H). Tais resultados podem ser atribuídos ao elevado número de células mitóticas identificadas neste tecido, conforme apontado pela seta (I). Imagens capturadas com objetivas de: $40 \times(A, D, E$ e G), $20 \times(I)$ e $10 \times(B, C$ e H). Barra de escala de $200 \mu \mathrm{m}$.

\subsubsection{Imunodeteccão do fator STAT3 Y705}

Os resultados da IHQ-P mostraram a ausência de imunomaracação do fator de transcrição nuclear STAT3 ativo (Y705) na amostra de pele saudável (figura 79B), indicando a manutenção da homeostasia tecidual. Já as amostras de papiloma cutâneo (figura 79C), fibropapiloma (figuras 79D-F) e CE (figuras 79G e H) mostraram uma expressiva imunomarcção nuclear deste mesmo fator de transcrição. A imunomarcação de STAT3 Y705 foi verificada na junção dermoepidermal, bem como na derme de todas as amostras de neoplasias infectadas pelo 
BPV (figura 79). Além do mais, as células imunomarcadas exibem um fenótipo despolarizado, característico da TEM. O controle negativo mostrou a ausência de imunomarcação inespecífica (figura 79A). 
Figura 79 - Imunodetecção do fator STAT3 Y705 em tecido parafinado

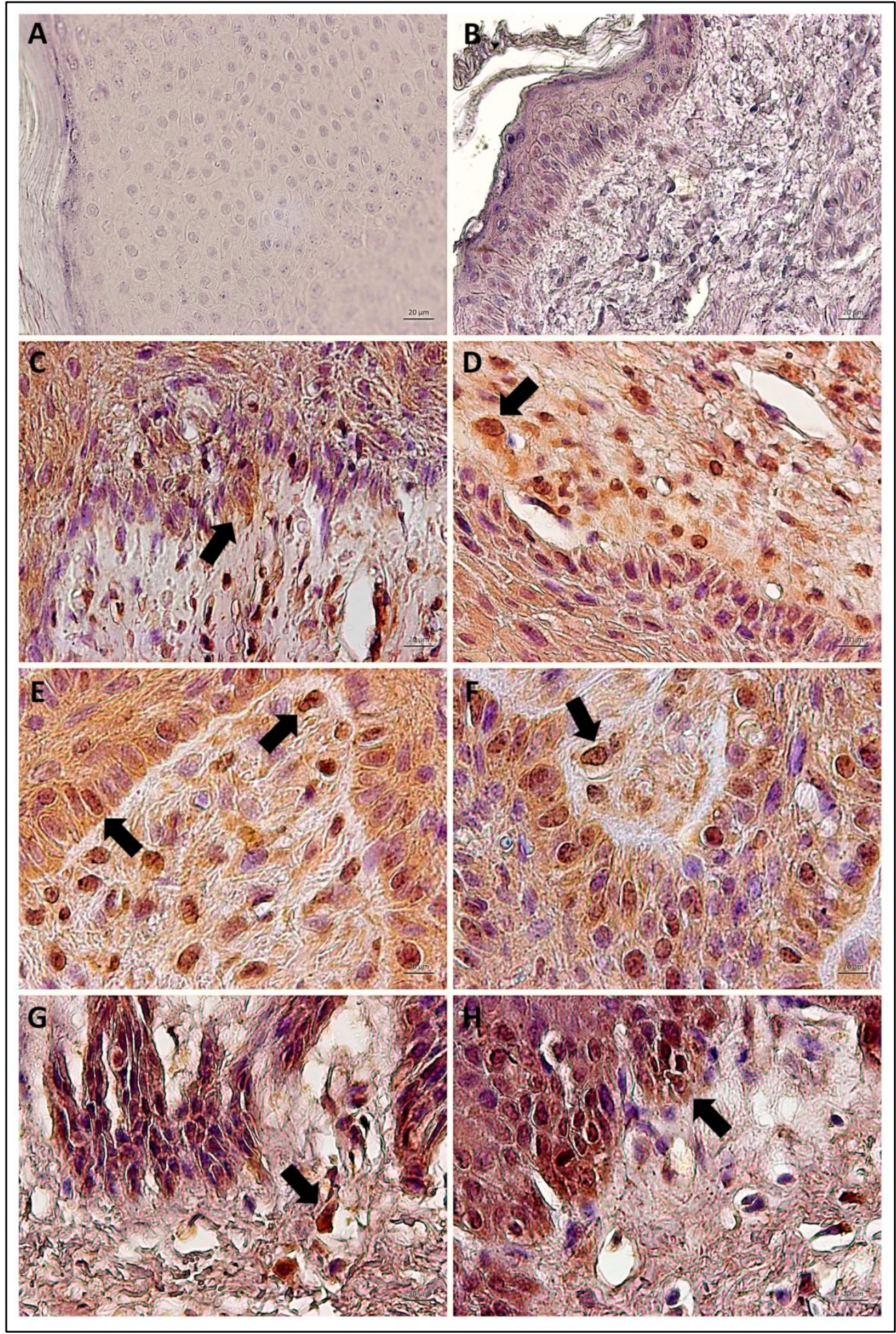

Fotomicrografias mostrando: A) ausência de marcação inespecífica no controle negativo (tecido de papiloma cutâneo incubado exclusivamente com 0 anticorpo secundário conjugado com HRP; ausência de imunodetecção do fator de transcrição nuclear STAT3 Y705 na amostra de pele saudável não infectada pelo BPV (B), imunodetecção citoplasmática e nuclear de STAT3 Y705 em região displásica do tecido de papiloma 01 (C e D - papiloma cutâneo); imunomarcação nuclear de STAT3 Y705 em células epitelióide, observadas na junção dermo-epidermal, e queratinócitos despolarizados, verificados na epiderme das amostras de papiloma 02 ( $E-F B$ ), papiloma 03 ( $F-F B$ ) e carcinoma de esôfago ( $\mathrm{G}$ e H). Verifica-se a expressão nuclear de STAT3 é observada em células despolarizadas da epiderme e epitelióides na derma, conforme mostrado pelas setas. Imagens capturadas com aumentos de 20 X (A, B, C e G) e 40 X (D, E, F e H). FB - fibropapiloma. 


\subsubsection{Imunodetecção da N-caderina}

Os resultados da IHQ-P mostraram a imunomarcação da glicoproteína Ncaderina junto a membrana plasmática de queratinócitos na amostra de pele saudável (figura $80 \mathrm{~B}$ ) e papiloma cutâneo (figura $80 \mathrm{C}$ ). Porém, foi verificada a redução da imunomarcação da $\mathrm{N}$-caderina em queratinócitos basais de áreas apresentando atipia na junção dermo-epidermal, sugerindo a redução da adesão intercelular nestas áreas (figura $80 \mathrm{C}$ ). As amostras de fibropapiloma e $\mathrm{CE}$, por sua vez, apresentaram uma expressiva redução dos níveis de N-caderina na membrana plasmática (figuras $80 \mathrm{~F}-\mathrm{J}$ ). Interessantemente, foi verificada a imunomarcação citoplasmática e nuclear da $\mathrm{N}$-caderina nas amostras de fibropapiloma (figura 80F$\mathrm{H}$ ), reforçando o sequestro citoplasmático desta glicoproteína. O controle negativo mostrou a asuência de imunomarcação inespecífica (figura 80A). 
Figura 80 - Imunodetecção da N-caderina em tecido parafinado

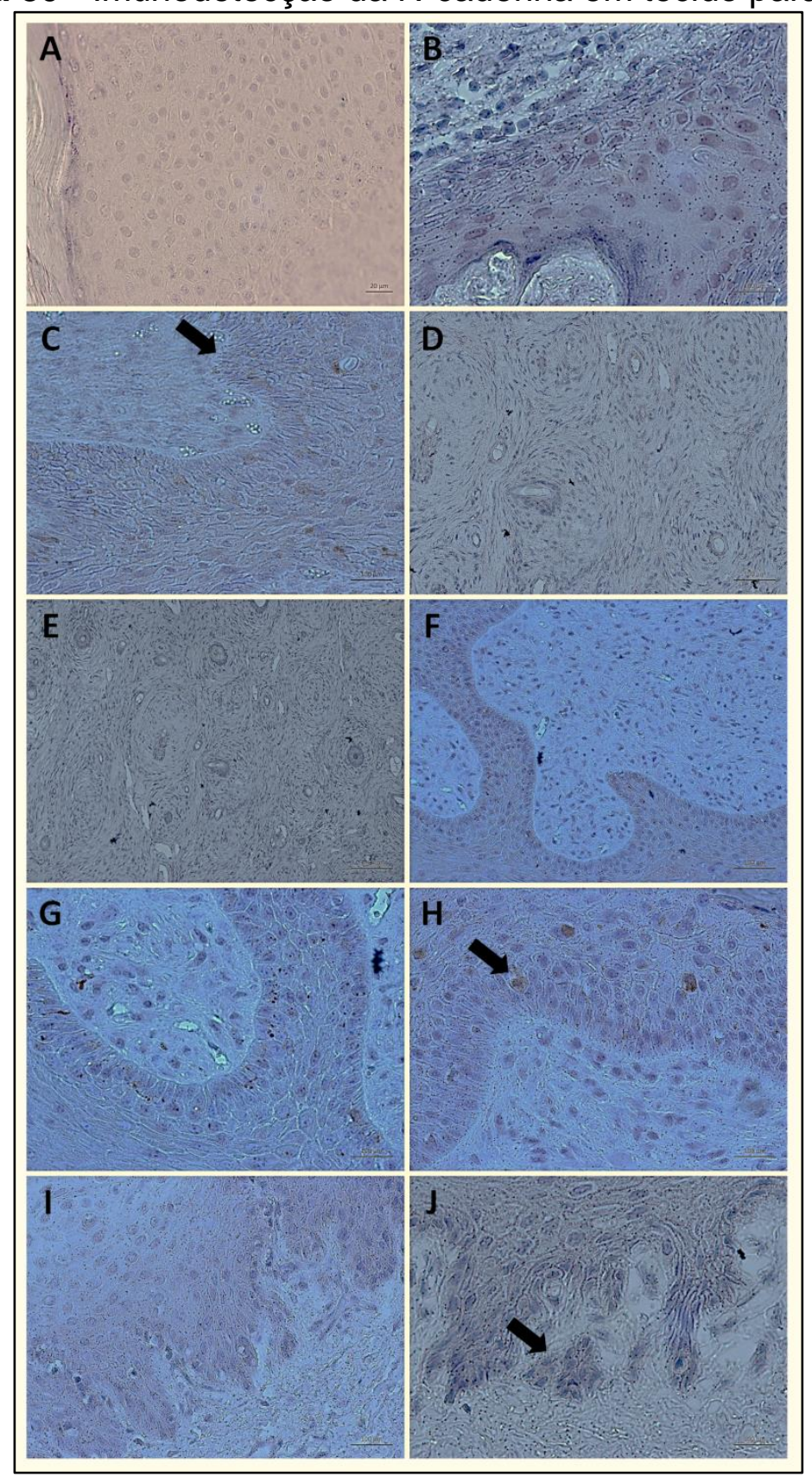

Fotomicrografia mostrando: A) ausência de imunomarcação inespecífica em amostra de papiloma cutâneo incubado exclusivamente com anticorpo secundário conjudago com HRP (controle negativo); B) imunomarcação de $\mathrm{N}$-caderina junto a membrabna plasmática de tecido de carcinoma labial humano (controle positivo); C) redução da imunumarcação de $\mathrm{N}$ caderina na membrana plasmática verificada em áreas de atipia (indicado pela seta) na amostra de papiloma 01 (papiloma cutâneo); estroma fibroelástico, com fibroblastos organizados em feixes fasculares, caracterizando fibropapilomas, observados nas amostras de papiloma 02 (D - FB) e 03 (E - FB); redução da expressão da N-caderina nas amostras de papiloma 02 (F - FB) e 03 (G - FB); imunomarcação citoplasmática da N-caderina na amostra de papiloma $03(\mathrm{H})$, sugerindo sequestro citolplasmático deste glicoproteína; redução da expressão da $\mathrm{N}$-caderina no carcinoma de esôfago (I), especialmente em ilhas metastáticas ( $\mathrm{J}$, apontada pela seta). Imagens capturadas com objetivas de $10 \mathrm{X}(\mathrm{E}), 20 \mathrm{X}$ (F) e $40 X(A, B, C, D, G, H, I$ e J). Barra de escala de $100 \mu \mathrm{m}$ (controle negativo) e $200 \mu \mathrm{m}$ (amostras clínicas). 


\subsubsection{Imunodetecção da proteína mesenquimal vimentina}

Os resultados da IHQ-P mostraram uma evidente imunomarcação da proteína mesenquimal vimentina na derme da amostra de pele saudável (figura 81D), papiloma cutâneo (figuras $81 \mathrm{E}$ e F), fibropapiloma (figuras $81 \mathrm{G}-\mathrm{J}$ ) e CE (figuras $81 \mathrm{~K}$ e L). Porém, foi verificada a imunomarcação deste marcador mesenquimal em queratinócitos, especialmente localizados na junção dermo-epidermal, nas amostras de neoplasias infectadas pelo BPV (figuras 81E-L). Considerando que a junção dermo-epidermal, após a malignização, corresponde a área do fronte de invasão neoplásica, estes resultados sugerem a aquisição de um fenótipo mesenquimal compatível com a TEM. O controle negativo mostrou a ausência de imunomarcção inespecífica (figura 81A), ao passo que o controle positivo carcinoma labial humano), mostrou a imunomarcação da vimentina na derme, bem como em queratinócitos da junção dermo-epidermal, que compõe o fronte de invasão tumoral (figuras 81B e C). 
Figura 81 - Imunodetecção da vimentina em tecido parafinado

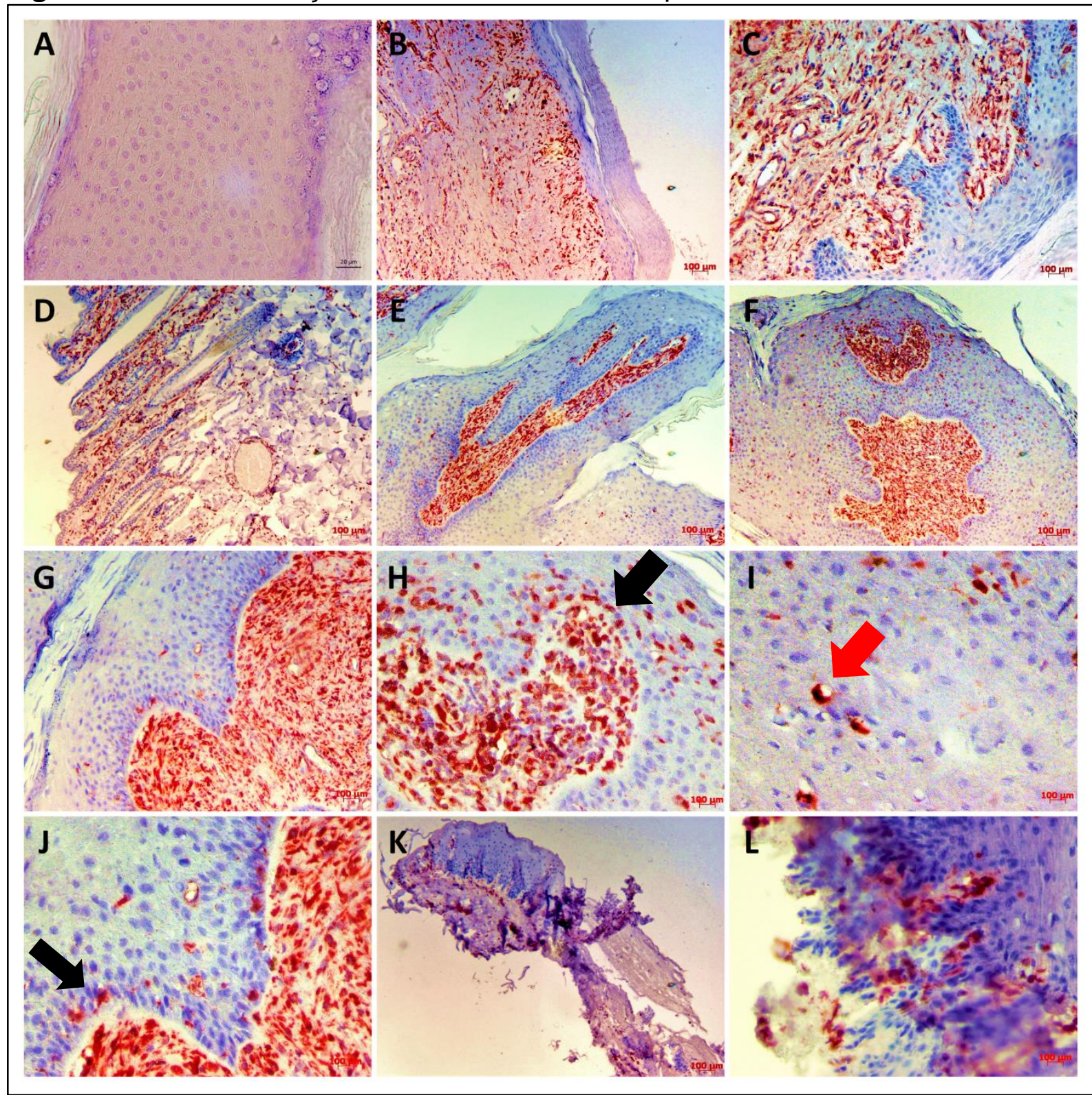

Fotomicrografias mostrando: A) ausência de marcação inespecífica no controle negativo (tecido de papiloma cutâneo incubado exclusivamente com o anticorpo secundário conjugado com HRP; imunomarcação citoplasmática da proteína mesenquimal vimentina na derme de: carcinoma labial humano, empregado como controle positivo (B e $\mathrm{C}$ ); pele saudável não infectada pelo BPV (D) papiloma 01 (E e F - papiloma cutâneo), papiloma 02 (G e H - FB), papiloma 03 (I e J - FB) e carcinoma esofágico (Ke L). Verifica-se a imunomarcação da vimentina em queratinócitos basais, próximos a junção dermo-epidermal (seta preta), bem como na camada basal, incluindo em coilócitos (seta em ). Imagens capturadas com objetivas de: 40 X (A, I e J), 20 X (C, H e L) e $10 \times(B, D, E, F$ e G) FB - fibropapiloma. Barra de escala de $200 \mu \mathrm{m}$

\subsection{Estudos metabólicos e genéticos da oncoproteína E6 do BPV}

\subsubsection{Efeitos da oncoproteína E6 do BPV sob o metabolismo celular}

Considerando que a oncoproteína E6* do HPV-16 mostrou ter um papel central na desregulação do metabolismo energético (WILLIAMS et al., 2014), este 
estudo avaliou pela primeira vez a ação da oncoproteína E6 do BPV-1 no metabolismo celular. Os resultados desta análise mostraram que o tratamento de células derivadas de pele saudável não infectadas pelo BPV com a oncoproteína recombinante E6 do BPV-1 leva a redução do $\Delta \psi \mathrm{m}$ (figura $82 \mathrm{~B}$ ), porém sem afetar a MIF das células que preservam o metabolismo oxidativo (figura 82C).

Figura 82 - Análise da ação da oncoproteína E6 do BPV-1 no $\Delta \Psi_{\mathrm{m}}$

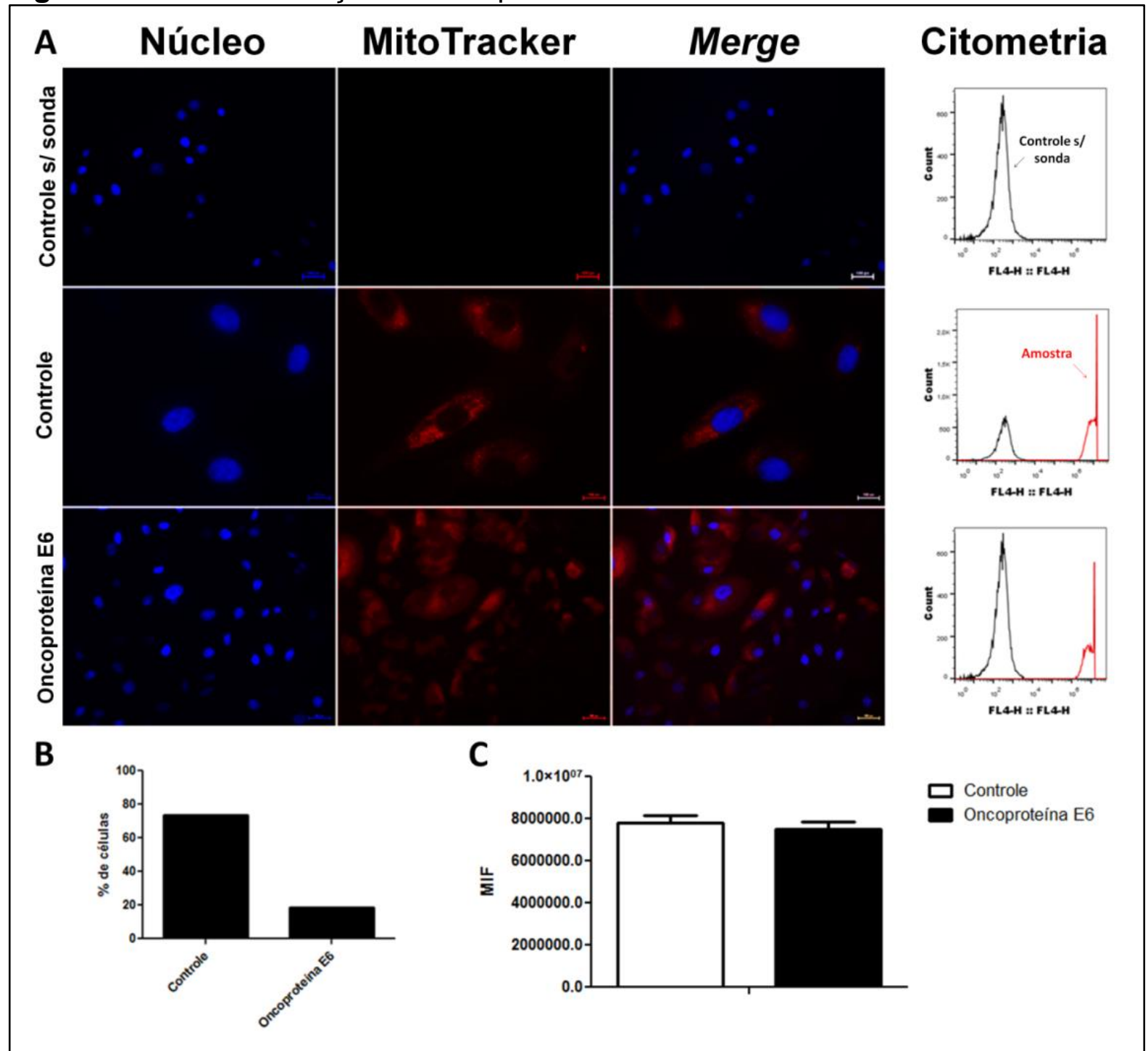

Fotomicrografias e histogramas mostrando: ausência de sinal de fluorescência em células de pele saudável não infectadas pelo BPV na ausência da sonda MitoTracker (controle sem sonda), células de pele saudável incubadas com a sonda MitoTracker na ausência (controle) e presença de $1 \mu \mathrm{g} / \mathrm{mL}$ da oncoproteína recombinante E6 do BPV-1 (oncoproteína E6). A adição da oncoproteína promove a redução do potencial de membrana mitocondrial $(\Delta \Psi \mathrm{m})$, verificado pela redução do percentual de células emitindo fluorescência (B), porém não afeta a média de intensidade de fluorescência (MIF) (C). Imagens obtidas com objetiva de $40 \mathrm{X}$, barra de escala de $100 \mu \mathrm{m}$. Total de 10.000 eventos analisados. Células analisadas na terceira passagem (P3).

Entretanto, assim como verificado nas linhagens celulares derivadas de cultivos primários de neoplasias infectadas pelo BPV (figura 36), o tratamento com a 
oncoproteína E6 do BPV-1 resultou no aumento da produção de EROs (figura 83E). Tais resultados sugerem que a oncoproteína E6 está diretamente associada ao estresse oxidativo.

Figura 83 - Níveis de EROs após a adição da oncoproteína E6 de BPV-1

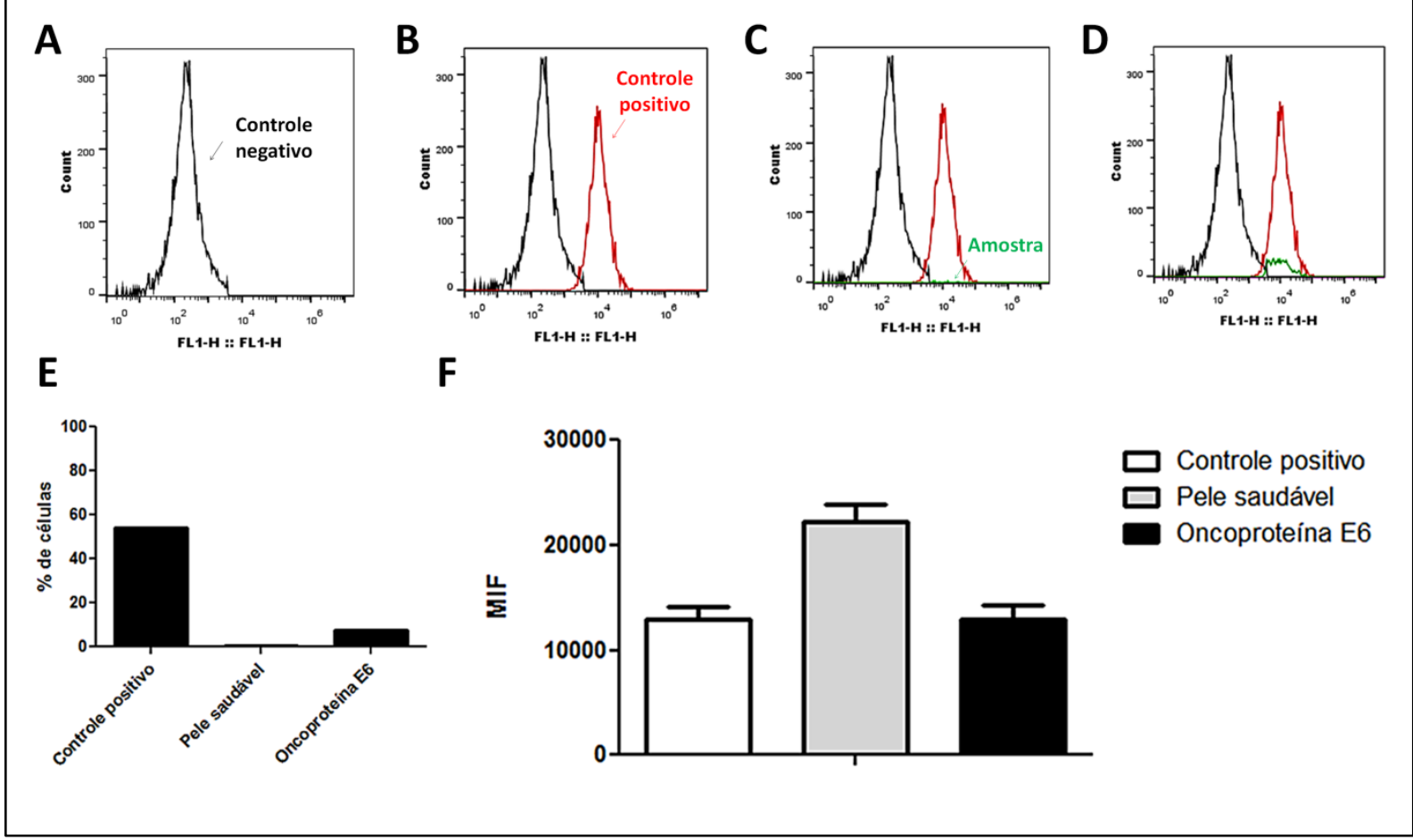

Ação da oncoproteína recombinante E6 do BPV-1 sob a produção de EROs: A) células de pele saudável não incubadas com a sonda DCFH-DA (controle negativo), mostrando ausência de marcação; B) células de pele saudável tratada com $100 \mu \mathrm{M}$ de peróxido de hidrogênio (controle positivo), mostrando produção de espécies reativas de oxigênio (EROs); C) pele saudável (não infectada pelo BPV) apresentando um reduzido percentual de células $(0,46 \%)$ produzindo EROs como subprodutos do metabolismo oxidativo normal; D) pele saudável incubada por 24 horas com 1 $\mu \mathrm{g} / \mathrm{mL}$ da oncoproteína recombinante E6 do BPV-1, mostrando aumento dos níveis de EROs; E) histograma baseado no percentual de células produtoras de EROs, sendo verificado o estresse oxidativo nas células tratadas com peróxido de hidrogênio (controle positivo) e naqueles tratadas com a oncoproteína E6 do BPV; F) média de intensidade de fluorescência (MIF) e desvio padrão (barras) mostrando que as células tratadas com peróxido de hidrogênio e com a oncoproteína E6 apresentam valores de MIF estatisticamente semelhantes, conforme verificado pelo teste de comparações múltiplas de Bonferroni $(p>0,05)$. Nota-se que as células de pele saudável embora apresentem o maior MIF (F), este está restrito a um reduzido percentual de células $(E)$. Total de 10.000 eventos analisados. Análises realizadas na terceira passagem (P3).

\subsubsection{Análise do potencial mutagênico da oncoproteína E6 do BPV}

\subsubsection{Teste do micronúcleo em sanque periférico}

Considerando que mesmo a infecção assintomática pelo BPV induz a clastogenicidade (ARALDI et al., 2013a), as cinco amostras de sangue periférico de bezerros sem papilomas visíveis foi submetida a extração de DNA e subsequente identificação de sequências de DNA viral por meio de PCR convencional. Os 
resultados desta análise mostraram a auência de infecção viral nas cinco amostras de sangue coletadas (figura 84), tornando-as elegíveis ao TMNBC. Nenhum amplicon foi verificado nos controles negativos, indicando a ausência de possíveis contaminações (figura 84). Entretanto, todos os controles positivos amplificaram, demonstrando a ausência de eventuais problemas nas reações que impedissem a não detecção viral em sangue periférico (figura 84).

Figura 84 - Identificação de sequências de DNA viral em sangue periférico

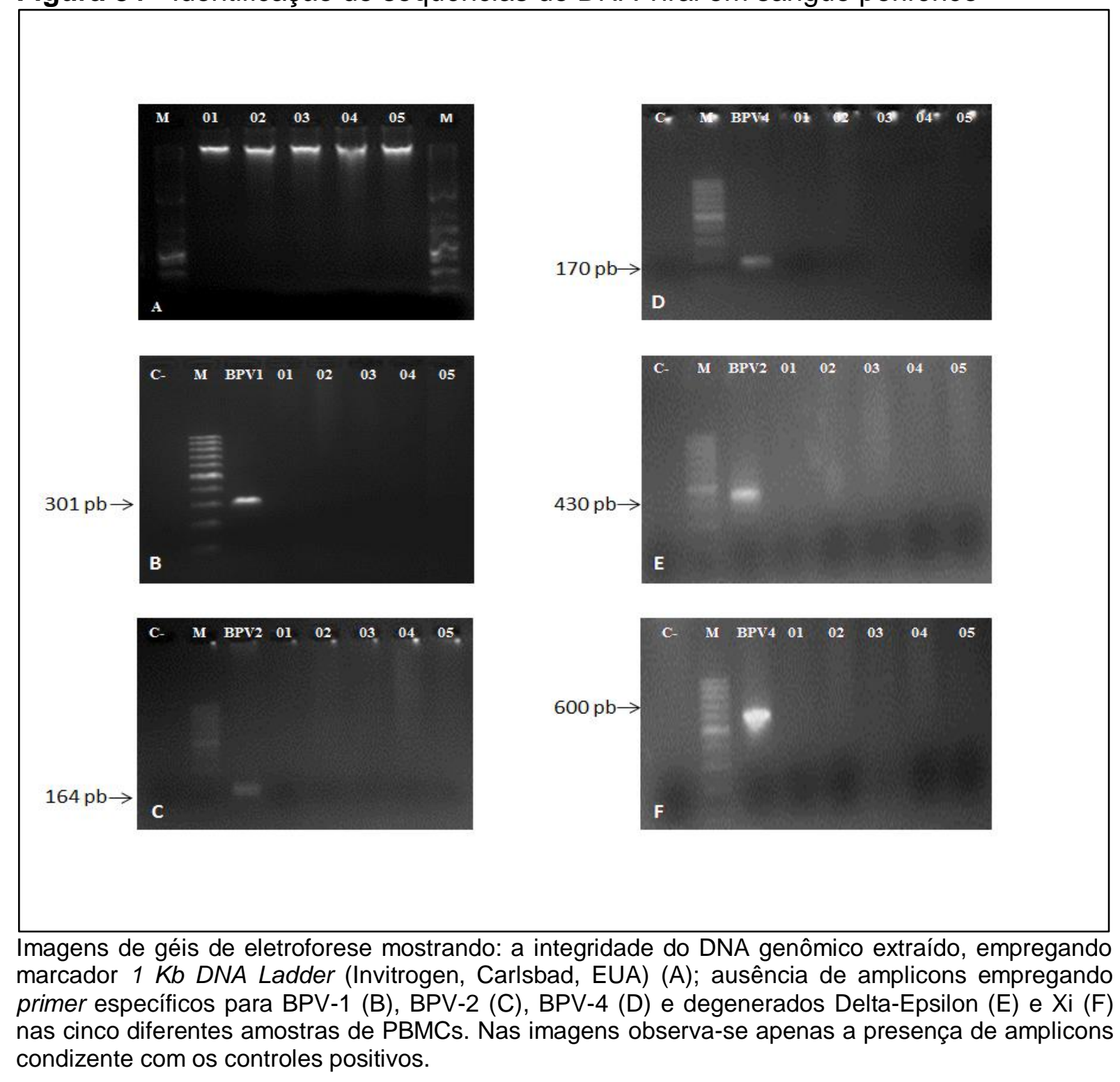

Os resultados do TMNBC mostraram um aumento da frequência de micronúcleos e pontes anafásicas nos linfócitos tratados com o agente alquilante ciclofosfamida (controle positivo) e com a oncoproteína recombinante E6 do BPV-1 (tabela 24, figura 85). 
Tabela 24 - Resultados do TMNBC em sangue periférico

\begin{tabular}{|c|c|c|c|c|c|c|c|}
\hline \multicolumn{8}{|c|}{ Controle negativo } \\
\hline Amostra & MN & $\mathbf{N}_{1}$ & $\mathbf{N}_{2}$ & $\mathbf{N}_{p}$ & PA & $\mathrm{MN}_{\mathrm{rO}}$ & IPBC \\
\hline 1 & 7 & 954 & 22 & 24 & 3 & 0,3181 & $3.022,272$ \\
\hline 2 & 5 & 963 & 19 & 18 & 3 & 0,2631 & $1.976,076$ \\
\hline 3 & 6 & 949 & 22 & 29 & 0 & 0,2727 & $3.632,772$ \\
\hline 4 & 3 & 953 & 17 & 30 & 1 & 0,1764 & $2.916,180$ \\
\hline 5 & 7 & 960 & 22 & 18 & 5 & 0,3181 & $2.280,960$ \\
\hline Total & 28 & 4.779 & 102 & 119 & 12 & $\bar{x}=0,2696$ & $\bar{x}=2.765,652$ \\
\hline \multicolumn{8}{|c|}{ Controle positivo (ciclofosfamida) } \\
\hline $\mathbf{C +}$ & MN & $\mathbf{N}_{1}$ & $\mathbf{N}_{2}$ & $\mathbf{N}_{\mathrm{p}}$ & PA & $\mathrm{MN}_{\mathrm{ro}}$ & IPBC \\
\hline 1 & 32 & 906 & 51 & 43 & 6 & 0,6274 & $11.921,148$ \\
\hline 2 & 31 & 873 & 62 & 65 & 8 & 0,5000 & $21.109,140$ \\
\hline 3 & 48 & 890 & 70 & 40 & 7 & 0,6857 & $14.952,000$ \\
\hline 4 & 54 & 903 & 62 & 35 & 14 & 0,8709 & $11.757,060$ \\
\hline 5 & 50 & 875 & 52 & 73 & 4 & 0,9615 & $19.929,000$ \\
\hline Total & 215 & 4.447 & 297 & 256 & 39 & $\bar{x}=0,7291$ & $\bar{x}=15.933,669$ \\
\hline \multicolumn{8}{|c|}{ Oncoproteína recombinante E6 do BPV } \\
\hline E6 & MN & $\mathbf{N}_{1}$ & $\mathbf{N}_{2}$ & $\mathbf{N}_{p}$ & PA & $\mathrm{MN}_{\mathrm{ro}}$ & IPBC \\
\hline 1 & 51 & 892 & 60 & 48 & 4 & 0,8500 & $15.413,760$ \\
\hline 2 & 50 & 894 & 74 & 32 & 9 & 0,6756 & $12.701,952$ \\
\hline 3 & 49 & 900 & 53 & 47 & 10 & 0,9245 & $13.451,400$ \\
\hline 4 & 40 & 901 & 41 & 58 & 10 & 0,9756 & $12.855,468$ \\
\hline 5 & 38 & 905 & 43 & 52 & 10 & 0,7307 & $12.141,480$ \\
\hline Total & 228 & 4.492 & 271 & 237 & 43 & $\bar{x}=0,8312$ & $\bar{x}=13.312,812$ \\
\hline
\end{tabular}

Número de micronúcleos $(M N)$, linfócitos mononucleados $\left(\mathrm{N}_{1}\right)$, binucleados $\left(\mathrm{N}_{2}\right)$, polinucleados $\left(\mathrm{N}_{\mathrm{p}}\right)$ e pontes anafásicas (PA) observadas nos grupos controle negativo (C-), positivo $(\mathrm{C}+)$ e tratado com a oncoproteína recombinante E6 de BPV-1. Com base nestes valores, são apresentados os valores da frequência de formação de micronúcleos $\left(\mathrm{MN}_{\mathrm{r}}\right)$ e o índice de proliferação de bloqueio de citocinese $\left(\right.$ IPBC $\left.=\left[1 \times N_{1}\right] \times\left[2 \times N_{2}\right] \times\left[3 \times N_{n}\right] / 1.000\right)$ por lâmina e a média $(\bar{x})$ por grupo. 
Figura 85 - Linfócitos binucleados com e sem alterações citogenéticas

A

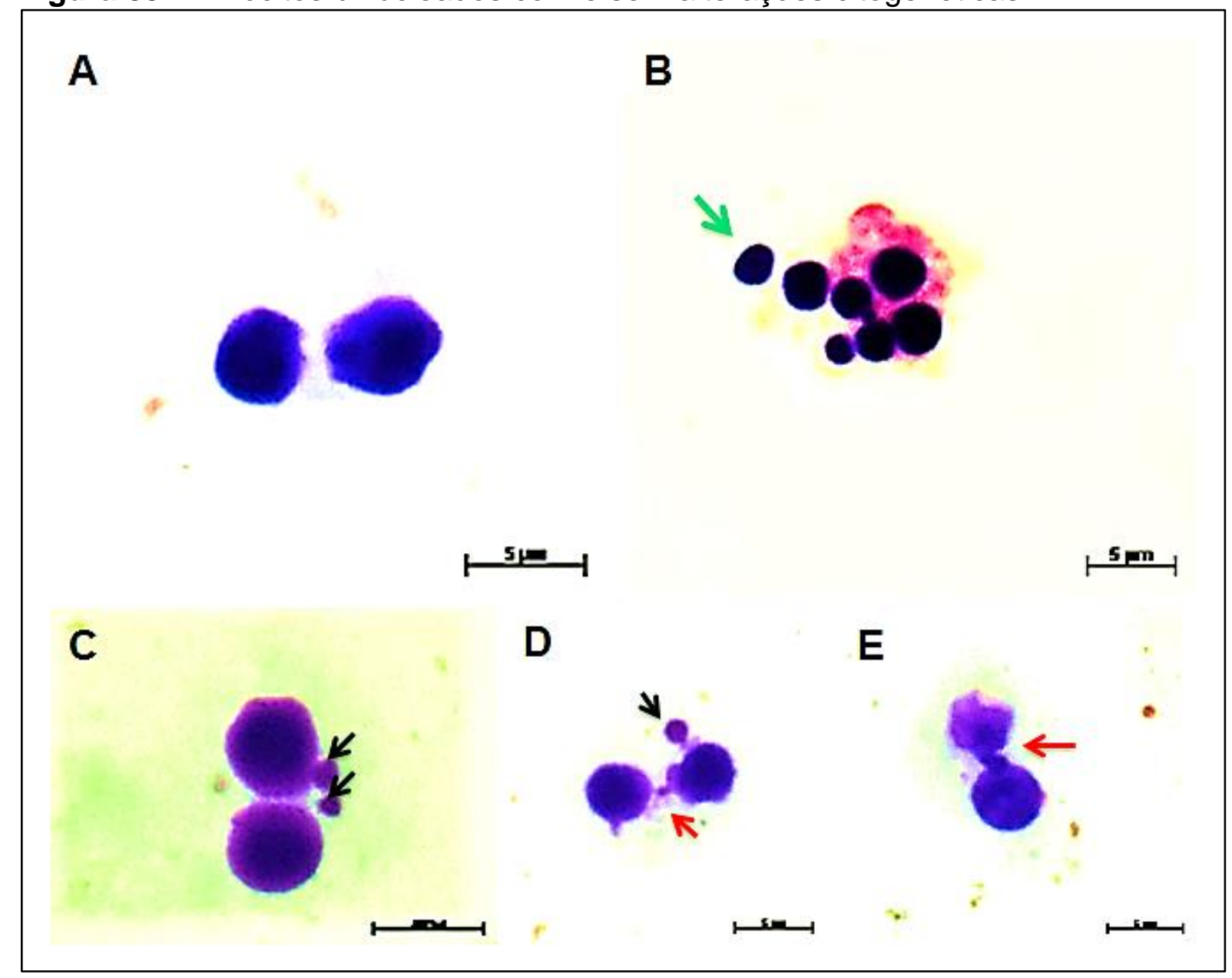

Fotomicrografias mostrando: A) Linfócito binucleado sem micronúcleo verificado no grupo controle negativo, B) célula neótica observada no grupo tratado com a oncoproteína E6 do BPV, C) linfócitos binucleados com micronúcleo (setas em preto), D) ponte anafásicas (seta em vermelho) (E) e linfócitos binucleados com pontes anafásicas (seta em vermelho), verificados no grupo tratado com a oncoproteína E6 do BPV. Imagens obtidas com objetiva de 100 X, barra de escala de $5 \mu \mathrm{m}$.

Com base no número de linfócitos micronucleados (tabela 24), foi realizado o teste do Qui-quadrado $\left(\chi^{2}\right)$, que indicou diferenças estatísticas significativas nos grupos tratados com ciclofosfamida e com a oncoproteína recombinante E6 do BPV1 (tabela 25), sugerindo que a oncoproteína E6 do BPV apresenta um elevado potencial genotóxico. Conforme esperado, o teste não revelou diferença estatística no grupo controle negativo (tabela 25). 
Tabela 25 - Resultados do teste do Qui-quadrado

\begin{tabular}{ccccc}
\hline Grupos & E & X2 & G.L. & p \\
\hline Controle negativo & 5,60 & 2,000 & 4 & 0,7358 \\
Controle positivo & 43,0 & 10,698 & 4 & 0,0302 \\
Oncoproteína E6 & 45,6 & 12,202 & 4 & 0,0159 \\
\hline
\end{tabular}

E- valor esperado, $x^{2}$ - valor do Qui-quadrado, G.L. - grau de liberdade e $p$ - probabilidade

Para comparar a frequência de MNs entre os diferentes grupos, foi realizado o teste de Kruskal-Wallis, que revelou diferenças estatísticas significativas entre os diferentes grupos $(H=9,7297, p=0,0087)$. Com base nestes dados, foi realizado 0 teste post-hoc de Dunn (tabela 26), que mostrou diferenças significativas entre os grupos controle negativo e positivo, bem como entre o controle negativo e aquele tratado com a oncoproteínas E6. Entretanto, não foram verificadas diferenças estatísticas entre os grupos controles positivo e tratado com a oncoproteína recombinante E6 (figura 86). Estes dados reforçam os resultados obtidos através do teste do Qui-quadrado (tabela 25), indicando a ação genotóxica da oncoproteína E6 do BPV.

Tabela 26 - Resultados do teste post-hoc de Dunn

\begin{tabular}{ccccc}
\hline Grupos & Diferença de postos & Z calculado & Z crítico & $\mathbf{p}$ \\
\hline C - e C + & 7,1 & 2,5102 & 2,394 & $<0,05$ \\
C - E E6 & 7,9 & 2,7931 & 2,394 & $<0,05$ \\
C + e E6 & 0,8 & 0,2828 & 2,394 & n.s. \\
\hline
\end{tabular}

Comparação do número de linfócitos micronucleados observados nos grupos controle negativo (C-), positivo $\left(\mathrm{C}^{+}\right)$e tratado com a proteína $\mathrm{E} 6$. n.s. - valores estatísticos não significativos. 
Figura 86 - Boxplot comparativo da frequência de micronúcleos

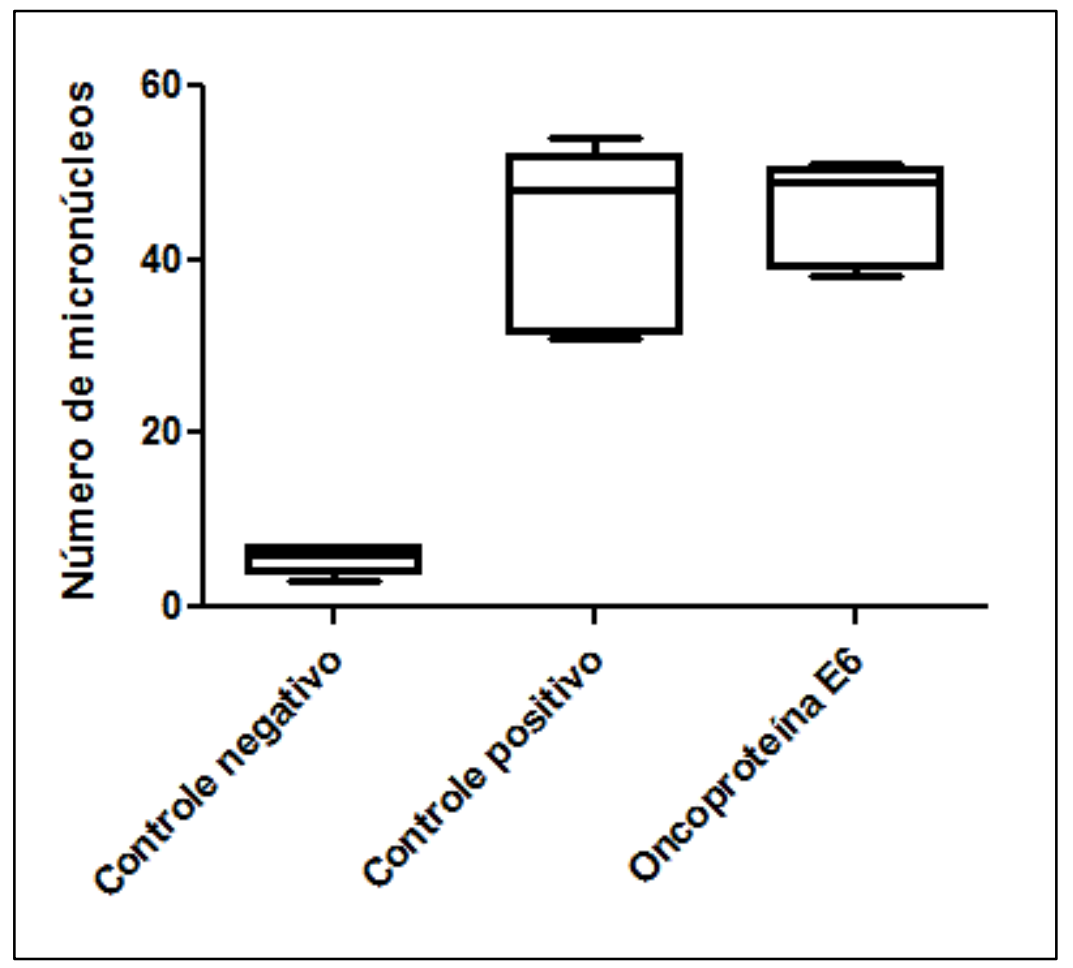

Comparação entre o número de linfócitos micronucleados observados nos grupos controle negativo, controle positivo e tratado com a oncoproteína E6, revelando medianas estatisticamente iguais entre controle positivo e E6.

Com base no número de pontes anafásicas (PA) (tabela 24), foi realizado o teste de Kruskal-Wallis, que indicou diferença estatística significativa entre os grupos $(H=8,3444, p=0,0154)$. Baseado nestes valores foi realizado o teste post-hoc de Student-Newman-Keuls, que mostrou a ausência de diferenças estatísticas significativas entre os grupos controle positivo e aquele tratado com a oncoproteína recombinante E6 do BPV-1 (tabela 27). Tais dados reforçam o potencial genotóxico desta oncoproteína viral.

Tabela 27 - Resultados do teste post-hoc de Student Newman-Keuls

\begin{tabular}{ccccc}
\hline Grupos & Diferença de postos & Z calculado & Z crítico & p \\
\hline C - e C + & 6,1 & 2,1567 & 2,394 & 0,0310 \\
C - e E6 & 7,7 & 2,7224 & 2,394 & 0,0065 \\
C + e E6 & 1,6 & 0,5657 & 2,394 & 0,5716 \\
\hline
\end{tabular}

Comparação do número de pontes anafásicas observadas nos grupos controle negativo (C-), positivo $(\mathrm{C}+)$ e tratado com a proteína E6.

A análise da cinética de divisão, realizada com base nos valores do índice de proliferação com bloqueio de citocinese (IPBC), mostrou que a oncoproteína E6 apresenta uma ação hiperproliferativa, verificada pelo aumento do número de linfócitos bi e polinucleados (tabela 24, figura 87 ). Tais resultados foram confirmados 
pelo teste Kruskal-Wallis, que apontou diferenças estatísticas significativas entre os grupos $(\mathrm{H}=9,42$ e $\mathrm{p}=0,0090)$. Baseado neste resultado, foi realizado o teste post-hoc de Dunn, que mostrou que a oncoproteína E6 do BPV-1 possui uma atividade proliferativa semelhante a da ciclofosfamida (tabela 28).

Figura 87 - Número de linfócitos mono, bi e polinucleados

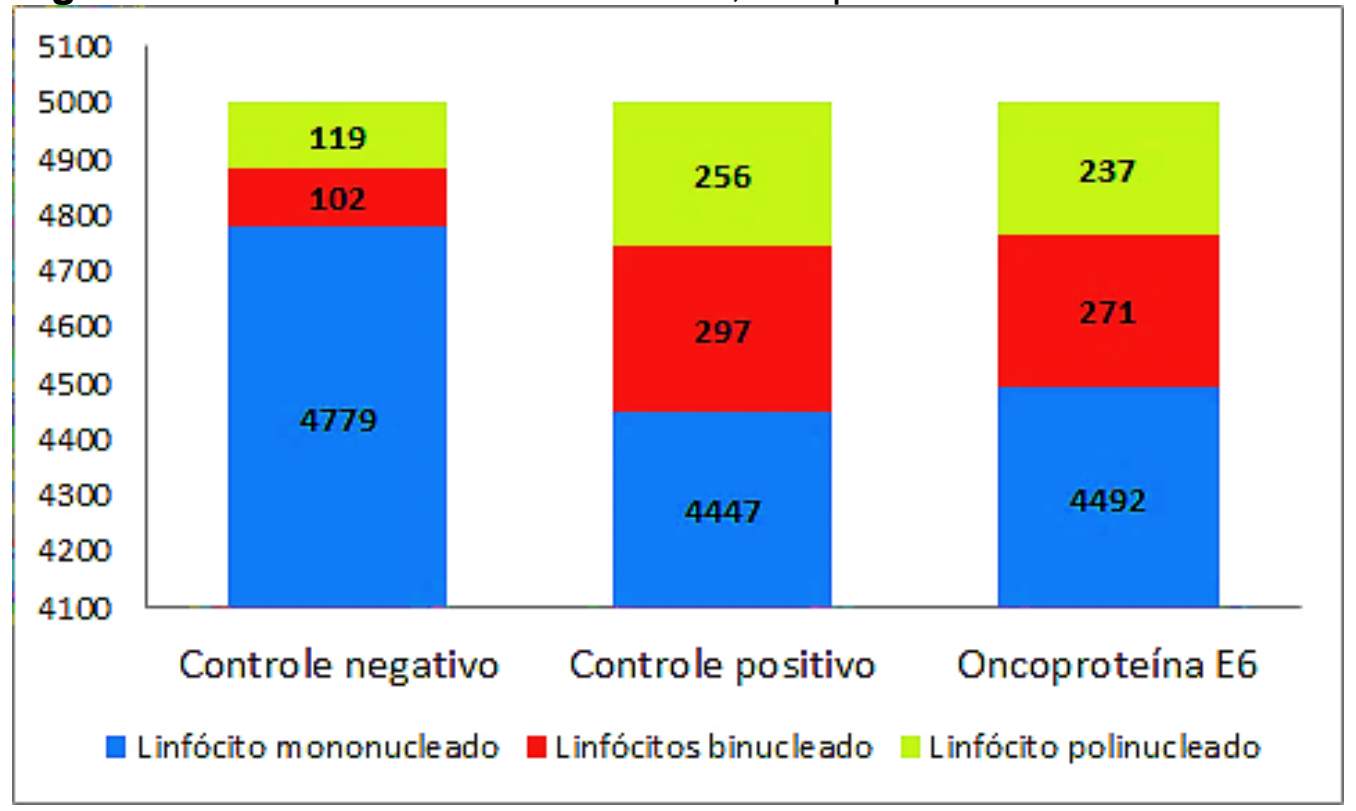

Histograma comparativo entre o número de linfócitos mononucleados, binucleados e polinucleados observados nos três diferentes grupos (controle negativo, positivo e tratado com a oncoproteína E6), indicando um aumento significativo do número de células bi e polinucleadas nos grupos controle positico e tratado com a oncoproteína E6, indicando ação hiperproliferativa nestes grupos.

Tabela 28 - Resultados do teste post-hoc de Dunn

\begin{tabular}{ccccc}
\hline Grupos & Diferença de postos & Z calculado & Z crítico & $\mathbf{p}$ \\
\hline C - e C + & 7,8 & 2,7577 & 2,394 & $<0,05$ \\
C - e E6 & 7,2 & 2,5456 & 2,394 & $<0,05$ \\
C + e E6 & 0,6 & 0,2121 & 2,394 & n.s. \\
\hline
\end{tabular}

Comparação do IPBC entre os grupos controle negativo (C-), positivo (C+) e tratado com a proteína E6. n.s. - valores estatísticos não significativos.

Além do mais, foi verificada a presença de células gigantes, polinucleadas e com figuras de endorreduplicação, caraterizada pela presença de citocinese intercelular no grupo tratado com a oncoproteína recombinante E6 do BPV-1 (figura 88). A presença destas células indica pela primeira vez o potencial neótico desta oncoproteína. 
Figura 88 - Célula com citocinese intercelular (neose)

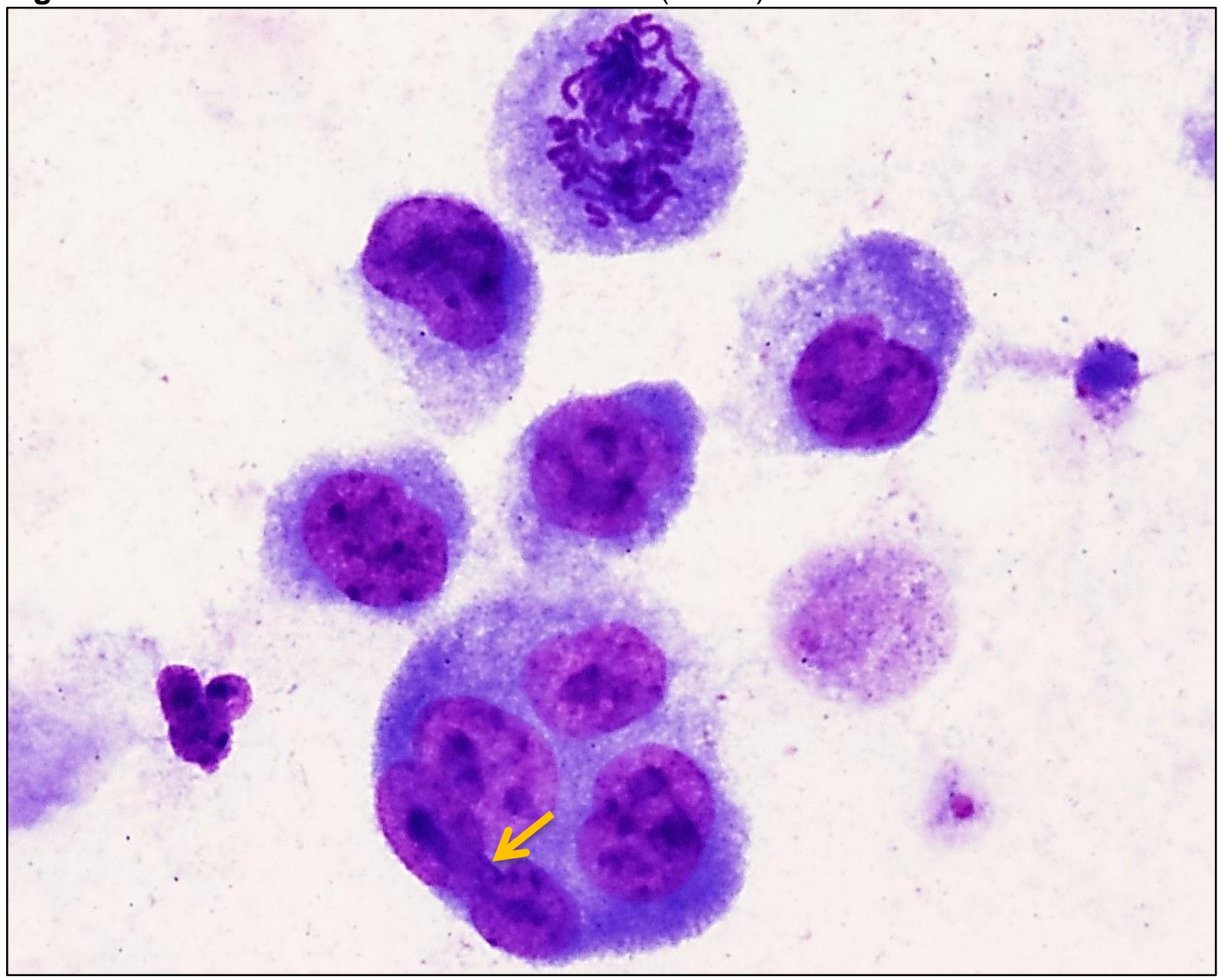

Fotomicrografia de PBMC apresentando citocinese intracelular (apontada pela seta amarela), indicando neose. Material analisado com aumento total de $1.000 \mathrm{X}$.

\subsubsection{Teste do micronúcleo citocinese em células epiteliais}

Considerando o caráter epiteliotrópico do BPV, foi realizado o TMNBC empregando a linhagem comercial CRIB, proveniente de células epiteliais de rim bovino não infectado pelo BPV. Os resultados desta avaliação mostraram que o tratamento com a oncoproteína recombinante E6 do BPV-1 induz a formação de micronúcleos (figura), reforçando a ação genótica desta oncoproteína previamente descrita pelo TMNBC em sangue periférico (seção 6.2.2.1). 
Figura 89 - Resultado do TMNBC em células CRIB

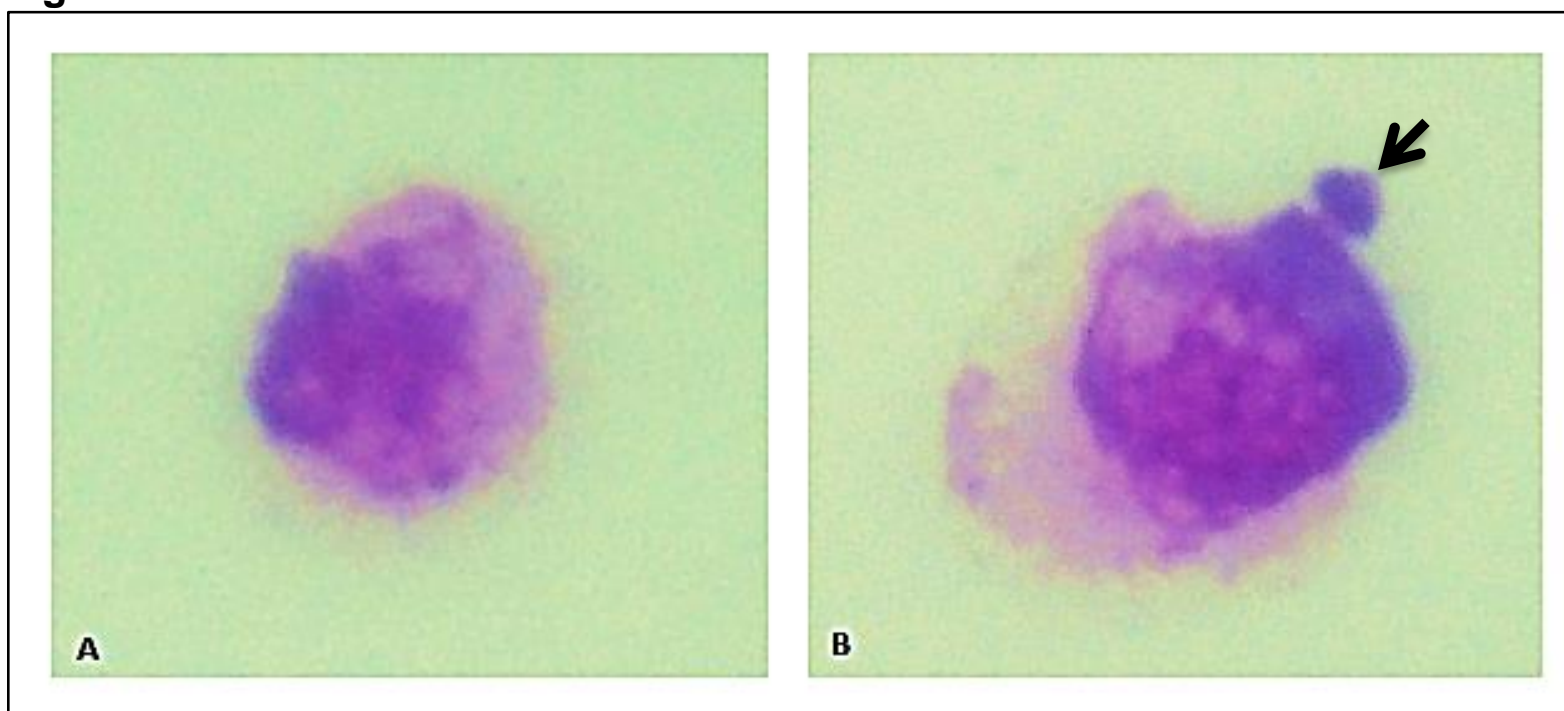

Fotomicroscopia de célula CRIB não tratada com nenhuma droga (controle negativo), mostrando ausência de dano citogenético (A) e, tratada com a oncoproteína recombinante E6 do BPV-1, apresentando micronúcleo (apontado pela seta) (B). Imagens obtidas em aumento total de $1.000 \mathrm{X}$.

Figura 90 - Número de micronúcleos verificados em células CRIB

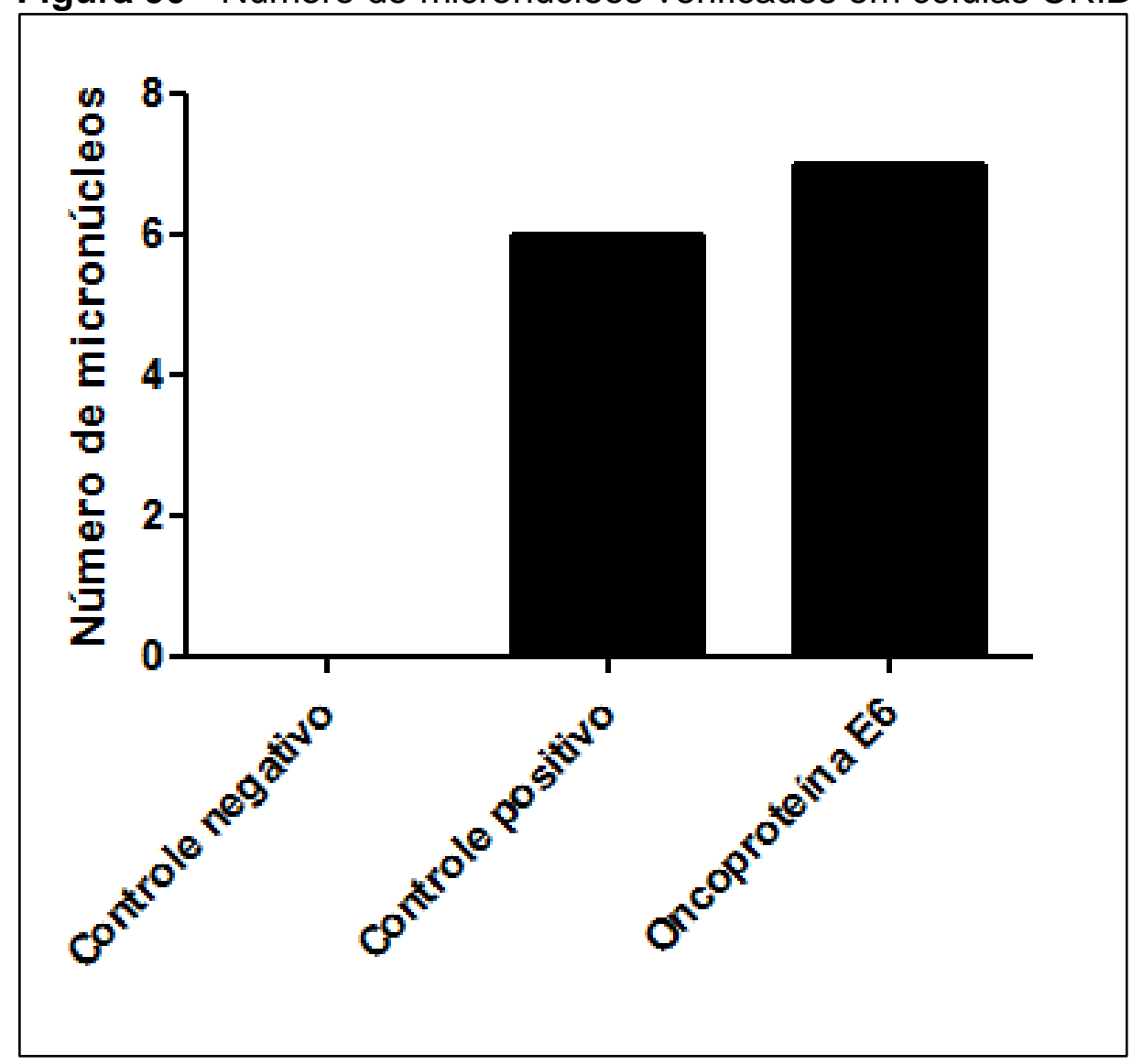




\subsubsection{Ensaio cometa em sanque periférico}

Com o objetivo de avaliar a ação clastogênica da oncoproteína E6 do BPV foi realizado o ensaio cometa em sague periférico. Os resultados deste ensaio mostraram que as células tratadas com a oncoproteína recombinante E6 do BPV-1, bem como com o quimioterápico ciclofosfamida (controle positivo), apresentaram um elevado número de nucleóides de classe dois (tabela 29, figura 91).

Tabela 29 - Análise do potencial clastogênico da oncoproteína E6 do BPV

\begin{tabular}{|c|c|c|c|c|c|}
\hline \multicolumn{6}{|c|}{ Controle negativo } \\
\hline Amostra & Classe 0 & Classe 1 & Classe 2 & Hedgehog & Escore \\
\hline 01 & 9 & 37 & 54 & 4 & 145 \\
\hline 02 & 19 & 36 & 45 & 3 & 126 \\
\hline 03 & 10 & 86 & 4 & 4 & 94 \\
\hline 04 & 2 & 52 & 46 & 2 & 144 \\
\hline 05 & 3 & 79 & 18 & 0 & 115 \\
\hline Total & 43 & 290 & 167 & 13 & 624 \\
\hline \multicolumn{6}{|c|}{ Controle positivo (50 $\mu \mathrm{g} / \mathrm{mL}$ de ciclofosfamida) } \\
\hline Amostra & Classe 0 & Classe 1 & Classe 2 & Hedgehog & Escore \\
\hline 01 & 0 & 2 & 98 & 5 & 198 \\
\hline 02 & 0 & 3 & 97 & 3 & 197 \\
\hline 03 & 3 & 0 & 97 & 8 & 194 \\
\hline 04 & 0 & 0 & 100 & 8 & 200 \\
\hline 05 & 0 & 0 & 100 & 6 & 200 \\
\hline Total & 3 & 5 & 492 & 30 & 989 \\
\hline \multicolumn{6}{|c|}{ Grupo experimental ( $1 \mu \mathrm{g} / \mathrm{mL}$ de E6 recombinante) } \\
\hline Amostra & Classe 0 & Classe 1 & Classe 2 & Hedgehog & Escore \\
\hline 01 & 2 & 6 & 92 & 8 & 190 \\
\hline 02 & 0 & 0 & 100 & 0 & 200 \\
\hline 03 & 0 & 0 & 100 & 6 & 200 \\
\hline 04 & 0 & 0 & 100 & 7 & 200 \\
\hline 05 & 0 & 0 & 100 & 10 & 200 \\
\hline Total & 2 & 6 & 492 & 31 & 990 \\
\hline
\end{tabular}

Número de nucleóides observadas por classe (0 - sem dano, 1 - dano intermediário e 2 - dano máximo), número de nucleóides hedgehog - nucleóides com ausência de "cabeça", classificados como classe 2, indicando apoptose. Valor do escore - obtido a partir da somatória do produto do número de nucleóides $(\mathrm{N})$ pelo respectivo valor da classe $(\mathrm{C})$, conforme a fórmula: $\Sigma=\left(\mathrm{NxC}_{0}\right)+$ $\left(\mathrm{NxC}_{1}\right)+\left(\mathrm{NxC}_{2}\right)$. 
Figura 91 - Análise do potencial clastogênico da oncoproteína E6 do BPV

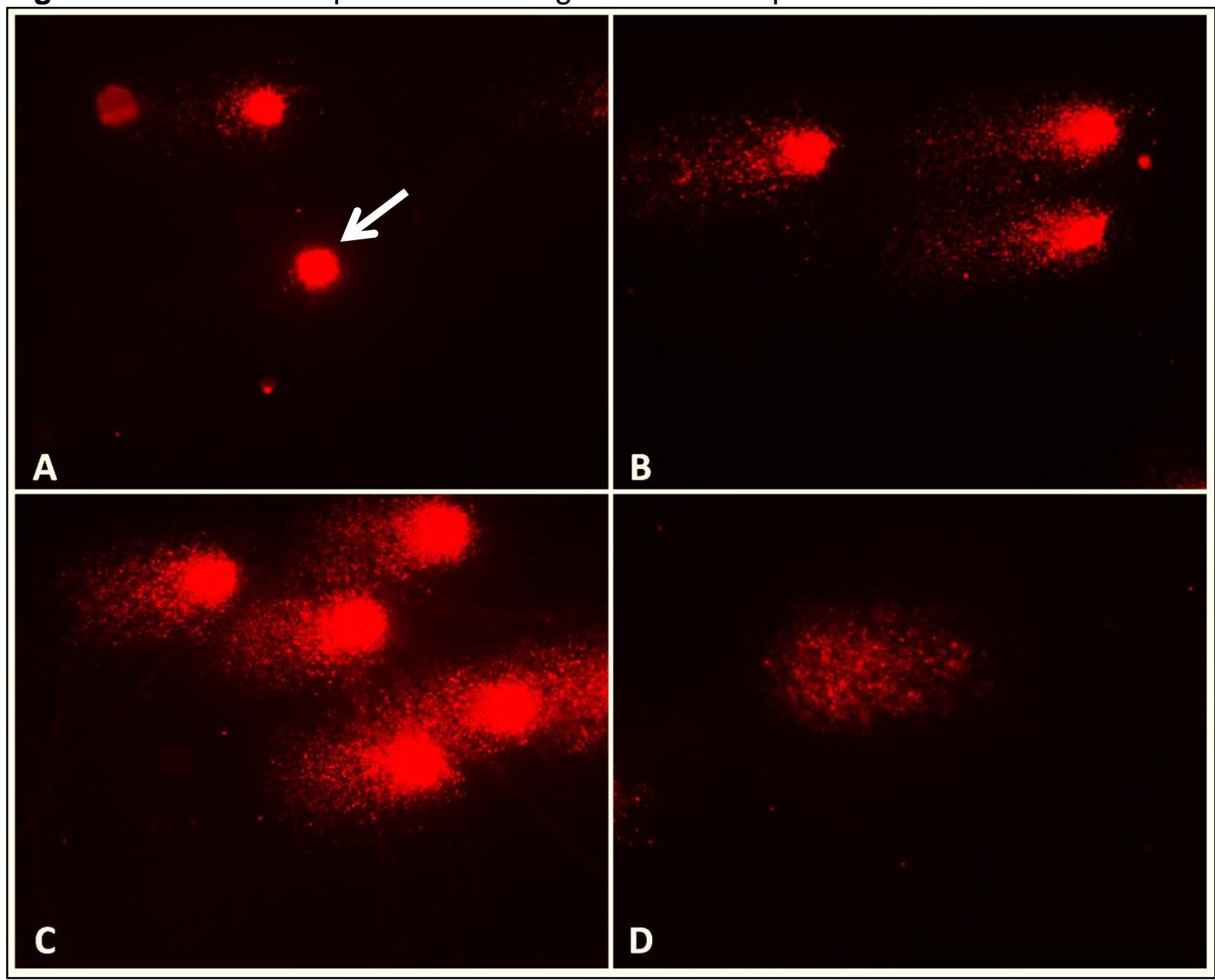

A) Nucleóide de classe 0 (sem dano) observado no controle negativo. B) Nucleóide de classe 2 (dano máximo) observado no controle positivo. C) Nucleóides de classe 2 observados no grupo tratado com a oncoproteína E6. D) Cometa hedgehog observado no grupo tratado com a oncoproteína E6. Imagens capturadas com aumento total de $400 \mathrm{X}$.

Com base nos valores de escores (tabela 29), foi realizado o teste de KruskalWallis, que apontou diferenças estatísticas significativas entre os grupos $(H=10,2613$ e $p=0,0059$ ). Baseado neste resultado foi realizado o teste post-hoc de Dunn, que indicou diferenças significativas entre o grupo controle negativo e positivo, bem como entre este e o grupo tratado com a oncoproteína recombinante E6 (tabela 30). Entretanto, não foram observadas diferenças significativas entre os grupos controle positivo e aquele tratado com a oncoproteína E6 (tabelas 30 e 31). A fim de verificar estes resultados, foi gerado o boxplot mostrado na figura 90 . 
Tabela 30 - Resultados estatísticos do teste post-hoc de Dunn

\begin{tabular}{ccccc}
\hline Grupos & Diferença dos postos & Z calculado & Z crítico & p \\
\hline C- e C+ & 6,8 & 2,4042 & 2,394 & $<0,5$ \\
C- e E6 & 8,2 & 2,8991 & 2,394 & $<0,5$ \\
C+ e E6 & 1,4 & 0,4950 & 2,394 & n.s. \\
\hline
\end{tabular}

n.s. - valor não significativo

Tabela 31 - Diferenças estatísticas entre os diferentes grupos

\begin{tabular}{cccc}
\hline Amostra & Controle negativo & Controle positivo & Oncoproteína E6 \\
\hline $\mathbf{0 1}$ & $145^{\mathrm{a}^{\mathrm{a}}}$ & $198^{\mathrm{b}}$ & $190^{\mathrm{b}}$ \\
$\mathbf{0 2}$ & $126^{\mathrm{a}}$ & $197^{\mathrm{b}}$ & $200^{\mathrm{b}}$ \\
$\mathbf{0 3}$ & $94^{\mathrm{a}}$ & $194^{\mathrm{b}}$ & $200^{\mathrm{b}}$ \\
$\mathbf{0 4}$ & $144^{\mathrm{a}}$ & $200^{\mathrm{b}}$ & $200^{\mathrm{b}}$ \\
$\mathbf{0 5}$ & $115^{\mathrm{a}}$ & $200^{\mathrm{b}}$ & $200^{\mathrm{b}}$ \\
\hline
\end{tabular}

*Valores seguidos de letras iguais indicam ausência de diferença estatística significativa.

Figura 92 - Boxplot comparativo entre os escores de cometa

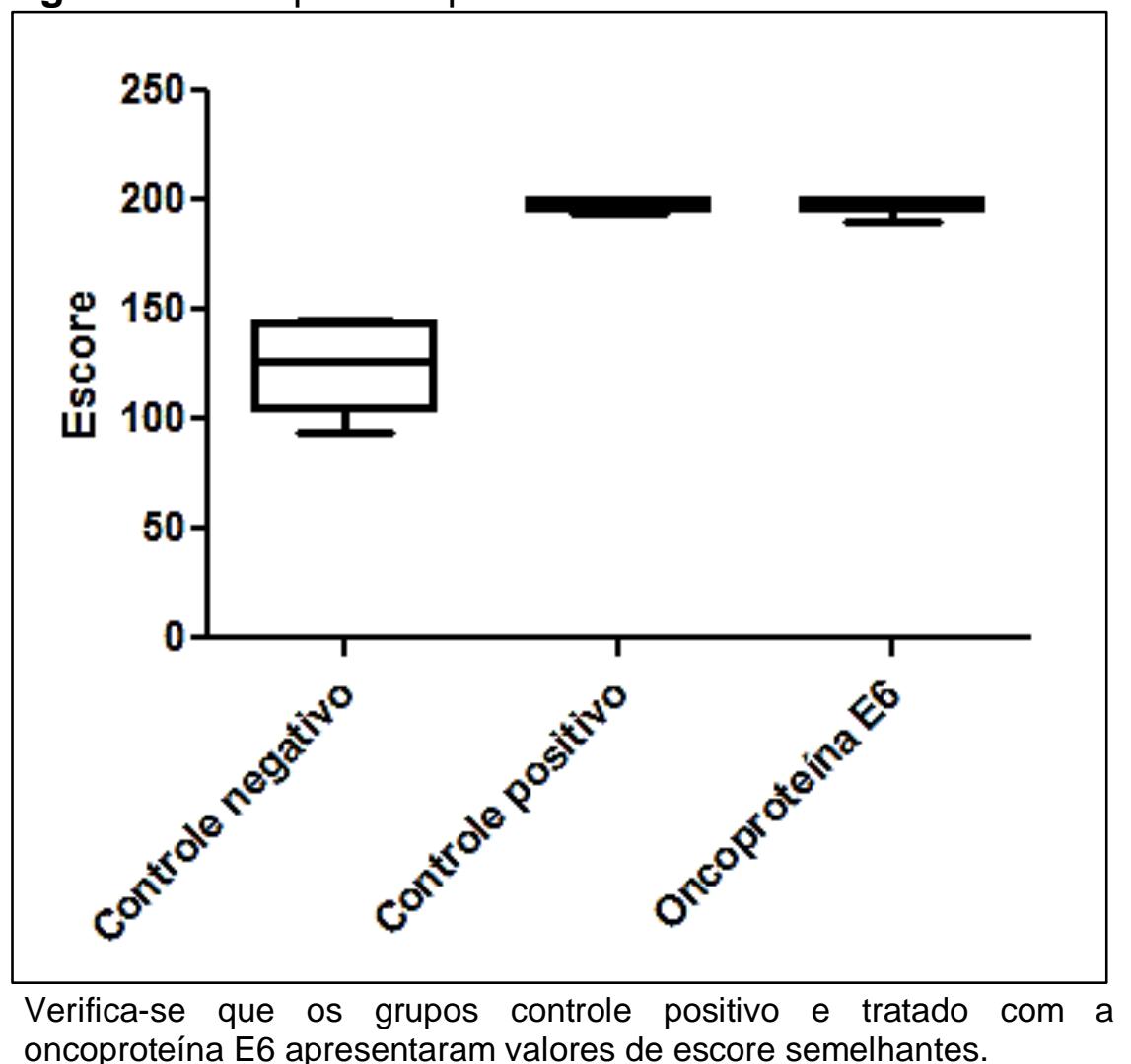

Desta forma, os resultados combinados do TMNBC em sangue periférico (seção 6.3.2.1) e em células CRIB (seção 6.3.2.2), bem como o ensaio cometa (figura 92) mostram, pela primeira vez, que a oncoproteína E6 do BPV apresenta uma ação mutagênica, podendo levar tanto a iniciação neoplásica, como contribuir com a heterogeneidade genética do micro-ambiente tumoral. 
7 DISCUSSÃO 


\subsection{Evidências de infecção produtiva in vitro}

De acordo com a biologia viral, os PVs apresentam um ciclo de replicação e montagem de seu capsídeo dependente do processo de diferenciação celular, como consequência da expressão diferencial das proteínas virais (MCBRIDE; DLUGOSZ; BAKER, 2000; MUNDAY, 2014b; WHITE; HOWLEY, 2013), Por este motivo, os sistemas in vitro são descritos como não permissivos ao estabelecimento de infecções produtivas (MCBRIDE; DLUGOSZ; BAKER, 2000; WHITE; HOWLEY, 2013), aquela na qual se observa a replicação e montagem de partículas virais (GREEN, 1970),

Entretanto, desde 2008, o Laboratório de Genética do Instituto Butantan tem reunido evidências de que os sistemas de cultura são passíveis de desenvolverem infecções produtivas (CAMPOS et al,, 2008, 2013; MELO, 2015), Neste sentido, este estudo identificou a presença de sequências de DNA do BPV ao longo das seis passagens das linhagens celulares derivadas de neoplasias infectadas pelo vírus, mas não na pele saudável (tabela 13, figura 26), Embora a especificidade dos primers específicos para BPV-1, 2 e 4, empregados neste estudo, já tenha sido demostrada (ARALDI et al,, 2014b), Melo (2015) confirmou a identidade destes vírus por meio de sequenciamento de DNA,

Os resultados da PCR também mostraram a co-infecção por mais de um tipo viral em $79,16 \%$ das amostras infectadas, incluindo as células derivadas de CE, malignidade normalmente atribuída a infecção pelo BPV-4 (tabela 13, figura 26), Resultados semelhantes, empregando estas mesmas linhagens celulares, foram previamente descritos por nosso grupo (CAMPOS et al,, 2013; MELO, 2015), Desta forma, a co-infecção pelos Deltapapillomavirus (BPV-1 e 2), verificada nas células de CE (tabela 13, figura 26), sugere que estes tipos virais podem ser agentes etiopatogênicos adicionais do câncer de esôfago em bovinos, Tal resultado reflete, ainda, a falta de estudos epidemiológicos que visam identificar sequências de BPV no CE, levando a literatura a atribuir a malignidade exclusivamente ao BPV-4,

Tendo em vista que a co-infecção viral tem sido frequentemente decrita em amostras clínicas de papilomas cutâneos infectados pelo BPV (ARALDI et al,, 2013, 2014a; CARVALHO et al, 2013; HE et al,, 2014; MELO et al, 2014; SILVA et al,, 2013b), como de retinoblastomas humanos infectados pelo HPV (PESSOA, 2014), os resultados reforçam que as linhagens celulares derivadas de neoplasias 
infectadas pelo BPV são modelos úteis no estudo da biologia do HPV, conforme discutido pela literatura (MUNDAY, 2014b), Entretanto, se por um lado a co-infecção denota a diversidade de tipos virais, por outro, ela representa uma nítida dificuldade no controle das infecções, exigindo o emprego de vacinas multivalentes, Além do mais, a co-infecção pode explicar o insucesso da vacina autógena, frequentemente verificado pela recidiva das lesões.

Os resultados da PCR também mostraram a manutenção das sequências de DNA de ao menos um dos tipos virais BPV-1, 2 e/ou 4 ao longo das seis passagens (P1-P6) das linhagens celulares derivadas de cultivos primários de papiloma cutâneo, fibropapiloma e CE (tabela 13, figura 26). Tais resultados podem ser atribuídos a presença de pontes intercitoplasmáticas, verificadas através da MEV (figura 67), bem como a replicação viral concomitante com a divisão celular.

A presença de pontes intercitoplasmáticas é frequentemente descrita em sistemas de cultura de células mamíferos (BENDICH; VIZOSO; HARRIS, 1967), tendo sido recentemente observada em carcinoma de células escamosas da orofaringe associado ao HPV (PITIYAGE et al., 2015). Tais estruturas apresentam cerca de $10 \mathrm{~nm}$, sendo constituídas por microtúbulos derivados do fuso mitótico (SCHULZE; BLOSE, 1984), formadas nos estágios tardios da telófase (SCHULZE; BLOSE, 1984).

As pontes intercitoplasmáticas são reconhecidas por facilitar o transporte intercelular (SCHULZE; BLOSE, 1984), constituindo importantes rotas de transferência de material genético, visto que a presença de DNA já foi identificada em tais estruturas, conforme mostrado na figura 93 (BENDICH; VIZOSO; HARRIS, 1967; SCHULZE; BLOSE, 1984). Entretanto, atualmente, pouca atenção tem sido dada a estas pontes. No entanto, a presença destas estruturas pode ter um importante significado no entendimento dos mecanismos de manutenção do genoma dos BPVs em sistema in vitro. Isto porque, diferente do HPV que é capaz de se integrar ao genoma hospedeiro, o BPV permanece na forma epissomal. Desta foma, as pontes intercitoplasmáticas podem contribuir com a disseminação horizontal de cópias do BPV, explicando assim os resultados verificados pela PCR (figura 26). 
Figura 93 - Transferência genética horizontal em pontes intercitoplasmáticas

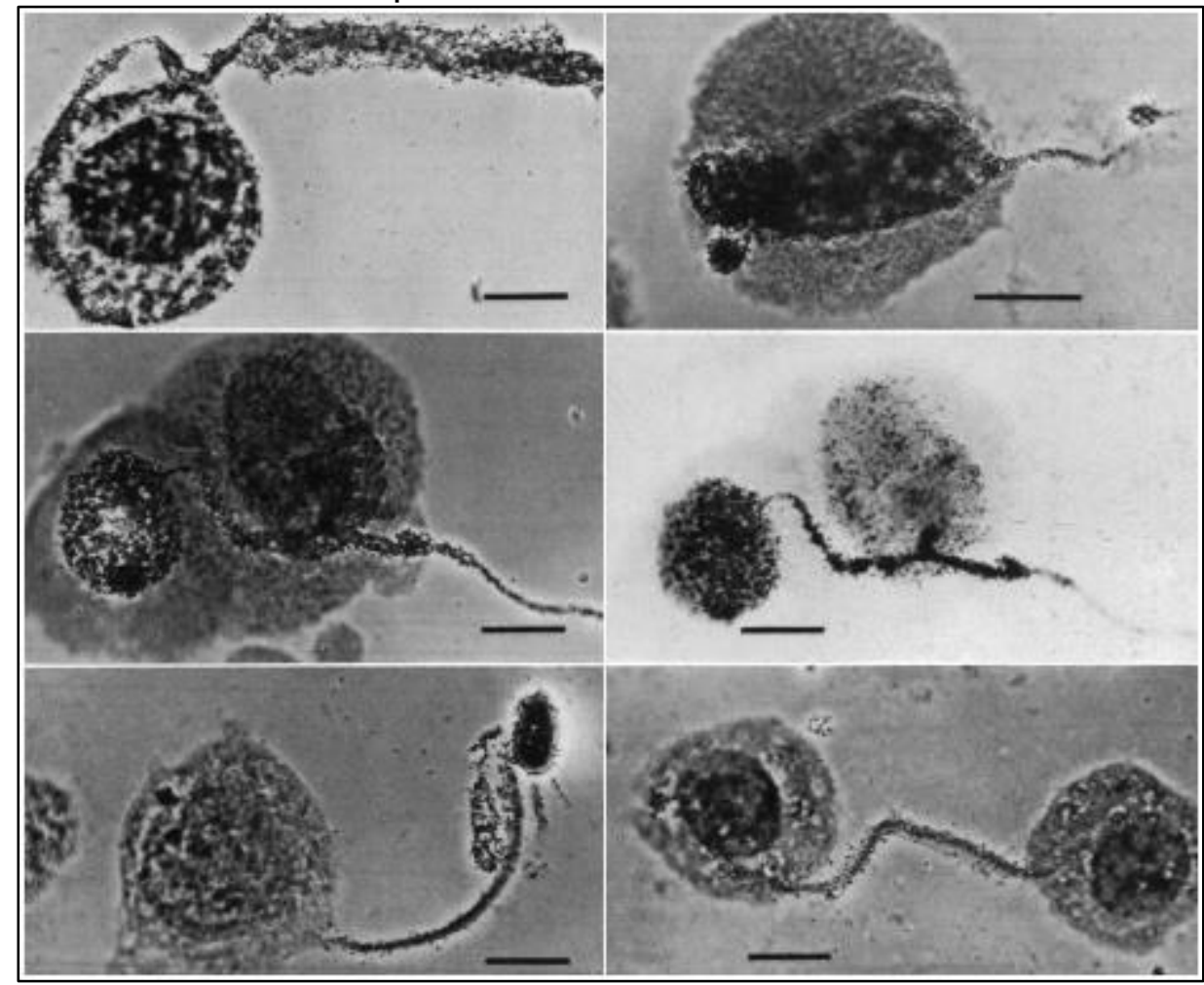

Hibridização in situ cromogênica mostrando a presença de DNA em pontes intercitoplasmáticas. Fonte: Bendich; Vizoso e Harris (1967).

A manutenção do genoma do BPV foi descrita em cultivos celulares pela primeira vez em 1986 (BERG; SINGH; BOTCHAN, 1986). A presença e manutenção de 50-200 cópias de DNA do HPV ao longo de diferentes passagens de queratinócitos humanos reportada por La Porta e Taichman (1982) mais uma vez reforça as linhagens celulares derivadas de neoplasias infectadas pelo BPV como modelo de estudo do HPV, sugerindo a replicação viral independente da diferenciação do epitélio.

A despeito das evidências moleculares, a imunodetecção da proteína L1 do BPV tem sido usada como a principal prova de infecção produtiva (NASIR; REID, 1999; ROPERTO et al,, 2012), Isto porque, a L1 só se expressa nas camadas mais diferenciadas do epitélio, onde se observa a presença de virions, conforme figura 10 (NASIR; REID, 1999; ROPERTO et al,, 2012), Baseado neste fato, este estudo identificou a expressão da proteína L1 do BPV nas linhagens celulares derivadas de cultivos primários de papiloma cutâneo, fibropapiloma e CE (figuras 27 e 28), Entretanto, não foi verificada a imunodetecção desta proteína viral nas células 
derivadas de cultivos primários de pele saudável (figuras 27 e 28), Estes dados reforçam os resultados obtidos pela PCR (figura 26),

Embora desde a década de 1970 seja reconhecido que células transformadas pelos PVs expressam proteínas virais (GREEN, 1970), considerando a natureza de obtenção de máximo efeito por menor custo energético, não seria esperada a expressão da proteína estrutural L1 nestes sistemas se não houvesse a montagem de partículas virais, Isto porque, a proteína L1 tem a capacidade de auto-organizar em pentâmeros, compondo o capsídeo viral (MÓDOLO et al., 2017), Além do mais, estudos que identificaram sequências de DNA e a expressão da proteína L1 do BPV também mostraram a presença de virions no citoplasma destas células, levando à descrição da infecção produtiva em sítios não passíveis de diferenciação celular, como: PBMCs (MELO et al,, 2015) e placenta (ROPERTO et al,, 2012),

Tendo em vista que os vírus são extremamente menores do que as células hospedeiras, a visualização de partículas virais requer técnicas microscópicas de alta resolução e capacidade de aumento para a detecção de partículas virais (OU et al,, 2015), Por esta razão, a MET é considerada o melhor técnica para a identificação de vírions de BPV (ARALDI et al,, 2014b),

A MET foi desenvolvida em 1932 por Ernst Ruska e Max Knoll (OU et al,, 2015), permitindo a análise da anatomia ultraestrural com resolução de até $10 \mathrm{~nm}$ (SHU et al,, 2011), valor este superior àquele verificado na microscopia de superresolução (SIM, STORM e PALM), que apresenta resolução de 10-60 nm (OU et al,, 2015), A técnica de coloração negativa, desenvolvida por Brenner e Horner em 1959, confere, ainda, um considerável aumento de contraste (TANAKA; JOAZEIRO, 1998), permitindo identificar a localização de partículas virais na ultraestrutura (OU et al, , 2015),

A MET teve grande importância histórica na virologia, sendo uma importante ferramenta diagnóstica usada por Peters et al, em 1962, durante a epidemia de varíola na Alemanha (TANAKA; JOAZEIRO, 1998), No entanto, com o avanço da biologia molecular, a MET tem perdido espaço para a PCR, Porém, os métodos baseados no DNA não permitem identificar a presença de partículas virais, impossibilitando a investigação de infecções produtivas,

Com o objetivo de identificar vírions de BPV, as diferentes linhagens foram submetidas à análise ultra-estrutural por meio MET, Nesta técnica, as partículas virais de BPV são visualizadas como estruturas isométricas, sem envoltório, com 
capsômeros evidentes, podendo apresentar morfologia tubular (TANAKA; JOAZEIRO, 1998), Tais vírions podem ser observados de forma isolada ou formando arranjos paracristalinos (TANAKA; JOAZEIRO, 1998), Os vírions de PVs apresentam uma morfologia circular e elétron-densa, com um diâmetro entre 45-60 nm, conforme figura 94 (ARALDI et al,, 2014b; BAKER et al,, 1991; MELO et al,, 2015).

Figura 94 - Vírions de BPV e HPV visualizados por meio de MET

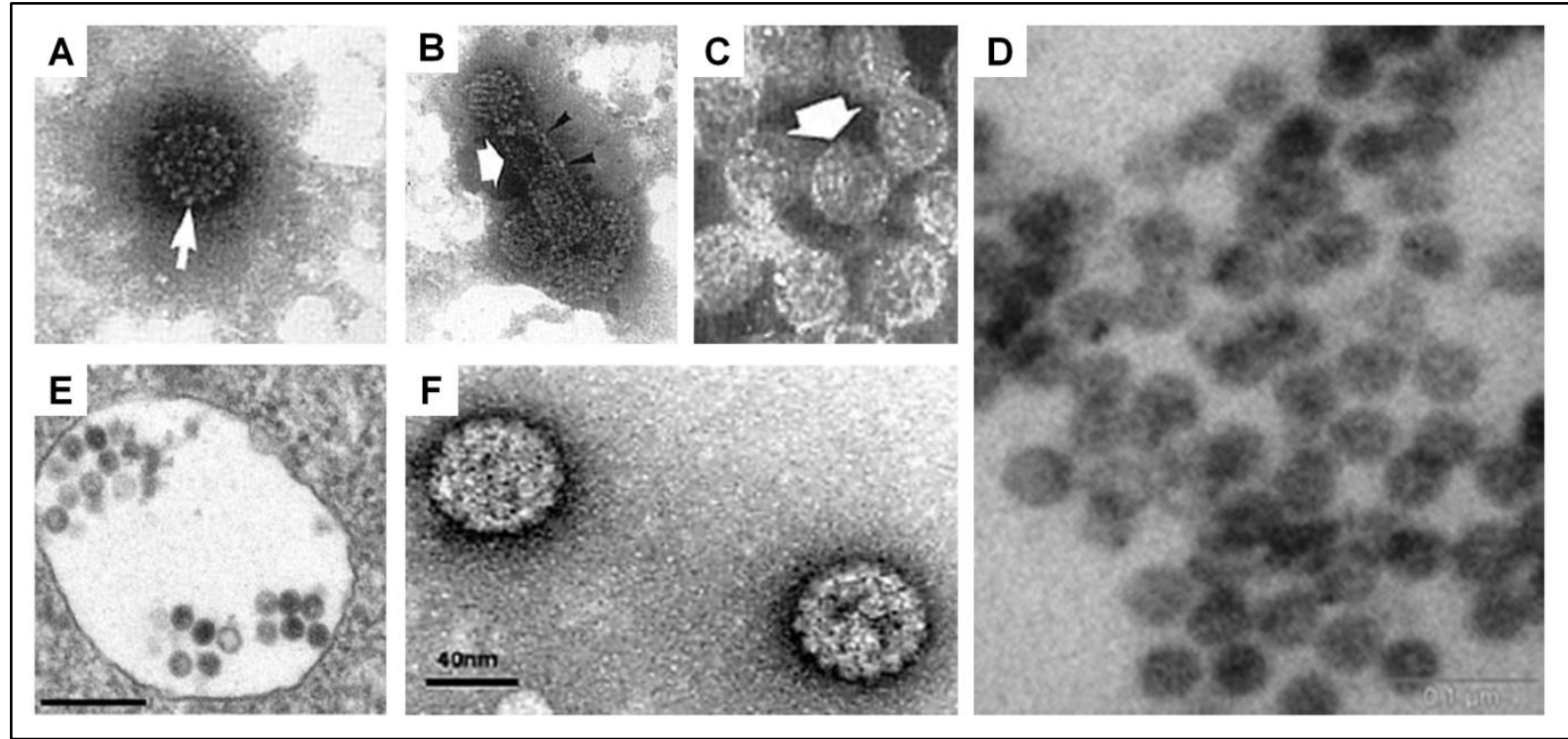

Partículas virais de HPV visualizadas por meio de microscopia eletrônica de transmissão (MET), mostrando morfologia isométrica circular dispersa no citoplasma $(A, C$ e $F)$, contida em vesícula citoplasmática (E) e morfolgia tubular (B), Partículas de BPV-2 isoladas, apresentando morfologia isométrica e circular, com aproximadamente $55 \mathrm{~nm}$, Fontes: Modificado de Araldi et al, (2014b); Schelhaas et al, (2008 e 2012); Tanaka; Joazeiro (1998).

A análise ultra-estrutural mostrou a presença de estruturas esféricas e elétron-densas, com morfologia isométrica e diâmetro entre 41,02 e 61,94 nm, presentes em vesículas citoplasmáticas das células de papiloma cutâneo, fibropapiloma e CE (figuras 29 e 30), Somado a estes resultados, um estudo recente demonstrou que a montagem de vírions de HPV-16 pode ocorrer mesmo na ausência de células (CERQUEIRA et al,, 2016), reforçando a necessidade de se revisar a história natural das infecções pelos PVs, conforme sugerido por Munday (MUNDAY, 2014b), Além do mais, embora os sistemas de cultura 2D não sejam reconhecidos como permissivos a infecção produtiva, havendo uma notória dificuldade de obtenção de vírions mesmo em sistemas organotípicos (3D) (DANOS et al,, 1985; DOORBAR, 2016; CERQUEIRA et al,, 2016), evidência de montagem viral nestes sistemas tem se acumulado nas últimas décadas (tabela 32). 
Tabela 32 - Evidências de infecção produtiva em sistemas in vitro

\begin{tabular}{lc}
\hline \multicolumn{1}{c}{ Identificação de } & Referências \\
\hline & Campos et al, (2008) \\
& Choo et al, (1989) \\
- sequências de DNA viral & Fang et al, (2006) \\
& Pater; Pater (1985) \\
& Reuter et al, (1991) \\
& Sterling et al, (1990) \\
& Yee et al, (1985) \\
\hline - transcritos virais & Smotkin; Wettstein (1986) \\
\hline - vírions em culturas organotípicas & Dollard et al, (1992) \\
& Flores et al, (1999) \\
& Laimins (1996) \\
& McBride; Dlugosz; Baker (2000) \\
& Meyers et al, (1992) \\
\hline
\end{tabular}

Desta forma, os resultados da MET (figura 29), associados aos da PCR (figura 26) e da imunodetecção da proteína L1 (figuras 27 e 30) são importantes evidências de que o vírus pode se replicar e montar in vitro, na ausência de diferenciação celular, Além do mais, os queratinócitos da epiderme e do esôfago podem crescer in vitro mesmo na ausência do estroma, formando um epitélio estratificado incompleto (TAICHMAN et al,, 1984), tornando possível a infecção produtiva, Tais dados fazem das linhagens celulares derivadas de cultivos primários de neoplasias infectadas pelo BPV um importante modelo no estudo da biologia viral, incluindo a patogênese do vírus,

\subsection{Análise do potencial proliferativo das diferentes linhagens celulares}

Embora o potencial proliferativo do BPV seja nitidamente reconhecido, especialmente pela hiperproliferação da camada suprabasal (acantose), verificada em papilomas cutâneos, ou de fibroblastos, em fibropapilomas (ARALDI et al., 2015a), a cinética de divisão das linhagens celulares derivadas de neoplasias infectadas pelo BPV permanecem pouco estudada. Por esta razão, este trabalho avaliou o potencial proliferativo das diferentes linhagens celulares por meio de citometria de fluxo, método amplamente empregado na análise da cinética de divisão devido sua simplicidade e acurácia (DARZYNKIEWICZ; BEDNER; SMOLEWSKI, 2001; YU; WOODS; LEVISON, 1992).

Em termos cinéticos, a proliferação celular é caracterizada pela presença de células em diferentes fases do ciclo celular de forma assincrônica (JAYAT; RATINAUD, 1993). Entretanto, o aumento do número de células nas fases $S$ e G2-M 
indica um aumento do potencial proliferativo, sugerindo um pior prognóstico no processo oncogênico (DARZYNKIEWICZ; BEDNER; SMOLEWSKI, 2001; JAYAT; RATINAUD, 1993). Neste sentido, os resultados da CF mostraram um expressivo aumento do percentual de células na fase $S$ nas linhagens derivadas de cultivos primários infectados pelo BPV (tabela 15, figura 31). Dentre estas linhagens, as células de fibropapiloma (papiloma 02) apresentaram o maior potencial proliferativo, verificado por um aumento de $445 \%$ do número de células em divisão, seguido das células derivadas de CE (254\%) e papiloma cutâneo (papiloma 01, 231\%), Interessantemente, as células de papiloma 02 (fibropapiloma) um potencial proliferativo semelhante a pele saudável, sugerindo a heterogeneidade dos fibropapilomas, a qual pode ser atribuída a história natural da lesão, já que alguns autores consideram estas lesões como precursores temporais do câncer (neoplasias pré-cancerígenas) (DIGIOVANNI, 1992; LACONI; DORATIOTTO; VINEIS, 2008). A manutenção do potencial proliferativo, mesmo em condições in vitro, foi previamente descrita em células de carcinoma de bexiga urinária (MELO, 2015) e sarcóide equino co-infectados por BPV-1 e 2 (POTOCKI et al., 2014).

$A$ ação hiperproliferativa do BPV é atribuída à ação sinérgica das oncoproteínas virais E5, E6 e E7 (ROBERTS, 2015). A oncoproteína E5 promove a dimerização do PDGFßR (CHAMBERS et al., 2003; COSTA; MEDEIROS, 2014; DIMAIO, 2014; NICOLAS et al., 2013; ROBERTS, 2015), ativando diferentes cinases que controlam o checkpoint $\mathrm{G}_{1}-\mathrm{S}$, como: ciclina A-cdk2, MAP, JNK, PI3K e c-Src (BORZACCHIELLO et al., 2007; CAMPO, 2006; VENUTI et al., 2011). A oncoproteína E7 promove a fosforilação de pRb, levando a liberação do fator de transcrição E2F (FERRARO et al., 2011; LIU; BALEJA, 2008; LONGO, 2013; MOODY; LAIMINS, 2010; WHITE; HOWLEY, 2013), resultando na expressão constitutiva das ciclinas A e E, (MOODY; LAIMINS, 2010). A oncoproteína E6 promove a regulação negativa do gene TP53, levando a perda do checkpoint (SCOBIE; JACKSON; CAMPO, 1997). Juntas, estas ações estimulam a entrada na fase $\mathrm{S}$, verificada pela CF (tabela 15, figura 31), disponibilizando DNA polimerases necessárias à replicação viral e, por consequência, favorecendo a carcinogênese (ARALDI, 2015; ARALDI et al., 2015a). 


\subsection{Análise do metabolismo celular}

Considerando as evidências de que as linhagens celulares derivadas de cultivos primários de neoplasias infectadas pelo BPV são permissivas à infecção produtiva (seção 6.1.1) e que tais linhagens apresentam um potencial proliferativo mimeticamente semelhante às condições in vivo (seção 6.1.2), seria esperado que células infectadas pelo vírus apresentassem uma maior atividade metabólica. Isto porque, o processo de replicação e montagem viral são energeticamente custosos, consumindo uma molécula de ATP/nucleotídeo hidrolisado para promover a abertura da dupla-fita de DNA viral e, 0,8-2,5 kcal/mol para o condensamento da cromatina viral, a qual é $70 \%$ mais condensada do que a cromatina eucariótica (HAUK; BERGER, 2016). As alterações no metabolismo celular são, ainda, eventos-chave para a TEM (AGUILAR et al., 2016; CHEN et al., 2007; MARCUCCI; STASSI; DE MARIA, 2016; SHIBANUMA; MORI; ISHIKAWA, 2016). Baseado nestes dados, o metabolismo energético das diferentes linhagens celulares foi analisado com 0 objetivo de identificar possíveis desregulações na via oxidativa.

Tendo em vista que o manutenção do potencial de membrana mitocondrial $(\Delta \Psi \mathrm{m})$ é crucial para a síntese de ATP (AKERMAN; WIKSTRIJM, 1976; GOTTLIEB et al., 2003), o $\Delta \psi \mathrm{m}$ das diferentes linhagens celulares foi analisado empregando a sonda MitoTracker. A MitoTracker é um derivado do corante fluorescente Xrosamina, que apresenta permeabilidade seletiva a membrana mitocondrial (TAKEDA et al., 2002). Logo, quanto quanto maior o $\Delta \Psi \mathrm{m}$, maior a abertura dos poros de permeabilidade transitória (PPTs) e, por consequência, a difusão passiva da sonda pela membrana mitocondrial, resultando na acumulação deste fluoróforo em mitocôndrias ativas (TAKEDA et al., 2002).

Os resultados desta análise mostraram um redução do $\Delta \psi \mathrm{m}$, verificada pela redução do número de células marcadas pela sonda MitoTracker, nas linhagens derivadas de cultivos primários de fibropapiloma (papilomas 02 e 03) e CE (figura 33A e B). Tal redução se mostrou mais expressiva nas células de CE (figura 33A e B). A linhagem de papiloma cutâneo (papiloma 01), por sua vez, apresentou um $\Delta \psi \mathrm{m}$ semelhante àquele verificado na linhagem derivada de pele saudável não infectada pelo vírus (figura 33A e B). Curiosamente, as linhagens que apresentaram as maiores reduções do $\Delta \psi m$ (papiloma 02 e $C E$, figura 33B) foram aqueles com maior potencial proliferativo (tabela 15, figura 31 ). 
Considerando a demanda de ATP requerida durante o processo replicativo, a redução do $\Delta \psi \mathrm{m}$ sugere a ativação da glicólise aeróbica ("efeito Warburg") como via alternativa de obtenção de energia, já que o ensaio de exclusão do corante azul de tripano mostrou a manutenção da viabilidade celular aos longo das passagens (figura 32). Outra evidência que sustenta esta desregulação metabólica é o aumento da MIF, verificado nas linhagens de papiloma 02 e CE (figura 33C). O aumento da intensidade de fluorescência sugere um aumento compensatório do metabolismo oxidativo restrito a um reduzido percentual de células em relação a pele saudável e papiloma cutâneo (papiloma 01). Resultados semelhantes foram observados em cultivos primários derivados de sarcóides equinos infectados pelos Deltapapillomavirus BPV-1 e 2 (POTOCKI et al., 2014). Considerando que as condições in vitro não interferem no $\Delta \Psi_{\mathrm{m}}$ de células bovinas (TAKEDA et al., 2002), a redução do $\Delta \Psi \mathrm{m}$ sugere a ativação da glicólise aeróbica ("efeito Warburg") nas linhagens celulares derivadas de fibropapilomas e CE.

O "efeito Warburg" é atribuído a hiperproliferação celular, que leva a condições de hipóxia, resultando na ativação do fator de transcrição HIF-1, que ao promover a regulação negativa da piruvato desidrogenase $(\mathrm{PDH})$, reduz a conversão do piruvato a acetil-CoA mesmo após o restabelecimento da pressão parcial de oxigênio, resultante da angiogênese (RODRIGUEZ, 2016). Entretanto, tal efeito não é observado em todas as células que compõem o microambiente tumoral (RODRIGUEZ, 2016). Neste sentido, a manutenção do metabolismo oxidativo em um restrito percentual de células, observada nas linhagens derivadas de fibropapiloma e CE (figura 33B e C), é mais uma evidência de que os sistemas in vitro são capazes de mimetizar as condições verificadas no contexto do microambiente neoplásico, reforçando o papel destas linhagens como modelo de estudo do processo oncogênico.

Estudos recentes também apontam que a p53 tem um papel-chave na regulação do metabolismo celular (HERNÁNDEZ-RESÉNDIZ et al., 2015; RODRIGUEZ, 2016). De acordo com Rodriguez (2016), a inativação da p53 leva a superregulação dos receptores de glicose GLUT1, 3 e 4, aumentando a captação deste carbohidrato de forma compensatória. Desta forma, a regulação negativa do gene TP53, decorrente da ação epigenética da oncoproteína E6 do BPV, pode representar um sucesso adaptativo da co-evolução do vírus com seus hospedeiros, garantindo o aporte energético mesmo necessário à replicação viral. A capacidade 
de aumentar o metabolismo glicolítico não é exclusiva do BPV. De acordo com McFadder et al. (2016), o vírus do sarcoma de Kaposi (KSHV) e o Epstein-Barr vírus (EBV) também são capazes de promover o "efeito Warburg".

Os resultados também sugerem que o acometimento da derme,verificado nos fibropapilomas e CE, tem um papel-chave na carcinogênese. Isto porque, a derme não somente fornece suporte físico ao epitélio hiperplásico (RÄSÄNEN; VAHERI, 2010), como também confere aporte energético adicional às células cancerígenas (ARALDI et al., 2015a; MARTINEZ-OUTSCHOORN et al., 2011). Neste sentido, as células estromais aumentam a expressão de receptores monocarboxilato (MCT1 e 2), elevando a captação do lactato resultante da glicólise aeróbica de queratinócitos transformados (RODRIGUEZ, 2016). Este processo promove a regeneração do piruvato, que pode ser importado por receptores MCT1 de células epiteliais transformadas, nas quais é direcionado ao metabolismo oxidativo (ARALDI et al., 2015a; RODRIGUEZ, 2016). Esta ação cria um mecanismo de transferência energética entre o compartimento epidérmico e dérmico, conferindo aporte de ATP necessário à progressão maligna.

A manutenção do $\Delta \psi m$ verificada na linhagem celular derivada de pele saudável sugere ainda que, mesmo em se tratanto de neoplasias benignas, os papilomas são heterogêneos, podendo ser divididos em subclasses com diferentes probabilidades de malignização, conforme proposto por DiGiovanni (1992). Desta forma, tendo em vista que o "efeito Warburg" é um evento sempre verificado na carcinogênese, os resultados sugerem que o papiloma 02 pode ser considerado como uma lesão pré-cancerígena (FERREIRA, 2010; HANAHAN; WEINBERG, 2011; LU; TAN; CAI, 2015).

Considerando que as EROs são produtos do metabolismo oxidativo (BALABAN; NEMOTO; FINKEL, 2005; LU; TAN; CAI, 2015), a redução do $\Delta \psi m$, verificada nas linhagens celulares derivadas de fibropapiloma e CE (figura 33B), deveria resultar na redução dos níveis de EROs nestas células. Entretanto, os resultados do ensaio de DCFH-DA mostraram um aumento do percentual de células marcadas pela sonda (figura $36 \mathrm{H}$ ), indicando um aumento da produção de EROs nas linhagens derivadas de neoplasias infectadas pelo BPV. Embora as células derivadas de pele saudável tenham apresentado a maior MIF (figura 36I), a produção de EROs foi restrita a um reduzido percentual de células (figura $36 \mathrm{H}$ ). 
Embora paradoxais, estes resultados sugerem que a oncoproteína E6 tem um papel central nas desregulações do metabolismo celular. Isto porque, um estudo baseado na variante de splicing da oncoproteína E6 (E6*) do HPV-16 mostrou que a oncoproteína é capaz de regular negativamente a expressão das enzimas antioxidantes SOD2 e Gpx, resultando no aumento dos níveis de superóxido e peróxido de hidrogênio (WILLIAMS et al., 2014). Porém, apesar das semelhanças estruturais entre a oncoproteína E6 do BPV e HPV (ZANIER et al., 2013), a ação dessa no metabolismo energético permanece desconhecida. Por esta razão, este trabalho avaliou os efeitos da adição da oncoproteína recombinante E6 do BPV-1 no metabolismo de células derivadas de pele saudável não infectada pelo vírus. Os resultados desta análise mostraram que as células tratadas com a oncoproteína recombinante E6 do BPV-1 tiveram uma redução do $\Delta \psi \mathrm{m}$, já que apenas $25,5 \%$ das células tratadas se mostraram marcadas pela sonda (figura 82). Porém assim como verificado nas linhagens celulares derivadas de neoplasias infectadas pelo BPV (figura 36), as células tratadas com a oncoproteína recombinante E6 do BPV-1 apresentaram um aumento dos níveis de EROs na ordem de 16,41 vezes (figura 83).

Dadas as semelhanças estruturais da oncoproteína E6 do HPV com a do BPV (ZANIER et al., 2013), estes resultados sugerem que ambas as oncoproteínas promovem a regulação negativa das enzimas SOD2 e Gpx (figura 95), causando o aumento dos níveis de EROs. Desta forma, as oncoproteínas E6 do HPV e BPV são funcionalemente semelhantes. Tais resultados também indicam que as oncoproteínas E6 do BPV/HPV agem de forma homóloga às proteínas NS3 e NS5A do HCV (CHOl et al., 2004; WARIS; AHSAN, 2006), M2 do influenza (LAZRAK et al., 2009), EBNA1 do EBV (GRUHNE et al., 2009) e NS1 do vírus da dengue (DENV) (YEN et al., 2008), inibindo a síntese de enzimas antioxidantes. Estes dados sugerem que as desregulações metabólicas são eventos comumente verificados em células infectadas por oncovírus. 
Figura 95 - Efeitos da oncoproteína E6 do BPV/HPV na produção de EROs

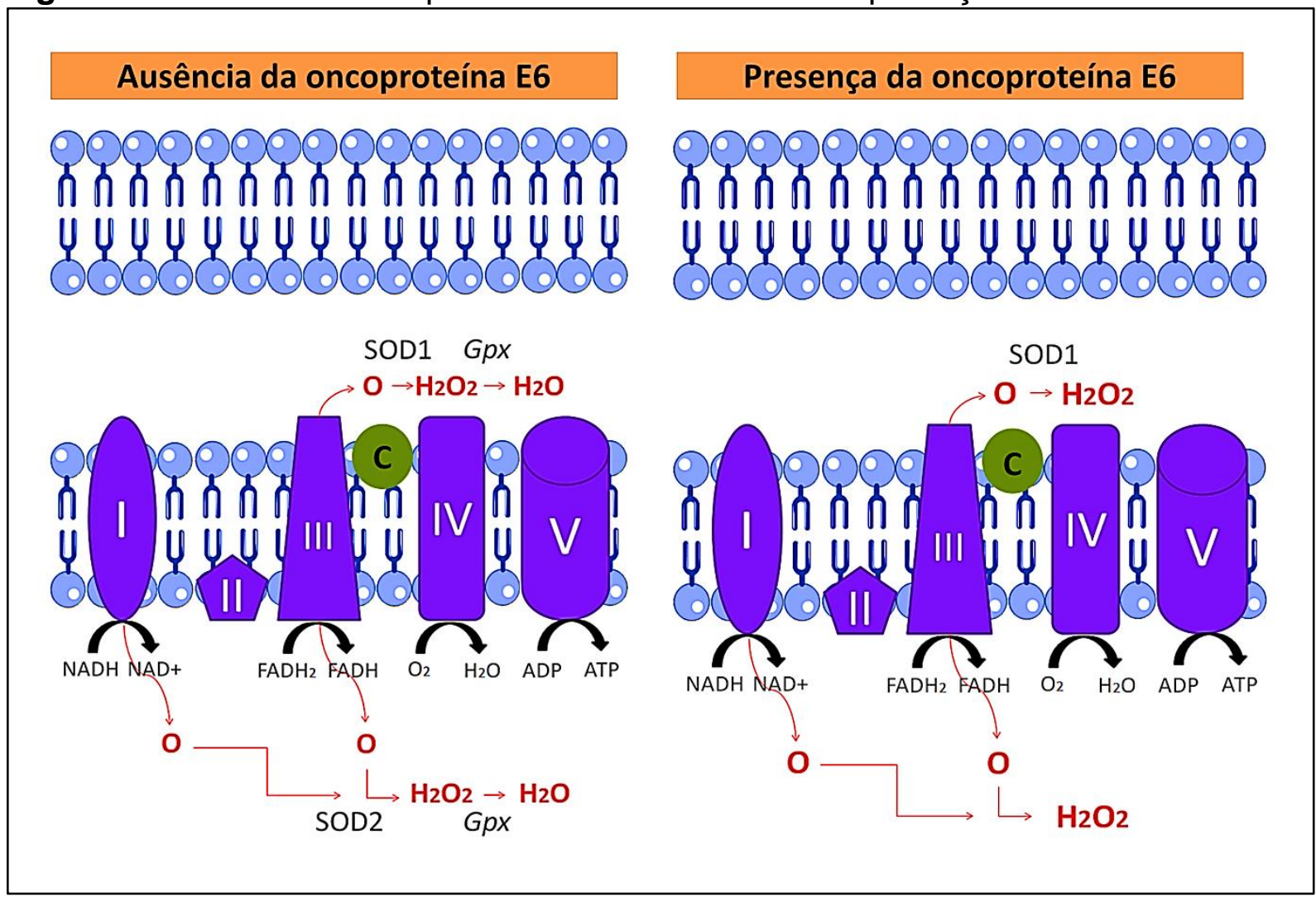

A expressão da oncoproteína E6 do BPV/HPV leva a regulação negativa das enzimas anti-oxidantes SOD2 e Gpx, resultando no aumento dos níveis do radical superóxido e peróxido de hidrogênio (EROs).

Considerando que a redução do $\Delta \Psi \mathrm{m}$ e/ou o aumento dos níveis de EROs podem levar a apoptose por mecanismos dependentes de p53, que ativa a transcrição na proteína pró-apoptótica Bax (LI; DIETZ; VAN HARSDORF, 1999), a repressão epigenética da p53 pela oncoproteína E6 (ZIMMERMANN et al., 1999, 2000) pode ser entendida como mais um sucesso da co-evolução do vírus com seu hospedeiro, garantindo a replicação viral. Outra evidência desta co-evolução é a interação da oncoproteína E5 dos PVs com receptores Toll-like 4 (TLR4), levando a regulação negativa deste (DELIGEOROGLOU et al., 2013; MOSSERI et al., 2014). As EROs podem ativar receptores TLR, que participam da resposta imune inata (LI; JIA; TRUSH, 2016; SCHIEBER; CHANDEL, 2014). Desta forma, a regulação negativa do TLR4 contribui com a imuno-evasão e, portanto, com a persistência da infecção viral.

As EROs também podem atuar como mensageiros secundários (BLEIER et al., 2015; CICHON; RADISKY, 2014; RECZEK; CHANDEL, 2015), ativando o fator de transcrição nuclear SLUG (BARRALLO-GIMENO; NIETO, 2005), cujos níveis de 
expressão se mostraram elevados na linhagem deriva de CE (figura 52), ao mesmo tempo em que regula microRNAs como o miR-200, levando à repressão do marcador de adesão E-caderina (WANG; LI; SARKAR, 2010). Outro exemplo da ação das EROs como mensageiros secundários é a capacidade de ativar a proteína cinase ativada por mitógenos (MAPK - mitogen activated protein kinase) (WARIS; AHSAN, 2006). Quando ativa, a MAPK leva a expressão das proteínas AP-1 e ciclina D1, estimulando a entrada na fase $S$ e migração celular (SALAZAR-ROA; MALUMBRES, 2016; WARIS; AHSAN, 2006). Isto porque, a MAPK contribui com a aquisição da morfologia fibroblastóide de queratinócitos, esperada durante a TEM (FUKAWA et al., 2012).

Desta forma, os resultados sugerem que a ação pró-oxidante da oncoproteína E6 age de forma sinérgica com as oncoproteínas E5 e E7 levando a proliferação celular e, portanto, participando da progressão maligna. Apesar dos Xipapillomavirus (BPV-4), tipo viral associado ao CE, não possuir a ORF E6, este estudo mostrou a co-infecção pelos Deltapapillomavirus BPV-1 e 2 nas linhagens celulares derivadas de cultivos primários de neoplasias infectadas pelo vírus (figura 26). Além do mais, estudos mostram que os Deltapapillomavirus, especialmente o BPV-2, são os tipos virais mais comumente observados tanto em neoplasias bovinas (ARALDI et al., 2014a, 2014b, 2015a; MAIOLINO et al., 2013; YUAN et al., 2008) como em sarcóides equinos (BOGAERT et al., 2008, 2010; OTTEN et al., 1993). Tais dados fazem da oncoproteína E6 um importante alvo biotecnológico para o desenho de drogas anti-câncer, já que moléculas capazes de aumentar os níveis de EROs têm revelado um elevado valor farmacêutico (NDOMBERA et al., 2016).

\subsection{Alterações na ultra-estrutura associadas as deregulações metabólicas}

A redução do $\Delta \psi \mathrm{m}$ verificado nas linhagens celulares derivadas de fibropapilomas e CE (figura 33) sugere a redução da fosforilação oxidativa e, por consequência, o aporte de ATP. Considerando o potencial proliferativo das linhagens celulares derivadas de neoplasias infectadas pelo BPV, discutido na seção 7.1.2, são esperados mecanismos compensatórios de obtenção de energia. Neste sentido, a análise da ultra-estrutura mostrou a presença de dilatações nas cisternas do reticulo endoplástico (RE), bem como inúmeros autofagolisossomos e corpos multivesiculares (CMV) nas células derivadas de papiloma cutâneo, fibropapiloma e CE (figura 37). Os CMV são estruturas com diâmetro superior a $250 \mathrm{~nm}$, contendo 
vesículas internas com diâmetro de 50-80 nm, descritos na década de 1950 (ALTICK et al., 2009). Tais estruturas atuam na via de degradação proteolítica e no sorting de proteínas que são direcionadas à membrana (ALTICK et al., 2009).

O RE é constituído por um extensivo complexo de membranas que totalizam $50 \%$ das membranas biológicas celulares, sendo responsável pelo síntese de proteínas, lipídeos e pelo armazenamento do cálcio intracelular (HØYER-HANSEN; JÄÄTTELÄ, 2007; MISSIROLI et al., 2017; WANG; YANG; ZHANG, 2010). O RE confere, ainda, um importante ambiente redox (MCCRACKEN; BRODSKY, 1996) para mudanças pós-traducionais, incluindo dobramento e oligomerização proteica (KAUFMAN, 1999). O RE se comunica diretamente com as mitocôndrias por meio de membranas associadas a mitocôndrias (MAM), que regulam o transporte do cálcio do RE para as mitocôndrias (CROTTÉS et al., 2013; MISSIROLI et al., 2017).

Sob condições patológicas nas quais se verifica uma superexpressão proteica ou o acúmulo de proteínas mal dobradas, o RE torna-se dilatado (HØYER-HANSEN; JÄÄTTELÄ, 2007). Neste sentido, estudos mostram que a oncoproteína E5 dos PVs é capaz de interagir com proteínas presentes na membrana do RE, tais como: a subunidade próton-adenosina trifosfatada de 16 kDa (V-ATPase), proteína Bap31 e calnexina (BOULENOUAR et al., 2010; CONDJELLA et al., 2009; GRUENER et al., 2007). A interação da oncoproteína E5 com a proteína Bap31 leva a acidificação das cisternas do RE, alterando o ambiente redox e, portanto, contribuindo com o acúmulo de proteínas mal dobradas (KAUFMAN, 1999). A oncoproteína E5 forma, ainda, um complexo ternário com o MHC-I e a calnexina, levando ao sequestro de MHC e, reduzindo a resposta imune adaptativa (GRUENER et al., 2007). Tais alterações podem resultar no estresse de RE e, por consequência, na liberação do cálcio armazenado nesta organela. Esta ação ativa a enzima dependente de calmodulina, promovendo alterações no citoesqueleto que contribuem com a aquisição do fenótipo migratório esperado durante a TEM (WEINSTEIN, 1988a). A interação de oncoproteínas virais com a membrana do RE é uma característica também verificada em outros oncovírus, como: flavivírus, HBV (CONDJELLA et al., 2009) e HCV (NEUFELDT et al., 2016; TARDIF; WARIS; SIDDIQUI, 2005).

$O$ estresse de RE também pode ser considerado uma evidência adicional da infecção produtiva in vitro, verificada na seção 6.1.1, uma vez que a montagem das partículas virais dos PVs requer vesículas membranosas (KAUFMAN, 1999; LIN; WALTER; YEN, 2008). Desta forma, o acúmulo de proteínas virais, necessárias para 
a montagem do capsídeo, leva a dilatação das cisternas do $R E$, resultando no estresse verificado nas linhagens celulares derivadas de papiloma cutâneo, fibropapiloma e CE (figura 37). Tal ação deflagra a ativação de diferentes cinases e proteases, levando a autofagia (Bl et al., 2005; HØYER-HANSEN; JÄÄTTELÄ, 2007).

A autofagia é importante processo catabólico no qual proteínas e/ou organelas são degradadas e, os produtos desta catálise são direcionados à biossíntese de macromoléculas ou a obtenção de energia, conferindo um efeito citoprotetor (HANAHAN; WEINBERG, 2011). Os autofagossomos são formados pelo envolvimento de regiões citoplasmática por membranas biológicas que se fundem a endolisossomos, corforme figura 96 (HØYER-HANSEN; JÄÄTTELÄ, 2007). Este processo é comandado pelo fosfoenositol-3-cinase (PI3K) e pela proteína Atg6 (autophage-related protein) (HØYER-HANSEN; JÄÄTTELÄ, 2007).

Figura 96 - Formação de vesículas autofágicas

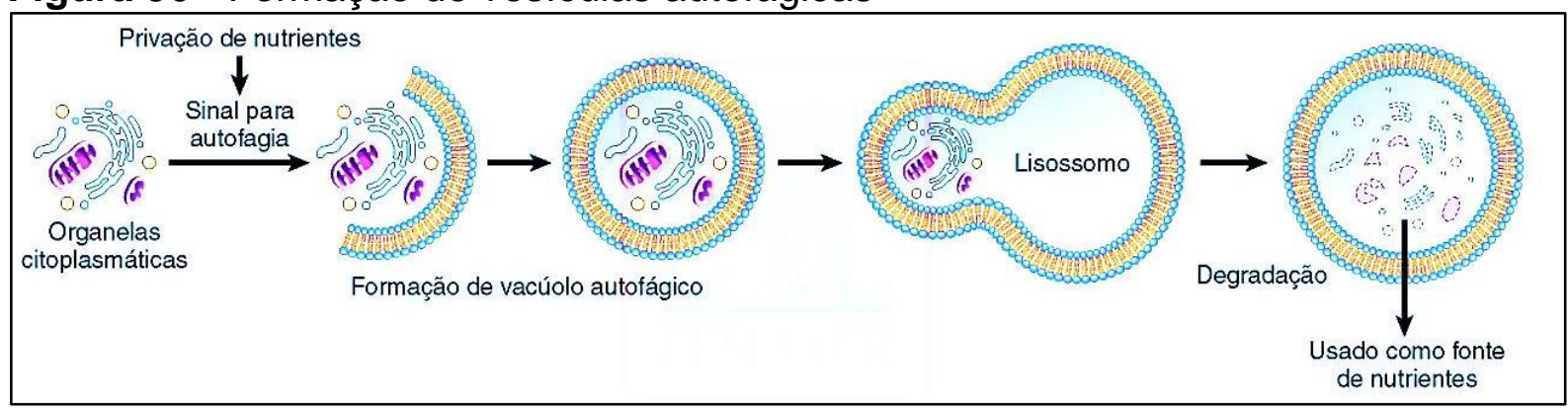

Modelo de formação de vesículas autofágicas, por meio do envolvimento de regiões citoplasmáticas por membrana biológica, resultando na formação de um vacúolo autofágico. Tal vacúolo se associa a lisossomos, resultando no catabolismo de macromoléculas e organelas, cujos produtos atuam como fonte de energia. Fonte: Modificado de Kumar, Abbas, Aster (2013).

A autofagia é comumente verificada na progressão maligna (MCFADDEN et al., 2016) em resposta a privação de nutrientes (DUNN, 1990). Considerando que o meio completo usado no cultivo mimetiza e fornece o aporte de nutrientes para o crescimento celular e que as células derivadas do cultivo primário de pele saudável não apresentaram estresse de RE, tampouco macro-autofagia (figura 37), os resultados sugerem que as alterações ultra-estruturais verificadas nas células derivadas de neoplasias infectadas pelo BPV (figura 37) são decorrentes da interação da oncoproteína E5 com proteínas presentes na membrana do RE. Neste sentido, Russo et al. (2016) mostraram que a oncoproteína E5 do BPV promove a superexpressão do oncogene Eras, que codifica a proteína GTPase, levando a fosforilação e ativação de PI3K, contribuindo com a formação de autofagolissomos. 
A macro-autofagia observada das células derivadas de neoplasias infectdas pelo BPV pode, ainda, promover a catálise de mitocôndrias que reduziram seu $\Delta \Psi_{\mathrm{m}}$ (HØYER-HANSEN; JÄÄTTELÄ, 2007), evitando assim a liberação do citocromo c e, portanto, a apoptose.

\subsection{Avaliação dos níveis de clastogenicidade}

Desde 1998, sabe-se que o BPV é capaz de interagir com a cromatina hospedeira, levando a uma série de alterações citogenéticas, incluindo SSBs e DSBs (ARALDI et al., 2013a, 2015a, MELO et al., 2015, 2011; STOCCO DOS SANTOS et al., 1998). Tais alterações também foram descritas em cultivos primários derivados de papiloma cutâneo, papiloma de esôfago, carcinoma de bexiga urinária (CAMPOS et al., 2013) e papilomas equinos e caninos infectados pelo vírus (SIMÕES; BARTH, 2016).

A fim de avaliar os níveis de clastogenicidade, as seis passagens das diferentes linhagens celulares foram submetidas ao ensaio cometa, método amplamente empregado para avaliar SSBs e DSBs em face de sua elevada sensibilidade (ARALDI et al., 2015a; CIGERCI et al., 2016; PARK; CHOI; AHN, 2016; ROY; MUKHERJEE; GIRI, 2016). Além do mais, este método permite avaliar a integridade do genoma ao longo das passagens, permitindo avaliar a possível influença das condições in vitro na instabilidade genômica e, portanto, na TEM (CARBAJAL-LÓPEZ et al., 2016). Os resultados do ensaio cometa mostraram um elevado número de nucleóides de classe dois nas células derivadas de neoplasias infectadas pelo BPV em relação a pele saudável (tabela 17, figura 39). As análises estatísticas mostraram que a linhagem derivada de cultivo primário de $\mathrm{CE}$ apresentou os maiores níveis de clastogenicidade (tabelas 18 e 19 e figura 40). As linhagens celulares derivadas de fibropapiloma apresentaram níveis intermediários de clastogenicidade (tabelas 18 e 19 e figura 40). Já as linhagens derivadas de pele saudável e papiloma cutâneo apresentaram os menores níveis de clastogenicidade (tabelas 18 e 19 e figura 40). Estes resultados são evidências adicionais de que os fibropapilomas são lesões pré-neoplásicas, reforçando que a desregulação metabólica verificada nestas células tem um papel-chave na iniciação e progressão neoplásica, conforme discutido na seção 7.4.

Com o objetivo de investigar a possível influência das múltiplas passagens (P1-P6) nos níveis de clastogenicidade, foi realizada a regressão linear simples. 
Nesta análise são considerados como significativos valores de coeficientes de correlação $(R)$ entre 0,98 e 1,00. Os resultados desta análise mostraram valores de coeficientes de correlação não significativos $(R<0,95)$ nas linhagens celulares derivadas de cultivos primários de neoplasias infectadas pelo BPV (figura 41). Estes resultados indicam que as condições da manipulação celular não afetam a estabilidade genômica. Desta forma, a clastogenicidade verificada nestas células pode ser atribuída a infecção viral. Entretanto, foi verificada uma uma correlação positiva entre os níveis de clastogenicidade em função das passagens na linhagem de pele saudável ( $R=0,9717$, figura 41 ). Porém, considerando que não foram verificados escores acima de 100 ao longo das passagens das células derivadas de pele saudável (tabela 17), estes resultados mostraram que os efeitos da manipulação celular não são suficientes para induzir a instabilidade genômica e, portanto, a iniciação neoplásica.

Os resultados do ensaio cometa mostraram que as linhagens celulares derivadas de fibropapiloma e CE (tabela 17) apresentam níveis de clastogenicidade semelhantes aqueles observados in vivo (ARALDI et al., 2015a). Resultados semelhantes também foram descritos em blastocistos (CALINISAN et al., 2002) e células da cérvice infectadas pelo HPV (CORTÉS-GUTIÉRREZ et al., 2010, 2012; LEAL-GARZA et al., 2002), sugerindo que a clastogênese é um evento comumente verificado nas infecções pelos PVs. Considerando que as quebras do DNA são eventos-chave para a integração do HPV ao genoma humano (MÜNGER et al., 2004), os resultados sugerem a necessidade de novos estudos que busquem avaliar a possível integração do BPV com o genoma bovino. Além do mais, a clastogênese pode justificar a presença de translocações, inversões e cromossomos em anéis descritas em células infectadas pelo BPV (CAMPOS et al., 2013; MELO et al., 2011; SIMÕES; BARTH, 2016; STOCCO DOS SANTOS et al., 1998), já que tais aberrações citogenéticas são dependentes de quebras no DNA (GORBUNOVA; SELUANOV, 2016; KASAHARA, 2009).

De acordo com o modelo estocástico, as mutações são requeridas na iniciação do processo oncogênico (ZUR HAUSEN, 2009). Porém, após esta etapa, verifica-se uma tendência de fixação das mutações, levando a expansão clonal de células cancerígenas (AMES; GOLD; WILLETT, 1995; VOLGELSTEIN; KINZIER, 1984). Neste sentido, a estabilização de elevados níveis clastogênicos a partir da 
P4, verificado nas linhagens infectadas pelo BPV (figura 41), sugere a fixação de mutações no genoma hospedeiro, levando a instabilidade genômica.

Se por um lado a clastogênese representa um efeito deletério sobre o cromatina hospedeira, podendo levar a inciação do câncer (DUTHIE; HAWDON, 1998; HANAHAN; WEINBERG, 2011; KADAJA et al., 2007; TLSTY et al., 1995) por outro, ela é necessária à replicação viral, uma vez que o BPV se replica por meio de círculo rolante (BRAVO; FELEZ-SANCHEZ, 2015). Desta forma, as quebras no DNA permitem a excisão e recircularização dos genomas virais recém-replicados, uma vez que estes permanecem concatenados. Desta forma, a ação clastogênica verificada neste estudo é mais uma evidência da replicação e manutenção das sequências virais no sistema in vitro, fazendo dos cultivos primários de neoplasias infectadas pelo BPV modelos úteis nos estudos do processo oncogênico associado aos PVs.

\subsection{Análise do potencial mutagênico da oncoproteína E6 do BPV}

Até a presente data, o potencial clastogênico do BPV tem sido atribuído a ação sinérgica das oncoproteína virais (E5, E6 e E7) (ARALDI et al., 2015a; DUENSING et al., 2000; DUENSING; MÜNGER, 2002). Isto porque, estudos baseados nas oncoproteínas E6 e E7 do HPV demonstraram que, juntas, estas oncoproteínas induzem diferentes aberrações cromossômicas, incluindo a presença de pontes anafásicas (DUENSING et al., 2000; DUENSING; MÜNGER, 2002). Entretanto, o aumento dos níveis de EROs verificados nas linhagens celulares infectadas pelo BPV (figura 36) e com níveis aumentados de clastogênese sugere que o estresse oxidativo é uma fonte adicional de DSBs.

Tendo em vista que o estresse oxidativo descreve um processo deletério resultante do aumento dos níveis de EROs frente a uma redução da defesa antioxidante (TURRENS, 2003), os resultados indicam que a oncoproteína E6 possui um papel chave na clastogênese. Isto porque, a E6 reduz os níveis de expressão da enzima SOD2 e da proteína Gpx, reduzindo a defesa anti-oxidante, conforme discutido na seção 7.3. Por esta razão, este estudo também analisou o potencial mutagênico da oncoproteína E6 do BPV per se.

Considerando que a fidedignidade dos resultados dos ensaios de mutagencidade dependem da ausência de infecção viral nas amostras biológicas, já que a presença de sequências de DNA de BPV em PBMCs está associada a 
alterações citogenéticas (MELO et al., 2011; STOCCO DOS SANTOS et al., 1998) e clastogênese (ARALDI et al., 2013a), as cinco amostras de sangue periférico foram submetidas à identificação molecular de sequências virais. Os resultados desta análise mostraram a ausência de sequências de DNA viral nas cinco amostras avaliadas (figura 84), tornando-as elegíveis para os testes mutagênicos.

O teste do micronúcleo (TMN) é um importante biomarcador in vivo e in vitro, extensivamente empregado para o biomonitoramento de populações expostas a agentes genotóxicos (BONASSI et al., 2007; CETINKAYA et al., 2016; DEGEN et al., 1997; SAMANTA; DEY, 2012; SOLONESKI; NIKOLOFF; LARRAMENDY, 2016; TERRADAS et al., 2010). O termo micronúcleo (MN), também conhecido por corpúsculo de Howel-Jolly (KRISHNA; HAYASHI, 2000), foi introduzido em 1951 em referência a fragmentos acêntricos expelidos do núcleo principal nos estágios tardios da anáfase (KIRSCH-VOLDERS et al., 2003). Os MNs são formados por cromossomos inteiros ou fragmentos cromossômicos que não se integram ao núcleo principal da célula durante a divisão (BONASSI et al., 2007; HAYASHI; SOFUNIT; ISHIDATE, 1984; SAMANTA; DEY, 2012). Estes MNs são, então, envelopados por membrana nuclear ao longo da telófase (FENECH, 2000), podendo ser visualizados no citoplasma (KRISHNA; URDA; PAULISSEN, 2000). Desta forma, uma elevada frequência de MNs indica danos cromossômicos (ARALDI et al., 2013b; BONASSI et al., 2007; KRISHNA; URDA; PAULISSEN, 2000).

Uma das vantagens do TMN é a sua versatilidade, posto que o método pode ser realizado tanto in vivo, empregando eritrócitos policromáticos de camundongos (ARALDI et al., 2014c), como in vitro, usando linfócitos binucleados (ARALDI et al., 2015b; FENECH; MORLEY, 1985). O método in vitro, conhecido por teste do micronúcleo com bloqueio de citocinese (TMNBC) não requer a inoculação da substância testada em animais, tampouco exige a eutanásia, estando em consonância com os princípios éticos regulamentados pela Lei Arouca (Lei no 11.794/2008).

Os resultados do TMNBC em sangue periférico mostraram que o grupo controle negativo apresentou o menor número de MNs (tabela 24, figura 86). Este resultado era esperado, pois o diagnóstico molecular mostrou a ausência de sequências de DNA de BPV nas amostras de sangue periférico (figura 84), reduzindo assim a influência de fatores ambientais endógenos que pudessem interferir na análise. Além do mais, o material biológico foi processado após três 
horas de sua coleta, reduzindo a influência de fatores ambientais exógenos que, eventualmente, poderiam promover danos ao DNA. Outro fator que justifica a ausência de danos citogenéticos neste grupo é a ausência da samambaia $P$. aquilinum na propriedade de origem do material biológico. Isto porque, esta samambaia apresenta compostos químicos reconhecidos por seus efeitos mutagênicos e imunossupressores, que poderiam induzir resultados falso-positivos (LEAL et al., 2003; RECOUSO et al., 2003; CARVALHO et al., 2016).

O grupo controle positivo apresentou um elevado número de MNs (tabela 24, figura 86). Tal resultado se deve à ação da ciclofosfamida, quimioterápico e imunossupressor conhecido por seu efeito mutagênico, citotóxico e teratogênico (ANDERSON; YU; MCGREGOR, 1998; BRITO et al., 2008). No entanto, os resultados estatísticos dos testes do Qui-quadrado (tabela 25) e post-hoc de Dunn (tabela 26) indicaram que a oncoproteína E6 do BPV apresenta um potencial mutagênico semelhante ou superior àquele observado com a ciclofosfamida. Isto porque o grupo tratado com a oncoproteína apresentou uma frequência de formação de micronúcleos ( $\mathrm{MN}_{\mathrm{r}}$ ) 14,003\% superior ao grupo tratado com o quimioterápico. Estes resultados também foram descritos em células epiteliais (CRIB), indicando a ação mutagênica da oncoproteína E6 (figuras 89 e 90).

Somado a estes resultados, foi verificado que as células tratadas com a oncoproteína E6 do BPV apresentaram um aumento do número do pontes anafásicas (tabela 24), alteração citogenética decorrente das DSBs (ACILAN; POTTER; SAUNDERS, 2007). A presença destas pontes anafásicas foi também descrita em células transfectadas com adenovírus contendo as ORFs E6 e E7 de HPV (DUENSING et al., 2000; DUENSING; MÜNGER, 2002), reforçando as semelhanças patogênicas da E6 do BPV com o HPV.

Outra vantagem do TMNBC é que o método permite avaliar a cinética de divisão celular por meio do índice de proliferação com bloqueio de citocinese (IPBC), calculado com base no número de linfócitos mono, bi e polinucleados. O IPBC mostrou que a oncoproteína E6 apresenta uma ação hiperproliferativa, verificada pelo aumento do número de linfócitos bi e polinucleados (figura 87). Estes resultados mostram, pela primeira vez, que oncoproteína E6 do BPV apresenta uma ação proliferativa homóloga a oncoproteína E7. Somados a este resultado, foi verificada a presença de células "gigantes", polinucleadas e apresentando citocinese intercelular nos linfócitos tratados com a oncoproteina recombinante E6 do BPV-1 (figura 88). 
A citocinese intercelular (endorreduplicação) foi amplamente discutida como uma evidência de catástrofe mitótica (ERENPREISA; CRAGG, 2007). No entanto, de acordo com um estudo recente, ela indica um novo modelo de divisão celular conhecido por neose (SUNDARAM et al., 2004). Este mecanismo de divisão celular é verificado em células com: (1) danos no DNA, (2) perda de controle de checkpoint, (3) instabilidade genômica, (4) erros de reparo como consequência da recombinação homóloga ou não homóloga e (5) endorreplicação (SUNDARAM et al., 2004). Neste sentido, as células tratadas com a oncoproteína E6 apresentaram as cinco características necessárias à neose. Isto porque, os resultados do TMNBC mostraram que a E6 induz a formação de MNs, resultando em danos no DNA e, portanto, em instabilidade genômica. Somado a isto, a oncoproteína E6 promove o silcenciamento epigenético do gene TP53, resultando na perda de controle de checkpoints (ZIMMERMANN et al., 2000), ao mesmo tempo em que se liga as junções de Holliday durante a recombinação homóloga, impedindo a resolução desta (RISTRIANI et al., 2000). Esta ação impede o reparo de DSBs, contribuindo com a fixação de mutações e, portanto, favorece a instabilidade genômica.

Desta forma, o potencial neótico e o elevado IPBC verificado nas células tratadas com a oncoproteína E6 do BPV demonstra, pela primeira vez, o potencial hiperproliferativo desta oncoproteína. Tais resultados indicam, portanto, que a oncoproteína E6 do BPV apresenta uma ação homóloga a E7. O potencial hiperproliferativo da oncoproteína E6 emerge como uma consequência indireta da interação desta oncoproteína com o complexo CBP/p300 (MANTOVANI; BANKS, 2001). Se por um lado esta interação é necessária para silenciar a expressão da p53, favorecendo a replicação viral, por outro, ela promove a expressão do fator de transcrição FoxM1 (Foxhead box M1) (CHEN; LEE, 2015). Esta ação resulta na superexpressão da ciclina B1, D1 e fosfatase Cdc25, levando a proliferação celular (CHEN; LEE, 2015), justificando o aumento do número de células na fase $\mathrm{S}$, verificiado na seção 6.2. O fator FoxM1 promove, ainda, a translocação nuclear da $\beta$-catenina, levando a expressão de vimentina e $\alpha$-SMA (HU et al., 2015; ZHANG et al., 2012). Tal ação contribui com a perda da adesão celular e aquisição de fenótipo tronco, características estas observadas durante a TEM. Tais ações podem ser potencializadas pela interação da região de ligação da oncoproteína E6 de HPVs a proteínas com domínio PDZ como Dlg e ZO-1 (BOON et al., 2015; MISCHO et al., 
2013; WATSON et al., 2003), que leva a expressão da vimentina, verificada neste estudo (seções 6.1.6.3 e 6.2.3.7).

A fim de avaliar o potencial clastogênico da oncoproteína com maior sensibilidade, foi realizado o ensaio cometa. Os resultados deste ensaio mostraram que a oncoproteína E6 do BPV é capaz de induzir quebras no DNA (SSBs e DSBs) (figuras 91 e 92), contribuindo para a instabilidade genômica e, portanto, para a iniciação neoplásica. Tais resutados demonstram que a oncoproteína E6 do BPV é um potente clastógeno, justificando as quebras no DNA verificadas nas linhagens celulares infectadas pelo BPV (figura 39).

Até a presente data, o potencial clastogênico do BPV tem sido atribuído a interação da proteína E1 do BPV com a topoisomerase I (SCHUCK; STENLUND, 2015) que, associada a ação hiperproliferativas das oncoproteínas E5, E6 e E7, levam ao colapso das forquilhas de replicação (ARALDI et al., 2015a; PARK; CHOI; AHN, 2016). Neste sentido, este estudo mostrou que a oncoproteína E6 do BPV é capaz de induzir danos no DNA per se.

A ação clastogênica da E6 se deve a sua atividade pró-oxidante, decorrente da repressão transcripcional das enzimas SOD2 e Gpx, que leva ao aumento dos níveis de EROs (figura 83). As EROs são reconhecidas por promover DSBs, confirgurando o tipo mais grave de dano genético (PASTINK; LOHMAN, 1999; SNYDER; GREEN, 2001). Entretanto, as DSBs podem ser reparadas por meio da recombinação homóloga $(\mathrm{RH})$ ou não homóloga $(\mathrm{RNH})$. Estes mecanismos de reparo aumentam os níveis de expressão da histona $\mathrm{H} 2 \mathrm{AX}$, uma variante da família de histonas $\mathrm{H} 2 \mathrm{~A}$ altamente conservada, permitindo o reparo de DSBs (PARK; CHOI; AHN, 2016; WEYEMI et al., 2016). Entretanto, o aumento dos níveis de EROs levam a superexpressão do fator de transcrição SLUG (figura 52) que promove a repressão transcripcional da histona H2AX (WEYEMl et al., 2016). Somado a esta ação, estudos mostram que a interação da oncoproteína E6 com a junção de Holliday durante o $\mathrm{RH}$ impede a resolução desta (RISTRIANI et al., 2002). Tais ações impedem o reparo das DSBs, resultando na instabilidade genômica. Isto porque, o silenciamento epigenético do gene TP53, decorrente da interação da oncoproteína E6 com o complexo CBP/p300 (ZIMMERMANN et al., 2000), resulta na inabilidade de promover a apoptose de células mutadas. Estas ações contribuem tanto com a iniciação do processo oncogênico como com a heterogeneidade genômica dos tipos celulares que compõe o microambiente neoplásico. 
Em resumo, os resultados mostraram que o estresse oxidativo induzido pela oncoproteína E6 promove a oxidação de nucleotídeos, levando a clastogênese. Estes efeitos são acentuados pela atividade hiperproliferativa das oncoproteínas E5 e E7, que leva a repetições em tandem no DNA (PYEON et al., 2009) e pela interação da oncoproteína E1 com a topoisomerase I promove o colapso das forquilhas de replicação (SCHUCK; STENLUND, 2015). Juntas estas ações resultam no estresse mitótico (BOYER; WALTER; SØRENSEN, 2016), evidenciado pela ação neótica da oncoproteína E6 (figura 88), levando a clivagem de endonucleotídeos e, portando, em DSBs. (BERTI; VINDIGNI, 2016; NEGRINI; GORGOULIS; HALAZONETIS, 2010).

Desta forma, células infectadas pelo BPV podem apresentar danos no material genético suficientes para promover a apoptose ou sobreviver, mesmo na presença de alterações genéticas/cromossômicas, levando a instabilidade genômica e a iniciação neoplásica, conforme figura 97. 
Figura 97 - Modelo do potencial mutagênico do BPV

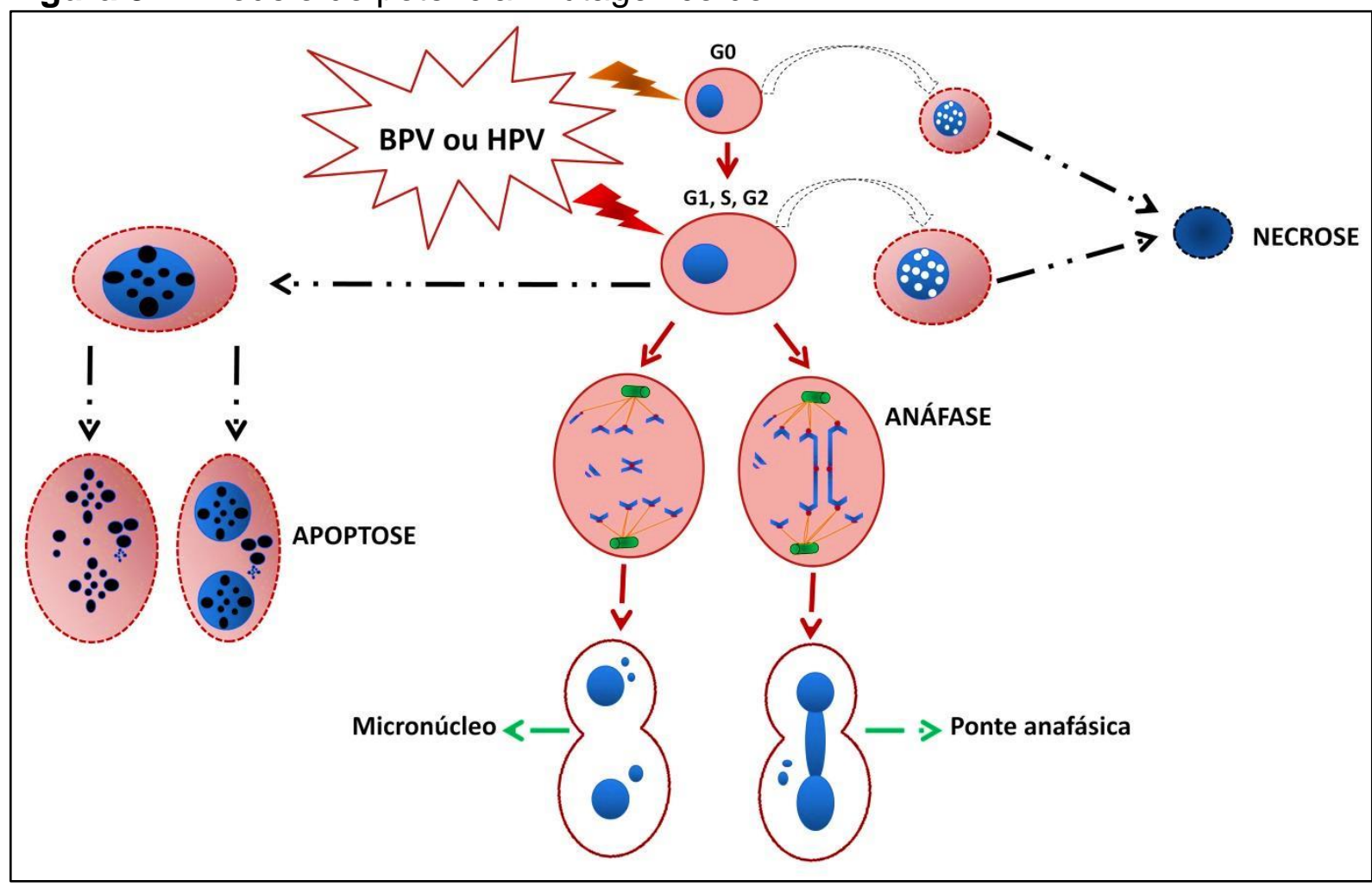

As oncoproteínas do BPV ou HPV inzudem o aumento dos níveis de EROs, mesmo em células quiescentes $\left(G_{0}\right)$, ao mesmo tempo que promovem um estímulo hiperproliferativo, resultando no colapso das forquilhas de replicação, induzindo quebras duplas no DNA (DSBs) na fase S. Tais ações resultam na clastogênese, evidenciada pela presença de micronúcleos. Sob condições fisiológicas, a célula poderia corrigir tais danos por meio do sistema de reparo ou, ativar mecanismos apoptóticos ou necróticos, resultando na morte celular. Porém, células infectadas pelo BPV ou HPV evadem os mecanismos de reparo ou apoptose. Isto porque, a oncoproteína E6 reduz os níveis da p53 e se liga às junções de Holliday durante o reparo ilegítimo (não homólogo), ao mesmo tempo em que reduz os níveis de p53 por meio de hipoacetilação de histonas (BPV) ou ubiquitinação da proteína (HPV), evadindo mecanismos de checkpoint.

\subsection{Aquisição de fenótipo-tronco}

As células-tronco adultas ocupam diferentes nichos, sendo responsáveis pela manutenção dos tecidos e órgãos. No entanto, eventos mutagênicos, tais como a clastogenicidade verificada nas linhagens celulares derivadas de neoplasias infectadas pelo BPV (seção 6.1.4), podem resultar na formação de células com fenótipo tronco, conhecidas por células-tronco cancerígenas (CTCs) (WIDSCHWENDTER et al., 2007).

As CTCs reprimem, de forma reversível, a expressão de genes associados a diferenciação celular (MASSAGUÉ; OBENAUF, 2010; WIDSCHWENDTER et al., 2007) e passam a se dividir de forma assimétrica (NEUMÜLLER; KNOBLICH, 2009). A divisão assimétrica favorece a clonogenicidade de células transformadas, orginando células-filhas com tamanho e grau de diferenciação distintos (DEY-GUHA 
et al., 2011), que contribuem com a manutenção da heterogeneidade (VICENTEDUEÑAS et al., 2009) e plasticidade do microambiente neoplásico (VON JOEST; BUA; LI, 2016).

De acordo com Marcucci, Stassi e De Maria (2016), células em TEM adquirem um fenótipo semelhante a CTCs (CTC-like) como consequência da ativação das vias de PI3K e AKT. A aquisição do fenótipo CTC-like confere resistência à apoptose, garantindo assim a sobrevivência celular durante os processos de invasão de metastatização (CLARKE; FULLER, 2006; MOORE; HOUGHTON; LYLE, 2012). Neste sentido, a ação pró-oxidante da oncoproteína E6 do BPV, verificada na seção 6.2.1, pode levar a ativação das vias de PI3K e AKT, resultando na aquisição do fenótipo CTC-like. Somado a isto, a clastogênese descrita na seção 6.1.4 pode levar a instabilidade genômica e, por consequência, a aquisição do fenótipo-tronco. Baseado nestes dados, a capacidade de formação de tumoresferas das diferentes linhagens celulares foi avaliada pelo ensaio de tumoresfera, método este reconhecido como "padrão-ouro" na pesquisa de CTC (CHANG et al., 2013). Os resultados deste ensaio mostraram que as linhagens celulares derivadas de cultivos primários de papiloma cutâneo, fibropapiloma e CE foram capazes de formar tumoesferas, sugerindo a aquisição do fenótipo-tronco (figura 42). A linhagem celular derivada do cultivo primário de pele saudável não infectada pelo BPV, por sua vez, não foi capaz de formar tumoesferas (figura 42A).

Tendo em vista que a aquisição do fenótipo CTC-like é sempre verificada durante a TEM (AGUILAR et al., 2016; RADISKY; LABARGE, 2008), os níveis de expressão do fator de transcrição nuclear Oct-3/4 (POU5F1) foram adicionalmente avaliados. Isto porque, a ligação deste fator de transcrição na sequência motivo AGTCAAAT, presente em genes alvos, contribui com a manutenção do fenótipo tronco (MATOBA et al., 2006; PAN et al., 2002; URA et al., 2008). Os resultados desta análise mostraram uma expressiva marcação citoplasmática e perinuclear do fator de transcrição Oct-3/4 nas células derivadas do cultivo primário de pele saudável não infectada pelo BPV, não sendo observada a imunodetecção nuclear deste fator (figura 43). As células derivadas do cultivo primário de papiloma cutâneo, fibropapiloma e CE, por sua vez, apresentaram um aumento do sinal de fluorescência, bem como a imunomarcação nuclear do fator Oct-3/4 (figura 43). 0 aumento dos níveis de expressão deste fator foi também verificado por meio de CF, que confirmou o aumento do percentual de células expressando Oct-3/4 nas 
linhagens derivadas de neoplasias infectadas pelo BPV (figura 44). Tais resultados foram confirmados pela IHQ-P, que mostrou a imunomarcação nuclear do fator Oct3/4 em queratinócitos e células epitelióides presentes na derme do papiloma cutâneo e fibropapilomas (figura 78). Interessantemente, as células apresentando marcação nuclear deste fator de transcrição mostraram a perda de polarização apical-basal (figura 78), sendo esta mais uma evidência da aquisição da participação do fator Oct-3/4 na TEM. Porém, não foi verificada a imunomarcação de Oct-3/4 no CE (figura 78). Tal resultado pode ser atribuído ao elevado número de células em proliferação observadas nesta amostra (figura 78). Isto porque, a aquisição do fenótipo-tronco está diretamente relacionado com a inibição do potencial proliferativo.

Desta forma, os resultados combinados do ensaio de tumoresferas e a imunodetecção do fator Oct-3/4 sugerem que as linhagens celulares derivadas de cultivos primários de neoplasias infectadas pelo BPV adquirem um fenótipo CTC-lke. A aquisição deste fenótipo pode ser discutida como uma consequência do aumento dos níveis de EROs verificados nestas células (figura 36) e o aumento da instabilidade genômica (figuras 39 e 40), causada pela oxidação das bases nitrogenadas, bem como pelo estresse das forquilhas de replicação, decorrente da ação proliferativa sinérgica das oncoproteinas E5, E6 e E7 do BPV.

A aquisição do fenótipo CTC-like tem importantes implicações na patogênese viral. Isto porque, tal fenótipo confere resistência à apoptose, inclusive de células geneticamente instáveis, favorecendo a clonogenicidade de células iniciadas e transformadas. Neste cenário, a redução dos níveis de expressão da proteína p53 confere uma ação anti-apoptótica adicional, impedindo a translocação da proteína Bax do complexo de Golgi para a mitocôndria (TESLAA; SETOGUCHI; TEITELL, 2016). Juntas, estas ações levam à instabilidade genômica (DENISENKO et al., 2016) e ao aumento do estatus entrópico (CSERMELY et al., 2014), conferindo resistência a anoikis (MASSAGUÉ; OBENAUF, 2010), crucial à sobrevivência da célula ao longo do processo de metastatização para órgãos distantes. Isto porque, durante o processo de migração, as células serão expostas a uma miríade de eventos que poderiam levar a morte. Além do mais, a desdiferenciação verificada durante a aquisição do fenótipo CTC-like confere um importante mecanismo de evasão imune, já que estas células reduzem a expressão de certos cluster differentiation (CDs) que poderiam levar a morte celular. 
Se por um lado a aquisição do fenótipo-tronco se faz necessária à metastatização, por outro ela possui efeitos clínicos que desafiam a habilidade citotóxica de quimioterápicos, bem como e eficácia da radioterapia (CHANG et al., 2013; LIANG et al., 2010). Considerando o BPV como modelo de estudo do HPV, a aquisição do fenótipo CTC-like, verificado neste estudo, pode justificar a baixa taxa de cura pelo CE em humanos, a qual se restringe a apenas $10 \%$ dos pacientes diagnosticados com a doença (FELIN et al., 2008). Isto porque, a presença de CTClike confere resistência a radioterapia, terapia preconizada para o tratamento do CE associado ao HPV (GILLISON et al., 2000; MORK et al., 2001; SETTLE et al., 2009).

Em última análise, a presença de CTC-like no microambiente neoplásico é uma evidência do processo microevolutivo do câncer. Isto porque, evolução pode ser definida pela "capacidade de gerar variação fenotípica herdável" (CSERMELY et al., 2014). Desta forma, os resultados mostram que as alterações fenotípicas verificadas na TEM são necessárias à mestastatização sendo que, após a extravasão para órgãos, as células tendem a retornar para um estado diferenciado, permitindo a colonização de sítios distantes (MASSAGUÉ; OBENAUF, 2010).

\subsection{Análise do nível de expressão de marcadores associados a TEM}

\subsubsection{Citoqueratina 10 (CK10): Marcador epitelial}

As citoqueratinas compõem a principal classe de proteínas estruturais expressa no tecido epitelial (VAN MUIJEN; WARNAAR; PONEC, 1987). Mais de 20 diferentes citoqueratinas já foram descritas (CARRILHO et al., 2004; VAN MUIJEN; WARNAAR; PONEC, 1987), as quais são classificadas de acordo com a Human Genome Organization (HUGO) com base no gene que as expressam (MOLL; DIVO; LANGBEIN, 2008). Tais citoqueratinas são divididas em: tipo I (polipeptídios ácidos, com peso molecular de 40-56 kDa, CK9-20) e tipo II (polipeptídios básicos a neutros, com peso de 53-68 kDa, CK1-8) (BARAK et al., 2004; MOLL; DIVO; LANGBEIN, 2008).

As citoqueratinas são expressas de forma multigênica (BARAK et al., 2004; MOLL; DIVO; LANGBEIN, 2008), sendo evolutivamente conservadas entre humanos e bovinos (RIEGER; FRANKE, 1988). Uma vez expressos, os monômeros de citoqueratina são rapidamente degradados (BARAK et al., 2004). Por este motivo, queratinas de tipo I e II se ligam por meio de ligações covalentes formando heterodímeros, que conferem estabilidade a estas proteínas (BARAK et al., 2004; 
MOLL; DIVO; LANGBEIN, 2008; RIEGER; FRANKE, 1988). As citoqueratinas compõem a rede de filamentos intermediários, constituindo os hemidesmossomos e desmossomos que conferem estabilidade mecânica às células (MOLL; DIVO; LANGBEIN, 2008).

O uso de anticorpos anti-citoqueratinas tem sido amplamente empregado na rotina histopatológica, uma vez que alterações nos níveis de expressão destes polipeptídios são verificadas em carcinomas (BARAK et al., 2004; CARRILHO et al., 2004; PÉREZ-MARTÍNEZ et al., 2001; YANG et al., 2008; ZAVIZION et al., 1996). Além do mais, alterações na expressão de citoqueratinas estão associadas às metástases em humanos (BARAK et al., 2004; YANG et al., 2008) e bovinos (PÉREZ-MARTÍNEZ et al., 2001), fazendo destas proteínas importantes marcadores prognósticos desde 1980 (BARAK et al., 2004; MOLL; DIVO; LANGBEIN, 2008; YANG et al., 2008).

Dentre as citoqueratinas conhecidas, a CK10 se destaca por ser um marcador de diferenciação celular, sendo expresso da camada suprabasal à córnea (BUCHANAN et al., 1998; CARRILHO et al., 2004; MADDOX et al., 1994). Por se tratar de um biomarcador tumoral expresso em células diferenciadas, os níveis de expressão da CK10 foram analisados. Os resultados desta análise mostraram um expressivo aumento dos níveis de expressão de CK10 nas linhagens celulares derivadas de cultivo primário de papiloma cutâneo e CE (figura 46). Embora a IHQ-P tenha mostrado uma expressiva imunomarcação de CK10 na amostra de papiloma cutâneo, foi verificada uma redução da expressão deste marcador no tecido de CE (figura 76). Considerando que as células de CE se mostraram co-infectadas pelo tipos virais BPV-1 e 2, que apresentam fibrotropismo, a reduzida imunomarcação de CK10 no tecido de CE pode ser atribuída ao fibrotropismo viral, justificando assim o aumento potencial proliferativo verificado tanto na linhagem celular derivada do cultivo primário de CE (figura 31), como pelas imagens de células em proliferação descritas na figura 78. Já o aumento do percentual de células expressando CK10 tanto na linhagem celular de CE pode ser justificado pelo caráter epiteliotrópico do BPV-4.

As linhagens celulares derivadas de cultivo primário de fibropapiloma, por sua vez, apresentaram níveis de expressão de CK10 semelhantes a pele saudável não infectada pelo vírus (figura 46). Resultados estes também verificados pela IHQ$\mathrm{P}$, que mostrou uma reduzida imunomarcação de CK10 no epitélio dos 
fibropapilomas, mesmo na presença da acantose (figura 76). Considerando a ação proliferativa do vírus, descrita na figura 31, os resultados da imunodetecção da CK10 reforçam o fibrotropismo do BPV descrito em fibropapilomas. Embora os resultados do Western blot não tenham permitido demostrar a especificidade do anticorpo antiCK10 (figura 64), uma vez que o anticorpo não é indicado para Western blot, o elevado grau de conservação evolutiva entre a CK10 bovina e humana permite confirmar a fidedignidade dos resultados obtidos (RIEGER; FRANKE, 1988).

\subsubsection{Switch gênico das caderinas}

As caderinas são glicoproteínas transmembrana unipasso, com peso molecular de 120-140 kDa (FRIXEN et al., 1991) que participam da adesão intercelular homotípica cálcio-dependente, conforme figura 98 (BREMNES et al., 2002; HAJRA; CHEN; FEARON, 2002). Atualmente, mais de dez diferentes grupos de caderinas são conhecidas, as quais são classificadas de acordo com o tecido em que se expressam (BREMNES et al., 2002). Dentre estas, a E-caderina, também conhecida por uvomorulina, Arc-1, célula-CAM 120/80 ou L-CAM, tem sido amplamente estudada na oncologia (BREMNES et al., 2002; FRIXEN et al., 1991). Isto porque, a redução dos níveis de expressão desta glicoproteína é observada tanto in vivo quanto in vitro durante a carcinogênese (ONDER et al., 2008), estando associada a um pior prognóstico (BRINGUIER et al., 1993; PERL; WILGENBUS; CHRISTOFORI, 1998; UMBAS et al., 1994). 
Figura 98 - Junção de aderência mediada pela E-caderina

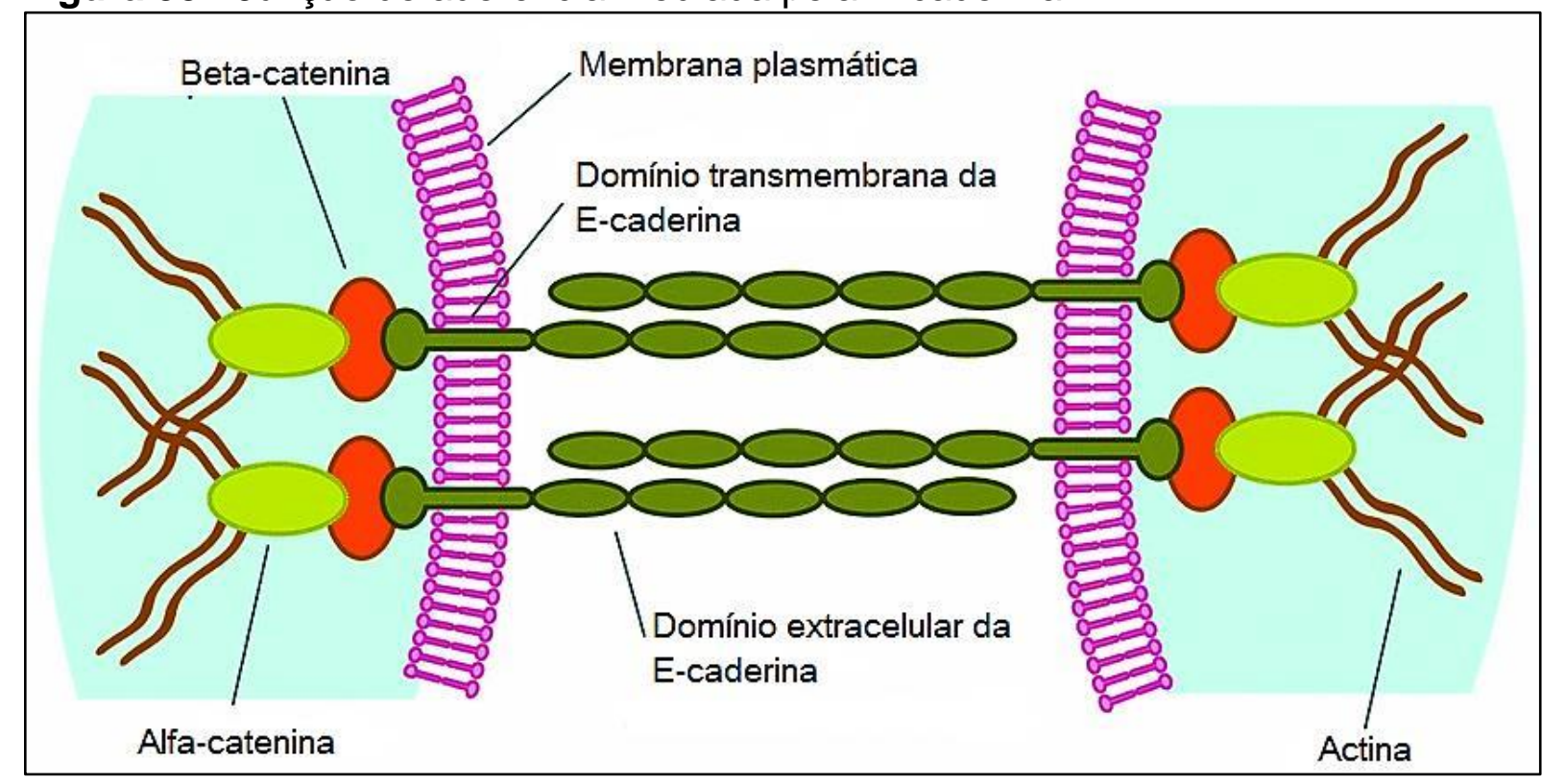

Modelo esquemático da junção de aderência mostrando a interação do domínio transmembrana da Ecaderina com proteínas citosólicas ( $\beta$-catenina, $\alpha$-catenina e citoesqueleto de actina). Porção extracitosólica estabelece ligação de forma dependente de cálico, resultando na junção de aderência. Fonte: Modificado de Perry et al. (2010).

A redução dos níveis de E-caderina é, frequentemente, acompanhada pelo aumento dos níveis de expressão da $\mathrm{N}$-caderina, efeito este resultante do switch gênico destas glicoproteínas (DEFAMIE; CHEPIED; MESNIL, 2014; LEE et al., 2006; LEE; NELSON, 2012; THIERY, 2002). O aumento dos níveis de expressão da Ncaderina e a redução dos níveis da E-caderina resulta na redução da adesão intercelular, favorecendo a aquisição do fenótipo migratório (DEFAMIE; CHEPIED; MESNIL, 2014; ONDER et al., 2008). Por esta razão, o switch gênico destas caderinas é apontado como um marcador da TEM (DEFAMIE; CHEPIED; MESNIL, 2014; ONDER et al., 2008).

Com base nestes dados, os níveis de expressão destas glicoproteínas foram avaliados. Os resultados destas análises mostraram um aumento dos níveis de expressão da E-caderina nas linhagens celulares derivadas de cultivos primários de papiloma cutâneo e fibropapiloma (figura $48 \mathrm{H}$ ). Estes resultados reforçam o caráter benigno destas neoplasias. No entanto, a linhagem celular derivada de CE mostrou uma expressiva redução dos níveis de expressão da E-caderina em relação a pele saudável não infectada pelo BPV (figura $48 \mathrm{H}$ ). Porém, as linhagens celulares derivadas de cultivos primários de neoplasias infectadas pelo BPV apresentaram uma expressiva imunomarcação nuclear e perinuclear da E-caderina (figura 47), sugerindo o sequestro citoplasmático desta glicoproteína. Tal ação pode ser 
atribuída às alterações do tráfego vesicular decorrentes da interação da oncoproteína E5 do BPV com o complexo de Golgi (BALCOS et al., 2008; BURKHARDT et al., 1989; ROBERTS, 2015), verificada pela imunomarcação desta oncoproteína viral nas amostras de papiloma cutâneo, fibropapiloma e CE (figura 75).

O complexo de Golgi é um importante sítio de processamento proteico póstraducional para diferentes proteínas, incluindo a E-caderina (DELVA; KOWALCZYK, 2009; GENG et al., 2012). Neste sentido, estudos mostram que a oncoproteína E5 pode se ligar a $\mathrm{H}^{+}$-ATPase (BURNETT; JAREBORG; DIMAIOT, 1992), resultando na alcalinização da membrana interna do complexo de Golgi e, por consequência, no sequestro de proteínas (KRAWCZYK et al., 2010).

Porém, quando no citosol, a E-caderina pode ser clivada e, os produtos desta clivagem podem ser translocados para o núcleo, aonde atuam como regulares da transcrição gênica (MASFERRER et al., 2015). Tal fato pode justificar a imunomarcação nuclear da E-caderina verificada nas linhagens celulares derivadas de papiloma cutâneo, fibropapiloma e CE (figura 47). Contudo, a reduzida imunomarcação da E-caderina junto a membrana plasmática, verificada nestas linhagens celulares (figura 47), contribui com a perda de adesão intercelular e, portanto, com a perda da homeostasia tecidual (GOTTARDI; WONG; GUMBINER, 2001; SEMB; CHRISTOFORI, 1998). Isto porque, a perda de adesão favorece a proliferação celular, justificando o aumento do percentual de células nas fases $\mathrm{S}$ e $\mathrm{G}_{2}-\mathrm{M}$ observado nas linhagens celulares derivadas de cultivos primários de neoplasias infectadas pelo BPV (figura31). Além do mais, a redução da E-caderina na membrana plasmática promove a imunomodulação do micro-ambiente neoplásico, já que esta glicoproteína medeia a adesão de queratinócitos com células de Langerhans, que constituem as únicas células apresentadoras de antígenos (APC) residentes na epiderme (CABERG et al., 2008; D'COSTA et al., 2012; LEONG et al., 2010). Desta forma, se por um lado a redução da adesão intercelular pode favorecer a TEM, por outro ela pode ser discutida como uma adaptação co-evolutiva do vírus, favorecendo a persistência da infecção viral.

Entretanto, a redução dos níveis da E-caderina, verificada nas células derivadas de CE (figura $48 \mathrm{H}$ ) pode ser atribuída a expressão aberrante do fator de transcrição SLUG observada nestas mesmas células (figura $52 \mathrm{H}$ ). Isto porque, este fator pode se ligar a região E-box, reprimindo a transcrição da E-caderina (BATLLE 
et al., 2000; YOSHIDA et al., 2009). Neste sentido, há fortes evidências na literatura de que vírus de DNA dupla-fita, como os PVs, são capazes de regular a adesão celular por meio da modulação da E-caderina (D'COSTA et al., 2012). Estudos baseados no HPV, por exemplo, mostram que as oncoproteínas E6 e E7 reduzem a expressão desta glicoproteína (CABERG et al., 2008; D'COSTA et al., 2012; LAURSON et al., 2010; LEONG et al., 2010; MORRISON et al., 2011). Isto porque a E6 promove a metilação do resíduo nove da lisina da histona nucleossômica H3, originando uma região heterocromática no locus gênico da E-caderina (D'COSTA et al., 2012), ao passo que a E7 aumenta os níveis de DNMT1, formando 5metilcitosina em ilhas CpG (D'COSTA et al., 2012; LAURSON et al., 2010). Trabalhos também mostram que o silenciamento gênico de E7 por meio da inserção de stop codon (LAURSON et al., 2010) ou da introdução de RNA de interferência (RNAsi) levam ao aumento dos níveis de expressão de E-caderina em células infectadas por HPV-16 (CABERG et al., 2008).

Considerando que mesmo em face da redução dos níveis da E-caderina nas células derivadas de CE foi verificada uma expressiva imunomarcação nuclear e perinuclear desta glicoproteína e, que a $\beta$-catenina livre regula 0 tráfego de caderinas (DELVA; KOWALCZYK, 2009), os níveis de expressão da $\beta$-catenina foram avaliados por CF. Porém, os resultados desta análise se mostraram inconclusivos. Isto porque, as linhagens celulares derivadas de cultivos primários de papiloma cutâneo e fibropapiloma apresentaram uma redução dos níveis de $\beta$ catenina, ao passo que a linhagem derivada de CE mostrou níveis de expressão semelhantes a pele saudável (apêndice 2). Entretanto, através da IHQ-P, foi verificada a imunomarcção nuclear da $\beta$-catenina na amostra de papiloma cutâneo e CE (figura 77).

Sob condições normais, a $\beta$-catenina se encontra na membrana plasmática (RODRIGUES et al., 2013), aonde se liga a E-caderina e a-catenina, participando das junções de aderência cálcio-dependentes (PEREZ-PLASENCIA; DUENASGONZALEZ; ALATORRE-TAVERA, 2008). Porém, estímulos migratórios induzem a superexpressão da $\beta$-catenina seguida de sua translocação nuclear (HU et al., 2015; MIR et al., 2007). No núcleo, a porção amino-terminal da $\beta$-catenina é capaz de se ligar a sequências alvo do DNA (WILLERT; NUSSET, 1998), levando a expressão de ciclina D1 e $c-M y c$, que conferem capacidade proliferativa e de geração de células com fenótipo tronco (KOAY; CROOK; STEWART, 2012; MIR et al., 2007). 
Porém, a ação regulatória dos PVs na expressão da $\beta$-catenina permanece inconclusiva. Isto porque, se por um lado estudos demonstram uma redução dos níveis de expressão da $\beta$-catenina em amostras de carcinoma cervical (KOAY; CROOK; STEWART, 2012) e vulvar associados ao HPV (RODRIGUES et al., 2013), por outro lado, trabalhos descrevem um aumento de até $73 \%$ nos níveis de expressão deste marcador em amostras de carcinoma cervical (PEREZPLASENCIA; DUENAS-GONZALEZ; ALATORRE-TAVERA, 2008) e linfonodos metastáticos de carcinoma tonsilar associado ao HPV-16 (STENNER et al., 2011). Neste cenário, uma possível justificativa para a divergência dos resultados pode ser atribuída ao fato da desregulação da via de $W n t / \beta$-catenina estar restrita a células no fronte de invasão. Isto porque, estudo baseado em IHQ-P mostrou um aumento dos níveis de $\beta$-catenina em linfonodos metastáticos, mas não no centro do tumor (STENNER et al., 2011).

Curiosamente, a redução dos níveis da E-caderina nas células derivadas de CE não foram acompanhados do aumento da expressão da N-caderina, mas sim da redução dos níveis desta glicoproteína (figura $54 \mathrm{H}$ ). Em contrapartida, as células derivadas de papiloma cutâneo e fibropapiloma mostraram um expressivo aumento dos níveis de $\mathrm{N}$-caderina em relação a pele saudável não infectada pelo BPV (figura $54 \mathrm{H}$ ). No entanto, foi verificada a co-marcação da N-caderina e F-actina em sítios de lamelipoidia, observados nas linhagens celulares derivadas de neoplasias infectadas pelo BPV (figura 53). Tais linhagens também mostraram a imunomarcação citoplasmática e nuclear de $\mathrm{N}$-caderina (figura 53), reforçando a participação da oncoproteína E5 no sequestro citoplasmático das caderinas. Estes resultados foram confirmados pelas análises imunoistoquimicas, que mostraram a imunomarcação citoplasmática e perinuclear da $\mathrm{N}$-caderina nas amostras de fibropapiloma (figura 80). Somado a estes dados, foi verificada uma redução da imunomarcação da Ncaderina em áreas de atipia, descritas no papiloma cutâneo (figura 80), bem como em ilhas mestastáticas do CE (figura 80). A especificidade dos anticorpos anti-Ecaderina e anti-Ncaderina foi confirmada por meio de Wester blot, que mostrou a presença de uma única banda com 120 e 140 kDa, respectivamente (figura 61).

Estes resultados sugerem que as células infectadas pelo BPV não apresentam o switch gênico das caderinas, mas sim alterações no tráfego vesicular que impedem que estas glicoproteínas atinjam a membrana plasmática. Somado a isto, os resultados sugerem que a redução dos níveis de expressão da E-caderina 
somente é verificado após a transformação maligna, quando se verifica a expressão aberrante (figura 52H) e a translocação nuclear do fator SLUG (figura 53). No entanto, a redução da E-caderina junto a membrana plasmática contribui com a perda da adesão, favorecendo a proliferação celular e persistência da infecção viral.

\subsubsection{Fator de transcrição nuclear STAT3 Y705}

A família STAT (Signal Transducer and Activator of Transcription) é composta por importantes fatores induzíveis de transcrição, sendo eles: STAT1, STAT2, STAT3, STAT4, STAT5A, STAT5b e STAT6 (SHUKLA et al., 2010). Tais fatores integram o sinal de citocinas presentes no meio extracitosólico com o núcleo, regulando a transcrição de genes STAT-responsivos (JOHNSTON; GRANDIS, 2011; LIN et al., 2011), levando a proliferação, sobrevivência, diferenciação, apoptose, migração, angiogênese e resistência a anoikis (SHUKLA et al., 2010). Dentre os membros desta família, o fator STAT3 tem sido amplamente estudado, sobretudo em cultura de células, devido sua participação em todos os estágios do processo oncogênico (JOHNSTON; GRANDIS, 2011; LEVY; LEE, 2002).

O fator STAT3 possui um domínio N-terminal conservado e um domínio de ligação ao DNA (LEVY; LEE, 2002). Atualmente são conhecidas três isoformas de STAT3: (1) a, que corresponde a principal isoforma expressa, contendo 770 aminoácidos e um peso molecular de $88 \mathrm{kDa}$, (2) $\beta$, variante por splicing que não apresenta o domínio C-terminal e (3) as isoformas y e $\delta$, que atuam em neutrófilos e granulócitos (WAKE; WATSON, 2015).

A atividade ótima de STAT3 é essencial para a manutenção das funções celulares no epitélio, incluindo a integridade da interação epitélio-mesênquima (LEVY; LEE, 2002; SRIURANPONG et al., 2003). No entanto, a ativação e/ou expressão aberrante deste fator promove a hiperproliferação celular, transformação maligna e metástase. (LIN et al., 2011; SHUKLA et al., 2010). Neste sentido, trabalhos relatam a presença de STAT3 ativo em diferentes malignidades, como: câncer de cabeça e pescoço, mama (LEVY; LEE, 2002), pâncreas (FOFARIA; SRIVASTAVA, 2014), pulmão, cólon e esôfago (YU et al., 2015). Por este motivo, este fator tem sido discutido como um importante marcador prognóstico (HADDAD, 2015; JOHNSTON; GRANDIS, 2011; YU et al., 2015).

O fator STAT3 permanece latente no citosol (TERUI et al., 2004), onde é ativado pela proteína Janus cinase (JAK) (YAMAOKA et al., 2004), que promove a 
fosforilação do: (1) resíduo de serina presente na posição 727 do domínio de transativação (S727) ou (2) do resíduo de tirosina presente na posição 705 do domínio carbóxi-terminal (Y705) (LEVY; LEE, 2002). Estudos apontam que a fosforilação de Y705 representa a principal via de ativação de STAT3 (FOFARIA; SRIVASTAVA, 2014; LEVY; LEE, 2002). Tal ativação promove a formação de homodímeros deste fator, que translocam para o núcleo, onde se ligam a regiões consenso do DNA localizadas a jusante de genes alvos (FOFARIA; SRIVASTAVA, 2014; SHUKLA et al., 2010). Um modelo esquemático da ativação de STAT3 é mostrado na figura 99.

Figura 99 - Ativação do fator STAT3

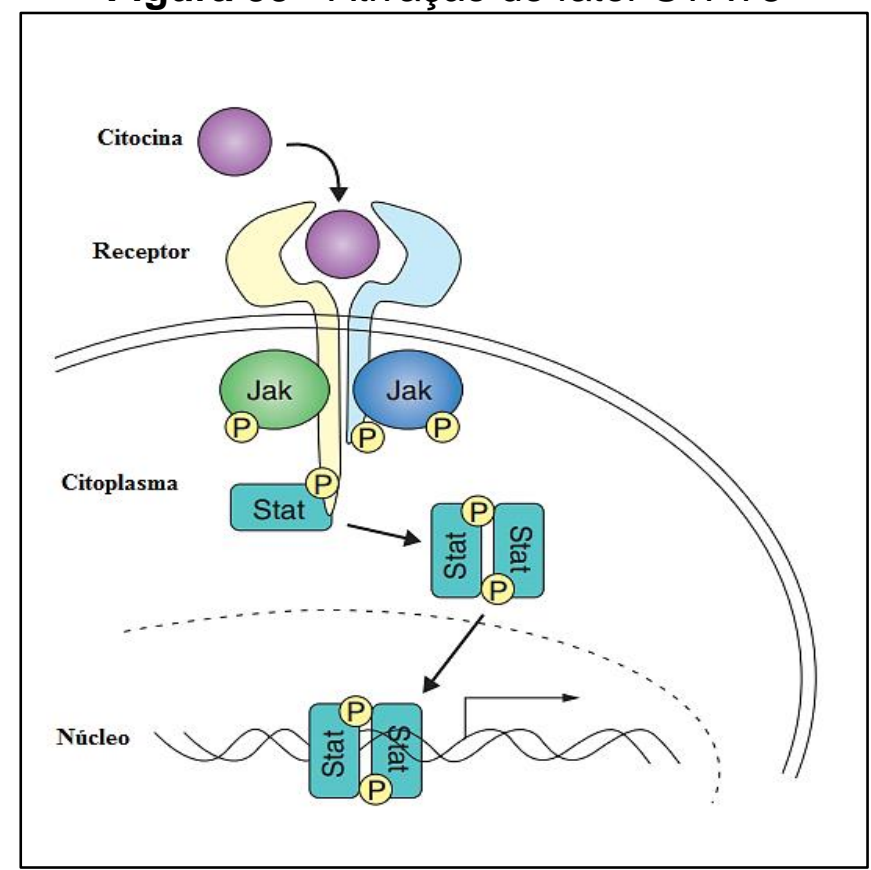

Ligação de citocina ao seu respectivo receptor promove a fosforilação da proteína Janus cinase (Jak), a qual fosforila - fator de transcrição STAT3. Esta fosforilação leva a formação de homodímeros de STAT3, que translocam para o núcleo, se ligando a região consenso do DNA a jusante de genes STAT-responsivos. Fonte: Modificado de Yamaoka et al. (2004).

A fosforilação de STAT3, resultante da ação de IL-6, EGF, PDGFß e receptores tirosina cinase (TERUI et al., 2004), leva a hiperproliferação celular (TRUSOLINO; BERTOTTI; COMOGLIO, 2010) e imunomodulação do microambiente tumoral através da quimioatração de macrófagos com fenótipo M2 (FERGUSON; SRINIVASAN; HEIMBERGER, 2015). Estes macrófagos recrutam VEGF e MMPs, que promovem a angiogênese e alterações na MEC, favorecendo a TEM (FERGUSON; SRINIVASAN; HEIMBERGER, 2015). 
Desta forma, dada a importância deste fator de transcrição no processo de transição epitélio-mesênquima, os níveis de expressão de STAT3 Y705 foram analisados. Os resultados desta análise mostraram um expressivo aumento dos níveis de expressão deste fator de transcrição nas células de papiloma cutâneo e fibropapiloma (figura 50). Estes resultados foram confirmados por meio da IHQ-P, que mostrou uma expressiva imunomarcação nuclera de STAT3 ativo (Y705) tanto em queratinócitos da junção dermo-epidermal, como em células epitelióides da derme de papiloma cutâneo, fibropapiloma e CE (figura 79). Interessantemente, as células expressando STAT3 ativo mostraram uma nítida despolarização, resultando na aquisição de um fenótipo fibroblastóide (figura 79), sendo está uma importante evidência da TEM. Embora as células de CE tenham apresentado níveis de expressão de STAT3 semelhantes à pele saudável (figura 50), a imunodetecção nuclear deste fator de transcrição, descrita nas linhagens celulares derivadas de cultivos primários de neoplasias infectadas pelo BPV (figura 49), confirma a ativação deste fator nas células infectadas pelo vírus.

Quando no núcleo, o fator STAT3 pode se ligar ao promotor P97 do genoma viral, atuando como um ativador transcripcional dos oncogenes E6 e E7, que promovem a entrada na fase S (SHUKLA et al., 2010). Adicionalmente, o fator STAT3 também pode promover a superexpressão das ciclinas D1 e D3, que juntas controlam a passagem da fase $\mathrm{G}_{1} / \mathrm{S}$ (WAKE; WATSON, 2015). Tais ações justificam o aumento da fase de síntese verificado nas linhagens infectadas pelo BPV (figura 31). Desta forma o fator STAT3 contribui significativamente para a progressão neoplásica.

O aumento dos níveis de STAT3 Y705 nas células de papiloma e fibropapiloma (figura 50) podem ser justificadas pelos elevados níveis de EROs verificados nestas células (figura 36). Considerando as evidências de que os fibropapilomas são lesões pré-malignas, os elevados níveis de STAT3 ativo pode reprimir a enzima frutose-1,6-bifosfato 1 (FBP1), suprimindo a atividade do complexo I da cadeia respiratória (NADH desidrogenase) (DONG et al., 2013). Esta ação emerge como uma consequência do processo oncogênico, justificando a perda de $\Delta \Psi_{\mathrm{m}}$ (figura 33) e a consecutiva redução dos níveis de EROs verificados nas células de CE (figura 36).

A ativação de STAT3 no microambiente tumoral leva ao aumento no número de células com fenótipo tronco CTC-like (LEVY; LEE, 2002), conhecidas por conferir 
resistência a quimioterápicos e por serem responsáveis pela recidiva do câncer (CAUSSINUS; GONZALEZ, 2005; VICENTE-DUEÑAS et al., 2009; VISVADER; LINDEMAN, 2008). Desta forma, o aumento dos níveis de expressão de STAT3 Y705 verificados nas linhagens celulares derivadas de cultivos primários de papiloma cutâneo e fibropapiloma (figura $50 \mathrm{H}$ ) pode justificar a presença das tumoresferas (figura 42) e o aumento dos níveis de expressão do fator de transcrição Oct-3/4 observados nestas células (figura $44 \mathrm{H}$ ).

A ativação e translocação nuclear de STAT3 não é restrita apenas a células infectadas pelo BPVs. Estudos já demonstraram que outros vírus oncogênicos, como o EBV (CHEN et al., 2003), vírus do sarcoma de Rous (RSV) (JOHNSTON; GRANDIS, 2011), HTLV (WAKE; WATSON, 2015), vírus da hepatite B (HBV) e C (HCV) (WILLIAMS et al., 2012) são capazes de regular a ativação de STAT3. Estudos mostram, ainda, que a citotoxina associada ao gene A ( $\operatorname{Cog} A)$ de Helicobacter pylori é capaz de promover a fosforilação de STAT3 (SUN et al., 2015). Estes resultados demonstram que a ativação e translocação nuclear é um evento conservado no processo oncogênico associado a agentes infecciosos.

\subsubsection{Marcadores mesenquimais: Vimentina e vinculina}

A vimentina (VIM) representa uma das proteínas mais expressas nos mamíferos (LAHAT et al., 2010), sendo primariamente encontrada em células mesenquimais (CASTRO-MUÑOZLEDO et al., 2014). A VIM é uma proteína solúvel (ANDREOLI; TREVOR, 1994), com peso molecular de $57 \mathrm{kDa}$ e evolutivamente conservada (SATELLI; LI, 2011). Por esta razão, os anticorpos monoclonais comercializados, sobretudo o clone V9, empregado neste estudo, demostram uma extensa reatividade cruzada com a VIM de todas as espécies de mamíferos (BOHN et al., 1992), incluindo bovinos (MARTANO et al., 2016; ROSSI et al., 2014).

A VIM forma uma rede que se estende da membrana plasmática ao núcleo, formando um arcabouço que confere suporte mecânico-estrutural, responsável pela manutenção da integridade celular (LAHAT et al., 2010). Esta proteína se caracteriza pela presença de múltiplos sítios de fosforilação (SATELLI; LI, 2011) que agem como substrato para diferentes proteínas cinases, incluindo as integrantes da família Rho (HUANG; DEVANNEY; KENNEDY, 1988; LAHAT et al., 2010). A fosforilação destes sítios leva a despolimerização da VIM, induzindo a sobrevivência e a motilidade celular, características estas presentes na TEM (LAHAT et al., 2010). Por 
estas razões, a VIM é considerada uma proteína pró-tumorigênica e pró-metastática (LAHAT et al., 2010), sendo um marcador canônico da TEM (SATELLI; LI, 2011). Além do mais, a VIM promove a superexpressão de ciclina D1, D3 e c-Myc, resultando em um estímulo hiperproliferativo (TSURUTA; JONES, 2003). Por esta razão, a expressão deste marcador mesenquimal foi analisada.

Os resultados mostraram um aumento dos níveis de expressão de VIM nas linhagens celulares derivadas de cultivo primário de papiloma cutâneo, fibropapiloma e CE em relação a pele saudável (figuras 55 e $56 \mathrm{H}$ ). Estes resultados foram confirmados pela IHQ-P, que mostrou uma expressiva imunomarcação da VIM tanto na derme, como em queratinóticos da junção dermo-epidermal de papiloma cutâneo, firbopapiloma e CE (figura 81). Resultados semelhantes têm sido descritos em diferentes carcinomas associados ao HPV, incluindo: cabeça e pescoço (BAYO et al., 2015; PITIYAGE et al., 2015), cervical (QURESHI; ARORA; RIZVI, 2015) e de células escamosas de pênis (MASFERRER et al., 2015). No entanto, estudos baseados em HPV demostraram que a carga viral não tem efeito sobre a expressão da VIM (PITIYAGE et al., 2015).

O aumento dos níveis de expressão da VIM pode ser atribuído a ativação dos fatores de transcrição STAT3 e SLUG (QURESHI; ARORA; RIZVI, 2015), verificado nas células infectadas pelo BPV (seção 6.1.6.2). Neste sentido, a sumoilação do resíduo 354 da VIM induz a ativação de STAT3 (SATELLI; LI, 2011), criando um sistema de feedback positivo que favorece a aquisição do fenótipo mesenquimal.

Somados a estes resultados, foi verificado o aumento dos níveis de expressão da vinculina nas linhagens celulares derivadas de cultivo primários de papiloma cutâneo e fibropapiloma (figura $58 \mathrm{H}$ ). A linhagem derivada de $\mathrm{CE}$, por sua vez, apresentou níveis de expressão de vinculina semelhantes aqueles observados na linhagem de pele saudável não infectada pelo BPV (figura $58 \mathrm{H}$ ). A especificidade dos anticorpos anti-VIM e anti-vinculina foi confirmada por meio de Western blot, que mostrou a presença de uma única banda com peso molecular de 57 e 116 kDa, respectivamente (figura 63).

A vinculina é uma proteína altamente conservada, com papel-chave na regulação da adesão e migração celular (BAKOLITSA et al., 2004). A proteína possui 116 kDa e 1.066 aminoácidos, sendo comsposta por uma cabeça globular e uma cauda em haste rica em prolina que se liga a paxilina (BAKOLITSA et al., 2004; EZZELL et al., 1997; GOLDMANN; INGBER, 2002; TURNER; GLENNEY; 
BURRIDGE, 1990). A vinculina é uma proteína multi-ligante, capaz de se autorregular (TURNER; GLENNEY; BURRIDGE, 1990). No citosol, a vinculina pode adquirir a conformação auto-inibida através da interação de sua cauda com a cabeça (BAKOLITSA et al., 2004; ZIEGLER; LIDDINGTON; CRITCHLEY, 2006).

A vinculina é uma das proteínas constituintes do citoesqueleto, sendo responsável pela interação célula-MEC (adesão focal) e célula-célula (junções de aderência cálcio-dependentes) (GILMORE; BURRIDGE, 1996), onde conecta as integrinas aos filamentos de actina (GRASHOFF et al., 2010). Desta forma, a expressão aberrante da vinculina está associada a formação de lamelipódios e, portanto, a migração celular (EZZELL et al., 1997).

Interessantemente, as células que apresentaram elevados níveis de expressão de VIM (figura 55) e vinculina (figura 57) também mostraram um significativo aumento do volume nuclear (cariomegalia). A cariomegalia foi confirmada por meio de MET (figura 100), sendo uma evidência adicional da montagem de vírions de BPV, já que este processo ocorre necessariamente no núcleo. 
Figura 100 - Cariomegalia verificada por microscopia eletrônica

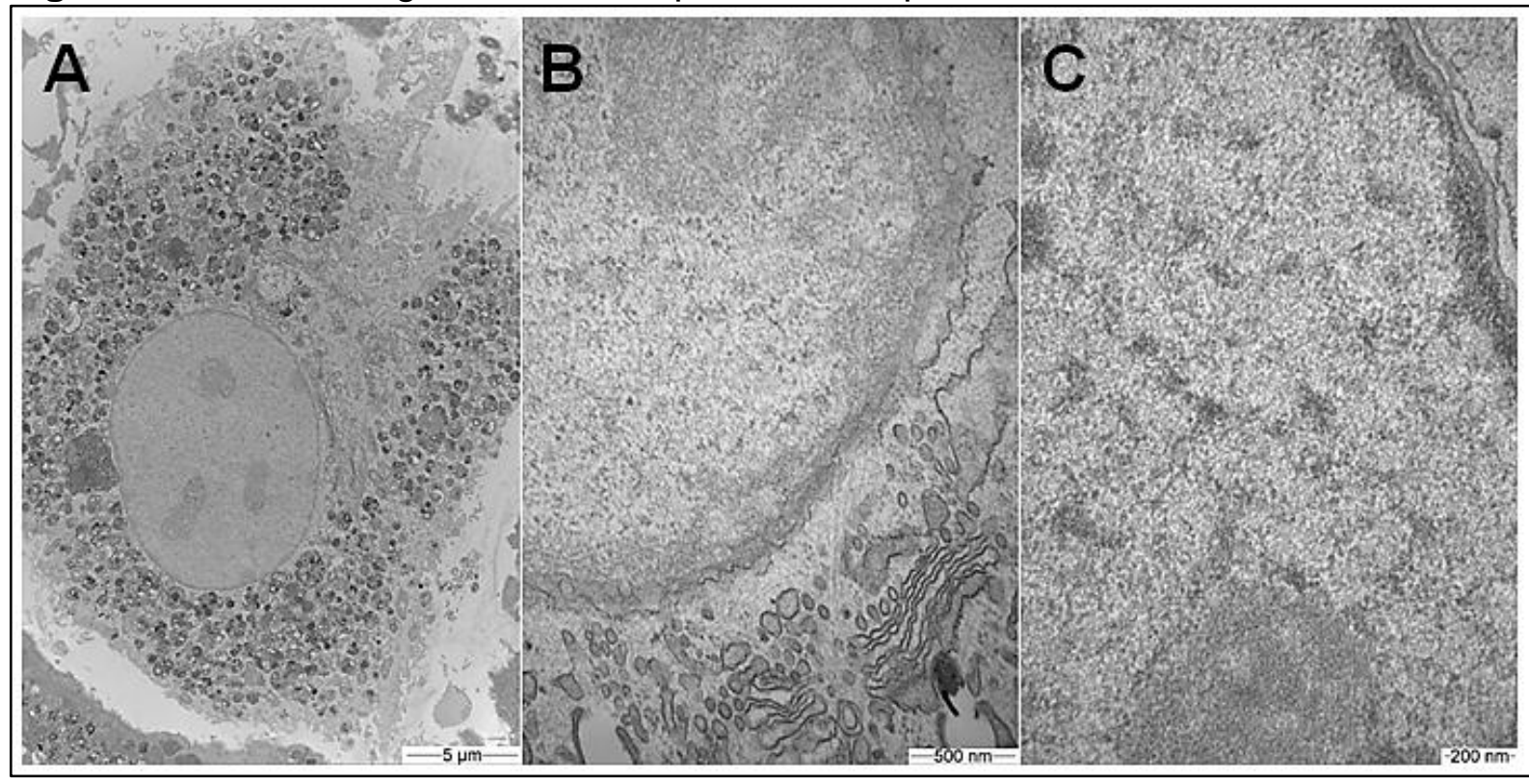

Aumento do volume nuclear verificado em célula de papiloma cutâneo infectado pelo BPV, apresentando abundante quantidade de vesículas autofágicas e estresse de retículo endoplasmático. Eletronfotomicrografias em aumento de: $3.597 \times(A), 35.760 \times(B)$ e 4.646 X (C).

\subsection{Análises morfológicas das diferentes linhagens celulares}

As análises morfológicas mostraram a perda de polaridade apical-basal nas linhagens celulares derivadas de cultivos primários de papiloma cutâneo, fibropapiloma e CE (figuras 65 e 66). A linhagem derivada de pele saudável não infectada pelo BPV, por sua vez, mostrou a preservação da polaridade (figura 65) e da morfologia de queratinócitos (figura 66A) e fibroblastos (figura 66B). A perda da polaridade é uma importante evidência da TEM, sendo resultante da redução da adesão celular decorrente do aumento dos níveis de expressão dos marcadores mesenquimais (seção 6.1.6.3). A perda da polaridade confere um fenótipo fibroblastóide aos queratinócitos, favorecendo a migração celular. Neste sentido, os resultados da MEV mostraram a aquisição de um fenótipo fibroblastóide nas células derivadas de papiloma cutâneo, fibropapiloma e CE (figura 66).

Os resultados da MEV também mostraram a presença de inúmeros filopódios nas células derivadas de neoplasias infectadas pelo BPV em relação à pele saudável (figura 66). Os filopódios são protusões digitiformes da membrana plasmática, apresentando entre 0,1-0,2 $\mu \mathrm{m}$ (SMALL et al., 2002), que se posicionam de forma assimétrica (MEYEN et al., 2015) e perpendicular aos lamelipódios (XUE; JANZEN; KNECHT, 2010). Considerando que os filopódios são organelas 
transientes, constituídas por monômeros de F-actina organizados em feixes paralelos (MATTILA; LAPPALAINEN, 2008), a marcação de F-actina verificada pelo método de HCS confirmou a presença destas protusões nas linhagens celulares derivadas de cultivos primários de papiloma cutâneo, fibropapiloma e CE (figura 68).

Desta forma, os resultados sugerem que a infecção pelo BPV afeta o tráfego de F-actina, criando sítios transientes de adesão celular (filopódios), necessários à motilidade. Tal ação já foi demonstrada em células infectadas pelo HPV, sendo atribuída à ação da proteína E4 (ROBERTS, 2015), sendo esta a proteína mais expressa pelos PVs (CAMPO, 1997b; DOORBAR, 2013). Netse sentido, os resultados sugerem que a proteína E2 do BPV interage com a Cdc42 (MORRISON et al., 2011), sinalizando o tráfego de F-actina ao complexo de formação de filopódios (CFF), junto à membrana basal, conforme figura 101 (FAIX et al., 2009). A Cdc42 é uma proteína ubiquamente expressa, pertencente a família Rho GTPases, que controla a organização do citoesqueleto, a apoptose e a expressão gênica (CZUCHRA et al., 2006; MATTILA; LAPPALAINEN, 2008). Desta forma, os dados sugerem que a proteína proteína E2 interage com a Cdc42, atraindo a F-actina para o CFF, ao passo que a E4 altera o tráfego desta para os filopódios. 
Figura 101 - Modelo esquemático da formação de protusões celulares

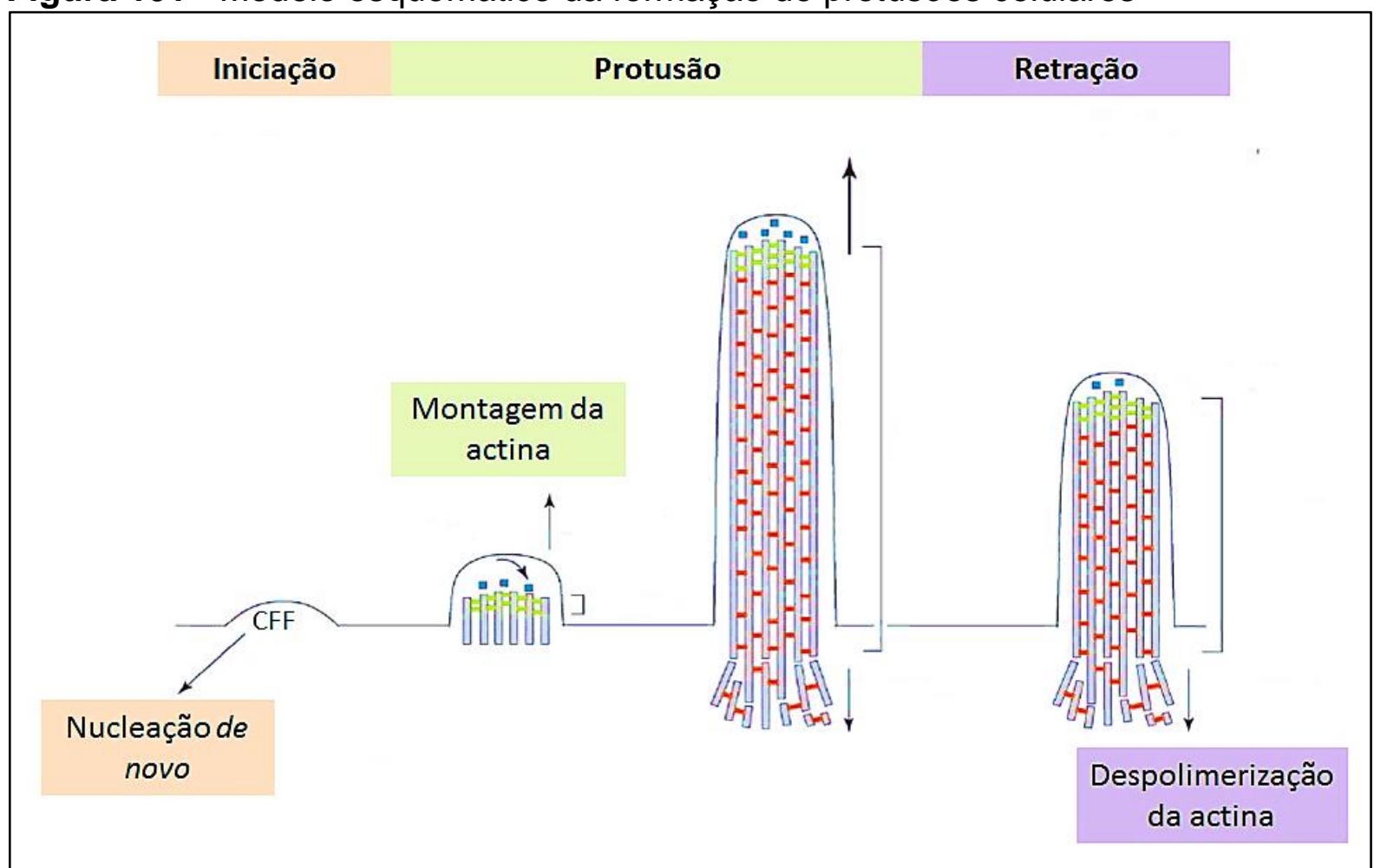

Processo de formação das protusões: (1) iniciação, através da qual tem início com o complexo de formação de filopódios (CFF), no qual há uma atração de F-actina cortical para a membrana plasmática; (2) protrusão - fase na qual ocorre a polimerização dos monômeros de actina (azul) e a estabilização dos filamentos formados por meio da formina (vermelho), originando feixes paralelos e; (3) retração - fase caracterizada pela despolimerização da actina, sendo observada após a migração celular. Fonte: Modificado de Faix e Rottner (2006).

A polimerização coordenada da F-actina em direção ao CFF resulta em uma dinâmica celular que leva a migração e morfogênese (MATTILA; LAPPALAINEN, 2008). A dinâmica de migração cria sítios transientes de adesão celular (SCHÄFER et al., 2009), levando ao redirecionamento de diferentes proteínas de adesão para os filopódios, tais como: integrinas e caderinas para os filopódios (ARJONEN; KAUKONEN; IVASKA, 2011; MATTILA; LAPPALAINEN, 2008), talina, cinase de adesão focal (FAK), paxilina (MATTILA; LAPPALAINEN, 2008; SCHÄFER et al., 2009), T-plastina e miosina II (XUE; JANZEN; KNECHT, 2010). Desta forma, os filopódios originam junções de aderência cálcio-dependente transientes, garantindo o movimento amebóide das células durante a migração.

Somado a estes resultados, foi verificada a marcação nuclear da F-actina, especialmente nas células derivadas de cutltivos primários infectados pelo BPV apresentando cariomegalia (figura 68). Tal resultado pode ser discutido como uma consequência do estresse de $\mathrm{RE}$, que leva a liberação de $\mathrm{Ca}^{2+}$ (figura 37), promovendo a regulação da actina (OLAVE; RECK-PETERSON; CRABTREE, 
2002). Considerando que a actina pode se associar a filamentos nucleoplasmáticos que emanam dos poros da carioteca (OLAVE; RECK-PETERSON; CRABTREE, 2002), a marcação nuclear da actina pode representar um mecanismo adicional de regulação gênica do vírus. Isto porque, estudos têm mostrado que a actina nuclear pode promover o remodelamento da cromatina, levando a formação de regiões eucromática e, por consequência, favorecer a transcrição de diferentes proteínas, incluindo aquelas associadas a replicação célular (OLAVE; RECK-PETERSON; CRABTREE, 2002; VARTIAINEN, 2008).

Adicionalmente, os resultados da velocidade de migração celular mostrou que as linhagens derivadas de CE e papiloma 03 (fibropapiloma) apresentam as maiores velocidade médias de deslocamento celular, indicando a aquisição de um fenótipo migratório (tabela 22, figura 69). A linhagem celular derivada do papiloma 02 (fibropapiloma), por sua vez, mostrou uma velocidade média de migração intermediária, ao passo que as linhagens derivdas de papiloma cutâneo e pele saudável não infectada pelo BPV apresentaram as menores velocidades de migração celular (tabela 22, figura 69).

Embora essencial na organogênese e na manutenção da homeostasia tecidual (MEYEN et al., 2015), a aquisição do fenótipo migratório é a principal característica da TEM (ZEISBERG; NEILSON, 2009), levando a penetração de células através de barreiras teciduais (intravasão) (KRAMER et al., 2012). Por esta razão, o fenótipo migratório está sempre presente em carcinomas invasivos (ARJONEN; KAUKONEN; IVASKA, 2011; MATTILA; LAPPALAINEN, 2008). Neste sentido, as culturas $2 \mathrm{D}$ representam o melhor modelo de estudo do fenótipo migratório (FRIEDL; GILMOUR, 2009; KRAMER et al., 2012), uma vez que evidências deste fenótipo são extremamente difíceis de serem avaliadas in vivo (ZEISBERG; NEILSON, 2009). Neste contexto, as linhagens celulares derivadas de cultivos primários de neoplasias infectadas pelo BPV se mostraram modelos eficientes para o estudo do processo oncogênico dos papilomavírus, especialmente no que diz respeito a análise da TEM.

Estes dados, somados aos resultados das análises de metabolismo (seção 6.1.3), a aquisição do fenótipo CTC-like (seção 6.1.5) e o aumentos dos níveis de expressão dos diferentes marcadores associados a TEM, analisados neste estudo (seção 6.1.8) indicam que a TEM decorre uma série de alterações genéticas, 
bioquímicas e morfológicas que estão associadas a história natural do processo oncogênico associado aos PVs.

\subsection{Análises teciduais: Demonstrando os resultados in vivo}

\subsubsection{Análises histopatológicas}

A análise histopatológica do fragmento de tecido de pele saudável mostrou a preservação da arquitetura tecidual, bem como a presença de anexos (figura 70), confirmando os resultados da PCR, que mostrou a ausência de sequências de DNA do BPV na linhagem celular derivada do cultivo primário deste tecido (figura 26).

Os fragmentos de tecido de papiloma cutâneo, fibropapiloma e CE apresentaram uma expressiva hiperplasia da camada suprabasal (acantose) (figura 71 e 72), reforçando o potencial hiperproliferativo do BPV, também descrito nas linhagens celulares derivadas do cultivo primário destas neoplasias (figura 31). A acontose é resultante da ação sinérgica das oncoproteínas virais E5, E6 e E7, que juntas estimulam a entrada na $S$, garantindo a disponibilidade de DNA polimerases necessárias à replicação do BPV. Diferentemente da amostra de papiloma 01 (papiloma cutâneo), as amostras de papiloma 02 e 03 apresentaram um estroma fibro-elástico, apresentando uma hiperproliferação fibroblástica (figura 71B e C). Tal característica permite classificar estas amostras como fibropapilomas.

Os fibropapilomas são são histologicamente semelhantes ao sarcóide equino, neoplasia fibroblástica localmente invasiva e não metastásica, que até 1963 era denominada fibropapiloma equino (LÖHRDR et al., 2005; LUNARDI et al., 2013; SCHULMAN; KRAFFT; JANCZEWSKI, 2001; TEIFKE et al., 2003). Os fibropapilomas estão associados aos tipos virais BPV-1, 2 (Deltapapillomavirus) e 5 (Epsilonpapillomavirus), sendo também verificadas em zebras (Equus burchelli), cavalos, búfalos, Ihamas, canelos, alpacas, burros e gatos infectados pelo BPV, bem como por ovinos infectados pelo OvPV-1 e 2 (ALBERTI et al., 2010; CAMPO, 1997b; CHALLBERG; KELLY, 1989; ELZEIN et al., 1991; SCHULMAN et al., 2003; SCHULMAN; KRAFFT; JANCZEWSKI, 2001; VAN DYK et al., 2011). Desta forma, tais resultados podem ser atribuídos a co-infecção pelos tipos virais BPV-1 e 2, verificados pela PCR (figura 26, tabela 13). Isto porque, o BPV-4 (Xipapillomavirus) não induz a proliferação fibroblástica devido à ausência da ORF E6 (CAMPO, 1997b). 
Considerando que os tipos virais BPV-1 e 2 são capazes de infectar fibroblastos, a hiperproliferação fibroblástica pode, ainda, ser discutida como uma efeito da ação pró-oxidante do vírus, verificada nas linhagens celulares derivadas destas neoplasias (figura 36). Isto proque, conforme verificado pelo ensaio do MTT, sob determinadas concentrações, as EROs podem apresentar uma ação proliferativa (figuras 34 e 35). A hiperproliferação fibroblástica associada ao estresse oxidativo já foi previamente verificada em células de sarcóides equinos infectados por BPV-1 e 2 (POTOCKI et al., 2014), bem como sugerida em fibropapilomas bovinos (ARALDI et al., 2015a).

As amostras de papiloma cutâneo, fibropapiloma (figuras 71B, F e I), CE (figura 72C) e papiloma de esôfago (figura 72I) mostraram a presença de coilócitos na camada hipergranulosa. Os coilócitos são queratinócitos em degeneração, destinados à morte celular ou à liberação do epitélio, caracterizados pela presença de um halo proeminente, que não se cora com eosina ou ácido periódico de Schiff, apresentando núcleo acêntrico e picnótico (FERRARO et al., 2011; FLETCHER, 1983). A coilocitose representa um achado histopatológico característico de infecções virais (MONTE; PEIXOTO, 2010), sendo observado em papilomas de diferentes espécies, incluindo cães (BIANCHI et al., 2012) e humanos (BETIOL et al., 2012; FERRARO et al., 2011; FLETCHER, 1983; ROGOVSKYY et al., 2012). Por esta razão, alguns autores têm discutido a coilocitose como um marcador patognomônico das infecções pelos PVs (ARALDI et al., 2015a; BETIOL et al., 2012; KRAWCZYK et al., 2008). Embora as vias envolvidas na vacuolização perinuclear sejam desconhecidas, acredita-se que ela possa contribuir para a fragilidade dos queratinócitos, facilitando a liberação de partículas virais para o meio ambiente (KRAWCZYK et al., 2008).

Os resultados também mostraram uma evidente hiperqueratose ortoqueratótica (figuras $71 E$ e $F$ ) e paraqueratótica (figuras $71 \mathrm{~A}$, I e J) nos fragmentos de papiloma e fibropapiloma. A paraqueratose representa mais uma evidência da hiperproliferação tecidual (CHEVILLE; OLSON, 1964; SOUSA et al., 2011), sendo o principal tipo de hiperqueratose observada em infecções pelos PVs (ARALDI et al., 2015a; FERNANDES et al., 2009; MARTELLI-MARZAGÃO et al., 2010; VELAZQUEZ; CHAUX; CUBILLA, 2012). De acordo com Rashad e Evans (1967), a hiperqueratinização do estrato córneo é atribuída à ausência de fosfatases e oxidases. Além do mais, está ação confere uma proteção adicional às partículas 
virais que são liberadas após a lise dos coilócitos. Isto porque, a queratina confere uma proteção física aos vírions, ao mesmo tempo em que impede uma resposta imune, já que a morfologia icosaédrica dos PVs é imunorreativa.

Somado a estes resultados, foi verificada uma abundante quantidade de grânulos de cerato-hialina na camada hipergranulosa, sobretudo da amostra 03 (fibropapiloma) (figura 73), a qual apresentou uma expressiva hiperquetose (figura 71). A presença destes grânulos foi observada pela primeira vez em 1869 por Auffhame e, descrita em 1873 por Langerhans (MATOLTSY; MATOLTSY, 1970). No entanto, o termo grânulos de cerato-hialina foi introduzido por Waldeyer em 1882 (MATOLTSY; MATOLTSY, 1970). A abundante presença destes grânulos na camada granulosa caracteriza a hipergranulose, sendo este um achado frequentemente observado em papilomas (ARALDI et al., 2015a; CARVALHO et al., 2013; FERNANDES et al., 2009; MARTELLI-MARZAGÃO et al., 2010). Os grânulos de cerato-hialina apresentam natureza proteica, sendo ricos em aminoácidos sulfurados. O grupo sulfidrila $(-\mathrm{SH})$ é responsável pela formação de ligações dissulfídicas, envolvidas no processo de queratinização (JESSEN, 1970; MATOLTSY; MATOLTSY, 1970). Além do mais, a hiperqueratose e a hipergranulose são responsáveis pela coloração branca-acinzentada característica dos papilomas (FERRARO et al., 2011).

Enquanto o tecido saudável mostrou-se estruturalmente bem diferenciado, apresentando células organizadas em nichos especializados (figura 70), a análise histopatológica do fragmento de CE revelou uma ampla desorganização tecidual (figura 72A, B e C), a qual pode ser atribuída a hiperproliferação celular (SCHWITALLA, 2014). Os resultamos também mostraram a presença de um estroma reativo, contendo ilhas de células epitelióides no fonte de invasão (figura $72 \mathrm{E}$ e F). A presença destas ilhas celulares no estroma indicam um fenótipo invasivo e migratório, representando uma fase avançada da doença. Além do mais, verifca-se que as células presentes no fronte de invasão e nas ilhas celulares presentes na derme apresentam uma morfologia fibroblastóide, com perda de polaridade apicalbasal, sendo compatíveis com o fenótipo esperado durante a TEM. 


\subsubsection{Análise da composição de colágeno na MEC}

A identificação e quantificação das fibras de colágeno usando o método Picrosírius red foi implementada em 1968 por Constantine e Mowry (DAYAN et al., 1989) em substituição a coloração com fucsina van Gienson (JUNQUEIRA; BIGNOLAS; BRENTANI, 1979). O método, que consiste no uso do corante Sírius red diluído em ácido pícrico, tem sido amplamente empregado na identificação das fibras de colágeno I e III (RIBEIRO et al., 2015), que são fundamentais na manutenção da integridade e função dos tecidos (RICH; WHITTAKER, 2005). Sob o comprimento de onda de $540 \mathrm{~nm}$ (luz polarizada), fibras de colágeno tipo I são visualizadas na cor vermelho-alaranjado, enquanto fibras de tipo III, na cor amareloesverdeado (RIBEIRO et al., 2015).

Os resultados da análise quantitativa das fibras de colágeno mostraram uma redução da quantidade de fibras de tipo III e um aumento das fibras de tipo I nas amostras de tecido infectadas pelo BPV (papiloma, fibropapiloma e carcinoma de esôfago) (tabela 23, figura 75). Estes resultados sugerem que o BPV é capaz de modular a MEC, promovendo o aumento das fibras de colágeno de tipo I.

O aumento das fibras de colágeno tipo I pode ativar a cinase de adesão focal (FAK), resultando na dissociação da E-caderina e, por consequência, favorecer a TEM (ARMSTRONG et al., 2004; KOENIG et al., 2006). A dissociação da E-caderina também resulta na liberação e translocação nuclear da $\beta$-catenina, promovendo a expressão da família de fatores de transcrição Lymphoid-enhancer fator/T-cell (Lcf/Tcf) (MENKE et al., 2001). Esta ação leva a repressão transcripcional da Ecaderina em células cancerígenas (MENKE et al., 2001), justificando a redução da expressão desta glicoproteína verificada nas células de CE (figura 48). Desta forma, o aumento das fibras de colágeno tipo I sugere que a infecção viral leva ao remodelamento da MEC, favorecendo a migração celular. Tal ação contribui para a desorganização tecidual verificada na análise histopatológica do fragmento de carcinoma de esôfago (figura 72).

\subsubsection{Imunodetecção da oncoproteína E5 do BPV}

A oncoproteína E5 do BPV-1 é uma proteína transmembrana (DIMAIO, 2014; TOMITA et al., 2007), responsável pelo fibrotropismo viral (DIMAIO, 2014). potencial oncogênico da oncoproteína E5 tem sido extensivamente estudado, já que ela participa da progressão e metastatização. Isto porque, a oncoproteína E5 é 
capaz de se ligar ao platelet-derived growth factor receptor beta (PDGF $\beta R$ ), promovendo a dimerização deste receptor (COSTA; MEDEIROS, 2014; DIMAIO, 2014; NICOLAS et al., 2013). Esta ação leva à ativação de diferentes cinases (Acdk2, MAPK, JNK, PI3K e c-Src), resultando na proliferação celular e progressão neoplásica (BORZACCHIELLO, 2007; CHAMBERS et al., 2003; DIMAIO, 2014). A oncoproteína E5 também promove a perda da adesão focal, contribuindo para a invasão de células cancerígenas no fronte neoplásico (RAMPIAS; SASAKI; PSYRRI, 2013). Por estas razões, a expressão da oncoproteína E5 do BPV foi avaliada por meio de IHQ-P. Os resultados desta análise mostraram a a expressão da E5 nas amostras de papiloma cutâneo, fibropapiloma e CE, sendo verificada uma imunodetecção junto a membrana citoplasmática de células da camada basal à córnea (figura 75). Tais resultados confirmam a presença do BPV nestes tecidos, reforçando os resultados da PCR (figura 26). A amostra de pele saudável, por sua vez, não mostrou a expressão desta oncoproteína, reforçando a ausência de infecção viral neste tecido.

A oncoproteína E5 possui um papel de destaque no processo oncogênico associado aos papilomavírus. Isto porque, a localização transmembrana desta oncoproteína promove a dimerização do PDGF $\beta R$, levando a proliferação celular. Esta ação pode justificar a acantose verificada na análise histopatológica dos fragmentos de tecido infectados pelo BPV (figuras 71 e 72). Além do mais, a oncoproteína E5 pode interagir com a proteína ductina, presente em conexóns que compõem as junções intercelulares tipo gap (CAMPO, 1997b, 2006; CORTEGGIO et al., 2011). A ductina é uma proteína hidrofóbica altamente conservada, com peso molecular entre 16-18 kDa, envolvida com a comunicação intercelular (FINBOW; PITTS, 1993). A interação da E5 com a ductina promove a perda de adesão intercelular, conferindo um estímulo proliferativo adicional ao mesmo tempo em que leva a favorece a aquisição do fenótipo migratório verificado durante a TEM.

A interação da oncoproteína E5 com a ductina tem um papel-chave nos mecanismos de evasão imune e persistência da infecção viral. Isto porque, a ductina é o principal constituinte da subunidade vacuolar $\mathrm{H}^{+}$ATPase, também conhecida por V-ATPase (BURNETT; JAREBORG; DIMAIOT, 1992). A interação E5-ductina promove a alcalinização da membrana interna do complexo de Golgi (KRAWCZYK et al., 2010), promovendo alterações no tráfego de proteínas (ROBERTS, 2015). Esta ação leva ao sequestro da cadeia pesada do MHC-II (VENUTI et al., 2011). A 
oncoproteína E5 promove, ainda, a repressão transcripcional do $\mathrm{MHC}-\mathrm{I}$ (BORZACCHIELLO, 2007; TOMITA et al., 2007; VENUTI et al., 2011), que associado à morfologia icosaédrica do capsídeo viral, garante ao vírus uma baixa antigenicidade, permitindo a persistência da infecção viral. Dentro do contexo patológico, a interação da E5 com a V-ATPase pode justificar a imunomarcação citoplasmática e nuclear das glicoproteína E- e N-caderina (figuras 47 e 53, respectivamente), favorecendo a aquisição do fenótipo invasivo. 
8 CONCLUSÃO 
Os resultados obtidos mostraram que o BPV é capaz de se replicar em sistemas de cultura celular (in vitro), conforme verificado pela manutenção das sequências de DNA viral ao longo das seis passagens das linhagens celulares derivadas de cultivos primários de neoplasias infectadas pelo BPV (seção 6.1.1.1). Neste contexto, as pontes intercitoplasmáticas, observadas por meio da MEV, podem contribuir com a transferência genética horizontal, já que o BPV não se integra a cromatina hospedeira, permanecendo na forma epissomal. Entretanto, a imunodetecção da proteína estrutural L1 (seção 6.1.1.2), bem como a presença de estruturas semelhantes a virions do BPV, identificadas tanto no citosol, como em vesículas citoplasmáticas (seção 6.1.1.3) sugerem que as culturas celulares não somente são capazes de sustentar a replicação do genoma viral, como também de apresentarem infecção produtiva. Tais resultados sugerem que a infecção produtiva do BPV pode ocorrer mesmo na ausência da diferenciação do epitélio, desmistificando o paradigma do ciclo de replicação/montagem deste vírus, estabelecido desde 1932. Tais resultados foram publicados no periódico Virology: Research and Review (anexo A).

As linhagens celulares derivadas de cultivos primários de neoplasias infectadas pelo BPV se mostraram capazes de mimetizar diferentes aspectos da patogênese viral. Isto porque, foi verificado que tais linhagens celulares apresentaram um aumento do percentual de células nas fases $S$ e $G_{2}-M$ (seção 6.1.2), condição esta observada pela hiperplasia da camada suprabasal (acantose), verificada na análise histopatológica dos tecidos de papiloma cutâneo, fibropapiloma e CE (seção 6.2.1). Estes resultados indicam a manutenção do potencial proliferativo do BPV in vitro, reforçando as evidências da infecção produtiva em culturas celulares.

Somado a estes dados, foi verificada uma redução do potencial de membrana mitocondrial $(\Delta \psi \mathrm{m})$ nas linhagens celulares derivadas de cultivos primários de papiloma cutâneo, fibropapiloma e CE (seção 6.1.3.1), sugerindo que o acometimento da derme, presente nos fibropapilomas e CE, leva a restrição do metabolismo oxidativo e a consequente ativação da glicólise aeróbica em um processo canônico da carcinogênese conhecido por "efeito Warburg". Porém, ao contrário do esperado, foi verificado um aumento da produção de espécies reativas de oxigênio (EROs) nestas linhagens (seção 6.1.3.2). Estes resultados podem ser atribuídos a oncoproteína E6 do BPV, já que a adição da oncoproteína recombinante 
E6 do BPV-1 a células de pele saudável não infectadas pelo vírus resultou na redução do $\Delta \psi m$, porém, no aumento da produção de EROs (seção 6.3.1). Tais dados sugerem que a oncoproteína E6 do BPV age de forma homóloga a variante de splicing $\mathrm{E}^{*}$ do HPV-16, promovendo a regulação negativa das enzimas antioxidantes SOD2 e GPx, resultando no estresse oxidativo.

$O$ estresse oxidativo descrito nas linhagens celulares derivadas do cultivo primário de neoplasias infectadas pelo BPV pode, ainda, justificar o estresse de retículo endoplasmático $(\mathrm{RE})$ e a macro-autofagia observados através da MET (seção 6.1.3.3). O estresse de RE é apontado como mais uma evidência da montagem de partículas virais, já que tal processo ocorre em vesículas citoplasmáticas. Neste sentido, a interação da oncoproteína E5 do BPV com a proteínas presentes na membrana do RE e do complexo de Golgi, favorece o sequestro de proteínas processadas por estas organelas, incluindo as caderinas. Desta forma, o estresse de RE contribui com a reorganização do citoesqueleto e, portanto, com a migração celular. A macro-autofagia, por sua vez, representa um efeito citoprotetor verificado em resposta a redução do $\Delta \psi m$, sendo uma característica observada durante a progressão neoplásica.

Os resultados também mostraram que as linhagens celulares derivadas de cultivos primários de neoplasias infectadas pelo BPV apresentam níveis de clastogenicidade variáveis (seção 6.1.4), sugerindo que a instabilidade genômica está associada a história natural da neoplasia e ao acometimento da derme. Embora os danos genéticos sejam atribuídos a ação sinérgica das oncoproteínas E5, E6 e E7, que juntas levam a hiperproliferação e, por consequência ao estresse das forquilhas de replicação, este estudo mostrou, pela primeira vez, que a oncoproteína E6 do BPV per se é capaz de induzir importantes alterações no DNA. Isto porque, foi verificado que a oncoproteína E6 do BPV é capaz de aumentar a frequência de micronúcleos e pontes anafásicas em sangue periférico e células epiteliais (seção 6.3.2), indicando o potencial genotóxico da E6. Além do mais, a oncoproteína foi capaz de induzir quebras no DNA (seção 6.3.2), identificadas pelo ensaio cometa, demonstrando seu potencial clastogênico. Somado a estes dados, foi observada a presença de linfócitos "gigantes", polinucleados e com endorreduplicação no grupo tratado com oncoproteína recombinante E6 do BPV-1 (seção 6.3.2), indicando, pela primeira vez, o potencial neótico da E6. Estes resultados sugerem que a oncoproteína E6 possui um papel-chave no processo oncogênico, favorecendo tanto 
a iniciação, pelo aumento da instabilidade genômica, como também a progressão, através das desregulações metabólicas, bem como contribuindo com a heterogeneidade genotípica das células que compõe o micro-ambiente neoplásico. Os resultados da análise de metabolismo celular, bem como do potencial mutagênico da oncoproteína E6 foram publicados nos periódicos Journal of Cancer Research and Therapeutic Oncology (anexo B) e BioMed Research International (anexo C). Uma revisão sobre o tema também foi publicada, estando disponível em Araldi et al. Genetics and metabolis deregulation following cancer initiation: $A$ world to explore. Biomedeicine \& Pharmacotherapy, v. 82, p. 449-58, 2016. Um revisão acerca dos métodos de análise do potencial oncogênico também foi publicada, estando disponível em Araldi et al. Using the comet and micronucleus assay for genotoxic studies: A review. Biomedicine \& Pharmacotherapy, v. 72, p. 74-82, 2015.

Considerando que a instabilidade genômica é apontada como responsável pela aquisição do fenótipo-tronco, este estudo avaliou a aquisição deste fenótipo nas diferentes linhagens celulares. Os resultados desta análise mostraram que as linhagens derivadas de cultivos primários de papiloma cutâneo, fibropapiloma e CE foram capazes de formar tumoresferas (seção 6.1.5), sugerindo a aquisição do fenótipo-tronco. Além do mais, foi verifica a expressão do fator de transcrição Oct3/4 nestas mesmas linhagens (seção 6.1.5), sugerindo a manutenção deste fenótipo. $A$ aquisição do fenótipo-tronco é um fenômeno esperado durante a TEM, já que a desdiferenciação celular confere um mecanismo de resistência a apoptose, necessário durante o processo de metastatização. A presença de células com fenótipo-tronco tanto em neoplasias bebignas (papiloma e fibropapilomas) como malignas (carcinoma de esôfago) tem importantes implicações clínicas. Isto porque, tais células podem permanecer quiescentes, mesmo após a remicisão das neoplasias, conferindo um reservatório de células geneticamente instáveis. Porém, a divisão assimétrica destas células pode levar ao desenvolvimento de tumores, justifcando a recidiva dos papilomas/fibropapilomas, bem como do sarcóide equino, neoplasia localmente infiltrante associada a infecções por Deltapapillomavirus.

Embora o switch gênico das caderinas seja apontado como um marcador canônico da TEM, este estudo mostrou uma expressiva redução dos níveis de expressão de ambas as caderinas (E-e $\mathrm{N}$-caderina) na linhagem derivada de cultivo primário de CE (seção 6.1.6). A repressão transcricional da E-caderina nas células de CE pode ser atribuída a expressão aberrante do fator de transcrição SLUG 
(seção 6.1.6.2). Isto porque, este fator pode se ligar a região E-box do promotor da E-caderinam levando a sua repressão. Porém, todas as linhagens celulares derivadas cultivos primários de neoplasias infectadas pelo BPV, incluindo papiloma e fibropapiloma, mostraram uma evidente imunomarcação citoplasmática, perinuclear e nuclear destas glicoproteínas. Estes resultados reforçam que a interação da oncoproteína E5 com proteínas do retículo endoplasmático e do complexo de Golgi, bem como a o estresse de RE decorrente da ação pró-oxidante da oncoproteína E6 são capazes de regular a adesão intercelular, contribuindo com a aquisição do fenótipo migratório e, portanto, com a TEM. Somado a estes dados, foi verificado um aumento dos níveis dos marcadores mesenquimais vimentina e vinculina, reforçando a aquisição do fenótipo mesenquimal. Interessantemente, foi verificada a expressão destes marcadores mesenquimais em queratinócitos basais com morfologia fibroblastóide, bem como em células epitelióides presentes na derme das neoplasias infectadas pelo vírus (seção 7.10.3). Tais resultados são evidências adicionais da TEM nestas células.

As linhagens celulares derivadas de cultivos primário de papiloma cutâneo e fibropapiloma apresentaram elevados níveis de expressão do fator de transcrição STAT3 ativo (Y705) (seção 6.1.6.2). Embora a linhagem derivada de CE tenha apresentado um menor nível de expressão desta fator, foi verificada a imunomacação nuclear de STAT3 Y705 nesta linhagem (seção 6.1.6.2). A expressão aberrante de STAT3 leva a aumento dos níveis de expressão da vimentina, verificados tanto nas linhagens celulares derivadas das neoplasias infectadas pelo BPV (seção 6.1.6.2), bem como nos fragmentos de tecido de papiloma cutâneo, fibropapiloma (seção 6.2.3.7). Interessantemente, as análises teciduais mostraram uma evidente imunomarcação nuclear de STAT3 Y705, bem como de vimentina em queratinócitos com morfologia fibroblastóide e células epitelióides, ambas localizadas na junção dermo-epidermal. Estes resultados conferem evidências adicionais da TEM, já que este processo patológico ocorre no fronte de invasão neoplásico, que corresponde a junção dermo-epidermal. Além do mais, a expressão aberrante de STAT3 leva a ativação de MMPs, justificando as alterações na matriz de colágeno verificadas nos tecidos de papiloma cutâneo, fibropapiloma e CE (seção 6.2.2). Considerando que tais resultados foram descritos tanto em neoplasias benignas, como malignas, os dados sugerem que os carcinoma é o produto final da história natural de uma infecção persistente de um papiloma, 
conforme figura 102. Neste contexto, os fibropapilomas podem ser discutidos como lesões pré-neoplásicas, conforme proposto desde a década de 1970.

Figura 102 - Evolução das alterações celulares em função da duração da lesão

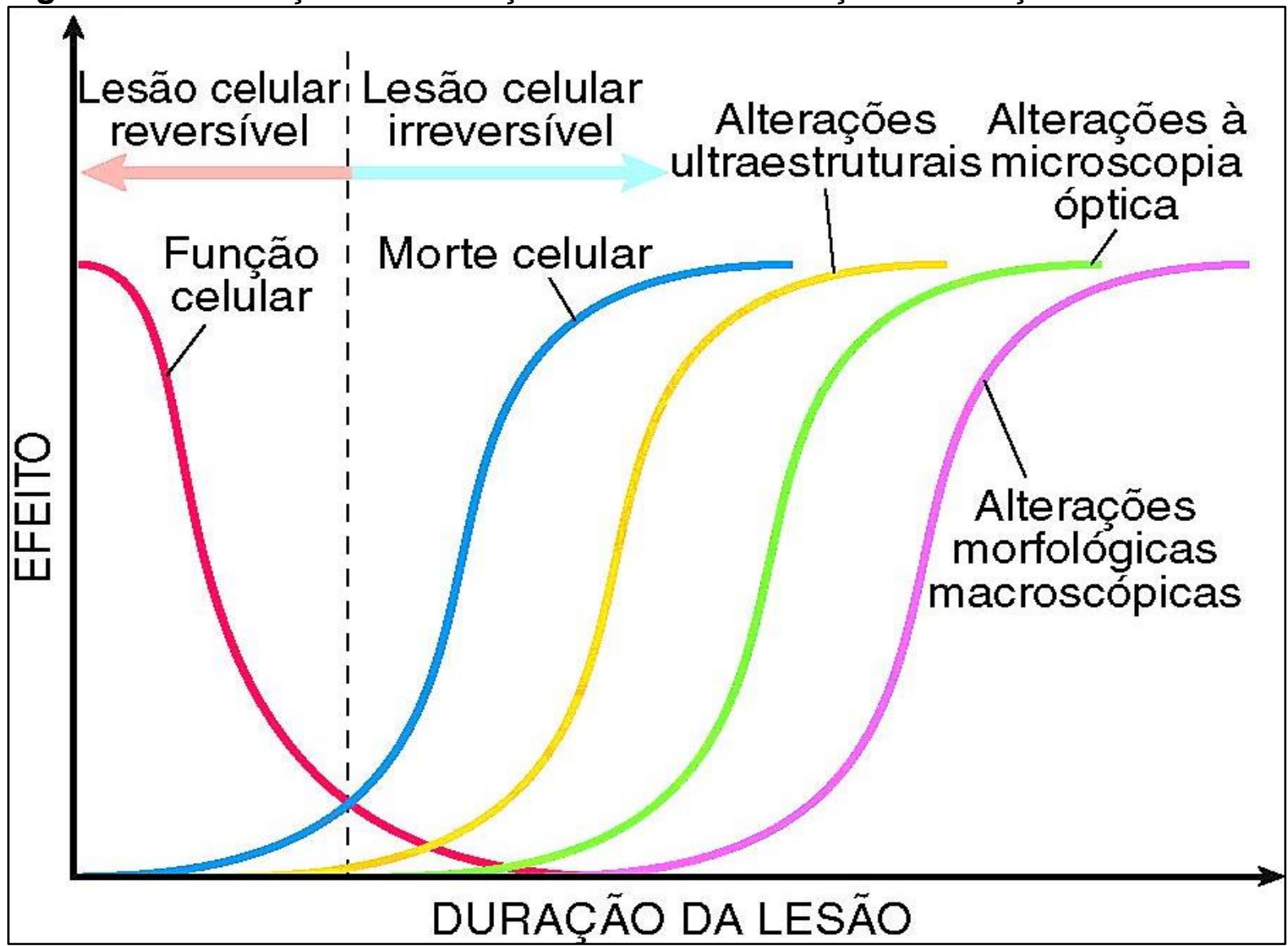

Modelo esquemático das diferentes alterações associadas a perda da homeostasia celular em função da duração da lesão. Nota-se que as alterações macroscópicas são verificadas nos últimos estágios da patogênese. Fonte: Kumar, Abbas e Aster (2013).

Em última análise, as linhagens celulares derivadas de cultivos primários de neoplasias infectadas pelo BPV apresentaram alterações morfológicas compatíveis com a TEM. Entre estas alterações estão: (1) a perda de polaridade apical-basal, levando a aquisição de uma morfologia fibroblastóide; (2) a presença de lamelipódios e filopódios, organelas associadas a motilidade celular; (3) a marcação de F-actina junto a membrana plasmática, confirmando a presença dos filopódios e; (4) o aumento da velocidade de migração celular, verificado nas células de fibropapiloma (papiloma 03) e CE (seção 6.1.8). Tais resultados foram publicados no periódico Journal of Cancer Research and Therapeutic Oncology (anexo D). 
Em resumo, os resultados mostraram que as linhagens celulares derivadas de cultivos primários de neoplasias infectadas pelo BPV são modelos úteis no estudo tanto da biologia, como da patogênese viral. Isto porque, tais linhagens mimetizam não somente a infecção produtiva, como ainda as desregulações bioquímicas, genéticas e morfológicas verificadas in vivo. Os dados também mostraram que, embora a oncoproteína E5 venha sendo discutida como a principal proteína transformante, a E6 tem um papel-chave nas alterações metabólicas, sendo um pivô tanto na iniciação e progressão neoplásica, como na TEM. Tais dados fazem da oncoproteína E6 um importante alvo biotecnológico para terapias futuras, já que a metástase é responsável por $90 \%$ de todos os óbitos por câncer. Além do mais, os resultados combinados deste estudo mostram que, após a infecção pelo BPV, células saudáveis adquirem progressivamente um estado neoplásico, sustentando o modelo estocástico da carcinogênese. Desta forma, mais atenção deve ser dada a infecção pelos papilomavirus, bem como as neoplasias benignas, já que estas podem representar lesões pré-neoplásicas quando há o acometimento da derme. Os dados obtidos neste estudo foram resumidos em um trabalhos de revisão sobre os papilomavírus, o qual foi publicado na edição comemorativa de 150 de Genética do periódico Genetics and Molecular Biology (anexo E). 


\section{REFERÊNCIAS*}

ACETO, G.; SOLANO, A.; NEUMAN, M.; VESCHI, S.; MORGANO, A.; MALATESTA, S.; CHACON, R.; PUPARELI, C.; LOMBARDI, M.; BATTISTA, P.; MARCHETTI, A.; MARIANI-COSTANTINI, R.; PODESTÀ, E. High-risk human papilloma virus infection, tumor pathophenotypes, and BRCA1/2 and TP53 status in juvenile breast cancer. Breast Cancer Research and Treatment, v. 122, n. 3, p. 671-683, 2010.

ACILAN, C.; POTTER, D.; SAUNDERS, W. DNA repair pathways involved in anaphase bridge formation. Genes and Chromosomes Cancer, v. 46, n. 6, p. 522531, 2007.

AGUILAR, E.; MARIN DE MAS, I.; ZODDA, E.; MARIN, S.; MORRISH, F.; SELIVANOV, V.; MECA-CORTÉS, O.; DELOWAR, H.; PONS, M.; IZQUIERDO, I.; CELIÀ-TERRASSA, T.; DE ATAURI, P.; CENTELLES, J.; HOCKENBERY, D.; THOMSON, T.; CASCANTE, M. Metabolic reprogramming and dependencies associated with epithelial cancer stem cells independent of the epithelialmesenchymal transition program. Stem Cells, v. 34, n. 5, p. 1163-1176, 2016.

AKERMAN, K.; WIKSTRIJM, M. Saframine as a probe of the mitochondrial membrane potential. FEBS Journal, v. 68, n. 2, p. 191-197, 1976.

ALBERTI, A.; PIRINO, S.; PINTORE, F.; ADDIS, M. F.; CHESSA, B.; CACCIOTTO, C.; CUBEDDU, T.; ANFOSSI, A.; BENENATI, G.; CORADDUZZA, E.; LECIS, R.; ANTUOFERMO, E.; CARCANGIU, L.; PITTAU, M. Ovis aries Papillomavirus 3: A prototype of a novel genus in the family Papillomaviridae associated with ovine squamous cell carcinoma. Virology, v. 407, n. 2, p. 352-359, 2010.

ALEXANDROV, L.; STRATTON, M. Mutational signatures: The patterns of somatic mutations hidden in cancer genomes. Current Opinion in Genetics and Development, v. 24, n. 1, p. 52-60, 2014.

ALFANDARI, J.; SHNITMAN MAGAL, S.; JACKMAN, a; SCHLEGEL, R.; GONEN, P.; SHERMAN, L. HPV16 E6 oncoprotein inhibits apoptosis induced during serumcalcium differentiation of foreskin human keratinocytes. Virology, v. 257, n. 2, p. 383-396, 1999.

ALTICK, A.; BARYSHNIKOVA, L.; VU, T.; VON BARTHELD, C. Quantitative analysis of multivesicular bodies (MVBs) in the hypoglossal nerve: Evidence that neutrophic factors do not use MVBs for retrograde axonal transport. Journal of Comparative Neurology, v. 514, n. 6, p. 641-657, 2009.

ALTMAN, S.; RANDERS, L.; RAO, G. Comparison of trypan blue dye exclusion and fluorometric assays for mammalian cell viability determinations. Biotechnology Program, v. 9, p. 671-674, 1993.

*De acordo com: ASSOCIAÇÃO BRASILEIRA DE NORMAS TÉCNICAS. NBR 6063: informação e documentação: referências: elaboração. Rio de Janaeiro, 2002. 
AMES, B.; GOLD, L.; WILLETT, W. The causes and prevention of cancer. Proceedings of the National Academy of Sciences of the United States of America, v. 92, n. 12, p. 5258-5265, 1995.

ANDERSON, D.; YU, T.; MCGREGOR, D. Comet assay responses as indicators of carcinogen exposure. Mutagenesis, v. 13, n. 6, p. 539-555, 1998.

ANDREOLI, J.; TREVOR, K. Fate of a headless vimentin protein in stable cell cultures: Soluble and cytoskeletal forms. Experimental Research, v. 214, p. 177188, 1994.

ANGELOS, J.; MARTI, E.; LAZARY, S.; CARMICHAEL, L. Characterization of BPVlike DNA in equine sarcoids. Archives of Virology, v. 119, p. 95-109, 1991.

ANJOS, B.; SILVA, M.; DIEFENBACH, A.; BRITO, M.; SEPPA, G.; BRUM, M. Sarcoide equino associado ao papilomavírus bovino BR-UEL-4. Ciência Rural, v. 40, n. 6, p. 1456-1459, 2010.

ANTONSSON, A.; HANSSON, B. Healthy skin of many animal species harbors papillomaviruses which are closely related to their human counterparts. Journal of Virology, v. 76, n. 24, p. 12537-12542, 2002.

ANTONSSON, A.; KNIGHT, L.; WHITEMAN, D. Human papillomavirus not detected in esophageal adenocarcinoma tumor specimens. Cancer Epidemiology, v. 41, p. 96-98, 2016.

ANTONSSON, A.; MCMILLAN, N. Papillomavirus in healthy skin of Australian animals. Journal of General Virology, v. 87, n. 11, p. 3195-3200, 2006.

ANTONSSON, A.; NANCARROW, D.; BROWN, I.; GREEN, A.; DREW, P.; WATSON, D.; HAYWARD, N.; WHITEMAN, D. High-risk human papillomavirus in esophageal squamous cell carcinoma. Cancer Epidemiology, Biomarkers \& Prevention, v. 19, n. 8, p. 2080-2087, 2010.

ARALDI, R. Isolamento e identificaçao do papilomavírus bovino em grupo experimental de bovinos para a obtençao de um banco de vírus. 2014a. Dissertação (Mestrado) - Universidade de São Paulo. Instituto de Ciências Biomédicas. Programa de Pós-graduação Interunidades em Biotecnologia USP/IPT/Instituto Butantan, 2014, p. 133.

ARALDI, R. Bovine papillomavirus: what we know and what we should know. Lambert Academic Publishing, p.125, 2015.

ARALDI, R.; CARVALHO, R.; MELO, T.; DINIZ, N.; SANT'ANA, T.; MAZZUCHELLIDE-SOUZA, J.; SPADACCI-MORENA, D.; BEÇAK, W.; STOCCO, R. Bovine papillomavirus in beef cattle: First description of BPV-12 and putative type BAPV8 in Brazil. Genetics and Molecular Research, v. 13, n. 3, p. 5644-5653, 2014a.

ARALDI, R.; GIOVANNI, D.; MELO, T.; DINIZ, N.; MAZZUCHELLI-DE-SOUZA, J.; SANT'ANA, T.; CARAVLHO, R.; BEÇAK, W.; STOCCO, R. Bovine papillomavirus 
isolation by ultracentrifugation. Journal of Virological Methods, v. 208, p. 119-124, 2014b.

ARALDI, R.; MELO, T.; DINIZ, N.; CARVALHO, R.; BEÇAK, W.; STOCCO, R. Bovine papillomavirus clastogenic effect analyzed in comet assay. BioMed Research International, v. 2013, p. 1-7, 2013a.

ARALDI, R.; MELO, T.; NEVES, A.; SPADACCI-MORENA, D.; MAGNELLI, R.; MÓDULO, D.; DE-SÁ-JÚNIO, P.; MAZZUCHELLI-DE-SOUZA, J.; CARVALHO, R.; BEÇAK, W.; STOCCO, R. Hyperproliferative action of bovine papillomavirus (BPV): Genetics and histopathological aspects. Genetics and Molecular Research, v. 14, n. 4, p. 12942-12954, $2015 a$.

ARALDI, R.; OLIVEIRA, D.; SILVA, D.; MENDES, T.; SOUZA, E. Análise do potencial mutagênico dos esteróides anabólicos androgênicos (EAA) e da LCarnitina mediatnte o teste do micronúcleo em eritrócitos policromáticos. Revista Brasileira de Medicina do Esporte, v. 19, n. 6, p. 448-451, 2013b.

ARALDI, R.; RECHIUTTI, B.; MENDES, T.; ITO, E.; SOUZA, E. Mutagenic potential of Cordia ecalyculata alone and in association with Spirulina maxima for their evaluation as candidate anti-obesity drugs. Genetics and Molecular Research, v. 13, n. 3, p. 5207-5220, 2014c.

ARALDI, R.; SANTOS, N.; MENDES, T.; CARVALHO, L.; ITO, E. Can Spirulina maxima reduce the mutagenic potential of sibutramine? Genetics and Molecular Research, v. 14, n. 4, p. 18452-18464, 2015 b.

ARANDA, A.; SEQUEDO, L.; TOLOSA, L.; QUINTAS, G.; BURELLO, E.; CASTELL, J.; GOMBAU, L. Dichloro-dihydro-fluorescein diacetate (DCFH-DA) assay: A quantitative method for oxidative stress assessment of nanoparticle-treated cells. Toxicology in Vitro, v. 27, n. 2, p. 954-963, 2013.

ARCHETTI, M. Heterogeneity and proliferation of invasive cancer subclones in game theory models of the Warburg effect. Cell Proliferation, v. 48, p. 259-269, 2015.

ARGYLE, D.; BLACKING, T. From viruses to cancer stem cells: Dissecting the pathways to malignancy. The Veterinary Journal, v. 177, n. 3, p. 311-323, 2008.

ARJONEN, A.; KAUKONEN, R.; IVASKA, J. Filopodia and adhesion in cancer cell motility. Cell Adhesion and Migration, v. 5, n. 5, p. 37-41, 2011.

ARMSTRONG, T.; PACKHAM, G.; MURPHY, L.; BATEMAN, A.; CONTI, J.; FINE, D.; JOHNSON, C.; BENYON, R.; IREDALE, J. Type I collagen promotes the malignant phenotype of pancreatic ductal adenocarcinoma. Clinical Cancer Resear, v. 10, n. 21, p. $7427-7437,2004$.

ARNAL, A.; TISSOT, T.; UJVARI, B.; NUNNEY, L.; SOLARY, E.; LAPLANE, L.; BONHOMME, F.; VITTECOQ, M.; TASIEMSKI, A.; RENAUD, F.; PUJOL, P.; ROCHE, B.; THOMAS, F. The guardians of inherited oncogenic vulnerabilities. Evolution, v. 70, n. 1, p. 1-6, 2016. 
ASGARI, Y.; ZABIHINPOUR, Z.; SCHREIBER, F.; MASOUDI-NEJAD, A. Alterations in cancer cells metabolism: the Warburg effect and metabolic adaptation. Genomics, v. 105, n. 5-6, p. 275-281, 2015.

ASTORI, G.; LAVERGNE, D.; BENTON, C.; HOCKMAYR, B.; EGAWA, K.; GARBE, C.; DE VILLIERS, E. Human papillomavirus are commonly found in normal skin of immunocompetent hosts. Journal of Investigative Dermatology, v. 110, p. $752-$ 755, 1998.

AURÉLIO-NETO, O. A pecuária extensiva em Goiás: a técnica no espaço rural e o crescimento horizontal da bovinocultura entre 1920 e 1960. Boletin Goiano de Geografia, v. 34, n. 3, p. 501-523, 2014.

AYRES, M.; AYRES, J.; AYRES, D.; SANTOS, A. BioEstat 5.0 - Aplicações estatísticas nas áreas de ciências biológicas e médicas. Belém. Socieda Civil Mamirauá, , 2007.

AZQUETA, A.; GUTZKOW, K.; BRUNBORG, G.; COLLINS, A. Towards a more reliable comet assay: optimising agarose concentration, unwinding time and electrophoresis conditions. Mutation Rsearch, v. 724, n. 1-2, p. 41-45, 2011.

AZZIMONTI, B.; DELL'OSTE, V.; BORGOGNA, C.; MONDINI, M.; GUGLIESI, F.; DE ANDREA, M.; CHIORINO, G.; SCATOLINI, M.; GHIMENTI, C.; LANDOLFO, S.; GARIGLIO, M. The epithelial-mesenchymal transition induced by keratinocyte growth conditions is overcome by E6 and E7 from HPV16, but not HPV8 and HPV38: Characterization of global transcription profiles. Virology, v. 388, n. 2, p. 260-269, 2009.

BAKER, M. Blame it on the antibodies. Nature, v. 521, p. 274-276, 2015.

BAKER, T.; NEWCOMB, W.; OLSON, N.; COWSERT, L.; OLSON, C.; BROWN, J. Structures of bovine and human papillomaviruses. Analysis by cryoelectron microscopy and three-dimensional image reconstruction. Biophysical Journal, v. 60 , n. 6, p. 1445-1456, 1991.

BAKOLITSA, C.; COHEN, D.; BANKSTON, L.; BOBKOV, A.; CADWELL, G.; JENNINGS, L.; CRITCHLEY, D.; CRAIG, S.; LIDDINGTON, R. Structural basis for vinculin activation at sites of cell adhesion. Nature, v. 430, n. 6999, p. 583-586, 2004.

BALABAN, R.; NEMOTO, S.; FINKEL, T. Mitochondria, oxidants, and aging. Cell, v. 120, n. 4, p. 483-495, 2005.

BALCOS, L.; BORZACCHIELLO, G.; RUSSO, V.; POPESCU, O.; ROPERTO, S.; ROPERTO, F. Association of bovine papillomavirus type-2 and urinary bladder tumours in cattle from Romania. Research in Veterinary Science, v. 85, n. 1, p. 145-148, 2008.

BARAK, V.; GOIKE, H.; PANARETAKIS, K.; EINARSSON, R. Clinical utility of 
cytokeratins as tumor markers. Clinical Biochemistry, v. 37, p. 529-540, 2004.

BARRALLO-GIMENO, A.; NIETO, M. The Snail genes as inducers of cell movement and survival: implications in development and cancer. Development, v. 132, n. 14, p. 3151-3161, 2005.

BASHASHATI, A.; BRINKMAN, R. A survey of flow cytometry data analysis methods. Advances in Bioinformatics, v. 2009, p. 584603, 2009.

BASSI, D.; MAHLOOGI, H.; AL-SALEEM, L.; DE CICCO, R.; RIDGE, J.; KLEINSZANTO, A. Elevated furin expression in aggressive human head and neck tumors and tumor cell lines. Molecular Carcinogenesis, v. 31, n. 4, p. 224-232, 2001.

BATLLE, E.; SANCHO, E.; FRANCÍ, C.; DOMÍNGUEZ, D.; MONFAR, M.; BAULIDA, J.; GARCÍA-DE-HERREROS, A. The transcription factor snail is a repressor of $E$ cadherin gene expression in epithelial tumour cells. Nature cell biology, v. 2, n. 2, p. 84-89, 2000.

BAYO, P.; JOU, A.; STENZINGER, A.; SHAO, C.; GROSS, M.; JENSEN, A.; GRABE, N.; MENDE, C.; RADOS, P.; DEBUS, J.; WEICHERT, W.; PLINKERT, P.; LICHTER, P.; FREIER, K.; HESS, J. Loss of SOX2 expression induces cell motility via vimentin up-regulation and is an unfavorable risk factor for survival of head and neck squamous cell carcinoma. Molecular Oncology, v. 9, n. 8, p. 1704-1719, 2015.

BENDICH, A.; VIZOSO, A.; HARRIS, R. Intercellular bridges between mammaliam cells in culture. Proceedings of the National Academy of Sciences of the United States of America, p. 1029-1035, 1967.

BENISTON, R. G.; MORGAN, I. M.; O'BRIEN, V.; CAMPO, M. S. Quercetin, E7 and p53 in papillomavirus oncogenic cell transformation. Carcinogenesis, v. 22, n. 7, p. 1069-1076, 2001.

BERG, L.; SINGH, K.; BOTCHAN, M. Complementation of a bovine papilloma virus low-copy-number mutant: Evidence for a temporal requirement of the complementing gene. Molecular and Cellular Biology, v. 6, n. 3, p. 859-869, 1986.

BERGVALL, K. Sarcoids. The Veterinary Clinics Equine, v. 29, n. 3, p. 657-71. 2013.

BERNARD, H. Coevoiution of papillomaviruses with human populations. Trends in Microbiology, v. 2, n. 4, p. 18-21, 1994.

BERNARD, H.; CALLEJA-MACIAS, I.; DUNN, S. Genome variation of human papillomavirus types: Phylogenetic and medical implications. International Journal of Cancer, v. 118, n. 5, p. 1071-1076, 2006.

BERTI, M.; VINDIGNI, A. Replication stress: getting back on track. Nature Structural \& Molecular Biology, v. 23, n. 2, p. 103-109, 2016. 
BETIOL, J.; KIGNEL, S.; TRSITÃO, W.; ARRUDA, A.; SANTOS, A.; BARBIERI, R.; BETTINI, J. HPV 18 prevalence in oral mucosa diagnosed with verrucous leukoplakia: cytological and molecular analysis. Journal of Clinical Pathology, v. 65, n. 8, p. 2012-2014, 2012.

BEY, E.; ALEXANDER, J.; WHITCUTT, J.; HUNT, J.; GEAR, J. Carcinoma of the esophagus in Africans: establishment of a continuously growing cell line from a tumor specimen. In Vitro, v. 12, n. 2, p. 107-114, 1976.

BI, M.; NACZKI, C.; KORITZINSKY, M.; FELS, D.; BLAIS, J.; HU, N.; HARDING, H.; NOVOA, I.; VARIA, M.; RALEIGH, J.; SCHEUNER, D.; KAUFMAN, R.; BELL, J.; RON, D.; WOUTERS, B.; KOUMENIS, C. ER stress-regulated translation increases tolerance to extreme hypoxia and promotes tumor growth. The EMBO Journal, v. 24, n. 19, p. 3470-3481, 2005.

BIANCHI, M.; CASAGRANDE, R.; WATANABE, T.; WOUTERS, A.; WOUTERS, F.; BOOS, G.; MENEGAT, M.; DRIEMEIER, D. Canine papillomatosis : A retrospective study of 24 cases. Pesuisa Veterinaria Brasileira, v. 32, n. 7, p. 653-657, 2012.

BJØRGE, T.; HAKULINEN, T.; ENGELAND, A.; JELLUM, E.; KOSKEL, P.; LEHTINEN, M.; LUOSTARINEN, T.; PAAVONEN, J.; SAPP, M.; SCHILLER, J.; THORESEN, S.; WANG, Z.; YOUNGMAN, L.; DILLNER, J. A prospective, seroepidemiological study of the role of human papillomavirus in esophageal cancer in Norway. Cancer Research, v. 57, p. 3989-3992, 1997.

BLACK, P. The oncogenic DNA viruses: a review of in vitro transformation studies. Annual Review of Microbiology, v. 22, p. 391-426, 1968.

BLEIER, L.; WITTIG, I.; HEIDE, H.; STEGER, M.; BRANDT, U.; DRÖSE, S. Generator-specific targets of mitochondrial reactive oxygen species. Free Radical Biology and Medicine, v. 78, p. 1-10, 2015.

BOCANETI, F.; ALTAMURA, G.; CORTEGGIO, A.; VELESCU, E.; ROPERTO, F.; BORZACCHIELLO, G. Bovine papillomavirus: new insights into an old disease. Transboundary and Emerging Diseases, p. 1-10, 2014.

BOCCARDO, E.; LEPIQUE, A. P.; VILLA, L. L. The role of inflammation in HPV carcinogenesis. Carcinogenesis, v. 31, n. 11, p. 1905-1912, 2010.

BODAGHI, S.; WOOD, L.; ROBY, G.; RYDER, C.; STEINBERG, S. Could human papillomaviruses be spread through blood? Journal of Clinical Mircobiology, v. 43, n. 11, p. 5428-5434, 2005.

BOGAERT, L.; MARTENS, A.; KAST, W.; VAN MARCK, E.; DE COCK, H. Bovine papillomavirus DNA can be detected in keratinocytes of equine sarcoid tumors. Veterinary Microbiology, v. 146, n. 3-4, p. 269-275, 2010.

BOGAERT, L.; MARTENS, A.; VAN POUCKE, M.; DUCATELLE, R.; DE COCK, H.; DEWULF, J.; DE BAERE, C.; PEELMAN, L.; GASTHUYS, F. High prevalence of bovine papillomaviral DNA in the normal skin of equine sarcoid-affected and healthy 
horses. Veterinary Microbiology, v. 129, n. 1-2, p. 58-68, 2008.

BOGAERT, L.; VAN POUCKE, M.; DE BAERE, C.; DEWULF, J.; PEELMAN, L.; DUCATELLE, R.; GASTHUYS, F.; MARTENS, A. Bovine papillomavirus load and mRNA expression, cell proliferation and p53 expression in four clinical types of equine sarcoid. The Journal of General Virology, v. 88, p. 2155-2161, 2007.

BOHL, J.; DAS, K.; DASGUPTA, B.; VANDE POL, S. Competitive binding to a charged leucine motif represses transformation by a papillomavirus E6 oncoprotein. Virology, v. 271, n. 1, p. 163-170, 2000.

BOHN, W.; WIEGERS, W.; BEUTTENMULLER, M.; TRAUB, P. Species-specific recognition patterns of monoclonal antibodies directed against vimentin. Experimental Cell Research, v. 201, n. 1, p. 1-7, 1992.

BOLÓS, V.; PEINADO, H.; PÉREZ-MORENO, M.; FRAGA, M.; ESTELLER, M.; CANO, A. The transcription factor Slug represses E-cadherin expression and induces epithelial to mesenchymal transitions: a comparison with Snail and E47 repressors. Journal of Cell Science, v. 116, p. 499-511, 2003.

BONADIES, F.; BORZACCHIELLO, G.; DEZZI, S.; NICOLETTI, R.; ROPERTO, S. Mass spectrometric analysis of ptaquiloside, the toxic sesquiterpene from bracken fern. Rapid Communication in Mass Spectometry, v. 18, n. 7, p. 825-828, 2004.

BONASSI, S.; ZNAOR, A.; CEPPI, M.; LANDO, C.; CHANG, W.; HOLLAND, N.; KIRSCH-VOLDERS, M.; ZEIGER, E.; BAN, S.; BARALE, R.; BIGATTI, M.; BOLOGNESI, C.; CEBULSKA-WASILEWSKA, A.; FABIANOVA, E.; FUCIC, A.; HAGMAR, L.; JOKSIC, G.; MARTELLI, A.; MIGLIORE, L.; MIRKOVA, E.; SCARFI, M.; ZIJNO, A.; NORPPA, H.; FENECH, M. An increased micronucleus frequency in peripheral blood lymphocytes predicts the risk of cancer in humans. Carcinogenesis, v. 28, n. 3, p. 625-631, 2007.

BOON, S.; TOMAIĆ, V.; THOMAS, M.; ROBERTS, S.; BANKS, L. Cancer-causing human papillomavirus E6 proteins display major differences in the phosphoregulation of their PDZ interactions. Journal of Virology, v. 89, n. 3, p. 1579-1586, 2015.

BÖRKÜ, M.; ATALAY, O.; KIBAR, M.; CAM, Y.; ATASEVER, A. Ivermectin is an effective treatment for bovine cutaneous papillomatosis. Research in Veterinary Scienceeterinary science, v. 83, n. 3, p. 360-363, 2007.

BORZACCHIELLO, G. Bovine papillomavirus infections in animals. Communicating Current Research and Educational Topics and Trends in Applied Microbiology, p. 673-679, 2007.

BORZACCHIELLO, G.; AMBROSIO, V.; ROPERTO, S.; POGGIALI, F.; TSIRIMONAKIS, E.; VENUTI, A.; CAMPO, M.; ROPERTO, F. Bovine papillomavirus type 4 in oesophageal papillomas of cattle from the South of Italy. Journal of Comparative Pathology, v. 128, n. 2, p. 203-206, 2003. 
BORZACCHIELLO, G.; ROPERTO, F. Bovine papillomaviruses, papillomas and cancer in cattle. Veterinary Research, v. 39, n. 5, p. 45, 2008.

BORZACCHIELLO, G.; RUSSO, V.; SPOLETO, C.; ROPERTO, S.; BALCOS, L.; RIZZO, C.; VENUTI, A.; ROPERTO, F. Bovine papillomavirus type-2 DNA and expression of $E 5$ and $E 7$ oncoproteins in vascular tumours of the urinary bladder in cattle. Cancer Letters, v. 250, n. 1, p. 82-91, 2007.

BOSSE, K.; CHRISTOPHERS, E. Beitrag zur epidemiologie der warzen. Hautarzt, v. 15, p. 80, 1964.

BOULENOUAR, S.; WEYN, C.; VAN NOPPEN, M.; ALI, M.; FAVRE, M.; DELVENNE, P.; BEX, F.; NOËL, A.; ENGLERT, Y.; FONTAINE, V. Effects of HPV-16 $E 5$, E6 and E7 proteins on survival, adhesion, migration and invasion of trophoblastic cells. Carcinogenesis, v. 31, n. 3, p. 473-480, 2010.

BOULET, G.; HORVATH, C.; VANDEN, B.; SAHEBALI, S.; BOGERS, J. Human papillomavirus: E6 and E7 oncogenes. The International Journal of Biochemistry \& Cell Biology, v. 39, n. 11, p. 2006-2011, 2007.

BOYER, A.; WALTER, D.; SØRENSEN, C. DNA replication and cancer: from dysfunctional replication origin activities to therapeutic opportunities. Seminars in Cancer Biology, v.37, p. 1-10, 2016.

BRANDT, S.; HARALAMBUS, R.; SCHOSTER, A.; KIRNBAUER, R.; STANEK, C. Peripheral blood mononuclear cells represent a reservoir of bovine papillomavirus DNA in sarcoid-affected equines. The Journal of general virology, v. 89, n. 6, p. 1390-1395,. 2008.

BRANDT, S.; SCHOSTER, A.; TOBER, R.; KAINZBAUER, C.; BURGSTALLER, J. P.; HARALAMBUS, R.; STEINBORN, R.; HINTERHOFER, C.; STANEK, C. Consistent detection of bovine papillomavirus in lesions, intact skin and peripheral blood mononuclear cells of horses affected by hoof canker. Equine Veterinary Journal, v. 43, p. 202-209, 2011.

BRAVO, I.; FELEZ-SANCHEZ, M. Papillomaviruses: viral evolution, cancer and evolutionary medicine. Evolution, Medicine, and Public Health, v. 2015, n. 1, p. 32-51, 2015.

BRAVO, I.; SANJOSÉ, S.; GOTTSCHLING, M. The clinical importance of understanding the evolution of papillomaviruses. Trends in Microbiology, v. 18, $\mathrm{n}$. 10, p. 432-438, 2010.

BREMNES, R.; VEVE, R.; HIRSCH, F.; FRANKLIN, W. The E-cadherin cell-cell adhesion complex and lung cancer invasion, metastasis, and prognosis. Lung Cancer, v. 36, p. 115-124, 2002.

BRINGUIER, P.; UMBAS, R.; SCHAAFSMA, H.; KARTHAUS, H.; DEBRUYNE, F.; SCHALKEN, J. Decreased E-cadherin immunoreactivity correlates with poor survival in patients with bladder tumors. Cancer Research, v. 53, n. 14, p. 3241-3245, 1993. 
BRITO, O.; FERNANDA, M.; RESENDE, B.; COSTA, C.; LANNA, D. Ciclofosfamida e função ovariana. Revista Brasileira de Reumatologia, v. 48, n. 1, p. 39-45, 2008.

BROBST, D.; HINSMAN, E. Electron microscopy of the bovine cutaneous papilloma. Veterinary Pathology, v. 3, n. 3, p. 196-207, 1966.

BRØNDEN, L.; FLAGSTAD, A.; KRISTENSEN, A. Veterinary cancer registries in companion animal cancer: A review. Veterinary and Comparative Oncology, v. 5, p. 133-144, 2007.

BRÜCHER, B.; JAMALL, I. Epistemology of the origin of cancer: a new paradigm. BMC Cancer, v. 15, n. 331, p. 1-15, 2014.

BRYAN, J.; BROWN, D. Transmission of human papillomavirus type 11 infection by desquamated cornified cells. Virology, v. 281, n. 1, p. 35-42, 2001.

BUCHANAN, D.; KURITA, T.; TAYLOR, J.; LUBAHN, D.; CUNHA, G.; COOKE, P. Role of stromal and epithelial estrogen receptors in vaginal epithelial proliferation, stratification, and cornification. Endocrinology, v. 139, n. 10, p. 4345-4352, 1998.

BUCK, C.; DAY, P.; TRUS, B. The papillomavirus major capsid protein L1. Virology, v. 445, p. 169-174, 2013.

BUCK, C.; PASTRANA, D.; LOWY, D.; SCHILLER, J. Efficient intracellular assembly of papillomaviral vectors. Journal of Virology, v. 78, n. 2, p. 751-757, 2004.

BURKHARDT, A.; WILLINGHAM, M.; GAY, C.; JEANG, K.; SCHLEGEL, R. The E5 oncoprotein of bovine papillomavirus is oriented asymmetrically in Golgi and plasma membranes. Virology, v. 339, p. 334-339, 1989.

BURNETT, S.; JAREBORG, N.; DIMAIOT, D. Localization of bovine papillomavirus type 1 E5 protein to transformed basal keratinocytes and permissive differentiated cells in fibropapilloma tissue. Proceedings of the National Academy of Sciences of the United States of America, v. 89, p. 5665-5669, 1992.

BURRELL, R.; SWANTON, C. The evolution of the unstable cancer genome. Current Opinion in Genetics and Development, v. 24, n. 1, p. 61-67, 2014.

BUTEL, J. Viral carcinogenesis: revelation of molecular mechanisms and etiology of human disease. Carcinogenesis, v. 21, n. 3, p. 405-426, 2000.

CABERG, J.; HUBERT, P.; BEGON, D.; HERFS, M.; RONCARATI, P.; BONIER, J.; DELVENNE, P. Silencing of E7 oncogene restores functional E-cadherin expression in human papillomavirus 16-transformed keratinocytes. Carcinogenesis, v. 29, n. 7, p. 1441-1447, 2008.

CAI, Q.; LV, L.; SHAO, Q.; LI, X.; DIAN, A. Human papillomavirus early proteins and apoptosis. Archives of Gynecology and Obstetrics, v. 287, n. 3, p. 541-548, 2013. 
CALINISAN, J.; CHAN, S.; KING, A.; CHAN, P. Human papillomavirus and blastocyst apoptosis. Journal of Assisted Reproduction and Genetics, v. 19, n. 3, p. 132136, 2002.

CAMPO, M. Vaccination against papillomavirus in cattle. Clinics in Dermatology, v. 15 , p. 275-283, 1997 .

CAMPO, M. Bovine papillomavirus and cancer. The Veterinary Journal, v. 154, p. 175-188, 1997b.

CAMPO, M. Animal models of papilloma virus pathogenesis. Virus Research, v. 89, p. 249-261, 2002.

CAMPO, M. Bovine papillomavirus : old system, new lessons ? In: CAMPO, M. (Ed.). Papillomavirus biology: from natural history to vaccine and beyond. Wymondham: Caister Academic Press, 2006.

CAMPO, M.; GRINDLAY, J.; O'NEIL, W.; CHANDRACHUD, L.; MCGARVIE, G.; JARRETT, W. Prophylactic and therapeutic vaccination against a mucosal papillomavirus. Journal of General Virology, v. 74, p. 945-953, 1993.

CAMPO, M.; O'NEIL, B.; GRINDLAY, G.; CURTIS, F.; KNOWLES, G.; CHANDRACHUD, L. A peptide encoding a B-cell epitope from the $\mathrm{N}$-terminus of the capsid protein L2 of bovine papillomavirus-4 prevents disease. Virology, v. 234, n. 2, p. 261-266, 1997.

CAMPOS, S.; MELO, T.; ASSAF, S.; ARALDI, R.; MAZZUCHELLI-DE-SOUZA, J.; SIRCILI, M.; CARVALHO, R.; ROPERTO, F.; BEÇAK, W.; STOCCO, R. Chromosome aberrations in cells infected with bovine papillomavirus: comparing cutaneous papilloma, esophagus papilloma, and urinary bladder lesion cells. ISRN oncology, v. 2013, p. 910849, 2013.

CAMPOS, S.; TRINDADE, C.; FERRAZ, O.; GIOVANNI, D.; LIMA, A.; CAETANO, H. A.; CARVALHO, R.; BIRGEL, E.; DAGLI, M.; MORI, E.; BRANDÃO, P.; RICHTZENHAIN, L.; BEÇAK, W.; STOCCO, R. Can established cultured papilloma cells harbor bovine papillomavirus? Genetics and Rolecular Research, v. 7, n. 4, p. 1119-1126, 2008.

CAO, B.; TIAN, X.; LI, Y.; JIANG, P.; NING, T.; XING, H.; ZHAO, Y.; ZHANG, C.; SHI, X.; CHEN, D.; SHEN, Y.; KE, Y. LMP7/TAP2 gene polymorphisms and HPV infection in esophageal carcinoma patients from a high incidence area in China. Carcinogenesis, v. 26, n. 7, p. 1280-1284, 2005.

CARBAJAL-LÓPEZ, Y.; GÓMEZ-ARROYO, S.; VILLALOBOS-PIETRINI, R.; CALDERÓN-SEGURA, M.; MARTÍNEZ-ARROYO, A. Biomonitoring of agricultural workers exposed to pesticide mixtures in Guerrero state, Mexico, with comet assay and micronucleus test. Environmental Science and Pollution Research, v. 23, p. 2513-2520, 2016.

CARR, E. New developments in diagnosis and treatment of equine sarcoids. In: 
ROBINSON, N.; SPRAYBERRY, K. (Ed.). Current therapy in equine medicine. 6. ed. St. Louis: Sauders Elsevier, 2009. p. 698.

CARRILHO, C.; ALBERTO, M.; BUANE, L.; DAVID, L. Keratins 8, 10, 13, and 17 are useful markers in the diagnosis of human cervix carcinomas. Journal of Human Pathology, v. 35, n. 5, p. 546-551, 2004.

CARVALHO, C.; BATISTA, M.; SILVA, M.; BALBINO, V.; FREITAS, A. Detection of bovine papillomavirus types, co-infection and a putative new BPV11 subtype in cattle. Transboundary and Emerging Diseases, v. 59, n. 5, p. 441-447, 2012.

CARVALHO, C.; FREITAS, A.; BRUNNER, O.; GÓES, L.; CAVALCANTE, A.; BEÇAK, W.; STOCCO DOS SANTOS, R. Bovine papillomavirus type 2 in reproductive tract and gametes of slaughtered bovine females. Brazilian Journal of Microbiology, v. 34, p. 82-84, 2003.

CARVALHO, R. F.; ARALDI, R. P.; LIMA, T. A. N.; MODOLO, D. G.; SOUZA, J. M.; BEÇAK, W.; STOCCO, R. Synergic associations between the bovine papillomavirus infection and alimentary cofactors. Reference Module in Food Science, v. 1, p. 110,2016

CARVALHO, R.; SAKATA, S.; GIOVANNI, D.; MORI, E.; BRANDÃO, P.; RICHTZENHAIN, L.; POZZI, C.; ARCARO, J.; MIRANDA, M.; MAZZUCHELLI-DESOUZA, J.; MELO, T.; COMENALE, G.; ASSAF, S.; BEÇAK, W.; STOCCO, R. Bovine papillomavirus in Brazil: detection of coinfection of unusual types by a PCRRFLP method. BioMed Research International, v. 2013, p. 270898, 2013.

CASCALES, R.; ALCANTARA, B.; MOLINARI, B.; BODNAR, L.; FILIPPSEN, P.; TOZATO, C.; MDEIROS, T.; ALFIERI, A. Estudo histopatológico de lesões neoplásicas benignas, determinadas pelo papilomavírus bovino, localizado em tetos e úberes de vacas leiteiras. In: Anais do XVIII Encontro Anual de Iniciação Científica, Anais. 2009.

CASTRO-MUÑOZLEDO, F.; VELEZ-DELVALLE, C.; MARSCH-MORENO, M.; HERNÁNDEZ-QUINTERO, M.; KURI-HARCUCH, W. Vimentin is necessary for colony growth of human diploid keratinocytes. Histochemistry and Cell Biology, v. 143, n. 1, p. 45-57, 2014.

CATROXO, M.; MARTINS, A.; PETRELLA, S.; SOUZA, F.; NASTARI, B. Ultrastructural study of bovine papillomavirus during outbreaks in Brazil. International Journal of Morphology, v. 31, n. 2, p. 777-784, 2013.

CAUSSINUS, E.; GONZALEZ, C. Induction of tumor growth by altered stem-cell asymmetric division in Drosophila melanogaster. Nature Genetics, v. 37, n. 10, p. 1125-1129, 2005.

CAVALCANTI-JÚNIOR, G.; KLUMB, C.; MAIA, R. p53 e as hemopatias malignas. Revista Brasileira de Cancerologia, v. 48, n. 3, p. 419-427, 2002.

CERQUEIRA, C.; PANG, Y.; DAY, P.; THOMPSON, C.; BUCK, C.; LOWY, D.; 
SCHILLER, J. A cell-free assembly system for generating infectious Human Papillomavirus Type 16 capsids implicates a size discrimination mechanism for preferential viral genome packaging. Journal of Virology, v. 90, n. 2, p. 1096-1107, 2016.

CERUTTI, P. Response modification creates promotability in multistage carcinogenesis. Carcinogenesis, v. 9, n. 4, p. 519-526, 1988.

CETINKAYA, N.; ERCIN, D.; ÖZVATAN, S.; EREL, Y. Quantification of applied dose in irradiated citrus fruits by DNA Comet Assay together with image analysis. Food Chemistry, v. 192, p. 370-373, 2016.

CHALLBERG, M.; KELLY, T. Animal virus DNA replication. Annual Review of Biochemistry, v. 58, p. 671-717, 1989.

CHAMBERS, G.; ELLSMORE, V.; O'BRIEN, P.; REID, S.; LOVE, S.; CAMPO, M.; NASIR, L. Association of bovine papillomavirus with the equine sarcoid. Journal of General Virology, v. 84, n. 5, p. 1055-1062, 2003.

CHAMBERS, G.; ELLSMORE, V.; O'BRIEN, P.; REID, S.; LOVE, S.; CAMPO, M.; NASIR, L. Sequence variants of bovine papillomavirus E5 detected in equine sarcoids. Virus Research, v. 96, p. 141-145, 2003.

CHANDRACHUD, L.; O'NEIL, B.; JARRETT, W.; GRINLAY, G.; MCGARVIE, G.; CAMPO, M. Humoral immune response to the E7 protein of bovine papillomavirus type 4 and identification of B-cell epitopes. Virology, v. 200, p. 98-104, 1994.

CHANDRACHUS, L.; GRINLAY, G.; MCGARVIE, G.; O'NEIL, B.; WAGNER, E.; JARRET, W.; CAMPO, M. Vaccinationa of cattle with N-terminus of $L 2$ is necessary and sufficient for preventing infection by bovine papillomavirus-4. Virology, v. 211, p. 204-208, 1995.

CHANG, F.; SYRJÄNEN, S.; SHEN, Q.; JI, H.; SYRJÄNEN, K. Human papillomavirus (HPV) DNA in esophageal precancer lesions and squamous cell carcinomas from china. International Journal of Cancer, v. 25, p. 21-25, 1990.

CHANG, F.; SYRJANEN, S.; SHEN, Q.; WANG, L.; SYRJANEN, K. Screening for human papillomavirus infections in esophageal squamous cell carcinomas by in situ hybridization. Cancer, v. 72, p. 2525-2530., 1993.

CHANG, F.; SYRJÄNEN, S.; SYRJÄNEN, K. Implications of the p53 tumorsuppressor gene in clinical oncology. Journal of Clinical Oncology, v. 13, p. 10091022, 1995.

CHANG, F.; SYRJANEN, S.; WANG, L.; SYRJANEN, K. Infectious agents in the etiology of esophageal cancer. Gastroenterology, v. 103, p. 1336-1348, 1992.

CHANG, F.; SYRJANENL, S.; TERVAHAUTA, A.; KURVINEN, K.; WANG, L.; SYRJINEN, K. Frequent mutations of p53 gene in oesophageal squamous cell carcinomas with and without human papiliomavirus (HPV) involvement suggest the 
dominant role of environmental carcinogens in oesophageal carcinogenesis. British Journal of Cancer, v. 70, p. 346-351, 1994.

CHANG, L.; GRAHAM, P.; HAO, J.; NI, J.; BUCCI, J.; COZZI, P. J.; KEARSLEY, J.; LI, Y. Acquisition of epithelial-mesenchymal transition and cancer stem cell phenotypes is associated with activation of the $\mathrm{PI3K} / \mathrm{Akt} / \mathrm{mTOR}$ pathway in prostate cancer radioresistance. Cell Death \& dDsease, v. 4, p. e875, 2013.

CHEN, H.; HUTT-FLETCHER, L.; CAO, L.; HAYWARD, S. D. A positive autoregulatory loop of LMP1 expression and STAT activation in epithelial cells latently infected with Epstein-Barr virus. Journal of Virology, v. 77, n. 7, p. 41394148, 2003.

CHEN, J.; HONG, Y.; ANDROPHY, E. Mutational analysis of transcriptional activation by the bovine papillomavirus type 1 E6. Virology, v. 236, n. 1, p. 30-36, 1997.

CHEN, L.; ASHE, S.; SINGHAL, M.; GALLOWAY, D.; HELLSTRÖM, I.; HELLSTRÖM, K. Metastatic conversion of cells by expression of human. Proceedings of the National Academy of Sciences of the United States of America, v. 90, p. 6523-6527, 1993.

CHEN, P.; LEE, H. FOXM1 induced by E6 oncoprotein promotes tumor invasion and chemoresistance in HPV-infected lung cancer. Cancer Cell \& Microenvironment, v. 2, p. 6-9, 2015.

CHEN, Z.; LU, W.; GARCIA-PRIETO, C.; HUANG, P. The Warburg effect and its cancer therapeutic implications. Journal of bioenergetics and biomembranes, $v$. 39, n. 3, p. 267-274, 2007.

CHEVILLE, N.; OLSON, C. Cytology of the canine oral papilloma. The American Journal of Pathology, v. 45, n. 5, p. 849-872, 1964.

CHINNADURAI, G. Opposing oncogenic activities of small DNA tumor virus transforming proteins. Trends in Microbiology, v. 19, n. 4, p. 174-183, 2011.

CHIOU, H.; WU, M.; LIAW, Y.; CHENG, Y.; WONG, R.; CHEN, C.; LEE, H. The presence of human papillomavirus type 16/18 DNA in blood circulation may act as a risk marker of lung cancer in Taiwan. Cancer, v. 97, n. 6, p. 1558-1563, 2003.

CHOI, J.; LEE, K.; ZHENG, Y.; YAMAGA, A.; LAI, M.; OU, J. Reactive oxygen species suppress hepatitis $C$ virus RNA replication in human hepatoma cells. Hepatology, v. 39, n. 1, p. 81-89, 2004.

CHOO, K.; CHEUNG, W.; LIEW, L.; LEE, H.; HAN, S. Presence of catenated human papillomavirus type 16 episomes in a cervical carcinoma cell line. Journal of Virology, v. 63, n. 2, p. 782-789, 1989.

CHOWDHURY, D.; KEOGH, M.; ISHII, H.; PETERSON, C.; BURATOWSKI, S.; LIEBERMAN, J. gamma-H2AX dephosphorylation by protein phosphatase $2 \mathrm{~A}$ 
facilitates DNA double-strand break repair. Molecular Cell, v. 20, p. 801-809, 2005.

CICHON, M.; NELSON, C.; RADISKY, D. Regulation of epithelial-mesenchymal transition in breast cancer cells by cell contact and adhesion. Cancer Informatics, v. 14, n. S3, p. 1-13, 2015.

CICHON, M.; RADISKY, D. ROS-induced epithelial-mesenchymal transition in mammary epithelial cells is mediated by NF-KB-dependent activation of Snail. Oncotarget, v. 5, n. 9, p. 2827-2838, 2014.

CIGERCI, I.; ALI, M.; KAYGISIZ, S.; LIMAN, R. Genotoxicity assessment of cobalt chloride in Eisenia hortensis earthworms coelomocytes by comet assay and micronucleus test. Chemosphere, v. 144, p. 754-757, 2016.

CLARKE, M.; FULLER, M. Stem cells and cancer: two faces of eve. Cell, v. 124, n. 6, p. 1111-1115, 2006.

CLAUS, M.; LUNARDI, M.; ALFIERI, A.; SARTORI, D.; FUNGARO, H.; ALFIERI, A. Identification of the recently described new type of bovine papillomavirus (BPV-8) in a Brazilian beef cattle herd. Pesquisa Veterinária Brasiliera, v. 29, n. 1, p. 25-28, 2009.

CLAUS, M.; VIVIAN, D.; LUNARDI, M.; ALFIERI, A.; ALFIERI, A. Análise filogenética de papilomavírus bovino associado com lesões cutâneas em rebanhos do Estado do Paraná. Pesquisa Veterinária Brasiliera, v. 27, n. 7, p. 314-318, 2007.

COBALEDA, C.; PÉREZ-CARO, M.; VICENTE-DUEÑAS, C.; SÁNCHEZ-GARCÍA, I. Function of the zinc-finger transcription factor SNAI2 in cancer and development. Annual Review of Genetics, v. 41, p. 41-61, 2007.

COLEMAN, M. War on cancer and the influence of the medical-industrial complex. Journal of Cancer Policy, v. 1, n. 3-4, p. e31-e34, 2013.

COLLINS, A. The comet assay for DNA damage and repair. Molecular Biotechnology, v. 26, p. 249-261, 2004.

CONDJELLA, R.; LIU, X.; SUPRYNOWICZ, F.; YUAN, H.; SUDARSHAN, S.; DAI, Y.; SCHLEGEL, R. The canine papillomavirus e5 protein signals from the endoplasmic reticulum. Journal of Virology, v. 83, n. 24, p. 12833-12841, 2009.

COOPER, J.; GSCHMEISSNER, S.; HOLT, P. Viral particles in a papilloma from a green lizard (Lacerta viridis). Laboratory Animals, v. 16, p. 12-13, 1982.

COOPER, K.; TAYLOR, L.; GOVIND, S. Human papillomavirus DNA in oesophageal carcinomas in South Africa. Journal of Pathology, v. 175, p. 273-277, 1995.

CORTEGGIO, A.; FLORIO, J.; ROPERTO, F.; BORZACCHIELLO, G. Expression of gap junction protein connexin 43 in bovine urinary bladder tumours. Journal of Comparative Pathology, v. 144, n. 1, p. 86-90, 2011. 
CORTÉS-GUTIÉRREZ, E.; DÁVILA-RODRÍGUEZ, M.; VARGAS-VILLARREAL, J.; HERNÁNDEZ-GARZA, F.; CERDA-FLORES, R. Association between human papilloma virus-type infections with micronuclei frequencies. Prague Medical Report, v. 111, n. 1, p. 35-41, 2010.

CORTÉS-GUTIÉRREZ, E.; HERNÁNDEZ-GARZA, F.; GARCÍA-PÉREZ, J.; DÁVILARODRÍGUEZ, M.; AGUADO-BARRERA, M.; CERDA-FLORES, R. Evaluation of DNA single and double strand breaks in women with cervical neoplasia based on alkaline and neutral comet assay techniques. Journal of Bomedicine \& Biotechnology, v. 2012, p. 385245, 2012.

COSTA, A.; SOUZA, D.; CAVALCANTE, T.; ARAÚJO, V.; RAMOS, A.; MARUO, M. Plantas tóxicas de interesse pecuário em região de ecótono amazônia e cerrado. Parte II: Araguaína, Norte do Tocantins. Acta Veterinaria Brasileira, v. 5, n. 3, p. 317-324, 2011.

COSTA, R.; MEDEIROS, R. Bovine papillomavirus: opening new trends for comparative pathology. Archives of Virology, v. 159, n. 2, p. 191-198, 2014.

COTA, J.; PELETEIRO, M.; PETTI, L.; TAVARES, L.; DUARTE, A. Detection and quantification of bovine papillomavirus type 2 in urinary bladders and lymph nodes in cases of Bovine Enzootic Hematuria from the endemic region of Azores. Veterinary Microbiology, v. 178, n. 1-2, p. 138-143, 2015.

COTCHIN, E. Problems of comparative oncology. Veterinary Pathology, v. 26, p. 633-648, 1962.

COTCHIN, E. Comparative oncology: the veterinary contribution. Proceedings of the Royal Society of Medicine, v. 69, p. 649-656, 1976.

CRAWFORD, L.; CRAWFORD, E. Study of polyoma and papilloma viruses. Virology, v. 263, p. 258-263, 1963.

CRESPI, B.; SUMMERS, K. Evolutionary biology of cancer. Trends in Ecology and Evolution, v. 20, n. 10, p. 545-552, 2005.

CROTTÉS, D.; GUIZOUARN, H.; MARTIN, P.; BORGESE, F.; SORIANI, O. The sigma-1 receptor: $A$ regulator of cancer cell electrical plasticity? Frontiers in Physiology, v. 4, p. 1-10, 2013.

CSERMELY, P.; HÓdSÁGI, J.; KORCSMÁROS, T.; MÓDOS, D.; PEREZ-LOPEZ, A.; SZALAY, K.; VERES, D.; LENTI, K.; WU, L.; ZHANG, X. Cancer stem cells display extremely large evolvability: alternating plastic and rigid networks as a potential Mechanism. Network models, novel therapeutic target strategies, and the contributions of hypoxia, inflammation and cellular senescence. Seminars in Cancer Biology, v. 30, p. 42-51, 2014.

CUBIE, $\mathrm{H}$. Diseases associated with human papillomavirus infection. Virology, v. 445, n. 1-2, p. 21-34, 2013. 
CUNINGHAME, S.; JACKSON, R.; ZEHBE, I. Hypoxia-inducible factor 1 and its role in viral carcinogenesis. Virology, v. 456-457, n. 1, p. 370-383, 2014.

CZUCHRA, A.; WU, X.; MEYER, H.; VAN HENGEL, J.; SCHROEDER, T.; GEFFERS, R.; ROTTNER, K.; BRAKEBUSCH, C. Role of the Hog1 stress-activated protein kinase in the global transcriptional response to stress in the fungal pathogen Candida albicans. Molecular Biology of the Cell, v. 17, n. 2, p. 1018-1032, 2006.

D'COSTA, Z.; JOLLY, C.; ANDROPHY, E.; MERCER, A.; MATTHEWS, C.; HIBMA, M. Transcriptional repression of E-cadherin by human papillomavirus type 16 E6. PloS one, v. 7, n. 11, p. e48954, 2012.

DAMANIA, B. A virological perspective on cancer. PLOS Pathogens, v. 12, n. 2, p. e1005326, 2016.

DANOS, O.; GEORGES, E.; ORTH, G.; YANIV, M. Fine structure of the cottontail rabbit papillomavirus mRNAs expressed in the transplantable VX2 carcinoma. Journal of Virology, v. 53, n. 3, p. 735-741, 1985.

DARZYNKIEWICZ, Z.; BEDNER, E.; SMOLEWSKI, P. Flow cytometry in analysis of cell cycle and apoptosis. Seminars in Hematology, v. 38, n. 2, p. 179-193, 2001.

DAS, K.; BOHL, J.; VANDE POL, S. B. Identification of a second transforming function in bovine papillomavirus type $1 \mathrm{E} 6$ and the role of $\mathrm{E} 6$ interactions with paxillin, E6BP, and E6AP. Journal of Virology, v. 74, n. 2, p. 812-816, 2000.

DAUDT, C.; DA SILVA, F.; STRECK, A.; WEBER, M.; MAYER, F.; CIBULSKI, S.; CANAL, C. How many papillomavirus species can go undetected in papilloma lesions? Scientific Reports, v. 6, p. 36480, 2016.

DAY, P.; LOWY, D.; SCHILLER, J. Papillomaviruses infect cells via a clathrindependent pathway. Virology, v. 307, p. 1-11, 2003.

DAYAN, D.; HISS, Y.; HIRSHBERG, A.; BUBIS, J. J.; WOLMAN, M. Are the polarization colors of picrosirius red-stained collagen determined only by the diameter of the fibers? Histochemistry, v. 93, n. 1, p. 27-29, 1989.

DE-SÁ-JÚNIOR, P.; CÂMARA, D.; COSTA, A.; RUIZ, J.; LEVY, D.; AZEVEDO, R.; PASQUALOTO, K.; OLIVEIRA, C.; MELO, T.; PESSOA, N.; FONSECA, P.; PEREIRA, A.; ARALDI, R.; FERREIRA, A. Apoptotic effect of eugenol envolves G2/M phase abrogation accompanied by mitochondrial damage and clastogenic effect on cancer cell in vitro. Phytomedicine, v. 23, n. 7, p. 725-735, 2016.

DE MARCO, F. Oxidative stress and HPV carcinogenesis. Viruses, v. 5, n. 2, p. 708-731, 2013.

DE VILLIERS, E. Cross-roads in the classification of papillomaviruses. Virology, v. 445, n. 1-2, p. 2-10, 2013.

DE VILLIERS, E.; FAUQUET, C.; BROKER, T.; BERNARD, H.; ZUR HAUSEN, H. 
Classification of papillomaviruses. Virology, v. 324, n. 1, p. 17-27, 2004.

DEFAMIE, N.; CHEPIED, A.; MESNIL, M. Connexins, gap junctions and tissue invasion. FEBS Letters, v. 588, n. 8, p. 1331-1338, 2014.

DEGEN, G.; GERBER, M.; OBRECHT-PFLUMINO, S.; DIEHEIMER, G. Induction of micronuclei with ochratoxin $A$ in ovine seminal vesicle cell cultures. Archieves of Toxicology, v. 71, p. 365-371, 1997.

DELIGEOROGLOU, E.; GIANNOULI, A.; ATHANASOPOULOS, N.; KAROUNTZOS, V.; VATOPOULOU, A.; DIMOPOULOS, K.; CREATSAS, G. HPV infection: immunological aspects and their utility in future therapy. Infectious Diseases in Obstetrics and Gynecology, v. 2013, p. 540850, 2013.

DELVA, E.; KOWALCZYK, A. Regulation of cadherin trafficking. Traffic, v. 10, n. 3, p. 259-267, 2009.

DEMONBREUN, W.; GOODPASTURE, E. Infectious oral papillomatosis of dogs. American Jounal of Pathology, v. 8, n. 1, p. 43-56, 1932.

DENISENKO, T.; SOROKINA, I.; GOGVADZE, V.; ZHIVOTOVSKY, B. Mitotic catastrophe and cancer drug resistance: a link that must to be broken. Drug Resistance Updates, v. 24, p. 1-12, 2016.

DEY-GUHA, I.; WOLFER, A.; YEH, A.; G ALBECK, J.; DARP, R.; LEON, E.; WULFKUHLE, J.; PETRICOIN, E.; WITTNER, B.; RAMASWAMY, S. Asymmetric cancer cell division regulated by AKT. Proceedings of the National Academy of Sciences of the United States of America, v. 108, n. 31, p. 12845-12850, 2011.

DIAS, J.; IGNACCHITI, M.; GIURIATO, P.; NUNES, L.; PEREIRA-JÚNIOR, O. Detecçao do papilomavírus bovino tipo 2 em bexigas de bovinos com hematúria enzoótica pela técnica de reaçao em cadeia de polimerase no Sul do Espirito Santo, Brasil. Revista Brasiliera de Medicina Veterinária, v. 34, n. 2, p. 146-151, 2012.

DIGIOVANNI, J. Multistage carcinogenesis in mouse skin. Pharmacology and Therapeutics, v. 54, n. 1, p. 63-128, 1992.

DILLNER, J.; KNEKT, P.; SCHILLER, J.; HAKULINEN, T. Prospective seroepidemiological evidence that human papillomavirus type 16 infection is a risk factor for oesophageal squamous cell carcinoma. BMJ, v. 311, p. 1346, 1995.

DIMAIO, D. Viral miniproteins. Annual Review of Microbiology, v. 68, p. 21-43, 2014.

DIMAIO, D.; MATTOON, D. Mechanisms of cell transformation by papillomavirus E5 proteins. Oncogene, v. 20, n. 54, p. 7866-7873, 2001.

DINIZ, N.; MELO, T.; SANTOS, J.; MORI, E.; BRANDÃO, P.; RICHTZENHAIN, L.; FREITAS, A.; BEÇAK, W.; CARVALHO, R.; STOCCO, R. Simultaneous presence of bovine papillomavirus in blood and in short-term lymphocyte cultures from dairy cattle 
in Pernambuco, Brazil. Genetics and Molecular Research, v. 8, n. 4, p. 1474-1480, 2009.

DOLLARD, S.; WILSON, J.; DEMETER, L.; BONNEZ, W.; REICHMAN, R.; BROKER, T.; CHOW, L. Production of human papillomavirus and modulation of the infectious program in epithelial raft cultures. Genes and Development, v. 6, n. 7, p. 1131-1142, 1992.

DONG, C.; YUAN, T.; WU, Y.; WANG, Y.; FAN, T.; MIRIYALA, S.; LIN, Y.; YAO, J.; SHI, J.; KANG, T.; LORKIEWICZ, P.; ST CLAIR, D.; HUNG, M.; EVERS, B.; ZHOU, B. Loss of FBP1 by snail-mediated repression provides metabolic advantages in basal-like breast cancer. Cancer Cell, v. 23, n. 3, p. 316-331, 2013.

DONG, J.; ZHU, W.; HAGA, T. Papillomavirus in yaks: the isolates of bovine papillomavirus type 1 have a high possibility of belonging to novel type. The Journal of Veterinary Medical Science, v. 78, n. 6, p. 1059-1071, 2016.

DONG, S.; PAI, S.; RHA, S.; HILDESHEIM, A.; KURMAN, R.; SCHWARTZ, P.; MORTEL, R.; MCGOWAN, L.; GREENBERG, M.; BARNES, W.; SIDRANSKY, D. Detection and quantitation of human papillomavirus DNA in the plasma of patients with cervical carcinoma 1. Cancer Epidemiology Biomarkers \& Prevention, v. 11, n. 6, p. 3-6, 2002.

DOORBAR, J. The E4 protein; structure, function and patterns of expression. Virology, v. 445, n. 1-2, p. 80-98, 2013.

DOORBAR, J. Model systems of human papillomavirus-associated disease. Journal of Pathology, v. 238, n. 2, p. 166-179, 2016.

DREILICH, M.; BERGQVIST, M.; MOBERG, M.; BRATTSTRÖM, D.; GUSTAVSSON, I.; BERGSTRÖM, S.; WANDERS, A.; HESSELIUS, P.; WAGENIUS, G.; GYLLENSTEN, U. High-risk human papilloma virus (HPV) and survival in patients with esophageal carcinoma: a pilot study. BMC Cancer, v. 6, p. 94, 2006.

DUENSING, S.; LEE, L.; DUENSING, A.; BASILE, J.; PIBOONNIYOM, S.; GONZALEZ, S.; CRUM, C.; MUNGER, K. The human papillomavirus type 16 E6 and E7 oncoproteins cooperate to induce mitotic defects and genomic instability by uncoupling centrosome uplication from the cell division cycle. Proceedings of the National Academy of Sciences of the United States of America, v. 97, n. 18, p. 10002-10007, 2000.

DUENSING, S.; MÜNGER, K. The human papillomavirus type 16 E6 and E7 oncoproteins independently induce numerical and structural chromosome instability. Cancer Research, v. 62, p. 7075-7082, 2002.

DUNN, W. Studies on the mechanisms of autophagy: Formation of the autophagic vacuole. The Journal of Cell Biology, v. 110, p. 1923-1933, 1990.

DUTHIE, S.; HAWDON, A. DNA instability (strand breakage, uracil misincorporation, and defective repair) is increased by folic acid depletion in human lymphocytes in 
vitro. FASEB Journal, v. 12, n. 14, p. 1491-1497, 1998.

ELBEL, M.; CARL, S.; SPADERNA, S.; IFTNER, T. A comparative analysis of the interactions of the E6 proteins from cutaneous and genital papillomaviruses with p53 and E6AP in correlation to their transforming potential. Virology, v. 239, n. 1, p. 132149, 1997.

ELZEIN, E.; SUNDBERG, J.; HOUSAWI, F.; GAMEEL, A.; RAMADAN, R.; HASSANEIN, M. Genital bovine papillomavirus infection in Saudi Arabia. Journal of Veterinary Diagnostic Investigation, v. 3, n. 1, p. 36-38, 1991.

ENEMARK, E.; CHEN, G.; VAUGHN, D.; STENLUND, A.; JOSHUA-TOR, L.; BROOK, S.; YORK, N. Crystal structure of the DNA binding domain of the replication initiation protein E1 from papillomavirus. Molecular Cell, v. 6, p. 149-158, 2000.

ERENPREISA, J.; CRAGG, M. Cancer: a matter of life cycle? Cell Biology International, v. 31, n. 12, p. 1507-1510, 2007.

EZZELL, R.; GOLDMANN, W.; WANG, N.; PARASHURAMA, N.; INGBER, D. Vinculin promotes cell spreading by mechanically coupling integrins to the cytoskeleton. Experimental Cell Research, v. 231, n. 231, p. 14-26, 1997.

FAIX, J.; BREITSPRECHER, D.; STRADAL, T.; ROTTNER, K. Filopodia: Complex models for simple rods. International Journal of Biochemistry and Cell Biology, v. 41, n. 8-9, p. 1656-1664, 2009.

FALK, M.; KELLS, R.; BERTHOUD, V. Degradation of connexins and gap junctions. FEBS letters, v. 588, n. 8, p. 1221-1229, 2014.

FANG, J.; GILLIES, R.; GATENBY, R. Adaptation to hypoxia and acidosis in carcinogenesis and tumor progression. Seminars in Cancer Biology, v. 18, n. 5, p. 330-337, 2008.

FANG, L.; MEYERS, C.; BUDGEON, L.; HOWETT, M. Induction of productive human papillomavirus type 11 life cycle in epithelial cells grown in organotypic raft cultures. Virology, v. 347, n. 1, p. 28-35, 2006.

FARBER, E. The multistep nature of cancer development. Cancer Research, v. 44, p. 4217-4223, 1984.

FARHADI, M.; TAHMASEBI, Z.; MERAT, S.; KAMANGAR, F.; NASROLLAHZADEH, D.; MALEKZADEH, R. Human papillomavirus in squamous cell carcinoma of esophagus in a high-risk population. World Journal of Gastroenterology, v. 11, n. 8, p. 1200-1203, 2005.

FELIN, I.; GRIVICICH, I.; FELIN, C.; REGNER, A.; ROCHA, A. Expressão de p53, p16 e COX-2 em carcinoma escamoso de esôfago e associaçao histopatológica. Arquivos de Gastroenterologia, v. 45, n. 4, p. 308-312, 2008.

FENECH, M. The in vitro micronucleus technique. Mutation Research, v. 455, n. 1- 
2, p. 81-95, 2000.

FENECH, M.; MORLEY, A. Measurement of micronuclei in lymphocytes. Mutation Research, v. 147, n. 1-2, p. 29-36, 1985.

FERGUSON, S.; SRINIVASAN, V.; HEIMBERGER, A. The role of STAT3 in tumormediated immune suppression. Journal of Neuro-Oncology, v. 123, n. 3, p. 385394, 2015.

FERNANDES, M.; RIBEIRO, M.; FEDATO, F.; PAES, A.; MEGID, J. Papilomatosis in dogs: literature review and study of twelve cases. Semina: Ciências Agrárias, v. 30, p. 215-224, 2009.

FERRARO, C.; CANEDO, M.; OLIVEIRA, S.; CARVALHO, M.; DIAS, E. Infecçao oral pelo HPV e lesões epiteliais proliferativas associadas. Jornal Brasileiro de Patologia Médica e Laboratorial, v. 47, n. 4, p. 451-459, 2011.

FERREIRA, A.; DE-SÁ-JÚNIOR, P.; PASQUALOTO, K.; AZEVEDO, R.; CÂMARA, D.; COSTA, A.; FIGUEIREDO, C.; MATSUO, A.; MASSAOKA, M.; AUADA, A.; LEBRUN, I.; DAMIÃI, M.; TAVARES, M.; MAGRI, F.; KERKIS, I.; PARISE-FILHO, R. Cytotoxic effects of dillapiole on MDA-MB-231 cells involve the induction of apoptosis through the mitochondrial pathway by inducing an oxidative stress while altering the cytoskeleton network. Biochimie, v. 99, n. 1, p. 195-207, 2014.

FERREIRA, F.; CRESTANA, S. Confinamento de gado de corte no estado de São Paulo: Legislação ambiental e automação. In: Simpósio Nacional de Instrumentação Agropecuária, São Carlos. Anais. São Carlos: 2014.

FERREIRA, L. M. R. Cancer metabolism: the Warburg effect today. Experimental and molecular pathology, v. 89, n. 3, p. 372-380, 2010.

FETT-CONTE, A.; SALLES, A. A importância do gene p53 na carcionogênese humana. Revista Brasileira de Hematologia e Hemoterapia, v. 24, n. 2, p. 85-89, 2002.

FICHOROVA, R.; RHEINWALD, J.; ANDERSON, D. Generation of papillomavirusimmortalized cell lines from normal human ectocervical, endocervical, and vaginal epithelium that maintain expression of tissue-specific differentiation proteins. Biology of Reproduction, v. 57, n. 4, p. 847-855, 1997.

FIDALFO, P.; CRAVO, M.; CHAVES, P.; LEITÃO, C.; MIRA, F. High prevalence of human papillomavirus in squamous cell carcinoma and matched normal esophageal mucosa assessment by polymerase chain reaction. Cancer, v. 76, n. 9, p. 15221528, 1995.

FINBOW, M.; PITTS, J. Is the gap junction channel--the connexon--made of connexin or ductin? Journal of Cell Science, v. 106, p. 463-471, 1993.

FINLAY, M.; YUAN, Z.; BURDEN, F.; TRAWFORD, A.; MORGAN, I.; CAMPO, M.; NASIR, L. The detection of bovine papillomavirus type 1 DNA flies. Virus Research, 
v. 144, n. 1-2, p. 315-317, 2009.

FLETCHER, S. Histopathology of papilloma virus infection of the cervix uteri: the history, taxonomy, nomenclature and reporting of koilocytic dysplasias. Journal of Clinical Pathology, n. 36, p. 616-624, 1983.

FLORES, E.; ALLEN-HOFFMANN, B.; LEE, D.; SATTLER, C.; LAMBERT, P. Establishment of the human papillomavirus type 16 (HPV-16) life cycle in an immortalized human foreskin keratinocyte cell line. Virology, v. 354, p. 344-354, 1999.

FLORIN, L.; SAPP, M.; SPODEN, G. Host-cell factors involved in papillomavirus entry. Medical Microbiology and Immunology, v. 201, n. 4, p. 437-448, 2012.

FOFARIA, N.; SRIVASTAVA, S. STAT3 induces anoikis resistance, promotes cell invasion and metastatic potential in pancreatic cancer cells. Carcinogenesis, v. 36, n. 1, p. 142-150, 2014.

FORESTA, C.; BERTOLDO, A.; GAROLLA, A.; PIZZOL, D.; MASON, S.; LENZI, A.; DE TONI, L. Human papillomavirus proteins are found in peripheral blood and semen Cd20+ and Cd56+ cells during Hpv-16 semen infection. BMC Infectious Diseases, v. 13, p. $593,2013$.

FORSLUND, O.; ANTONSSON, A.; NORDIN, P.; STENQUIST, B.; HANSSON, B. G. A broad range of human papillomavirus types detected with a general PCR method suitable for analysis of cutaneous tumours and normal skin. The Journal of General Virology, v. 80, p. 2437-2443, 1999.

FORSLUND, O.; LIDELOF, B.; HRAIL, E.; NORIN, P.; STENQUIST, B.; KIMBAUER, P.; SLUPTZKY, K.; DILLNER, J. High prevalence of cutaneous human papillomavirus DNA on the top of skin tumors but not in "stripped" biopsies from the same tumors. Journal of Investigative Dermatology, v. 123, p. 388-394, 2004.

FREITAS, A.; SILVA, M.; CARVALHO, C.; BIRGEL-JÚNIRO, E.; SANTOS, J.; BEÇAK, W.; STOCCO DOS SANTOS, R. Papillomavirus DNA detection in non epithelial tissues: a discussion about bovine papillomavirus. Communicating Current Research and Educational Topics and Trends in Applied Microbiology, p. 697-704, 2007.

FREITAS, A.; SILVA, M.; JESUS, A.; MARIZ, F.; CORDEIRO, M.; ALBUQUERQUE, B.; BATISTA, M. Recent insights into bovine papillomavirus. African Journal of Microbiology Research, v. 5, n. 33, p. 6004-6012, 2011.

FREITAS, A. C. De; CARVALHO, C. De; BRUNNER, O.; BIRGEL-JUNIOR, E. H.; MARIA, A.; PAIVA, M.; BENESI, F. J.; GREGORY, L.; BEÇAK, W.; CASSIA, R. De. Viral DNA sequences in peripheral blood and vertical transmission of the virus: $A$ discussion about BPV-1. Brazilian Journal of Microbiology, v. 34, p. 76-78, 2003.

FRIEDL, P.; GILMOUR, D. Collective cell migration in morphogenesis, regeneration and cancer. Nature Reviews, v. 10, n. 7, p. 445-457, 2009. 
FRIXEN, U.; BEHRENS, J.; SACHS, M.; EBERLE, G.; VOSS, B.; WARDA, A. ECadherin-mediated cell-cell adhesion prevents invasiveness of human carcinoma cells. The Journal of Cell Biology, v. 1, n. 1, p. 173-185, 1991.

FUKAWA, T.; KAJIYA, H.; OZEKI, S.; IKEBE, T.; OKABE, K. Reactive oxygen species stimulates epithelial mesenchymal transition in normal human epidermal keratinocytes via TGF-beta secretion. Experimental Cell Research, v. 318, n. 15, p. 1926-1932, 2012.

FURUKAWA, T.; DUGUID, W.; ROSENBERG, L.; VIALLET, J.; GALLOWAY, D.; TSAO, M. Long-term culture and immortalization of epithelial cells from normal adult human pancreatic ducts transfected by the E6E7 gene of human papilloma virus 16 . The American Journal of Pathology, v. 148, n. 6, p. 1763-1770, 1996

GARBER, K. Energy boost: The Warburg effect. Journal of the National Cancer Institute, v. 96, n. 24, p. 1805-1806, 2004.

GARCÍA-VALLVÉ, S.; ALONSO, A.; BRAVO, I. Papillomaviruses: different genes have different histories. Trends in Microbiologyicrobiology, v. 13, n. 11, p. 514521, 2005.

GAUKROGER, J. M.; CHANDRACHUD, L. M.; O’NEIL, B. W.; GRINDLAY, G. J.; KNOWLES, G.; CAMPO, M. S. Vaccination of cattle with bovine papillomavirus type 4 L2 elicits the production of virus-neutralizing antibodies. Journal of General Virology, v. 77, p. 1577-1583, 1996.

GAUSON, E.; WANG, X.; DORNAN, E.; HERZYK, P.; BRISTOL, M.; MORGAN, I. Failure to interact with Brd4 alters the ability of HPV16 E2 to regulate host genome expression and cellular movement. Virus Research, v. 211, p. 1-8, 2016.

GAYNOR, A.; ZHU, K.; CRUZ, F.; AFFOLTER, V.; PESAVENTO, P. Localization of bovine papillomavirus nucleic acid in equine sarcoids. Veterinary Pathology, p. 1-7, 2015.

GENG, F.; ZHU, W.; ANDERSON, R.; LEBER, B.; ANDREWS, D. Multiple posttranslational modifications regulate E-cadherin transport during apoptosis. Journal of Cell Science, v. 125, n. 11, p. 2615-2625, 2012.

GERLINGER, M.; MCGRANAHAN, N.; DEWHURST, S. M.; BURRELL, R. A.; TOMLINSON, I.; SWANTON, C. Cancer: evolution within a lifetime. Annual Review of Genetics, v. 48, p. 215-236, 2014.

GEWIN, L.; MYERS, H.; KIYONO, T.; GALLOWAY, D. Identification of a novel telomerase repressor that interacts with the human papillomavirus type-16 E6/E6-AP complex. Genes \& Development, v. 18, n. 18, p. 2269-2282, 2004.

GILLISON, M.; KOCH, W.; CAPONE, R.; SPAFFORD, M.; WESTRA, W.; WU, L.; ZAHURAK, M.; DANIEL, R.; SYMER, D.; SHAH, K.; SIDRANSKY, D. Evidence for a causal association between human papillomavirus and a subset of head and neck 
cancers. Journal of National Cancer Institute, v. 92, n. 9, p. 709-720, 2000.

GILMORE, P.; BURRIDGE, K. Regulation of vinculin binding to talin and actin by phosphatidyl-inositol-4-5-bisphosphate. Nature, v.381, n. 6582, p.531-535, 1996.

GOLDMANN, W.; INGBER, D. Intact vinculin protein is required for control of cell shape, cell mechanics, and rac-dependent lamellipodia formation. Biochemical and Biophysical Research Communications, v. 290, n. 2, p. 749-55, 2002.

GOLDSMITH, C.; MILLER, S. Modern uses of electron microscopy for detection of viruses. Clinical Microbiology Reviews, v. 22, n. 4, p. 552-563, 2009.

GOMES, A.; FERNANDES, E.; LIMA, J. Fluorescence probes used for detection of reactive oxygen species. Journal of Biochemical and Biophysical Methods, v. 65, n. 2-3, p. 45-80, 2005.

GONZALES, M.; CARRASCO, L. Viroporins. FEBS Letters, v. 552, n. 1, p. 28-34, 2003.

GOODRICH, L.; GERBER, H.; MARTI, E.; ANTCZAK, D. Equine sarcoids. The Veterinary Clinics of North America Equine Practice, v. 14, n. 3, p. 607-623, 1998.

GORBUNOVA, V.; SELUANOV, A. DNA double strand break repair, aging and the chromatin connection. Mutation Research/Fundamental and Molecular Mechanisms of Mutagenesis, v. 788, p. 2-6, 2016.

GOTTARDI, C.; WONG, E.; GUMBINER, B. E-Cadherin suppresses cellular transformation by inhibiting $\mathrm{B}$-catenin signaling in an adhesion-independent manner. The Journal of Cell Biology, v. 153, n. 5, p. 1049-1059, 2001.

GOTTLIEB, E.; ARMOUR, S.; HARRIS, M.; THOMPSON, C. Mitochondrial membrane potential regulates matrix configuration and cytochrome $c$ release during apoptosis. Cell Death and Differentiation, v. 10, n. 6, p. 709-717, 2003.

GOTTSCHLING, M.; GÖKER, M.; STAMATAKIS, A.; BININDA-EMONDS, O.; NINDL, I.; BRAVO, I. Quantifying the phylodynamic forces driving papillomavirus evolution. Molecular Biology and Evolution, v. 28, n. 7, p. 2101-2113, 2011.

GOTTSCHLING, M.; STAMATAKIS, A.; NINDL, I.; STOCKFLETH, E.; ALONSO, A.; BRAVO, I. Multiple evolutionary mechanisms drive papillomavirus diversification. Molecular Biology and Evolution, v. 24, n. 5, p. 1242-1258, 2007.

GRANER, J. History of infectious diseases oncology, from Galen to Rous. In: GOEDERT, J. (Ed.). Infectious causes of cancer. Nova Jersey: Humana Press, 2000. p. 3-30.

GRASHOFF, C.; HOFFMAN, B.; BRENNER, M.; ZHOU, R.; PARSONS, M.; YANG, M.; MCLEAN, M.; SLIGAR, S.; CHEN, C.; HA, T.; SCHWARTZ, M. Measuring mechanical tension across vinculin reveals regulation of focal adhesion dynamics. 
Nature, v. 466, n. 7303, p. 263-266, 2010.

GREBER, U. Virus and host mechanics support membrane penetration and cell entry. Journal of Virology, v. 90, n. 8, p. 3802-3805, 2016.

GREEN, M. Oncogenic viruses. Annual Review of Biochemistry, v. 39, p. 701-756, 1970.

GREEN, M. Molecular basis for the attack on cancer. Proceedings of the National Academy of Sciences of the United States of America, v. 69, n. 4, p. 1036-1041, 1972.

GRIGOLO, B.; ROSETI, L.; NERI, S.; GOBBI, P.; JENSEN, P.; MAJOR, E.; FACCHINI, A. Human articular chondrocytes immortalized by HPV-16 E6 and E7 genes: Maintenance of differentiated phenotype under defined culture conditions. Osteoarthritis and Cartilage, v. 10, n. 11, p. 879-889, 2002.

GRINDATTO, A.; FERRARO, G.; VARELLO, K.; CRESCIO, M.; MICELI, I.; BOZZETTA, E.; GORIA, M.; NAPPI, R. Molecular and histological characterization of bovine papillomavirus in North West Italy. Veterinary Microbiology,v. 180, n. 1-2, p. 113-117, 2015.

GRUENER, M.; BRAVO, I.; MOMBURG, F.; ALONSO, A.; TOMAKIDI, P. The E5 protein of the human papillomavirus type 16 down-regulates HLA-I surface expression in calnexin-expressing but not in calnexin-deficient cells. Virology Journal, v. 4, p. 116, 2007.

GRUHNE, B.; SOMPALLAE, R.; MARESCOTTI, D.; KAMRANVAR, S.; GASTALDELLO, S.; MASUCCI, M. The Epstein-Barr virus nuclear antigen-1 promotes genomic instability via induction of reactive oxygen species. Proceedings of the National Academy of Sciences of the United States of America, v. 106, n. 7, p. 2313-2318, 2009.

GUO, F.; LIU, Y.; WANG, X.; HE, Z.; WEISS, N.; MADELEINE, M.; LIU, F.; TIAN, X.; SONG, Y.; PAN, Y.; NING, T.; YANG, H.; SHI, X.; LU, C.; CAI, H.; KE, Y. Human papillomavirus infection and esophageal squamous cell carcinoma: a case-control study. Cancer Epidemiology, Biomarkers \& Prevention, v. 21, n. 5, p. 780-785, 2012.

GUO, Y.; MENG, X.; MA, J.; ZHENG, Y.; WANG, Q.; WANG, Y.; SHANG, H. Human papillomavirus 16 E6 contributes HIF-1a induced Warburg effect by attenuating the VHL-HIF-1a. International Journal of Molecular Sciences, v. 15, n. 5, p. 79747986, 2014.

HADDAD, E. STAT3: too much may be worse than not enough! Blood, v. 125, n. 4, p. 583-585, 2015.

HADI, A.; MOUCHAERS, K.; SCHALIJ, I.; GRUNBERG, K.; MEIJER, G.; VONKNOORDEGRAAF, A.; VAN DER LAARSE, W.; BELIËN, J. Rapid quantification of myocardial fibrosis: A new macro-based automated analysis. Cellular Oncology, $v$. 
34, n. 4, p. 343-354, 2011.

HAGA, T.; DONG, J.; ZHU, W.; BURK, R. The many unknown aspects of bovine papillomavirus diversity, infection and pathogenesis. Veterinary Journal, v. 197, n. 2, p. 122-123, 2013.

HAJRA, K.; CHEN, D.; FEARON, E. Advances in brief the SLUG zinc-finger protein represses E-cadherin in breast cancer 1. Cancer Research, n. 734, p. 1613-1618, 2002.

HAMAD, M.; AL-BANNA, A.; YASEEN, N. Cell culture established from warts of bovine papilloma. Journal of Veterinary Science, v. 4, p. 77-81, 2011.

HAMAD, M.; AL-BANNA, A.; YASEEN, N. Treatment of bovine papilloma. In: Proceeding of the Eleventh Veterinary Scientific Conference, 2, Anais.2012.

HAN, C.; QIAO, G.; HUBBERT, N.; LI, L.; SUN, C.; WANG, Y.; YAN, M.; XU, D.; LI, Y.; LOWY, D.; SCHILLER, J. Serologic association between human papillomavirus type 16 infection and esophageal cancer in Shaanxi Province, China. Journal of the National Cancer Institute, v. 88, n. 20, p. 1467-1471, 1996.

HANAHAN, D.; WEINBERG, R. Hallmarks of cancer: the next generation. Cell, v. 144, n. 5, p. 646-674, 2011.

HANDISURYA, A.; DAY, P.; THOMPSON, C.; BUCK, C.; PANG, Y.; LOWY, D.; SCHILLER, J. Characterization of Mus musculus papillomavirus 1 infection in situ reveals an unusual pattern of late gene expression and capsid protein localization. Journal of Virology, v. 87, n. 24, p. 13214-13125, 2013.

HARTL, B.; HAINISCH, E.; SHAFTI-KERAMAT, S.; KIRNBAUER, R.; CORTEGGIO, A.; BORZACCHIELLO, G.; TOBER, R.; KAINZBAUER, C.; PRATSCHER, B.; BRANDT, S. Inoculation of young horses with bovine papillomavirus type 1 virions leads to early infection of PBMCs prior to pseudo-sarcoid formation. The Journal of General Virology, v. 92, p. 2437-2445, 2011.

HARTMANN, A.; AGURELL, E.; BEEVERS, C.; SMITH, A.; SPEIT, G.; THYBAUD, V.; TICE, R. Recommendations for conducting the in vivo alkaline Comet assay. Mutagenesis, v. 18, n. 1, p. 45-51, 2003.

HASAN, U. a; BATES, E.; TAKESHITA, F.; BILIATO, A.; ACCARDI, R.; BOUVARD, V.; MANSOUR, M.; VINCENT, I.; GISSMANN, L.; IFTNER, T.; SIDERI, M.; STUBENRAUCH, F.; TOMMASINO, M. TLR9 expression and function is abolished by the cervical cancer-associated human papillomavirus type 16 . Journal of immunology (Baltimore, Md. : 1950), v. 178, n. 5, p. 3186-3197, 2007.

HASTER, W.; OWYANG, C. Abordagem do paciente com doença gastrointestinal. In: LONGO, D.; KASPER, D.; JAMENSON, J.; FAUCI, A.; HAUSER, D.; LOSCALZO, J. (Ed.). Medicina Interna de Harrinson. $18^{\mathrm{a}}$ ed. Porto Alegre: Artmed, 2013. p. 24022426. 
HATAMA, S.; NOBUMOTO, K.; KANNO, T. Genomic and phylogenetic analysis of two novel bovine papillomaviruses, BPV-9 and BPV-10. The Journal of General Virology, v. 89, p. 158-163, 2008.

HAUK, G.; BERGER, J. The role of ATP-dependent machines in regulating genome topology. Current Opinion in Structural Biology, v. 36, p. 85-96, 2016.

HAY, E. The mesenchymal cell, its role in the embryo, and the remarkable signaling mechanisms that create it. Developmental Dynamics, v. 233, n. 3, p. 706-720, 2005.

HAYASHI, M.; SOFUNIT; ISHIDATE, M. Kinetics of micronucleus formation in relation to chromosomal aberrations in mouse bone marrow. Mutation Research, $v$. 127, n. 2, p. 129-137, 1984.

HE, Z.; MENG, Q.; QIAO, J.; PENG, Y.; XIE, K.; LIU, Y.; CAI, X.; ZHANG, J.; CHEN, $C$. Mixed nipple infections caused by variant of BPV3 and a putative new subtype of BPV in cattle. Transboundary and Emerging Diseases, p. 1-4, 2014.

HELFER, C.; YAN, J.; YOU, J. The cellular bromodomain protein Brd4 has multiple functions in E2-mediated papillomavirus transcription activation. Viruses, v. 6, n. 8, p. 3228-3249, 2014.

HELGASON, C.; MILLER, C. Methods in molecular biology: basic cell culture protocols. $3^{\mathrm{a}}$ ed. Totowa, New Jersey: Humana Press, 2004.

HENNESSY, B.; SMITH, D.; RAM, P.; LU, Y.; MILLS, G. Exploiting the PI3K/AKT pathway for cancer drug discovery. Nature Reviews Drug Discovery, v. 4, n. 12, p. 988-1004, 2005.

HERBSTER, S.; FERRARO, C.; KOFF, N.; ROSSINI, A.; KRUEL, C.; ANDREOLLO, N.; RAPOZO, D.; BLANCO, T.; FARIA, P.; SANTOS, P.; ALBANO, R.; SIMÃO, T.; PINTO, L. HPV infection in Brazilian patients with esophageal squamous cell carcinoma: interpopulational differences, lack of correlation with surrogate markers and clinicopathological parameters. Cancer Letters, v. 326, n. 1, p. 52-58, 2012.

HERNÁNDEZ-RESÉNDIZ, I.; ROMÁN-ROSALES, A.; GARCÍA-VILLA, E.; LÓPEZMACAY, A.; PINEDA, E.; SAAVEDRA, E.; GALLARDO-PÉREZ, J.; ALVAREZ-RÍOS, E.; GARIGLIO, P.; MORENO-SÁNCHEZ, R.; RODRÍGUEZ-ENRÍQUEZ, S. Dual regulation of energy metabolism by p53 in human cervix and breast cancer cells. Biochimica et Biophysica Acta - Molecular Cell Research, v. 1853, n. 12, p. 3266-3278, 2015.

HEUSER, V.; ANDRADE, V.; PERES, A.; BRAGA, L.; CHIES, J. Influence of age and sex on the spontaneous DNA damage detected by micronucleus test and comet assay in mice peripheral blood cells. Cell Bology International, v. 32, n. 10, p. 1223-1229, 2008.

HILLE, J.; MARGOLIUS, K.; MARKOWITZ, S.; ISAACSON, C. Human papillomavirus infection related to oesophageal carcinoma in black South Africans. Soth Africa 
Medical Journal, v. 69, p. 417-420, 1986.

HOLLAND, J.; DOMINGO, E. Origin and evolution of viruses. Virus Genes, v. 16, n. 1, p. 13-21, 1998.

HØYER-HANSEN, M.; JÄÄTTELÄ, M. Connecting endoplasmic reticulum stress to autophagy by unfolded protein response and calcium. Cell Death and Differentiation, v. 14, n. 9, p. 1576-1582, 2007.

HU, Z.; MÜLLER, S.; QIAN, Q.; XU, J.; KIM, S.; CHEN, Z.; JIANG, N.; WANG, D.; ZHANG, H.; SABA, N.; SHIN, D.; CHEN, Z. Human papillomavirus 16 oncoprotein regulates the translocation of $\beta$-catenin via the activation of epidermal growth factor receptor. Cancer, v. 121, n. 2, p. 214-225, 2015.

HUANG, C.; DEVANNEY, J.; KENNEDY, S. Vimentin, a cytoskeletal substrate of protein kinase C. Biochemical and Biophysical Research Communications, v. 150, n. 3, p. 1006-1011, 1988.

HUBER, M.; KRAUT, N.; BEUG, H. Molecular requirements for epithelialmesenchymal transition during tumor progression. Current Opinion in Cell Biology, v. 17, n. 5 , p. $548-558,2005$.

HUFBAUER, M.; BIDDLE, A.; BORGOGNA, C.; GARIGLIO, M.; DOORBAR, J.; STOREY, A.; PFISTER, H.; MACKENZIE, I.; AKGUL, B. Expression of Betapapillomavirus oncogenes increases the number of keratinocytes with stem celllike properties. Journal of Virology, v. 87, n. 22, p. 12158-12165, 2013.

HYLAND, P.; MCDADE, S.; MCCLOSKEY, R.; DICKSON, G.; ARTHUR, K.; MCCANCE, D.; PATEL, D. Evidence for alteration of EZH2, BMI1, and KDM6A and epigenetic reprogramming in Human papillomavirus type 16 E6/E7-expressing keratinocytes. Journal of Virology, v. 85, n. 21, p. 10999, 2011.

ICTV. ICTV taxonomy history for Papillomaviridae. Disponível em: $<\mathrm{http}: / /$ www.ictvonline.org/taxonomyHistory.asp?taxnode_id=20132322\&taxa_name= Papillomaviridaes.

INCA. Estimativas 2014 - Incidência de Câncer no Brasil. Rio de Janeiro. 2014, p. 134.

INCA. Estimativas 2016 - Incidência de Câncer no Brasil. Rio de Janeiro. 2016, p. 122.

INGBER, D. E. Can cancer be reversed by engineering the tumor microenvironment? Seminars in Cancer Biology, v. 18, n. 5, p. 356-364, 2008.

JACKSON, C. The incidence and pathology of tumours of domestic animals in South Africa. Onderstepoort Journal of Veterinary Science and Animal Industry, v. 6, p. 378-385, 1936.

JACKSON, S.; STOREY, A. E6 proteins from diverse cutaneous HPV types inhibit 
apoptosis in response to UV damage. Oncogene, v. 19, n. 4, p. 592-598, 2000.

JACQUIN, E.; BARAQUIN, A.; RAMANAH, R.; CARCOPINO, X.; MOREL, A.; VALMARY-DEGANO, S.; BRAVO, I.; DE SANJOSÉ, S.; RIETHMULLER, D.; MOUGIN, C.; PRÉTET, J. Methylation of human papillomavirus type $16 \mathrm{CpG}$ sites at E2-binding site 1 (E2BS1), E2BS2, and the Sp1-binding site in cervical cancer samples as determined by high-resolution melting analysis-PCR. Journal of Clinical Microbiology, v. 51, n. 10, p. 3207-3215, 2013.

JAMES, C.; ROBERTS, S. Viral interactions with PDZ domain-containing proteinsAn oncogenic trait? Pathogens, v. 5, n. 1, p. 1-22, 2016.

JANG, M.; SHEN, K.; MCBRIDE, A. Papillomavirus genomes associate with BRD4 to replicate at fragile sites in the host genome. PLoS Pathogens, v. 10, n. 5, p. e1004117, 2014.

JAYAT, C.; RATINAUD, M. Cell cycle analysis by flow cytometry: principles and applications. Biology of The Cell, v. 78, p. 15-25, 1993.

JELÍNEK, F.; TACHEZY, R. Cutaneous papillomatosis in cattle. Journal of Comparative Pathology, v. 132, n. 1, p. 70-81, 2005.

JEMAL, A.; BRAY, F.; FERLAY, J. Global cancer statistics. CA Cancer Journal Clinical, v. 61, n. 2, p. 69-90, 2011.

JESSEN, H. Two types of keratohyalin granules. Journal of Ultrastructure Research, v. 33, p. 95-115, 1970.

JETHWA, P.; NAQVI, M.; HARDY, R.; HOTCHIN, N.; ROBERTS, S.; SPYCHAL, R.; TSELEPIS, C. Overexpression of Slug is associated with malignant progression of esophageal adenocarcinoma. World Journal of Gastroenterology, v. 14, n. 7, p. 1044-1052, 2008.

JOHNSTON, P.; GRANDIS, J. STAT3 signaling: anticancer strategies and challenges. Molecular Inerventions, v. 11, n. 1, p. 18-26, 2011.

JUNQUEIRA, L.; BIGNOLAS, G.; BRENTANI, R. A simple and sensitive method for the quantitative estimation of collagen. Analytical Biochemistry, v. 94, n. 1, p. 9699, 1979.

KADAJA, M.; ISOK-PAAS, H.; LAOS, T.; USTAV, E.; USTAV, M. Mechanism of genomic instability in cells infected with the high-risk human papillomaviruses. PLoS Pathogens, v. 5, n. 4, 2009.

KADAJA, M.; SUMERINA, A.; OJARAND, M.; USTAV, E.; USTAV, M. Genomic instability of the host cell induced by the human papillomavirus replication machinery. The EMBO Journal, v. 26, n. 8, p. 2180-2191, 2007.

KAHRILAS, P.; HIRANO, E. Doenças do esôfago. In: LONGO, D.; KASPER, D.; JAMENSON, J.; FAUCl, A.; HAUSER, S.; LOSCALZO, J. (Ed.). Medicina Interna de 
Harrinson. $18^{\mathrm{a}}$ ed. Porto Alegre: Artmed, 2013. p. 2437-37.

KAJITA, M.; MCCLINIC, K.; WADE, P. Aberrant expression of the transcription factors Snail and Slug alters the response to genotoxic stress. Molecular and Cellular Biology, v. 24, n. 17, p. 7559-7566, 2004.

KALLURI, R.; WEINBERG, R. The basics of epithelial-mesenchymal transition. The Journal od Clinical Investigation, v. 119, n. 6, p. 1420-1428, 2009.

KAMANGAR, F.; MALEKZADEH, R.; DAWSEY, S.; SAID, S. Esophageal cancer in northeastern Iran: A review. Archives of Iranian Medicine, v. 10, n. 1, p. 70-82, 2007.

KAO, W.; BEAUDENON, S.; TALIS, A.; HUIBREGTSE, J.; HOWLEY, P. Human papillomavirus type $16 \mathrm{E} 6$ induces self-ubiquitination of the E6AP ubiquitin-protein ligase. Journal of Virology, v. 74, n. 14, p. 6408-6417, 2000.

KARLIN, S.; GHANDOUR, G.; FOUSLER, D.; KORN, L. Comparative analysis of human and bovine papillomaviruses. Molecular Biology and Evolution, v. 1, n. 4, p. 357-70, 1984.

KASAHARA, S. Introdução à pesquisa em citogenética de vertebrados. Ribeirão Preto: Sociedade Brasileira de Genética (SBG), 2009.

KAUFMAN, R. Stress signaling from the lumen of the endoplasmic reticulum: coordination of gene transcriptional and translational controls. Genes \& Development, v. 13, n. 10, p. 1211-1233, 1999.

KAWAGUCHI, H.; OHNO, S.; ARAKI, K.; MIYAZAKI, M.; SAEKI, H.; WATANABE, M.; TANAKA, S.; SUGIMACHI, K. p53 polymorphism in human papillomavirusassociated esophageal cancer. Cancer Reserach, v. 60, p. 2753-2755, 2000.

KAWAUCHI, K.; TAKAHASHI, C.; ISHIHARA, R.; HATAMA, S. Development of a novel PCR-RFLP assay for improved detection and typing of bovine papillomaviruses. Journal of Virological Methods, v. 218, p. 23-26, 2015.

KHAN, J.; DAVY, C.; MCINTOSH, P.; JACKSON, D.; HINZ, S.; WANG, Q.; DOORBAR, J. Role of calpain in the formation of human papillomavirus type 16 $\mathrm{E} 1^{\wedge} \mathrm{E} 4$ amyloid fibers and reorganization of the keratin network. Journal of Virology, v. 85, n. 19, p. 9984-9997, 2011.

KIDNEY, B.; BERROCAL, A. Sarcoids in two captive tapirs (Tapirus bairdii): clinical, pathological and molecular study. Veterinary Dermatology, v. 19, n. 6, p. 380-384, 2008.

KINES, R.; CERIO, R.; ROBERTS, J.; THOMPSON, C.; PINOS, E.; LOWY, D.; SCHILLER, J. Human papillomavirus capsides prefentially bind and infect tumor cells. International Journal od Cancer, v. 138, n. 4, p. 901-911, 2016.

KIRNBAUER, R.; CHANDRACHUD, L.; O'NEIL, W.; WAGNER, E.; GRINDLAY, G.; 
ARMSTRONG, A.; MCGRARVIE, G.; SCHILLER, J.; LOWY, D.; CAMPO, M. Viruslike particles of bovine papillomavirus type 4 in prophylactic and therapeutic immunization. Virology, v. 219, p. 37-44, 1996.

KIRSCH-VOLDERS, M.; SOFUNI, T.; AARDEMA, M.; ALBERTINI, S.; EASTMOND, D.; FENECH, M.; ISHIDATE, M.; KIRCHNER, S.; LORGE, E.; MORITA, T.; NORPPA, H.; SURRALLÉS, J.; VANHAUWAERT, A.; WAKATA, A. Report from the in vitro micronucleus assay working group. Mutation Research, v. 540, n. 2, p. 153163, 2003.

KISE, K.; KINUGASA-KATAYAMA, Y.; TAKAKURA, N. Tumor microenvironment for cancer stem cells. Advanced Drug Delivery Reviews, v. 99, p. 197-205, 2016.

KLAUNIG, J.; KAMENDULIS, L. The role of oxidative stress in carcinogenesis. Annual Review of Immunology, v. 44, n. 1, p. 239-267, 2004.

KLINGELHUTZ, A.; FOSTER, S.; MCDOUGALL, J. Telomerase activation by the E6 gene product of human papillomavirus type 16 . Nature, v. 380 , n. 6569 , p. $79-82$, 1996.

KNOTTENBELT, D. A suggested clinical classification for the equine sarcoid. Clinical Techniques in Equine Practice, v. 4, n. 4, p. 278-295, 2005.

KOAY, M.; CROOK, M.; STEWART, C. Cyclin D1, E-cadherin and beta-catenin expression in FIGO Stage IA cervical squamous carcinoma: diagnostic value and evidence for epithelial-mesenchymal transition. Histopathology, v. 61, n. 6, p. 11251133, 2012.

KOENIG, A.; MUELLER, C.; HASEL, C.; ADLER, G.; MENKE, A. Collagen type I induces disruption of E-cadherin-mediated cell-cell contacts and promotes proliferation of pancreatic carcinoma cells. Cancer Research, v. 66, n. 9, p. 46624671, 2006.

KOLLER, L.; OLSON, C. Attempted transmission of warts from man, cattle, and horses and of deer fibroma, to selected hosts. The Journal of Investigative Dermatology, v. 58, n. 6, p. 366-368, 1972.

KRÁL, J.; BANĎOUCHOVÁ, H.; BRICHTA, J.; KOVÁČOVÁ, V.; ONDRÁČEK, K.; OSIČKOVÁ, J.; HRUBÁ, H.; HUTAŘOVÁ, Z.; KOMÍNKOVÁ, M.; CERNEI, N.; KONEČNÁ, M.; TMEJOVÁ, K.; ZÍTKA, O.; ADAM, V.; KIZEK, R.; ŠKORIČ, M.; TREMLOVÁ, B.; TREML, F.; PIKULA, J. Papillomavirus infection of roe deer in the Czech Republic and fibropapilloma-associated levels of metallothionein, zinc, and oxidative stress. Acta Veterinaria Brno, v. 84, n. 2, p. 105-111, 2015.

KRAMER, N.; WALZL, A.; UNGER, C.; ROSNER, M.; KRUPITZA, G.; HENGSTSCHLÄGER, M.; DOLZNIG, $H$. In vitro cell migration and invasion assays. Mutation Research/Reviews in Mutation Research, v. 752, p. 10-24, 2012.

KRAWCZYK, E.; SUPRYNOWICZ, F.; LIU, X.; DAI, Y.; HARTMANN, D.; HANOVER, J.; SCHLEGEL, R. Koilocytosis: a cooperative interaction between the human 
papillomavirus. The American Journal of Pathology, v. 173, n. 3, p. 682-688, 2008.

KRAWCZYK, E.; SUPRYNOWICZ, F.; SUDARSHAN, S.; SCHLEGEL, R. Membrane orientation of the human papillomavirus type 16 E5 oncoprotein. Journal of Virology, v. 84, n. 4, p. 1696, 2010.

KRISHNA, G.; HAYASHI, M. In vivo rodent micronucleus assay: protocol, conduct and data interpretation. Mutation Research, v. 455, n. 1-2, p. 155-166, 2000.

KRISHNA, G.; URDA, G.; PAULISSEN, J. Historical vehicle and positive control micronucleus data in mice and rats. Mutation Research, v. 453, n. 1, p. 45-50, 2000.

KULSKI, J.; DEMETER, T.; STERRETT, G.; KB., S. Human papilloma virus DNA in oesophageal carcinoma. Lancet, v. 2, n. Letter, p. 683-4, 1986.

KUMAR, V.; ABBAS, A.; ASTER, J. Robbins, patologia básica. 9a ed. Rio de Janeiro: Elsevier, 2013.

KUO, L. J.; YANG, L.-X. Gamma-H2AX - a novel biomarker for DNA double-strand breaks. In Vivo, v. 22, n. 3, p. 305-309, 2008.

KUSEWITT, D.; CHOI, C.; NEWKIRK, K.; LEROY, P.; LI, Y.; CHAVEZ, M.; HUDSON, L. Slug/Snai2 is a downstream mediator of epidermal growth factor receptor-stimulated reepithelialization. The Journal of Investigative Dermatology, v. 129, n. 2, p. 491-495, 2009.

LACONI, E.; DORATIOTTO, S.; VINEIS, P. The microenvironments of multistage carcinogenesis. Seminars in Cancer Biology, v. 18, n. 5, p. 322-329, 2008.

LAGERGREN, J.; WANG, Z.; BERGSTRO, R.; DILLNER, J.; NYRE, O. Human papillomavirus infection and esophageal cancer: a nationwide seroepidemiologic case-control study in Sweden. Journal of the National Cancer Institute, v. 91, n. 2, p. 156-162, 1999.

LAHAT, Q.; ZHU, Q.; HUANG, K.; WANG, S.; BOLSHAKOV, S.; LIU, J.; TORRES, K.; LANGLEY, R.; LAZAR, A.; HUNG, M.; LEV, D. Vimentin is a novel anti-cancer therapeutic target; insights from In Vitro and In Vivo mice xenograft studies. PLoS ONE, v. 5, n. 4, 2010.

LAIMINS, L. Human papillomaviruses target differentiating epithelia for virion production and malignant conversion. Seminars in Virology, v. 7, p. 305-313, 1996.

LANCASTER, W.; OLSONF, C.; MEINKE, W. Bovine papilloma virus: presence of virus-specific DNA sequences in naturally occuring equine tumors. Proceedings of the National Academy of Sciences of the United States of America, v. 74, n. 2, p. 524-528, 1977.

LANGE, C.; VETSCH, E.; ACKERMANN, M.; FAVROT, C.; TOBLER, K. Four novel 
papillomavirus sequences support a broad diversity among equine papillomaviruses. The Journal of General Virology, v. 94, p. 1365-72, 2013.

LAPORTA, R.; TAICHMAN, L. Human papilloma viral DNA replicates as a stable episome in cultured epidermal keratinocytes. Proc. Natl. Acad. Sci. USA, v. 79, p. 3393-3397, 1982.

LARSEN, P.; STORGAARD, L.; FEY, S. Proteins present in bovine papillomavirus particles. Journal of Virology, v. 61, n. 11, p. 3596-601, 1987.

LAURSON, J.; KHAN, S.; CHUNG, R.; CROSS, K.; RAJ, K. Epigenetic repression of E-cadherin by human papillomavirus 16 E7 protein. Carcinogenesis, v. 31, n. 5, p. 918-926, 2010.

LAVERGNE, D.; DE VILLIERS, E. Papillomavirus in esophageal papillomas and carcinomas. International Journal of Cancer, v. 80, p. 681-684, 1999.

LAWSON, J.; GLENN, W.; HENG, B.; YE, Y.; TRAN, B.; LUTZE-MANN, L.; WHITAKER, N. Koilocytes indicate a role for human papilloma virus in breast cancer. British Journal of Cancer, v. 101, n. 8, p. 1351-1356, 2009.

LAZRAK, A.; ILES, K.; LIU, G.; NOAH, D.; NOAH, J.; MATALON, S. Influenza virus M2 protein inhibits epithelial sodium channels by increasing reactive oxygen species. The FASEB Journal, v. 23, n. 11, p. 3829-3842, 2009.

LEAL-GARZA, C.; CERDA-FLORES, R.; LEAL-ELIZONDO, E.; CORTÉSGUTIÉRREZ, E. Micronuclei in cervical smears and peripheral blood lymphocytes from women with and without cervical uterine cancer. Mutation Research, v. 515, n. $1-2$, p. 57-62, 2002.

LEAL, A.; FERRAZ, O.; CARVALHO, C.; FREITAS, A.; BENISTON, R.; BEÇAK, W.; CAMPO, M.; STOCCO DOS SANTOS, R. Quercetin induces structural chromosomal aberrations and uncommon rearrangements in bovine cells transformed by the E7 protein of bovine papillomavirus type 4 . Veterinary and Comparative Oncology, v. 1, n. 1, p. 15-21, 2003.

LEATHERWOOD, J. Emerging mechanisms of eukaryotic DNA replication initiation. Current Opinion in Cell Biology, v. 10, n. 6, p. 742-748, 1998.

LEE, J.; DEDHAR, S.; KALLURI, R.; THOMPSON, E. The epithelial-mesenchymal transition: new insights in signaling, development, and disease. The Journal of Cell Biology, v. 172, n. 7, p. 973-981, 2006.

LEE, K.; NELSON, C. New insights into the regulation of epithelialmesenchymal transition and tissue fibrosis. 1. ed. [s.I.] Elsevier Inc., 2012. v. 294

LEE, S.; CHO, Y.; CHO, M.; SHIM, J.; LEE, K. A.; KO, K.; CHOE, Y.; PARK, S.; HOSHINO, T.; KIM, S.; DINARELLO, C.; YOON, D. Both E6 and E7 oncoproteins of human papillomavirus 16 inhibit IL-18-induced IFN-gamma production in human peripheral blood mononuclear and NK cells. Journal of Immunology, v. 167, n. 1, p. 
497-504, 2001.

LEONARD, S.; WEI, W.; COLLINS, S.; PEREIRA, M.; DIYAF, A.; CONSTANDINOU, C.; YOUNG, L.; ROBERTS, S.; WOODMAN, C. Oncogenic human papillomavirus imposes an instructive pattern of DNA methylation changes which parallel the natural history of cervical HPV infection in young women. Carcinogenesis, v. 33, n. 7, p. 1286-1293, 2012.

LEONG, C.; DOORBAR, J.; NINDL, I.; YOON, H.; HIBMA, M. H. Deregulation of Ecadherin by human papillomavirus is not confined to high-risk, cancer-causing types. British Journal of Dermatology, v. 163, p. 1253-1263, 2010.

LEPIQUE, A. P.; DAGHASTANLI, K. R. P.; CUCCOVIA, I. M.; VILLA, L. L. HPV16 tumor associated macrophages suppress antitumor $T$ cell responses. Clinical cancer research : an official journal of the American Association for Cancer Research, v. 15, n. 13, p. 4391-4400, 2009.

LETO, M.; SANTOS-JÚNIOR, G.; PORRO, A.; TOMIMORI, J. Human papillomavirus infection: etiopathogenesis, molecular biology and clinical manifestations. Anais Brasilieros de Dermatologia, v. 86, n. 2, p. 306-317, 2011.

LEUNG, C.; BRUGGE, J. Outgrowth of single oncogene-expressing cells from suppressive epithelial environments. Nature, v. 482, n. 7385, p. 410-413, 2012.

LEVY, D.; LEE, C. What does Stat3 do? Journal of Clinical Investigation, v. 109, n. 9, p. 1143-1148, 2002.

LI, L.; LI, W. Epithelial-mesenchymal transition in human cancer: Comprehensive reprogramming of metabolism, epigenetics, and differentiation. Pharmacology \& Therapeutics, v. 150, p. 33-46, 2015.

LI, P.; DIETZ, R.; VAN HARSDORF, R. p53 regulates mitochondrial membrane potential through reactive oxygen species and induces cytochrome $c$-independent apoptosis blocked by Bcl-2. The EMBO Journal, v. 18, n. 21, p. 6027-6036, 1999.

LI, T.; LU, Z. M.; CHEN, K. N.; GUO, M.; XING, H. P.; MEI, Q.; YANG, H. H.; LECHNER, J. F.; KE, Y. Human papillomavirus type 16 is an important infectious factor in the high incidence of esophageal cancer in Anyang area of China. Carcinogenesis, v. 22, n. 6, p. 929-934, 2001.

LI, X.; FANG, P.; MAI, J.; CHOI, E.; WANG, H.; YANG, X. Targeting mitochondrial reactive oxygen species as novel therapy for inflammatory diseases and cancers. Journal of Hematology \& Oncology, v. 6, n. 1, p. 19, 2013.

LI, Y.; JIA, Z.; TRUSH, M. Defining ROS in biology and medicine. Cell and Medicine Press, v. 1, n. 1, p. 9-21, 2016.

LIANG, Y.; ZHONG, Z.; HUANG, Y.; DENG, W.; CAO, J.; TSAO, G.; LIU, Q.; PEI, D.; KANG, T.; ZENG, Y.-X. Stem-like cancer cells are inducible by increasing genomic instability in cancer cells. The Journal of Biological Chemistry, v. 285, n. 7, p. 
4931-4940, 2010.

LIBERTI, M.; LOCASALE, J. The Warburg effect: how does it benefit cancer cells? Trends in Biochemical Sciences, v. 41, n. 3, p. 211-218, 2016.

LIN, J.; WALTER, P.; YEN, B. Endoplasmic reticulum stress in disease pathogenesis. Annual Review of Pathology, v. 3, p. 399-425, 2008.

LIN, L.; FUCHS, L.; LI, C.; OLSON, V.; BEKAII-SAAB, T.; LIN, J. STAT3 signaling pathway is necessary for cell survival and tumorsphere forming capacity in ALDH +/CD133 + stem cell-like human colon cancer cells. Biochemical and Biophysical Research Communications, v. 416, n. 3-4, p. 246-251, 2011.

LINDGREN, V.; SIPPOLA-THIELE, M.; SKOWRONSKI, J.; WETZEL, E.; HOWLEY, P.; HANAHAN, D. Specific chromosomal abnormalities characterize fibrosarcomas of bovine papillomavirus type 1 transgenic mice. Proceedings of the National Academy of Sciences of the United States of America, v. 86, n. 13, p. 50255029, 1989.

LINDSEY, C.; ALMEIDA, M.; VICARI, C.; CARVALHO, C.; YAGUIU, A.; FREITAS, A.; BEÇAK, W.; STOCCO, R. Bovine papillomavirus DNA in milk, blood, urine, semen, and spermatozoa of bovine papillomavirus-infected animals. Genetics and Molecular Research, v. 8, n. 1, p. 310-318, 2009.

LIU, L.; TRIMARCHI, J.; SMITH, P.; KEEFE, D. Mitochondrial dysfunction leads to telomere attrition and genomic instability. Aging Cell, v. 1, n. 1, p. 40-46, $2002 a$.

LIU, W.; GISSMANN, L.; SUN, X.; KANJANAHALUETHAI, A.; MÜLLER, M.; DOORBAR, J.; ZHOU, J. Sequence close to the N-terminus of $L 2$ protein is displayed on the surface of bovine papillomavirus type 1 virions. Virology, v. 227, n. 2, p. 474483, 1997.

LIU, Y.; BALEJA, J. Structure and function of the papillomavirus E6 protein and its interacting proteins. Frontier Bioscience, v. 1, n. 13, p. 121-134, 2008.

LIU, Y.; LIU, Z.; GAO, H.; ZHOU, Y.; ANDROPHY, E.; CHEN, J. Opposing effects of bovine papillomavirus type $1 \mathrm{E} 6$ and $\mathrm{E} 7$ genes on Fas-mediated apoptosis. Oncogene, v. 24, n. 24, p. 3942-3953, 2005.

LIU, Z.; LIU, Y.; HONG, Y.; RAPP, L.; ANDROPHY, E.; CHEN, J. Bovine papillomavirus type 1 E6-induced sensitization to apoptosis is distinct from its transforming activity. Virology, v. 295, n. 2, p. 230-237, 2002b.

LJUBOJEVIC, S.; SKERLEV, M. HPV-associated diseases. Clinics in Dermatology, v. 32, n. 2, p. 227-234, 2014.

LÖHRDR, C.; JUAN-SALLÉSD, C.; ROSAS-ROSAS, A.; GARCÍA, A.; GARNERD, M.; TEIFKE, J. Sarcoids in captive zebras (Equus burchellii): association with bovine papillomavirus type 1 infection. Journal of Zoo and Wildlife Medicine, v. 36, p. 7481, 2005. 
LONGO, D. Biologia celular e angiogênese do câncer. In: LONGO, D.; FAUCl, A.; KASPER, D.; HAUSER, S.; JAMESON, J.; LOSCALZO, J. (Ed.). Medicina Interna de Harrinson. $18^{\mathrm{a}}$ ed. Porto Alegre - RS: Artmed, 2013. p. 672-688.

LONGWORTH, M.; LAIMINS, L. Pathogenesis of human papillomaviruses in differentiating epithelia. Microbiology and Molecular Biology Reviews, v. 68, n. 2, p. 362-372, 2004.

LÓPEZ-OCEJO, O.; VILORIA-PETIT, A.; BEQUET-ROMERO, M.; MUKHOPADHYAY, D.; RAK, J.; KERBEL, R. Oncogenes and tumor angiogenesis: the HPV-16 E6 oncoprotein activates the vascular endothelial growth factor (VEGF) gene promoter in a p53 independent manner. Oncogene, v. 19, p. 4611-4620, 2000.

LOUIS, K.; SIEGEL, A. Cell viability analysis using trypan blue: Manual and automated methods. In: LOUIS, K.; SIEGEL, A. (Ed.). Mammalian Cell Viability Methods in Molecular Biology. 740p. 7-12.

LOWY, D. HPV vaccination to prevent cervical cancer and other HPV-associated disease: from basic science to effective interventions. Journal of Clinical Investigation, v. 126, n. 1, p. 5-11, 2016.

LU, H.; FORBES, R. a; VERMA, A. Hypoxia-inducible factor 1 activation by aerobic glycolysis implicates the Warburg effect in carcinogenesis. The Journal of biological chemistry, v. 277, n. 26, p. 23111-5, 2002.

LU, J.; TAN, M.; CAI, Q. The Warburg effect in tumor progression: mitochondrial oxidative metabolism as an anti-metastasis mechanism. Cancer Letters, v. 356, n. 2, p. 156-164, 2015.

LUGLI, E.; ROEDERER, M.; COSSARIZZA, A. Data analysis in flow cytometry: The future just started. Cytometry Part A, v. 77, n. 7, p. 705-713, 2010.

LUNARDI, M.; ALCÂNTARA, B.; OTONEL, R.; RODRIGUES, W.; ALFIERI, A.; ALFIERI, A. Bovine papillomavirus type 13 DNA in equine sarcoids. Journal of Clinical Microbiology, v. 51, n. 7, p. 2167-2171, 2013.

LY, J.; GRUBB, D.; LAWEN, A. The mitochondrial membrane potential $(\delta \psi m)$ in apoptosis; an update. Apoptosis, v. 8, n. 2, p. 115-128, 2003.

MAC-LEAN-FLETCHER, S.; POLLARD, T. Mechanism of action of cytochalasin B on actin. Cell, v. 20, n. 2, p. 329-341, 1980.

MADDOX, P.; SZAREWSKI, A.; DYSON, J.; CUZICK, J. Cytokeratin expression and acetowhite change in cervical epithelium. Journal of Clinical Pathology, v. 47, p. 15-17, 1994.

MADOFF, L.; KASPER, D. Introdução às doenças infecciosas: interações patógenohospedeiro. In: LONGO, D.; AS, F.; DL, K.; SL, H.; JL, J.; J, L. (Ed.). Medicina Interna de Harrinson. 18. ed. Porto Alegre - RS: Artmed, 2013. p. 1007-1012. 
MAIOLINO, P.; OZKUL, A.; SEPICI-DINCEL, A.; ROPERTO, F.; YÜCEL, G.; RUSSO, V.; URRARO, C.; LUCÀ, R.; RICCARDI, M.; MARTANO, M.; BORZACCHIELLO, G.; ESPOSITO, I.; ROPERTO, S. Bovine papillomavirus type 2 infection and microscopic patterns of urothelial tumors of the urinary bladder in water buffaloes. BioMed Research International, v. 2013, p. 937918, 2013.

MANGLENNON, G.; DOOBAR, J. The biology of papillomavirus latency. The Open Virology Journal, v. 6, n. Suppl.2:14, p. 190-197, 2012.

MANTOVANI, F.; BANKS, L. The human papillomavirus E6 protein and its contribution to malignant progression. Oncogene, v. 20, n. 54, p. 7874-7887, 2001.

MAPA. Agronegócio tem particpação record de $51,5 \%$ nas exportações brasilieras em maio. Disponível em: <http://www.agricultura.gov.br/comunicacao/noticias/2015/06/agronegocio-temparticipacao-recorde-de-51 porcento-nas-exportacoes-brasileiras-em-maio>. Acesso em: 11 nov. 2016.

MARAN, A.; AMELLA, C.; DILORENZO, T.; AUBORN, K.; TAICHMAN, L.; STEINBERG, B. Human papillomavirus type-11 transcripts are present at low abundance in latently infected respiratory tissue. Virology, v. 212, p. 285-294, 1995.

MARCUCCI, F.; STASSI, G.; DE MARIA, R. Epithelial-mesenchymal transition: a new target in anticancer drug discovery. Nature Reviews Drug Discovery, p. 1-15, 2016.

MARIGLIANI, B.; KAVATI, E. A.; SAKAUCHI, D.; OLIVEIRA, H.; CANALI, R.; SASAKI, A. Intracellular distribution of recombinant human papillomavirus capsid proteins. Current Microscopy Contributions to Advances in Science and Technology, p. 678-684, 2012.

MARTANO, M.; CORTEGGIO, A.; RESTUCCI, B.; BIASE, M.; BORZACCHIELLO, G.; MAIOLINO, P. Extracellular matrix remodeling in equine sarcoid: an immunohistochemical and molecular study. BMC Veterinary Research, v. 12, n. 1, p. 24, 2016.

MARTELLI-MARZAGÃO, F.; YAMASHIRO, A.; OGAWA, M.; SANTOS-JÚNIOR, G.; TOMIMORI, J.; PORRO, A. Caracterização clínica e histopatológica e tipagem do papilomavírus humano das verrugas vulgares nos receptores de transplante renal. Anais Brasilieros de Dermatologia, v. 85, n. 5, p. 743-746, 2010.

MARTENS, A.; DE MOOR, A.; DEMEULEMEESTER, J.; DUCATELLE, R. Histopathological characteristics of five clinical types of equine sarcoid. Research in Veterinary Science, v. 69, n. 3, p. 295-300, 2000.

MARTENS, A.; DE MOOR, A.; DUCATELLE, R. PCR detection of bovine papilloma virus DNA in superficial swabs and scrapings from equine sarcoids. Veterinary Journal, v. 161, n. 3, p. 280-286, 2001. 
MARTENS, A.; DE MOOR, A.; VLAMINCK, L.; PILLE, F.; STEENHAUT, M. Evaluation of excision, cryosurgery and local BCG vaccination for the treatment of equine sarcoids. The Veterinary Record, v. 49, n. 22, p. 665-669, 2001.

MARTINEZ-OUTSCHOORN, U.; PAVLIDES, S.; HOWELL, A.; PESTELL, R.; TANOWITZ, H.; SOTGIA, F.; LISANTI, M. Stromal-epithelial metabolic coupling in cancer: integrating autophagy and metabolism in the tumor microenvironment. The International Journal of Biochemistry \& Cell Biology, v. 43, n. 7, p. 1045-1051, 2011.

MASCOTTI, K.; MCCULLOUGH, J.; BURGER, S. HPC viability measurement: trypan blue versus acridine orange and propidium iodide. Transfusion, v. 40, p. 693-696, 2000.

MASFERRER, E.; FERRÁNDIZ-PULIDO, C.; MASFERRER-NIUBÒ, M.; RODRÍGUEZ-RODRÍGUEZ, A.; GIL, I.; PONT, A.; SERVITJE, O.; GARCÍA-DEHERREROS, A.; LLOVERAS, B.; GARCÍA-PATOS, V.; PUJOL, R.; TOLL, A.; HERNÁNDEZ-MUÑOZ, I. Epithelial-to-mesenchymal transition in penile squamous cell carcinoma. The Journal of Urology, v. 193, n. 2, p. 699-705, 2015.

MASSAGUÉ, J.; OBENAUF, A. Metastatic colonization by circulating tumor cells. Science, v. 5, n. 1, p. 2010, 2010.

MASUDA, E.; KOMMERS, G.; ROSA, F.; BARROS, C.; FIGHERA, R.; PIAZER, J. Relação entre a linfopenia e a persistência da papilomatose alimentar em bovinos intoxicados crônica e espontaneamente por samambaia (Pteridium aquilinum). Pesquisa Veterinaria Brasileira, v. 31, n. 5, p. 383-388, 2011.

MATOBA, R.; NIWA, H.; MASUI, S.; OHTSUKA, S.; CARTER, M.; SHAROV, A.; KO, $M$. Dissecting Oct3/4-regulated gene networks in embryonic stem cells by expression profiling. PLoS ONE, v. 1, n. 1, p. e26, 2006.

MATOLTSY, A.; MATOLTSY, M. The chemical nature of keratohyalin granules of the epidermis. The Journal of Cell Biology, v. 47, p. 593-603, 1970.

MATTILA, P.; LAPPALAINEN, P. Filopodia: molecular architecture and cellular functions. Nature Reviews, v. 9, n. 6, p. 446-454, 2008.

MAZZUCHELLI-DE-SOUZA, J.; CARVALHO, R.; RUIZ, R.; MELO, T.; ARALDI, R.; CARVALHO, E.; THOMPSON, C.; SIRCILI, M.; BEÇAK, W.; STOCCO, R. Expression and in silico analysis of the recombinant bovine papillomavirus E6 protein as a model for viral oncoproteins studies. BioMed Research International, v. 2013, p. $421398,2013$.

MCBRIDE, A.; DLUGOSZ, A.; BAKER, C. Production of infectious bovine papillomavirus from cloned viral DNA by using an organotypic raft/xenograft technique. Proceedings of the National Academy of Sciences of the United States of America, v. 97, n. 10, p. 1-6, 2000. 
MCCANCE, D.; KOPAN, R.; FUCHS, E.; LAIMINS, L. Human papillomavirus type 16 alters human epithelial cell differentiation in vitro. Proceedings of the National Academy of Sciences of the United States of America, v. 85, p. 7169-7173, 1988.

MCCRACKEN, A.; BRODSKY, J. Assembly of ER-associated protein degradation in vitro: Dependence on cytosol, calnexin, and ATP. Journal of Cell Biology, v. 132, n. 3, p. 291-298, 1996.

MCFADDEN, K.; HAFEZ, A. Y.; KISHTON, R.; MESSINGER, J. E.; NIKITIN, P. A.; RATHMELL, J. C.; LUFTIG, M. A. Metabolic stress is a barrier to Epstein-Barr virusmediated B-cell immortalization. Proceedings of the National Academy of Sciences, v. 113, n. 6, p. E782-90, 2016.

MCKELVEY-MARTIN, V.; GREEN, M.; SCHMEZER, P.; POOL-ZOBEL, B.; DE MÉO, M.; COLLINS, A. The single cell gel electrophoresis assay (comet assay): a European review. Mutation Research, v. 288, n. 1, p. 47-63, 1993.

MEISCHKE, $\mathrm{H}$. In vitro transformation by bovine papilloma virus. Journal of General Virology, v. 43, p. 473-487, 1979.

MELO, T. Avaliação da interação entre o papilomavírus bovino e a célula hospedeira. 2015. Universidade Federal de São Paulo (UNIFESP), 2015.

MELO, T.; ARALDI, R.; PESSOA, N.; DE-SÁ-JÚNIOR, P.; CARVALHO, R.; BEÇAK, W.; STOCCO. Bos taurus papillomavirus activity in peripheral blood mononuclear cells : demonstrating a productive infection. Genetics and Molecular Research, v. 14, n. 4, p. 16712-16727, 2015.

MELO, T. C.; DINIZ, N.; CAMPOS, S. R. C.; FERRAZ, O. P.; LINDSEY, C. J.; RIEGER, T. T.; BEÇAK, W.; STOCCO, R. C. Cytogenetic studies in peripheral blood of bovines afflicted by papillomatosis. Veterinary and comparative oncology, v. 9 , n. 4, p. 269-274, 2011.

MELO, T.; CARVALHO, R.; MAZZUCCHELLI-DE-SOUZA, J.; DINIZ, N.; VASCONCELOS, S.; ASSAF, S.; ARALDI, R.; RUIZ, R.; KERKIS, I.; BEÇAK, W.; STOCCO, R. Phylogenetic classification and clinical aspects of a new putative Deltapapillomavirus associated with skin lesions in cattle. Genetics and Molecular Research, v. 13, n. 2, p. 2458-2469, 2014.

MENKE, A.; PHILIPPI, C.; VOGELMANN, R.; SEIDEL, B.; LUTZ, M.; ADLER, G.; WEDLICH, D. Down-regulation of E-cadherin gene expression by collagen type I and Ttype III in pancreatic cancer cell lines 1. Biochemistry, v. 61, p. 3508-3517, 2001.

MEYEN, D.; TARBASHEVICH, K.; BANISCH, T.; WITTWER, C.; REICHMAN-FRIED, M.; MAUGIS, B.; GRIMALDI, C.; MESSERSCHMIDT, E.; RAZ, E. Dynamic filopodia are required for chemokine-dependent intracellular polarization during guided cell migration in vivo. eLife, v. 4, p. e05279, 2015.

MEYERS, C.; FRATTINI, M.; HUDSON, J.; LAIMINS, L. Biosynthesis of human 
papillomavirus from a continuous cell line upon epithelial differentiation. Science, v. 257, n. 5072, p. 971-973, 1992.

MIR, M.; DAR, J.; DAR, N.; SYED, A.; LONE, G. The association of beta-catenin gene mutation and human papillomavirus in carcinoma of esophagus in a high-risk population od India. International Journal of Health Sciences, v. 1, n. 2, p. 177183, 2007.

MISCHO, A.; OHLENSCHLÄGER, O.; HORTSCHANSKY, P.; RAMACHANDRAN, R.; GÖRLACH, M. Structural insights into a wildtype domain of the oncoprotein E6 and its interaction with a PDZ domain. PLoS ONE, v. 8, n. 4, p. e6284, 2013.

MISDORP, W. Veterinary cancer epidemiology. The Veterinary Quarterly, v. 18, n. 1, p. 32-36, 1996.

MISSIROLI, S.; DANESE, A.; IANNITTI, T.; PATERGNANI, S.; PERRONE, M.; PREVIATI, M.; GIORGI, C.; PINTON, P. Endoplasmic reticulum-mitochondria Ca2+ crosstalk in the control of the tumor cell fate. Biochimica et Biophysica Acta Molecular Cell Research, v. 1864, n. 6, p. 858-864, 2017.

MITTAL, S.; BANKS, L. Molecular mechanisms underlying human papillomavirus E6 and E7 oncoprotein-induced cell transformation. Mutation Research/Reviews in Mutation Research, no prelo.

MÓDOLO, D. G.; ARALDI, R. P.; MAZZUCHELLI-DE-SOUZA, J.; PEREIRA, A.; PIMENTA, D. C.; ZANPHORLIN, L. M.; BEÇAK, W.; MENOSSI, M.; STOCCO, R.; CARVALHO, R. F. Integrated analysis of recombinant BPV-1 L1 protein for the production of a bovine papillomavirus VLP vaccine. Vaccine, v. 35, n. 12, p. 15901593, 2017.

MOLL, R.; DIVO, M.; LANGBEIN, L. The human keratins: Biology and pathology. Histochemistry and Cell Biology, v. 129, n. 6, p. 705-733, 2008.

MONTE, T.; PEIXOTO, G. A incidência de papilomavírus humano em mulheres no Hospital Universitário Sul Fluminense. Revista Brasileira de Análises Clínicas, v. 42, n. 2, p. 131-139, 2010.

MONTEIRO, V.; COELHO, M.; CARNEIRO, A.; SILVA, R.; TEIXEIRA, M.; WANDERLEY, A.; WANDERLEY, E.; FRANCO, E. Descrição clínica e histopatológica da papilomatose cutânea bovina (BPV). Ciência Animal Brasileira, v. 10 , p. $550-60,2008$.

MOODY, C.; LAIMINS, L. Human papillomavirus oncoproteins: pathways to transformation. Nature Reviews - Cancer, v. 10, n. 8, p. 550-60, 2010.

MOORE, N.; HOUGHTON, J.; LYLE, S. Slow-cycling therapy-resistant cancer cells. Stem Cells and Development, v. 21, n. 10, p. 1822-30, 2012.

MORENO-SÁNCHEZ, R.; MARÍN-HERNÁNDEZ, A.; SAAVEDRA, E.; PARDO, J. P.; RALPH, S. J.; RODRÍGUEZ-ENRÍQUEZ, S. Who controls the ATP supply in cancer 
cells? Biochemistry lessons to understand cancer energy metabolism. The international journal of biochemistry \& cell biology, v. 50C, p. 10-23, 2014.

MORIN, P.; TRENT, J.; COLLINS, F.; VOGES, B. Genética do câncer. In: LONGO, D.; FAUCI, A.; KASPER, D.; HAUSER, S.; JAMESON, J.; LOSCALZO, J. (Ed.). Medicina Interna de Harrinson. $18^{\mathrm{a}}$ ed. Porto Alegre - RS: Artmed, 2013. p. 66375.

MORK, J.; LIE, K.; GLATTRE, E.; HALLMANS, G.; JELLUM, E.; KOSKELA, P.; MOLLER, B.; PUKKALA, E.; SCHILLER, J.; YOUNGMAN, L.; LEHTINEN, M.; DILLNER, J. Human papillomavirus infection as a risk factor for squamous-cell carcinoma of the head and neck. New England Jounal of Medicine, v. 344, n. 15, p. 1125-1131, 2001.

MORRISON, A.; HIGHLAND, J.; KROGAN, N.; ARBEL-EDEN, A.; GREENBLATT, J.; HABER, J.; SHEN, X. INO80 and gamma-H2AX interaction links ATP-dependent chromatin remodeling to DNA damage repair. Cell, v. 119, p. 767-775, 2004.

MORRISON, M.; MORREALE, R.; AKUNURU, S.; KOFRON, M.; ZHENG, Y.; WELLS, S. Targeting the human papillomavirus E6 and E7 oncogenes through expression of the bovine papillomavirus type $1 \mathrm{E} 2$ protein stimulates cellular motility. Journal of Virology, v. 85, n. 20, p. 10487-10498, 2011.

MOSSERI, S.; HETZEL, U.; HAHN, S.; MICHALOUPOULOU, E.; SALLABANK, H. C.; KNOTTENBELT, D. C.; KIPAR, a. Equine sarcoid: in situ demonstration of matrix metalloproteinase expression. The Veterinary Journal, v. 202, n. 2, p. 279-285, 2014.

MUNDAY, J. Papillomaviruses in felids. Veterinary Journal, v. 199, n. 3, p. 340-7, mar. 2014a.

MUNDAY, J. Bovine and human papillomaviruses: A comparative review. Veterinary Pathology, p. 1-13, 2014b.

MUNDAY, J.; KIUPEL, M. Papillomavirus-associated cutaneous neoplasia in mammals. Veterinary Pathologyathology, v. 47, n. 2, p. 254-264, 2010.

MUNDAY, J.; THOMSON, N.; DUNOWSKA, M.; KNIGHT, C.; LAURIE, R.; HILLS, S. Genomic characterisation of the feline sarcoid-associated papillomavirus and proposed classification as Bos taurus papillomavirus type 14. Veterinary Microbiology, v. 177, n. 3-4, p.289-295, 2015.

MÜNGER, K.; BALDWIN, A.; EDWARDS, K.; NGUYEN, C.; OWENS, M.; HUH, K.; MU, K.; HAYAKAWA, H.; GRACE, M. Mechanisms of human papillomavirus-induced oncogenesis. Journal of Virology, v. 78, n. 21, p. 11451-11460, 2004.

MURO, L.; BOTTEIRA, C.; PICCININ, A. Papilomatose bovina. Revista Científica Eletrônica de Medicina Veterinária, v. 10, 2008.

MURPHY, M. How mitochondria produce reactive oxygen species. The Biochemical 
Journal, v. 417, n. 1, p. 1-13, 2009.

MUSHTAQ, M.; DAREKAR, S.; KASHUBA, E. DNA tumor viruses and cell metabolism. Oxidative Medicine and Cellular Longevity, v. 2016, p. 1-9, 2016.

NASIR, L.; CAMPO, M. Bovine papillomaviruses: Their role in the aetiology of cutaneous tumours of bovids and equids. Veterinary Dermatology, v. 19, n. 5, p. 243-254, 2008.

NASIR, L.; MCFARLANE, S.; TORRONTEGUI, B.; REID, S. Screening for bovine papillomavirus in peripheral blood cells of donkeys with and without sarcoids. Research in Veterinary Science, v. 63, n. 1991, p. 289-290, 1997.

NASIR, L.; REID, S. Bovine papillomaviral gene expression in equine sarcoid tumours. Virus Research, v. 61, n. 2, p. 171-175, 1999.

NASROLLAHZADEH, D.; YE, W.; SHAKERI, R.; SOTOUDEH, M.; MERAT, S.; KAMANGAR, F.; ABNET, C.; ISLAMI, F.; BOFFETTA, P.; DAWSEY, S.; BRENNAN, P.; MALEKZADEH, R. Contact with ruminants is associated with esophageal squamous cell carcinoma risk. International Journal of Cancer, v. 136, n. 6, p. 1468-74, 2014.

$\mathrm{NCl}$. Paths forward in infection-related epidemiologic cancer research. Disponível em: <http://epi.grants.cancer.gov/blog/archive/2014/10-28.html>. Acesso em: 11 fev. 2016.

NDOMBERA, F.; VANHECKE, G.; NAGI, S.; AHN, Y. Carbohydrate-based inducers of cellular stress for targeting cancer cells. Bioorganic \& Medicinal Chemistry Letters, v. 26, n. 5, p. 1452-1456, 2016.

NEGRINI, S.; GORGOULIS, V.; HALAZONETIS, T. Genomic instability--an evolving hallmark of cancer. Nature Reviews, v. 11, n. 3, p. 220-228, 2010.

NEUFELDT, C.; JOYCE, M.; VAN BUUREN, N.; LEVIN, A.; KIRKEGAARD, K.; GALE JR., M.; TYRRELL, D.; WOZNIAK, R. The hepatitis C virus-induced membranous web and associated nuclear transport machinery limit access of pattern recognition receptors to viral replication sites. PLOS Pathogens, v. 12, n. 2, p. e1005428, 2016.

NEUMÜLLER, R.; KNOBLICH, J. Dividing cellular asymmetry: asymmetric cell division and its implications for stem cells and cancer. Genes \& Development, v. 23, n. 23, p. 2675-2699, 2009.

NICHOLLS, P.; KLAUNBERG, B.; MOORE, R.; SANTOS, E.; PARRY, N.; GOUGH, G.; STANLEY, M. Naturally occurring, nonregressing canine oral papillomavirus infection: host immunity, virus characterization, and experimental infection. Virology, v. 265 , p. $365-374,1999$.

NICOLAS, G.; POTTIER, C.; MALTÊTE, D.; COUTANT, S.; ROVELET-LECRUX, A.; LEGALLIC, S.; ROUSSEAU, S.; VASCHALDE, Y.; GUYANT-MARÉCHAL, L.; 
AUGUSTIN, J.; MARTINAUD, O.; DEFEBVRE, L.; KRYSTKOWIAK, P.; PARIENTE, J.; CLANET, M.; LABAUGE, P.; AYRIGNAC, X.; LEFAUCHEUR, R.; LE BER, I.; FRÉBOURG, T.; HANNEQUIN, D.; CAMPION, D. Mutation of the PDGFRB gene as a cause of idiopathic basal ganglia calcification. Neurology, v. 80, n. 2, p. 181-187, 2013.

NIETO, M. The snail superfamily of zinc-finger transcription factors. Nature Reviews - Molecular Cell Biology, v. 3, n. 3, p. 155-166, 2002.

$\mathrm{NIH}$. Survillance, epidemiology and end results program. Disponível em: $<$ https://seer.cancer.gov/statfacts/html/esoph.html . Acesso em: 13 fev. 2017.

NOMINÉ, Y.; MASSON, M.; CHARBONNIER, S.; ZANIER, K.; RISTRIANI, T.; DERYCKÈRE, F.; SIBLER, A.; DESPLANCQ, D.; ATKINSON, R.; WEISS, E.; ORFANOUDAKIS, G.; KIEFFER, B.; TRAVÉ, G. Structural and functional analysis of E6 oncoprotein: insights in the molecular pathways of human papillomavirusmediated pathogenesis. Molecular Cell, v. 21, n. 5, p. 665-678, 2006.

NUNEZ, R. DNA measurement and cell cycle analysis by flow cytometry. Current Issues in Molecular Biology, v. 3, p. 67-70, 2001.

OGAWA, T.; TOMITA, Y.; OKADA, M.; SHINOZAKI, K.; KUBONOYA, H.; KAIHO, I.; SHIRASAWA, $\mathrm{H}$. Broad-spectrum detection of papillomaviruses in bovine teat papillomas and healthy teat skin. The Journal of General Virology, v. 85, p. 21917, 2004.

OLAVE, I.; RECK-PETERSON, S.; CRABTREE, G. Nuclear actin and actin-related proteins in chromatin remodeling. Annual Review of Biochemistry, v. 71, p. 755781, 2002.

OLIVEIRA, D.; MÜLLER-COAN, B.; PAGANO, J. Viral carcinogenesis beyond malignant transformation: EBV in the progression of human cancers. Trends in Microbiology, v. 24, n. 8, p. 649-664, 2016.

OLIVEIRA, R. Studies on the biopathological actions of pteridium aquilinun. 2012. Universiade do Porto, 2012.

OLSON, K.; SCHELL, J.; RUTTER, J. Pyruvate and metabolic flexibility: illuminating a path toward selective cancer therapies. Trends in Biochemical Sciences, v. 41, n. 3, p. 219-230, 2016.

ONDER, T.; GUPTA, P.; MANI, S.; YANG, J.; LANDER, E.; WEINBERG, R. Loss of E-cadherin promotes metastasis via multiple downstream transcriptional pathways. Cancer Research, n. 10, p. 3645-3655, 2008.

OTTEN, N.; VON TSCHARNER, C.; LAZARY, S.; ANTCZAK, D.; GERBER, H. DNA of bovine papillomavirus type 1 and 2 in equine sarcoids: PCR detection and direct sequencing. Archives of Virology, v. 132, p. 121-131, 1993.

OU, H.; DEERINCK, T.; BUSHONG, E.; ELLISMAN, M.; O'SHEA, C. Visualizing viral protein structures in cells using genetic probes for correlated light and electron 
microscopy. Methods, v. 15, n. 90, p. 39-48, 2015.

ÖZSOY, Ş.; ÖZYILDIZ, Z.; GÜZEL, M. Clinical, pathological and immunohistochemical findings of bovine cutaneous papillomatosis. Ankara Üniv Vet Fak Derg, v. 58, p. 161-165, 2011.

PAMUKCU, A.; GOKSOY, S.; PRICE, J. Urinary bladder neoplasms induced (Pteris aquilina) to cows 1 by feeding bracken fern. Cancer Research, v. 27, n. 1, p. 917924, 1967.

PAMUKCU, A.; PRICE, J.; BRYAN, G. Naturally occurring and bracken-fern-induced bovine urinary bladder turnouts. Veterinary Pathology, v. 13, p. 110-122, 1976.

PAN, G.; CHANG, Z.; SCHÖLER, H.; PEI, D. Stem cell pluripotency and transcription factor Oct4. Cell Research, v. 12, n. 5-6, p. 321-329, 2002.

PANGTY, K.; SINGH, S.; GOSWAMI, R.; SAIKUMAR, G.; SOMVANSHI, R. Detection of BPV-1 and -2 and quantification of BPV-1 by real-time PCR in cutaneous warts in cattle and buffaloes. Transboundary and Emerging Diseases, v. 57, n. 3, p. 185-196, 2010.

PAO, C.; HOR, J.; YANG, F.; LIN, C.; TSENG, C. Detection of human papillomavirus mRNA and cervical cancer cells in peripheral blood of cervical cancer patients with metastasis. Journal of Clinical Oncology, v. 15, n. 3, p. 1008-1012, 2014.

PAO, C.; LIN, S.; LIN, C.; MAA, I.; LAI, C.; HSIEH, T. Identification of human papillomavirus DNA sequences in peripheral blood mononuclear cells. Journal of Clinical Pathology, v. 95, p. 540-546, 1991.

PAOLI, P.; GIANNONI, E.; CHIARUGI, P. Anoikis molecular pathways and its role in cancer progression. Biochimica et Biophysica Actaiophysica acta, v. 1833, n. 12, p. 3481-98, 2013.

PARK, J.; NICKEL, K.; TORRES, A.; LEE, D.; LAMBERT, P.; KIMPLE, R. Human papillomavirus type 16 E7 oncoprotein causes a delay in repair of DNA damage. Radiotherapy and Oncology, v. 113, n. 3, p. 337-344, 2014.

PARK, S.; CHOI, S.; AHN, B. DNA strand breaks in mitotic germ cells of Caenorhabditis elegans evaluated by comet assay. Molecules and Cells, v. 38, n. 9, p. 204-210, 2016.

PASI, C.; DERELI-ÖZ, A.; NEGRINI, S.; FRIEDLI, M.; FRAGOLA, G.; LOMBARDO, A.; VAN HOUWE, G.; NALDINI, L.; CASOLA, S.; TESTA, G.; TRONO, D.; PELICCI, P. G.; HALAZONETIS, T. D. Genomic instability in induced stem cells. Cell Death and Differentiation, v. 18, n. 5, p. 745-753, 2011.

PASTINK, A.; LOHMAN, P. Repair and consequences of double-strand breaks in DNA. Mutation Research/Fundamental and Molecular Mechanisms of Mutagenesis, v. 428, n. 1-2, p. 141-156, 1999. 
PATER, M.; PATER, A. Human papillomavirus types 16 and 18 sequences in carcinoma cell lines of the cervix. Virology, v. 145, n. 2, p. 313-8, 1985.

PAVELSKI, M.; OLLHOFF, R.; BARROS-FILHO, I.; DECONTO, I.; BIONDO, A.; DORNBUSCH, P. Evaluation of urine dipstick and cystoscopy in bovine enzootic haematuria. Semina: Ciências Agrárias, v. 35, n. 3, p. 1369, 2014.

PEINADO, H.; OLMEDA, D.; CANO, A. Snail, Zeb and bHLH factors in tumour progression: an alliance against the epithelial phenotype? Nature Reviews Cancer, v. 7 , n. 6 , p. $415-428,2007$.

PEREIRA, J. Manual de virologia prática. 3. ed. Lisboa: Mestrado Integrado em Ciências Farmacêuticas da Faculdade de Farmácia da Universidade de Lisboa, 2008.

PÉREZ-MARTÍNEZ, C.; GARCÍA-FERNÁNDEZ, R.; ESCUDERO, A.; FERRERAS, M.; GARCÍA-IGLESIAS, M. Expression of cytokeratins and vimentin in normal and neoplastic tissue from the bovine female reproductive tract. Journal of Comparative Pathology, v. 124, p. 70-78, 2001.

PEREZ-PLASENCIA, C.; DUENAS-GONZALEZ, A.; ALATORRE-TAVERA, B. Second hit in cervical carcinogenesis process: involvement of wnt/beta catenin pathway. International Archives of Medicine, v. 1, n. 1, p. 10, 2008.

PERL, A.; WILGENBUS, P.; CHRISTOFORI, G. A causal role for E-cadherin in the transition from adenoma to carcinoma. Nature, v. 392, p. 711-714, 1998.

PERRY, J.; LINS, R.; LOBIE, P.; MITCHELL, M. Regulation of invasive growth: similar epigenetic mechanisms underpin tumour progression and implantation in human pregnancy. Clinical Science, v. 118, p. 451-457, 2010.

PESQUISA FAPESP. Pecuaristas e ambientalistas juntos. 240, p. 34-37, 2016.

PESSOA, N. Estudos sobre a expressão do papilomavirus humano (hpv): avaliação comparativa sobre lesões cervicais, sangue periférico e retinoblastomas. 2014. Universidade de São Paulo, 2014.

PIER, G. Mecanismos moleculares da patogênese microbiana. In: LONGO, D.; FAUCI, A.; KASPER, D.; HAUSER, S.; JAMESON, J.; LOSCALZO, J. (Ed.). Medicina Interna de Harrinson. $18^{a}$ ed. Porto Alegre - RS: Artmed, 2013. p. 10131030.

PIETRAS, K.; OSTMAN, A. Hallmarks of cancer: interactions with the tumor stroma. Experimental Cell Research, v. 316, n. 8, p. 1324-1331, 2010.

PITIYAGE, G.; LEI, M.; GUERERRO-URBANO, T.; ODELL, E.; THAVARAJ, S. Biphenotypic human papillomavirus-associated head and neck squamous cell carcinoma: a report of two cases. Diagnostic Pathology, v. 10, n. 1, p. 97, 2015.

PLOWRIGH, W. Malignant neoplasia of the oesophagus and rumen of cattle in 
Kenya. Journal of Comparative Pathology, v. 65, p. 108-114, 1955.

PLOWRIGHT, W.; LINSELL, C.; PEERS, F. A focus of rumenal cancer kenyan cattle. p. 72-80, 1970.

POTOCKI, L.; LEWINSKA, A.; KLUKOWSKA-RÖTZLER, J.; BIELAK-ZMIJEWSKA, A.; GRABOWSKA, W.; RZESZUTEK, I.; KAMINSKA, P.; ROGA, E.; BUGNOPONIEWIERSKA, M.; SLOTA, E.; MÄHLMANN, K.; KOCH, C.; WNUK, M. Sarcoidderived fibroblasts: links between genomic instability, energy metabolism and senescence. Biochimie, v. 92, p. 163-172, 2014.

POTTER, D.; BAIRD, M. Carcinogenic effects of ptaquiloside in bracken fern and related compounds. British Journal of Cancerournal of cancer, v. 83, p. 914-920, 2000.

PYEON, D.; PEARCE, S.; LANK, S.; AHLQUIST, P.; LAMBERT, P. Establishment of human papillomavirus infection requires cell cycle progression. PLoS Pathogens, $v$. 5, n. 2, 2009.

QURESHI, R.; ARORA, H.; RIZVI, M. EMT in cervical cancer: Its role in tumour progression and response to therapy. Cancer Letters, v. 356, n. 2, p. 321-331, 2015.

RADISKY, D. Epithelial-mesenchymal transition. Journal of Cell Science, v. 118, p. 4325-4326, 2005.

RADISKY, D.; LABARGE, M. Epithelial-mesenchymal transition and the stem cell phenotype. Cell Stem Cell, v. 2, n. 6, p. 511-512, 2008.

RAMIREZ, J.; POIRSON, J.; FOLTZ, C.; CHEBARO, Y.; SCHRAPP, M.; MEYER, A.; BONETTA, A.; FORSTER, A.; JACOB, Y.; MASSON, M.; DERYCKËRE, F.; TRAVÉ, G. Angewandte targeting the two oncogenic functional sites of the HPV E6 oncoprotein with a high-affinity bivalent ligand. Angewandte Communications, v. 54, p. 7958-7962, 2015.

RAMPIAS, T.; SASAKI, C.; PSYRRI, A. Molecular mechanisms of HPV induced carcinogenesis in head and neck. Oral Oncology, v. 50, n. 5, p. 356-363, 2013.

RÄSÄNEN, K.; VAHERI, A. Activation of fibroblasts in cancer stroma. Experimental Cell Research, v. 316, n. 17, p. 2713-22, 2010.

RASHAD, A.; EVANS, C. Histologic features of virus-rich and virus-poor Shope papillomas of cottontail rabbits. Cancer Research, v. 27, p. 1855-1860, 1967.

RASTOGI, R.; SINGH, S.; HÄDER, D.; SINHA, R. Detection of reactive oxygen species (ROS) by the oxidant-sensing probe 2',7'-dichlorodihydrofluorescein diacetate in the cyanobacterium Anabaena variabilis PCC 7937. Biochemical and Biophysical Research Communications, v. 397, n. 3, p. 603-607, 2010.

RECOUSO, R.; STOCCO DOS SANTOS, R.; FREITAS, R.; SANTOS, R.; FREITAS, 
A.; BRUNNER, O.; BEÇAK, W.; LINDSEY, C. Clastogenic effect of bracken fern (Pteridium aquilinum $v$. arachnoideum) diet in peripheral lymphocytes of human consumers: preliminary data. Veterinary and Comparative Oncology, v. 1, p. 2229, 2003.

RECTOR, A.; MOSTMANS, S.; VAN DOORSLAER, K.; MCKNIGHT, C.; MAES, R.; WISE, A.; KIUPEL, M.; VAN RANST, M. Genetic characterization of the first chiropteran papillomavirus, isolated from a basosquamous carcinoma in an Egyptian fruit bat: the Rousettus aegyptiacus papillomavirus type 1. Veterinary Microbiology, v. 117, n. 2-4, p. 267-275, 2006.

RECTOR, A.; VAN RANST, M. Animal papillomaviruses. Virology, v. 445, n. 1-2, p. 213-223, 2013.

RECZEK, C.; CHANDEL, N. ROS-dependent signal transduction. Current Opinion in Cell Biology, v. 33, p. 8-13, 2015.

REPUCCI, A.; DILORENZO, T.; ABRANSOM, A.; STEIMBERGBM. In vitro modulation of human laryngeal papilloma cell differentiation by retenoic acid. Otolaryngology -Head and Neck Surgery, v. 105, n. 4, p. 528-532, 1991.

RESENDES, A.; ROPERTO, S.; TRAPANI, F.; URRARO, C.; RODRIGUES, A.; ROPERTO, F.; BORZACCHIELLO, G. Association of bovine papillomavirus type 2 (BPV-2) and urinary bladder tumours in cattle from the Azores archipelago. Research in veterinary science, v. 90, n. 3, p. 526-529, 2011.

REUTER, S.; DELIUS, H.; KAHN, T.; HOFMANN, B.; ZUR HAUSEN, H.; SCHWARZ, E. Characterization of a novel human papillomavirus DNA in the cervical carcinoma cell line ME180. Journal of Virology, v. 65, n. 10, p. 5564-5568, 1991.

REVISTA AGRONALYSIS. Pecuária brasileira: ciclo em alta. Fundação Getúlio Vargas (FGV), p. 31-33, 2014.

RIBEIRO-MÜLLER, L.; MÜLLER, M. Prophylactic papillomavirus vaccines. Clinics in Dermatology, v. 32, n. 2, p. 235-247, 2014.

RIBEIRO, F.; CARVALHO, M.; PEREIRA, C.; TATENO, D. Análise da concentração de colágeno tipo I e III presente no reparo de feridas tratadas com Mitomicina $C$ em ratos. Arquivos Médicos dos Hospitais e da Faculdade de Ciências Médicas da Santa Casa de São Paulo, v. 60, n. 11, p. 22-26, 2015.

RICH, L.; WHITTAKER, P. Collagen and Picrosirius red staining: a polarized light assessment of fibrillar hue and spatial distribution. Brazilian Journal of Microbiology, v. 22, n. 2, p. 97-104, 2005.

RIEGER, M.; FRANKE, W. Identification of an orthologous mammalian cytokeratin gene. High degree of intron sequence conservation during evolution of human cytokeratin 10. Journal of Molecular Biology, v. 204, n. 4, p. 841-856, 1988.

RISTRIANI, T.; MASSON, M.; NOMINÉ, Y.; LAURENT, C.; LEFEVRE, J. F.; WEISS, 
E.; TRAVÉ, G. HPV oncoprotein E6 is a structure-dependent DNA-binding protein that recognizes four-way junctions. Journal of Molecular Biology, v. 296, n. 5, p. 1189-1203, 2000.

RISTRIANI, T.; NOMINÉ, Y.; LAURENT, C.; WEISS, E.; TRAVÉ, G. Protein mutagenesis with monodispersity-based quality probing: selective inactivation of p53 degradation and DNA-binding properties of HPV E6 oncoprotein. Protein Expression and Purification, v. 26, n. 3, p. 357-367, 2002.

ROBERTS, S. Papillomaviruses. eLS John Wiley \& Sons, p. 1-11, 2015.

RODRIGUES, I.; LAVORATO-ROCHA, A.; MAIA, B.; STIEPCICH, M.; CARVALHO, F.; BAIOCCHI, G.; SOARES, F.; ROCHA, R. Epithelial-mesenchymal transition-like events in vulvar cancer and its relation with HPV. British Journal of Cancer, v. 109, n. 1, p. 184-194, 2013.

RODRIGUEZ, M. Deregulation of energy metabolism as a cause and consequence of oncogenic process: review of literature. Anatomy \& Physiology, v. 6, n. 2, p. 1-5, 2016.

ROGOVSKYY, A.; BASZLER, T.; BRADWAY, D.; BRUNING, D.; DAVITT, C.; EVERMANN, J.; BURK, R.; CHEN, Z.; MANSFIELD, K.; HALDORSON, G. A novel papillomavirus isolated from proliferative skin lesions of a wild American beaver (Castor canadensis). Journal of Veterinary Diagnostic Investigation, v. 24, n. 4, p. 750-754, 2012.

ROJAS, E.; LOPEZ, M. C.; VALVERDE, M. Single cell gel electrophoresis assay: methodology and applications. Journal of Chromatography B, v. 722, n. 1-2, p. 225-254, 1999.

ROPERTO, S.; AMBROSIO, V.; BORZACCHIELLO, G.; GALATI, P.; PACIELLO, O.; RUSSO, V.; ROPERTO, F. Bovine papillomavirus type-2 (BPV-2) infection and expression of uroplakin Illb, a novel urothelial cell marker, in urinary bladder tumors of cows. Veterinary Pathology, v. 42, n. 6, p. 812-818, 2005.

ROPERTO, S.; BORZACCHIELLO, G.; ESPOSITO, I.; RICCARDI, M.; URRARO, C.; CERMOLA, M.; PACIELLO, O.; CORTEGGIO, A.; TATE, R. Productive infection of bovine papillomavirus type 2 in the placenta of pregnant cows affected with urinary bladder tumors. PloS one, v. 7, n. 3, p. 1-9, 2012.

ROPERTO, S.; BRUN, R.; PAOLINI, F.; URRARO, C.; RUSSO, V.; BORZACCHIELLO, G.; PAGNINI, U.; RASO, C.; RIZZO, C.; ROPERTO, F.; VENUTI, A. Detection of bovine papillomavirus type 2 in the peripheral blood of cattle with urinary bladder tumours: possible biological role. The Journal of General Virology, v. 89 , n. 12, p. 3027-33, 2008.

ROPERTO, S.; COMAZZI, S.; CIUSANI, E.; PAOLINI, F.; BORZACCHIELLO, G.; ESPOSITO, I.; LUCA, R.; RUSSO, V.; URRARO, C.; VENUTI, A.; ROPERTO, F. PBMCs are additional sites of productive infection of bovine papillomavirus type 2 . The Journal of General Virology, v. 92, p. 1787-1794, 2011. 
ROPERTO, S.; RUSSO, V.; ESPOSITO, I.; CECCARELLI, D.; PACIELLO, O.; AVALLONE, L.; CAPPARELLI, R.; ROPERTO, F. Mincle, an innate immune receptor, is expressed in urothelial cancer cells of papillomavirus-associated urothelial tumors of cattle. PloS One, v. 10, n. 10, p. e0141624, 2015a.

ROPERTO, S.; RUSSO, V.; LEONARDI, L.; MARTANO, M.; CORRADO, F.; RICCARDI, M.; ROPERTO, F. Bovine papillomavirus type 13 expression in the urothelial bladder tumours of cattle. Transboundary and Emerging Diseases, p. 17, 2015b.

ROSSI, B.; MERLO, B.; COLLEONI, S.; IACONO, E.; TAZZARI, P. L.; RICCI, F.; LAZZARI, G.; GALLI, C. Isolation and in vitro characterization of bovine amniotic fluid derived stem cells at different trimesters of pregnancy. Stem Cell Reviews, v. 10, p. 712-724, 2014.

ROY, P.; MUKHERJEE, A.; GIRI, S. Evaluation of genetic damage in tobacco and arsenic exposed population of Southern Assam, India using buccal cytome assay and comet assay. Ecotoxicology and Environmental Safety, v. 124, p. 169-176, 2016.

ROYER, C.; LU, X. Epithelial cell polarity: a major gatekeeper against cancer? Cell Death and Differentiationeath, v. 18, n. 9, p. 1470-7, 2011.

RUBIN, H. Cancer as a dynamic developmental disorder. Cancer Research, v. 45, p. 2935-2942, 1985.

RUSSO, V.; ROPERTO, F.; ESPOSITO, I.; CECCARELLI, D.; ZIZZO, N.; LEONARDI, L.; CAPPARELLI, R.; BORZACCHIELLO, G.; ROPERTO, S. ERas protein is overexpressed and binds to the activated platelet-derived growth factor $\beta$ receptor in bovine urothelial tumour cells associated with papillomavirus infection. The Veterinary Journal, v. 212, p. 444-447, 2016.

SABOO, S.; TUMBAN, E.; PEABODY, J.; WAFULA, D.; PEABODY, D.; CHACKERIAN, B.; MUTTIL, P. An optimized formulation of a thermostable spraydried virus-like particles vaccine against human papillomavirus. Molecular Pharmaceutics, v. 13, n. 5, p. 1646-1655, 2016.

SACCO, A.; SIEPI, F.; CRESCENZI, M. HPV E7 expression in skeletal muscle cells distinguishes initiation of the postmitotic state from its maintenance. Oncogene, $v$. 22, n. 26, p. 4027-4034, 2003.

SACHS, N.; CLEVERS, H. Organoid cultures for the analysis of cancer phenotypes. Current Opinion in Genetics and Development, v. 24, n. 1, p. 68-73, 2014.

SALAZAR-ROA, M.; MALUMBRES, M. Fueling the cell division cycle. Trends in Cell Biology, v. 0, n. 0, p. 757-765, 2016.

SAMANTA, S.; DEY, P. Micronucleus and its applications. Diagnostic Cytopathology, v. 40, n. 1, p. 84-90, 2012. 
SANTOS, E.; SILVA, M.; PONTES, N.; COUTINHO, L.; PAIVA, S.; CASTRO, R.; FREITAS, A. Detection of different bovine papillomavirus types and co-infection in bloodstream of cattle. Transboundary and Emerging Diseases, v. 63, n. 1, p. 103108, 2014.

SATELLI, A.; LI, S. Vimentin in cancer and its potential as a molecular target for cancer therapy. Cellular and Molecular Life Sciences, v. 68, n. 18, p. 3033-3046, 2011.

SCADUTO, R.; GROTYOHANN, L. Measurement of mitochondrial membrane potential using fluorescent Rhodamine derivatives. Biophysical Journal, v. 76, n. 1, p. 469-477, 1999.

SCANLON, C.; VAN TUBERGEN, E.; INGLEHART, R.; D'SILVA, N. Biomarkers of epithelial-mesenchymal transition in squamous cell carcinoma. Journal of Dental Research, v. 92, n. 2, p. 114-121, 2013.

SCHÄFER, C.; BORM, B.; BORN, S.; MÖHL, C.; EIBL, E.; HOFFMANN, B. One step ahead: Role of filopodia in adhesion formation during cell migration of keratinocytes.

Experimental Cell Research, v. 315, n. 7, p. 1212-1224, 2009.

SCHELHAAS, M.; EWERS, H.; RAJAMÄKI, M.; DAY, P.; SCHILLER, J.; HELENIUS, A. Human papillomavirus type 16 entry: retrograde cell surface transport along actinrich protrusions. PLoS Pathogens, v. 4, n. 9, p. e1000148, 2008.

SCHELHAAS, M.; SHAH, B.; HOLZER, M.; BLATTMANN, P.; KÜHLING, L.; DAY, P.; SCHILLER, J.; HELENIUS, A. Entry of human papillomavirus type 16 by actindependent, clathrin- and lipid raft-independent endocytosis. PLoS Pathogens, v. 8, n. 4, p. e1002657, 2012.

SCHIEBER, M.; CHANDEL, N. ROS function in redox signaling and oxidative stress. Current Biology, v. 24, n. 10, p. R453-R462, 2014.

SCHIFFMAN, M.; HERRERO, R.; DESALLE, R.; HILDESHEIM, A.; WACHOLDER, S.; CECILIA, A.; BRATTI, M.; SHERMAN, M.; MORALES, J.; GUILLEN, D.; ALFARO, M.; HUTCHINSON, M.; WRIGHT, T.; SOLOMON, D.; CHEN, Z.; SCHUSSLER, J.; CASTLE, P.; BURK, R. The carcinogenicity of human papillomavirus types reflects viral evolution. Virology, v. 337, p. 76-84, 2005.

SCHILLER, J.; VASS, W.; LOWY, D. Identification of a second transforming region in bovine papillomavirus DNA. Proceedings of the National Academy of Sciences of the United States of America, v. 81, n. 24, p. 7880-7884, 1984.

SCHUCHAT, A.; JACKSON, L. Princípios de imunizaçao e uso de vacinas. In: LONGO, D.; FAUCI, A.; KASPER, D.; HAUSER, S.; JAMESON, J.; LOSCALZO, J. (Ed.). Medicina Interna de Harrinson. $18^{\mathrm{a}}$ ed. Porto Alegre - RS: Artmed, 2013. p. 1031-1041.

SCHUCK, S.; STENLUND, A. A conserved regulatory module at the C-terminus of 
the papillomavirus E1 helicase domain controls E1 helicase assembly. Journal of Virology, v. 89, n. 2, p. 1129-1142, 2015.

SCHULMAN, F.; KRAFFT, A.; JANCZEWSKI, T. Feline cutaneous fibropapillomas: Clinicopathologic findings and association with papillomavirus infection. Veterinary Pathology, v. 38, n. 3, p. 291-296, 2001.

SCHULMAN, F.; KRAFFT, A.; JANCZEWSKI, T.; REUPERT, R.; JACKSON, K.; GARNER, M. Camelid mucoutaneous fibropapillomas: clinicopathologic findings and association with papillomavirus. Veterinary Pathology, v. 40, p. 103-107, 2003.

SCHULZE, E.; BLOSE, S. Passage of molecules across the intercellular bridge between post-mitotic daughter cells. Experimental Cell Research, v. 151, n. 2, p. 367-373, 1984.

SCHWEIGER, M.; OTTINGER, M.; YOU, J.; HOWLEY, P. Brd4-independent transcriptional repression function of the papillomavirus e2 proteins. Journal of virology, v. 81, n. 18, p. 9612-9622, 2007.

SCHWEIGER, M.; YOU, J.; HOWLEY, P. Bromodomain protein 4 mediates the papillomavirus E2 transcriptional activation function. Journal of Virology, v. 80, n. 9, p. 4276-4285, 2006.

SCHWITALLA, S. Tumor cell plasticity: the challenge to catch a moving target. Journal of Gastroenterology, v. 49, n. 4, p. 618-627, 2014.

SCOBIE, L.; JACKSON, M.; CAMPO, M. The role of exogenous p53 and E6 oncoproteins in in vitro transformation by bovine papillomavirus type 4 (BPV-4): Significance of the absence of an E6 ORF in the BPV-4 genome. Journal of General Virology, v. 78, n. 11, p. 3001-3008, 1997.

SEDELNIKOVA, O.; PILCH, D. Histone H2AX in DNA damage and repair. Cancer Biology \& Therapy, v. 2, n. 3, p. 233-235, 2003.

SEDMAN, J.; STENLUND, A. The papillomavirus E1 protein forms a DNA-dependent hexameric complex with ATPase and DNA helicase activities. Journal of virology, v. 72, n. 8, p. 6893-6897, 1998.

SEMB, H.; CHRISTOFORI, G. The tumor-suppressor function of E-cadherin. American Journal of Human Genetics, v. 63, p. 1588-1593, 1998.

SEO, Y.; MÜLLER, F.; LUSKY, M.; HURWITZ, J. Bovine papilloma virus (BPV)encoded E1 protein contains multiple activities required for BPV DNA replication. Proceedings of the National Academy of Sciences of the United States of America, v. 90, n. 2, p. 702-706, 1993.

SETTLE, K.; POSNER, M.; SCHUMAKER, L.; TAN, M.; SUNTHARALINGAM, M.; GOLOUBEVA, O.; STROME, S.; HADDAD, R.; PATEL, S.; CAMBELL, E.; SARLIS, N.; LORCH, J.; CULLEN, K. Racial survival disparity in head and neck cancer results from low prevalence of human papillomavirus infection in black oropharyngeal cancer 
patients. Cancer Prevention Research, v. 2, n. 9, p. 776-781, 2009.

SHAFTI-KERAMAT, S.; HANDISURYA, A.; MENEGUZZI, G.; SLUPETZKY, K.; KIRNBAUER, R.; KRIEHUBER, E. Different heparan sulfate proteoglycans serve as cellular receptors for human papillomaviruses. Journal of Virology, v. 77, n. 24, p. 13215, 2003.

SHAFTI-KERAMAT, S.; SCHELLENBACHER, C.; HANDISURYA, A.; CHRISTENSEN, N.; REININGER, B.; BRANDT, S.; KIRNBAUER, R. Bovine papillomavirus type 1 (BPV1) and BPV2 are closely related serotypes. Virology, v. 393, n. 1, p. 1-6, 2009.

SHAHIN, M.; SMITH, B.; PRAKASH, A. Bracken carcinogens in the human diet. Mutation Research - Genetic Toxicology and Environmental Mutagenesis, v. 443, p. 69-79, 1999.

SHAMANNA, R.; HOQUE, M.; PE'ERY, T.; MATHEWS, M. Induction of p53, p21 and apoptosis by silencing the NF90/NF45 complex in human papilloma virustransformed cervical carcinoma cells. Oncogene, v. 32, n. 43, p. 5176-5185, 2013.

SHEN, M.; WU, S.; CHOU, C. Volume-sensitive chloride channels in the primary culture cell of human cervical carcinoma. Biochemical and Biophysical Acta, v. 1315, p. 138-144, 1996.

SHIBANUMA, M.; MORI, K.; ISHIKAWA, F. Intracellular redox and mitochondria regulation by transforming growth factor- $\beta$ - its implication in induction of epithelialmesenchymal transition. Journal of Cell Signaling, v. 1, n. 1, p. 1-3, 2016.

SHOPE, R. Immunization of rabbits to infectious papillomatosis. Journal of Experimental Medicine, v. 65, n. 2, p. 219-231, 1937.

SHU, X.; LEV-RAM, V.; DEERINCK, T.; QI, Y.; RAMKO, E.; DAVIDSON, M.; JIN, Y.; ELLISMAN, M.; TSIEN, R. A genetically encoded tag for correlated light and electron microscopy of intact cells, tissues, and organisms. PLoS Biology, v. 9, n. 4, p. e1001041, 2011.

SHUKLA, S.; SHISHODIA, G.; MAHATA, S.; HEDAU, S.; PANDEY, A.; BHAMBHANI, S.; BATRA, S.; BASIR, S.; DAS, B.; BHARTI, A. Aberrant expression and constitutive activation of STAT3 in cervical carcinogenesis: implications in highrisk human papillomavirus infection. Molecular Cancer, v. 9, n. 1, p. 282, 2010.

SIBBET, G.; ROMERO-GRAILLET, C.; MENEGUZZI, G.; CAMPO, M. S. Alpha6 integrin is not the obligatory cell receptor for bovine papillomavirus type 4 . The Journal of General Virology, v. 81, p. 327-334, 2000.

SILVA, F.; CIBULSKI, S.; DAUDT, C.; WEBER, M.; GUIMARÃES, L.; STRECK, A.; MAYER, F.; RIEHE, P.; CANAL, C. Novel bovine papillomavirus type discovered by rolling-circle amplification coupled with next-generation sequencing. PLoS ONE, v. 11, n. 9, p. 1-11, 2016. 
SILVA, G.; ABRITA, M.; SANTOS, A. Análise do comportamento dos preços do boi gordo e do boi magro na pecurária de corte paulista, no período de 1995 a 2006. In: $2^{\circ}$ Seminário Internacional de Integração e Desenvolvimento Regional, Ponta Porã MS. Anais. Ponta Porã - MS: 2014.

SILVA, M. A. R.; DE ALBUQUERQUE, B. M. F.; PONTES, N. E.; COUTINHO, L. C. a; LEITÃO, M. C. G.; REIS, M. C.; CASTRO, R. S.; FREITAS, a C. Detection and expression of bovine papillomavirus in blood of healthy and papillomatosis-affected cattle. Genetics and molecular research : GMR, v. 12, n. 3, p. 3150-3156, 2013a.

SILVA, M.; BATISTA, M.; PONTES, N.; SANTOS, E.; COUTINHO, L.; CASTRO, R.; BLABINO, V.; FREITAS, A. Comparison of two PCR strategies for the detection of bovine papillomavirus. Journal of Virological Methods, v. 192, n. 1-2, p. 55-58, 2013b.

SILVESTRE, O.; BORZACCHIELLO, G.; NAVA, D.; IOVANE, G.; RUSSO, V.; VECCHIO, D.; D’AUSILIO, F.; GAULT, E. a; CAMPO, M. S.; PACIELLO, O. Bovine papillomavirus type 1 DNA and E5 oncoprotein expression in water buffalo fibropapillomas. Veterinary Pathology, v. 46, p. 636-641, 2009.

SIMÕES, R.; BARTH, O. Chromosome aberrations as a biomarker for genomic instability in cell cultures originated from bovines, canines and equines infected with papillomavirus. International Journal of Applied Sciences and Biotechnology, v. 4, n. 1, p. 104-112, 2016.

SIMPSON, C.; ANYIWE, K.; SCHIMMER, A. Anoikis resistance and tumor metastasis. Cancer Letters, v. 272, n. 2, p. 177-185, 2008.

SMALL, J.; STRADAL, T.; VIGNAL, E.; ROTTNER, K. The lamellipodium: Where motility begins. Trends in Cell Biology, v. 12, n. 3, p. 112-120, 2002.

SMALLBONE, K.; GATENBY, R. A.; GILLIES, R. J.; MAINI, P. K.; GAVAGHAN, D. J. Metabolic changes during carcinogenesis: potential impact on invasiveness. Journal of Theoretical Biology, v. 244, p. 703-713, 2007.

SMITH, P. K.; KROHN, R. I.; HERMANSON, G. T.; MALLIA, A. K.; GARTNER, F. H.; PROVENZANO, M. D.; FUJIMOTO, E. K.; GOEKE, N. M.; OLSON, B. J.; KLENK, D. C. Measurement of protein using bicinchoninic acid. Analytical Biochemistry, v. 150, n. 1, p. 76-85, 1985.

SMOTKIN, D.; WETTSTEIN, F. Transcription of human papillomavirus type 16 early genes in a cervical cancer and a cancer-derived cell line and identification of the E7 protein. Proceedings of the National Academy of Sciences of the United States of America, v. 83, n. 13, p. 4680-4684, 1986.

SNYDER, R.; GREEN, J. A review of the genotoxicity of marketed pharmaceuticals. Mutation Research, v. 488, n. 2, p. 151-169, 2001.

SOLONESKI, S.; NIKOLOFF, N.; LARRAMENDY, M. Analysis of possible genotoxicity of the herbicide flurochloridone and its commercial formulations: Endo III 
and Fpg alkaline comet assays in Chinese hamster ovary (CHO-K1) cells. Mutation Research/Genetic Toxicology and Environmental Mutagenesis, v. 797, p. 46-52, 2016.

SONNENSCHEIN, C.; SOTO, A. Theories of carcinogenesis: An emerging perspective. Seminars in Cancer Biology, v. 18, n. 5, p. 372-377, 2008.

SOUSA, N.; ALVES, R.; MARTINS, M.; BARROS, N.; RIBEIRO, A.; ZEFERINO, L.; DUFLOTH, R.; RABELO-SANTOS, S. Cytopathic effects of human papillomavirus infection and the severity of cervical intraepithelial neoplasia: a frequency study. Diagnostic Cytopathology, v. 40, n. 10, p. 871-875, 2011.

SRIURANPONG, V.; PARK, J.; AMORNPHIMOLTHAM, P.; PATEL, V.; NELKIN, B.; GUTKIND, J. Epidermal growth factor receptor-independent constitutive activation of STAT3 in head and neck squamous cell carcinoma is mediated by the autocrine/paracrine stimulation of the interleukin 6/gp130 cytokine system. Cancer Research, v. 63, p. 2948-2956, 2003.

STEINBERG, B.; ABRAMSON, A.; MEADE, R. Culture of human laryngeal papilloma cells in vitro. Otolaryngology -- Head and Neck Surgery, v. 90, n. 6, p. 728-735, 1982.

STENNER, M.; YOSEF, B.; HUEBBERS, C.; PREUSS, S.; DIENES, H.; SPEEL, E.; ODENTHAL, M.; KLUSSMANN, J. Nuclear translocation of beta-catenin and decreased expression of epithelial cadherin in human papillomavirus-positive tonsillar cancer: An early event in human papillomavirus-related tumour progression? Histopathology, v. 58, n. 7, p. 1117-1126, 2011.

STERLING, J.; STANLEY, M.; GATWARD, G.; MINSON, T. Production of human papillomavirus type 16 virions in a keratinicyte cell line. Journal of Virology, v. 64, n. 12, p. 6305-6307, 1990.

STEVENS, H.; RECTOR, A.; BERTELSEN, M.; LEIFSSON, P.; VAN RANST, M. Novel papillomavirus isolated from the oral mucosa of a polar bear does not cluster with other papillomaviruses of carnivores. Veterinary Microbiology, v. 129, n. 1-2, p. 108-116, 2008.

STEWART, A.; RUSH, B.; DAVIS, E. The efficacy of intratumoral 5-fluorouracil for the treatment of equine sarcoids. Australian Veterinary Journal, v. 84, n. 3, p. 101106, 2006.

STOCCO DOS SANTOS, R. C.; LINDSEY, C. J.; FERRAZ, O. P.; PINTO, J. R.; MIRANDOLA, R. S.; BENESI, F. J.; BIRGEL, E. H.; PEREIRA, C. a; BEÇAK, W. Bovine papillomavirus transmission and chromosomal aberrations: an experimental model. The Journal of general virology, v. 79 ( Pt 9), p. 2127-2135, 1998.

STÖPPLER, H.; HARTMANN, D.; SHERMAN, L.; SCHLEGEL, R. The human papillomavirus type $16 \mathrm{E} 6$ and $E 7$ oncoproteins dissociate cellular telomerase activity from the maintenance of telomere length. Journal of Biological Chemistry, v. 272, n. 20, p. 13332-13337, 1997. 
STROBER, W. Trypan blue exclusion test of cell viability. Current Protocols in Immunology, 2001.

SUN, T.; TANG, J.; DU, W.; ZHAO, H.; ZHAO, G.; YANG, S.; CHEN, H.; HONG, J.; FANG, J. Bidirectional regulation between TMEFF2 and STAT3 may contribute to Helicobacter pylori-associated gastric carcinogenesis. International Journal of Cancer, v. 136, n. 5, p. 1053-1064, 2015.

SUNDARAM, M.; GUERNSEY, D.; RAJARAMAN, M.; RAJARAMAN, R. Neosis: a novel type of cell division in cancer. Cancer Biology \& Therapy, v. 3, n. 2, p. 207218, 2004.

SURESH, S. Biomechanics and biophysics of cancer cells. Acta Materialia, v. 55, n. 12, p. 3989-4014, 2007.

SUZUK, L.; NOFFSINGER, A.; HUI, U.; FENOGLIO-PREISER, C. Detection of human papillomavirus in esophageal. Cancer, v. 78, n. 4, p. 704-710, 1996.

SYRJÄNEN, K. Histological changes identical to those condylomatous lesions found in esophageal squamous cell carcinomas. Archives Geschwulsforsh, v. 52, n. 4, p. 283-294, 1982.

SYRJÄNEN, K. HPV infections and oesophageal cancer. Journal of Clinical Pathology, v. 55, p. 721-728, 2002.

SYRJANEN, S.; PURANEN, M. Human papillomavirus infections in children: the potential role of maternal transmission. Critical Reviews in Oral Biology \& Medicine, v. 11, n. 2, p. 259-274, 2000.

TACHEZY, R.; RECTOR, A.; HAVELKOVA, M.; WOLLANTS, E.; FITEN, P.; OPDENAKKER, G.; JENSON, B.; SUNDBERG, J.; VAN RANST, M. Avian papillomaviruses: the parrot Psittacus erithacus papillomavirus (PePV) genome has a unique organization of the early protein region and is phylogenetically related to the chaffinch papillomavirus. BMC Microbiology, v. 2, p. 19, 2002.

TAICHMAN, L.; BREITBURD, F.; CROISSANT, O.; ORTH, G. The search for a culture system for papillomavirus. The Joournal of Investigative Dermatology, v. 83, n. 1, p. 2s-6s, 1984.

TAKEDA, K.; AKAGI, S.; TAKAHASHI, S.; ONISHI, A.; HANADA, H.; PINKERT, C. Mitochondrial activity in response to serum starvation in bovine (Bos taurus) cell culture. Cloning and Ctem Cells, v. 4, n. 3, p. 223-229, 2002.

TAN, M.; WHITE, E.; SOWA, M.; HARPER, J.; ASTER, J.; HOWLEY, P. Cutaneous $\beta$-human papillomavirus E6 proteins bind Mastermind-like coactivators and repress Notch signaling. Proceedings of the National Academy of Sciences of the United States of America, v. 109, n. 23, p. e1473-80, 2012a.

TAN, M.; YILDIRIM, Y.; MAHMUT, S.; DAGALP, S.; YILMAZ, V.; KIRMIZIGUL, A.; 
GOKCE, E. A histopathological, immunohistochemical and molecular study of cutaneous bovine papillomatosis. Kafkas Univ Vet Derg, v. 18, n. 5, p. 739-744, 2012b.

TANAKA, H.; JOAZEIRO, P. Microscopia eletrônica de transmissão no diagnóstico de papilomavírus. In: BIBBO, M.; MORAES-FILHO, A. (Ed.). Lesões relacionadas à infecção por HPV no tratao anogenital. $1^{\text {a }}$ ed. Rio de Janeiro: Revinter, 1998. p. 166.

TARDIF, K.; WARIS, G.; SIDDIQUI, A. Hepatitis C virus, ER stress, and oxidative stress. Trends in Microbiology, v. 13, n. 4, p. 159-163, 2005.

TAYLOR, S.; TOTH, B.; BASELER, L.; CHARNEY, V.; MILLER, M. Lack of correlation between papillomaviral DNA in surgical margins and recurrence of equine sarcoids. Journal of Equine Veterinary Science, v. 34, n. 5, p. 722-725, 2014.

TEIFKE, J.; KIDNEY, B.; LÖHR, C.; YAGER, J. Detection of papillomavirus-DNA in mesenchymal tumour cells and not in the hyperplastic epithelium of feline sarcoids.

Veterinary Dermatology, v. 14, n. 1, p. 47-56, 2003.

TEIXEIRA, J.; HESPANHOL, A. The trajectory of Brazil's beef cattle. Caderno Prudentino de Geografia, v. 36, n. 1, p. 26-38, 2014.

TERRADAS, M.; MARTÍN, M.; TUSELL, L.; GENESCÀ, A. Genetic activities in micronuclei: is the DNA entrapped in micronuclei lost for the cell? Mutation Research, v. 705, n. 1, p. 60-67, 2010.

TERUI, K.; ENOSAWA, S.; HAGA, S.; ZHANG, H.; KURODA, H.; KOUCHI, K.; MATSUNAGA, T.; YOSHIDA, H.; ENGELHARDT, J.; IRANI, K.; OHNUMA, N.; OZAKI, M. Stat3 confers resistance against hypoxia/reoxygenation-induced oxidative injury in hepatocytes through upregulation of Mn-SOD. Journal of Hepathology, v. 41, p. 957-965, 2004.

TESLAA, T.; SETOGUCHI, K.; TEITELL, M. Mitochondria in human pluripotent stem cell apoptosis. Seminars in Cell \& Developmental Biology, p. 1-8, 2016.

THARWAT, M.; ENDOH, D.; OIKAWA, S. DNA damage in peripheral blood mononuclear cells and neutrophils of dairy cows during the transition period. Open Veterinary Journal, v. 2, p. 65-68, 2012.

THIERY, J. Epithelial-mesenchymal transitions in tumour progression. Nature Reviews, v. 2, n. 6, p. 442-454, 2002.

TIAN, Y.; XIE, Q.; HE, J.; LUO, X.; ZHOU, T.; LIU, Y.; HUANG, Z.; TIAN, Y.; SUN, D.; YAO, K. Radioactive 125 I seeds inhibit cell growth and epithelial-mesenchymal transition in human glioblastoma multiforme via a ROS-mediated signaling pathway. BMC Cancer, v. 15, p. 1-13, 2015.

TLSTY, T.; BRIOT, A.; GUALBERTO, A.; HALL, I.; HESS, S.; HIXON, M.; KUPPUSWAMY, D.; ROMANOV, S.; SAGE, M.; WHITE, A. Genomic instability and 
cancer. Mutation Research, v. 337, n. 1, p. 1-7, 1995.

TOBAR, A.; FAZ, E.; MURILLO, V.; VEGA, V. Reporte de casos de hematuria enzoótica bovina por ingestíon de Pteridium arachnoideum en la regíon ganadera de San Miguel de Bolívar, provincia Bolívar, Ecuador. Revista Salud Animal, v. 33, n. 3, p. 197-202, 2011.

TOGAWA, K.; JASKIEWICZ, K.; TAKAHASHI, H.; MELTZER, S.; RUSTGI, A. Human papillomavirus DNA in esophageal squamous cell carcinoma. Gastroenterology, v. 107, p. 128-136, 1994.

TOH, Y.; KUWANO, H.; TANAKA, S.; SUGIRNACHI, K.; MORI, R. Detection of human papillomavirus DNA in esophageal carcinoma in Japan by polymerase chain reaction. Cancer, v. 70, n. 9, p. 2234-2238, 1992.

TOKARNIA, C.; DOBERREINER, J.; PEIXOTO, P. Plantas de ação radiomimética. In: TOKARNIA, C.; DOBERREINER, J.; PEIXOTO, P. (Ed.). Plantas tóxicas do Brasil. Rio de Janeiro: Helianthus, 2000. p. 178-187.

TOMITA, Y.; OGAWA, T.; JIN, Z.; SHIRASAWA, H. Genus specific features of bovine papillomavirus E6, E7, E5 and E8 proteins. Virus research, v. 124, n. 1-2, p. 231236, 2007.

TONG, X.; BOLL, W.; KIRCHHAUSEN, T.; PETER, M. Interaction of the bovine papillomavirus E6 protein with the clathrin adaptor complex AP-1. Journal of Virology, v. 72, n. 1, p. 476, 1998.

TRUSOLINO, L.; BERTOTTI, A.; COMOGLIO, P. MET signalling: principles and functions in development, organ regeneration and cancer. Nature Reviews Cancer, v. 11, n. 12, p. 834-848, 2010.

TSIRIMONAKI, E.; NEIL, B.; WILLIAMS, R.; CAMPO, M. Extensive papillomatosis of the bovine upper gastrointestinal tract. Journal of Comparative Pathology, v. 129, n. 3, p. 93-99, 2003.

TSUNOKAWA, Y.; TAKEBE, N.; KASAMATSU, T.; TERADA, M.; SUGIMURA, T. Transforming activity of human papillomavirus type 16 DNA sequence in a cervical cancer. Proceedings of the National Academy of Sciences of the United States of America, v. 83, n. 7, p. 2200-2203, 1986.

TSURUTA, D.; JONES, J. The vimentin cytoskeleton regulates focal contact size and adhesion of endothelial cells subjected to shear stress. Journal of Cell Science, v. 116, n. 24, p. 4977-4984, 2003.

TURK, N.; ŽUPANČIĆ, Ž.; STAREŠINA, V.; KOVAČ, S.; BABIĆ, T.; KRESZINGER, M.; ĆURIĆ, S.; BARBIĆ, L.; MILAS, Z. Severe bovine papillomatosis: detection of bovine papillomavirus in tumour tissue and efficacy of treatment using autogenous vaccine and parammunity inducer. Veterinarski Arhiv, v. 75, n. 5, p. 391-397, 2005. 
TURNER, C. Paxillin interactions. Journal of Cell Science, v. 113, p. 4139-4140, 2000.

TURNER, C.; GLENNEY, J.; BURRIDGE, K. Paxillin: A new vinculin-binding protein present in focal adhesions. Journal of Cell Biology, v. 111, n. 3, p. 1059-1068, 1990.

TURRENS, J. Mitochondrial formation of reactive oxygen species. Journal of Physiology, v. 552, p. 335-344, 2003.

UMBAS, R.; ISAACS, W.; BRINGUIER, P.; SCHAAFSMA, H.; KARTHAUS, H.; OOSTERHOF, G.; DEBRUYNE, F.; SCHALKEN, J. Decreased E-cadherin expression is associated with poor prognosis in patients with prostate cancer. Cancer Research, v. 54, p. 3929-3934, 1994.

URA, H.; USUDA, M.; KINOSHITA, K.; SUN, C.; MORI, K.; AKAGI, T.; MATSUDA, T.; KOIDE, H.; YOKOTA, T. STAT3 and Oct-3/4 control histone modification through induction of Eed in embryonic stem cells. Journal of Biological Chemistry, v. 283, n. 15, p. 9713-9723, 2008.

VALLE, V.; PEREIRA-DA-SILVA, L.; VERCESI, A. Undesirable feature of saframine as a probe for mitochondrial membrane potential. Biochemical and Biophysical Research Communications, v. 135, n. 1, p. 189-195, 1986.

VAN DOORLAER, K.; BURK, R. Evolution of humana papillomavirus carcinogenicity. Advances in Virus Research, v. 77, p. 41-62, 2010.

VAN DOORSLAER, K. Evolution of the papillomaviridae. Virology, v. 445, n. 1-2, p. 11-20, 2013.

VAN DOORSLAER, K.; RECTOR, A.; VOS, P.; VAN RANST, M. Genetic characterization of the Capra hircus papillomavirus: a novel close-to-root artiodactyl papillomavirus. Virus Research, v. 118, n. 1-2, p. 164-169, 2006.

VAN DYK, E.; BOSMAN, A.; VAN WILPE, E.; WILLIANS, J.; BENGIS, R.; VAN HEERDEN, J.; VENTER, E. Detection and characterisation of papillomavirus in skin lesions of giraffe and sable antelope in South Africa. Journal of South Africa Veterninary Assiciation, v. 82, n. 2, p. 80-85, 2011.

VAN MUIJEN, G.; WARNAAR, S.; PONEC, M. Differentiation-related changes of cytokeratin expression in cultured keratinocytes and in fetal, newborn, and adult epidermis. Experimental Cell Research, v. 171, n. 2, p. 331-345, 1987.

VANDER HEIDEN, M. G.; CANTLEY, L. C.; THOMPSON, C. B. Understanding the Warburg effect: the metabolic requirements of cell proliferation. Science (New York, N.Y.), v. 324, n. 5930, p. 1029-1033, 2009.

VARGA, J.; OLIVEIRA, T.; GRETEN, F. The architect who never sleeps: Tumorinduced plasticity. FEBS Letters, v. 588, n. 15, p. 2422-2427, 2014. 
VARSANI, A.; VAN DER WALT, E.; HEATH, L.; RYBICKI, E.; WILLIAMSON, A.; MARTIN, D. Evidence of ancient papillomavirus recombination. Journal of General Virology, v. 87, p. 2527-2531, 2006.

VARTIAINEN, M. Nuclear actin dynamics - From form to function. FEBS Letters, v. 582, n. 14, p. 2033-2040, 2008.

VELAZQUEZ, E.; CHAUX, A.; CUBILLA, A. Histologic classification of penile intraepithelial neoplasia. Seminars in Diagnostic Pathology, v. 29, n. 2, p. 96-102, 2012.

VENUTI, A.; PAOLINI, F.; NASIR, L.; CORTEGGIO, A.; ROPERTO, S.; CAMPO, M.; BORZACCHIELLO, G. Papillomavirus E5: the smallest oncoprotein with many functions. Molecular Cancer, v. 10, n. 1, p. 140, 2011.

VICENTE-DUEÑAS, C.; PÉREZ-CARO, M.; ABOLLO-JIMÉNEZ, F.; CABALEDA, C.; SÁNCHEZ-GARCÍA. Stem-cell driven cancer. Cell Cycle, v. 8, n. 9, p. 1314-1318, 2009.

VIEIRA, C.; LOPES, J.; VELOSA, J. A case of esophageal squamous cell carcinoma with positive HPV 11. Gastroenterología y Hepatología, v. 36, n. 5, p. 311-315, 2013.

VILLARREAL, L.; DEFILIPPIS, V. A hypothesis for DNA viruses as the origin of eukaryotic replication proteins. Journal of Virology, v. 74, n. 15, p. 7079-7084, 2000.

VISVADER, J.; LINDEMAN, G. Cancer stem cells in solid tumours: accumulating evidence and unresolved questions. Nature Reviews, v. 8, n. 10, p. 755-768, 2008.

VIVANCO, I.; SAWYERS, C. The phosphatidylinositol 3-Kinase-AKT pathway in human cancer. Nature Reviews - Cancer, v. 2, n. 7, p. 489-501, 2002.

VIVAS, R.; CORDEIRO, L.; RUIZ, E.; CÁRDENAS, M.; MELINA, M.; NAVARRO, R.; MARÍN, J. Papilomatosis bovina en el trópico mexicano: presentación clínica y control. Bioagrociências, v. 8, n. 1, p. 45-52, 2015.

VOLGELSTEIN, B.; KINZIER, K. The multistep nature of cancer development. Cancer Research, v. 44, n. 10, p. 4217-4223, 1984.

VON JOEST, M.; BUA, S.; LI, H. Genomic stability during cellular reprogramming: mission impossible? Mutation Research/Fundamental and Molecular Mechanisms of Mutagenesis, p. 1-5, 2016.

WAKE, M.; WATSON, C. STAT3 the oncogene - still eluding therapy? FEBS Journal, p. n/a-n/a, 2015.

WALDECK, W.; RÖSL, F.; ZENTGRAF, H. Origin of replication in episomal bovine papilloma virus type 1 DNA isolated from transformed cells. The EMBO journal, v. 3, n. 9, p. 2173-2178, 1984. 
WALLACE, D. A mitochondrial paradigm of metabolic and degenerative diseases, aging, and cancer: A dawn for evolutionary medicine. Annual Review of Genetic, v. 39, p. 359, 2010.

WALLACE, N.; GALLOWAY, D. Manipulation of cellular DNA damage repair machinery facilitates propagation of human papillomaviruses. Seminars in Cancer Biology, v. 26, p. 30-42, 2014.

WANG, F.; KIEFF, E. Virologia médica. In: LONGO, D.; FAUCI, A.; KASPER, D.; HAUSER, S.; JAMESON, J.; LOSCALZO, J. (Ed.). Medicina Interna de Harrinson. 18. ed. Porto Alegre - RS: Artmed, 2013. p. 1432-1441.

WANG, G.; YANG, Z.; ZHANG, K. Endoplasmic reticulum stress response in cancer: molecular mechanism and therapeutic potential. American Journal of Translational Research, v. 2, n. 1, p. 65-74, 2010.

WANG, J.; RODEN, R. L2, the minor capsid protein of papillomavirus. Virology, v. 445, n. 1-2, p. 175-186, 2013.

WANG, X.; TIAN, X.; LIU, F.; ZHAO, Y.; SUN, M.; CHEN, D.; LU, C.; WANG, Z.; SHI, X.; ZHANG, Q.; ZHANG, D.; SHEN, Z.; LI, F.; HARRIS, C. C.; CAI, H.; KE, Y. Detection of HPV DNA in esophageal cancer specimens from different regions and ethnic groups: a descriptive study. BMC Cancer, v. 10, n. 1, p. 19, 2010.

WANG, Z.; LI, Y.; SARKAR, F. Signaling mechanism(s) of reactive oxygen species in epithelial-msenchymal transition reminiscent of cancer stem cells in tumor progression. Currently Stem Cell Research and Therapy, v. 5, n. 1, p. 74-80, 2010.

WARBURG, O. On the origin of cancer cells. Science, v. 123, n. 3191, p. 309-314, 1953.

WARIS, G.; AHSAN, H. Reactive oxygen species: role in the development of cancer and various chronic conditions. Journal of Carcinogenesis, v. 5, p. 14, 2006.

WATSON, R.; THOMAS, M.; BANKS, L.; ROBERTS, S. Activity of the human papillomavirus E6 PDZ-binding motif correlates with an enhanced morphological transformation of immortalized human keratinocytes. Journal of Cell Science, v. 116, n. Pt 24, p. 4925-4934, 2003.

WEINSTEIN, I. The origins of human cancer: Molecular mechanisms of carcinogenesis and their implications for cancer prevention and treatment. Cancer Research, v. 48, n. 15, p. 4135-4143, 1988a.

WEINSTEIN, I. Strategies for inhibiting multistage carcinogenesis based on signal transduction pathways. Mutation Research - Fundamental and Molecular Mechanisms of Mutagenesis, v. 202, n. 2, p. 413-420, 1988b.

WEINSTEIN, I.; GATTONI-CELLI, S.; KIRSCHMEIER, P.; LAMBERT, M.; HSIAO, 
W.; BACKER, J.; JEFFREY, A. Multistage carcinogenesis involves multiple genes and multiple mechanisms. Journal of Cellular Physiology, v. 121, n. 3 S, p. 127137, 1984.

WERNESS, B.; LEVINE, A.; HOWLEY, P. Association of human papillomavirus types 16 and 18 E6 proteins with p5. Sciencence, v. 248, p. 76-79, 1990.

WETHERILL, L.; HOLMES, K.; VEROW, M.; MÜLLER, M.; HOWELL, G.; HARRIS, M.; FISHWICK, C.; STONEHOUSE, N.; FOSTER, R.; BLAIR, G.; GRIFFIN, S.; MACDONALD, A. High-risk human papillomavirus E5 oncoprotein displays channelforming activity sensitive to small-molecule inhibitors. Journal of virology, v. $86, \mathrm{n}$. 9, p. 5341-5351, 2012.

WEYEMI, U.; REDON, C.; CHOUDHURI, R.; AZIZ, T.; MAEDA, D.; BOUFRAQECH, M.; PAREKH, P.; SETHI, T.; KASOJI, M.; ABRAMS, N.; MERCHANT, A.; RAJAPAKSE, V.; BONNER, W. The histone variant H2A.X is a regulator of the epithelial-mesenchymal transition. Nature Communications, v. 7, p. 1-12, 2016.

WHITE, E.; HOWLEY, P. Proteomic approaches to the study of papillomavirus - host interactions. Virology, v. 435, p. 57-69, 2013.

WHITE, E.; KRAMER, R.; HWANG, J.; PORES, F.; NAETAR, N.; HAHN, W.; ROBERTS, T.; SCHAFFHAUSEN, B.; LIVINGSTON, D.; HOWLEY, P. Papillomavirus E7 oncoproteins share functions with polyomavirus small $\mathrm{T}$ antigens. Journal of Virology, v. 89, n. 5, p. 2857-2865, 2015.

WIDSCHWENDTER, M.; FIEGL, H.; EGLE, D.; MUELLER-HOLZNER, E.; SPIZZO, G.; MARTH, C.; WEISENBERGER, D.; CAMPAN, M.; YOUNG, J.; JACOBS, I.; LAIRD, P. Epigenetic stem cell signature in cancer. Nature Genetics, v. 39, n. 2, p. 157-158, 2007.

WILLERT, K.; NUSSET, R. 13-catenin: a key mediator of Wnt signaling. Current Opinion in Genetics \& Development, , v. 8, n. 1, p. 95-102, 1998.

WILLIAM, J.; KIRUBAHARAN, J.; UTHUMANN, K. Survey on incidence and complications of bovine cutaneous papillomatosis. Indian Journal of Veterinary, v. 69, p. 842-844, 1992.

WILLIAMS, J.; VAN DYK, E.; NEL, P.; LANE, E.; VAN WILPE, E.; BENGIS, R. Pathology and immunohistochemistry of papillomavirus-associated cutaneous lesions in Cape mountain zebra, giraffe, sable antelope and African buffalo in South Africa. Journal of South Africa Veterninary Assiciation, v. 82, n. 2, p. 97-106, 2011.

WILLIAMS, V.; BRICHLER, S.; KHAN, E.; CHAMI, M.; DÉNY, P.; KREMSDORF, D.; GORDEIN, E. Large hepatitis delta antigen activates STAT-3 and NF-kB via oxidative stress. Journal of Viral Hepatitis, v. 19, p. 744-753, 2012.

WILLIAMS, V.; FILIPPOVA, M.; FILIPPOV, V.; PAYNE, K.; DUERKSEN-HUGHES, P. Human papillomavirus type $16 \mathrm{e}^{*}$ induces oxidative stress and DNA damage. 
Journal of Virology, v. 88, n. 12, p. 6751-6761, 2014.

WINKLER, B.; CAPO, V.; REUMANN, W.; MA, A.; LA PORTA, R.; REILLY, S.; GREEN, P.; RICHART, R.; CRUM, C. Human papillomavirus infection of the esophagus. A clinicopathologic study with demonstration of papillomavirus antigen by the Immunoperoxidase technique. Cancer, v. 55, p. 149-155, 1985.

WOLKE, R.; MURCHELANO, R. A case report of an epidermal papilloma in Mustelus canis. Journal of Wildlife Diseases, v. 12, n. 2, p. 167-171, 1976.

WONGWORAWAT, Y.; FILIPPOVA, M.; WILLIAMS, V.; FILIPPOV, V.; DUERKSENHUGHES, P. Chronic oxidative stress increases the integration frequency of foreign DNA and human papillomavirus 16 in human keratinocytes. American Journal of Cancer Research, v. 6, n. 4, p. 764-780, 2016.

WOSIACKI, S.; CARLOS, A.; ALFIERI, A.; ALFIERI, A. Bovine papillomavirus type 2 in enzootic haematuria aetiology. Semina: Ciências Agrárias, v. 1, p. 121-130, 2002.

WOSIACKI, S.; CLAUS, M.; ALFIERI, A.; ALFIERI, A. Bovine papillomavirus type 2 detection in the urinary bladder of cattle with chronic enzootic haematuria. Memórias do Instituto Oswaldo Cruz, v. 101, n. 6, p. 635-638, 2006.

$\mathrm{XU}, \mathrm{L}$. R. Bracken poisoning and enzootic haematuria in cattle in China. Research in Veterinary Science, v. 53, n. 1, p. 116-121, 1992.

XUE, F.; JANZEN, D.; KNECHT, D. Contribution of filopodia to cell migration: A mechanical link between protrusion and contraction. International Journal of Cell Biology, v. 2010, p. 1-13, 2010.

YAGUIU, A.; CARVALHO, C.; FREITAS, A.; GUSTAVO, L.; GÓES, B.; DAGLI, L.; BIRGEL-JÚNIOR, E.; BEÇAK, W.; STOCCO DOS SANTOS, R. Papillomatosis in cattle: in situ detection of bovine papillomavirus DNA sequences in reproductive tissues. Brazilian Journal of Morphology Science, v. 23, n. 3-4, p. 525-529, 2006.

YAGUIU, A.; DAGLI, M.; BIRGEL-JÚNIOR, E.; REIS, B.; FERRAZ, O.; PITUCO, E.; FREITAS, A.; BEÇAK, W.; STOCCO, R. Simultaneous presence of bovine papillomavirus and bovine leukemia virus in different bovine tissues: in situ hybridization and cytogenetic analysis. Genetics and Molecular Research, v. 7, n. 2, p. 487-497, 2008.

YAMAGUCHI, H.; CONDEELIS, J. Regulation of the actin cytoskeleton in cancer cell migration and invasion. Biochimica et Biophysica Acta, v. 1773, n. 5, p. 642-652, 2007.

YAMAOKA, K.; SAHARINEN, P.; PESU, M.; HOLT, V.; SILVENNOINEN, O.; O'SHEA, J. The Janus kinases (Jaks). Genome Biology, v. 5, n. 12, p. 253, 2004.

YANG, X.; XU, Y.; SHI, G.; FAN, J.; ZHOU, J.; JI, Y.; SUN, H.; QIU, S.; YU, B.; GAO, Q.; HE, Y.; QIN, W.; CHEN, R.; YANG, G.; WU, B.; LU, Q.; WU, Z.; TANG, Z. 
Cytokeratin 10 and cytokeratin 19: Predictive markers for poor prognosis in hepatocellular carcinoma patients after curative resection. Clinical Cancer Research, v. 14, n. 12, p. 3850-3859, 2008.

YANG, Y.; OKAYAMA, H.; HOWLEY, P. Bovine papillomavirus contains multiple transforming genes. Proceedings of the National Academy of Sciences of the United States of America, v. 82, n. 4, p. 1030-1034, 1985.

YAO, P.; LI, G.; LI, J.; XIA, H.; YANG, X.; HUANG, H.; FU, Y.; WANG, R.; WANG, X.; SHA, J. Evidence of human papilloma virus infection and its epidemiology in esophageal squamous cell carcinoma. World Journal of Gastroenterology, v. 12, n. 9, p. 1352-1355, 2006.

YEE, C.; KRISHNAN-HEWLETT, I.; BAKER, C.; SCHLEGEL, R.; HOWLEY, P. Presence and expression of human papillomavirus sequences in human cervical carcinoma cell lines. The American Journal of Pathology, v. 119, n. 3, p. 361-366, 1985.

YEN, Y.; CHEN, H.; LIN, Y.; SHIEH, C.; WU-HSIEH, B. Enhancement by tumor necrosis factor alpha of dengue virus-induced endothelial cell production of reactive nitrogen and oxygen species is key to hemorrhage development. Journal of Virology, v. 82, n. 24, p. 12312-12324, 2008.

YOSHIDA, J.; HORIUCHI, A.; KIKUCHI, N.; HAYASHI, A.; OSADA, R.; OHIRA, S.; SHIOZAWA, T.; KONISHI, I. Changes in the expression of E-cadherin repressors, Snail, Slug, SIP1, and Twist, in the development and progression of ovarian carcinoma: the important role of Snail in ovarian tumorigenesis and progression. Medical Molecular Morphology, v. 42, n. 2, p. 82-91, 2009.

YU, C.; HUO, X.; AGOSTON, A. T.; ZHANG, X.; THEISS, A. L.; ZHANG, Q.; ZAIKA, A.; PHAM, T. H.; WANG, D. H.; PETER, E.; ODZE, R. D.; SPECHLER, S. J.; SOUZA, R. F.; SOUTHWESTERN, T.; BIOLOGY, C.; SOUZA, R. F. Mitochondrial STAT3 contributes to transformation of Barrett's epithelial cells that express oncogenic Ras in a p53-independent fashion. American Journal of Physiology and Gastroenterology and Liver Physiology, v. 309, n. 3, p. 146-161, 2015.

YU, C.; WOODS, A.; LEVISON, D. The assessment of cellular proliferation by immunohistochemistry: A review of currently available methods and their applications. The Histochemical Journal, v. 24, p. 121-131, 1992.

YU, H.; MOUW, J. K.; WEAVER, V. M. Forcing form and function: Biomechanical regulation of tumor evolution. Trends in Cell Biology, v. 21, n. 1, p. 47-56, 2011.

YUAN, Z.; GALLAGHER, A.; GAULT, E. a; CAMPO, M. S.; NASIR, L. Bovine papillomavirus infection in equine sarcoids and in bovine bladder cancers. Veterinary journal (London, England : 1997), v. 174, n. 3, p. 599-604, 2007a.

YUAN, Z.; GALLAGHER, A.; GAULT, E.; CAMPO, M.; NASIR, L. Bovine papillomavirus infection in equine sarcoids and in bovine bladder cancers. Veterinary Journal, v. 174, n. 3, p. 599-604, 2007b. 
YUAN, Z.; GAULT, E.; GOBEIL, P.; NIXON, C.; CAMPO, M.; NASIR, L. Establishment and characterization of equine fibroblast cell lines transformed in vivo and in vitro by BPV-1: model systems for equine sarcoids. Virology, v. 373, n. 2, p. 352-361, 2008.

YUAN, Z.; GOBEIL, P.; CAMPO, M.; NASIR, L. Equine sarcoid fibroblasts overexpress matrix metalloproteinases and are invasive. Virology, v. 396, n. 1, p. 143$151,2010$.

ZANIER, K.; CHARBONNIER, S.; BALTZINGER, M.; NOMINÉ, Y.; ALTSCHUH, D.; TRAVÉ, $G$. Kinetic analysis of the interactions of human papillomavirus E6 oncoproteins with the ubiquitin ligase E6AP using surface plasmon resonance. Journal of Molecular Biology, v. 349, n. 2, p. 401-412, 2005.

ZANIER, K.; CHARBONNIER, S.; SIDI, A.; MCEWEN, A.; FERRRARIO, M.; POUSSIN-COURMONTAGNE, E.; CURA, V.; BRIMER, N.; BABABH, K.; AANSARI, T.; MULLER, I.; STORE, R.; CAVARELLI, J.; VANDE POL, S.; TRAVÉ, G. Structural basis for hijacking of cellular LxxLL motifs by papillomavirus E6 oncoproteins. Science, v. 339, n. 694, p. 694-698, 2013.

ZANIER, K.; NOMINÉ, Y.; CHARBONNIER, S.; RUHLMANN, C.; SCHULTZ, P.; SCHWEIZER, J.; TRAVÉ, G. Formation of well-defined soluble aggregates upon fusion to MBP is a generic property of $E 6$ proteins from various human papillomavirus species. Protein Expression and Purification, v. 51, n. 1, p. 59-70, jan. 2007.

ZAVADIL, J.; HALEY, J.; KALLURI, R.; MUTHUSWAMY, S.; THOMPSON, E. Epithelial-mesenchymal transition. Cancer Research, v. 68, n. 23, p. 9574-9577, 2008.

ZAVIZION, B.; VAN DUFFELEN, M.; SCHAEFFER, W.; POLITIS, I. Establishment and characterization of a bovine mammary myoepithelial cell line. In viVtro Cellular \& Developmental Biology, v. 32, p. 149-158, 1996.

ZEISBERG, M.; NEILSON, E. Review series personal perspective Biomarkers for epithelial-mesenchymal transitions. The Journal od Clinical Investigation, v. 119, n. 6, p. 1429-1437, 2009.

ZHANG, N.; WEI, P.; GONG, A.; CHIU, W.; LEE, H.; COLMAN, H7HUANG, H.; XUE, J.; LIU, M.; WANG, Y.; SAWAYA, R.; XIE, K.; YUNG, W.; MEDEMA, R.; HE, X.; HUNAG, S. FoM1 promotes B-catenin nuclear localization and controls Wnt targetgene expression and glioma tumorigenesis. Cancer Cell, v. 127, n. 4, p. 358-366, 2012.

ZHOU, J.; SCHMID, T.; SCHNITZER, S.; BRÜNE, B. Tumor hypoxia and cancer progression. Cancer Letters, v. 237, n. 1, p. 10-21, 2006.

ZHU, X.; DONG, J.; UCHIDA, K.; WATANABE, K.; NAKAYAMA, H.; GOTO, Y.; HAGA, T. Bovine papillomavirus type 10 with a deletion associated with a lingual papilloma in a cow. The Veterinary Journal, v. 199, n. 2, p. 303-305, 2014. 
ZIEGLER, W.; LIDDINGTON, R.; CRITCHLEY, D. The structure and regulation of vinculin. Trends in Cell Biology, v. 16, n. 9, p. 453-460, 2006.

ZIMMERMANN, H.; DEGENKOLBE, R.; BERNARD, H.; O'CONNOR, M. The human papillomavirus type $16 \mathrm{E} 6$ oncoprotein can down-regulate p53 activity by targeting the transcriptional coactivator CBP/p300. Journal of Virology, v. 73 , n. 8, p. 6209, 1999.

ZIMMERMANN, H.; KOH, C.; DEGENKOLBE, R.; O'CONNOR, M.; MULLER, A.; STEGER, G.; CHEN, J.; LUI, Y.; ANDROPHY, E.; BERNARD, H. Interaction with $\mathrm{CBP} / \mathrm{p} 300$ enables the bovine papillomavirus type $1 \mathrm{E} 6$ oncoprotein to downregulate CBP/p300-mediated transactivation by p53. Journal of General Virology, v. 81, n. 11, p. 2617-2623, 2000.

ZUR HAUSEN, $\mathrm{H}$. The search for infectious causes of human cancers: where and why. Virology, v. 392, n. 1, p. 1-10, 2009.

ZUR HAUSEN, H. Red meat consumption and cancer: reasons to suspect involvement of bovine infectious factors in colorectal cancer. International Journal of Cancer, v. 2483, p. 2475-2483, 2012. 


\title{
APÊNDICE 1 - Regiões de anelamento e extensão dos primers utilizados
}

\author{
Primer específico para BPV-1: Gene L1, BPV-1 (GenBank X02346,1)
}

AtGGCGTTGTGGCAACAAGGCCAGAAGCTGTATCTCCCTCCAACCCCTGTAAGCAAGGTGCTTTGCAGTG AAACCTATGTGCAAAGAAAAAGCATTTTTTATCATGCAGAAACGGAGCGCCTGCTAACTATAGGACATCC ATATTACCCAGTGTCTATCGGGGCCAAAACTGTTCCTAAGGTCTCTGCAAATCAGTATAGGGTATTTAAA ATACAACTACCTGATCCCAATCAATTTGCACTACCTGACAGGACTGTTCACAACCCAAGTAAAGAGCGGC TGGTGTGGGCAGTCATAGGTGTGCAGGTGTCCAGAGGGCAGCCTCTTGGAGGTACTGTAACTGGGCACCC CACTTTTAATGCTTTGCTTGATGCAGAAAATGTGAATAGAAAAGTCACCACCCAAACAACAGATGACAGG AAACAAACAGGCCTAGATGCTAAGCAACAACAGATTCTGTTGCTAGGCTGTACCCCTGCTGAAGGGGAAT ATTGGACAACAGCCCGTCCATGTGTTACTGATCGTCTAGAAAATGGCGCCTGCCCTCCTCTTGAATTAAA AAACAAGCACATAGAAGATGGGGATATGATGGAAATTGGGTTTGGTGCAGCCAACTTCAAAGAAATTAAT GCAAGTAAATCAGATCTACCTCTTGACATTCAAAATGAGATCTGCTTGTACCCAGACTACCTCAAAATGG CTGAGGACGCTGCTGGTAATAGCATGTTCTTTTTTGCAAGGAAAGAACAGGTGTATGTTAGACACATCTG GACCAGAGGGGGCTCGGAGAAAGAAGCCCCTACCACAGATTTTTATTTAAAGAATAATAAAGGGGATGCC ACCCTTAAAATACCCAGTGTGCATTTTGGTAGTCCCAGTGGCTCACTAGTCTCAACTGATAATCAAATTT TTAATCGGCCCTACTGGCTATTCCGTGCCCAGGGCATGAACAATGGAATTGCATGGAATAATTTATTGTT TTTAACAGTGGGGGACAATACACGTGGTACTAATCTTACCATAAGTGTAGCCTCAGATGGAACCCCACTA ACAGAGTATGATAGCTCAAAATTCAATGTATACCATAGACATATGGAAGAATATAAGCTAGCCTTTATAT TAGAGCTATGCTCTGTGGAAATCACAGCTCAAACTGTGTCACATCTGCAAGGACTTATGCCCTCTGTGCT TGAAAATTGGGAAATAGGTGTGCAGCCTCCTACCTCATCGATATTAGAGGACACCTATCGCTATATAGAG TCTCCTGCAACTAAATGTGCAAGCAATGTAATTCCTGCAAAAGAAGACCCTTATGCAGGGTTTAAGTTTT GGAACATAGATCTTAAAGAAAAGCTTTCTTTGGACTTAGATCAATTTCCCTTGGGAAGAAGATTTTTAGC ACAGCAAGGGGCAGGATGTTCAACTGTGAGAAAACGAAGAATTAGCCAAAAAACTTCCAGTAAGCCTGCA AAAAAAAAAAAAAAATAA

\section{Primer específico para BPV-2: Gene L1, BPV-2 (GenBank M20219,1)}

ATGGCGTTGTGGCAACAAGGCCAAAAGCTGTATCTCCCTCCAACCCCTGTAAGCAAGGTGCTATGCAGTG AAACCTATGTGCAAAGAAAAAGCATATTCTATCATGCAGAAACGGAACGCCTGTTAACTGTAGGACATCC ATACTACCAAGTCACTGTGGGGGACAAAACTGTTCCCAAAGTGTCTGCTAATCAATTTAGAGTTTTTAAA ATACAGCTCCCCGATCCCAATCAGTTTGCATTGCCTGATAGGACTGTGCACAATCCAAGCAAGGAGCGCC TGGTTTGGGCTGTAATAGGGGTTCAAGTATCTCGTGGCCAACCACTAGGAGGCACAGTTACTGGGCACCC CACTTTTAATGCTCTGCTTGATGCAGAAAATGTTAATAGAAAAGTTACTGCACAAACAACAGATGACAGG AAGCAAACAGGATTAGATGCTAAGCAACAACAGATTCTGTTGCTGGGCTGTACCCCTGCAGAAGGGGAAT ACTGGACCACAGCCCGTCCATGTGTTACTGATAGACTAGAAAATGGTGCGTGTCCTCCTTTAGAATTAAA GAACAAACACATAGAAGATGGAGACATGATGGAAATAGGGTTTGGTGCTGCTGACTTTAAAACACTAAAT GCCAGTAAATCAGATCTACCTCTTGACATTCAAAATGAAATATGCCTGTATCCAGACTACCTCAAAATGG CTGAAGATGCTGCTGGAAACAGTATGTTCTTCTTTGCAAGAAAAGAACAAGTGTATGTAAGGCATATATG GACTCGGGGGGGCTCTGAAAAAGAAGCACCCAGTAAAGACTTCTACCTCAAAAATGGTAGAGGTGAAGAA ACTCTAAAAATACCTAGTGTGCACTTTGGCAGTCCCAGTGGATCCTTGGTGTCCACTGATAATCAAATAT TTAACAGGCCTTATTGGCTATTCAGGGCTCAGGGCATGAACAATGGGATTGCATGGAATAATTTATTATT TTTAACTGTAGGGGATAACACACGGGGAACTAACCTTAGTATTAGTGTAGCTGCAGATGGAAACGCATTG TCAGAGTATGATACTGGCAAATTTAACCTATACCATAGGCATATGGAAGAATATAAGCTAGCATTTATAT TGGAGCTGTGCTCTGTTGAGATTACTGCACAAACACTGTCACATCTGCAAGGACTGATGCCCTCTGTGCT ACAAAACTGGGAAATCGGGGTGCAACCTCCTGCTTCTTCTATTTTAGAAGATACTTATAGGTACATAGAG TCTCCTGCAACTAAATGTGCAAGTAATGTTATACCACCCAAAGAAGACCCTTATGCAGGGCTTAAGTTTT GGAGCATAGACTTAAAAGAAAAGCTGTCTTTGGACTTAGACCAATTTCCCTTGGGAAGAAGATTCTTAGC TCAGCAAGGGGCAGGATGTTCAACTGTGAGAAAGAGAGCTGTTGCAACCAGAAATTCCAGTAAGCCTGCA AAAAGAAAAAAAATCAAAGCTTAA 
Primer específico para BPV-4: Gene E7, BPV-4 (GenBank X05817,1)

GCTGACCTTCCAGTCTTAATTGCAGTAGGCGCCTAAGAGGGTGGTGGTGGTATAAGTTCAAGTTTTTCAA GAAAATGAAGGGGCAGAACGTGACATTACAGGACATTGCAATAGAATTAGAGGATACAATTAGTCCAATT AACTTGCATTGTGAAGAGGAGATTGAAACTGAGGAGGTGGACACCCCTAACCCTTTTGCAATAACAGCAA CTTGTTATGCTTGCGAGCAAGTCCTTCGTTTAGCTGTTGTAACGTCAACAGAAGGAATTCATCAACTGCA GCAACTGCTGTTCGACAACCTCTTTCTACTGTGTGCAGCTTGCTCCAAACAAGTGTTCTGTAACCGCAGA CCCGAGCGAAATGGACCC 
APÊNDICE 2 - Níveis de expressão de $\beta$-catenina

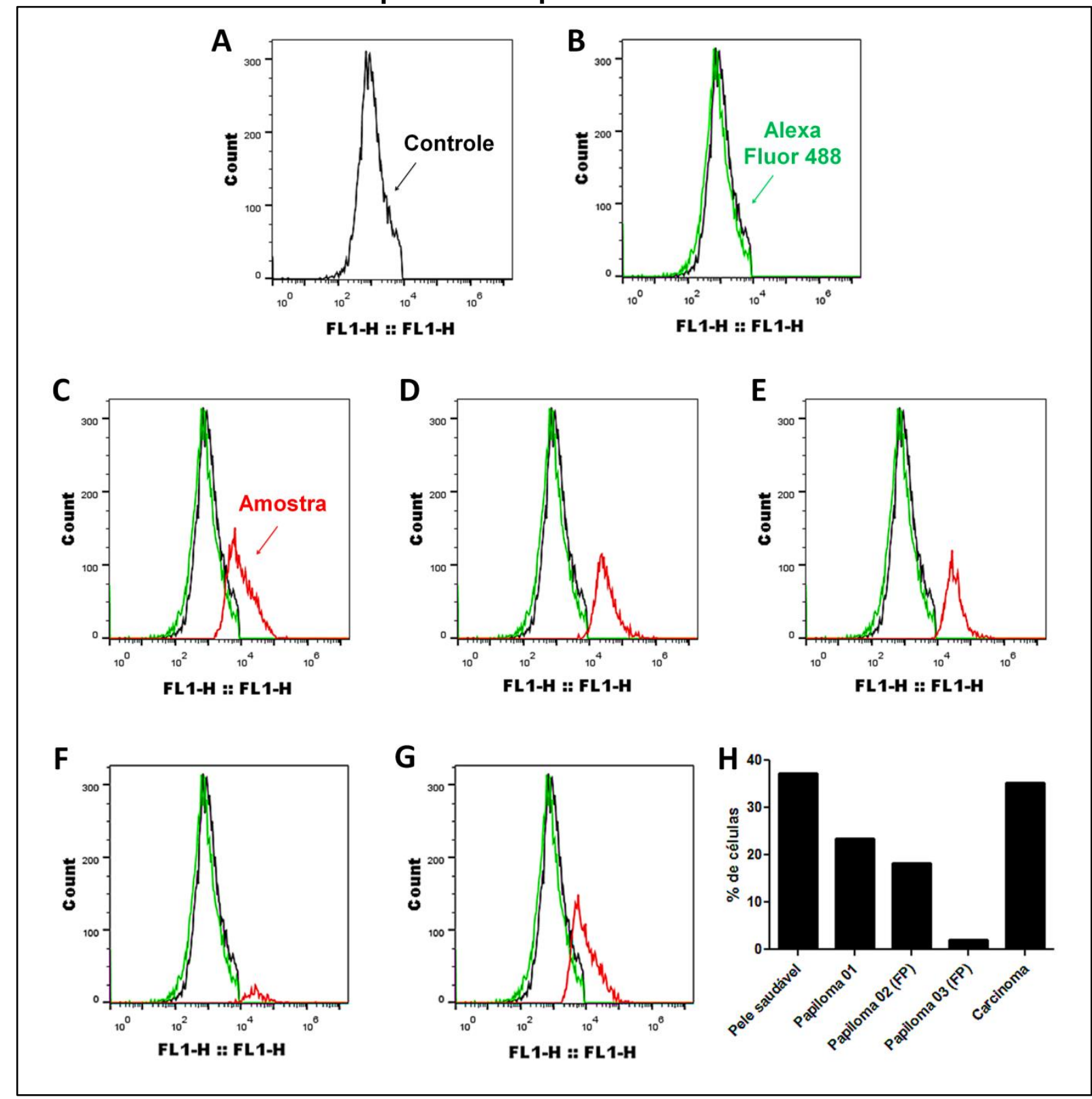

Resultados da citometria de fluxo empregando o anticorpo anti- $\beta$-catenina: A) células de papiloma cutâneo não incubada com anticorpo primário e/ou secundário (controle); B células de papiloma cutâneo incubada exclusivamente com anticorpo secundário (Alexa Fluor 488), mostrando ausência de imunomarcação inespecífica; células incubadas com anticorpo primário e secundário (amostra): C) pele saudável, D) papiloma 01 (papiloma cutâneo), E) papiloma 02 (FP), F) papiloma 03 (FP) e G) carcinoma de esôfago. H) Histograma baseado no percentual de células imunomarcadas mostrando redução dos níveis de expressão de $\beta$-catenina nas linahgens de papiloma e fibropapiloma (neoplasia benigna).Verifica-se que as células de pele saudável e carcinoma apresentam níveis de expressão de $\beta$-catenina semelhantes. Total de 10.000 eventos analisados. Células analisadas na segunda passagem (P2). FP - fibropapiloma. 
APÊNDICE 3 - Velocidade de migração celular

1A - Pele saudável

\begin{tabular}{|c|c|c|c|c|c|c|}
\hline \multirow{2}{*}{$\begin{array}{l}\text { Time- } \\
\text { point }\end{array}$} & \multicolumn{5}{|c|}{ Velocidade em $\mu \mathrm{m} / \mathrm{min}$} & \multirow[b]{2}{*}{$\bar{x}$} \\
\hline & Célula 1 & Célula 2 & Célula 3 & Célula 4 & Célula 5 & \\
\hline 1 & 0,034 & 0,2200 & 0,172 & 0,172 & 0,138 & 0,1472 \\
\hline 2 & 0,069 & 0,2310 & 0,034 & 0,000 & 0,124 & 0,0916 \\
\hline 3 & 0,077 & 0,1380 & 0,000 & 0,175 & 0,109 & 0,0998 \\
\hline 4 & 0,109 & 0,1420 & 0,077 & 0,206 & 0,000 & 0,1068 \\
\hline 5 & 0,175 & 0,1030 & 0,103 & 0,109 & 0,175 & 0,1330 \\
\hline 6 & 0,284 & 0,1380 & 0,243 & 0,308 & 0,172 & 0,2290 \\
\hline 7 & 0,231 & 0,1720 & 0,077 & 0,284 & 0,243 & 0,2014 \\
\hline 8 & 0,077 & 0,1540 & 0,097 & 0,124 & 0,172 & 0,1248 \\
\hline 9 & 0,097 & 0,0690 & 0,049 & 0,069 & 0,000 & 0,0568 \\
\hline 10 & 0,103 & 0,1750 & 0,069 & 0,172 & 0,109 & 0,1256 \\
\hline 11 & 0,392 & 0,2180 & 0,049 & 0,069 & 0,109 & 0,1674 \\
\hline 12 & 0,069 & 0,1540 & 0,000 & 0,312 & 0,172 & 0,1414 \\
\hline 13 & 0,069 & 0,0000 & 0,034 & 0,292 & 0,103 & 0,0996 \\
\hline 14 & 0,097 & 0,0000 & 0,069 & 0,154 & 0,049 & 0,0738 \\
\hline 15 & 0,201 & 0,0690 & 0,097 & 0,103 & 0,154 & 0,1248 \\
\hline 16 & 0,231 & 0,0340 & 0,172 & 0,034 & 0,000 & 0,0942 \\
\hline 17 & 0,209 & 0,0770 & 0,103 & 0,000 & 0,146 & 0,1070 \\
\hline 18 & 0,142 & 0,0690 & 0,069 & 0,218 & 0,049 & 0,1094 \\
\hline 19 & 0,077 & 0,0000 & 0,049 & 0,209 & 0,103 & 0,0876 \\
\hline 20 & 0,097 & 0,1380 & 0,262 & 0,185 & 0,201 & 0,1766 \\
\hline 21 & 0,103 & 0,1850 & 0,138 & 0,243 & 0,138 & 0,1614 \\
\hline 22 & 0,310 & 0,0340 & 0,000 & 0,275 & 0,142 & 0,1522 \\
\hline 23 & 0,351 & 0,0000 & 0,000 & 0,069 & 0,109 & 0,1058 \\
\hline 24 & 0,185 & 0,2770 & 0,034 & 0,034 & 0,034 & 0,1128 \\
\hline 25 & 0,209 & 0,1090 & 0,000 & 0,689 & 0,103 & 0,2220 \\
\hline 26 & 0,069 & 0,2500 & 0,172 & 0,103 & 0,000 & 0,1188 \\
\hline 27 & 0,000 & 0,1750 & 0,000 & 0,097 & 0,000 & 0,0544 \\
\hline 28 & 0,172 & 0,4620 & 0,103 & 0,069 & 0,138 & 0,1888 \\
\hline 29 & 0,124 & 0,4180 & 0,077 & 0,000 & 0,069 & 0,1376 \\
\hline 30 & 0,097 & 0,2180 & 0,146 & 0,317 & 0,154 & 0,1864 \\
\hline 31 & 0,185 & 0,2180 & 0,195 & 0,103 & 0,138 & 0,1678 \\
\hline 32 & 0,154 & 0,0490 & 0,000 & 0,138 & 0,243 & 0,1168 \\
\hline 33 & 0,185 & 0,0340 & 0,449 & 0,154 & 0,392 & 0,2428 \\
\hline 34 & 0,103 & 0,1090 & 0,294 & 0,109 & 0,124 & 0,1478 \\
\hline 35 & 0,154 & 0,2180 & 0,000 & 0,172 & 0,077 & 0,1242 \\
\hline 36 & 0,250 & 0,1240 & 0,069 & 0,564 & 0,185 & 0,2384 \\
\hline 37 & 0,103 & 0,1720 & 0,124 & 0,243 & 0,000 & 0,1284 \\
\hline 38 & 0,172 & 0,0970 & 0,138 & 0,034 & 0,069 & 0,1020 \\
\hline 39 & 0,154 & 0,1240 & 0,000 & 0,138 & 0,218 & 0,1268 \\
\hline 40 & 0,000 & 0,0970 & 0,000 & 0,000 & 0,034 & 0,0262 \\
\hline 41 & 0,069 & 0,0690 & 0,109 & 0,109 & 0,124 & 0,0960 \\
\hline 42 & 0,220 & 0,0000 & 0,097 & 0,138 & 0,308 & 0,1526 \\
\hline 43 & 0,142 & 0,0000 & 0,034 & 0,000 & 0,175 & 0,0702 \\
\hline 44 & 0,000 & 0,0770 & 0,000 & 0,049 & 0,034 & 0,0320 \\
\hline
\end{tabular}




\begin{tabular}{|c|c|c|c|c|c|c|}
\hline 45 & 0,138 & 0,0970 & 0,262 & 0,172 & 0,069 & 0,1476 \\
\hline 46 & 0,250 & 0,1380 & 0,034 & 0,069 & 0,142 & 0,1266 \\
\hline 47 & 0,146 & 0,0000 & 0,069 & 0,000 & 0,441 & 0,1312 \\
\hline 48 & 0,172 & 0,0000 & 0,034 & 0,000 & 0,000 & 0,0412 \\
\hline 49 & 0,124 & 0,2010 & 0,154 & 0,077 & 0,000 & 0,1112 \\
\hline 50 & 0,000 & 0,1380 & 0,109 & 0,138 & 0,000 & 0,0770 \\
\hline 51 & 0,275 & 0,0000 & 0,109 & 0,000 & 0,034 & 0,0836 \\
\hline 52 & 0,508 & 0,0000 & 0,034 & 0,049 & 0,034 & 0,1250 \\
\hline 53 & 0,103 & 0,0000 & 0,000 & 0,103 & 0,000 & 0,0412 \\
\hline 54 & 0,069 & 0,1420 & 0,034 & 0,000 & 0,069 & 0,0628 \\
\hline 55 & 0,069 & 0,2770 & 0,000 & 0,000 & 0,000 & 0,0692 \\
\hline 56 & 0,069 & 0,1090 & 0,000 & 0,146 & 0,000 & 0,0648 \\
\hline 57 & 0,248 & 0,1750 & 0,077 & 0,206 & 0,000 & 0,1412 \\
\hline 58 & 0,077 & 0,1240 & 0,000 & 0,000 & 0,138 & 0,0678 \\
\hline 59 & 0,109 & 0,0770 & 0,034 & 0,000 & 0,175 & 0,0790 \\
\hline 60 & 0,077 & 0,2180 & 0,069 & 0,326 & 0,138 & 0,1656 \\
\hline 61 & 0,154 & 0,2750 & 0,277 & 0,154 & 0,034 & 0,1788 \\
\hline 62 & 0,172 & 0,2940 & 0,109 & 0,209 & 0,000 & 0,1568 \\
\hline 63 & 0,262 & 0,3170 & 0,109 & 0,077 & 0,209 & 0,1948 \\
\hline 64 & 0,201 & 0,2010 & 0,000 & 0,308 & 0,049 & 0,1518 \\
\hline 65 & 0,077 & 0,2480 & 0,097 & 0,124 & 0,000 & 0,1092 \\
\hline 66 & 0,218 & 0,1420 & 0,049 & 0,000 & 0,209 & 0,1236 \\
\hline 67 & 0,154 & 0,1090 & 0,049 & 0,109 & 0,034 & 0,0910 \\
\hline 68 & 0,034 & 0,2090 & 0,000 & 0,077 & 0,034 & 0,0708 \\
\hline 69 & 0,175 & 0,0770 & 0,097 & 0,034 & 0,049 & 0,0864 \\
\hline 70 & 0,069 & 0,2690 & 0,097 & 0,109 & 0,000 & 0,1088 \\
\hline 71 & 0,392 & 0,3170 & 0,185 & 0,034 & 0,312 & 0,2480 \\
\hline 72 & 0,172 & 0,1950 & 0,154 & 0,034 & 0,049 & 0,1208 \\
\hline 73 & 0,175 & 0,2480 & 0,034 & 0,000 & 0,201 & 0,1316 \\
\hline 74 & 0,218 & 0,3510 & 0,241 & 0,172 & 0,077 & 0,2118 \\
\hline 75 & 0,077 & 0,1460 & 0,248 & 0,172 & 0,284 & 0,1854 \\
\hline 76 & 0,185 & 0,0000 & 0,077 & 0,185 & 0,310 & 0,1514 \\
\hline 77 & 0,097 & 0,3390 & 0,172 & 0,000 & 0,277 & 0,1770 \\
\hline 78 & 0,124 & 0,3100 & 0,109 & 0,220 & 0,077 & 0,1680 \\
\hline 79 & 0,049 & 0,2410 & 0,000 & 0,172 & 0,201 & 0,1326 \\
\hline 80 & 0,142 & 0,0034 & 0,000 & 0,077 & 0,142 & 0,0728 \\
\hline $\bar{x}$ & 0,14915 & 0,14756 & 0,08909 & 0,13244 & 0,11405 & 0,126456 \\
\hline$\sigma$ & 0,09345 & 0,10708 & 0,08714 & 0,1226 & 0,09868 & 0,050200 \\
\hline
\end{tabular}




\begin{tabular}{|c|c|c|c|c|c|c|}
\hline \multirow{2}{*}{$\begin{array}{l}\text { Time- } \\
\text { point }\end{array}$} & \multicolumn{5}{|c|}{ Velocidade em $\mu \mathrm{m} / \mathrm{min}$} & \multirow[b]{2}{*}{$\bar{x}$} \\
\hline & Célula 1 & Célula 2 & Célula 3 & Célula 4 & Célula 5 & \\
\hline 1 & 0,171 & 0,058 & 0,090 & 0,000 & 0,000 & 0,0638 \\
\hline 2 & 0,300 & 0,000 & 0,086 & 0,090 & 0,000 & 0,0952 \\
\hline 3 & 0,220 & 0,158 & 0,077 & 0,082 & 0,165 & 0,1404 \\
\hline 4 & 0,086 & 0,079 & 0,026 & 0,090 & 0,198 & 0,0958 \\
\hline 5 & 0,163 & 0,000 & 0,116 & 0,000 & 0,103 & 0,0764 \\
\hline 6 & 0,191 & 0,000 & 0,000 & 0,195 & 0,242 & 0,1256 \\
\hline 7 & 0,301 & 0,093 & 0,000 & 0,000 & 0,000 & 0,0788 \\
\hline 8 & 0,293 & 0,138 & 0,115 & 0,000 & 0,036 & 0,1164 \\
\hline 9 & 0,301 & 0,026 & 0,058 & 0,221 & 0,036 & 0,1284 \\
\hline 10 & 0,000 & 0,026 & 0,036 & 0,026 & 0,000 & 0,0176 \\
\hline 11 & 0,177 & 0,163 & 0,214 & 0,328 & 0,115 & 0,1994 \\
\hline 12 & 0,077 & 0,138 & 0,141 & 0,036 & 0,103 & 0,0990 \\
\hline 13 & 0,112 & 0,086 & 0,077 & 0,136 & 0,093 & 0,1008 \\
\hline 14 & 0,000 & 0,155 & 0,000 & 0,000 & 0,058 & 0,0426 \\
\hline 15 & 0,138 & 0,229 & 0,500 & 0,158 & 0,058 & 0,2166 \\
\hline 16 & 0,191 & 0,090 & 0,214 & 0,191 & 0,000 & 0,1372 \\
\hline 17 & 0,196 & 0,073 & 0,165 & 0,026 & 0,204 & 0,1328 \\
\hline 18 & 0,305 & 0,195 & 0,138 & 0,093 & 0,065 & 0,1592 \\
\hline 19 & 0,484 & 0,052 & 0,026 & 0,174 & 0,026 & 0,1524 \\
\hline 20 & 0,090 & 0,065 & 0,528 & 0,214 & 0,000 & 0,1794 \\
\hline 21 & 0,163 & 0,181 & 0,361 & 0,122 & 0,298 & 0,2250 \\
\hline 22 & 0,122 & 0,060 & 0,305 & 0,000 & 0,112 & 0,1198 \\
\hline 23 & 0,172 & 0,052 & 0,000 & 0,129 & 0,115 & 0,0936 \\
\hline 24 & 0,268 & 0,215 & 0,229 & 0,065 & 0,086 & 0,1726 \\
\hline 25 & 0,127 & 0,086 & 0,174 & 0,052 & 0,163 & 0,1204 \\
\hline 26 & 0,052 & 0,431 & 0,060 & 0,026 & 0,026 & 0,1190 \\
\hline 27 & 0,177 & 0,000 & 0,052 & 0,043 & 0,036 & 0,0616 \\
\hline 28 & 0,191 & 0,351 & 0,331 & 0,079 & 0,036 & 0,1976 \\
\hline 29 & 0,000 & 0,000 & 0,082 & 0,058 & 0,090 & 0,0460 \\
\hline 30 & 0,140 & 0,162 & 0,147 & 0,026 & 0,163 & 0,1276 \\
\hline 31 & 0,298 & 0,215 & 0,073 & 0,195 & 0,165 & 0,1892 \\
\hline 32 & 0,136 & 0,112 & 0,069 & 0,077 & 0,026 & 0,0840 \\
\hline 33 & 0,195 & 0,077 & 0,000 & 0,138 & 0,077 & 0,0974 \\
\hline 34 & 0,105 & 0,123 & 0,129 & 0,052 & 0,115 & 0,1048 \\
\hline 35 & 0,000 & 0,109 & 0,311 & 0,286 & 0,119 & 0,1650 \\
\hline 36 & 0,150 & 0,204 & 0,086 & 0,112 & 0,034 & 0,1172 \\
\hline 37 & 0,060 & 0,000 & 0,103 & 0,000 & 0,026 & 0,0378 \\
\hline 38 & 1,681 & 0,077 & 0,171 & 0,052 & 0,150 & 0,4262 \\
\hline 39 & 0,249 & 0,034 & 0,329 & 0,286 & 0,069 & 0,1934 \\
\hline 40 & 0,077 & 0,129 & 0,212 & 0,375 & 0,158 & 0,1902 \\
\hline 41 & 0,073 & 0,000 & 0,327 & 0,000 & 0,191 & 0,1182 \\
\hline 42 & 0,760 & 0,115 & 0,163 & 0,000 & 0,138 & 0,2352 \\
\hline 43 & 0,000 & 0,036 & 0,093 & 0,129 & 0,090 & 0,0696 \\
\hline 44 & 0,276 & 0,105 & 0,158 & 0,485 & 0,000 & 0,2048 \\
\hline 45 & 0,112 & 0,036 & 0,163 & 0,100 & 0,086 & 0,0994 \\
\hline 46 & 0,218 & 0,191 & 0,216 & 0,313 & 0,163 & 0,2202 \\
\hline 47 & 0,301 & 0,079 & 0,378 & 0,123 & 0,383 & 0,2528 \\
\hline
\end{tabular}




\begin{tabular}{rrrrrrr}
\hline $\mathbf{4 8}$ & 0,060 & 0,165 & 0,163 & 0,000 & 0,086 & 0,0948 \\
$\mathbf{4 9}$ & 0,000 & 0,115 & 0,301 & 1,423 & 0,077 & 0,3832 \\
$\mathbf{5 0}$ & 0,286 & 0,026 & 0,478 & 0,115 & 0,052 & 0,1914 \\
$\mathbf{5 1}$ & 0,090 & 0,378 & 0,500 & 0,026 & 0,093 & 0,2174 \\
$\mathbf{5 2}$ & 0,117 & 0,026 & 0,079 & 0,224 & 0,036 & 0,0964 \\
$\mathbf{5 3}$ & 0,336 & 0,060 & 0,208 & 0,658 & 0,052 & 0,2628 \\
$\mathbf{5 4}$ & 0,000 & 0,026 & 0,127 & 0,378 & 0,060 & 0,1182 \\
$\mathbf{5 5}$ & 0,026 & 0,476 & 0,192 & 0,215 & 0,093 & 0,2004 \\
$\mathbf{5 6}$ & 0,189 & 0,000 & 0,139 & 0,327 & 0,115 & 0,1540 \\
$\mathbf{5 7}$ & 0,378 & 0,060 & 0,085 & 0,115 & 0,036 & 0,1348 \\
$\mathbf{5 8}$ & 0,198 & 0,103 & 0,185 & 0,000 & 0,185 & 0,1342 \\
$\mathbf{5 9}$ & 0,062 & 0,000 & 0,000 & 0,026 & 0,105 & 0,0386 \\
$\mathbf{6 0}$ & 0,163 & 0,181 & 0,106 & 0,077 & 0,026 & 0,1106 \\
$\mathbf{6 1}$ & 0,000 & 0,225 & 0,140 & 0,244 & 0,163 & 0,1544 \\
$\mathbf{6 2}$ & 0,277 & 0,119 & 0,026 & 0,240 & 0,103 & 0,1530 \\
$\mathbf{6 3}$ & 0,000 & 0,000 & 0,026 & 0,403 & 0,112 & 0,1082 \\
$\mathbf{6 4}$ & 0,058 & 0,000 & 0,034 & 0,204 & 0,093 & 0,0778 \\
$\mathbf{6 5}$ & 0,052 & 0,298 & 0,109 & 0,000 & 0,163 & 0,1244 \\
$\mathbf{6 6}$ & 0,122 & 0,165 & 0,468 & 0,196 & 0,086 & 0,2074 \\
$\mathbf{6 7}$ & 0,000 & 0,112 & 0,286 & 0,085 & 0,142 & 0,1250 \\
$\mathbf{6 8}$ & 0,036 & 0,086 & 0,026 & 0,405 & 0,270 & 0,1646 \\
$\mathbf{6 9}$ & 0,082 & 0,000 & 0,199 & 0,307 & 0,405 & 0,1986 \\
$\mathbf{7 0}$ & 0,069 & 0,026 & 0,331 & 0,106 & 0,100 & 0,1264 \\
$\mathbf{7 1}$ & 0,036 & 1,215 & 0,152 & 0,198 & 0,136 & 0,3474 \\
$\mathbf{7 2}$ & 0,000 & 0,217 & 0,165 & 0,214 & 0,370 & 0,1932 \\
$\mathbf{7 3}$ & 0,026 & 0,000 & 0,171 & 0,268 & 0,090 & 0,1110 \\
$\mathbf{7 4}$ & 0,112 & 0,115 & 0,105 & 0,426 & 0,036 & 0,1588 \\
$\mathbf{7 5}$ & 0,103 & 0,198 & 0,115 & 0,000 & 0,026 & 0,0884 \\
$\mathbf{7 6}$ & 0,034 & 0,277 & 0,112 & 0,250 & 0,000 & 0,1346 \\
$\mathbf{7 7}$ & 0,052 & 0,060 & 0,843 & 0,026 & 0,136 & 0,2234 \\
$\mathbf{7 8}$ & 0,433 & 0,272 & 0,000 & 0,382 & 0,052 & 0,2278 \\
$\mathbf{7 9}$ & 0,060 & 0,034 & 0,365 & 0,223 & 0,000 & 0,1364 \\
$\mathbf{8 0}$ & 0,000 & 0,880 & 0,026 & 0,026 & 0,112 & 0,2088 \\
\hline$\overline{\boldsymbol{X}}$ & $\mathbf{0 , 1 6 6 9 5}$ & $\mathbf{0 , 1 3 6 4 9}$ & $\mathbf{0 , 1 6 9 8 9}$ & $\mathbf{0 , 1 6 4 6 3 0}$ & $\mathbf{0 , 1 0 2 8 5 0}$ & $\mathbf{0 , 1 4 8 1 6}$ \\
$\mathbf{\sigma}$ & $\mathbf{0 , 2 1 6 0 9}$ & $\mathbf{0 , 1 8 0 9 0}$ & $\mathbf{0 , 1 5 1 4 0}$ & $\mathbf{0 , 0 1 9 8 0 9}$ & $\mathbf{0 , 0 8 5 9 6 0}$ & $\mathbf{0 , 0 7 2 5 2}$ \\
\hline$\overline{\boldsymbol{x}} \mathbf{\text { média }}, \boldsymbol{\sigma}-$ desvio padrão & & & & & \\
& & & & & &
\end{tabular}


1C - Papiloma 02

\begin{tabular}{|c|c|c|c|c|c|c|}
\hline \multirow{2}{*}{$\begin{array}{l}\text { Time- } \\
\text { point }\end{array}$} & \multicolumn{5}{|c|}{ Velocidade em $\mu \mathrm{m} / \mathrm{min}$} & \multirow[b]{2}{*}{$\bar{x}$} \\
\hline & Célula 1 & Célula 2 & Célula 3 & Célula 4 & Célula 5 & \\
\hline 1 & 0,317 & 0,034 & 0,058 & 0,000 & 0,000 & 0,0818 \\
\hline 2 & 0,209 & 0,172 & 0,049 & 0,000 & 0,000 & 0,0860 \\
\hline 3 & 0,097 & 0,103 & 0,331 & 0,000 & 0,163 & 0,1388 \\
\hline 4 & 0,034 & 0,109 & 0,199 & 0,181 & 0,000 & 0,1046 \\
\hline 5 & 0,077 & 0,034 & 0,043 & 0,214 & 0,000 & 0,0736 \\
\hline 6 & 0,077 & 0,034 & 0,150 & 0,000 & 0,000 & 0,0522 \\
\hline 7 & 0,000 & 0,172 & 0,000 & 0,026 & 0,034 & 0,0464 \\
\hline 8 & 0,154 & 0,034 & 0,026 & 0,060 & 0,036 & 0,0620 \\
\hline 9 & 0,049 & 0,069 & 0,106 & 0,442 & 0,000 & 0,1332 \\
\hline 10 & 0,109 & 0,000 & 0,065 & 0,000 & 0,000 & 0,0348 \\
\hline 11 & 0,577 & 0,000 & 0,085 & 0,000 & 0,163 & 0,1650 \\
\hline 12 & 0,077 & 0,000 & 0,224 & 0,026 & 0,123 & 0,0900 \\
\hline 13 & 0,312 & 0,142 & 0,103 & 0,226 & 0,093 & 0,1752 \\
\hline 14 & 0,175 & 0,138 & 0,026 & 0,026 & 0,086 & 0,0902 \\
\hline 15 & 0,097 & 0,034 & 0,060 & 0,163 & 0,000 & 0,0708 \\
\hline 16 & 0,000 & 0,069 & 0,058 & 0,223 & 0,082 & 0,0864 \\
\hline 17 & 0,069 & 0,034 & 0,191 & 0,052 & 0,127 & 0,0946 \\
\hline 18 & 0,000 & 0,103 & 0,150 & 0,000 & 0,026 & 0,0558 \\
\hline 19 & 0,284 & 0,103 & 0,136 & 0,112 & 0,026 & 0,1322 \\
\hline 20 & 0,142 & 0,069 & 0,082 & 0,000 & 0,09 & 0,0766 \\
\hline 21 & 0,069 & 0,034 & 0,086 & 0,000 & 0,073 & 0,0524 \\
\hline 22 & 0,034 & 0,034 & 0,077 & 0,215 & 0,000 & 0,0720 \\
\hline 23 & 0,392 & 0,231 & 0,140 & 0,177 & 0,062 & 0,2004 \\
\hline 24 & 0,602 & 0,195 & 0,000 & 0,058 & 0,147 & 0,2004 \\
\hline 25 & 0,195 & 0,034 & 0,123 & 0,073 & 0,026 & 0,0902 \\
\hline 26 & 0,241 & 0,077 & 0,255 & 0,185 & 0,000 & 0,1516 \\
\hline 27 & 0,109 & 0,359 & 0,193 & 0,237 & 0,026 & 0,1848 \\
\hline 28 & 0,000 & 0,524 & 0,221 & 0,134 & 0,034 & 0,1826 \\
\hline 29 & 0,000 & 0,209 & 0,171 & 0,000 & 0,155 & 0,1070 \\
\hline 30 & 0,034 & 0,000 & 0,077 & 0,036 & 0,000 & 0,0294 \\
\hline 31 & 0,000 & 0,142 & 0,026 & 0,265 & 0,026 & 0,0918 \\
\hline 32 & 0,069 & 0,206 & 0,086 & 0,225 & 0,000 & 0,1172 \\
\hline 33 & 0,325 & 0,142 & 0,167 & 0,000 & 0,052 & 0,1372 \\
\hline 34 & 0,172 & 0,000 & 0,361 & 0,298 & 0,000 & 0,1662 \\
\hline 35 & 0,069 & 0,069 & 0,217 & 0,389 & 0,026 & 0,1540 \\
\hline 36 & 0,000 & 0,109 & 0,109 & 0,077 & 0,162 & 0,0914 \\
\hline 37 & 0,262 & 0,142 & 0,134 & 0,177 & 0,000 & 0,1430 \\
\hline 38 & 0,172 & 0,000 & 0,528 & 0,163 & 0,000 & 0,1726 \\
\hline 39 & 0,069 & 0,069 & 0,147 & 0,277 & 0,177 & 0,1478 \\
\hline 40 & 0,000 & 0,124 & 0,174 & 0,026 & 0,000 & 0,0648 \\
\hline 41 & 0,185 & 0,138 & 0,000 & 0,158 & 0,026 & 0,1014 \\
\hline 42 & 0,109 & 0,138 & 0,196 & 0,171 & 0,036 & 0,1300 \\
\hline 43 & 0,077 & 0,248 & 0,318 & 0,026 & 0,060 & 0,1458 \\
\hline 44 & 0,185 & 0,000 & 0,242 & 0,052 & 0,036 & 0,1030 \\
\hline 45 & 0,284 & 0,000 & 0,036 & 0,093 & 0,000 & 0,0826 \\
\hline 46 & 0,069 & 0,034 & 0,115 & 0,090 & 0,058 & 0,0732 \\
\hline 47 & 0,069 & 0,069 & 0,199 & 0,123 & 0,000 & 0,0920 \\
\hline
\end{tabular}




\begin{tabular}{|c|c|c|c|c|c|c|}
\hline 48 & 0,241 & 0,069 & 0,246 & 0,026 & 0,090 & 0,1344 \\
\hline 49 & 0,000 & 0,109 & 0,079 & 0,090 & 0,098 & 0,0752 \\
\hline 50 & 0,138 & 0,034 & 0,177 & 0,026 & 0,052 & 0,0854 \\
\hline 51 & 0,069 & 0,049 & 0,280 & 0,454 & 0,000 & 0,1704 \\
\hline 52 & 0,000 & 0,069 & 0,060 & 0,139 & 0,062 & 0,0660 \\
\hline 53 & 0,351 & 0,034 & 0,123 & 0,171 & 0,082 & 0,1522 \\
\hline 54 & 0,138 & 0,049 & 0,100 & 0,036 & 0,036 & 0,0718 \\
\hline 55 & 0,000 & 0,049 & 0,077 & 0,251 & 0,026 & 0,0806 \\
\hline 56 & 0,103 & 0,109 & 0,052 & 0,065 & 0,060 & 0,0778 \\
\hline 57 & 0,049 & 0,000 & 0,115 & 0,232 & 0,000 & 0,0792 \\
\hline 58 & 0,269 & 0,000 & 0,115 & 0,280 & 0,301 & 0,1930 \\
\hline 59 & 0,262 & 0,573 & 0,000 & 0,243 & 0,065 & 0,2286 \\
\hline 60 & 0,034 & 0,146 & 0,085 & 0,189 & 0,052 & 0,1012 \\
\hline 61 & 0,209 & 0,069 & 0,115 & 0,216 & 0,026 & 0,1270 \\
\hline 62 & 0,000 & 0,172 & 0,026 & 0,395 & 0,192 & 0,1570 \\
\hline 63 & 0,250 & 0,034 & 0,052 & 0,286 & 0,060 & 0,1364 \\
\hline 64 & 0,000 & 0,758 & 0,117 & 0,000 & 0,036 & 0,1822 \\
\hline 65 & 0,034 & 0,195 & 0,052 & 0,189 & 0,382 & 0,1704 \\
\hline 66 & 0,034 & 0,516 & 0,106 & 0,036 & 0,000 & 0,1384 \\
\hline 67 & 0,124 & 0,138 & 0,138 & 0,000 & 0,026 & 0,0852 \\
\hline 68 & 0,069 & 0,049 & 0,171 & 0,000 & 0,065 & 0,0708 \\
\hline 69 & 0,175 & 0,103 & 0,478 & 0,275 & 0,026 & 0,2114 \\
\hline 70 & 0,034 & 0,760 & 0,073 & 0,138 & 0,036 & 0,2082 \\
\hline 71 & 0,248 & 0,154 & 0,026 & 0,500 & 0,052 & 0,1960 \\
\hline 72 & 0,462 & 0,069 & 0,082 & 0,199 & 0,103 & 0,1830 \\
\hline 73 & 0,310 & 0,818 & 0,065 & 0,328 & 0,086 & 0,3214 \\
\hline 74 & 0,069 & 0,124 & 0,103 & 0,163 & 0,115 & 0,1148 \\
\hline 75 & 0,103 & 0,154 & 0,115 & 0,000 & 0,000 & 0,0744 \\
\hline 76 & 0,172 & 0,000 & 0,127 & 0,115 & 0,481 & 0,1790 \\
\hline 77 & 0,209 & 0,154 & 0,286 & 0,052 & 0,134 & 0,1670 \\
\hline 78 & 0,195 & 0,38 & 0,026 & 0,174 & 0,026 & 0,1602 \\
\hline 79 & 0,034 & 0,142 & 0,026 & 0,000 & 0,198 & 0,0800 \\
\hline 80 & 0,109 & 0,069 & 0,289 & 0,174 & 0,000 & 0,1282 \\
\hline $\bar{x}$ & 0,13928 & 0,13660 & 0,13153 & 0,13647 & 0,06499 & 0,12177 \\
\hline$\sigma$ & 0,13026 & 0,17099 & 0,10212 & 0,10212 & 0,08441 & 0,52210 \\
\hline
\end{tabular}


1D - Papiloma 03

\begin{tabular}{|c|c|c|c|c|c|c|}
\hline \multirow{2}{*}{$\begin{array}{l}\text { Time- } \\
\text { point }\end{array}$} & \multicolumn{5}{|c|}{ Velocidade em $\mu \mathrm{m} / \mathrm{min}$} & \multirow[b]{2}{*}{$\bar{x}$} \\
\hline & Célula 1 & Célula 2 & Célula 3 & Célula 4 & Célula 5 & \\
\hline 1 & 0,103 & 0,220 & 0,000 & 0,026 & 0,172 & 0,1042 \\
\hline 2 & 0,103 & 0,218 & 0,000 & 0,217 & 0,100 & 0,1276 \\
\hline 3 & 0,206 & 0,195 & 0,077 & 0,090 & 0,115 & 0,1366 \\
\hline 4 & 0,034 & 0,000 & 0,077 & 0,140 & 0,255 & 0,1012 \\
\hline 5 & 0,146 & 0,000 & 0,185 & 0,286 & 0,216 & 0,1666 \\
\hline 6 & 0,000 & 0,662 & 0,000 & 0,155 & 0,129 & 0,1892 \\
\hline 7 & 0,109 & 0,154 & 0,172 & 0,251 & 0,163 & 0,1698 \\
\hline 8 & 0,124 & 0,206 & 0,103 & 0,136 & 0,098 & 0,1334 \\
\hline 9 & 0,109 & 0,124 & 0,069 & 0,427 & 0,077 & 0,1612 \\
\hline 10 & 0,000 & 0,034 & 0,103 & 0,177 & 0,217 & 0,1062 \\
\hline 11 & 0,103 & 0,077 & 0,142 & 0,085 & 0,366 & 0,1546 \\
\hline 12 & 0,172 & 0,034 & 0,049 & 0,093 & 0,093 & 0,0882 \\
\hline 13 & 0,103 & 0,138 & 0,248 & 0,082 & 0,158 & 0,1458 \\
\hline 14 & 0,077 & 0,124 & 0,077 & 0,465 & 0,138 & 0,1762 \\
\hline 15 & 0,124 & 0,269 & 0,077 & 0,140 & 0,103 & 0,1426 \\
\hline 16 & 0,077 & 0,438 & 0,077 & 0,181 & 0,229 & 0,2004 \\
\hline 17 & 0,124 & 0,185 & 0,069 & 0,668 & 0,391 & 0,2874 \\
\hline 18 & 0,142 & 0,109 & 0,231 & 0,185 & 0,112 & 0,1558 \\
\hline 19 & 0,185 & 0,138 & 0,109 & 0,000 & 0,198 & 0,1260 \\
\hline 20 & 0,146 & 0,097 & 0,206 & 0,273 & 0,093 & 0,1630 \\
\hline 21 & 0,069 & 0,172 & 0,103 & 0,000 & 0,165 & 0,1018 \\
\hline 22 & 0,172 & 0,185 & 0,049 & 0,171 & 0,526 & 0,2206 \\
\hline 23 & 0,344 & 1,132 & 0,077 & 0,115 & 0,303 & 0,3942 \\
\hline 24 & 0,231 & 0,124 & 0,000 & 0,329 & 0,000 & 0,1368 \\
\hline 25 & 0,154 & 0,077 & 0,138 & 0,193 & 0,103 & 0,1330 \\
\hline 26 & 0,146 & 0,185 & 0,000 & 0,385 & 0,275 & 0,1982 \\
\hline 27 & 0,069 & 0,124 & 0,034 & 0,335 & 0,225 & 0,1574 \\
\hline 28 & 0,220 & 0,296 & 0,201 & 0,655 & 0,191 & 0,3126 \\
\hline 29 & 0,154 & 0,142 & 0,138 & 0,242 & 0,243 & 0,1838 \\
\hline 30 & 0,154 & 0,154 & 0,069 & 0,158 & 0,199 & 0,1468 \\
\hline 31 & 0,218 & 0,317 & 0,000 & 0,079 & 0,000 & 0,1228 \\
\hline 32 & 0,172 & 0,000 & 0,069 & 0,252 & 0,000 & 0,0986 \\
\hline 33 & 0,248 & 0,000 & 0,103 & 0,119 & 0,312 & 0,1564 \\
\hline 34 & 0,069 & 0,000 & 0,262 & 0,389 & 0,115 & 0,1670 \\
\hline 35 & 0,077 & 0,000 & 0,109 & 0,215 & 0,471 & 0,1744 \\
\hline 36 & 0,034 & 0,000 & 0,201 & 0,276 & 0,255 & 0,1532 \\
\hline 37 & 0,103 & 0,034 & 0,277 & 0,140 & 0,158 & 0,1424 \\
\hline 38 & 0,486 & 0,154 & 0,185 & 0,591 & 0,163 & 0,3158 \\
\hline 39 & 0,154 & 0,034 & 0,243 & 0,165 & 0,217 & 0,1626 \\
\hline 40 & 0,109 & 0,034 & 0,248 & 0,165 & 0,518 & 0,2148 \\
\hline 41 & 0,231 & 0,049 & 0,231 & 0,388 & 0,138 & 0,2074 \\
\hline 42 & 0,218 & 0,000 & 0,206 & 0,163 & 0,267 & 0,1708 \\
\hline 43 & 0,154 & 0,220 & 0,146 & 0,527 & 0,227 & 0,2548 \\
\hline 44 & 0,077 & 0,277 & 0,109 & 0,058 & 0,278 & 0,1598 \\
\hline 45 & 0,346 & 0,185 & 0,069 & 0,676 & 0,162 & 0,2876 \\
\hline 46 & 0,294 & 0,109 & 0,124 & 0,026 & 0,077 & 0,1260 \\
\hline 47 & 0,138 & 0,000 & 0,138 & 0,112 & 0,191 & 0,1158 \\
\hline
\end{tabular}




\begin{tabular}{|c|c|c|c|c|c|c|}
\hline 48 & 0,142 & 0,000 & 0,109 & 0,115 & 0,636 & 0,2004 \\
\hline 49 & 0,069 & 0,000 & 0,172 & 0,090 & 0,204 & 0,1070 \\
\hline 50 & 0,109 & 0,034 & 0,109 & 0,306 & 0,000 & 0,1116 \\
\hline 51 & 0,103 & 1,647 & 0,154 & 0,217 & 0,163 & 0,4568 \\
\hline 52 & 0,447 & 0,241 & 0,172 & 0,138 & 0,231 & 0,2458 \\
\hline 53 & 0,034 & 0,146 & 0,069 & 0,214 & 0,189 & 0,1304 \\
\hline 54 & 0,138 & 0,077 & 0,077 & 0,093 & 0,496 & 0,1762 \\
\hline 55 & 0,034 & 0,154 & 0,124 & 0,215 & 0,342 & 0,1738 \\
\hline 56 & 0,154 & 0,034 & 0,069 & 0,077 & 0,196 & 0,1060 \\
\hline 57 & 0,000 & 0,142 & 0,034 & 0,026 & 0,356 & 0,1116 \\
\hline 58 & 0,220 & 0,069 & 0,034 & 0,251 & 0,162 & 0,1472 \\
\hline 59 & 0,206 & 0,077 & 0,154 & 0,331 & 0,165 & 0,1866 \\
\hline 60 & 0,124 & 0,138 & 0,000 & 0,112 & 0,256 & 0,1260 \\
\hline 61 & 0,000 & 0,069 & 0,034 & 0,077 & 0,223 & 0,0806 \\
\hline 62 & 0,034 & 0,209 & 0,124 & 0,098 & 0,115 & 0,1160 \\
\hline 63 & 0,000 & 0,154 & 0,142 & 0,450 & 0,106 & 0,1704 \\
\hline 64 & 0,124 & 0,209 & 0,209 & 0,331 & 0,297 & 0,2340 \\
\hline 65 & 0,124 & 0,124 & 0,000 & 0,026 & 0,14 & 0,0828 \\
\hline 66 & 0,069 & 0,034 & 0,000 & 0,229 & 0,22 & 0,1104 \\
\hline 67 & 1,481 & 0,138 & 0,124 & 0,140 & 0,123 & 0,4012 \\
\hline 68 & 0,262 & 0,000 & 0,034 & 0,365 & 0,323 & 0,1968 \\
\hline 69 & 0,185 & 0,138 & 0,000 & 0,162 & 0,297 & 0,1564 \\
\hline 70 & 0,154 & 0,034 & 0,138 & 0,052 & 0,276 & 0,1308 \\
\hline 71 & 0,146 & 0,049 & 0,142 & 0,936 & 0,519 & 0,3584 \\
\hline 72 & 0,077 & 0,000 & 0,103 & 0,103 & 0,458 & 0,1482 \\
\hline 73 & 0,069 & 0,731 & 0,138 & 0,000 & 0,396 & 0,2668 \\
\hline 74 & 0,049 & 0,138 & 0,431 & 0,136 & 0,208 & 0,1924 \\
\hline 75 & 0,034 & 0,000 & 0,296 & 0,000 & 0,058 & 0,0776 \\
\hline 76 & 0,034 & 0,049 & 0,077 & 0,112 & 0,248 & 0,1040 \\
\hline 77 & 0,172 & 0,588 & 0,109 & 0,277 & 0,191 & 0,2674 \\
\hline 78 & 0,138 & 0,034 & 0,097 & 0,165 & 0,026 & 0,0920 \\
\hline 79 & 0,034 & 0,754 & 0,142 & 0,378 & 0,404 & 0,3424 \\
\hline 80 & 0,049 & 0,426 & 0,366 & 0,214 & 0,122 & 0,2354 \\
\hline$\overline{\bar{x}}$ & 0,15054 & 0,17579 & 0,11979 & 0,21796 & 0,21685 & 0,17619 \\
\hline$\sigma$ & 0,17667 & 0,25439 & 0,08652 & 0,17570 & 0,13187 & 0,07793 \\
\hline
\end{tabular}


1E - Carcinoma de esôfago

\begin{tabular}{|c|c|c|c|c|c|c|}
\hline \multirow{2}{*}{$\begin{array}{l}\text { Time- } \\
\text { point }\end{array}$} & \multicolumn{5}{|c|}{ Velocidade em $\mu \mathrm{m} / \mathrm{min}$} & \multirow[b]{2}{*}{$\bar{x}$} \\
\hline & Célula 1 & Célula 2 & Célula 3 & Célula 4 & Célula 5 & \\
\hline 1 & 0,109 & 0,077 & 0,103 & 0,109 & 0,296 & 0,1388 \\
\hline 2 & 0,175 & 0,077 & 0,142 & 0,034 & 0,243 & 0,1342 \\
\hline 3 & 0,049 & 0,220 & 0,034 & 0,220 & 0,294 & 0,1634 \\
\hline 4 & 0,209 & 0,344 & 0,218 & 0,103 & 0,175 & 0,2098 \\
\hline 5 & 0,310 & 0,109 & 0,069 & 0,172 & 0,103 & 0,1526 \\
\hline 6 & 0,555 & 0,640 & 0,142 & 0,175 & 0,250 & 0,3524 \\
\hline 7 & 0,201 & 0,077 & 0,000 & 0,034 & 0,308 & 0,1240 \\
\hline 8 & 0,077 & 0,201 & 0,142 & 0,172 & 0,284 & 0,1752 \\
\hline 9 & 0,154 & 0,172 & 0,034 & 0,312 & 0,220 & 0,1784 \\
\hline 10 & 0,069 & 0,069 & 0,077 & 0,220 & 0,142 & 0,1154 \\
\hline 11 & 0,138 & 0,172 & 0,172 & 0,269 & 0,142 & 0,1786 \\
\hline 12 & 0,296 & 0,097 & 0,077 & 0,097 & 0,097 & 0,1328 \\
\hline 13 & 0,493 & 0,138 & 0,109 & 0,294 & 0,077 & 0,2222 \\
\hline 14 & 0,385 & 0,103 & 0,000 & 0,154 & 0,077 & 0,1438 \\
\hline 15 & 0,218 & 0,103 & 0,154 & 0,209 & 0,209 & 0,1786 \\
\hline 16 & 0,317 & 0,146 & 0,146 & 0,185 & 0,185 & 0,1958 \\
\hline 17 & 0,317 & 0,243 & 0,142 & 0,000 & 0,185 & 0,1774 \\
\hline 18 & 0,154 & 0,034 & 0,172 & 0,308 & 0,142 & 0,1620 \\
\hline 19 & 0,209 & 0,077 & 0,077 & 0,508 & 0,138 & 0,2018 \\
\hline 20 & 0,172 & 0,049 & 0,142 & 0,612 & 0,241 & 0,2432 \\
\hline 21 & 0,172 & 0,138 & 0,097 & 1,067 & 0,206 & 0,336 \\
\hline 22 & 0,218 & 0,231 & 0,049 & 0,109 & 0,172 & 0,1558 \\
\hline 23 & 0,175 & 0,354 & 0,103 & 0,175 & 0,049 & 0,1712 \\
\hline 24 & 0,142 & 0,069 & 0,000 & 0,000 & 0,077 & 0,0576 \\
\hline 25 & 0,262 & 0,109 & 0,000 & 0,209 & 0,241 & 0,1642 \\
\hline 26 & 0,296 & 0,172 & 0,103 & 0,034 & 0,378 & 0,1966 \\
\hline 27 & 0,250 & 0,142 & 0,138 & 0,034 & 0,284 & 0,1696 \\
\hline 28 & 0,420 & 0,000 & 0,000 & 0,175 & 0,544 & 0,2278 \\
\hline 29 & 0,370 & 0,069 & 0,109 & 0,077 & 0,243 & 0,1736 \\
\hline 30 & 0,441 & 0,172 & 0,138 & 0,175 & 0,069 & 0,1990 \\
\hline 31 & 0,142 & 1,031 & 0,000 & 0,172 & 0,243 & 0,3176 \\
\hline 32 & 0,441 & 0,764 & 0,069 & 0,034 & 0,317 & 0,3250 \\
\hline 33 & 0,308 & 0,175 & 0,077 & 0,269 & 0,903 & 0,3464 \\
\hline 34 & 0,175 & 0,201 & 0,049 & 0,000 & 0,154 & 0,1158 \\
\hline 35 & 0,175 & 0,277 & 0,172 & 0,077 & 0,248 & 0,1898 \\
\hline 36 & 0,220 & 0,664 & 0,185 & 0,175 & 0,248 & 0,2984 \\
\hline 37 & 0,175 & 0,206 & 0,034 & 0,034 & 0,462 & 0,1822 \\
\hline 38 & 0,248 & 0,069 & 0,175 & 0,000 & 0,284 & 0,1552 \\
\hline 39 & 0,262 & 0,109 & 0,000 & 0,175 & 0,277 & 0,1646 \\
\hline 40 & 0,241 & 0,077 & 0,103 & 0,077 & 0,069 & 0,1134 \\
\hline 41 & 0,284 & 0,138 & 0,077 & 0,000 & 0,206 & 0,1410 \\
\hline 42 & 0,185 & 0,097 & 0,077 & 0,077 & 1,828 & 0,4528 \\
\hline 43 & 0,294 & 0,154 & 0,231 & 0,142 & 0,339 & 0,2320 \\
\hline 44 & 0,049 & 1,404 & 0,000 & 0,201 & 0,175 & 0,3658 \\
\hline 45 & 0,124 & 0,185 & 0,172 & 0,000 & 0,034 & 0,1030 \\
\hline 46 & 0,185 & 0,049 & 0,103 & 0,077 & 0,185 & 0,1198 \\
\hline 47 & 0,201 & 0,154 & 0,277 & 0,326 & 0,142 & 0,2200 \\
\hline
\end{tabular}




\begin{tabular}{rrrrrrr}
\hline $\mathbf{4 8}$ & 0,209 & 0,077 & 0,049 & 1,026 & 0,103 & 0,2928 \\
$\mathbf{4 9}$ & 0,195 & 0,069 & 0,185 & 0,366 & 0,146 & 0,1922 \\
$\mathbf{5 0}$ & 0,220 & 0,882 & 0,146 & 0,124 & 0,172 & 0,3088 \\
$\mathbf{5 1}$ & 0,034 & 0,218 & 0,034 & 0,124 & 1,269 & 0,3358 \\
$\mathbf{5 2}$ & 0,097 & 0,209 & 0,000 & 0,292 & 0,403 & 0,2002 \\
$\mathbf{5 3}$ & 0,175 & 0,154 & 0,069 & 0,185 & 0,209 & 0,1584 \\
$\mathbf{5 4}$ & 0,731 & 0,000 & 0,175 & 0,250 & 1,164 & 0,4640 \\
$\mathbf{5 5}$ & 0,370 & 0,124 & 0,185 & 0,312 & 0,109 & 0,2200 \\
$\mathbf{5 6}$ & 0,418 & 0,000 & 0,142 & 0,142 & 0,310 & 0,2024 \\
$\mathbf{5 7}$ & 0,185 & 0,034 & 0,000 & 0,034 & 0,479 & 0,1464 \\
$\mathbf{5 8}$ & 0,243 & 0,034 & 0,172 & 0,103 & 0,172 & 0,1448 \\
$\mathbf{5 9}$ & 0,109 & 0,146 & 0,000 & 0,250 & 0,069 & 0,1148 \\
$\mathbf{6 0}$ & 0,447 & 0,462 & 0,097 & 0,231 & 0,077 & 0,2628 \\
$\mathbf{6 1}$ & 0,175 & 0,346 & 0,103 & 0,109 & 0,000 & 0,1466 \\
$\mathbf{6 2}$ & 0,277 & 0,142 & 0,000 & 0,341 & 0,069 & 0,1658 \\
$\mathbf{6 3}$ & 0,154 & 0,142 & 0,124 & 0,344 & 0,284 & 0,2096 \\
$\mathbf{6 4}$ & 0,277 & 0,069 & 0,000 & 0,175 & 0,142 & 0,1326 \\
$\mathbf{6 5}$ & 0,175 & 0,124 & 0,296 & 0,124 & 0,209 & 0,1856 \\
$\mathbf{6 6}$ & 0,154 & 0,172 & 0,308 & 0,049 & 0,034 & 0,1434 \\
$\mathbf{6 7}$ & 0,248 & 0,588 & 0,034 & 0,172 & 0,175 & 0,2434 \\
$\mathbf{6 8}$ & 0,154 & 0,142 & 0,936 & 0,269 & 0,103 & 0,3208 \\
$\mathbf{6 9}$ & 0,389 & 0,097 & 0,000 & 0,243 & 0,000 & 0,1458 \\
$\mathbf{7 0}$ & 0,317 & 0,034 & 0,142 & 0,310 & 0,000 & 0,1606 \\
$\mathbf{7 1}$ & 0,243 & 0,034 & 0,103 & 0,248 & 0,262 & 0,1780 \\
$\mathbf{7 2}$ & 0,201 & 0,109 & 0,310 & 0,069 & 0,000 & 0,1378 \\
$\mathbf{7 3}$ & 0,034 & 0,124 & 0,142 & 0,000 & 0,000 & 0,0600 \\
$\mathbf{7 4}$ & 0,000 & 0,206 & 0,154 & 0,172 & 0,000 & 0,1064 \\
$\mathbf{7 5}$ & 1,034 & 0,034 & 0,138 & 0,142 & 0,175 & 0,3046 \\
$\mathbf{7 6}$ & 0,206 & 0,195 & 0,000 & 0,000 & 0,000 & 0,0802 \\
$\mathbf{7 7}$ & 0,231 & 0,109 & 0,277 & 0,049 & 0,000 & 0,1332 \\
$\mathbf{7 8}$ & 0,103 & 0,049 & 0,000 & 0,124 & 0,344 & 0,1240 \\
$\mathbf{7 9}$ & 0,109 & 0,077 & 0,138 & 0,220 & 0,077 & 0,1242 \\
$\mathbf{8 0}$ & 0,109 & 0,034 & 0,000 & 0,034 & 0,000 & 0,0354 \\
\hline$\overline{\boldsymbol{1}}$ & $\mathbf{0 , 2 3 8 5 6}$ & $\mathbf{0 , 1 9 4 9 3}$ & $\mathbf{0 , 1 1 4 3 6}$ & $\mathbf{0 , 1 8 3 8 9}$ & $\mathbf{0 , 2 3 4 2 6}$ & $\mathbf{0 , 1 9 3 2 0}$ \\
\hline $\boldsymbol{\sigma}$ & $\mathbf{0 , 1 5 3 6 7}$ & $\mathbf{0 , 2 3 5 1 0}$ & $\mathbf{0 , 1 2 3 1 0}$ & $\mathbf{0 , 1 8 2 4 9}$ & $\mathbf{0 , 2 8 1 7 5}$ & $\mathbf{0 , 0 8 3 9 3}$ \\
\hline $\bar{x}-\mathbf{m e ́} d i a, \sigma-$ desvio padrão & & & & & \\
& & & & & &
\end{tabular}




\section{Anexo A - Publicação: Infecção produtiva in vitro}

Virology: Research \& Reviews

oat

Resecrich Article

ISSN: 2514-4138

Bovine papillomavirus productive infection in cell cultures:

First evidences

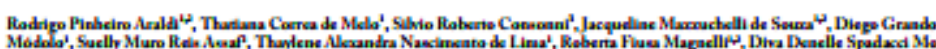

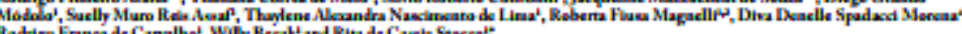

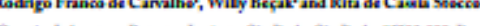

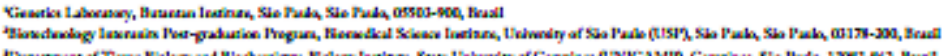

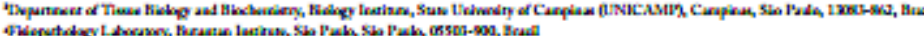

Ahetract

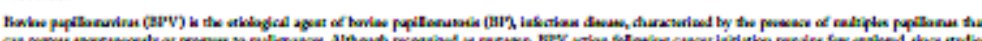
at ng w

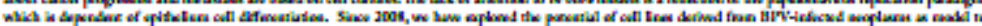

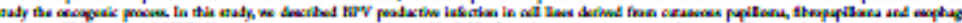

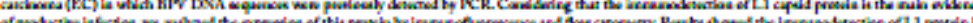

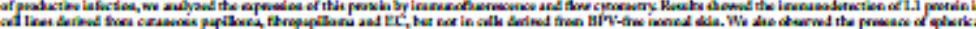

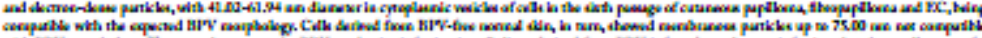

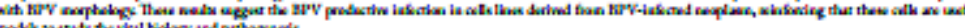

Highlights

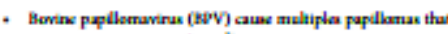

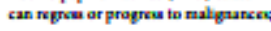

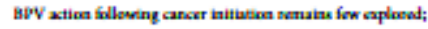

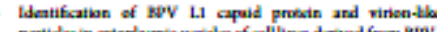

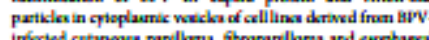
inforcied ce:

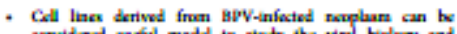
parhologe.

Introduction

Besine pupileseasirus (BVW) is the stabogial went of bevine

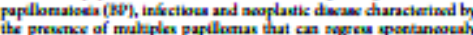

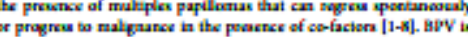

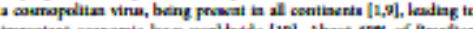

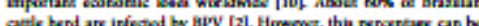

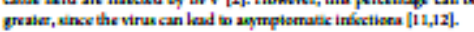

Cumsatly thene ae 15 kW typs dacthed, wich ans

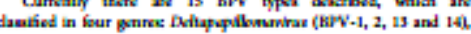

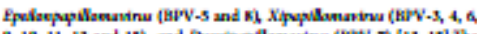

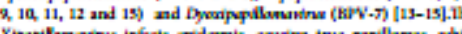

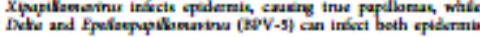

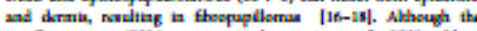

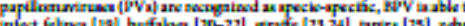

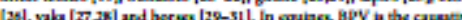

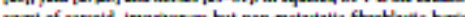

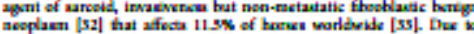

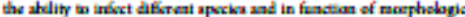

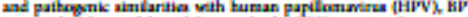

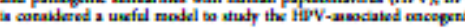
proses $|x, 4-36|$.

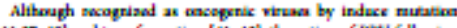

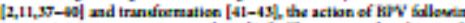

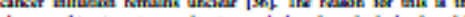

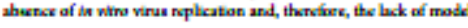

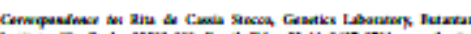
mexiptet teriag puls

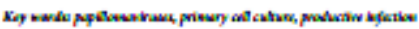

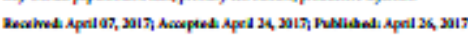




\title{
Anexo B - Publicação: Alterações metabólicas induzidas pelo BPV
}

Journal of
Cancer Research and Therapeutic Oncology
Research

Primary Cultures Derived From Bovine Papillomavirus-Infected Lesions As Model To Study Metabolic Deregulation

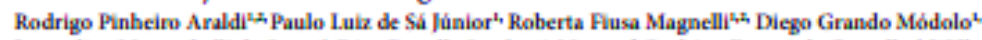
Jacqueline Mazzuchelli de Souza" Diva Denelle Spadacel-Morena $a^{2}$ Rodrigo Franoo de Carvalho ${ }^{1}$, Willy Beçak ${ }^{1}$ Rita de Cassia Stoccoti"

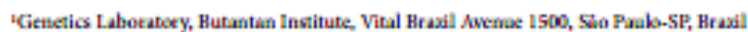

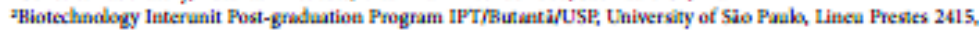
Sỉo Pwale-SP, Rrazil

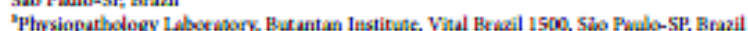

"Coerspoeding author: Rira de Ciosia Stocca, Genctics L.aboratory (Viral Oncogenesis), Hutaman Insitute, Viral

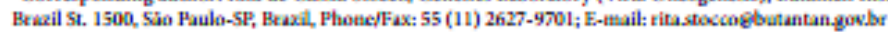

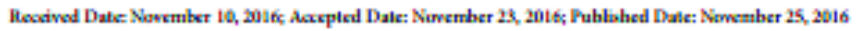

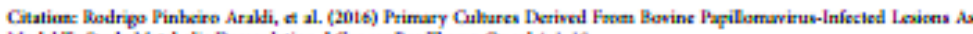

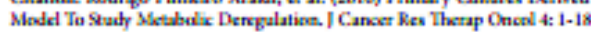

\begin{abstract}

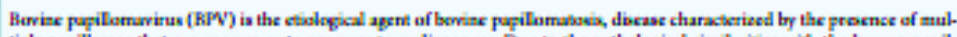

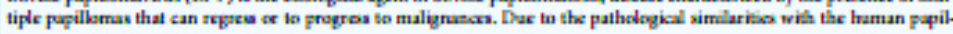

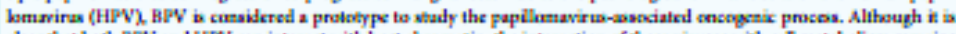

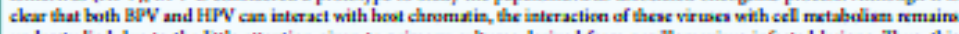

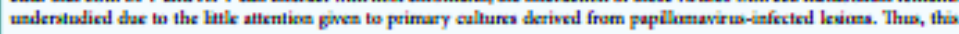

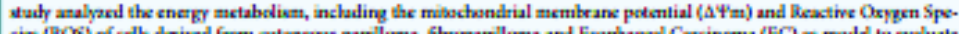

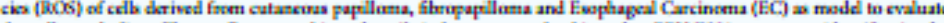

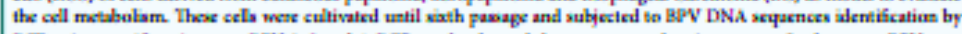

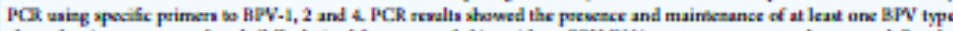

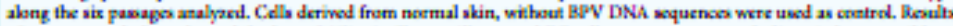

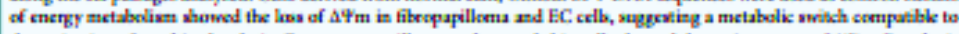

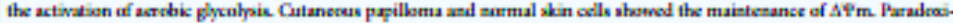

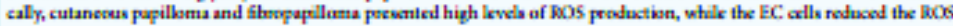

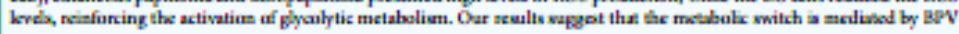

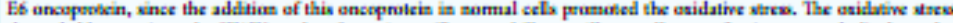

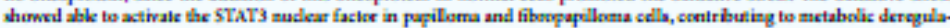
tien. Those da vapget thri primary cellures are uosfal model to staly the imeraction between RPV and cel metskubm.

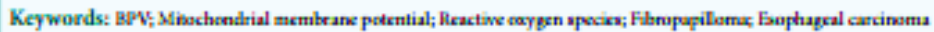

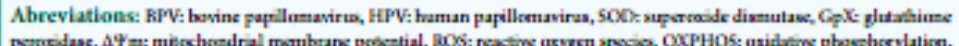

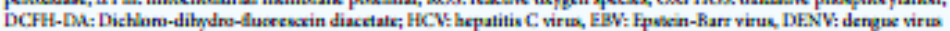




\section{Anexo C - Publicação: potencial mutagênico da E6}

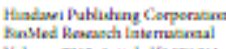

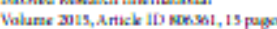

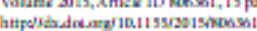

Research Article

Mutagenic Potential of Bos taurus Papillomavirus Type 1 E6 Recombinant Protein: First Description

Rodrigo Pinheiro Araldi, ${ }^{1,2}$ Jacqueline Mazzuchelli-de-Souza, ${ }^{1,2}$

Diego Grando Modolo, ${ }^{1}$ Edislane Barreiros de Souza, ${ }^{3}$ Thatiana Corréa de Melo,

Diva Denelle Spadacci-Morena, ${ }^{4}$ Roberta Fiusa Magnelli, ${ }^{1}$

Márcio Augusto Caldas Rocha de Carvalho, ${ }^{1}$ Paulo Luis de Sá Júnior,

Rodrigo Franco de Carvalho, ${ }^{1}$ Willy Beçak, ${ }^{1}$ and Rita de Cassia Stocco

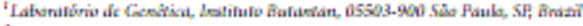

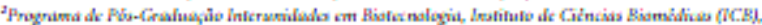

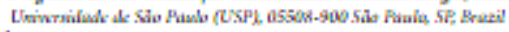

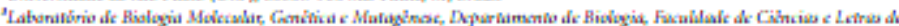

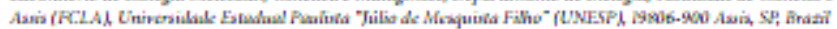

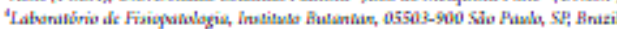

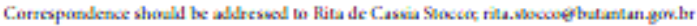

Rectived I6 Juky 2015, Reriwed 7 October 2015; Actepted is Otedort 2015

Acalemic Elitor: |larasz Rlasiak

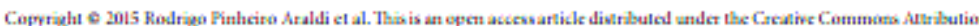

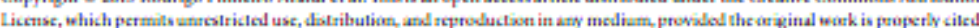

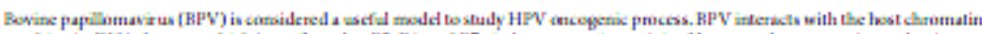

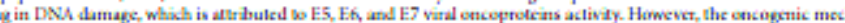

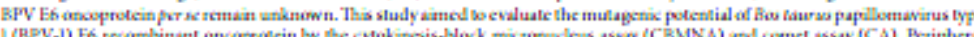
الم إن

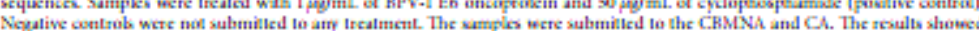

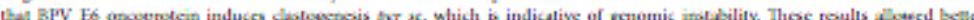

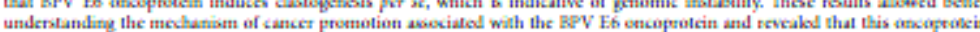

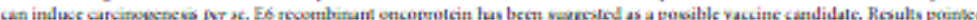

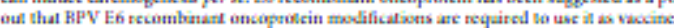

\section{Introduction}

Papillomaviruses ( $P$ Vs) are a group ơ viruses with eptheliur and mucous tropism [1, 2], PYs on infect all verteorates, including rabbiss [3-5], dogss [6, 7], goonts [8], humins [9-12], and borines [1,13-15]. In the last decades, an increasing interest in studies invalving these viruses has been observed II6, 17]. This fact is justifed because the PVs are aseociated with besign (papillomas) and malignans lesions, which can affeat both human $[16,18]$ and animals $[1,15,19]$. In this scenario,
Fas taunus papillomavirus is considered the best model for ancogenic process studies assoclated with PVs $\mid 20-23]$

Hes taurus popillomaviruses, also knoun as bavine papt.

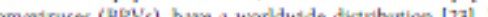

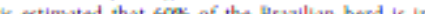

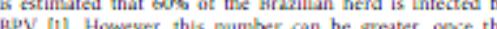

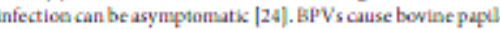
lomatosis, an infectious disease characterized by the presence of multiple papillomas, which cas regress spontaneously or progress to malignancy [1]. Among the 14 BPV's types already 


\section{Anexo D - Publicação: ação do BPV na metástase}

Journal of
Cancer Research and Therapeutic Oncology
Research

Analysis of Stem-Cell and Migratory Phenotype in Primary Cultures Derived From BPV-Infected Benign and Malignat Neoplasms

Rodrigo Pinheiro Araldi² Thaylene Alexandra do Nascimento Lima', Diego, Grando Módolo', Jac. queline Mazzuchelli de Souza ${ }^{1,1}$, Roberta Fiusa Magnelli², Beatriz Mauricio', Diva Denelle Spadacci Morena", Paulo Luiz de Si lúnior', Rodrigo Franoo de Carvalho', Willy Beçak', Rita de Cassia Stocco ${ }^{2}$

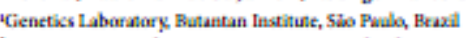

Imerunit Past-graduation Program in Riccechnologẹ. Biomedicine lnstitunt, Unürersity of Sio Paulo (USP), Sío Paulo, Brazil

Cel Biology Laborwarg, Bunantan Institunt, Sio Pwala, Heaxi

"Fhysioputhalagy L.aboeatory, Butaman lnstitute, Säo Paula, Brazil

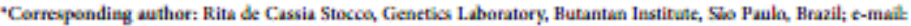
ritustoccogbutantangovibr Phone/Fax: 455 (011) 2627-9701

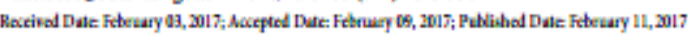

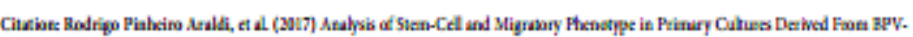

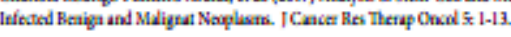

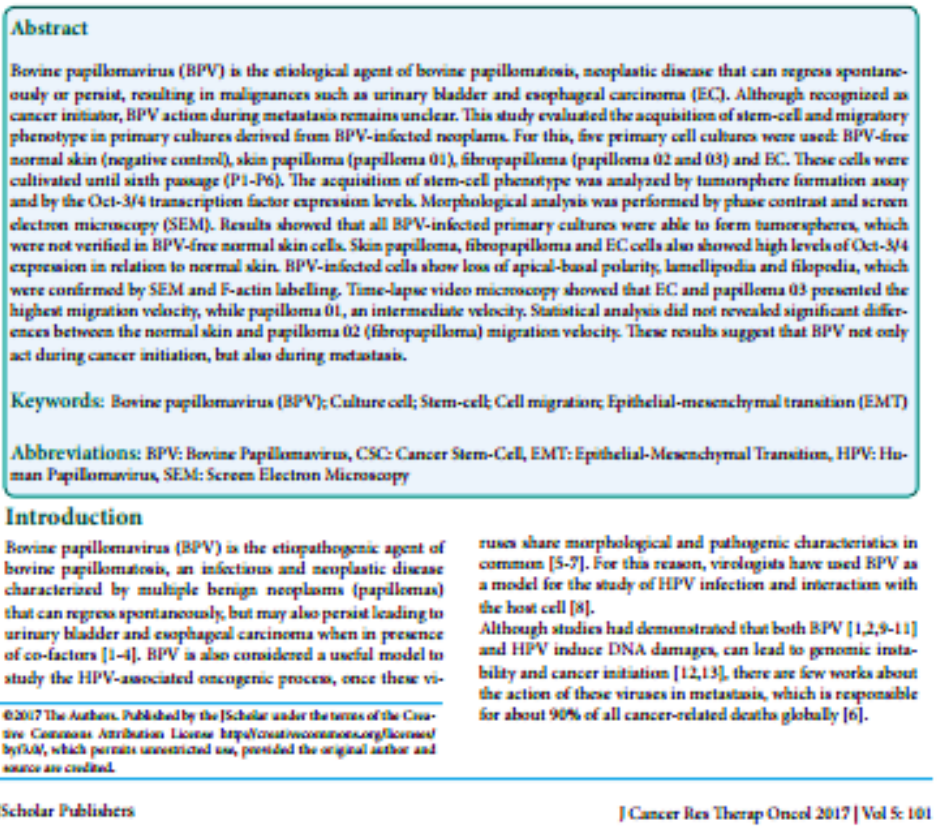




\section{Anexo E - Revisão sistemática sobre papilomavírus}

Papillomaviruses: a systematic review

Radrigo Pinheiro Araldi ${ }^{12}$, Suely Muro Reis Assaf', Rodrigo Franco de Carvalho', Mircio Augusto Caldas Rocha de Carvalho ${ }^{1,3}$, Jaequeline Mazsuchelli de Souzz ${ }^{1,2}$, Roberta Fiusa Magnelli ${ }^{1,2}$, Diego Giando Módalo ${ }^{1}$, Franco Peppino Roperto ${ }^{4}$, Rita de Cassia Stoceco and Willy Beçak ${ }^{1}$

'Lahanatörio de Genétick, Instî̀tuto Butantan, São Paulo, SP, Brozil.

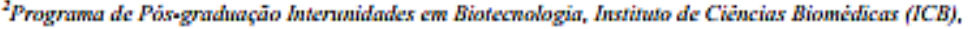
Universidade de Säo Paulo (USP), Säo Paulo, SP. Brazil.

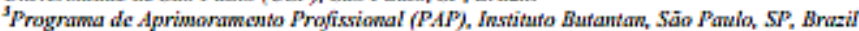

'Dipartimento di Medicina Vetcrinaria e Produzioni Animali, Università degli Studi di Napoli Federico ll, Napoli, Campania, Italy.

Abstract

In the last decodes, a group of viruses has rooetved great attention due to is relationship with concer development and its wide dstribution throughous the vertabrates: the papllamaviruses. In this artida, wa aim to review some of the

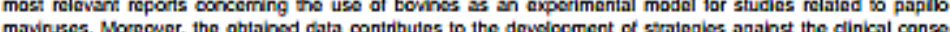

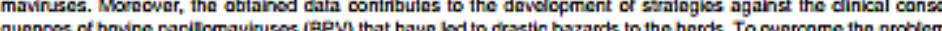

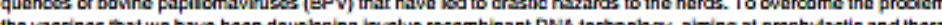

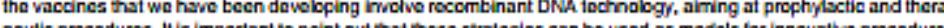

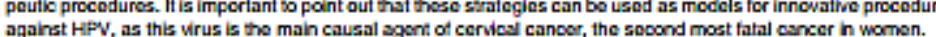

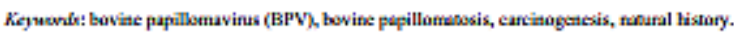

Reteived: May 09, 2016; Acrepead: Scplember 23, 2016.

A brief history of the papillomavirus (PVs) on carcinogenesis

In the last decades, novel diagnastic methods and therapies have been implememed in an attempt to combat cancer. However, the number of patients that succumb to the disease has increased globally (Varga ef ol., 2014). This negutive result emphasizes the complexity of the onoogenic process, which has a multifictorial cause. Amongentic process, which has a mention zqenten, soch as hacteria and viruses.

The association between cancer and infectious agents has been discussed far centuries (Graner, 2000). In 1858, George B. Wood stated in his book Practice of Modicise that cancer could be disseminated as an infectioas disease (Graner, 2000). However, the association berween cancer and infectious agems was only implied in the second halfof $19^{*}$ century by Rudolf Maier (Graner, 2000; zur Hanesen, 2009). The major difficulty in demonstrating this associztion can be attributed to the time-lapse of $13-40$ years be

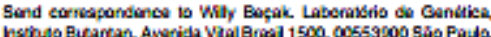
SP, Enazi. E-mail: whocake nhoseom b tween the infection and the developusent of the first clinical signs that would allow cancer dizgnosis (zur Hausen, 2009 . Yet, in the last decades, the involvensent of infortious agents with cancer has anoused great attention, $2 s$ one in ten haman malignancies is caused by these pathogens (Ribeiro-Maller and Muller, 2014).

Current studies estimate that $23 \%$ of all human malignuncies are associated with infectioas agents (zur Hausen, 2009; WHO 2013; Bricher and Jamall, 2014; Bravo and Felez-Sanchez, 2015). Among them, human popillomz. vinus (HPV) is responsible for 27.9\% (zur Hausen, 2009) to $30.0 \%$ (Bravo of al., 2010) of all incident cancer cases in the world. This data is very concerning, once $79 \%$ of the global population lives in developing countries (Marrazso and Holmes, 2013), where the lack of information about the HPV and ochers sexually transmitted diseases (STD) contributes to the increase of HPV-associzted canoers. Acconding to the World Health Organization (WHO)

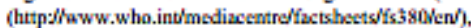
$85 \%$ of cervical cancer cases occurs in less developed countries.

Papillomavinases (PVs) are not only associated to human cancers, but akso with animal malignancies. Although 